
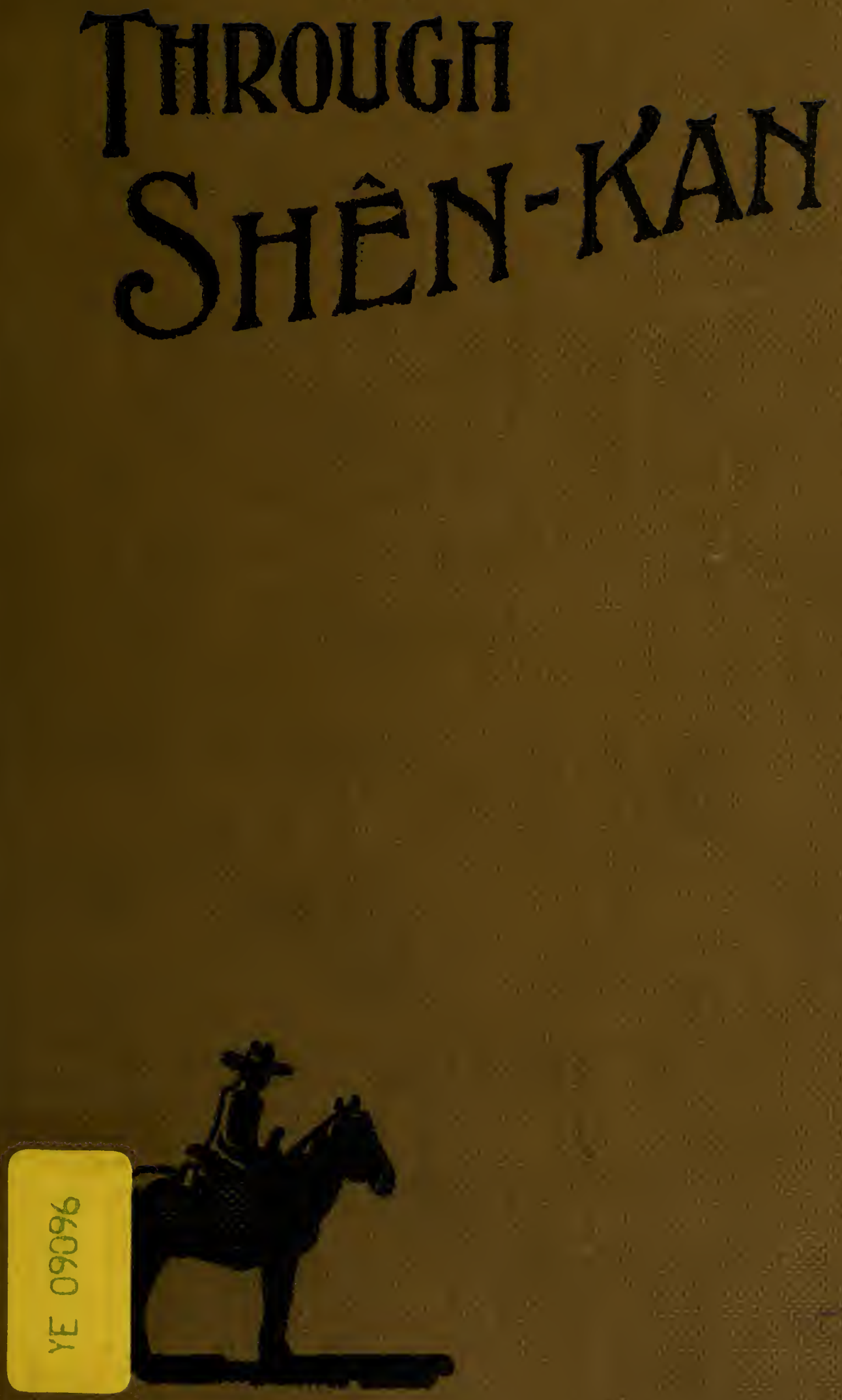


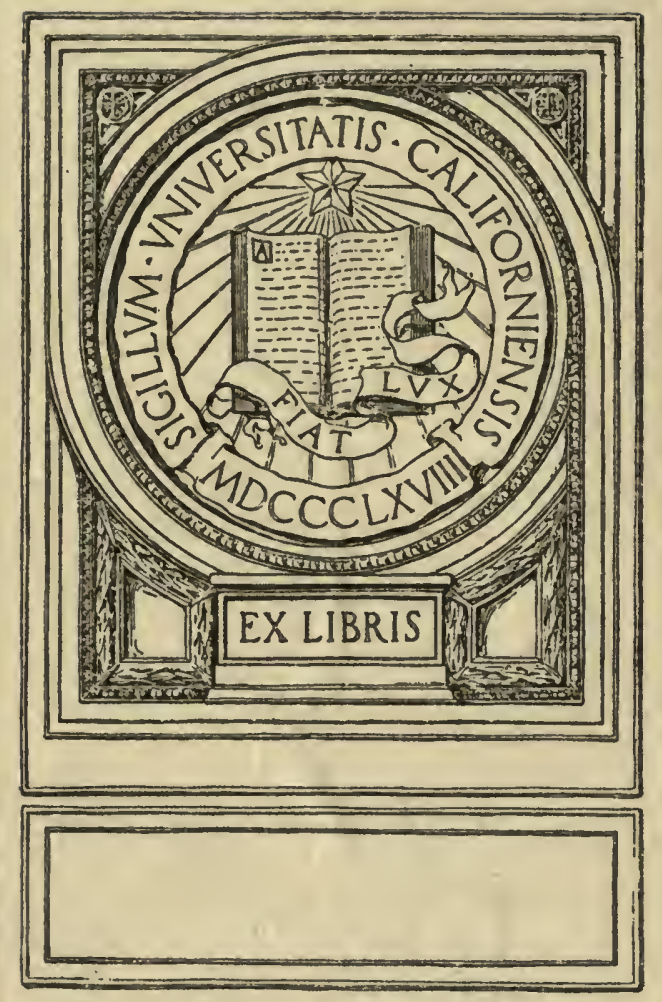



Digitized by the Internet Archive in 2008 with funding from Microsoft Corporation 


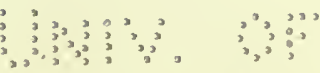

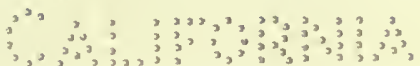




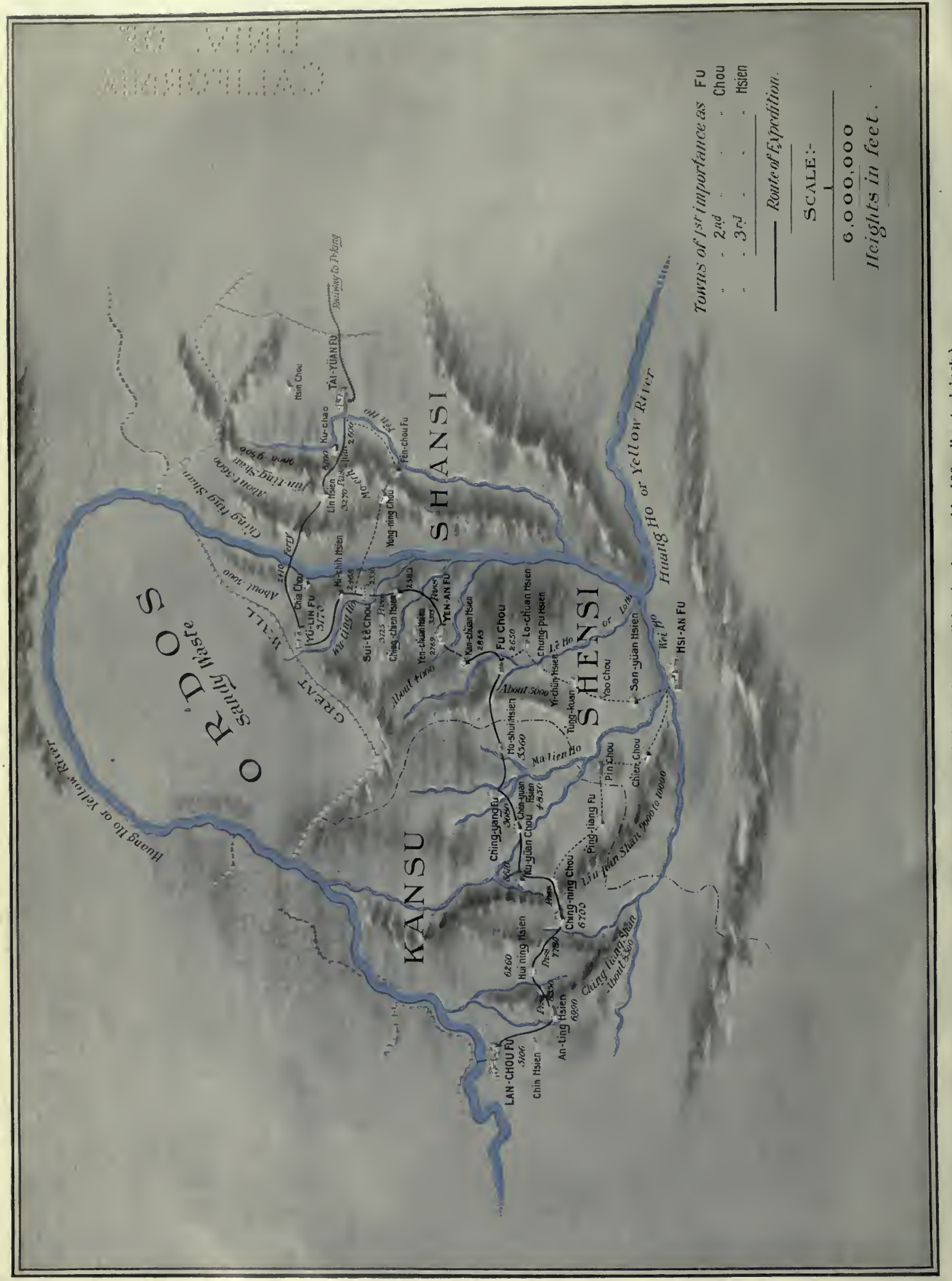

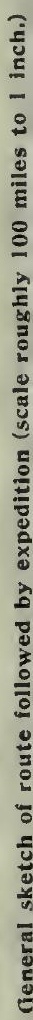




\title{
Through SHÊN-KAN \\ THE ACCOUNT OF THE CLARK EXPEDITION \\ IN NORTH CHINA, I908-9.
}

\author{
By \\ ROBERT STERLING CLARK \\ and \\ ARTHUR de C. SOWERBY
}

Edited by Major C. H. Chepmell

T. FISHER U N W I N

LONDON: ADELPHI TERRACE

LEIPSIC: INSELSTRASSE 20

I9I2 


\section{5710 \\ $\mathrm{Cb} 3$}

ALL RIGHTS RESERVED.

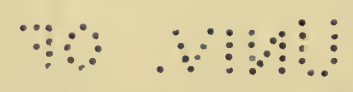

a 


\section{INTRODUCTION.}

THIS book is issued in the hope that it may be of some interest to the general public, at a time when China is once again fixing the attention of all Western peoples.

In its compilation an attempt has been made to carry the imagination of the general reader-by pen, brush, and film-into the very heart of the Celestial Empire; and further, to set down with accuracy, and in as comprehensive a way as possible, such facts and figures as may form a solid basis for the future explorer in North China.

Including preparations, the expedition, in the course of which these facts and figures were obtained, extended over a period of eighteen months. During this time about two thousand miles of road were traversed. The names of convenient halting-places are, of course, mentioned as we reach them in the narrative, but complete itineraries for the use of future travellers in these regions are given in Appendix I., together with a table containing the latitudes and longitudes of all those places, whose positions were determined by observation. We venture to think that future explorers may rely safely on these figures, as very great pains have been taken to ensure their accuracy, and much of the route having been traversed twice, ample opportunity was afforded for checking results. It should perhaps be pointed out that figures given in the text are usually in round numbers, greater exactitude being reserved for the Appendices.

The large Map (scale $\mathrm{I} / \mathrm{I}, 000,000$ ), which accompanies the book (in a pocket at the end), has been compiled from the plane-table survey made on the expedition by an expert. The original survey was on the scale of four miles to the inch, and the work was checked by astronomical observations, taken at intervals of not more than one hundred miles, along the line of march. A short description of the means and methods employed to ensure accuracy, together with a slight sketch of similar work previously done in the locality, will be found in Chap. XIV. For the general reader, a birdseye map is given showing the more important points along the route. 
Special attention has been devoted to the Zoological work of the expedition, in which connection some very interesting discoveries were made. Detailed scientific papers on the Mammals and Insects collected have been embodied in Appendices (II.-V.); but as the collections of Birds and ColdBlooded Vertebrates contain no new species, scientific déscriptions are not necessary, though the reader will find Chapters dealing in a more or less popular way with both these branches of Biology, as well as a review of the whole Biological work.

The Meteorological observations will be found in tabulated form (App. VI.), interesting points concerning the climatic conditions of the country being detailed in Chapter XV. An attempt, too, has been made to give a general sketch of the Geology of the country passed through.

The photographs and coloured plates which illustrate the book, have been chosen with a view to presenting different types of natives, geological formations, scenery, and other matters of general interest. It is unfortunate that, owing to the necessity for a distribution of the plates throughout the volume, these cannot always fall at-or even near-the mention of them in the text; but, as far as possible, references are given where they illustrate places visited or explain points raised, as, for example, in the Chapters on Natural History and Geology.

We take this opportunity of acknowledging our debt of gratitude to the British War Office for lending the services of Captain H. E. M. Douglas, V.C., D.S.O., R.A.M.C. ; and to the Survey of India for those of Hazrat Ali, our surveyor, whose sad death in the performance of his duty is so deeply regretted by every member of the expedition.

Out best thanks are also due to the "Hon. N. Charles Rothschild, M.A., F.L.S., for the paper on Siphonaptera; to Mr. H. R. Hogg, M.A., F.Z.S., for his contribution on Araneidae; to the members of the British Museum Staff, who kindly examined and classified the specimens belonging to the orders of Invertebrates contained in the collection; to Mr. Gerrit S. Miller, of the Smithsonian Institution, for his description of five new species in the collection of Mammals; and to the Rev. Frank Madeley for his assistance in connection with the history of the mounds and monuments examined round about $\mathrm{Hsi}$-an Fu.

Major L. D. Fraser, Royal Artillery, afforded invaluable assistance in undertaking the preparation of the Map, in correcting the spelling of Chinese 
place-names, and in so many other ways-not only in the production of the book, but also in the original arrangement and fitting-out of the expedition - that it is impossible to over-estimate our obligation to his kindness.

Owing to the circumstances under which a great part of the manuscript was produced, it stood in need of considerable revision and compilation, and in the absence of both authors from England, Major C. H. Chepmell, late R.A., kindly undertook these duties, and has carried out a difficult task with painstaking skill. Expert assistance was obtained where special knowledge was required; and our best thanks are due to Mr. R. I. Pocock, F.R.S., Professor J. Logan Lobley, F.G.S., F.R.G.S., and Mr. R. Corless, M.A., F.R.Met.Soc., for consenting to revise our proofs dealing with Natural History, Geology, and Meteorology respectively.

ROBERT STERLING CLARK. ARTHUR DE C. SOWERBY.

August, 1912. 


\section{CONTENTS.}

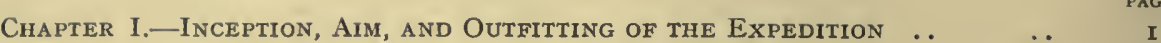

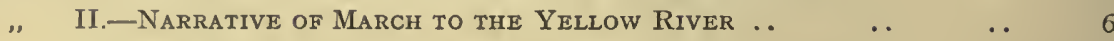

", III.—Passage of the Yellow River-March to Yü-LiN Fu.. . . I

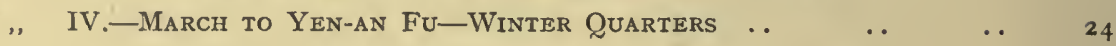

" V.-Clark and Sowerby's Narrative of Journey to Hsi-an Fu .. 34

"VI.-Description of Hsi-An Fu-Clark and Sowerby's Journey to LAN-CHOU FU . .

"VII.-March of Douglas and Grant to Lan-chou-Description of LAN-CHOU Fu .. $\quad$.

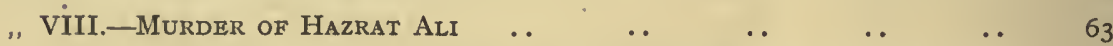

" IX.-Return March of Grant and Sowerby from Lan-chou to $\begin{array}{llllllll}\text { T'AI-YÜAN } & \text {. } & \ldots & \ldots & \ldots & \ldots & \ldots & 70\end{array}$

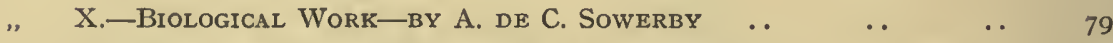

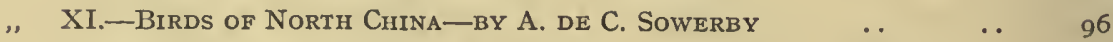

" XII.-Reptiles, Batrachians and Fishes-By A. de C. Sowerby .. Iog

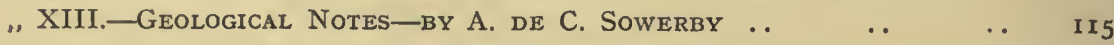

„, XIV.-Survey Work of the Expedition-By R. S. Clark .. $\quad$..

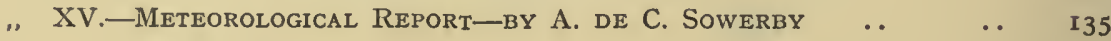

APPENDIX I. (A),-Itineraries $\quad$.

I. (B).-Table of Latitudes and Longitudes $\quad \ldots \quad$.

II. -Mammals Collected in Shansi, Shensi and Kansu-by A. De $\begin{array}{lllllllll}\text { C. SOWERBY } & \text {. } & \ldots & \ldots & \ldots & \ldots & \ldots & \text { I } 7 \text { I }\end{array}$

ili. - Invertebrates Collected on the Expedition-By A. de C. $\begin{array}{lllllllll}\text { SOWERBY } & \ldots & \ldots & \ldots & \ldots & \ldots & \ldots & \text { I } 86\end{array}$

" IV. -Description of three New Species of Siphonaptera,-BY the Hon. N. Charles Rothschild, M.A., F.L.S. $\quad$. $\quad$.. $\quad 194$

V. -Araneidae of the Clark Expedition to Northern China(Diagrams p. 2I8)-BY H. R. Hogg, M.A., F.Z.S. _. 204

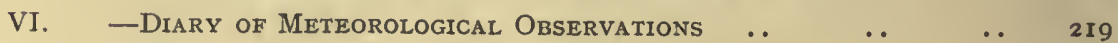




\section{COLOURED PLATES.} The Fort, near Yï-lin Fu, Ordos Border .. .. 20

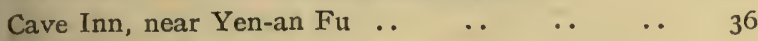
The Yellow River, near IK'ang-chia-t'a, Shansi 76
Brown Snake and Toad-headed Lizard Sunset on the Ordos Border

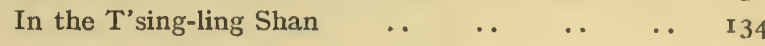

\section{PLATES.}

Plate I.-Hazrat Ali

2.-Native Hunters, T'ai-yiian-Fu, Shansi. .

3.-Camp at Chao-chuang, T'ai-yüan Plain. Washing Sheep .. . . . 4.-Chin-ssŭ Miao Pagoda, near T'ai-yüan Fu, Shansi .. $\quad$. $\quad$.. . . 5.-View from Summit of Mo-êrh Shan, $\begin{array}{llllll}\text { Shansi } & \text {. } & \text {.. } & \text {. } & \text {. } & 8\end{array}$ 6.-Threshing Floor, Shansi _. . . 7.-Ch'êng-wu Miao (Temple), Ch'ing-ting $\begin{array}{lllll}\text { Shan, Shansi } & \text {. } & \text {. } & \text {.. } & \text { I2 }\end{array}$

8.-Washing Clothes. Shansi Type .. I4

9.-The Yellow River at Huang-ho-yiieh .. I6

Io.- -Sand Dunes, east of Yü-lin Fu, Shensi I 8

I I.-Pi Jung-pei, Head of the Police, Yü-lin Fu, Shensi .. .. . . . 12.-Chinese Lady $\quad \ldots \quad$. $\quad \ldots \quad$.. 13.-Towers of the Great Wall, north of Yü-lin Fu, Shensi .. . . ..

I4.-View of the Great Wall, showing encroaching sands .. .. ..

15.-Epitaphs in Sandstone Outcrop, near Yü-lin Fu, North Shensi .. ..

I6.-Horse Fair, outside South Gate, Yü-lin Fu, Shensi .. . . . . ..

I 7.-The Sandstone Strata near Ch'ing-chien Hsien, Shensi, in winter .. ..

I8.-Cave Temple (Sung Dynasty) at Yen-an Fu, Shansi .. .. .. .. 19.-Representation of Buddhist Hell, in the Lung-wang Miao, at Yen-an Fu, Shensi

20.- "Goddess of Mercy" in the Cave Temple atYen-an Fu, Shensi .. 20A.-Cormorant Fishing on the Wei Ho,

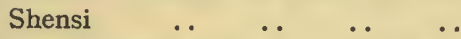

21.-Robert S. Clark (left) and Arthur de C. Sowerby (right) with Christmas Day's Bag of Pheasants .. . .

" 22.-Loess Cañon and Plateaux, south of Fu-chou .. .. .. .. 23.-Sowerby and his First Bustard
I

2
Plate 24.-Gateway marking Boundary between the Provinces of Shensi and Honan

25.-Roadside Scene, Honan. . . . .

" 26.--Rubbing from Tablet in the Pei Ling (Monument Grove), Hsi-an Fu .

27.-Camel Inn at Ta-yü-ch'êng, Shensi .. 28.-Hua-kuo Shan, Shensi .. . . . .

29. - Colossal Buddha, at Ta-fu-ssŭ, Shensi. . 30.-General Ma's Avenue, Kansu .. . .

31.-Criminal in cage on his way to execution in Lan-chou Fu, Kansu .. . .

32.-Temple on Loess Spur at Kan-ts'aotien, near Lan-chou Fu, Kansu ..

33.-Yellow River at Shao-shui-tzŭ, near Lan-chou Fu, Kansu. The river here cuts through granite .. .. 70

34.-Peasant Woman. Kansu Type .. 72

35.-Ssŭ-ch'uan Women, settlers in Kansu.. 74

36.-Peasant Woman. Kansu Type $\quad$. $\quad 78$

37.-Wang Tao-t'ai of Ku-yüan Chou, with his Secretaries and Guard.. .. 80

" 38.-Loess Valley, near Hui-ning Hsien,

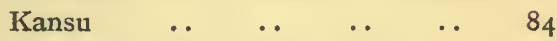

" 39.-Loess Cañon, Ying-t'ao-ho, Kansu .. 88

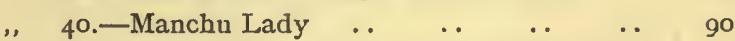

4I.-Our Military Escort from Lan-chou Fu 94

42.-Exiles in Chains. Hui-ning Hsien,

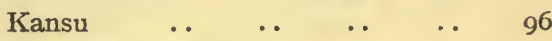

43.-Chang-t'ai-p'u, Kansu $\ldots \quad$.. $\quad \ldots \quad$ Ioo

" 44.-Guard House on Hsi-an to Lan-chou Road, Kansu .. .. .. 44A.-Peculiar Head-dress. Only worn in the vicinity of Chên-yüan Hsien,

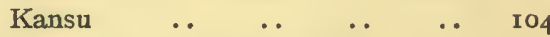

45.-Deserted Cave Village, Kansu .. . . 106 46.-Isolated Column of Sandstone, Haishui-ssŭ, Kansu and Shensi border

108

47.-Wild Boar shot near Yen-an Fu .. II2 48.-Chipmunk. (Eutamias asiaticus sene-

$\begin{array}{llllll}\text { scens) } & \ldots & \ldots & \ldots & \ldots & \text { II4 }\end{array}$

" 48A.-Mole-rat. (Myospalax cansus) .. II4 " 49.-Sand Hamster. (Phodopus bedfordia)..

\section{0}

60

4

8

80

4

8

o

6

o

.

4

6

8

2


Plate 49A.-David's Squirrel. (Sciurotamias davidianus) $\quad$. $\quad$. . $\quad$. $\quad \ldots \quad 120$

" 50.-Three-toed Jerboa. (Dipus sowerbyi) .. $\quad$ I22

, 51.-Suslik. (Citellus mongolicus) .. $\quad$.. 126

, 5 IA.-Polecat. (Mustela lavvata) .. $\quad$.. $\quad 126$

, 52.-Allactaga. (Allactagamongolicalongior) 128

, 52A.-The Pika. (Ochotona annectens) .. 128

" 53.-Wild Pig. (Sus moupinensis). Shot near Yen-an Fu, Shensi .. . . $\quad 136$

, 53A.-Domostic Pig . $\quad$. . $\quad \ldots \quad$.. $\quad$ I36

" 54.-Mud Turtle. (Trionyx sinensis) .. I 40

" 54A.-Day's Bag near Yen-an Fu. Roedeer, pheasants and hare $\quad . . \quad \ldots \quad$ I 40
Plate 55.-The Summit of Mo-êrh Shan, Shansi ..

„55A.-Sandstone Beds, west of the Chiaoch'êng Shan, Shansi

....

" 56.-Loess Plateaux, east of Fu-chou, Shensi

" 56A.-Loess showing stratification, Shansi ..

" 57.-Valley near Chên-yüan Hsien, showing the dip of the Sandstone beds ..

" 58.-Sandstone Strata at Sui-tê Chou, Shensi $\quad$. $\quad \ldots \quad \ldots . \quad \ldots \quad$ I54

, 58A.-Cañon in Limestone Formation west of Fên-chou Fu, Shansi _. $\quad$.. I 54

\section{MAPS.}

General sketch of route followed by expedition (Scale $\mathrm{r} / 6,000,000$ )
.. Frontispiece.
Route of the Clark Expedition through Shansi, Shensi and Kansu (Scale $I / I, 000,000$ ) (In pocket at the end) 


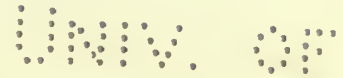

$$
\begin{aligned}
& \text { טים }
\end{aligned}
$$




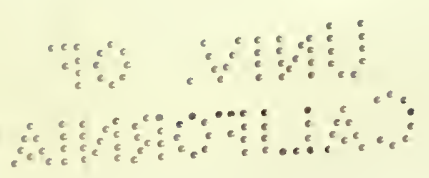

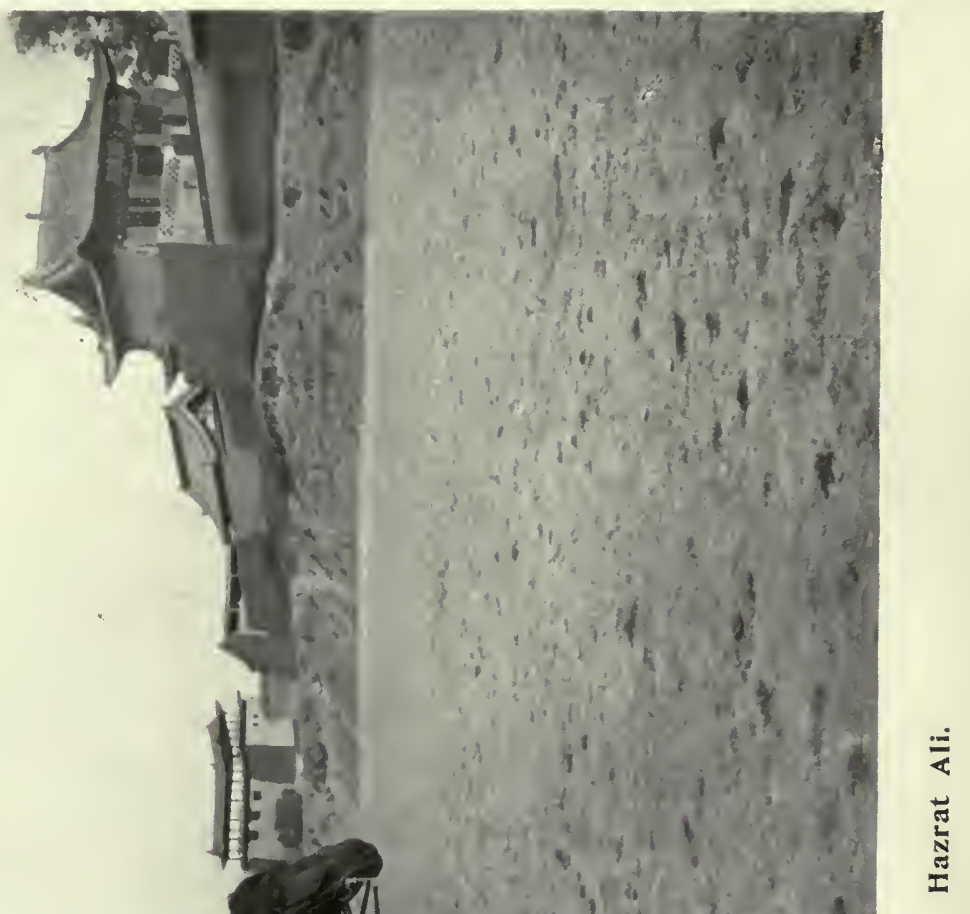




\section{CHAPTER I.}

\section{INCEPTION, AIM, AND OUTFITTING OF THE EXPEDITION.}

SIX centuries have elapsed since Marco Polo returned to Europe from his long sojourning in the unknown East. Wonderful indeed were the tales he brought, but none surpassing his description-incredible as it seemed-of the mighty dominions of the Grand Khan. It is related that on his death-bed the Venetian traveller was adjured to recant his narrative. But he remained firm; succeeding years have steadily piled up an overwhelming weight of testimony to his truthfulness; and never throughout this whole period have the peoples of the West failed to find in China a source of most lively interest and unlimited speculation.

Nor, indeed, has this interest been of a purely abstract character, for, as century has followed century, merchants, missionaries, explorers and scholars, have made their way in ever-increasing numbers, to the shores and boundaries of the Celestial Empire. They have penetrated into the interior, studied the language, and investigated customs, classics, and folk-lore. They have written many books, compiled maps, and brought away pictorial records on film and canvas. Numerous Treaty Ports have been established, each with a large and increasing European population. In many towns of the interior, schools, colleges, and hospitals have been started under the direction of Europeans, who, living thus amongst the Chinese, obtain ample opportunity of studying their characteristics. Railways, too, have been opened, connecting the large cities of the maritime provinces, as well as those of the Hinterland. With all these facts in view, we may be tempted to wonder whether any great scope for the explorer still remains.

And yet how little is really known. Cathay, with its paradox of barbarism and civilisation, its teeming millions of yellow-skinned agriculturaliststoiling to-day with implements as rude as those their forefathers wielded two thousand years ago-its mighty rivers and mountain ranges, its rich mineral deposits, its ancient tombs, and its relics of a bygone prosperity, remains still a land of mystery-enigmatic, perhaps inscrutable. Who can say that he knows the Chinese people? What scholar has wrested from their classics and their records all the secrets of that dim past, when war raged without cease along the Tartar marches, and the first dynasties of the infant Empire were emerging from the tumult and the strife? Can we be confident that even in the littoral and more traversed regions the flora and fauna hold 
in store no new surprise for the biologist? Can the geologist explain intricate hill systems, or tell the formation of high mountain ranges and vast plains that occur throughout the length and breadth of the land?

No. All these questions must be answered in the negative. Much useful knowledge has been brought to light by many and eminent explorers; much has been done, much remains to do; and this, too, in almost every branch of human knowledge. A reliable map is useful to the explorer; a complete and accurate survey indispensable to the geographer; and yet at the present time vast areas remain still unmapped, whilst a large proportion of the maps in use are misleading in their detail. The naturalist needs good collections of animals from all parts, in order that he may form a comprehensive idea of the spread of species in Eastern Asia, and of their relationship to the creatures of the surrounding islands. The enormous mineral resources of the country are only now beginning to be realised in the West, and great financial schemesdepending for their successful development on an increased knowledge of potential markets-all tend to augment the clamour for full and trustworthy information. And thus it came about that the expedition, of which this book gives the account, was undertaken in the hope of rendering some service to the Western world by increasing-be it only by a fraction-the knowledge of China and things Chinese.

The expedition, organised and financed by Mr. Robert Sterling Clark, of New York, should start, it was proposed, in the autum of 1908 , from T'ai-yüan $\mathrm{Fu}$ in Shansi, and after traversing Shên-kan (i.e., the provinces of Shensi and Kansu), skirt the Tibetan border to Ch'êng-tu Fu, in Ssŭch'uan; then descending the Min River to Sui-fu (Hsü-chou Fu) return to Shanghai viâ the Yangtzŭ. Its primary objects were, a careful plane-table survey of the whole route followed, and astronomical observations for latitude and longitude of all important towns visited along the line of march. In addition, it was decided to take and record daily meteorological observations; and photography was to play a great part in many ways. A useful and extensive outfit of instruments for all these branches of work was purchased in Europe, in addition to tents, camp furniture, stores, and other equipment required for a long trip in Palæarctic regions.

Mr. Clark, after making all preparations possible in England, proceeded to India, and was there fortunate in securing the services of an expert native draughtsman, kindly placed at his disposal by the Survey of India. This was Hazrat Ali, a native of the Panjab, who, with fifteen years' experience of survey work in the Army, and speaking seven languages (including English 
PLATE 2.
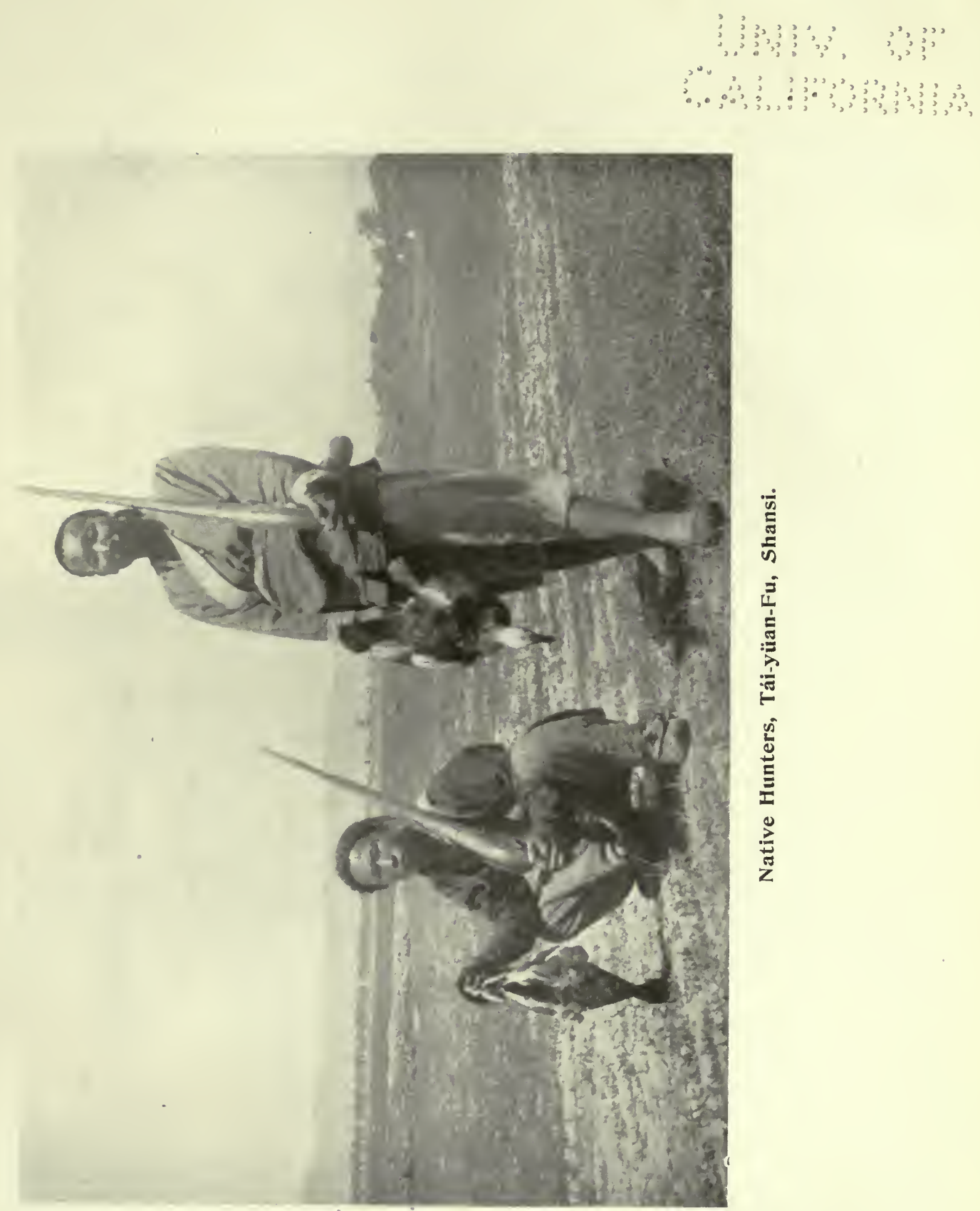


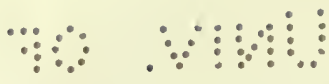

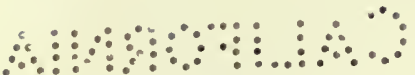


and Chinese), had every qualification for the undertaking. A good Mussulman, he required a co-religionist to do his cooking, and in consequence a second Panjabi, Muhammad Husein, who had been a camp follower in the Soudan and South African wars, was also engaged. Accompanied by these two men, Mr. Clark continued his journey to Peking, and there engaged the services of Mr. Grant, a gentleman who had resided in China for several years, as interpreter, and to assist in the general management of the expedition. Mules and horses had been purchased already in Honan, and these were sent to T'ai-yüan Fu, the city which, as stated above, was to be the starting-point. Thither, too, the party proceeded by rail, with a following of native servants, and the numerous boxes and panniers containing stores, and settled down to perfect their preparations for the long journey westward, meteorological observations being commenced on May I6th.

On May 27th a camp was made close to a small village named Chaochuang, situated on the plain about five miles north-west of T'ai-yüan Fu. Here Messrs. Clark and Grant, with Hazrat Ali, Muhammad Husein, and some of the Chinese servants, took up their quarters for the purpose of measuring a "base line." Owing to many interruptions this work took a long time, but eventually a base line of 2400 feet was measured twice over by means of an invar tape; the probable error working out to one in fifty thousand ( $I$ in 50,000 ). A visit of four days duration was paid to a temple in the hills about ten miles north-west of T'ai-ytian Fu. From a peak close to this, angles were observed to various other peaks and stations, including both ends of the base line in the plain, and various other points in the vicinity were fixed. Hazrat Ali, then commenced his plane-tabling, and before very long had mapped out a wide sweep of the country extending north-east and north-west of T'ai-yüan $\mathrm{Fu}$ for a distance varying from twenty to fifty miles. A splendid view of the surrounding country was obtained, and a good idea of its configuration could be formed. The following description is taken from a diary kept at the time: "Fifteen hundred feet below, the valley of the Fên Ho, now covered with bright green rice-fields and the golden ripening corn, spreads southwards in an ever-widening plain of rich alluvial soil, irrigated by numerous canals from the river. Ten miles beyond the river, to the east, the mountains, which, running northwards, ultimately join the Wu-t'ai Shan, rise in successive terraces of loess to a height of 5000 feet. To the north-east of this position rugged bare mountains form a half-circle, and join up with this range, which is rocky and steep on its eastern side, but slopes gently in the usual loess terraces towards the river on the west. A little to the north the 
Fên Ho cuts through the range, and there the sides are precipitous. Beyond this and away to the west stretch range upon range of mauve-blue mountains, some of the peaks in which are from 8000 to ro,000 feet high."

During our visit frequent thunderstorms and heavy rains were experienced so that the river was continually on the rise and fall. After rain in the mountains to the north-west, there would be a great rush of water, and the river would become impassable for several hours. Every time the water rose large quantities of silt were brought down, and the fords had to be moved repeatedly, owing to the treacherous and shifting nature of the river bottom. On several occasions different members of the party got into trouble with their ponies in crossing; but although the animals would sink rapidly in the quicksands up to their haunches, they always succeeded in scrambling out again. The camp was frequently visited by sick natives asking for help, which they usually received in the form of simple drugs, or "first aid" treatment in the case of injury. A lad with his head cut open would be brought in, or an old man with a shoulder dislocated would hobble from his work in the fields expecting some miraculous cure! The mules during this time were kept in T'ai-yuaan $\mathrm{Fu}$, but the ponies, being required for work continually, were kept tethered in the open out at camp.

By July I6th everything in connection with the base line and triangulation had been completed, and the party returned to $\mathrm{T}^{\prime}$ 'ai-yüan $\mathrm{Fu}$, where they put up at a private house, rented for the purpose, to await the arrival of further supplies. Preparations in the way of packing the provisions and outfit, in loads suitable for mule transport, were commenced. This was no light task, as can be imagined, when we consider the length of journey contemplated, and the varied nature of outfit necessary; and it kept all at work. Further, it had been decided to have a medical man with the party, and the services of Captain H. E. M. Douglas, V.C., D.S.O., of the Royal Army Medical Corps, were very kindly lent by the War Office for this purpose. On arrival, Captain Douglas at once took over the meteorological work. Mr. Clark desired, moreover, to add a zoological department to the expedition, and to undertake the charge of this he engaged the services of Mr. A. de C. Sowerby, who had recently returned from a collecting trip in Shensi.

This increase in personnel naturally entailed a further store of provisions, to obtain which Mr. Grant paid a visit to Shanghai, at which place, too, he took over an additional supply of photographic material just arrived from Europe.

Arrangements, too, were made for the telegraphic determination (from 
PLATE 3.
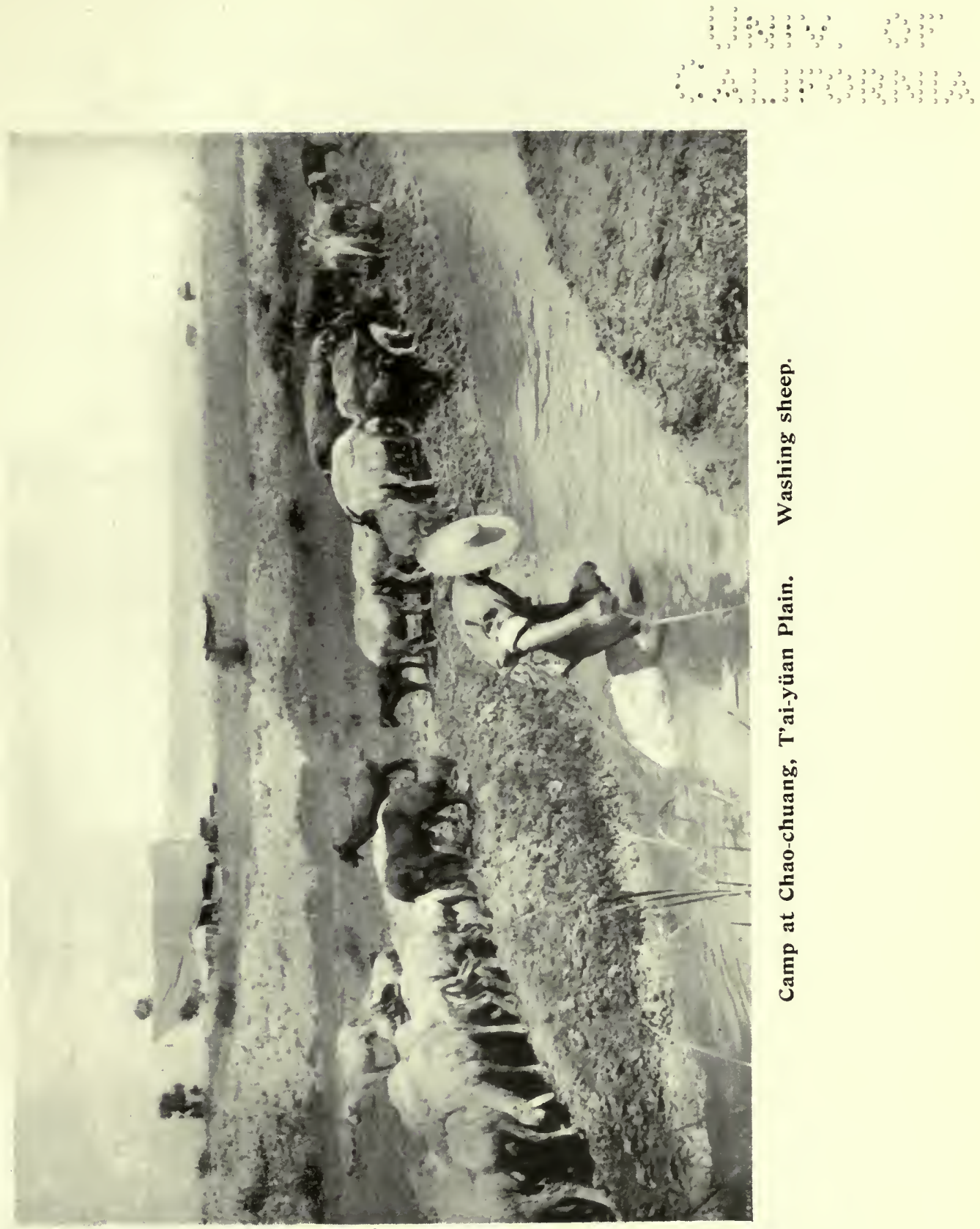


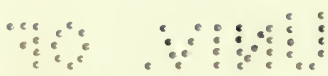

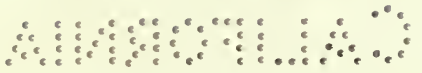


Tientsin) of the longitude of T'ai-yüan Fu. Major Davies, of the General Staff, a well-known Chinese explorer, very kindly undertook to perform the observations necessary at Tientsin, whilst everybody was kept busy at the T'ai-yüan end of the line on the nights of September gth and Ioth. The determination was entirely successful, and the longitude thus obtainedtogether with the latitudes already taken-were reduced to the Hsin-an Men (the Eastern Gate of the Southern Wall of the city), the position of which was found to be : longitude, $112^{\circ}-33^{\circ}-55^{\prime \prime} .73 \mathrm{E}$., and latitude, $37^{\circ}-5 \mathrm{r}^{\prime}-36^{\prime \prime} .3 \mathrm{~N}$.

After this, final preparations for an early start westward were pushed on with all speed and completed by September 27 th. All stores were packed away in suitable cases, the surveying instruments carefully stowed, the photographic material arranged so as to be easily accessible, and each member of the party finally told off to his individual task.

The constitution of the expedition then at starting was as follows :-

$$
\begin{aligned}
& \text { Leader - - - - - R. S. Clark. } \\
& \text { Doctor and Meteorologist - - Captain H. E. M. Douglas, } \\
& \text { V.C., D.S.O., R.A.M.C. } \\
& \text { Artist - - - - - Haviland B. Cobb. } \\
& \text { Interpreter and General Manager G. A. Grant. } \\
& \text { Naturalist - - - - A. de C. Sowerby. } \\
& \text { Surveyor - - - - - Hazrat Ali. }
\end{aligned}
$$

Muhammad Husein, fifteen muleteers, three grooms, two survey coolies, eight personal servants, and Josephus, a young shikari, engaged for two months only ; making a total of thirty-six persons.

At the last moment it was found necessary to hire several extra pack animals, so that the expedition started with forty-four mules and five donkeys. There were besides eight ponies for the use of the Staff and two attendant grooms. 


\section{CHAPTER II. \\ NARRATIVE OF MARCH TO THE YELLOW RIVER.}

THE 28th of September broke fine and clear, and in the courtyard of the house which had sheltered the members of the expedition since the middle of July all was bustle and excitement. Outside, the street was crowded with mules, braying and kicking, their drivers busy roping up the last few loads. But by eleven o'clock the last load had been hoisted on to the last mule, and the long train, slowly working its way across the city, passed out through the Western gate to a stretch of level flats already bared of their rich crops of grain. It made a striking picture as it crossed the low-lying land between the muddy waters of the Fên Ho and the great dyke raised to shield the city from the summer floods. The pack-animals, each with his jangling bells, swinging tassels and waving pompons, were kept in single file by their drivers, who swore at them, cracked their whips, and seemed anxious generally to outrival the bellowing of their charges. The animals were all fresh, wellconditioned, and full of fight, and, though their spirits calmed down wonderfully after a few marches, always ready to give trouble.

It had been decided to make the first stage a very short one, so after fording the river without any mishap, we pitched our camp on the threshingfloor of a village named Nan-shih, about five miles west of T'ai-yuian Fu. This village was the home of our shikari, Josephus, and he and all his people did their best to make things comfortable for us. The loads were deposited in a field hard by, and the servants set to work with a will on pitching tents and erecting our cooking-stove, and although their good intentions were hampered by a lack of experience, everybody was comparatively snug and comfortable by nightfall. Two policemen had been sent by the Yang-wu-chü (Board of Foreign Affairs) "to protect the foreigners," and were set to guard the loads. These worthies, not relishing the task, hunted up the head-man of the village, and warning him that he would be held responsible in case of theft, ordered him to send someone to watch the things. This proved to be a very sound and sensible arrangement, and the practice was adhered to throughout the whole expedition. The servants, as was to be expected, found the greatest difficulty in preparing food; but as they gained in experience, and got at home in the new conditions, our meals became soon quite appetizing. There were five tents in all, of which two were occupied by the Staff, one by 
PLATE 4.
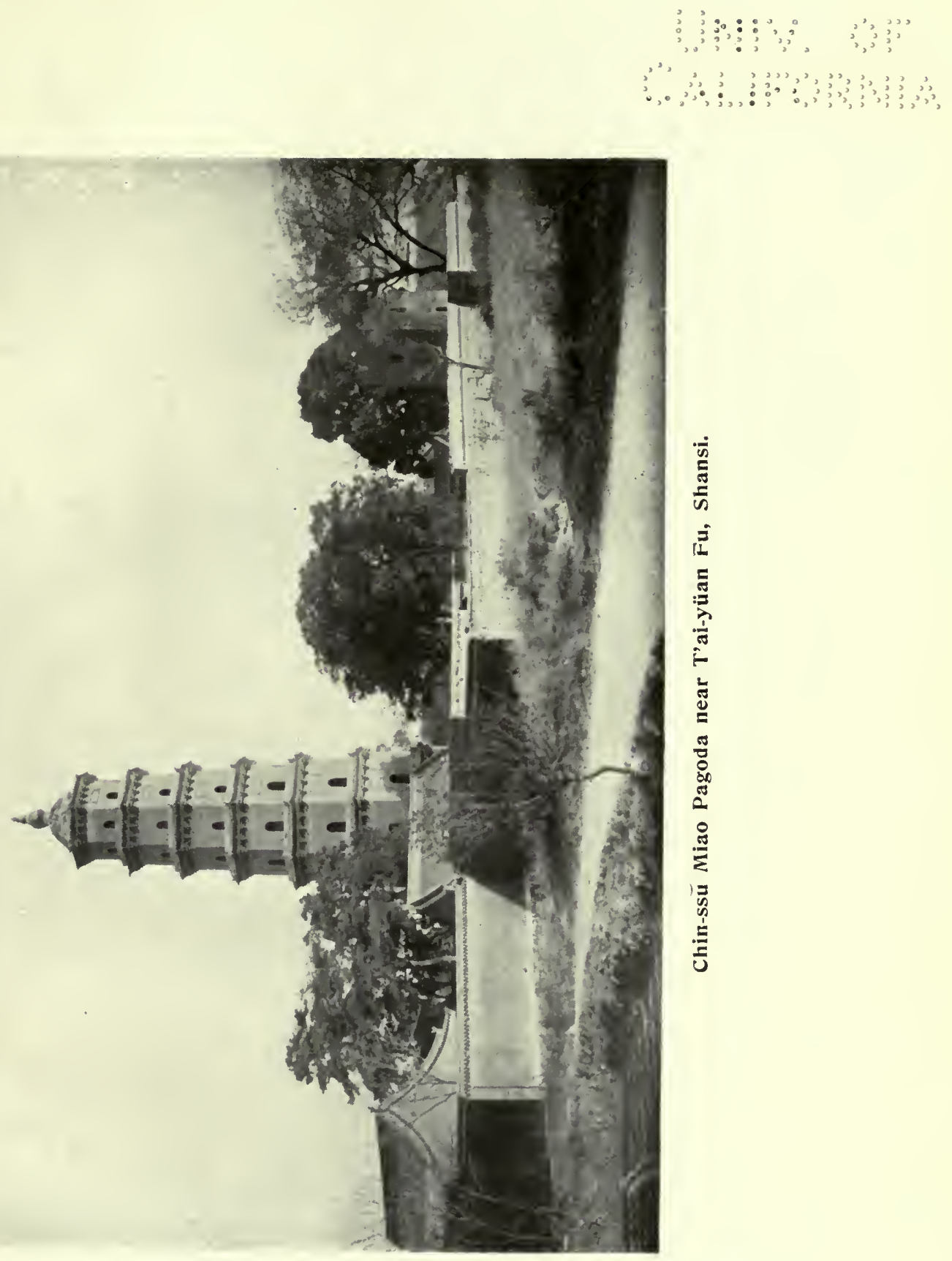


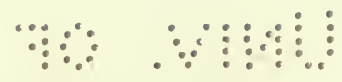

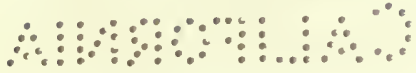


Hazrat Ali and his compatriot, and the remaining two by the personal servants. The muleteers and grooms found quarters for themselves and their animals in the village, and, during the time that tents were used, campinggrounds were always chosen to be within easy reach of some suitable village.

On September 29th an early start was made. Just before camp was struck we received a farewell visit from Mr. and Mrs. McCoy, who, with Miss Sowerby, had ridden over from T'ai-yüan $\mathrm{Fu}$ to see the last of the expedition.

For the first five miles our road gradually ascended the dry boulder-strewn bed of a mountain stream. It then entered a deep, narrow gorge, and up this we travelled for several miles, and after a sharp ascent reached the village of Hsieh-tao-ts'un. From this point we obtained a last view of T'ai-yuian as it lay in the plain, a thousand feet below us, with its gate-towers and sweeping city walls.

From Hsieh-tao to Shêng-yi, where camp was pitched, the road lay along the tops of shale ridges; in places it was very rough, but no great difficulty was experienced by the sure-footed mules. The country along this part of the road was wild and covered with scrub, whilst the slopes surrounding Shêng-yi were clothed in conifers. This district is full of small game and wild pig, and in consequence is frequently visited by residents of $T$ 'ai-yüan $\mathrm{Fu}$ during the shooting season. The natives we found to be very poor, sufficient crops to last them through the winter being raised only with the greatest difficulty. Several coal mines were noticed near Hsieh-tao; but the low price of coal in T'ai-yüan affords the miner but a poor return for his labour. The coal, after being carried for fifteen miles on mules, is delivered to the consumer at the rate of two and a half cash per catty, which works out at about eight shillings a ton.

From the figures recorded on the road-wheel, Shêng-yi was estimated to be sixteen miles from T'ai-yuian $\mathrm{Fu}$, and almost due west of it. On September 30 th the caravan left Shêng-yi, and continued its route over the mountains, still in a westerly direction, patches of scrub, pine spinneys and small spaces of cultivated ground being met with. By climbing a peak to the left of the bridle-path, which served as a road, an extended view of the surrounding country could be obtained. Ahead of us some eighty miles towered the Chiao-ch'êng Shan, and so clear was the air that in every direction the peaks stood out sharply defined, as though viewed through some powerful telescope.

Throughout the march a sharp look-out for game was kept by the more enthusiastic sportsmen of the party. Clark and Grant found abundance of 
subjects for their cameras; the naturalist busied himself in the pursuit of chipmunks through the ravines; and from time to time Hazrat Ali and his coolies could be seen hard at work in country which, for the purposes of the surveyor, it would be hard to beat.

After reaching an altitude of well over 5000 feet, we commenced to descend; at first gradually, but after some distance the end of the ridge was reached, and the road fell away sharply as the valley of the Fên Ho came in sight. At about four o'clock we entered Ku-chao, a large village situated on the right bank of the river, and some thirteen miles from Shêng-yi. It may be noted that the river runs from $\mathrm{Ku}$.chao in a south-easterly direction, but then taking a turn enters the plain fifteen miles north-west of T'ai-yüan $F_{u}$ and, having fallen 300 feet since leaving Ku-chao, flows past that city in a southerly course, thus forming two sides of a triangle, along the base of which we had travelled. The population of Ku-chao was estimated at five hundred, including women and children. A peculiar square-built tower, rising above the rest of the buildings, was found to mark the house of a local magnate. Several other small villages could be seen scattered along the valley in both directions. We halted at this place for a day to afford the servants an opportunity of getting things straight, for, unaccustomed to this nomadic life, they had allowed our commissariat to get in a terrible state of muddle.

On the following day, October Ist, the journey was continued still in a westerly direction. At a spot about a mile from Ku-chao the Fên Ho, coming from the north-west, changes direction as a large affluent joins it from the west, and up this latter lay our road to the Chiao-ch'êng Shan, so that the caravan had perforce to quit the bed of the main stream. The road was good all the way to Tsa-k'ou, where we pitched camp. During the day we passed some nine small villages, with an average population of from a hundred to a hundred and fifty. In one was a little Roman Catholic church, and all the villagers appeared to be converts. The valley varied in width from one to four furlongs, and though boulder-strewn or sandy in places, contained occasional cultivated fields. The hills on either side were covered with the usual loess terraces, bearing rich crops of millet, buckwheat, castor-oil, and potatoes, and the natives were busy harvesting after a very good season.

On October 3rd our march was resumed up the valley, the sides of which were now lined with lofty. straight-boled poplars. The road soon became very rough, and began to ascend sharply, until at last a high pass was reached at a height of over 6000 feet. The descent from here into the bed of a second wide stream, running from south to north, and consequently at right 
PLATE 5.
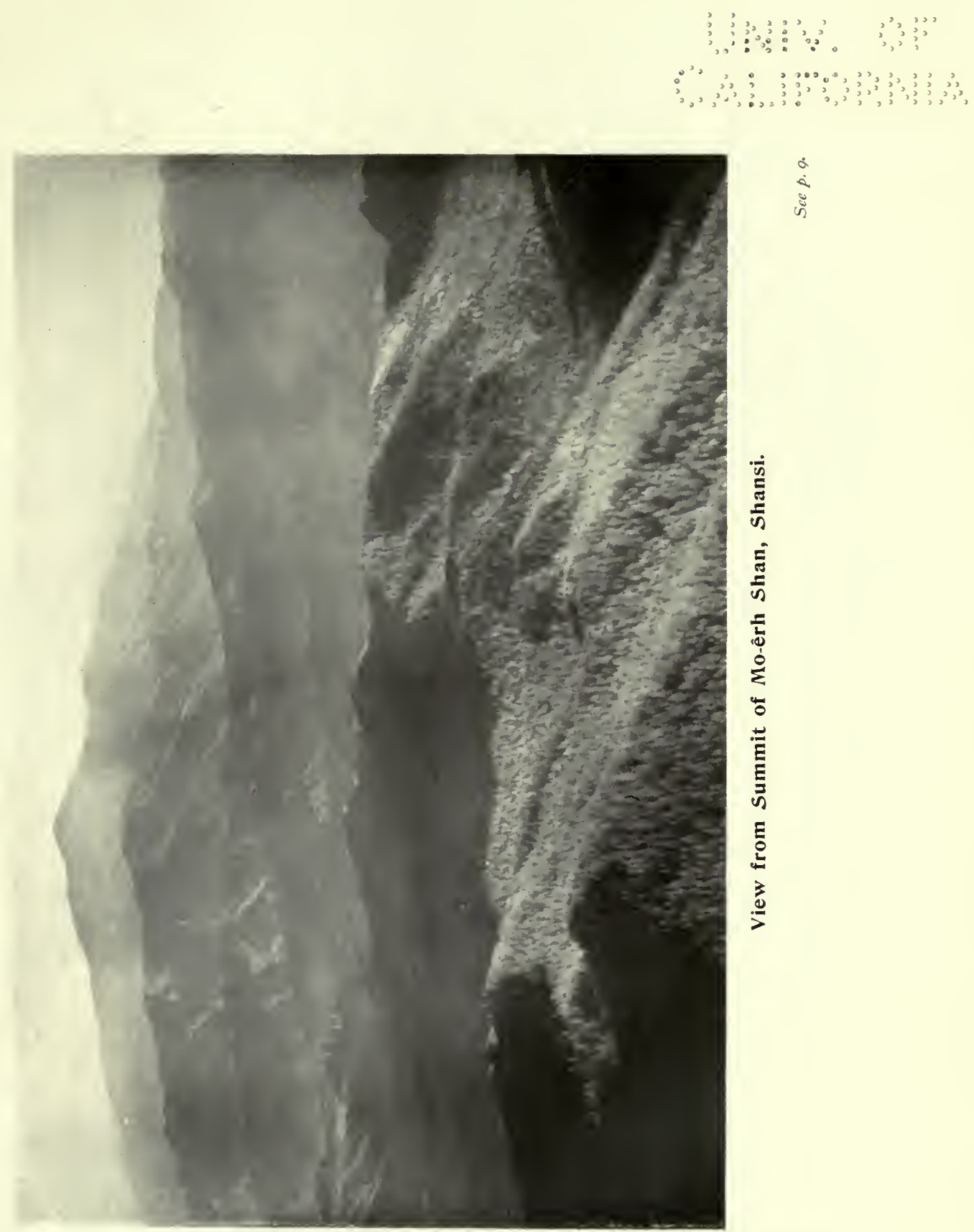

$\dot{a}$
$\dot{\Xi}$
के

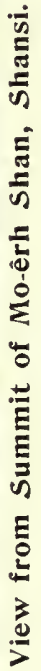


"

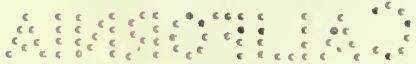


angles to that just quitted, was very steep and rough, but it was negotiated without mishap. Mi-yüeh-ch'êng, distant from Tsa-k'ou about nineteen miles, was reached in the afternoon, and we encamped in a grassy field close to the village.

From Mi-yüeh-ch'êng the road ran southward up the valley, the country becoming wilder and the mountains higher with each succeeding mile, until at last the valley narrowing and changing direction we began to ascend, westwards again, to another high pass. Here an altitude of nearly 8000 feet was attained, lofty forest-clad peaks rising still higher to right and left. A descent of about rooo feet brought us into the Mo-an valley, and a camping-ground was chosen in a sheltered ravine at the foot of a mountain named Yün-t'ing Shan ("Cloud-roof Mountain "). No village was passed during this day's march ; only here and there a cluster of two or three huts, and the muleteers were forced to go on down the valley for about five miles to a village, where they could stable their mules. The grooms, however, managed to find sufficient accommodation for the ponies in the cattle-sheds of a tiny hamlet across the valley, near the camp.

The ravine chosen for the camp was comparatively wide, and opened towards the north, so that astronomical observations could be made comfortably. Towards the south it soon narrowed, ascending rapidly at the same time until lost in the forest-clad slopes of Yün-t'ing Shan. The ridge to which this mountain belongs runs east and west, commencing with a series of peaks, heavily covered with forests of larch and fir, and diminishing in size till they merge into the shale and loess foothills, and terminating in the supreme grey granite crest of Mo-êrh Shan. From its base again branch out several lower ridges, of which the largest, curving towards the south, splits into a number of sharp peaks. As a rule, the slopes facing north are clothed in dense forests of pine, spruce, larch, and birch, interspersed with patches of impenetrable hazel scrub, whilst the slopes facing south are grassy, or covered with low herbaceous growth. The forests commence at about 7500 feet, and extend to the summits of the ridges. At the season of our visit the larch's autumn foliage of bright gold and the coppery tints of the hazel stood out in striking contrast to the deep blue-green of spruce and pine.

A trip was made during our stay in camp to the summit of Mo-èrh Shan for the purpose of taking a round of angles to check the plane-table work. From this point the panorama that stretched itself before us was magnificent in the extreme. In every direction winding valleys threaded by sparkling streams; granite crests and rugged scaurs, all ablaze with colour; and, as a 
background, the more distant ranges shading away, wave upon wave, in every tone, from mauve to deepest blue. Eastward, beyond the T'ai-yuian valley, the Lung-wang Shan were plainly discernible, flanked to north and south by ranges marshalled in complex and bewildering formation. Only to the northwest was the horizon flat, indicating the wastes of the great Ordos desert. To the west, ridge upon ridge of rounded loess hills, broken only by the three lonely peaks of the Ch'ing-ting Shan. It is no exaggeration to say that our view extended for over a hundred miles in every direction, except perhaps the south-a scene indeed not easy to match in either the Old World or the New.

The expedition remained in this neighbourhood for nearly a fortnight. Deer were reported plentiful, and several hunting trips were organized, but without any very remarkable success, though hare, pheasant and partridge were frequently bagged. Sowerby, however, was more successful on a miniature scale, and managed to secure a good collection of mice and voles. The vegetation of the district is luxuriant, and comprises not only the forest trees and hazel already mentioned, but herbaceous. trees and shrubs in countless variety. The natives, though poor, are healthy-looking; the men stalwart and well-built, the women decidedly better looking than those in and around T'ai-yüan Fu. However, goitre seems not uncommon, and we noticed many cases of sore eyes, the result, no doubt, of smoky wood fires. The cultivation of oats and potatoes-the only crops that will ripen at such an altitude-affords a meagre source of livelihood. The cutting and hauling of timber, though supplying fuel and building material for the rude huts, are useless for trade purposes, no easy means of transport existing, such as the Fên Ho provides to the people of the Ning-wu district further north. During the winter months musk-hunters visit the district, and medicine-hunters from Ssūch'uan prosecute their search for genseng and other roots at all times of the year. Roman Catholic missionaries have penetrated these mountains and made many converts, who abjure the smoking of opium. One or other of the Fathers from T'ai-yuan Fu visits the district twice yearly. In I90o, during the. Boxer troubles, Yü-hsien, the Governor of T'ai-yüan, sent troops to execute the converts; but the people, most of whom own a firearm of some sort, and are of a sporting turn, rose at once, and chasing the soldiers over the mountains killed them almost to a man.

On its becoming known that one of the party was a doctor, the usual deputations begging for medicine invaded the camp. One and all received attention and a "cure" in some tangible form, even were this nothing more 

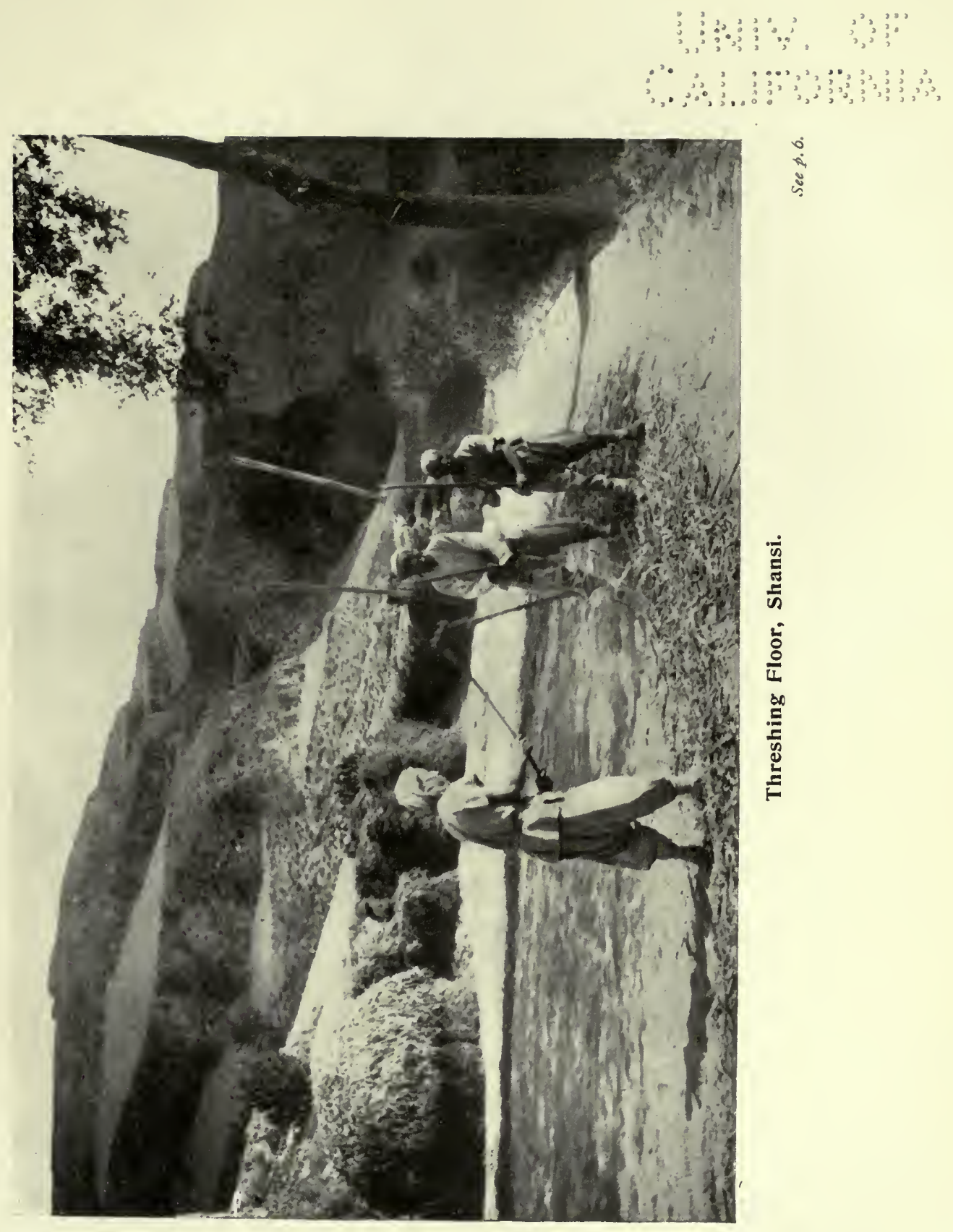


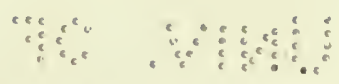

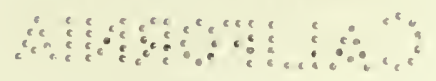


imposing than a reliable pill. The weather was now becoming very cold, and before the party left the neighbourhood a heavy fall of snow had draped the mountains in its thick white mantle. At last, on October r6th, camp was struck, and the caravan moved slowly down the valley, winding from side to side like some monstrous serpent. Several large villages were passed, and word having gone ahead, the inhabitants turned out en masse and stood in groups, mouths agape and eyes wide open, to stare at our procession. We felt gratified at the thought that they evidently regarded us as some sort of travelling circus. After the first two or three miles of rough and rocky going, the valley opened to a width of about a quarter of a mile, and the path became less uneven, sloping gently to the west. Soon the high ridges and wooded slopes were left behind, and we found ourselves once more amidst the shale and loess. Camp was pitched at Ma-fêng, a village situated at an altitude of about 4500 feet, and some ten miles from Yün-t'ing Shan. The inhabitants, about three hundred in number, took the greatest interest in our proceedings, crowding eagerly round the camp. This was natural enough, as the only Europeans they had seen before were Roman Catholic missionaries, who adopt the native style of dress. The explorers, with upturned moustaches, outlandish clothes, leather saddles, and countless strange accoutrements, were indeed something to see, and will probably afford a subject of conversation for many years to come.

That night our larder was raided by a wolf. He got away safe, and no doubt satisfied, for the servants thought it necessary to send to the village for Josephus and his gun, though several members of the party would have been only too happy to exchange their chances of sleep for a shot at the robber.

On October 17 th the journey was continued down the valley, which here bends to the south, and Fêng-hsiang-ch'êng, a village of some size, was reached. From Ma-fêng to this point, a distance of about eight miles, and on to Yung-ning Chou, a good cart-road exists, though no carts were met with. Just beyond Fêng-hsiang we turned up into the loess hills to the west. Our road ascending gradually, and becoming more and more rough as the loess gave place to shale, finally reached the head of the pass, at a height of about 5300 feet. From here the valley of the Yellow River was distinctly visible. Descending slopes, covered with scrub-oak and hazel, into a deep and narrow ravine called Sung-chia-k'ou, we passed three tiny hamlets, and pitched our tents in a ploughed field lying between a towering cliff and a sheer drop of about fifty feet. This latter bid fair to become a death-trap to many of the mules, rampaging madly round after being relieved of their loads. At this 
place it was found necessary to get rid of the head-groom. He was found to have been habitually under-feeding the ponies and bullying his subordinates, and was dismissed on the spot. From his departure there was a very marked improvement in the condition and spirit of the animals; some which, till now, had seemed lazy and unwilling, developing a liveliness which made it imperative to ransack our stores for curb-bits. The altitude of this camp was estimated at about 3900 feet, and its distance from the last halt about seventeen miles.

The following day after continuing down the ravine for another ten or twelve miles, we arrived at the walled town of Lin Hsien, situated on the slope of a broad valley. Just before we quitted the ravine, a fine golden eagle was shot whilst feeding on the body of an infant child by the roadway. Such a sight is by no means uncommon in a country where the people refuse to bury dead babies under the curious belief that if eaten by a wild animal the child is born again to its original parents. On hearing of our approach, scores of men, women, and children, poured forth from the town gates. They flocked round the camp, and were only kept from entering our tents with the very greatest difficulty. The gentleman acting as deputy in the absence of the Hsien magistrate certainly did his best to make things comfortable for us, but he had no real authority over the crowds that surrounded the camp. The party entertained him, however, together with a native Roman Catholic evangelist at dinner the same evening, and they seemed to appreciate the meal. We had another visit that night, this time from three wolves; however they contented themselves with a serenade. Sowerby went after them, but the moonlight was insufficient to afford any chance of a shot.

Lin Hsien, a well built town, surrounded by a wall in an unusually good state of preservation, contains a population of about 3000. The Roman Catholics have established here a Mission station, where a priest resides. The place owes its prosperity mainly to the fact that it forms the mart and distributing centre for a large stretch of country. Situated, as already stated, on the western slope of a broad valley, running north and south, a part of its wall ascends and encloses the crest of the hill overlooking the main portion of the town. This is a means of protection very frequently employed in a land where towns and cities are perforce built under high cliffs and hills. In the river bed to the eastern side of the town a strong dyke of massive stone blocks has been constructed to withstand the fierce attack of mountain torrents. These sweeping down the valley in the rainy season, unbroken sheets of water eight or ten feet deep, and filling it from side to side, would very quickly 
PLATE 7.
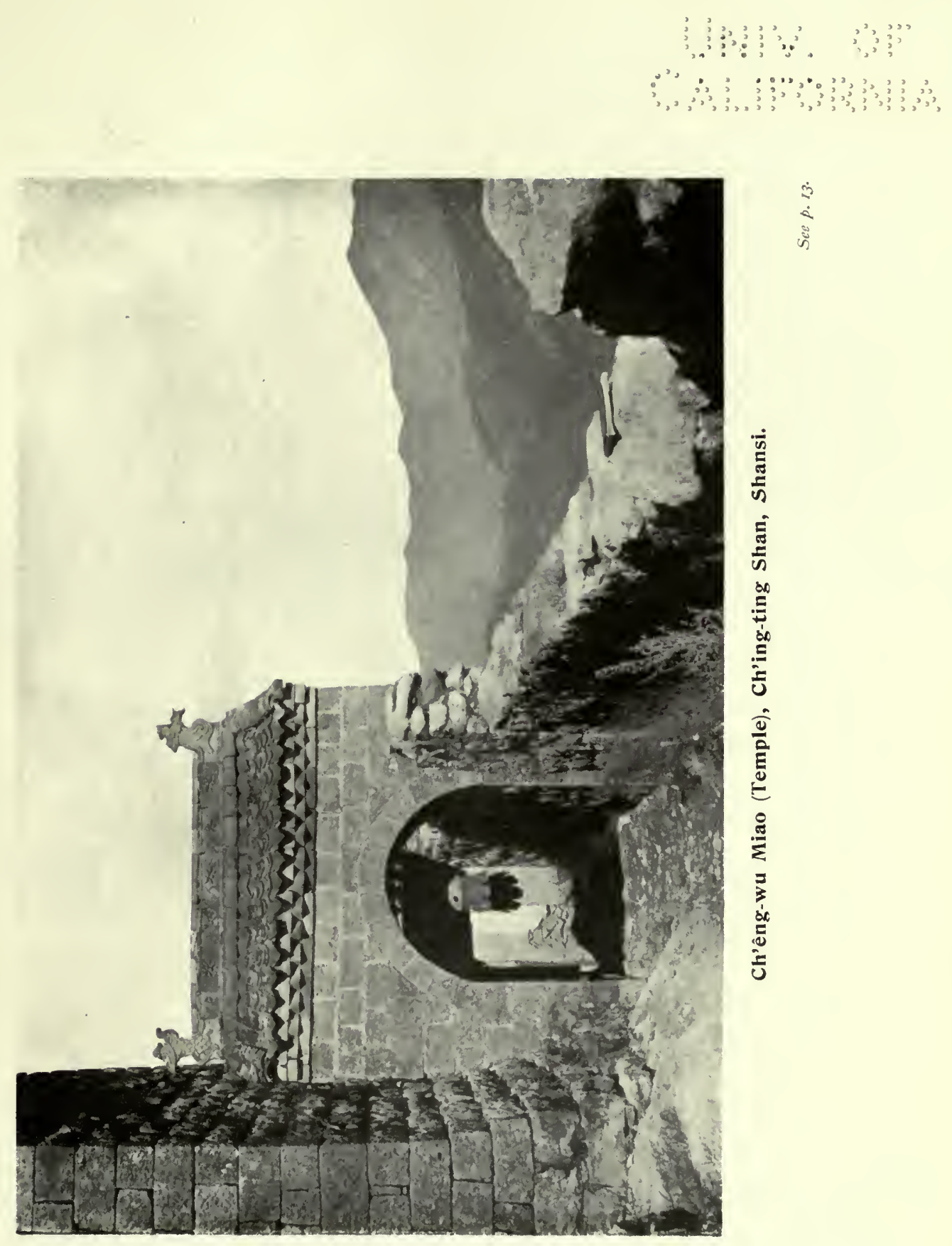


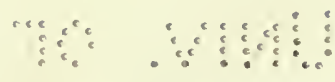

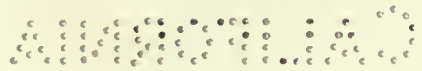


undermine the walls, were it not for the protection given by the dyke, which stretches the whole length of the wall, and incidentally forms an excellent esplanade.

Next day camp was struck, and our march resumed. For the first three miles the road lay in a northerly direction up the valley, and then entered a ravine on the west. The rest of the day's journey was up this ravine, which, commencing of some width, where it meets the Lin Hsien valley, gradually dwindles to a chasm in the loess. At Kan-tsao-k'ou, where a suitable camping ground was found, it again widens out, and divides up into several branches, which run up into and drain the eastern slopes of the Ch'ing-ting Shan about two miles distant. Kan-tsao-k'ou means literally "dry grass pass"the name being applied equally to ravine and village. This nomenclature is almost invariably adopted where a village lies near the head of a long ravine. For example, Sung-chia-k'ou (literally "the pass of the Sung family") was the name applied not only to the ravine where the expedition passed the night of October 1 7th, but also to the village just above that camp.

From Kan-tsao-k'ou it was decided to make a trip to the summit of one of the Ch'ing-ting Shan peaks, to estimate the altitude, latitude, and longitude, and also to secure a round of angles to check the plane-table work. As this would necessitate a halt of a few days duration, Cobb and Sowerby decided to go on in advance of the main body. The former was anxious to get to Yü-lin $\mathrm{Fu}$ that he might set up a temporary studio, and fix his impressions on canvas; the latter to make a collection of the desert fauna before the cold weather definitely set in. Marching from Kan-tsao-k'ou with their baggage and the mules necessary on October 2Ist, these two gentlemen reached Yü-lin Fu six days later without adventure. They found quarters first at an inn inside the town, and afterwards in a fine temple, San-yeh Miao, outside the south gate.

Meanwhile at Kan-tsao-k'ou we had been obliged to postpone our ascent of the mountain for several days owing to heavy rains; but on October 24th, after a stiff climb, the temple of Ch'êng-wu Miao was reached. This is a building curiously like a mediæval fortress. No observations were possible that night owing to cloud and mist ; but next day was clear and sunny, and a fine view was obtained. This isolated upland covers an area of not more than twenty-five square miles, and protrudes in a peculiar manner above the surrounding loess, of which the whole neighbourhood on three sides, save one low range across the Yellow River, is formed. This gives the scenery a very curious and distinctive character; the country with its hummocks and water 
courses resembling nothing so much as a Titanic crumple of brown paper. Eastward, the hills are more rocky, and gradually increasing in height fade away into the blue and lofty peaks of the Chiao-ch'êng Shan.

We returned to camp on October 26th, and the following day resumed our march to the Yellow River. A high pass, about 5400 feet, between two of the peaks of the Ch'ing-ting Shan, was easily negotiated, the ascent being neither rough norsteep. An equally easy descent brought us into yet another deep ravine, along which our route was continued till Ts'ai-chia-wei, a village of about 300 inhabitants, was reached. The first five miles of this march had lain through limestone and shale, which then gave place entirely to loess, cut and hollowed by many rains into the most fantastic shapes: weird grottoes, deep chasms, narrow ridges, and isolated columns.

On October 28th, after leaving this village and following the ravine for about ten miles, we ascended about rooo feet, and kept along the top of a winding ridge, terminated by the steep descent to the bed of the Huang Ho, facing the little village of Huang-ho-yeh. The altitude here was estimated at 2400 feet. As it was found impossible to cross the river that night, camp was pitched on the eastern bank.

The slope behind the village opposite being very steep, it had been found necessary to build platforms for the houses. These were constructed in the form of rows of Roman arches, with the result that the whole village had the appearance of the ancient Roman ruins so common in Italy, In fact $\mathrm{Mr}$. Cobb, the artist of the party, has declared that the hills and general scenery of Western Shansi recall in a most striking manner the clear and sunny atmosphere of the Apennines. These vaulted platforms, supporting similarly vaulted houses, are characteristic of the villages along the banks of the Yellow River, in this district. They are also found in other parts of Shansi and Shensi, but nowhere so frequently as here.

A good idea of the formation of the sedimentary rock, which extends - through a large part of Western Shansi and over the whole of Shensi north of the Hsi-an Fu plain, was obtained at this spot. The Yellow River having cut deeply into this bed, a section some five hundred feet deep is exposed. Nowhere were any faults noticed, though the strata were found to be in places slightly undulating.

The general conformation of the country between the Fên Ho and the Yellow River may now be considered briefly. The most striking feature is, of course, the range of high mountains, which, commencing near Ning-wu Fu, about one hundred miles north-west of T'ai-yüan $\mathrm{Fu}$, and stretching south- 
PLATE 8.

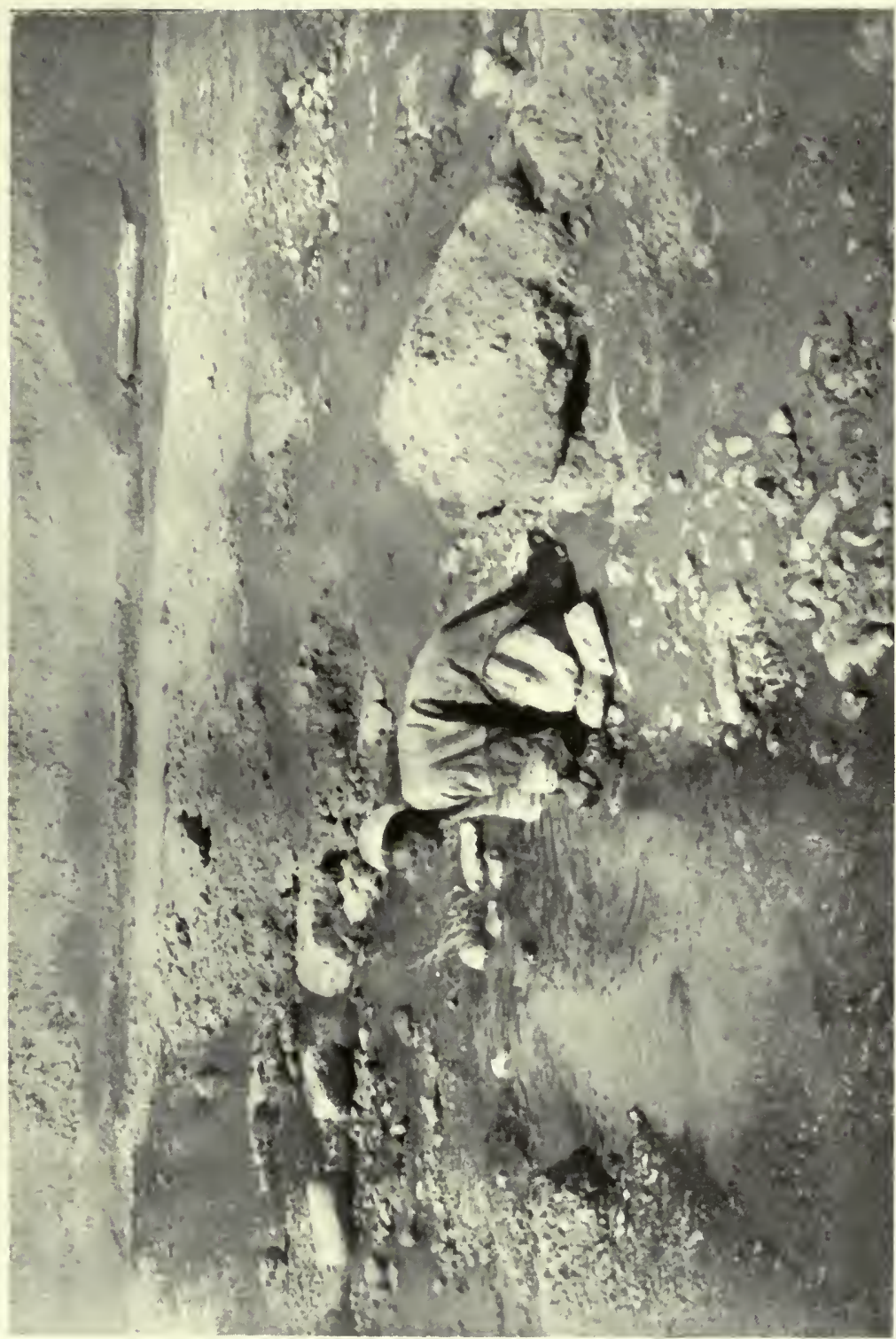

ह

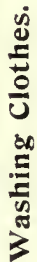




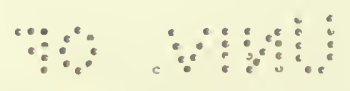

$\therefore$ 
ward in a more or less unbroken line beyond Fên-chou $\mathrm{Fu}$, a large city about seventy miles to the south-west, forms the watershed between the two rivers, Fên and Huang. The average height of this chain is between 7000 and 8000 feet, but here and there great peaks like Mo-êrh Shan rise to a far greater altitude. These are usually of granite, or some similar crystalline rock, probably of an intrusive nature. On the eastern side of this divide numerous ravines running together form valleys, which vary in width from one to four furlongs, and extend in a more or less easterly direction. Those near the source of the Fên Ho in the Ning-wu district run south-south-east, and are succeeded a few miles further down the course of the river by others running south-east, whilst in the country west of T'ai-yüan $\mathrm{Fu}$ the valleys run almost due east. West of the divide there are fewer large valleys, but these are broader and run more nearly north and south between ridges of shale and loess. They are joined on either side by numerous gorges, which cut down through the strata to a considerable depth. The broad valleys join the bed of the Yellow River some distance southwards. It was noticed that the country east of the divide was much rougher and more irregular than that on the west, whilst the hills were uniformly higher and more pointed. Reference has been made already to the peculiar isolated peaks of Ch'ing-ting Shan. West of these the ravines all had a south-westerly direction, opening finally into the bed of the Huang Ho. 


\section{CHAPTER III.}

\section{PASSAGE OF THE YELLOW RIVER-MARCH TO YÜ-LIN FU.}

ON October 29th we proceeded to cross the river, an undertaking which required some little management owing to the recent heavy rains. Several large ferry-boats were brought over from Huang-ho-yeh, and into these the mules and baggage were all bundled without further ceremony; though anyone who knows the Chinese boatman, and the Chinese muleteer and mule, will realise that the operations were conducted without any very elaborate regard to silence. Each ferry-boat was divided into three compartments, of which two were occupied by the animals, and the third by their loads. The crossing-effected by keeping the nose of the boat pointed at an angle up and across the stream-was a perilous undertaking. As each of the unwieldy craft approached the western shore it was caught in a swirling eddy, and seemed. bound to capsize, but at this juncture, the ferrymen, bending vigorously to their oars, forced it slowly to the land. These oars are effective but very primitive in pattern, usually split tree-trunks, one end pared down to form a handle, and each is manned by two or three men. The mules showed no reluctance to leave the ferry-boats, which, by the end of a passage, contained several inches of water. It took five hours to get the whole caravan across, and we were fortunate in that no losses were sustained. The current was running like a mill-race, and, had one of the oars broken under the strain to which it was subjected, the result would have been disaster.

At last, when all had been landed safely, the pack-train, preceded by the Staff on their ponies, entered the mouth of a deep gorge leading westward. The walls of this cañon rose sheer for over a hundred feet and the floor was very rough, strewn with boulders and square masses of rock. A comparatively large stream flowed through the cañon, and the strata, which were of sandstone, exhibited surfaces honeycombed in a peculiar manner. The remains of a well-paved road were in places recognisable, and seemed to suggest that this had been at one time an important highway. For some distance the cañon continued rugged and bare, but at one place, where it narrowed, a small stone fort guarded the passage. At last the loess began to show on the sides, and we noticed the first village, or sign of cultivation, since leaving Huang-ho-yeh. A steep ascent was made and camp was pitched near a village named 
PLATE 9.
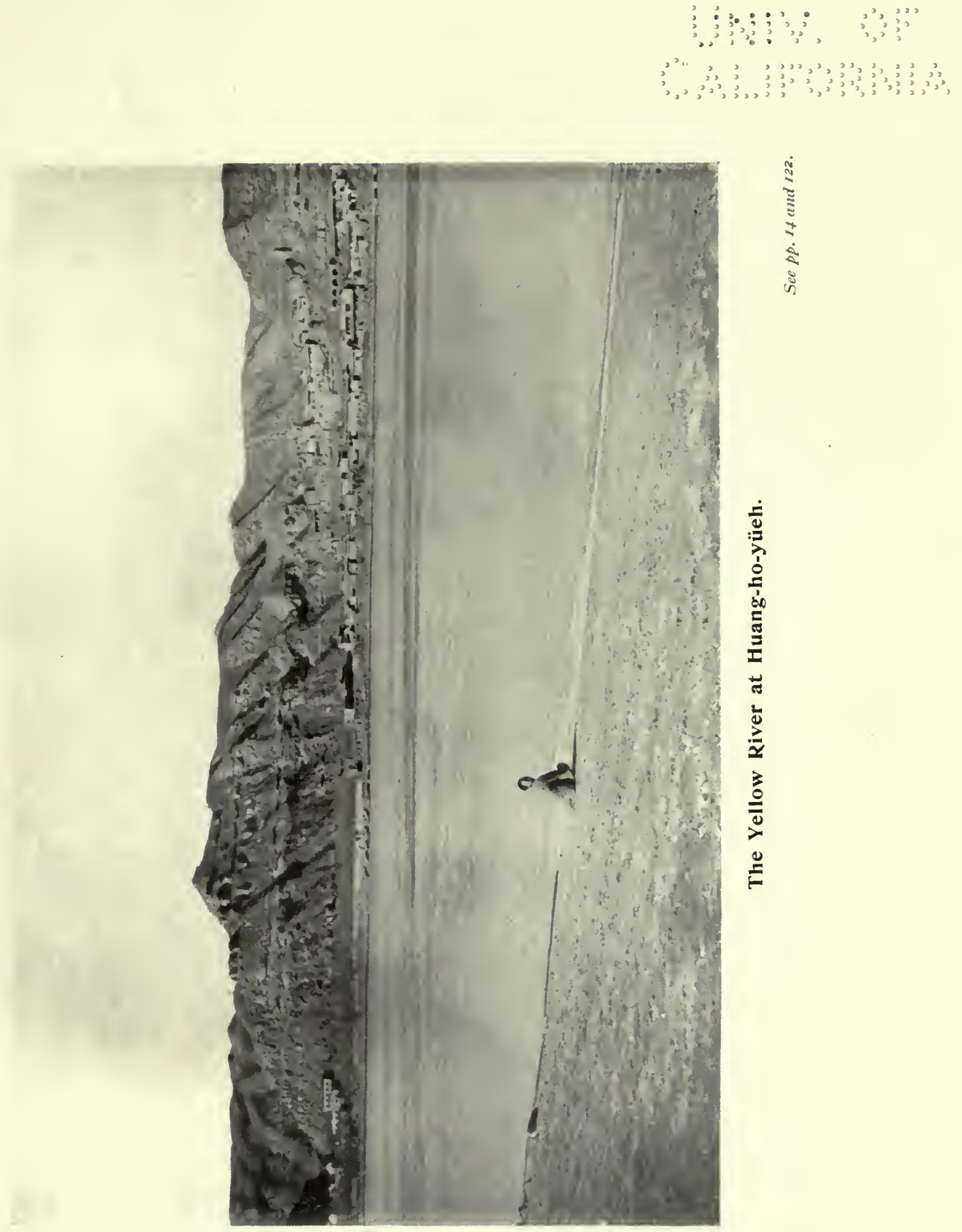

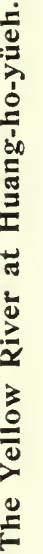




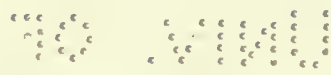

¿ 
Liu-chia-mo, some five and a half miles from Huang-ho-yeh and at an altitude of about 3100 feet. Sand from the desert, in small patches, was noticed here for the first time.

The following day, October $30 t h$, our road led first over a small plateau, from which it descended into the sandy valley of the Tui Ho. This river, though not large, flows swiftly down a channel which it has worn out of the rock, leaving the greater part of the valley to the wind-borne sand, drifted doubtless from the Ordos. After crossing the Tui Ho near a small village, the road ascends another rough ravine. For the rest of the day's march no villages and but very little cultivation were seen; the country was growing steadily wilder and more desolate, desert sand was noticed, and the loess itself was composed of larger particles of silica. The ravines and gorges were found to shelter large coveys of red-legged partridges, many of which were bagged for the pot. We reached camp rather late. This had already been pitched by the now expert servants at Chin-chia-k'ou, a village some seventeen miles from Liu-chia-mo. The weather was becoming a trifle too cold for tents; the stoves leaked abominably, and no fuel but a very smoky bituminous coal was obtainable. The minimum temperature at Chin-chia-k'ou was $23^{\circ} 5$ Fah., which gives sufficient indication of our experience. The altitude worked out to about 3400 feet.

Next day a march of five miles brought us to Chiu-ts'ai, a hamlet on a stream called Chia-lu. This lies slightly lower than our last camp, but the going was very bad, the road being mainly across an isolated belt of sand-the first really definite sign of the great Ordos Desert towards which the expedition was gradually working.

On November Ist the journey was up a broad valley, varying in width from a quarter to half a mile. A good road extended all the way. Sand in patches was frequently seen, and it was also observed on the coarse-grained loess forming the sides of the valley. Two tiny hamlets were the only signs of habitation noticed; but camels loaded with soda, and donkeys bearing coal and salt were encountered, giving some idea of the products of the neighbourhood. After a march of about nine miles we halted at Yang-chia-tien, where quarters were secured in a large Buddhist temple. Of this the priest seemed rather the landlord than an officiating minister; however, to show his piety, he had instituted religious processions, in which apparently all the ragamuffins of the locality took part twice daily. The impossibility of serving God and Mammon holds as little real place in Chinese ethics as perhaps in those of some other nations. So comfortable were the quarters that we were loath to 
hurry, and it was decided to spend a day in idleness. This fact was turned to account by the sick and ailing, who came to Captain Douglas with their troubles. A good many proved to be malades imaginaires, and were treated to Livingston Rousers, which the experienced Army Surgeon declares of the highest efficacy in this class of case. Several of the native servants were noticed during the day sitting in the sun with their coats off, conducting exhaustive investigations into the probable cause, or causes, of a personal discomfort from which they had for some time suffered. It may be mentioned in this connection that the Staff of the expedition had recently found it advisable to make their own beds.

On November 3 rd the march was continued up the valley for about two miles, and then up a narrower gully for three more; the latter portion running along an overhanging path but a few feet wide. Then, a loess divide being crossed, our tents were pitched near the small but well-built and prosperous village of Liu-chien-hua. It was estimated that at least one quarter of the terrain passed over that day was of loose sand. The cliffs and hills, too, were very sandy in their composition, and it was only on the highest and most wind-swept ridges that loose sand was not in evidence. Vegetation had been for some time very scarce, and the stunted trees were everywhere half buried in the sand. Nevertheless there was no sign of drought, for every ravine held its stream of fresh, if not always very clear, water. The salt, of which we had seen some fifty donkey-loads in the day, was for distribution amongst the villages on the Yellow River. The altitude of this camping-ground was estimated at 3500 feet.

Next morning, November 5 th, an early start was made with a view to covering the fifteen miles lying between us and Yü-lin Fu in good time. The road proved to be satisfactory almost the whole way, but the sand became markedly more abundant. The sides of the streams were no longer cliffs, but high banks of loose sand sloping sharply to the water's edge. At last Yü-lin was reached, and we gladly took up our quarters in the warm and comfortable accommodation provided by the hospitable officials of the city.

San-yeh Miao, a Buddhist temple of considerable dimensions, and admirably suited for the purpose, had been placed at our disposal. It comprised two large courts, one some ten feet higher than the other. Into the former opened several smaller courts, containing the living rooms which had been done up for our reception. The large upper room and side rooms of this court were devoted to images of Buddha with his attendant spirits; whilst the far end of the lower court was occupied by the usual theatre-stage. One 
PLATE 10.
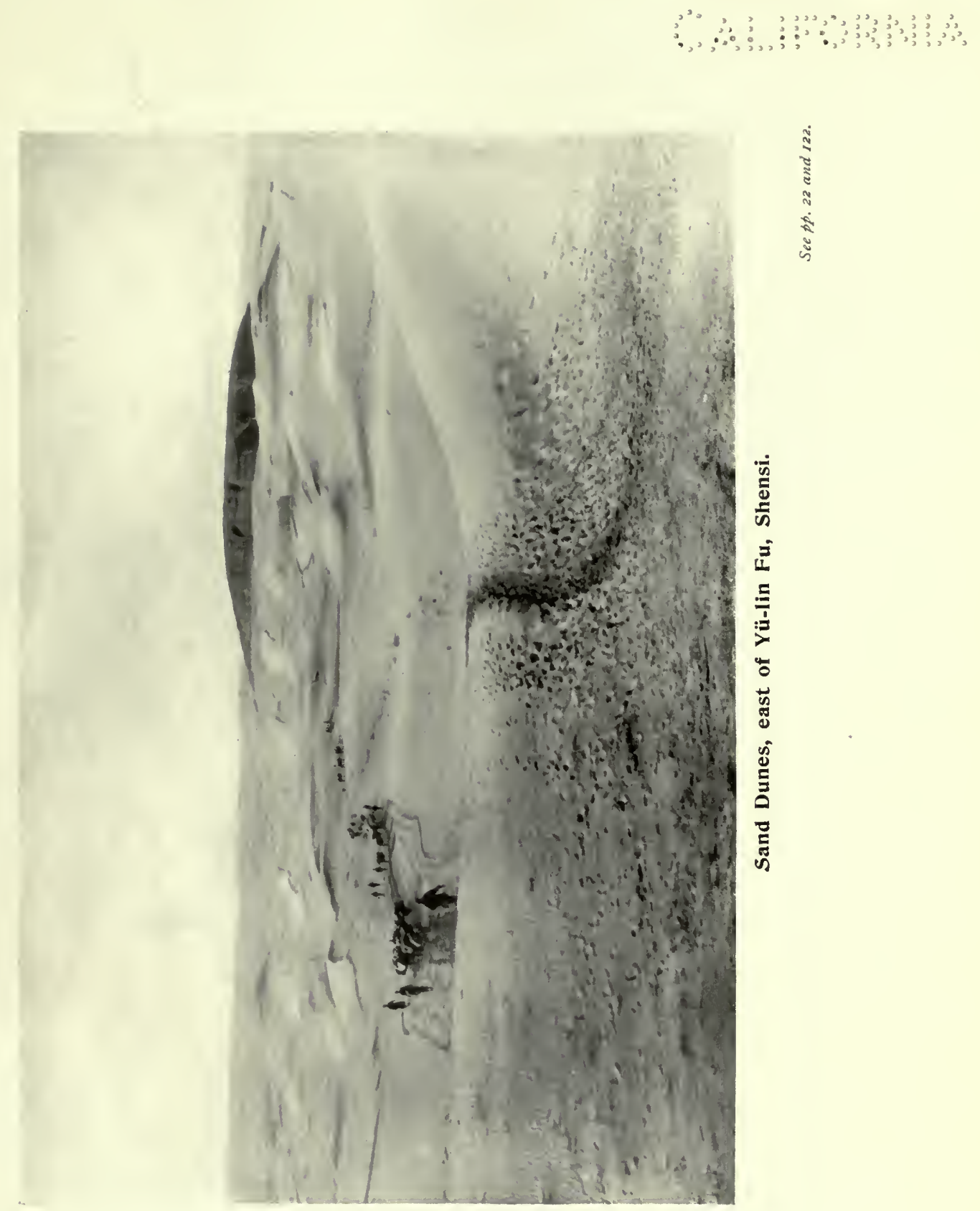


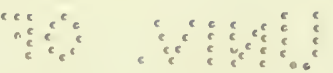

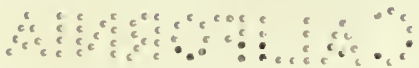


large room was set aside as our dining and general living room, adjoining which was a small sleeping chamber. This latter was converted into a darkroom, and Grant, who had a large number of plates to develope, had his bed set up in the living room. Clark and Sowerby found comfortable quarters in two cave rooms, and above was Cobb's studio, where he had his bed and a small stove. Douglas, preferring quiet and early hours, betook himself to a well-ventilated apartment adjoining the outer court, where it was only by a most lavish use of rugs and blankets that he survived the cold. It was decided to stay some time in $\mathrm{Yü}$-lin $\mathrm{Fu}$, as there was plenty to be done. A large number of exposed plates had accumulated since the commencement of the journey, and it was thought best to get these developed and packed away out of hand. Some time, too, was necessary for making the good collection of desert fauna, upon which the naturalist had set his heart; and, in addition, the surrounding district had to be investigated. It was also desirable to get a good set of astronomical observations, and considerable interest would attach to a series of meteorological data collected over a lengthy period.

Cobb and Sowerby had, at their arrival, called upon the Chih-hsien (District Magistrate), at whose residence they met several other local officials. They were kindly received, and, presenting their cards and that of Mr. Clark, explained the objects and work of the expedition. The mention of astronomical research seemed to awaken particular interest, and it transpired subsequently, through certain remarks made by the Chih-fu (Prefect), that these eminent public servants had jumped to the conclusion that Clark was a learned astrologer, and his failure to predict deaths in the Imperial Family, which occurred a few weeks later, was to them a source of the most grave disappointment. On his arrival, Mr. Clark, in turn, accompanied by Sowerby as interpreter, paid a round of visits to all the officials, who promptly returned the calls. One and all sent presents-sheep, chickens, eggs, and sweetmeats - to which Clark responded by taking their photographs and presenting them with copies, which were highly appreciated. Although long conversations were held with the Chih-fu and the Head of the Police, little of interest concerning the history of $\mathrm{Yu}$-lin $\mathrm{Fu}$ was obtained. The informants seemed as ignorant of the subject as their interrogators. The Head of the Police, Pi Jung-pei, was a particularly pleasant and agreeable old man, and he often called for a little chat, or when some official communication had to be made. The highest military official in Yü-lin Fu was the Brigadier-General, or Chent'ai ("Commander of One Thousand Men"), of whose force, however, 
some six hundred had existence on paper only. At the date of our visit he was suffering from chest trouble, and the severe effects of having to abandon the use of opium. For this reason he excused himself for not calling; but a professional visit from Douglas seemed to be much appreciated by the invalid.

Yü-lin Fu, an ancient border city on the eastern bank of the Yü-lin Ho, is a busy place, forming, as it does, the chief mart for all commerce between the Southern Ordos Mongols and the Shensi Chinese. On the eastern side, sand from the desert has in many places banked itself up in a ramp against the city wall, thus affording an easy means of entrance to belated travellers. The western wall runs along the valley of the Yü-lin Ho. There are numerous temples within the city, in one of which, situated on high ground at the eastern end, a fine spring rises and pours its waters into a stream which, flowing through the town, fills in turn some large ponds within the western wall. From these the water escapes through a low heavily-barred archway, and is utilised to irrigate a large tract of cultivated land lying between the river and the city. One long street runs north and south from gate to gate, and from this issue many side streets. The main street, lined as it is with shops and pedlars' stalls, presents a busy and interesting scene. Hides in great numbers lie pinned out to dry in the sun, whilst on all sides blacksmiths are busy turning out Mongol stoves, wolf-traps, household utensils and agricultural implements. Provisions, such as flour, vegetables, fowls, and mutton are very cheap. Excellent mutton may be bought at thirty-five cash per catty, or about a penny a pound; ten cabbages can be bought for the same sum. The chief commercial products of the city and district are horse and cow hides, the skins of antelopes, foxes, sheep, and goats, camel's wool, and various sorts of hair and wool, both unmanufactured and in the form of felt and sacking. We obtained some very serviceable felt socks, made to fit over the boot, whilst the servants and muleteers laid in an ample stock of the strong native boots, for the manufacture of which the city is famous. A bituminous coal, which burns well, though with too much smoke, is obtained from a mine about a mile from the south gate. Outside the same gate several horse fairs are held annually, to which Mongols from every part of the Ordos bring their ponies, shaggy and unbroken, for sale or barter. One of these fairs took place during our stay, and an opportunity was thus afforded us of seeing some of these typical desert-dwellers.

Just within the Great Wall, and about three miles north of the city, stands a large fort built originally to guard the entrance, through which runs the 


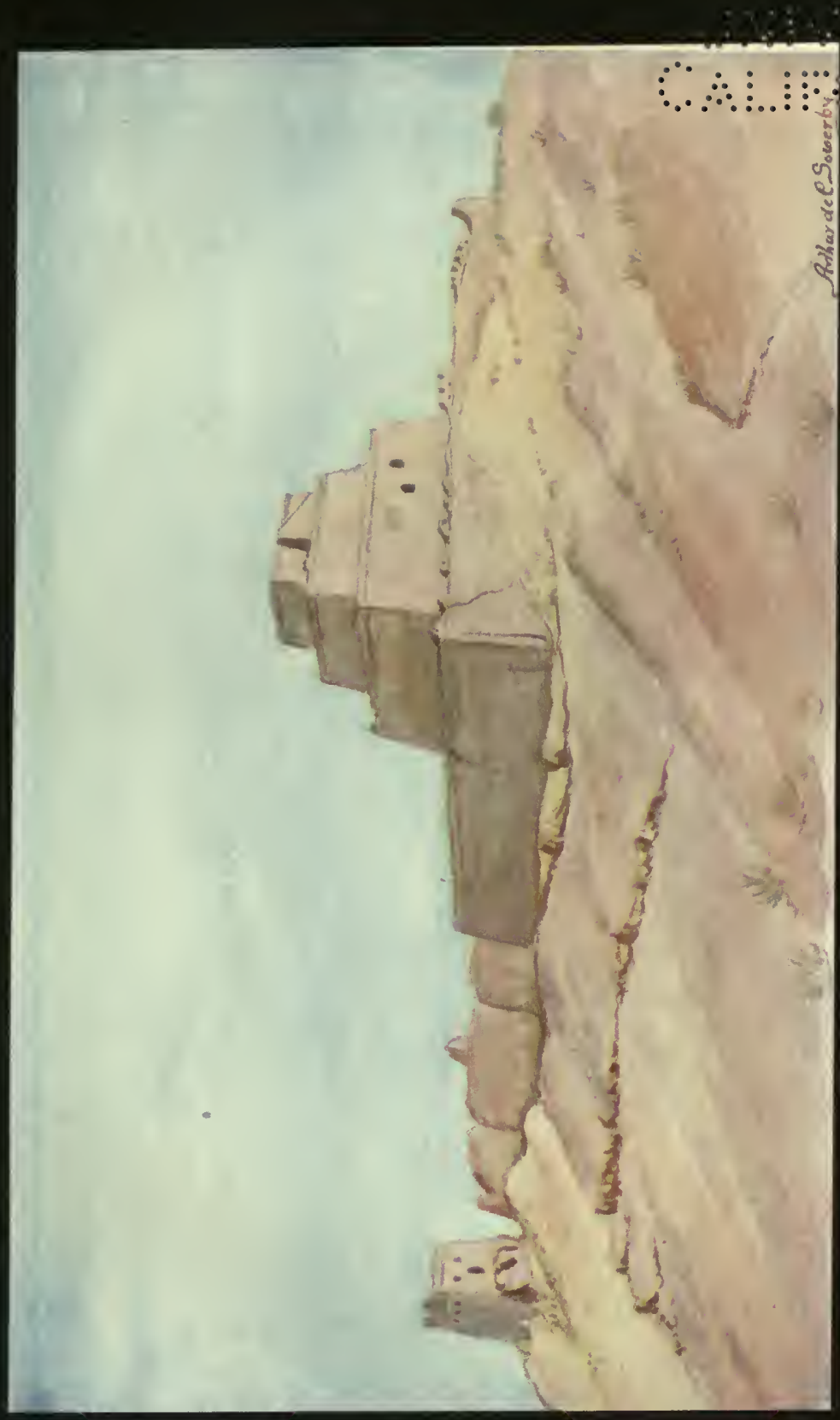




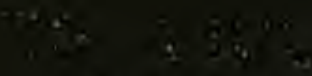

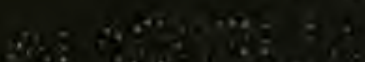

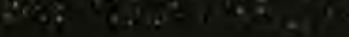


main road from the Ordos. It is some ninety feet in height and surrounded by a high wall. There are three storeys : the first a solid block of masonry about thirty feet square; the second and third similar, but lessening in size. Access to the second storey is gained by a stairway inside the lowest, but the steps from this to the top are on the outside. From here a splendid birdseye view of the desert is obtainable-countless sandhills stretching away north and south to the horizon; in the near distance two affluents of the Yü-lin Ho, their banks marked out by elms and willows. The sandhills assume varying hues of pink and yellow, swept from time to time by a darker patch of mauve, the shadow of a-drifting cloud. The delicacy of the colouring, remarkable at all times, becomes specially so at sunset. A peculiar phenomenon was noticed from the temple, the great sandbank that lies beyond the river taking on at night a deep red glow particularly noticeable in the moonlight. The Great Wall at this point, and indeed along the whole boundary-line between the Ordos and Shensi, is little more than a low ridge of earth. Its course, however, is easily distinguishable by the watch towers still existing at intervals of about three hundred yards. In many cases these' are in admirable preservation, leading to the supposition that the Wall in this part was not itself faced with brick or stone. It seems possible that there were battlements of brick, but there is no indication of any further masonry. It has been suggested that the towers are of later date than the Wall, or that they alone have been kept in repair; but there is no good reason for either view, and certainly there is no trace of any repair whatever.* But so much has been written about this stupendous work that any further discussion or remarks here would be superfluous.

An interesting visit was paid to a temple situated on the bank of the Yü-lin Ho, at the point where it cuts through the Wall. It is formed mainly by caves hewn out of the solid sandstone, which appears here as a massive outcrop. Opposite the temple, on the western bank of the river, are numerous epitaphs carved on the tace of the cliffs in Chinese and Tartar characters. They are to the memory of officials and Mongol princes, whose sepulchres can be seen as deep excavations below. Photographs of the fort and temple, and of the Wall at various points, were secured. A series of astronomical observations of both sun and stars, reduced to the South Gate, seemed to indicate that the old Jesuit longitude is about twenty-eight miles out.

\footnotetext{
- As a matter of historical irterest, it may be mentioned that the Wall was repaired by Chien Shên, of the Ming dynasty $\left(x_{4} 65-87\right)$.
} 
The country about Yü-lin Fu is wild and inexpressibly dreary. Very few trees are to be seen, and the bare brown cliffs and yellow sand are devoid of any vegetation, save an occasional tuft of some sage scrub. In places, especially where, as in the north-east, it rises to any prominence, gloomy chasms, with deadly quicksands lurking in their depths, gape in the sandstone and the half-formed shale. To north and west the prospect is heart-breaking. Sand-dunes and sand-dunes, and again sand-dunes-shifting with every storm and obliterating every landmark. Only here and there, as tiny islands in a sea of desolation, small clusters of mud huts, where some little oasis marks the site of a spring or well.

An unpleasant discovery was made soon after our arrival at Yü-lin Fu. The current expenses of the expedition had been under-estimated, with the result that there was a serious shortage in the silver available. After some consultation it was decided that Cobb and Grant should start at once for Hsi-an Fu, the capital of Shensi, where it would be possible to negotiate certain drafts and wire to Peking for a further supply of specie. As Cobb's time was nearly up, and there were urgent reasons for his early return to Europe, he decided to make this his farewell to the expedition, and to push straight on to the coast from Hsi-an Fu. Grant would return with the silver as far as Yen-an $\mathrm{Fu}_{\mathrm{u}}$, a city midway between Yü-lin and $\mathrm{Hsi}$-an, where the main body would meet him. After a farewell dinner, and amidst the customary leave-takings and regrets, Cobb and Grant, with a small caravan of mules, started southward on November 27 th.

The winter was now coming on apace, and it was thought wise to set about making an early start for Yen-an Fu, where we could go into winter quarters, and accordingly the remaining members commenced to busy themselves packing and preparing to resume the march. A few days later we were all astounded by the news of the three deaths in the Imperial Family-those of the Dowager Empress, Emperor, and Emperor's uncle. This was indeed startling. What would happen? Would the long-expected revolution break out and sweep all before it? Where were Cobb and Grant? These and a hundred similar questions tormented our minds, for there was nothing to be gained by ignoring the fact that we were in the heart of a country where very many atrocities had from time to time been committed. However, after discussing matters, we came to the conclusion that everything would pass off quietly, and that there was little need for anxiety. Nevertheless, as a precautionary measure, the rifles were overhauled and a good supply of I2-bore cartridges filled with buckshot and issued to all hands. The Chinese 
PLATE 11.
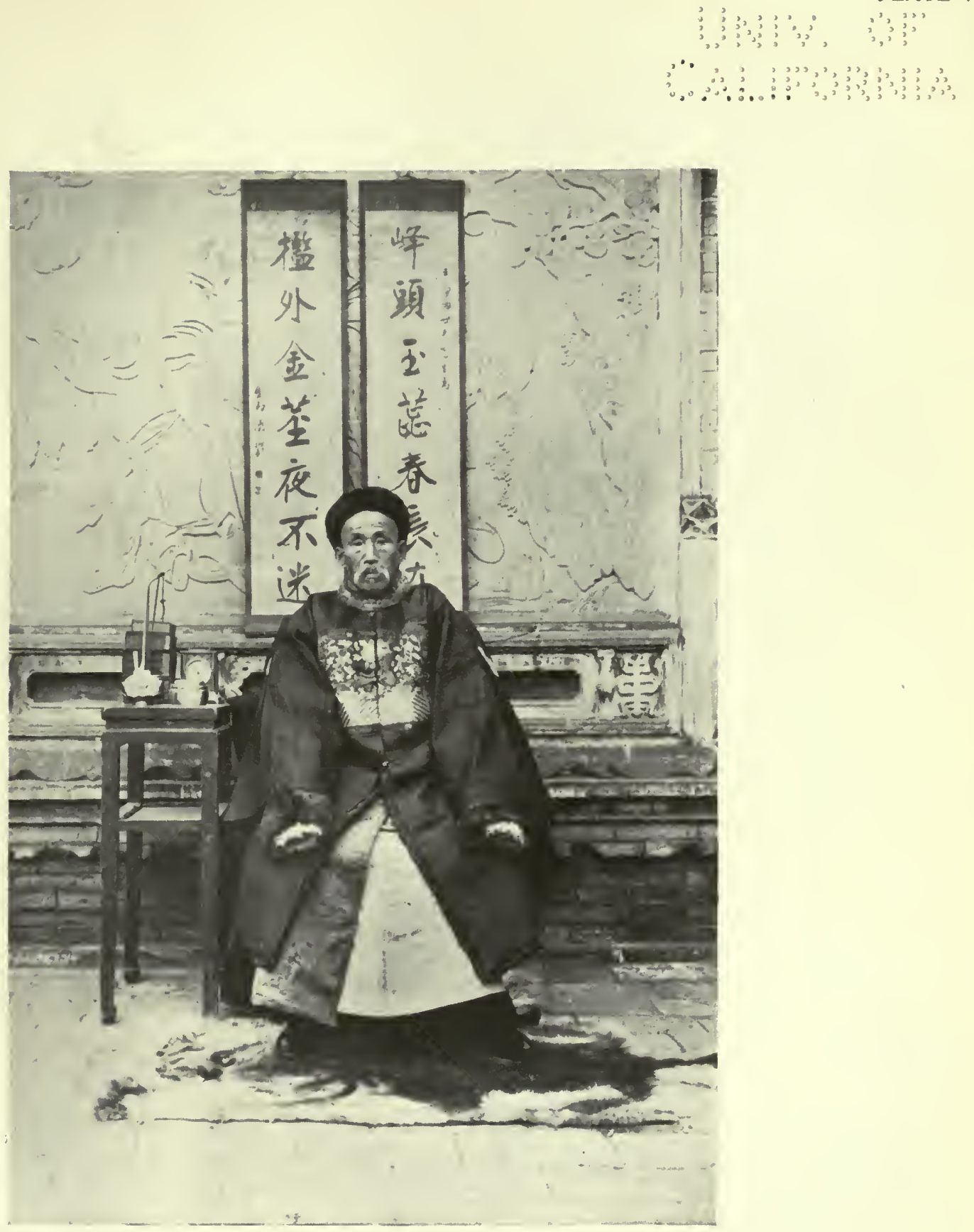

Pi Jung-pei, Head of the Police, Yü=lin Fu, Shensi.

See p. 19 


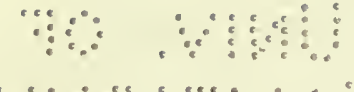

and 
officials sent reassuring messages to the leader of the expedition by the mouth of $\mathrm{Pi}$, the Head of the Police, who himself anticipated no trouble whatever. And thus reassured, the party continued their preparations for an early move southward. 


\section{CHAPTER IV.}

\section{MARCH TO YEN-AN FU-WINTER QUARTERS.}

$\mathrm{O}^{\mathrm{N}}$ December $5^{\text {th }}$ our long string of animals were once more on the march.

The mules, after their month's rest, were particularly obstreperous. Loads were pitched off in every direction, and kicking, braying animals went careering over the sandy flats. However, after much trouble, the refractory brutes were captured, the loads straightened out or re-made, and the train continued on its way. The cold was now severe, and the travellers often suffered acutely. The stoves were hardly adequate in such temperatures as were now registered; and the doors of the inns en route were as a rule ricketty, ramshackle contrivances, miracles of ventilation, calculated to admit the maximum of air in the minimum of time. Very often too the only fuel available was a smoky coal, which caused many severe headaches and considerable discomfort generally. It should be remarked that tents had been discarded for the time being.

The whole journey between Yü-lin and Yen-an occupied fifteen days; the country passed through taking the form of loess hills of from 500 to 1000 feet in height above the valley bottoms, and their summits characterised by a singular uniformity of level, which in conjunction with the excessive cold, rendered Hazrat Ali's work extremely difficult. However, he stuck bravely to his plane-table, though of course the extent of country mapped on either side of the road was of necessity reduced. This uniformity of level is the natural result of the geological formation. A huge deposit of loess, cut up in every direction by deep ravines and gulleys, lies upon a substratum of carboniferous rock-sandstone, shale, and slate. In many places there are seams of coal, and at one spot there were thought to be signs of mineral oil. This is by no means improbable, as the famous oil wells of Yen-ch'ang Hsien are not far distant. Unlike those of Shansi, every ravine and gully here has its stream of sweet clear water, which flows into some affluent of the Yellow River. The majority of these affluents are of a quite respectable size, and all flow in an easterly direction.

Except for the eccentric behaviour of the mules at starting, the first day's journey was without incident. The road followed the course of the Yü-lin Ho all the way. The country was covered with thick layers of sand, and very little cultivation was noticed. Many little streams enter the river on either 


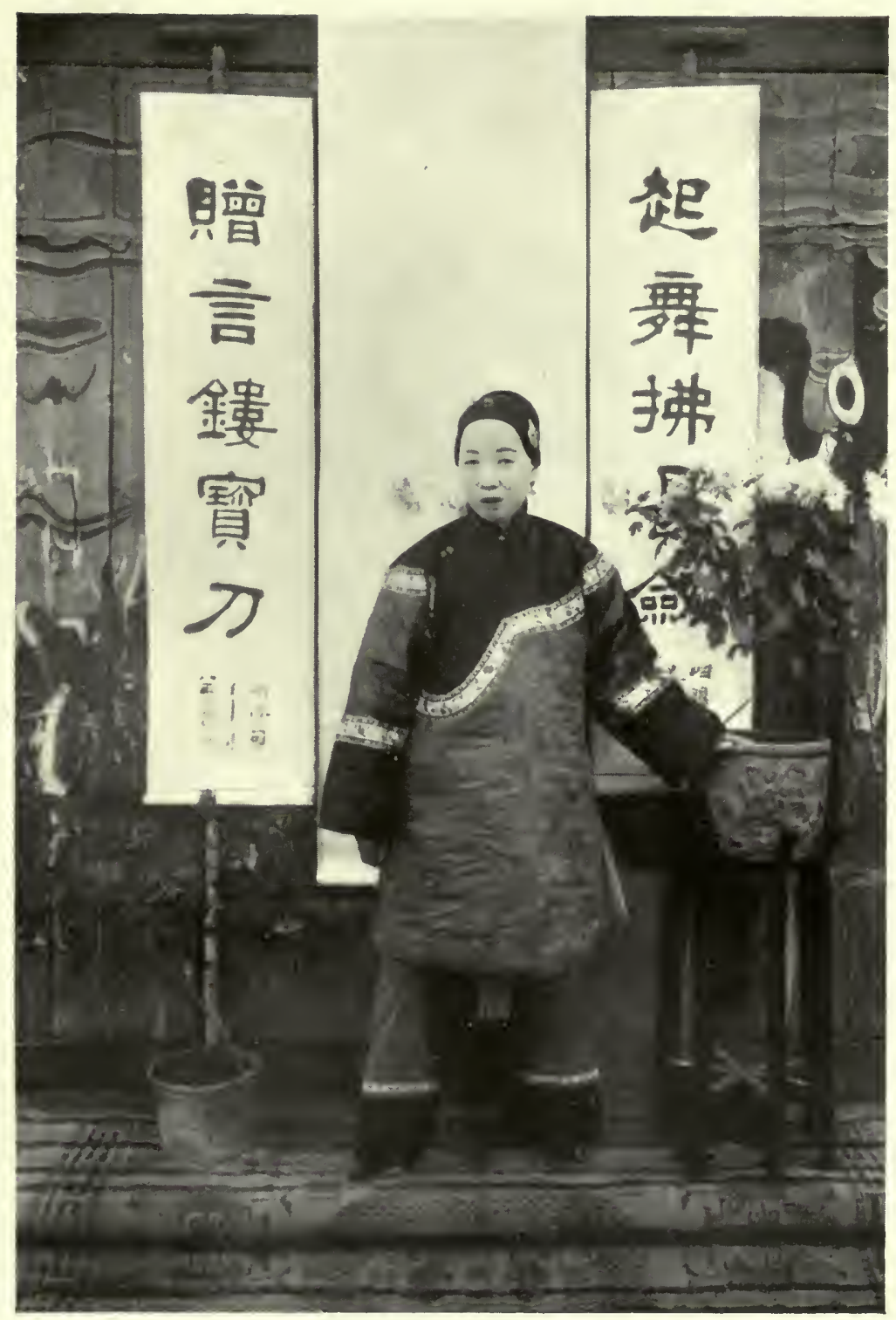

Chinese Lady. 


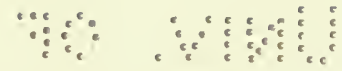

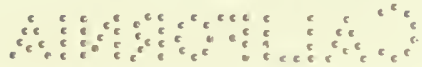


side. A mile or two south of Yü-lin $\mathrm{Fu}$ we passed a massive stone bridge spanning the river at a point where it cuts through an outcrop of rock, and some miles further south came upon the remains of a swinging chain bridge. So far as could be gathered, two chains, their ends fastened to rocks on either side, had carried across the river a roadway of timber, In any case the contrivance had long fallen into disuse, the chains were rusted nearly through, and but fragments of the planking still visible. At other points the passage of the river had to be effected by fords, or ferries. Seven small villages were passed, and towards the end of the day, after covering twenty-one miles, we reached Yü-ho-p'u, a small walled town which at one time held a garrison of soldiers, though the present population cannot exceed two hundred all told. Our entry was effected over the top of the north wall, where sand had banked up to such an extent as to render this possible. Huge mounds of sand from twenty to thirty feet high were also noticed inside the wall.

December 6 th saw us once more on the march. The road still continued down the valley of the Yü-lin Ho, and was excellent throughout. Shortly after leaving Yu-ho-p'u, the last of the sand was left behind. The valley widened out considerably, being bounded on either side by low loess hills overlying a thick, faultless and slightly undulating stratum of shale. The bed of the river was cobbly, but no signs of limestone, or anything but slate, sandstone, and shale were visible. The river flowed down a bed some ten to twenty feet below the level of the rest of the valley. Round the villages we noticed numerous plantations of jujubes valued for their sweet, date-like fruit. It was ascertained that wheat, millet, and sorghum form the chief crops grown in the valley, and on the surrounding hills. The latter are not so carefully terraced as in Shansi, where the natives dislike cultivating any but level surfaces. At a village named Yen-wa (literally "salt scrape" or "scratch") extensive salt works were found. To collect the salt, flat surfaces are prepared, and allowed to remain for a few days, at the end of which time an efflorescence appears. This is scraped off, and put into large perforated earthenware jars, through which water is allowed to percolate, thus dissolving out the salt. The impregnated liquid is next boiled down, and the salt extracted. This product, containing as it did a considerable portion of alkali which could not be separated, was found to be of very poor quality. The whole population was engaged in this industry, and the village looks a very dismal place. We noticed the remains of numerous forts, some perched on the hills, others extending across the valley; whilst high mounds at half-mile intervals marked the sites of watch towers, which had run in a regular chain 
from Yü-lin Fu. Mi-chih Hsien, a walled town of about two thousand inhabitants, was reached after a long march of over twenty miles. As at Lin Hsien, the wall encloses the hill behind the town. In this case, however, the hill is extremely steep, and rises to about 700 feet above the valley. Satisfactory quarters having been secured at the inn, it was decided to remain here for two days. Moreover, it had been found that in this class of country Hazrat Ali could only manage from eight to ten miles a day, and it was thought best that the main body should rest and march on alternate days, covering from eighteen to twenty miles at a time; thus the number of our halts would be halved, and the surveyor, without losing touch with us, could work along daily at the rate which best suited him. During our stay we were fortunate in escaping what might have been a nasty accident ; one of Clark's trunks had its bottom burnt through, having been placed on the kang immediately over the fireplace; the smell of burning wool was noticed just in time for the explosion of a case of Express cartridges in the trunk to be prevented. The maximum and minimum thermometer was stolen during the night, but on investigation it was "discovered" by one of the inn servants some twenty feet away from the window-sill, where it had been placed.

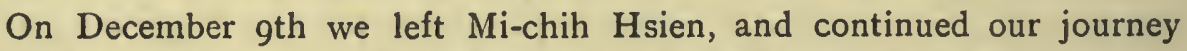
southward. The road was still excellent, and followed the valley of the Yü-lin Ho till Sui-tê Chou was reached. Here the Yü-lin changes its name, and becomes the Wu-ting Ho (literally "river of no certainty.") This name is given to it owing to the uncertainty with which it rises and falls. The same features which had characterised the country between Yü-ho-p'u and Mi-chih still prevailed, though the valley was considerably wider, and the hills much higher. The road in places skirted the edge of the valley, with the river some thirty feet below it. Everywhere the country was under cultivation, and the villages looked decidedly more prosperous. Sui-tê Chou is situated some twenty-one miles south of Mi-chih Hsien, and on the opposite (right) bank of the river. The walls here are of stone, and embrace a large portion of ridge to the south. Just before reaching the town the river makes a sharp turn to the east, and is crossed by a temporary trestle bridge, very shaky and insecure. The town is a picturesque place of some importance, four high roads meeting here, viz., those from Yü-lin Fu, T'ai-yüan Fu, Yen-an Fu, and Ning-ling $T$ 'ing in Kansu. That a considerable amount of traffic passes through may be gathered from the number of inns. Few of these, however, offer accommodation suitable for European travellers, and it was with difficulty that we managed to secure rooms at all passable in the southern suburb. 
PLATE 13.

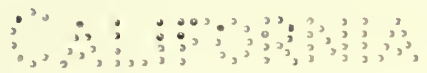

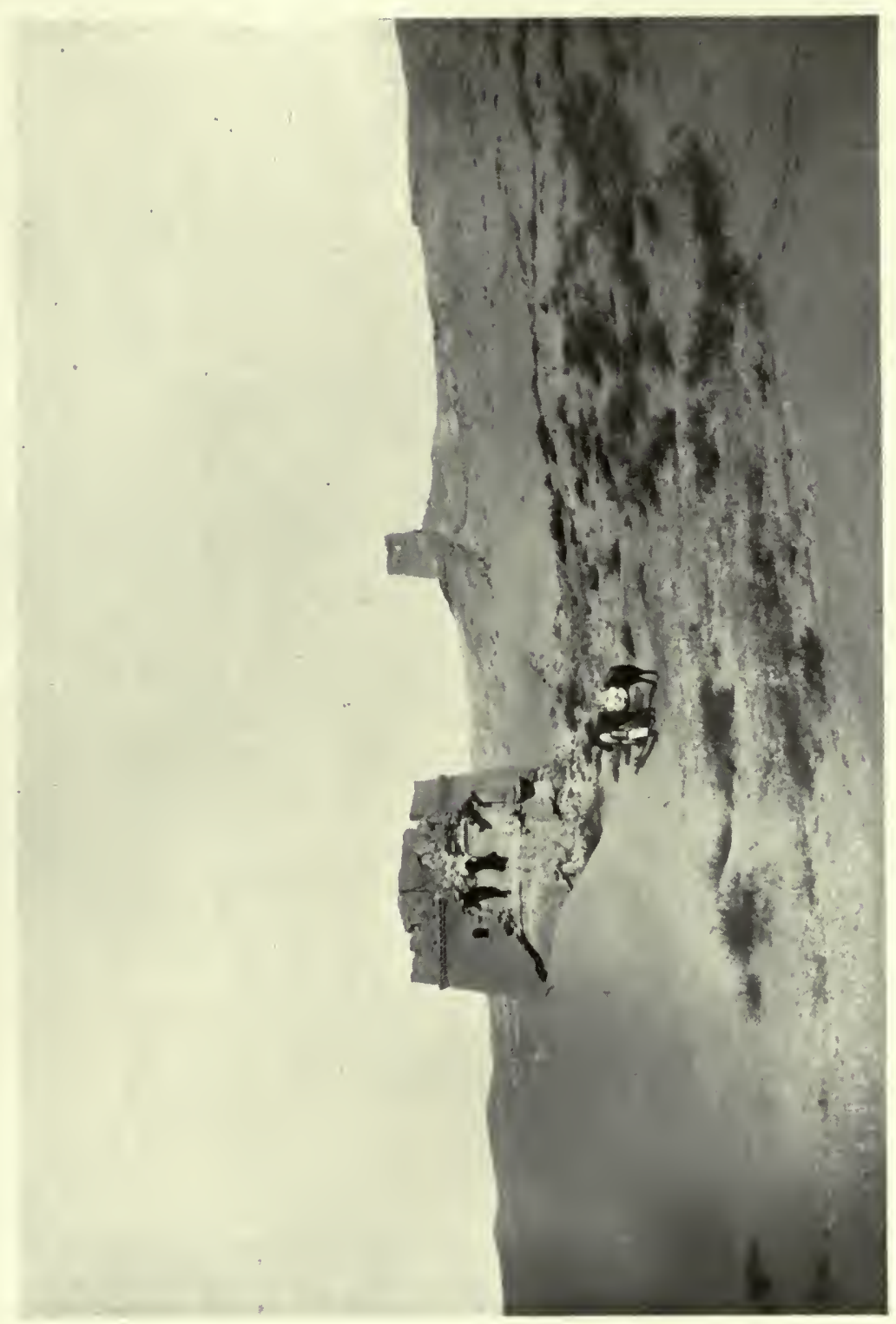

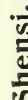

iี

$\Xi$

:

"음

E

$\bar{\Xi}$

$\sum$

苞

$\stackrel{Ð}{\Xi}$

5

है 


$$
\begin{aligned}
& \text { “早 }
\end{aligned}
$$

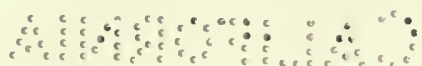


On December IIth, the expedition left Sui-tê Chou, and entering the hills to the south commenced to wind up and down a tortuous ravine, usually not more than sixty or seventy feet wide, and with perpendicular sides of considerable height. In this ravine, as in all the others encountered during the day, a stream, now covered with a thick layer of ice, flowed down a channel carved from the bedrock. Here and there large hollows held deep pools; numerous frozen waterfalls were passed, and from the sides of the ravine hung great masses of icicles. In short there was every indication of an abundant supply of water for the inhabitants of the small villages dotted at frequent intervals along the line of march. Soon after leaving Sui-tê the end of the first ravine was reached, and after crossing a high pass we entered a second. This was followed throughout its course until a small village named T'ien-chuang was reached, and here we halted for lunch. The road turned up next into a third ravine, which was followed to within a short distance of its head, and here quarters were secured in a small village named Shih-ts'ui-yi. This, as the name indicates, was at one time a changing post for the quick horse-courier service. This organisation has long been dispensed with owing to the peaceful state of the border, but in the days when constant watch had to be kept for Mongol raiders the village must have been a highly important place. The present population cannot be more than one hundred and fifty, and the houses are roughly built of shale slabs rudely cut and arranged in herring-bone pattern. The distance from Sui-tê Chou is about nineteen miles, and the road being newly cut was excellent, though some of the gradients would not allow of wheeled traffic. Hazrat Ali arrived on the evening of the $\mathrm{I} 2 \mathrm{th}$, having completed his survey up to this point. It was fortunate that he passed this night within reach of medical assistance, as he was taken violently ill : a result of poisonous fumes after his long exposure to the cold. This necessitated our spending another day at this place.

On December I4th the journey was resumed, and we crossed a high pass, 3725 feet, a few miles south of Shih-ts'ui-yi. The top of the pass was barely a hundred feet lower than the surrounding hills, so that a view to the south and east was obtainable. The horizon was remarkably level, the summits of the loess hills being, as usual, of uniform height. The descent into the valley, which we followed for the rest of the day as far as Ch'ing-chien Hsien, was very steep. The road though good, was frequently on the bedrock, into which the stream had cut very deeply. Ch'ing-chien, an insignificant town, is distant from Shih-ts'ui-yi about eighteen miles. Here an excellent quality 
of lignite is obtainable; this is mined at An-ting $\mathrm{H}$ sien, another small town about twenty miles higher up the valley, to the west.

One day was spent at Ch'ing-chien, and on December I6th, after a march of nearly twenty-two miles, we put up at a miserable village named Ma-chiak'ou. The road for the first two-thirds of the way followed down the same valley as before, but just before reaching the dilapidated and almost deserted town of Yen-ch'uan Hsien, it turned to the west up another ravine. The same geological formation was noticed, and nothing worthy of note occurred. The whole country from Yü-lin Fu to this point was remarkably bare of vegetation, and almost equally devoid of game; only a few small coveys of partridges, and some large flocks of rock-doves being sighted. Adhering to the decision made at Mi-chih Hsien, we halted here for a day to enable Hazrat Ali to keep pace with us. Only very poor coal is obtainable in the place.

Next day a distance of twenty-four miles was accomplished; a high pass -about 3600 feet-being surmounted without difficulty, thanks to the good quality of the road; and after following down a wide valley for some miles, we entered that of the Yen Shui, a short distance up which lay Kan-ku-yü. This day's journey was somewhat more interesting. Pheasants were seen in considerable numbers, whilst a flock of several hundred pigeons came in for its fair share of attention. Out of this flock thirteen birds were bagged at one shot. There was considerably more vegetation in the valleys, which were themselves broader than any met with since the Yü-lin Ho had been left behind. This night we had thirty-eight degrees of frost. Kan-ku-yü must have been at one time an important town, as indicated by the remains of a high and well built wall. At present it contains but one small street of very poor houses and inns. It is probable that, but for its being a regular stopping place for travellers passing between Sui-tê Chou and Yen-an Fu, the place would be utterly deserted, The country generally was under cultivation, though very thinly populated.

On December Igth a start was made with the intention of covering not more than ten miles, but no suitable quarters being found anywhere on the road it became necessary to push on to Yen-an $\mathrm{Fu}$, which place we reached late in the evening. All along the valley, which was fully a mile wide in places, the patches of scrub yielded any number of pheasants, so that we managed to enjoy the best shooting yet secured on the expedition. Only very small hamlets had been passed'during the day, and but little traffic was noticed. The Yen Shui was frozen over to a depth of several inches. Really 
PLATE 14.
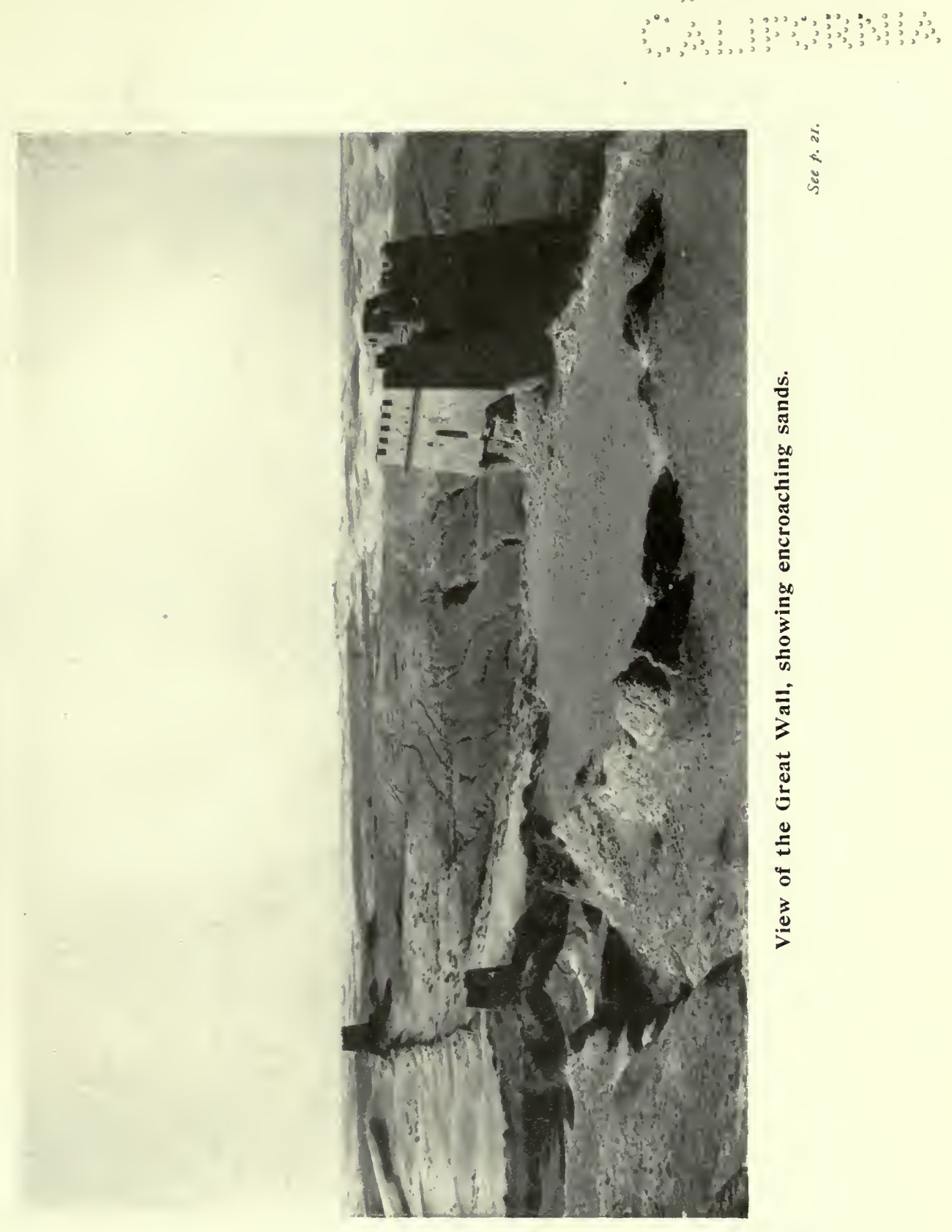


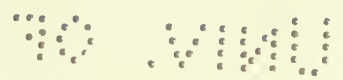

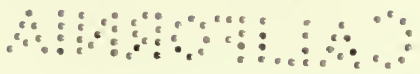


good quarters were obtained in Yen-an Fu, and we all settled down to spend Christmas and New Year in comfort.

Yen-an, a city of about three thousand inhabitants, was built, it is believed, early in the Sung dynasty. It has sustained many sieges from time to time, these chiefly at the hands of the Mongols, whose ravaging hordes poured in from the Ordos by the valley of the Yen Shui, on which river Yen-an Fu is situated. During the Ming dynasty the northern part of Shensi was in the hands of the Mongols, from whom it was wrested by the famous Yang. This intrepid soldier, making his headquarters in Yen-an, drove the intruders back across the border, and there held them successfully at bay. His remains lie in a large cemetery situated in the valley about a mile to the north of the city. In more recent times the city was sacked by Mohammedan rebels, the inhabitants cruelly massacred, and the temples-in part at leastdestroyed. It is built under the brow of a high and precipitous hill, and the wall as usual runs up the steep slope taking in the crest, which is divided from the rest of the ridge by a deep chasm cut by the original builders to preclude the possibility of attack from that quarter. Immediately outside the eastern wall flow the muddy waters of the Yen Shui.

Up the side of a high sandstone cliff, facing the city on the left bank of the river, is built a most beautiful temple-a relic of the Sung dynasty. Its most interesting feature is an enormous hall hewn out of the solid rock, in which sit three colossal Buddhas, each on the sacred lotus lily. These, however, received but little of our attention, as though large and very gorgeously painted they are made only of mud. But the walls of the hall itself are lined with thousands of little Buddhas carved from the rock in strong relief, not one square foot of wall being left blank. Here and there were larger statues of other deities; one of which, a beautifully carved figure of the Goddess of Mercy in a reclining attitude, called forth our special admiration, and considerable pains were taken to obtain a good photograph of this exquisite piece of work. There were evidences that the carvings and statues had been at one time coated with paint; but that they look far better in their present condition we have no doubt. There were signs of a strong Indian influence in this artistic work. The priest attached to the temple told us, on being questioned, that it was six hundred years old. On the crest of a high hill above, and beyond this, there are still visible the remains of what must have been at one time another magnificent temple. It was evidently of very considerable proportions, and is said to have been destroyed by the Mohammedans. Sections of an immense stone stairway are still visible on 
the sides of the steep hill. Inside the city walls are several other temples, Confucian and Buddhist, whilst in the cliff near the northern gate is another cave similar to the one across the river, but in a sad state of disrepair.

From the sportsman's point of view, Yen-an Fu affords winter quarters hard to beat. Several large valleys meet at this point, and in these the numerous patches of thorn-scrub shelter great numbers of hares and pheasants. The rocky sides of the valleys form the homes of large coveys of red-legged partridges, and at no great distance from the town roe-deer and wild pig are abundant; the former having been seen even within a mile of the town walls. Wild fowl, chiefly mallard and teal, may be shot on the Yen Shui, where they are often to be found disporting themselves in the open spaces of an otherwise ice-bound river. They afforded a very welcome addition to our bill of fare; in fact during our stay we may be said to have lived almost entirely on the spoils of the chase; deer, hare, pheasant, partridge, pigeon, mallard, or teal always contributing to our table.

It was a great disappointment to find that Josephine, who had come with us from T'ai-yüan and had the looks of a good setter, was useless in the field. The birds would lie low till the guns were right on top of them, when they would break cover with a terrific thundering of wings, flying in every direction. The result was disconcerting in the extreme. On being disturbed they would always make for the hills, when long tiring scrambles would become necessary, if more birds were to be secured. Needless to say that shooting under these conditions was often erratic, whilst the bags were never very large in spite of the abundance of game. However, hot corners were frequent, where the sportsman could have managed very well with two or three loaders. Even as things were, it was often possible to load two, three, or even four times before the last bird rose from the surrounding scrub. On Christmas Day, Clark and Sowerby had a particularly good day's pheasant shooting. The latter on his specimen-trapping excursions had obtained a good idea of the spots where pheasants were most likely to be found in large numbers. Riding out at about ro a.m. with their guns and a mounted attendant, they made for a large patch of thorn-scrub some distance from the Yen Shui valley. It was their intention to work back slowly from here to the city, and then up another valley till daylight failed. The sport commenced with a hot corner, where the guns got right into the thick of a large flock of pheasants, bringing down six birds with the first few shots. From that spot onwards the place seemed to be alive with birds, and throughout the day the party never once drew blank. Here a bouquet yielded its quota of fine fat 
PLATE 15.

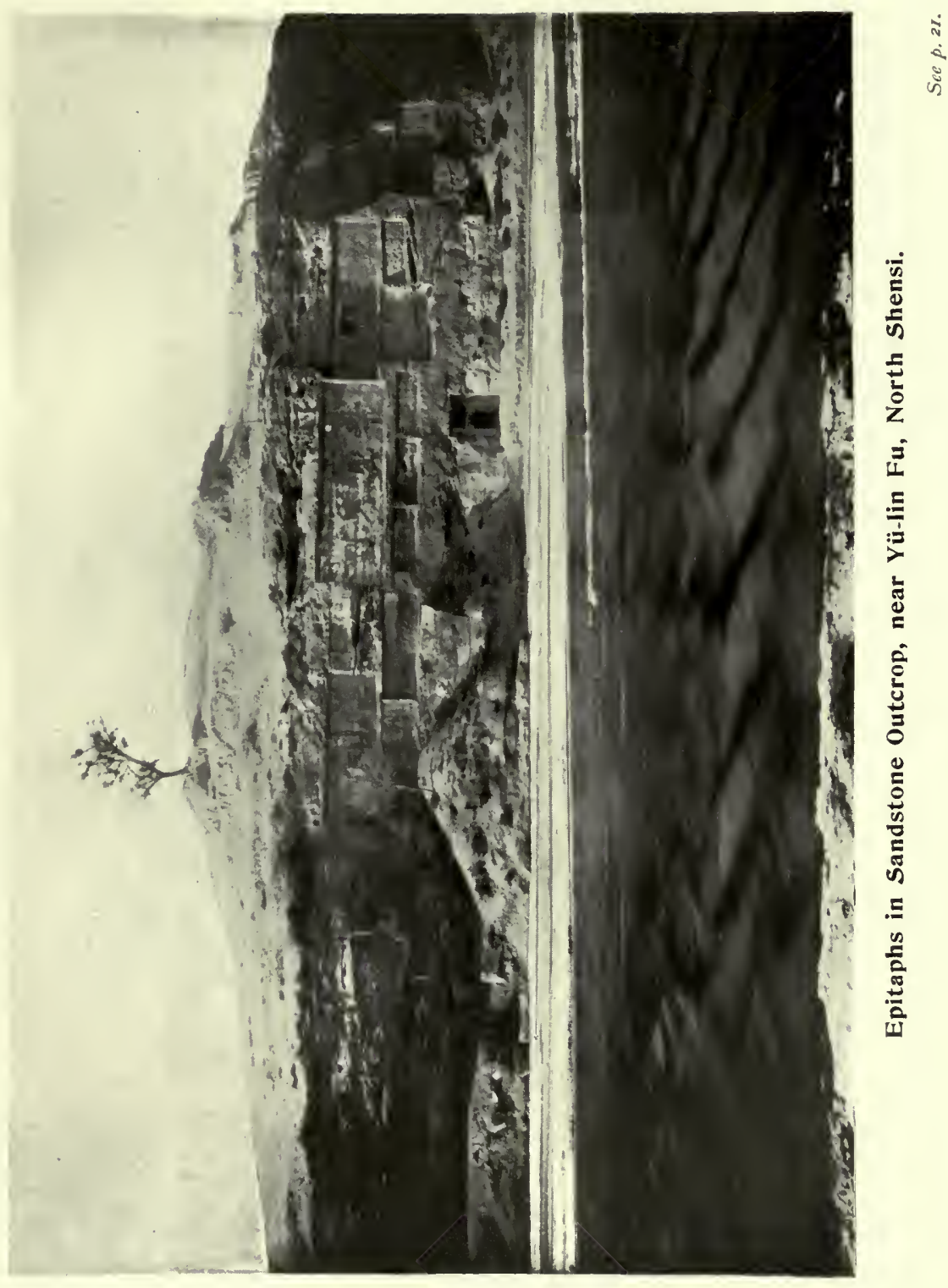




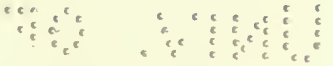

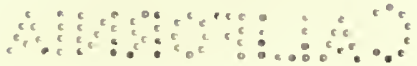


cocks; there a couple of hens, driven up by the groom, were neatly bagged as they headed for the hillside. At last a long patch of scrub was reached, from which it seemed impossible to drive the birds away. They flew out and back again; a bird or two being secured each time they rose. A couple of hares breaking cover were bowled over before they had gone a dozen yards. Then as the day drew to a close and the pheasants had all gone away to roost up the deep ravines, the sportsmen, tired and hungry but in high spirits, returned homewards with a bag of twenty-five pheasants and two hares. A certain amount of rivalry had only sufficed to make both men more keen, and the day's shooting ended in Clark's favour, with two hares and three birds to the good. As usual, several wounded birds got away into the thick scrub, and were lost. In some places the shooting was so hot and the birds rose in such numbers that it was impossible to mark every bird that was hit. The groom who was holding the ponies was able, by watching the proceeedings carefully, to point out many lost birds, but a good many escaped even his hawk-like eyes.

The absence of reliable dogs is certainly to be regretted, but they are very difficult to obtain in the interior; Josephine, in fact, had only been lent to us by a friend in T'ai-yüan. Later on, when Clark visited Shanghai, he brought back two good pointers, but the season was by that time rather far advanced, and the expedition came to an end before we could get the full benetit of their services. The natives occasionally use dogs-half pariah and half wolf-for hunting pig, but they are not of much use. No doubt if good boar-hounds were procurable, a fine old-fashioned form of sport could be enjoyed : the hounds bringing the boar to bay, and the hunter using the spear on foot. The native dog of the hilly and mountainous country is a fine looking animal, closely resembling a wolf in appearance, and capable of enduring extremes of both heat and cold, but so far as is known he has not been trained to the chase.

Hazrat Ali was a shikari of a very high order. His object, however, was not sport, but rather to make sure of a good bag. With this intent he might be seen creeping cat-like upon a covey of unsuspecting birds, and when he fired two or three brace were often the result. He prided himself that the number of birds killed usually exceeded the number of cartidges expended. He kept careful tally of both, and could give a good account of each cartridge he used. A ludicrous incident occurred, in which this quiet but deadly fowler drew down upon himself vials of wrath from the rest of the guns. The whole party was on its way to take observations from a peak to the north of the city, 
when a flock of mallard was spied on a small open patch of water in the river. Clark, Grant, and Sowerby at once dismounted, and started off down stream with the intention of working round, and coming upon the ducks under cover of a high bank on the opposite side of the river, where they could take the birds as they rose. Meanwhile Hazrat Ali, who apparently had not grasped the meaning of their manœuvre, advanced upon the ducks in the open. The rest of the party, having caught sight of the intruder moving rapidly upon what they justly considered their game, howled at him to desist. Not hearing the remonstrances hurled at him, he continued to move towards the apparently mesmerised ducks, and when within easy range opened fire killing three. This was typical of all his shooting; heedless of the rules of sport, he was, nevertheless, an excellent pot-filler, which is after all a very useful attribute on an expedition of this nature.

On December 28th, Grant arrived back from Hsi-an with a huge mailbag. $\mathrm{He}$ reported all quiet at the capital, and gave us the account of a pleasant journey to Hsi-an and back again. Cobb had started off safely in a litter for Honan, whence he could proceed by rail to Hankow. Grant reported excellent game country almost all the way to Hsi-an, in support of which intelligence he had several brace of pheasant and duck, beside a couple of geese on his mules. He stated that $\mathrm{Cobb}$ and he had been somewhat alarmed at the news of the deaths in the Imperial family, and that on the day of its receipt they seemed to meet an unusual number of men travelling northward with their women and children, and noticed also several bands of disreputable beggars hurrying south. The former they took to be fugitives; the latter human vultures flocking to scenes of butchery. Their fears, however, were dissipated, for on reaching Yen-an Fu they found everything quiet.

Amongst the letters brought back by Grant were some advising of the landing of provisions, etc., at Shanghai ; these being to enable the expedition to prolong its duration and extend its work. As matters now stood, our equipment was inadequate for extended work on the Tibetan frontier; our ammunition especially was running very short; the tents though good were found to be insufficient for the party; and the stoves were by this time almost useless. Nothing but charcoal could be used in them without their smoking badly; their chimneys were too narrow, and indeed the rough handling of careless natives had practically demolished them. It was therefore decided to separate for the time being as follows; Clark and Sowerby would hurry down to Hsi-an Fu, from which place Clark would go on alone to Shanghai, take 
PLATE 16.
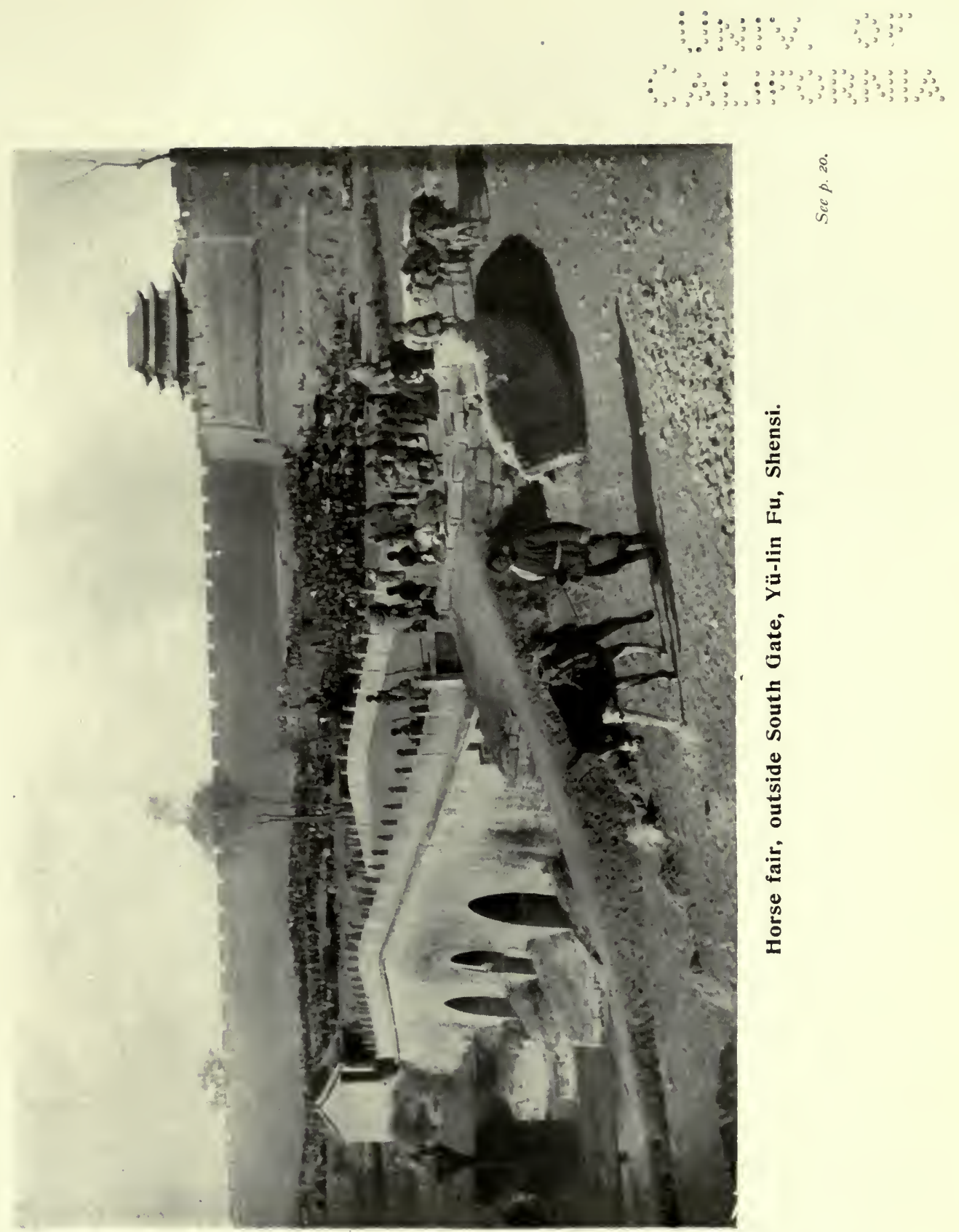

क्ष 


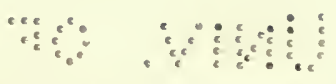

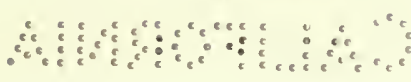


over the provisions and two large tents specially ordered for the summer work, procure suitable stoves, and with all speed proceed to Lan-chou Fu, picking up Sowerby again on his way. Sowerby, after Clark's departure from Hsi-an, would stay in that neighbourhood and collect, until on the receipt of a.wire from Shanghai he would proceed to Honan, and there re-join Clark. In the meantime Douglas and Grant, with the greater part of the pack-train and stores, were to proceed westward into Kansu, taking an unfrequented road to Lan-chou, at which place they would await the arrival of Clark and Sowerby. Hazrat Ali would accompany this party, and carry on his plane table survey from Yen-an to Lan-chou. Everything having been arranged in this way, the party set about re-packing stores, etc., to suit the altered plans; and on January 28th Clark and Sowerby left Yen-an Fu on their southward journey. A few days later the remaining division, having completed their arrangements, started westwards. 


\section{CHAPTER V.}

CLARK AND SOWERBY'S NARRATIVE OF JOURNEY TO HSI-AN FU.

$\mathrm{A}^{\mathrm{S}}$ already stated in the last chapter, we left Yen-an $\mathrm{Fu}$ on January 28 th on our way south to $\mathrm{Hsi}$-an $\mathrm{Fu}$, the capital of the province of Shensi. We took with us a small caravan of hired mules and three ponies. A groom to look after the ponies, and three personal servants including Lao Chao, a muleteer temporarily promoted, formed our retinue. The mules, of course, were accompanied by their owners, but these last devoted their energies mainly to opium-smoking, and incidentally to driving and feeding their animals. Lao Chao had first attracted attention in camp at Chao-chuang by his courage and unusual strength-on one occasion he forded the Fên Ho in flood to get provisions for the party. Showing himself very ready to be of use, he had been selected to accompany Cobb and Grant on their journey to $\mathrm{Hsi}$-an $\mathrm{Fu}$, and even went with the former as far as Honan, working his way back independently just in time to come with us on this trip.

Grant had kept notes of the country passed through on his journey some weeks earlier, and these supplied us with a list of halting-places and intervening distances, information always warmly appreciated by travellers in China. The first day's journey was across some very fine game country, which had already been visited by Grant and Sowerby deer-hunting. The travellers followed a long valley to its head in the high shrub-covered loess hills; a pass was crossed and a second valley entered, similar to the first. Numbers of charcoal-burners were noticed in this wooded area. Near the pass stood a roughly made hut, sheltering a small detachment of soldiers, who were stationed there to protect travellers against highwaymen, for whose atrocities this lonely stretch of country was at one time notorious. The robbers found ready cover in the many ravines branching off from the main valley; but since the opening of the new road, and the posting of this little garrison, they had found it advisable to disappear. The first halt was made at a small town named Kan-ch'üan $\mathrm{Hsien}$, ninety $l i$ from Yen-an Fu, and here comparatively comfortable quarters were found.

An early start, and a long journey down an ever-widening valley, where large numbers of pheasants were seen and a few shot, brought us next day to a village not far from the large town of $\mathrm{Fu}$ Chou. 
PLATE 17.

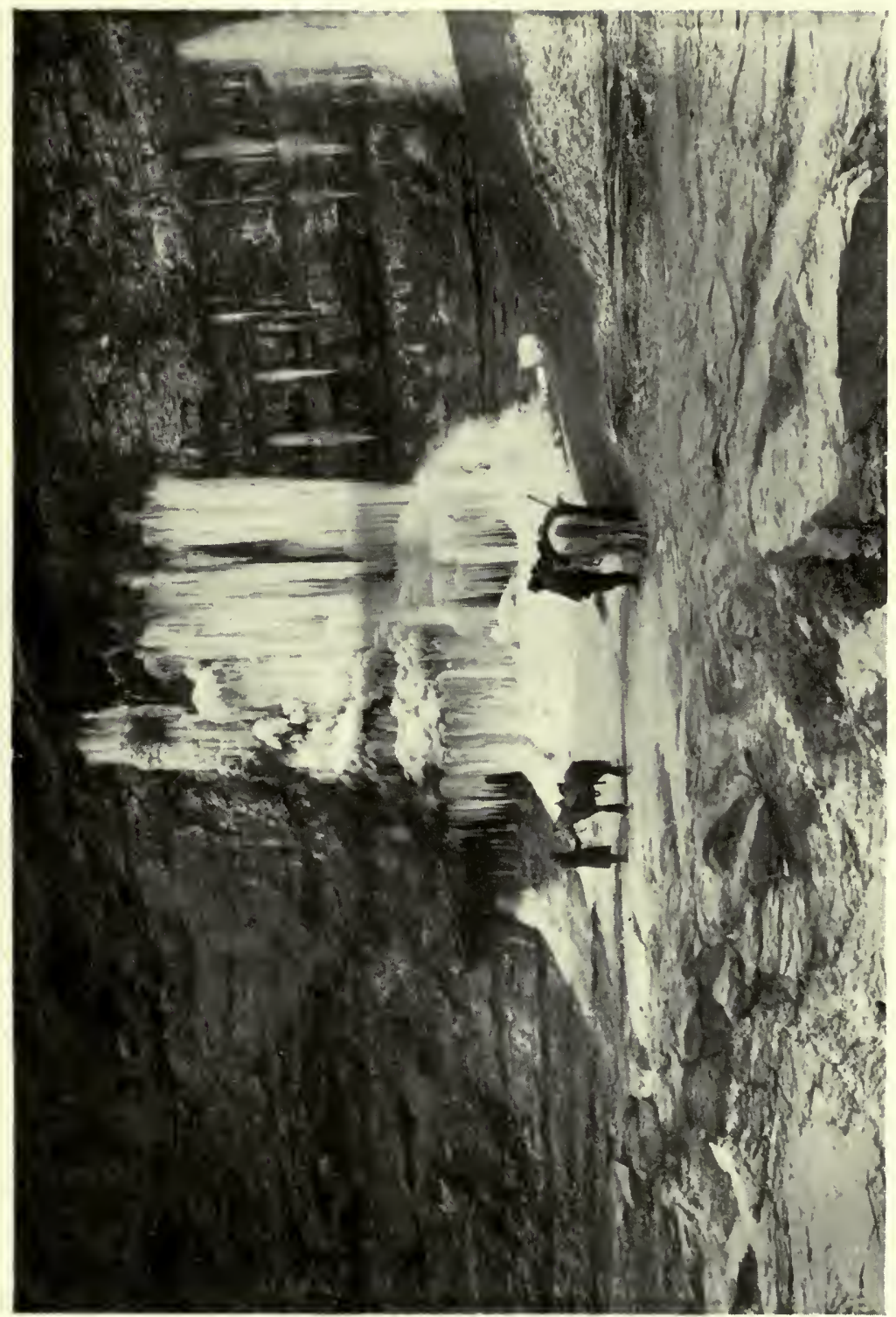




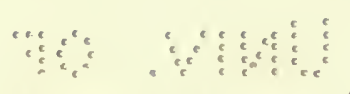

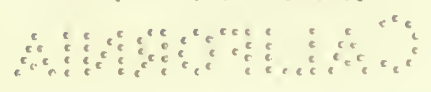


The road branched off to the east up a small ravine about a mile north of Fu Chou, and at this point two or three inns and a few miserable houses formed the village of Ts'a-fêng; and here we halted. This stage is reckoned to be eighty-five $l i$. At this time of year travelling was anything but pleasant, owing to the severe cold. The inns were never warm, the badly-fitting doors and torn windows admitted streams of cold air, which effectually counteracted any benefits accruing from the use of charcoal braziers and a small portable stove. The innkeepers are far too poor to keep the kang fires lighted during the day, and as these estimable contrivances take some hours to heat up, and in addition smoke abominably, they were tabooed. By hanging up waterproof sheets over the doors and windows we could manage to render the temperature a little more endurable; but bed was the only really comfortable place. The early rising, necessitated by our desire to cover long stages every day, was perhaps the hardest trial, although again precedence might be given to the keen head wind which, in spite of the heaviest clothing, seemed on some days to cut through to the very bone. Usually, however, when once fairly on the move, we found that the interests of the road, the not infrequent opportunities of sport, and the varying scenery kept us from noticing the low temperature and the biting wind. The road was in excellent condition, and in that way did credit to the soldiers who made it. But it is probable that the absence of wheeled traffic had more to do with its present smooth surface than anything else. At first it was hard to understand why no carts made use of this magnificent road, but after seeing some of the gradients no further explanation was necessary. The only wonder that remained then was why so much labour should have been expended to construct a cart road, whilst such important details as suitable gradients, easily obtainable with very little extra work, had been utterly neglected. However, even this is explainable by the reflection that the work was carried out by Chinese.

Leaving Ts'a-fêng before daybreak, we travelled for a short distance up the small ravine which we had entered the night before. Snow commenced to fall, and alas! for hastily formed opinions, the road became abominable. Its smooth surface becoming greasy offered no foothold, and as several steep ascents had to be made, travelling became not only unpleasant, but distinctly dangerous. The mules with their heavy loads had the greater difficulty in keeping their feet, but even the ponies floundered about in a most distressing manner. However, the badness of the road led to no mishap, though Clark met in another fashion with a most unfortunate accident. In stepping from a high kang in an inn, where the party stopped for lunch, he slipped and 
sprained his ankle severely. Coming, as it did, soon after an earlier injury sustained out pheasant-shooting, just before we left Yen-an, the sprain assumed a dangerous aspect. It was only by exercising the greatest care that he could set foot to the ground by the time Hsi-an was reached. Needless to say, the rest of the journey was rendered anything but enjoyable to the victim of such misfortune. Soon after the departure from Ts'a-fêng a steep ascent was made, and we found ourselves upon a flat wide plateau of loess, cut up in every direction by cañons of considerable depth. These, however, were not noticeable till the observer got within fifty, or one hundred yards. After travelling across this table of loess for some five or six miles, the party came to the edge of a vast valley, across which lay the road. On the other side of the valley could be seen the commencement of a second tableland, and this sort of experience was repeated all this day, and half of the next. It seems probable that this formation represents a great loess deposit in its early stages, before the action of rain and water has rounded the great sections between the cañons and ravines into the hills and ridges so typical of most loess country. Indeed, the moulding process was noticed along the sides of the larger valleys, where, instead of the abrupt cliffs and sharp edges of the ravines and cañons, the sides were rounded off, and sloped with comparative ease to the stream below. On the plateaux some bustards were seen not far from the road, whilst a fox was put up from a clump of graves. Pheasants were noticed still on the fields, but they were few in number and very shy. The surfaces of the plateaux were under cultivation, but nowhere could any villages be seen. This was explained, when it was discovered that the villages were either built on the sides of the smaller ravines, or formed by extensive excavations below the surface level. In the latter case each dwelling would consist of one large square pit, twenty to thirty feet deep, and forming the courtyard, from which opened deep cave-rooms, occupied by the members of the family and their live stock. The courtyards were reached by long and gently sloping shafts, fitted at their lower ends with stout wooden doors. The villages built above ground were the larger and more important, and few and far between. After crossing three plateaux, the caravan stopped, late in the evening, at the town of Lo-ch'uan Hsien, where the usual well-ventilated quarters were secured. This day's journey was eighty $l i$.

The following day, after crossing two more plateaux, and winding up and down several deep valleys, the party reached Chung-pu Hsien, close to which is situated a huge mound, supposed to be the grave of the great $\mathrm{Huang} \mathrm{T} i$, or Yellow Emperor (B.C. 2700), one of the five mythical emperors of Chinese 


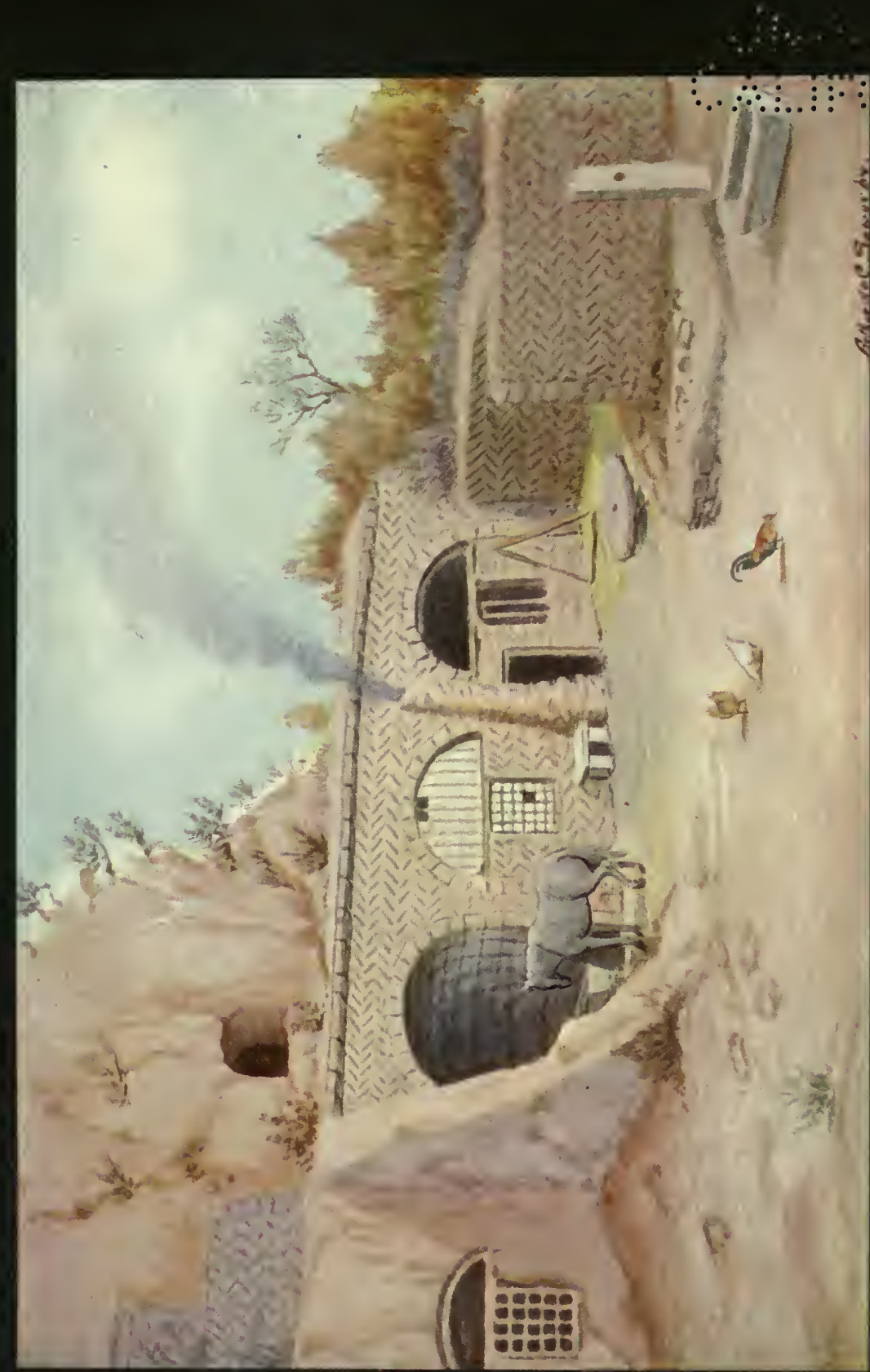




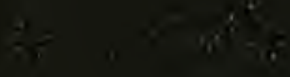

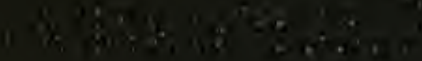


history. The mound was noticed certainly, but so great is it, that we actually took it for a hill. A large grove of cypress trees, planted near the town in memory of the same monarch, was also observed.

The country immediately to the south of Chung-pu Hsien was uninhabited, and very wild. As in the case of the deserted area south of Yen-an, this district was well wooded, and large flocks of pheasants were seen. The travellers amused themselves by shooting at these with their revolvers; so much good shooting had been enjoyed that it needed something more than a pheasant to draw anything but a few revolver shots. It snowed heavily half the day, and in consequence much difficulty was experienced in negotiating the heavy gradients of the road. It was fortunate for Clark that he was riding a particularly sagacious and careful pony, for he was, of course, unable to dismount at difficult places, as the others did. Even as it was, poor Blacky, as the pony was called, slipped once, and rolling over, threatened to crush his rider. Sowerby and the groom left their ponies and rushed to the rescue, helping Clark up on to his sound foot. At this juncture all three ponies took it into their heads to bolt, and were soon lost to view round a bend in the road. Things looked decidedly bad, as the mules were a considerable distance away, and the nearest village was ten miles off. The ponies did not go far, however, and, stopping to feed on the stubble by the roadside, allowed themselves to be caught. Later on, one of the mules went down a steep slope, and as it frantically struggled to regain its feet, was momentarily within an ace of destruction by falling over the edge of the deep ravine. From this terrible predicament it was only rescued with the greatest difficulty. A halt was made that night at a small town named Yi-chün Hsien, seventy $l i$ from Chung-pu Hsien.

The following day we passed through a splendid game country, where the beauty of the scenery seemed emphasised and enhanced by its covering of new-fallen snow. The road for the first eight miles led along the top of a long ridge of high shale mountains. Many deer were seen from the road, and in one place a huge wild boar was chased right across our path by a pack of hounds, followed shortly by their master. Unfortunately the necessity for haste on this journey prevented us from joining in the chase. The last twothirds of the day's march were along a deep, rocky, and very beautiful ravine, which widened out into a fine valley towards the end of the day. In the ravine we saw, besides many other birds, a large number of handsome blue magpies. Here, for the first time in North Shensi, was any faultiness noticed 
in the sandstone and shale strata. In places immense folds existed, and everywhere were evidences of considerable disturbance.

At a small village, where the midday halt was made, a band of Ssŭch'uan emigrants was encountered. These people, in their light summer clothing and hemp sandals, seemed to be suffering great distress. It was a pathetic sight to see little children of four and five trudging along in the snow and slush, each carrying a little bundle. The still younger children were carried on their mothers' backs. These unhappy folks had travelled up from Ssŭch'uan, viâ Han-chung $F u$, in the coldest part of the cruel winter, in order to reach their destination in time to till the ground for a summer crop. They seemed to be possessed of but few goods and chattels; what they had, being carried on their backs, or in wheelbarrows. Their faces were rounder, and the features flatter, than in the natives of this portion of the country; and they wore turbans. The hemp sandals formed their only footgear, and they seemed to have little in the way of quilted or wadded clothing, just braving the winter in their thin cotton things. Such men and women could hardly fail to make good settlers, and, in later journeys in Kansu, opportunity was given to some members of the expedition of seeing the good results obtained by these hardy peasants.

That night, T'ung-kuan, a military town, was reached, and a visit was received from the Secretary to the Head Military Official, who made apology for the absence of his chief. He offered the,party a small escort of soldiers to see them safely to $\mathrm{Hsi}$-an $\mathrm{Fu}$. This offer, however, was politely declined, there being no necessity for such guardianship. This town is situated ninety li from Yi-chün Hsien, the stage being long and difficult. T'ung-kuan produces a fine class of dried persimmon, than which few more palatable and nourishing dried fruits exist.

The next halting-place was Yao Chou, a large and busy town, but of no particular interest. On the road between T'ung-kuan and Yao Chou a belt of limestone was traversed, the first sign of this rock yet noticed in Shensi. The day's journey was not so long and fatiguing as the one before, the distance covered being seventy $l i$.

Throughout the greater part of the following day, the road led down a broad valley, which finally opened out into a series of great loess terraces or steps, on which were observed several large flocks of bustard. Sowerby tried hard to secure one of these magnificent game-birds, and was rewarded finally with a nice sixteen-pounder. Towards the end of the day the little party descended from the heights to a great plain-the valley of the Wei $\mathrm{Ho}$-in 


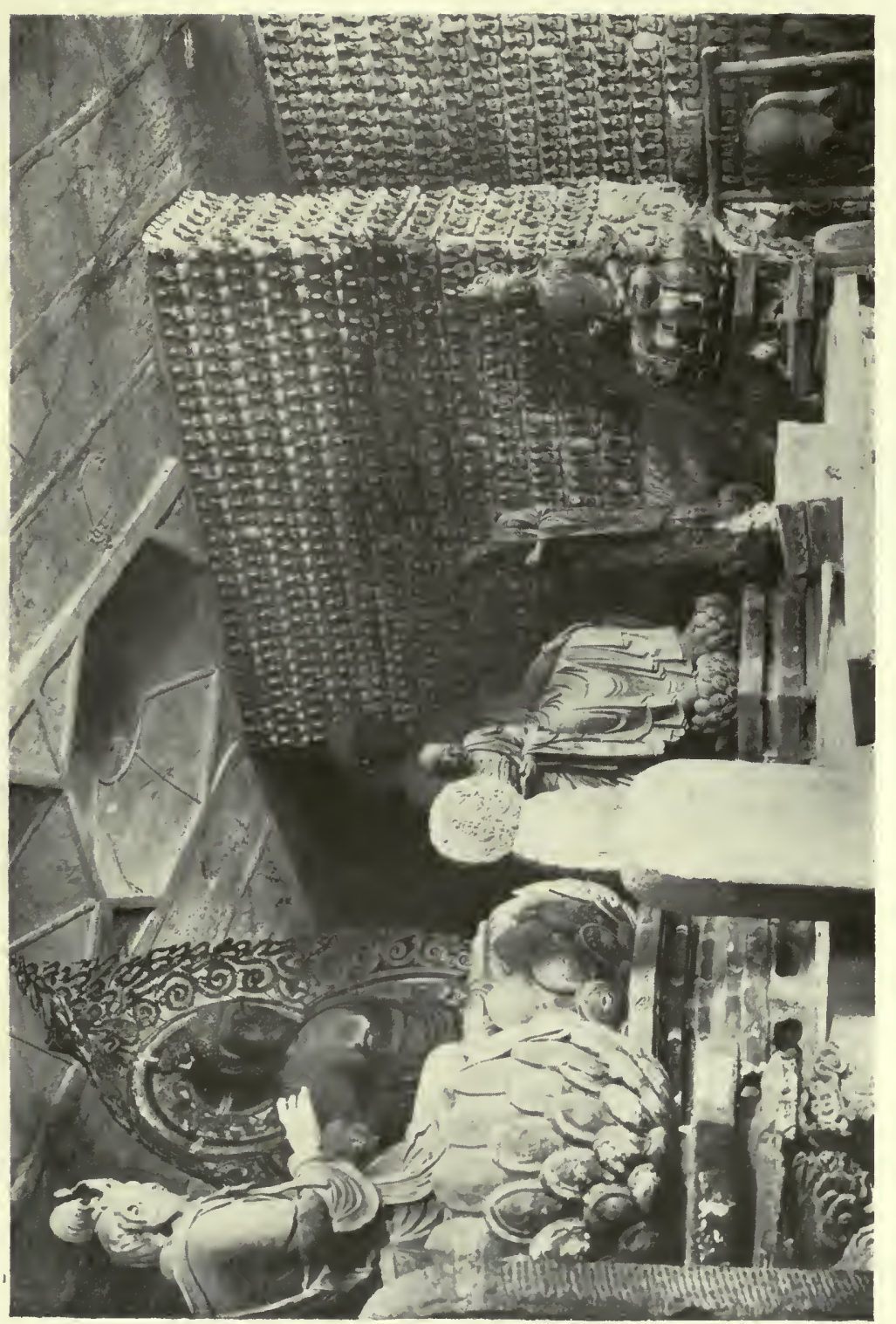




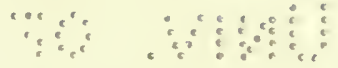

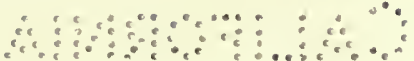


which is situated Hsi-an Fu, one of the ancient capitals of China. That night we put up at a miserable inn in the large, busy and populous city of San-yüan Hsien, Though only a "Hsien" (i.e., sub-prefecture), San-yüan is larger than any of the prefectural cities in the province north of this point. An immense ravine has been eroded by water since the city was built, and is now spanned by a large and well-constructed bridge. The sides of this bridge are built over with shops, after the fashion of old European bridges, so that, but for a glimpse he gets as he approaches it, the traveller would not suspect that he is crossing a ravine of considerable width and depth. Many industries are carried on in the southern, and by far busiest, portion of the town. Brasswork of all descriptions forms the most important of these ; but there is also a considerable amount of carpentry and bamboo-work. It may be noted that there are not more than 400,000 inhabitants in the province north of this.

The change from the mountainous to the flat country was also accompanied by a decided difference in the character and appearance of the people. Not only do these stamp them as being of a southern type, but their manners and customs are also markedly distinct from those in the country just left. A great difference was noticeable in the food, and method of eating. It seemed as if everybody ate their meals in the street, purchasing them from stallkeepers, who prepare them on the spot. And not food only, but boiling water as well, for it is only the more wealthy citizens who keep fires in their houses. There was something not at all displeasing in this mode of taking meals, extreme sociability being the keynote. Numerous tables, on either side of the street, and sheltered by light mat roofs from sun or rain, afforded accommodation to scores of merry diners. Travellers from all parts of the Empire freely mixed and chatted with the citizens of the town, and everybody seemed thoroughly happy, and perfectly contented with the prevailing conditions. A distinctly southern touch was added to the streets by the huge bamboo baskets of oranges, pommeloes, and sugar-cane-delicacies never seen in towns of the northern interior. The streets, paved with huge stones and crowded to suffocation, formed a marked contrast to the wide and dusty streets of the towns recently passed through. San-yüan Hsien may be considered in some respects a rival of $\mathrm{Hsi}$-an $\mathrm{Fu}$ itself. It is situated eighty $l i$ from Yao Chou.

Being anxious to reach Hsi-an in good time, we made an unusually early start on February 5th. Our intention was to ride hard so as to arrive in time for lunch, knowing as we did full well the hospitality of the missionaries whom we were likely to meet. It was still dark as we rode clear of the suburbs of 
San-yüan; but ere long a faint glow in the east heralded the approach of day. The air was filled with the distant honking of geese; and, with the spreading of the glow in the east, long chains of wild fowl became visible, flying southward. Presently a small river was reached, and there, thick upon the southern bank, were hundreds of geese and duck, the latter being of the species Sheldrake, or as it is usually called in China "Yellow Duck." Soon after sunrise we passed a large pagoda, which had been noticed standing out against the gathering mists as we descended the heights the preceding afternoon. At last the bank of the Wei Ho was reached, and considerable delay experienced in getting across. The weather was very gloomy, whilst the mournful calling of the ducks, the dismal flats, and grey sombre river all combined to enhance the feeling of depression which seized the travellers as the heavily-laden ferry moved slowly across the sluggish water. Though the temperature was not in reality very low the cold seemed unbearable, a result doubtless of the moisture in the atmosphere. Moored alongside either bank of the river were huge coal-barges with quaint roofs and dragon-headed josspoles, which, in the morning mist, seemed to assume strange forms, gigantic and menacing. As the ferry-boat passed close to a sandbank in the middle of the river, an immense cloud of duck rose with a thundering whirr. After circling overhead, and flying up and down the river in a rapidly moving, everchanging cloud, the birds suddenly swooped into the water, countless little jets of spray marking the spot where they had struck its smooth surface.

On landing we noticed some geese not far off, and Sowerby, riding up to the small flock, managed to secure one from the saddle. The rest of the journey to Hsi-an lay over a flat country, the first part of which was much intersected by irrigation canals, supplying water to the swampy rice fields. Here many mallard and teal were feeding, and round the villages the beautiful pink and white ibis waded knee-deep in the black, oozy mud. As Hsi-an was neared, the rice fields and canals gave place to wide, rolling fields of early wheat, the green of which was hailed by the party with the liveliest satisfaction. The pleasure afforded to the eye by a green field, after the yellow, grey, and brown of a North China winter, cannot be expressed. A quaint charm was added to the scene by strong battalions of geese drawn up in serried ranks, as if on parade. In every direction, too, were little detachments, giving the impression of the outposts, pickets, and scouts of main opposing armies. When approached and fired upon, the flocks arose en masse, honking wildly The noise was deafening, and the sky black with frightened birds till, breaking into chains, they flew off in all directions. 
PLATE 19.
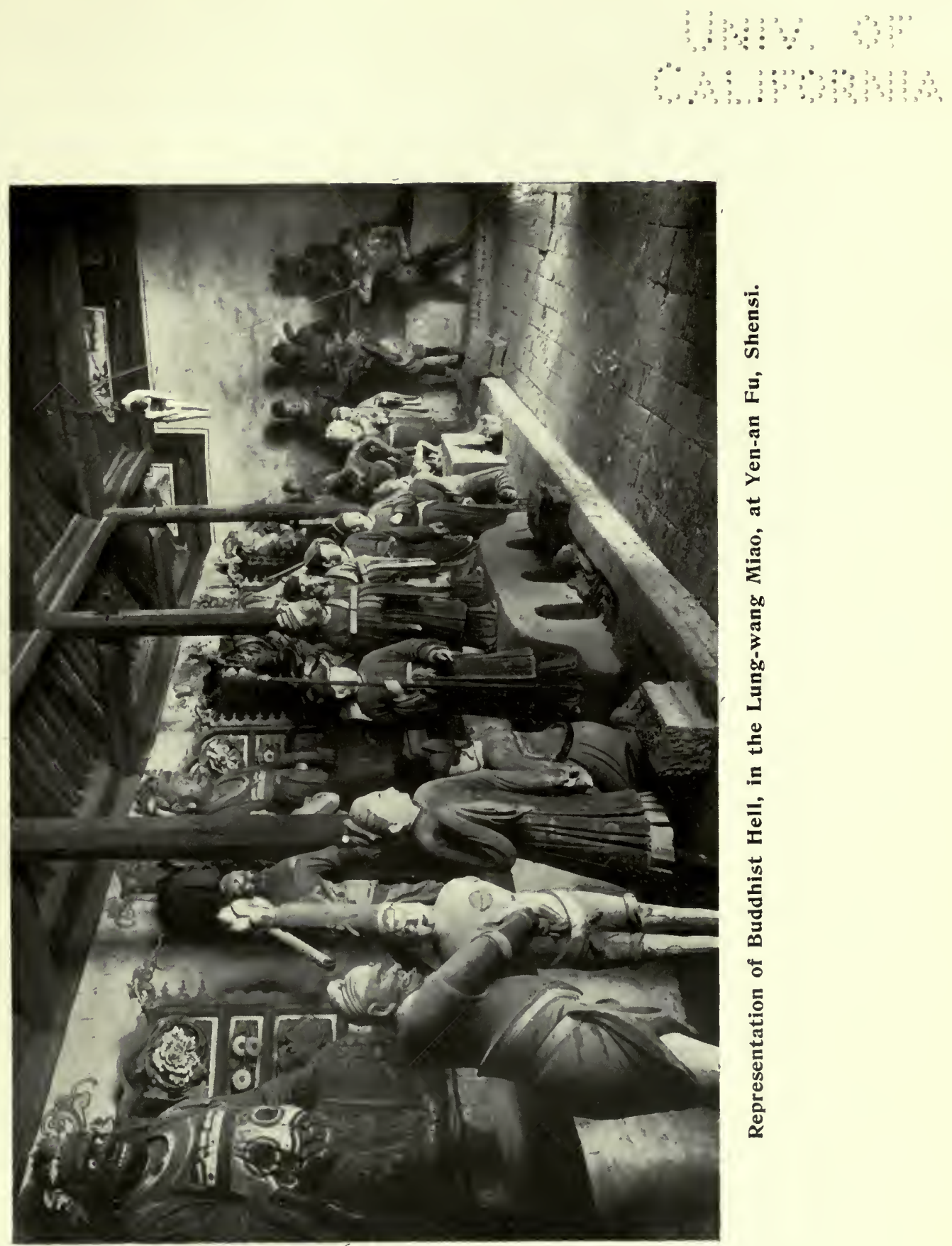

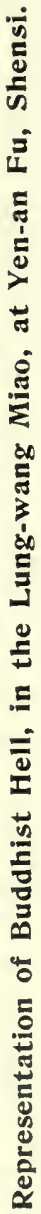


\%

and 
For some time we had been straining our eyes for a sight of the city of Hsi-an Fu. It seemed difficult to believe the natives, who declared it to be close at hand; but when the travellers were within a quarter of a mile of the place, suddenly the massive towers and solid walls sprang into view, and the capital lay revealed in a large depression. Entering by the East Gate we made straight for the Baptist Missionary Hospital, where Dr. and Mrs. Jenkins gave us a warm welcome, and entertained us royally. Then a visit to the Post Office, to secure any letters that might be there; and Mr. Mullen, the Postmaster, insisted on his visitors taking their evening meal with him, an invitation which, after months of rough and often badly cooked food, they were only too ready to accept. The inn at which accommodation was secured turned out to be surprisingly poor, especially when the size and importance of the city are remembered. However, paradoxical as it may appear, it seems to be the rule in North China that the quarters obtainable vary inversely with the size and prosperity of the town. Away in some lonely place, where the people hardly know how to secure a living, it is almost invariably possible to find roomy and comfortable lodgings; but in a large and populous city such as Hsi-an, full of fine residences, large shops, and all signs of considerable luxury, the only accommodation procurable is of the very dirtiest and poorest nature imaginable. We could, of course, have accepted the hospitality generously offered by the Missionaries or the Postmaster, but a short stay only being anticipated, it seemed a pity to disturb the routine of their quiet households.

Observations were taken at $\mathrm{Hsi}$-an on the $5^{\text {th }}$ and 6 th, and the rate of the chronometer-watch determined; and on the 7 th the party left the city and reached Lin-t'ung, a place fifty $l i$ distant, where some famous hot-springs exist. Quarters were secured in the grounds of the gardens attached to the springs, and the exquisite luxury of a hot mineral bath was enjoyed.

The discovery of the springs goes back to a very early date, but the building of the present commodious baths is attributed to the famous $\mathrm{K}$ 'ang-hsi (1662-1723). There is no charge for the use of the baths, a small tip to the attendant securing privacy in the warmest and cleanest of the series. This spacious bath lies under the arch of a large cave, and is capable of holding comfortably some fifty or sixty bathers. It is fed from a spring that issues directly from the back of the cave, and is divided from a second bath by a wide stone platform, pierced by several low arches through which the water flows. This second bath lies in the open, but is enclosed by a high wall. From here the water is conducted underground to two small private baths, 
adjoining large staterooms. From these in turn the water escapes into a beautiful artificial lake, planted with lotus-lilies and full of fish ; its sides steep, and overhung with masses of yellow jessamine. In the centre of the lake stands a pretty $T^{\prime}$ ing-tzu, or summer-house, intended as a dining-room for visitors. The grounds are planted with flowering shrubs and stately trees; and the clear placid lake, its surface faithfully reflecting summer-house, trees, and wealth of golden flowers, presents an entrancing picture. In an adjoining compound, a second series of baths fed.by another spring is devoted to the use of the common people. When first built this series was intended for $\mathrm{K}$ 'ang-hsi's queen and her court, whilst her lord and master disported himself in the beautiful grounds first described. The waters are slightly sulphurous in composition, and having, therefore, a very relaxing effect upon the system, are far-famed for their medicinal properties. The temperature of the water was found to be ro8 Fahr., and entering the bath is a slow process, as it is necessary to accustom the body to the great heat gradually. So hot indeed is the water that bathers, after leaving it, can dry and dress themselves in a keen wintry wind, without suffering any inconvenience. From both series of baths the water, still quite warm, flows out eventually into small canals, covered in with matting, and is thus conducted over ground carefully cultivated, where rich crops of vegetables are raised. These-onions, and a special variety of garlic during the winter months-are grown in hollows, and are also covered with matting. There can be little doubt that the splendid crops obtained, as well as the wonderful display of jessamine-blossom round the lake, are largely due to the warmth of the water which permeates the soil. A large pool, just outside the grounds, must not be forgotten; here all the pigs in the neighbourhood wallow, their snouts just showing above the surface.

On February 8th, Clark tore himself reluctantly away from Lin-t'ung and started off for Shanghai, viâ Ho-nan Fu and Hankow; and three or four days later Sowerby returned to $\mathrm{Hsi}$-an $\mathrm{Fu}$, and proceeded to investigate the fauna of the mountains to the south of that place.

At the end of a fortnight, spent in the collection of mammals and birds, Sowerby received a telegram from Shanghai, and in accordance with its instructions started for Ho-nan $\mathrm{Fu}$, from which place he would proceed by rail to Hankow, there to await Clark's arrival. Leaving Hsi-an Fu, he marched to T'ung-kuan Hsien, a town situated close to the junction of the three provinces of Shensi, Shansi and Honan. The road, though exceedingly bad and marshy, is very interesting, running a few miles north of, and parallel to a chain of magnificent, and precipitous mountains. At Hua-yi Miao a 


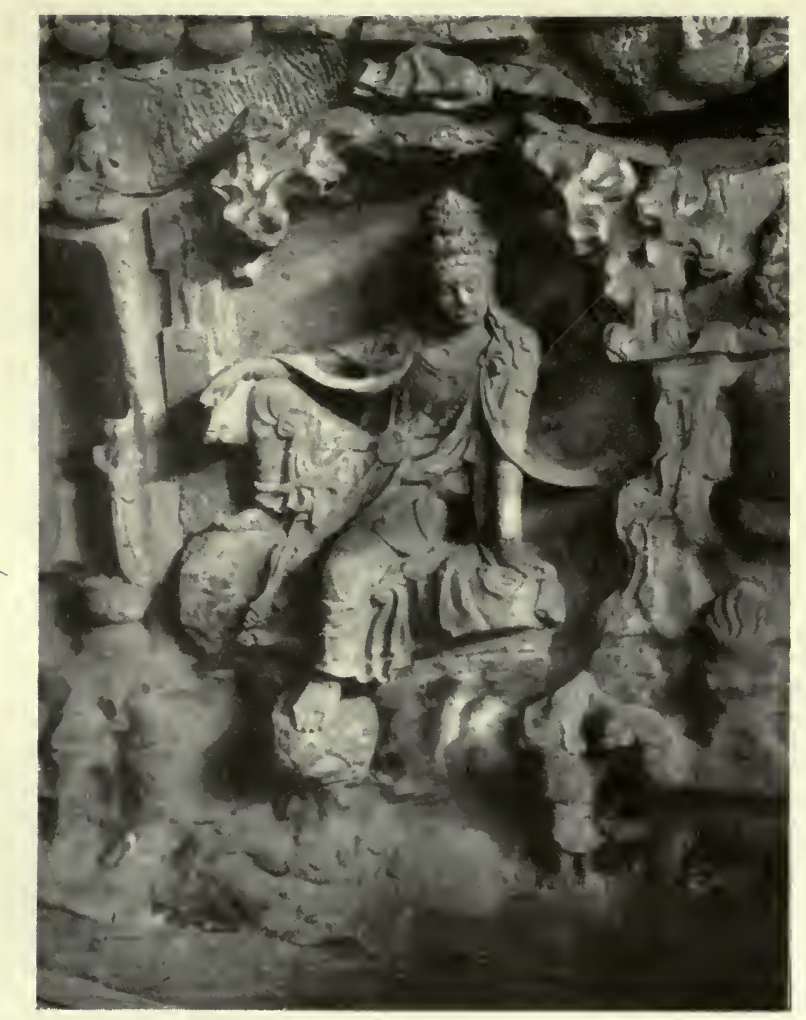

3

o.

"Goddess of Mercy" in the Cave Temple at Yen-an Fu, Shensi.

Seep. 20.

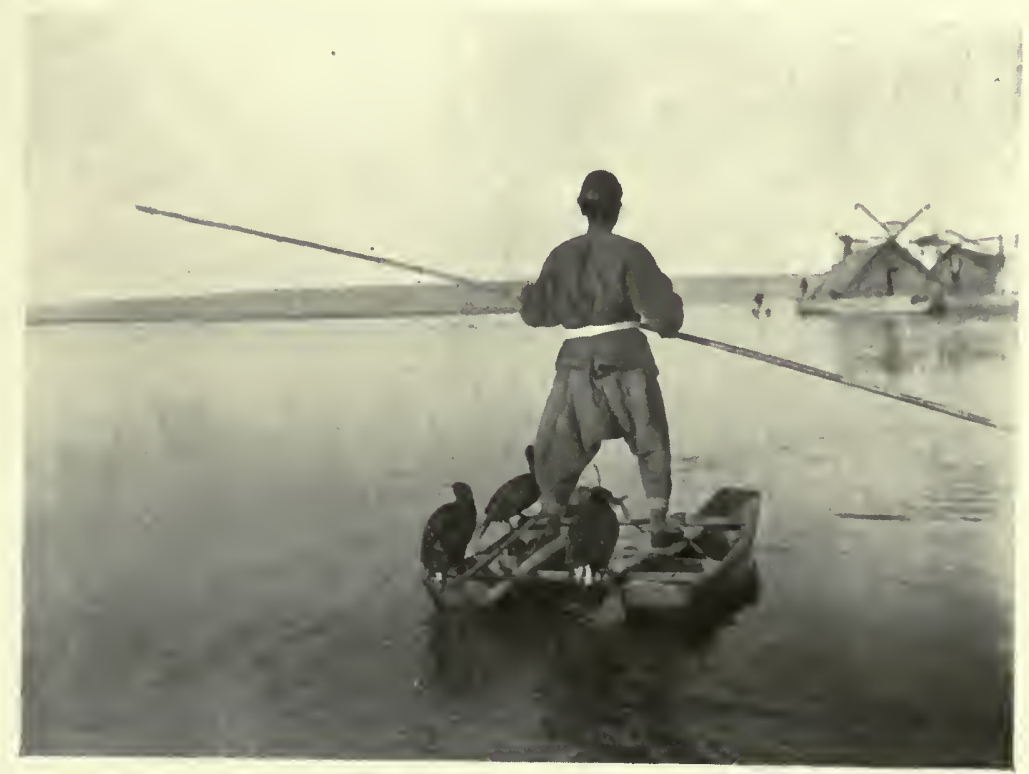

Cormorant Fishi ig on the Wei Ho, Shensi. 


$$
\begin{gathered}
0 \\
0 \\
0
\end{gathered}
$$


palatial temple with gold-tiled roof and beautiful grounds is to be seen, built in the face of a precipitous and castle-like mountain, Hua Shan, one of the five sacred peaks of China," famous as representing Buddha's hand. Indeed, several deep chasms, cutting perpendicularly through the massive square-topped peak, seem to suggest the fingers and thumb of a Titanic hand. Numerous Buddhist temples are perched about its summit, and these form places of pilgrimage for the devout, as well as admirable summer resorts for the wealthy people of the plains. At T'ung-kuan Hsien, the Yellow River, after having flowed southward between the provinces of Shansi and Shensi, turns abruptly to the east. All along the road from $\mathrm{Hsi}$-an $\mathrm{Fu}$ to this point waterfowl of every description were very abundant, and remarkably tame; so much so, indeed, that on one occasion Sowerby was able to ride into a small flock, and bag a goose with a cut of his whip. From T'ung-kuan eastward the road lies along deep, and most disagreeable loess gullies. Dust lies on the surface of the road to a depth of a foot or eighteen inches, the depth of the gullies preventing any possibility of its removal by the wind. The result being that in dry weather it is raised in high, choking clouds by every passing vehicle, and in wet it forms a veritable morass. After experience of both wet and dry weather in the district the opinion may be expressed with confidence that this is the very worst road in North China.

Being, of course, anxious to reach Ho-nan Fu by the date given in the telegram, Sowerby managed to accomplish the last four day's' journey-1og miles-in thirty-six hours; a performance which, considering the state of the roads, speaks well for the endurance of his mount, a typical Manchurian pony of thirteen hands.

Nothing of any particular interest occurred at either Hankow, or Ho-nan Fu. Some difficulty was experienced in obtaining the carts necessary for the transport of the additional stores at Ho-nan Fu, but eventually arrangements were made, and we left this place on April 13 th, and regained $\mathrm{Hsi}-\mathrm{an} \mathrm{Fu}$ on the 24th after an uneventful journey.

* The five Sacred Peaks of China are: Hang Shan, in Shansi; Hua Shan, in Shensi; Sung Shan, in Honan ; Heng Shan, in Hunan; and T'ai Shan, in Shantung. 


\section{CHAPTER VI.}

DESCRIPTION OF HSI-AN FU-CLARK AND SOWERBY'S JOURNEY TO

LAN-CHOU FU.

HSI-AN FU, the Western City of Peace, ancient capital of China, the home and burial-place of many illustrious emperors, lies in a great plain watered by the Wei Ho, a navigable and important tributary of the still mightier Huang Ho or Yellow River. A city of no mean appearance, its extensive walls and massive gate-towers rival those of the modern capital. The population, fixed and floating, is very large; merchants, pedlars, and other travellers of every sort flocking hither from all parts of the empire. The traffic of six great highways pours daily through its streets. The road from Peking, joined at the frontier of the province by that from Honan, enters on the east; a second from the south-east, in which direction lie Hankow and the Han River, with the water-borne commerce of Shang Chou; a third taps the produce of Han-chung $\mathrm{Fu}$ and Ssŭch'uan in the south-west; a fourth enters the western side from Kansu, and its north-western extension, the New Dominion, and from Tibet; a fifth and sixth from the north-west, and north respectively, bringing with them, the former skins and wool from Ning-hsia $\mathrm{Fu}$, the latter the trade of North Shensi, and Mongolia. The unceasing $\mathrm{ebb}$ and flow of wealth from this enormous area places Hsi-an Fu in the first rank of importance as a distributing centre.

The plan of the city differs but little from that of any other large Chinese capital. Outside are the usual extensive suburbs, and within long streets lined with shops, and crossed at intervals by shorter streets; some of the points of intersection being spanned by square, four-arched towers. The most important and central tower in the place, the Ku-lu* (or Drum Tower), is, however, set slightly back from the main street, and astride of one of the cross streets. The open spaces in front of the various Ya-mên are thronged with busy crowds; cooked food of every description is sold and eaten in the streets; and on all sides hawkers display their wares under booths of strawmat or blue cloth. The fat lands round the city produce great quantities of wheat, rice, and cotton. Of these, the last is sent off in wheelbarrows to the railhead t at Ho-nan Fu, whilst the surplus grain is distributed over Kansu and South Shansi.

- Our observations for latirude and longitude were reduced to the centre of the base of this tower.

† The projected railway from Honan-Fu to Hsi-an Fu via Shau Chou and T'ung-kuan Hsien, has as yet only fifty miles of eartbwork under construction, starting from the first-named. 
PLATE 21.

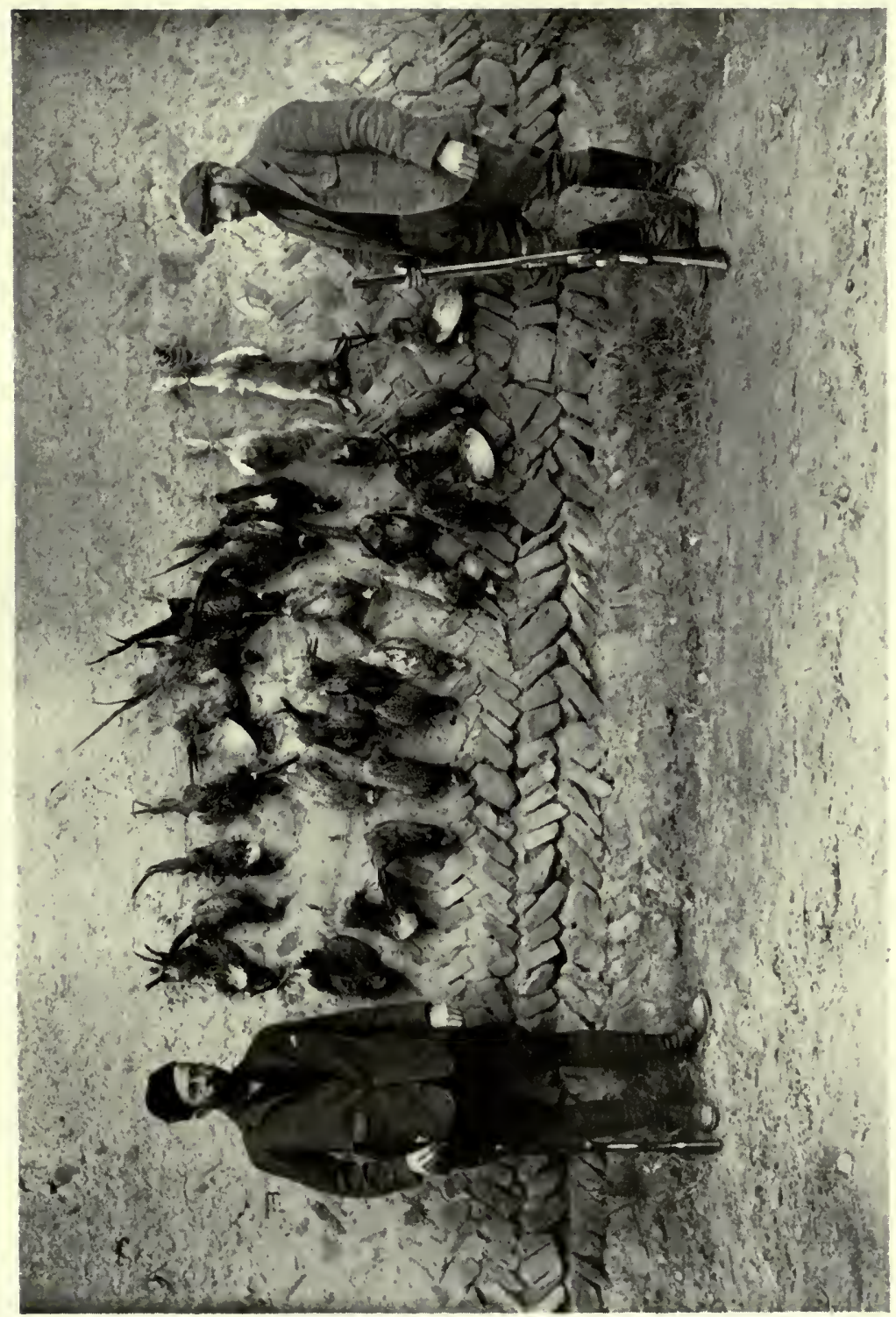

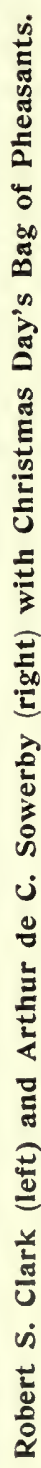


अव

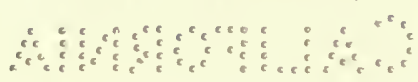


Living in $\mathrm{Hsi}$-an $\mathrm{Fu}$ is extremely cheap, flour being sold at eighteen to twenty cash per catty, or about a half-penny a pound. Vegetables are sold at correspondingly low rates, and even meat is less expensive than in most places further north. Oranges, pommeloes, pears, persimmons, and grapes are particularly abundant, though only the last three are actually grown in the district. The two-first, together with sugar-cane, bamboo-shoots, and innumerable dried luxuries-cuttlefish, mushrooms, shrimps, and sharksfinsare imported at comparatively low prices from the south-east and south-west.

But in the present chapter it is proposed to deal, not so much with the commercial importance of Hsi-an, as with the many interesting relics which are to be found in the neighbourhood, and which bear witness to the former glory and prosperity of the ancient capital. A thorough examination of these. would demand months, at least, of patient research; an adequate description would fill several volumes; so that we must content ourselves with making mention of such objects of archæological interest as were brought to our notice, and setting down any legends or stories about them which came to our ears.

The visitor to Hsi-an, as he travels over the rolling plain from no matter what direction, cannot fail to notice numerous mounds of unusual shape dotted about everywhere like immense molehills, often attaining a height of at least roo feet, and standing on bases of very considerable area. So remarkable are they that he will instinctively seek information concerning them, and will learn that they are the tombs of kings and emperors, and their wives, and of scholars and sages notable in their day. But few indeed have anything in the way of tombstone or epitaph to tell who sleeps beneath the tons of yellow earth; though, concerning some, fantastic legends still linger in the minds of the people. Perhaps the best known of the many hundred mounds that go to make the Hsi-an plain a veritable Royal Cemetery, is the one that marks the burial place of Shih Huang-ti, of the Chin dynasty, the builder of the Great Wall. This mound is situated some twelve or fifteen miles to the east of Hsi-an and close to the small town of Lin-t'ung Hsien, famous for the hot springs already described. This mound differs from the others in resembling a bell-tent, much depressed, instead of a camel's hump, and in being surmounted by a monument. It rises to a height of about thirty feet, and is said to contain vast treasure. The story goes that extraordinary precautions were taken to prevent the rifling of the tomb; special mechanism was devised to secure the vault, and the workmen who constructed it were buried inside. Shih Huang-ti (né Prince Ch'êng) was hated by the literati of his age because 
he ordered the destruction of many classics and other valued books, and eventually, on remonstrance being made, burnt alive 400 of the philosophers themselves. He sought to strengthen the nation by means of martial exercises rather than by increased book-learning, with the result that his countrymen, averse to militarism in any form, remember him with odium to this day. In fact the people living in the immediate vicinity of his tomb still use his name to frighten their children into good behaviour, and as a term of abuse in scoldings and quarrels.

The next mound of more than ordinary interest is situated on a loess rise some six miles south of the city. It contains the remains of Kao-ti the first Emperor of the Western Han dynasty, which lasted from 206 B.C. to 25 A.D. Not far distant, on another prominence in the luess, lies a third mound, wherein rests the Empress Dowager, illustrious mother of Kao-ti, and heroine of a quaint legend. Of humble parentage, it seems that when but a girl she had a dream in which an old man informed her that she would become the mother of an emperor. She told her strange dream to the neighbours; and being spread abroad, it came to the ears of the reigning emperor. With true Oriental cunning, this superstitious but wily ruler hit upon the simple expedient of marrying the woman, who, in due course, presented him with a son. In this way the succession was assured to his family without any opposition being offered to the supposed divine prophecy. As already indicated, the son, although as born of a secondary wife, not the real heir, actually succeeded to the throne, and became the first Emperor of the glorious Han dynasty, and at his death was buried in the spot now marked by a huge mound. Both these famous mounds can be seen from the walls of the city. Before leaving this subject we will refer to the mound which marks the burial. place of the famous Yellow Emperor at Chung-pu Hsien. One of the five semi-mythical emperors of China, Huang-ti*, is supposed to have begun his reign in the year 2698 B.C., and to have continued on the throne for 100 years. Beyond this, little is known of the warrior king. It may be interesting to note that according to our generally received chronology, Noah must have been a comparatively young man-about 250 years old-at the time of Huang-ti's accession. Other mounds contain the remains of emperors of the Western Han and Chou dynasties.

The district further abounds in ancient tablets and monuments of stone, some adorned with beautiful pictures, others studded with characters and

* This monarch is far excellence the Huang.ti (Yellow Emperor) of Chinese history, though all his successors have borne the sanie title. 
PLATE 22.
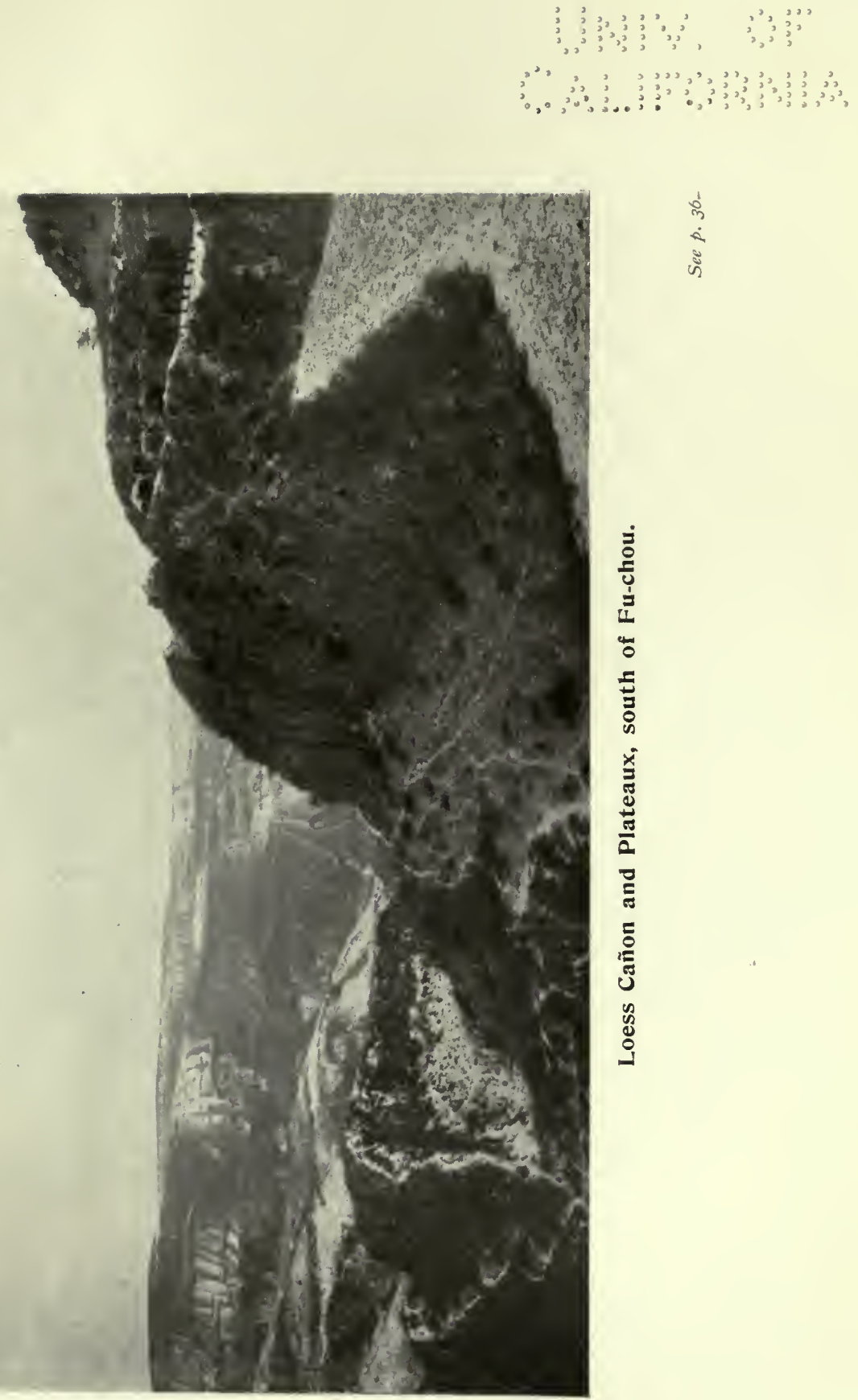
and 
recording interesting historical events. Thus of the many large and beautiful temples within the confines of the city, the famous Pei-ling (Monument Grove) is perhaps the most interesting. Here are preserved over a thousand tablets of stone, on which are carved many of the ancient masterpieces of Chinese brushwork, both literary and pictorial. All styles of writing are represented, many being of extraordinary beauty and quaintness. The temple is a somewhat rambling place, and the tablets are arranged in rows in long halls, or grouped under shed roofs. Others are let into the walls, but these are smaller and would be more liable to unauthorised removal. The place of honour in the grand upper hall is occupied by a large portrait of Confucius, and to this the Chinese who visit the place always make obeisance on entering the hall, or in crossing the pavement that leads up to it. There is a certain dignity in the features of the Oriental teacher, as depicted on the tablet, but it cannot be said to equal several portraits of the sage extant in various parts of China. In the same hall there are full-length portraits of other celebrities and deities. To the left the Goddess of Mercy is shown on a large monument. The artist, in this instance, has succeeded in getting wonderful grace of line in the sweeping curves of the drapery. The typically Indian features, pose, and attire only serve to emphasise the strong influence which that country has had upon the Chinese in religion, culture, and art. A smaller monument near to the sacred Confucian portrait gives a remarkable picture representing a certain Ta-mo (pron. "Dah-mah"), who, according to ancient legends, came from the West about the beginning of the Christian era as the teacher of a new religion. He is supposed to have carried his religion to the Japanese, crossing the sea by miraculous agency on a straw. A picture of the missionary standing on a stem of wheat, which floats on the conventional waves of Chinese art, also stands in the Confucian hall. In both pictures the head is remarkable by its difference from the Mongol type. The abundance of curly hair, the markedly Semitic nose, the thick eyebrows, moustache, and beardall suggest the Jew. From the Rev. F. Madeley comes a tentative suggestion that the original of these portraits and legends was no other than St. Thomas the Apostle, who is supposed to have travelled into Central Asia as a missionary. The name is distinctively suggestive.

Kuan Li (or Kuan Kung), the God of War, is also represented in this wonderful stone portrait gallery. In the accounts of this redoubtable warrior, fact and fiction are so inextricably mingled that it is difficult to know what to believe concerning him. However, it seems fairly certain that, originally a market-huckster (circa I80 A.D.), on becoming a soldier he espoused the cause 
of Liu-pei, towards the end of the second century A.D., and became a national hero. He was canonised in the Iath century, "became in time a tutelary deity" at the end of the I6th century, and was "promoted" to the "rank of God " by the Emperor Wan Li (Ming).

Let into the wall, and immediately behind the Confucian portrait, is a small tablet on which are shown the two sides of a fan. On the one side, amongst reeds and water lilies, stand two cranes, on the other is neatly written a quotation, or composition. The original picture and writings, from which the'cuttings were made, are acknowledged to be the handiwork of the scholarly Emperor K'ang-hsi ; and they certainly attest his ability.

Leaving the grand upper hall, we pass down a roofed pavement, lined on either side with large tablets covered with various writings in every conceivable style of character. To-day some of these even Chinese scholars cannot decipher. Here and there a single large rendering of the character "Fu" (prosperity) occupies the whole surface of a tablet, and is much admired by scholars as the work of some famous scribe. One example, executed with a single continuous sweep and flourish of a large brush, is placed to the credit of $\mathrm{K}$ 'ang-hsi, and is especially valued and admired.

Turning to the right, when about half way along the avenue of monuments, one reaches shortly a large side room, wherein a fine collection of massive monuments are arranged in picturesque confusion, some standing on solid cubical bases, some leaning against the walls or propped against one another. This room seems to be devoted to artistic productions rather than to literary works, and some of the pictures it contains reach a high standard. Particularly is this the case with a large tablet that faces the door; a reproduction of a rubbing from this stone is given in Plate 26, so that a description is unnecessary. On another tablet, of equal size, are given the eight principal views round $\mathrm{Hsi}$-an $\mathrm{Fu}$, a description of each appearing below it. This tablet, and two others bearing quaintly executed representations of T'ai-pei Shan and Hua Shan, two of the five sacred mountains of China, show that scenic beauty appeals to the cultivated Chinese mind. T'ai-pei Shan is a lofty peak lying some days' journey south-west of Hsi-an. It is studded with temples, but extensive and very precipitous, giving shelter to the Tahkin (a peculiar animal, looking like a cross between an ox and a goat), the goral (goatantelope), and other animals of shy and retiring habits. The priests of the temples, and the natives of the district, being good Buddhists, do not chase these animals, which fact no doubt accounts for their presence in great numbers. Hua Shan, as stated in the preceding chapter, is situated close to 
PLATE 23.
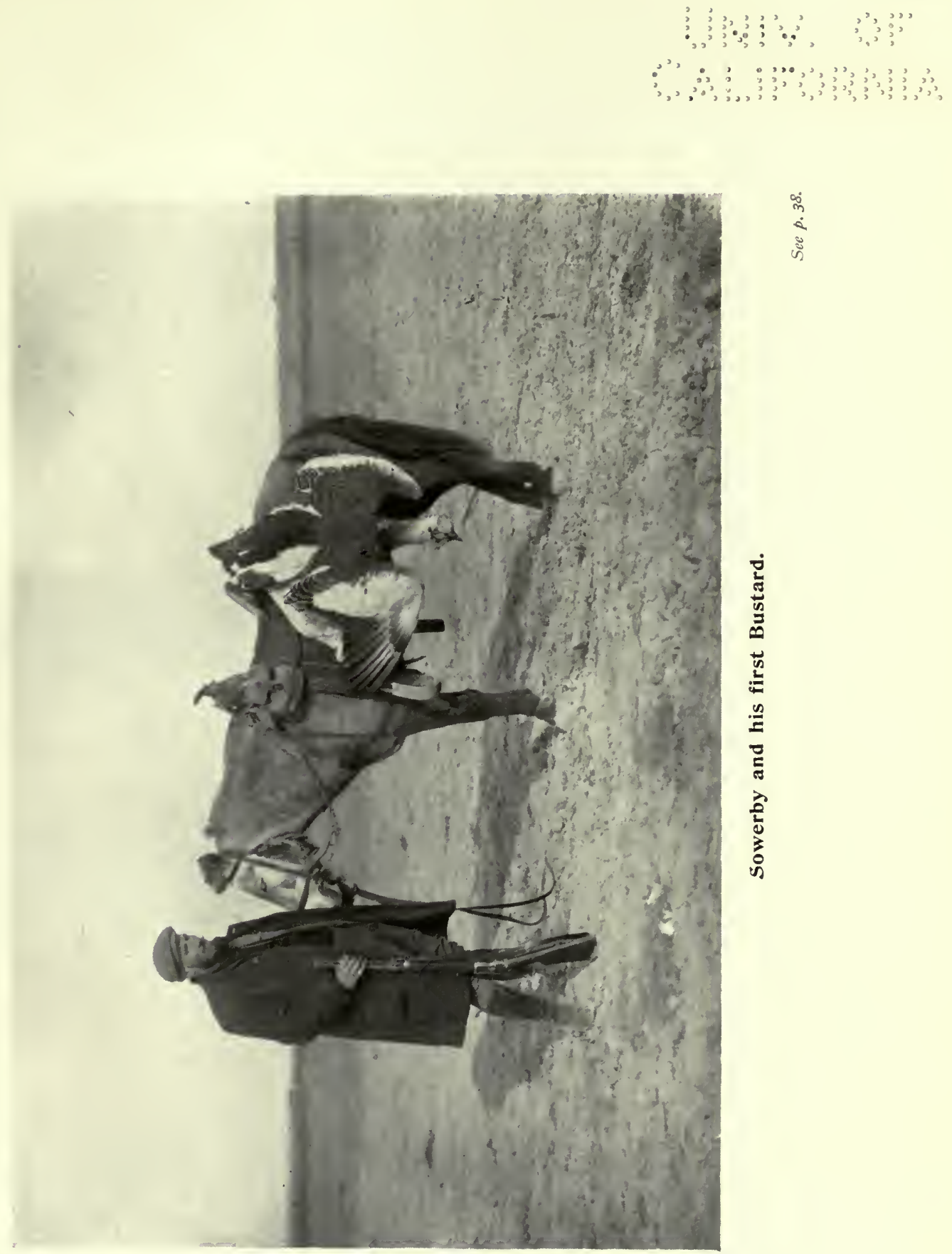

$\infty$
$\dot{a}$
$\dot{\omega}$

 


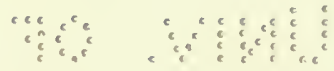

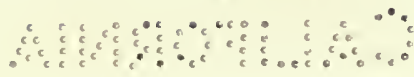


the eastern border of the province of Shensi, not far from T'ung-kuan, and is supposed to represent Buddha's hand. The pictures of both mountains have something of the form of charts, each temple baving its name cut beside it; whilst the paths up to them are marked by dotted lines. Sweeping clouds, mountain torrents, lakes and waterfalls are all represented conventionally, but with wonderful grace.

Our attention is next drawn to what is known as the Kuo-t'ing, a sort of lobby that divides one court from another in large Chinese buildings. Here we find the famous Nestorian tablet,* about which so much has been written. This was erected about $78 \mathrm{r}, A . D .$, to commemorate the advent of Christianity into China in the 6th century, the followers of Nestorius founding a church in Shensi about this period. Up till about two years before our visit, the tablet stood unprotected in the west suburb of the city; but on an attempt being made by a Swedish collector to carry it off for some western museum, the Chinese authorities realised that what was worth removing was worth retaining, and it was placed amongst the other tablets in the Monument Grove. This interesting relic of early Christianity in China stands upon a large stone tortoise and is of considerable size. The combined height of tablet and tortoise must be over ten feet, so that one does not envy the collector the task he had set himself in endeavouring to transport it out of the country. As a matter of fact, this enterprising gentleman had an exact counterpart of the monument made, and this he almost succeeded in getting out of the country; but after endless troubles with Customs officials and others, he dumped it down and left it somewhere along the Yang-tzŭ. The mention of museums recalls a story told by one of the missionaries at Hsi-an Fu. He had bought a complete set of rubbings of all the massive stone monuments in the Pei-ling-one thousand odd, and sent them to a famous museum in Europe. The rubbings were returned with thanks, and an intimation that the originals would be greatly appreciated!

A set of galleries-in many ways the most interesting part of Monument Grove-is next reached. The sixteen classics are here set forth in ordinary caligraphy, written upon both sides of some one hundred and fifty tablets of immense size. These alone would serve to mark the galleries for special veneration and respect amongst all classes in China ; but there are, in addition, many other tablets of interest and renown. What are supposed to be the oldest of Mohammedan monuments find shelter within these sacred walls.

* A very interesting accuunt of the Nestorian tablet is given in "China and Keligion," by Professor E. H. Parker, M.A. 
They are dated 742 A.D. and are specially interesting as giving early Arabic and Chinese history. The Rev. Frank Madeley, for some years resident in Hsi-an, was the first to draw the attention of Mr. Marshall Broomhall (of the Chinese Inland Mission) to the two monuments, and the latter subsequently brought out a book upon them.

The monument Hsia Yü Ch'ü Shui Pi ("How Yü of the Hsia dynasty controlled the flood") is also ensconced within this building. As the description sets forth, it deals with the controlling of a flood by one Yü, who lived in the 2Ist century B.C. The flood referred to was doubtless due to the overflow of the Wei Ho, and to this day the banks of the river have to be carefully watched, continuous earthworks running parallel to its course some little distance from the water's edge. The story goes that the great Yü was deputed by the then ruler of the kingdom to reclaim the flooded lands, and confine the river to its proper course. He showed great devotion to this duty by labouring unceasingly for two years; nor did he once during that time cross the threshold of his home to see his newly-wedded wife. Even when he heard the cry of his infant son, as he passed the house, he refused to enter. $\mathrm{He}$ eventually succeeded in bringing the water under subjection in the year 2286 B.C., and was ennobled. In 2205 he ascended the throne and founded the Hsia dynasty. His death took place in 2107 B.C.; from which it will be seen that he enjoyed a portion of the longevity so common at that period of the world's history. This monument is in the "bird-foot" character, with ordinary Chinese character added where the meaning is known.

A quaint picture carved upon a small tablet and representing a clump of bamboos-the leaves cunningly arranged to form a number of Chinese characters-is supposed to be the work of Kuan $\mathrm{Li}$, the God of War. Close by stands another interesting tablet of about the same size. This has, carved on alternate squares, what seem at first five weird symbols, and paragraphs of descriptive writing. The five symbols are supposed to be maps of the Five Sacred Mountains already mentioned.

The pictures and writings in most cases were executed originally not on stone, but on paper. They were carefully preserved, but in spite of all precautions began to show signs of perishing. Accordingly, the famous and scholarly Emperor K'ang-hsi had the valuable inscriptions and pictures accurately transferred to stone, so that they might be everlastingly preserved to the Chinese people. Thus many of the monuments themselves are not more than 250 years old, though the originals of the writings and drawings preserved upon them are mostly of great age. A fair proportion of the actual 
PLATE 24.
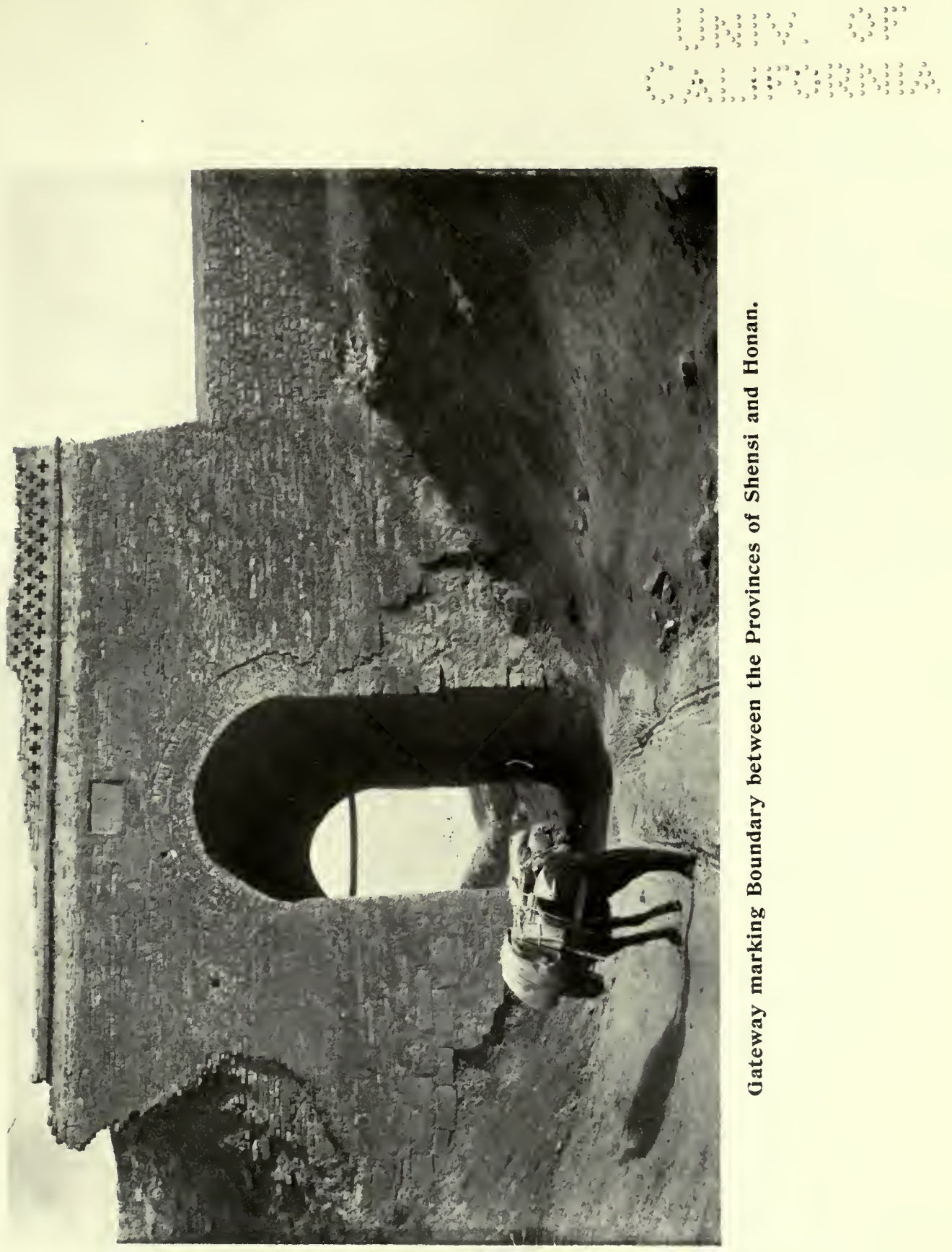
46 min

manas 
monuments themselves are of considerable antiquity, notably the Hsia Yü Ch'ü Shui $\mathrm{Pi}$, the pair of Mohammedan monuments, the Nestorian tablet, and the sixteen classics. The stones are usually oblong in shape, and over six inches thick. In many, the sides have been decorated with beautiful scroll work, showing marked signs of Indian influence. In some of these designs are figures of animals and birds that strongly call to mind the Assyrian sculptures. Especially is this the case with some lions, which bear no resemblance whatever to the conventional Chinese form. For a moderate sum excellent rubbings of all the monuments can be bought from the gate-keepers of Monument Grove, who are moreover ready with any amount of information, accurate or otherwise.

In a large pagoda a mile or so south of Hsi-an are two Buddhist monuments dated the fourth year of Yung Hui, which corresponds to the year 653.4 A.D. of our Calendar. They tell of the visit of a Chinese pilgrim to India to learn what he could of Buddhism; of how, after crossing the Ganges, he studied the language of the country and the new faith; and of his eventual return to Hsi-an, where he was loaded with honours. The stones further relate how he translated 250 Buddhist books into Chinese; but perhaps their date is the most interesting feature, coming as it does within a year or so of a date upon the Nestorian tablet. This seems to suggest that Christianity and Buddhism may have reached parts of China almost simultaneously.

A few other monuments or tablets may be noticed here, though they cannot be said strictly to belong to Hsi-an Fu. Two of these form a pair near Chou-chih Hsien, a small town situated at the foot of the Middle-South Mountains (Chung-nan Shan), fifty miles west of $\mathrm{Hsi}$-an. On these monuments are inscribed the whole of the Tao-tei-ching, the Taoist classics. At Yao Chou, a large town some fifty miles north of Hsi-an, is a broken Buddhist tablet dated 529 A.D. This is one of the oldest monuments in the district, but is otherwise of no great interest. There are besides, tablets, though of no very ancient date, cemented into the walls of the buildings within the grounds of the hot springs at Lin-t'ung Hsien, and testifying to the healing properties of the waters.

At Hsi-an we were detained some days by the necessity of taking astronomical observations, but by May 6th we were once more on the road to Lan-chou. After clearing the western suburb and traversing some ten miles of low-lying country, we once more crossed the Wei Ho, and stopped the first night at Hsien-yang $\mathrm{Hsien}$, which lies on the bank of that river. About three miles from this town the road begins to ascend a series of loess steps, and from 
there onward steadily rises till it reaches an altitude of nearly 9000 feet at the summit of the Yung-yao Pass to the west of P'ing-liang Fu (Kansu). These mountains make a formidable barrier and can only be negotiated with great difficulty. The eastern slope is about three miles in length, in which distance it rises about 3000 feet. To accomplish this ascent, each cart needs about treble its usual number of mules, and several carters have to combine to help one another, their wretched animals being forced to make the heart-breaking journey two or even three times during the day. Not infrequently a caravan will spend the whole day in getting across this difficult pass. The severity of the strain on the animals may be gathered from the innumerable skeletons that litter the slopes close to the road. The difference in temperature between the eastern and western slopes of these mountains was very noticeable. On the eastern side foliage was well advanced; the valleys and ravines were filled with dense bushes already in full leaf; the slopes were covered with scrub in an equally advanced condition; whilst the trees that lined the roads had assumed their summer livery. The western side presented a very different aspect; the slopes, valleys, and ravines were almost nude; no green was to be seen; a few straggling trees stood bare and brown in the bottoms of the hollows. In crossing the pass the travellers had stepped from a beautiful country, rich in animal life and sylvan scenery, into a dry, cold, and barren wilderness.

At a small village about five days journey from Hsi-an, we came across a temple of the T'ang dynasty, Ta-fu-ssŭ (Great Sage Temple). This consists of a cave close upon seventy feet high, and proportionately wide and deep, in which sits a colossal Buddha placidly contemplating the eternal cycle of things, and supported on either side by gigantic attendant deities. The figures, as well as the cave itself, have all been hewn with infinite labour out of the solid cliff. This temple had been repaired recently, and the figures were covered with plaster and gorgeously painted. It is possible to view this Buddha from three different points; the ground floor, a balcony at about half the height of the figure, and a second balcony on a level with the face. From this last a photograph of the face was obtained, and is reproduced in this volume.

It may not be out of place here to mention another temple of the same dynasty lying some six miles south of Ho-nan Fu, and known as Lung-k'ou Miao (Dragon's Mouth Temple). This consists of a series of large caves in the side of a deep gorge cutting through a range of low, rocky mountains. Within the caves are large images of Buddha, and attendant sages, all hewn 
PLATE 25.
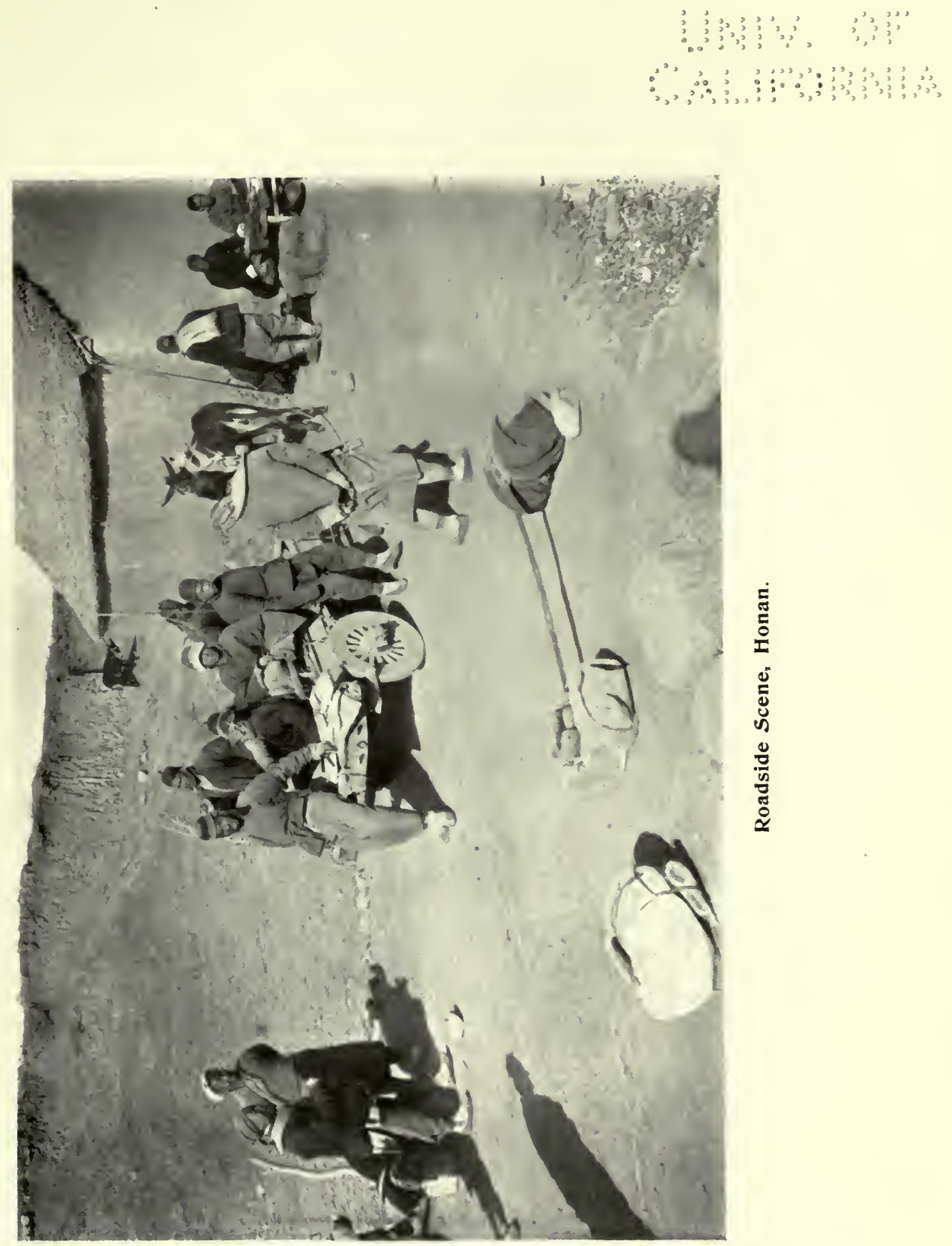


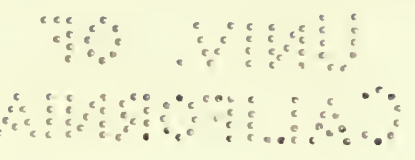


from the solid rock. The Buddhas, seated as usual on lotus lily pedestals, must be from twenty-five to thirty feet high, whilst the figures grouped around, all of which are standing, must be from twelve to eighteen feet.

All the figures in both these temples are exceedingly ugly and illproportioned, in strong contrast to the beautiful statues found in the Sung dynasty temples of a later date round Yen-an $\mathrm{Fu}$, and in north-central Shensi generally. Other points of difference between temples of the two periods are that the T'ang temples are much higher, and contain fewer but larger figures; on the other hand the Sung temples have their walls lined with innumerable little images of Buddha carved out of the rock. It would seem as if at the earlier date the idea of multiplying images of Buddha, as an act of merit, had not been developed, though what may be regarded as the germ of the later idea is traceable in the Lung-k'ou Miao by tablets and slabs of rock, on which have been carved in low relief rows of little Buddhas an inch or so in height. It is interesting to note that the idea of excavating Buddhist temples from solid rock cliffs and mountains seems to have originated in India. The mouths of these caves are usually built up with beams, bricks, and mortar, and afterwards finished with tiling to form the roofs, verandahs and balconies, in imitation of the fronts of ordinary temples.

But little of interest happened to us during our march to Lan-chou. We found the inn-keepers more artful and cunning than further north; certainly more sophisticated than a man near Yü-lin $F u$, who had run after us for three miles to enquire if we had taken his dish-cloth. At one place on this road we noticed a sediment in some hot water supplied to us; this the inn-keeper tried to explain away as "only a few millet grains." But on being crossexamined he admitted that he had put the millet in on purpose to disguise the sediment, or at least to have an explanation ready. $\mathrm{He}$ was outdone, however, by another man who, on being asked for tea, gave us what seemed to be hot water with some grains and bits of stick in it. The sticks he described as "mountain tea." On being asked for millet gruel, he pointed to the grains, "This is millet gruel." On being asked for hot water, he again pointed, "This is hot water"; thus keeping one fluid to meet all requirements. It was certainly as much like one as another.

This road from Hsi-an to Lan-chou has been described in detail by other travellers, and consequently requires but little description here. It runs through Hsien-yang Hsien, Li-ch'üan Hsien, Ch'ien Chou, Yung-shou Hsien, Pin Chou, Ch'ang-wu Hsien, and, passing into Kansu, traverses Kan-chou Fu, P'ing-liang $\mathrm{Fu}$, Ching-ning Chou, and then viâ Hui-ning and An-ting (vide pp. 58, 59). 
For the greater part it is lined with rows of lofty trees, limes, elms, and poplars. The majority of these were planted by General Ma's troops after they had quelled the Mohammedan rebellion; hence the road is known as "Ma's Avenue." The notorious Tung Fu-shang similarly planted with trees many of the parts neglected by General Ma. Needless to say in a country so barren as the greater part of Kansu, these trees afford an inestimable boon to the jaded traveller. There are, of course, some pleasant spots along this wearisome highroad, such as the eastern slopes of the Yung-yao Pass, and the country adjoining the Yung-shou Hsien Pass, about four days' journey from Hsi-an Fu ; but for days together the traveller may see nothing but bare, brown hills, and dry, stony valleys. The country from Ching-ning Chou to Lan-chou $\mathrm{Fu}$ was suffering from a protracted drought. The natives said that insufficient rain had fallen for three years. The dust was terrible, and it was with no little satisfaction that we arrived at the end of our nineteen days' journey, to find the other members of the expedition, whom we had not seen for months, comfortably ensconced in a pleasant garden outside the walls of Lan-chou. 
PLATE 26

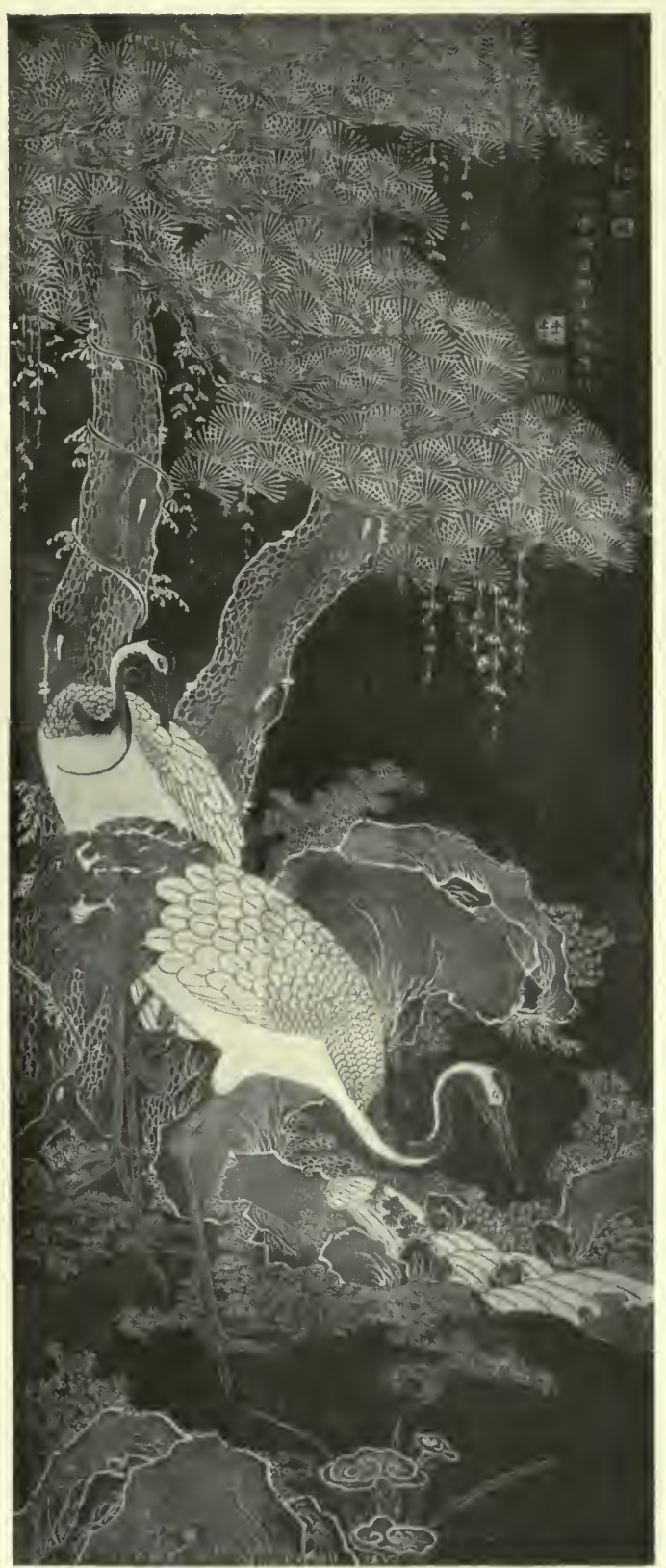

Rubbing from Tablet in the Pei Ling (Monument Grove), Hsi an Fu.

See p. ps. 
ar a

and 


\section{CHAPTER VII.}

MARCH OF DOUGLAS AND GRANT TO LAN-CHOU-DESCRIPTION OF LAN-CHOU FU.

THE other division of the expedition, under Captain Douglas and Mr. Grant, had left Yen-an Fu on January 3oth, and moving by easy stages and with halts of varying duration, reached Lan-chou on April 6th.

Following the same road as Clark and Sowerby as far south as Fu-chou, the caravan then turned westward, ascending almost immediately a long slope which led up to some loess plateaux similar to those encountered by the others to the east of that town. Ch'ang-ts'un-yi, distant from Fu-chou some I $7 \frac{1}{2}$ miles, was the first halting place reached after that town was left on February 5th. The road, owing to frozen snow and steep gradients, was very bad. Bustard were seen on the plateau, but none were secured.

After resting a day at Ch'ang-ts'un-yi, the march was resumed and Hai-shui-ssŭ was reached on February 7 th. This place is nearly seventeen miles from Ch'ang-ts'un-yi and is situated in an open fertile valley at an altitude of a little over 3000 feet. The journey was accomplished without difficulty as the road was good. A narrow plateau, reaching an altitude of 3600 feet, was crossed during the day; but elsewhere the road wound up and down ravines and valleys, all of which seemed to unite towards the south. The population of Hai-shui-ssŭ seemed to be about two hundred and fifty.

On February gth, the border line between Shensi and Kansu was crossed soon after leaving Hai-shui-ssŭ. After travelling for twenty miles along a good road through a well wooded country, the caravan reached T'ai-pei-ch'êng, a dilapidated village containing scarcely a hundred souls. All along the road lay ruined and deserted villages-results, it was ascertained, of the Mohammedan rebellion, and the great famine. Most of the people now in the district were found to be from Ssŭch'uan, and they, but recent settlers, had not yet effaced the terrible marks of these ravaging influences. Miao-ts'un was reached on February IIth, after a journey through very wild, heavily-wooded and almost deserted country. The timber was not large, showing that it had only been allowed to grow from a comparatively recent date. The distance between this village and T'ai-pei-ch'êng was, by roadwheel, seventeen miles. Hazrat Ali shot two roedeer in this country, and other game was plentiful. 
The expedition continued its westward march on February 14 th, and after crossing a pass at an altitude of over 5000 feet, and descending into a steadily widening and very fertile valley, reached the small walled town of Ho-shui Hsien. The hills on either side of the road were covered with scrub, and but few villages were seen. The road, since leaving Ch'ang-ts'un-yi, had been excellent for mule traffic, whilst the country consisted of loess, with here and there signs of carboniferous bed-rock. There was plenty of water, perennial streams, now frozen over, flowing at the bottom of each ravine, and in every valley. This last stage was nineteen miles. The following day Ch'ing-yang Fu was reached after a journey of over twenty miles through a terraced loess country, which, however, showed few signs of cultivation, and was but sparsely populated. There was every evidence that Ch'ing-yang $\mathrm{Fu}$ had been at one time a fine and prosperous city, but its population had fallen victims to a massacre in the Mohammedan rebellion, and the place had never regained its former importance, containing now at a liberal estimate not more than rooo inhabitants. A halt was made here till February 2Ist, when the journey westward was resumed. Pai-ma-p'u, a miserable village situated on a plateau, was reached that night after a march of fourteen miles through poor country. On the following day Hsi-fêng-chên was reached, and here a halt was made till February 25th. The distance between this and the last stopping-place was twenty-one miles along a good cart-road lying over the loess plateau. Many bustard were seen, and Grant secured one at long range.

On February 25th, the journey was continued still over similar country till T'ai-pei-ch'êng was reached, this being the second village of that name met with in Kansu; it is about sixteen miles from Hsi-fêng-chên. Chên-yüan Hsien, the next halting-place, was reached on February 27th after a journey of fifteen miles, again over loess plateaux, on the western limit of which the town is situated. It is decidedly more prosperous than any of the places passed by the expedition since leaving Fu-chou in Shensi, and contains a Protestant Mission Station. Between Ch'ing-yang Fu and Chên-yüan Hsien runs a cart-road, which, although not very good for carts, is excellent for mule traffic. From Chên-yüan it goes southward to P'ing-liang Fu.

After one day's stay at Chên-yüan, the expedition continued its journey towards Lan-chou. Yang-shu-wan, situated at an altitude of about 5300 feet, was reached on March Ist. The country passed through looked much more prosperous, and the land was all under cultivation. The road was good, so that the twenty-one miles between this village and Chên-yüan were accomplished in good time, the usual loess hills being encountered. Owing to the 
PLATE 27.
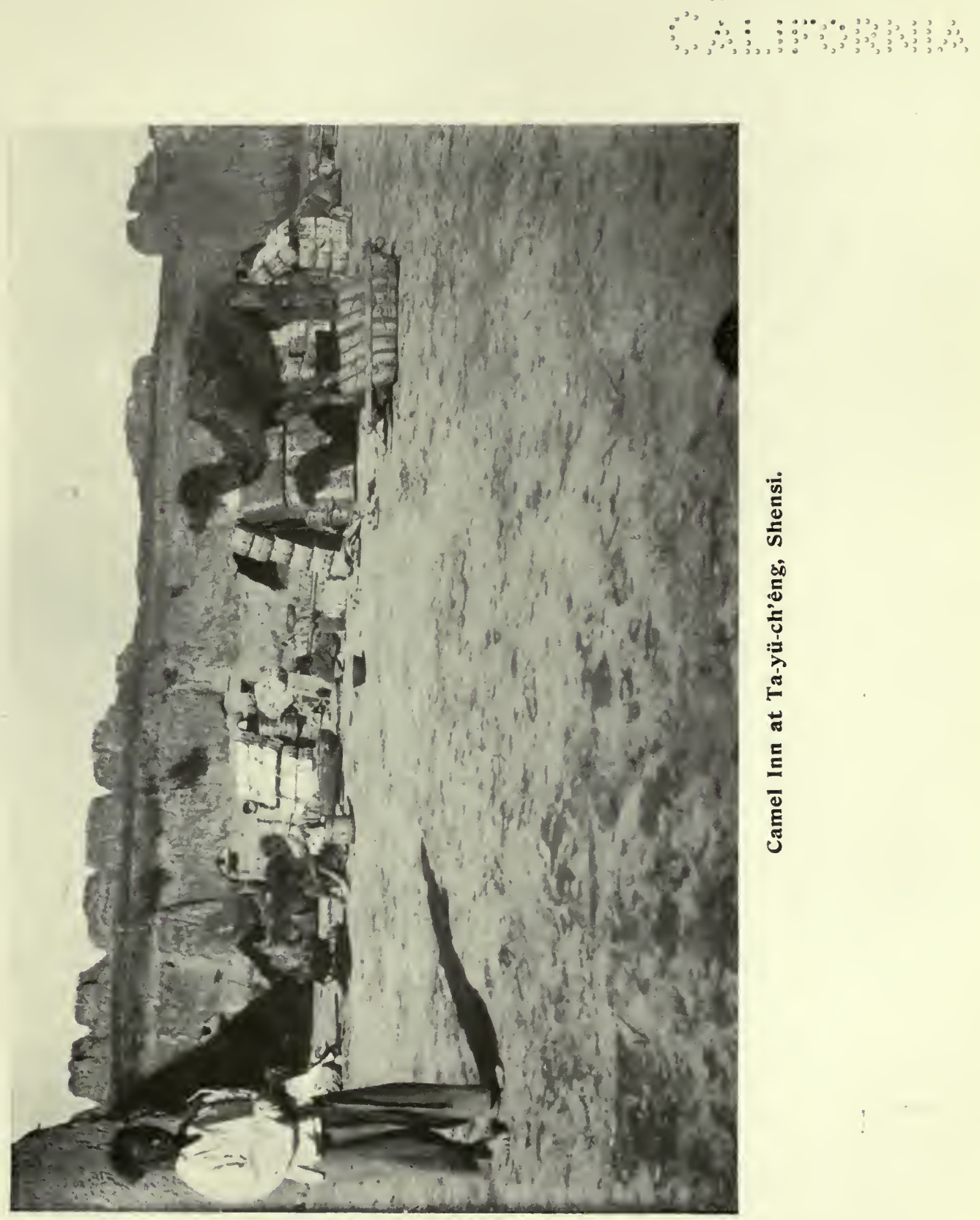


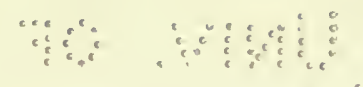

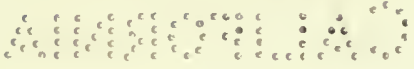


melting of the recent heavy snows, the Chien-tsai Ho, up the right bank of which the caravan travelled all day, was slightly in flood, and the current was rapid, flowing at about six miles an hour.

On March $3^{\text {rd }}$ Liu-chia-hua was reached, a village situated another eighteen miles up the same valley. The road, though good, was very winding in its course, whilst the country was prosperous-looking and well cultivated. Leaving Liu-chia-hua on March 5th, the caravan continued up the valley for fifteen miles, finally reaching a small village named Jên-sa-ho. From here a high range of mountains could be discerned stretching away to the south. The following day a loess pass of some 7600 feet was crossed, and a descent made into Ku-yüan Chou. This large and prosperous town is situated close to the hills, and at the commencement of a somewhat extensive plain. Away to the south can be seen the massive peaks and ridges of the Liu-p'an Shan, whilst to the north and west the country rises very gradually into loess hills. The population of this town must be close upon 5000, and it is the distributing centre of a large area; its prosperity being due to the large number of Mohammedans, both in the town itself and in the surrounding district. The expedition rested here till March I6th, comfortable quarters having been found in the suburb outside the south gate. The town is about fourteen miles from Jên-sa-ho and has an altitude of about 6300 feet.

On leaving Ku-yüan, the travellers encountered country which differed considerably from anything they had yet traversed, either in Shensi or Kansu. The road for the first few miles lay in a south-westerly direction, slowly ascending to the foot of a rocky ridge. Crossing this ridge, the caravan descended into a narrow valley running in a southerly direction between two other high and rocky ridges. For some miles the road slowly ascended the valley, which grew steadily narrower, ending finally in a low pass. The sides of the valley were very precipitous, ascending to the height of some thousand feet above the road. There was a certain amount of vegetation, but for the most part the highest slopes were covered with grass only. After crossing the pass the caravan followed a ravine, which extended in a south-westerly direction. The sides of this ravine were lower than those of that previously ascended, whilst rich, red earth took the place of the limestone hitherto encountered. To the east could be seen a chain of high, rugged and snowcovered mountains extending in a south-easterly direction. There was now more vegetation along the roadside, and the slopes of the red-earth hills were under cultivation. At last the ravine widened out, and a small village situated within and below the remains of an old garrison town was reached. This was 
Ch'ang-yi-p'u, about twenty miles from Ku-yüan, and containing perhaps a score of tumble-down houses. To the north and south ran ridges of high rounded hills, and eastward the massive peaks of the Liu-p'an Shan rose to an altitude of 10,000 feet. The country opened out to the west into a wide and fertile valley, bordered by comparatively low loess hills.

On March I8th the descent was continued down the wide valley to the west, and after fourteen miles of pleasant, well-cultivated country had been traversed, Ch'ang-t'ai-p'u, a pretty walled village, was reached. Here the houses, though small and built mainly of sun-dried bricks, were in good repair, and the inhabitants looked prosperous. Once more the loess country had been reached, and only in the watercourses were there any signs of the rocky country just traversed.

The next stage-a long one of twenty-four miles-brought the travellers to the large and busy walled-town of Ching-ning Chou. Just before this town was reached, the valley, which had been followed in its south-westerly direction from Ch'ang-t'ai-p'u, narrowed down to a deep gorge winding through a ridge of limestone. The villages passed through during the day were mostly Mohammedan, and were all prosperous-looking places, whilst the population of Ching-ning could not be less than 5000. Two days were spent here and on March 23rd the march to Lan-chou was resumed. At this point the road hitherto followed joins the great highway from $\mathrm{Hsi}$-an $\mathrm{Fu}$ to Lan-chou $\mathrm{Fu}$, so that the expedition was no longer traversing regions hitherto unexplored. The road from $\mathrm{Ku}$-yüan Chou to Ching-ning Chou is suitable for wheeled traffic, and a considerable number of carts were passed. In places the going was a bit rough, but no heavy gradients exist, and the route is excellent for mule transport. The country west of Ching-ning consisted for the most part of high loess mountains, and was very barren, though everywhere the surface showed signs of actual or recent cultivation. The natives complained of the want of rain, and were very poverty-stricken. Immense cañons winding through vast deposits of loess were noticed frequently. Sometimes the road would follow one of these, and at other times it would lie over the top or along the ridges.

On the first day after leaving Ching-ning, a pass of about 7500 feet was crossed, the caravan subsequently finding quarters in a village named Ching-chia-yi after a march of twenty-three and a half miles. Many villages were passed during the day's journey, but none were very large or important. On March 25th Hui-ning Hsien was reached after a hard journey of nearly twenty-six miles. This town is used as an exile-station, and although of 
PLATE 28.
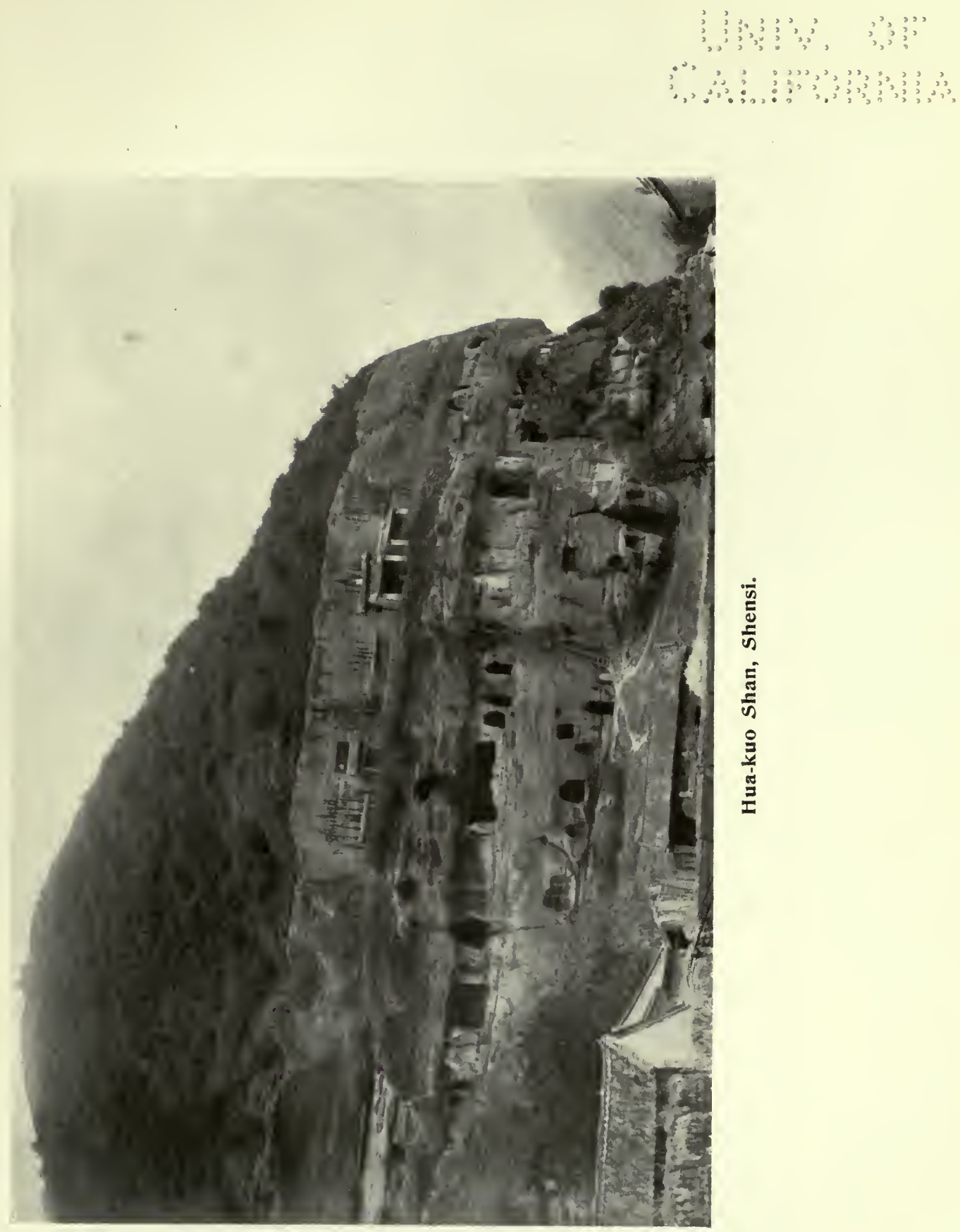
ㅈa

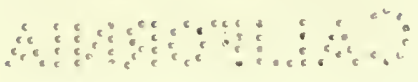


considerable extent is almost in ruins, the population not exceeding 500 all told. On March 27th Hsi-kung-yi was reached, after a short day's journey of fifteen miles. The country passed through was entirely of loess, and no bed rock was seen, though the bottom of a deep cañon, up which the road lay, was noticed to be full of boulders, cobbles, and gravel, all of which had evidently been brought down by water from high mountains somewhere to the west.

Soon after leaving. Hsi-kung-yi the caravan ascended the high loess mountains called Ching-liang Shan, and for some time continued along ridges of the same. In places, outcrops of rock explained the existence of the boulders and cobbles noticed on the preceding day. Towards the end of the day and after a long descent into a wide valley, a large walled town named An-ting Hsien was reached. This place is situated seventeen miles from Hsi-kung-yi, and has a population of about 3000. During the day's march many carts were encountered laden with waterpipe tobacco. Heavy snow was experienced during the forenoon, rendering the road, which was otherwise good, very slushy.

On April Ist the caravan left An-ting Hsien, and after travelling for seventeen miles over a good road through the usual loess valleys, put up at a small place named Ch'eng-k'ou-yi, the population of which was estimated at about 200. The inns being very bad, the travellers availed themselves of the privilege of stopping at the official rest-house. The following day the journey was continued; the road gradually ascending till an altitude of 8000 feet was reached. From this point high mountains could be seen to the south and south-west. The road then followed the top of the ridge for a distance of seven miles; the slopes on either side were very steep, whilst the ravinebottom was judged to be a thousand feet, or more, below the road level. The ridge was composed chiefly of very hard and compact loess, though rock was noticed occasionally further down the slopes and along the beds of the ravines. Just before reaching Kan-tsao-tien - a prosperous-looking village some fourteen miles from Ch'êng-k'ou-yi-the caravan made a sharp descent from the high loess ridges into the valley. The road traversed during the day was, in places, very bad, especially for cart traffic. The slopes on either side were all under cultivation.

On April 4th, after crossing a low spur of loess, and travelling for some distance along a wide stream-bed, thickly strewn with cobbles and boulders, the caravan reached Hsiao-shui-tzŭ, a little village perched upon a rocky cliff on the south bank of the Yellow River. The stream, whose course had been 
followed most of the day, joins the river close to this village, after forcing its way through a thick layer of rock. At this point too, the Yellow River itself cuts deeply through the thick layer of igneous rock-its course being very tortuous, and the current swift. Immediately on leaving Hsiao-shui-tzŭ it turns northwards, continuing its way through a series of much contorted hills of igneous and water-formed rock. This day's march was found to be twentysix-and-half miles.

The following day Lan-chou $\mathrm{Fu}$ was reached after a journey of fifteen miles along dusty roads, lying for the most part over loess and sandstone hills. Three miles from Lan-chou, the road descends into a wide valley through which flows the Yellow River. The country here looked very deserted, the high loess hills on either side of the valley being bare of vegetation, whilst the valley itself presented the appearance of a sandy waste, thickly covered with graves. Notwithstanding the desolate appearance of the place, the travellers were heartily glad to have reached the end of their long overland journey. It was difficult to find quarters, all the inns being wretchedly small and dirty. Visits were made to many places, including a beautiful temple situated a little to the east of the city at Lien-hua-ch'ih (Lotus Flower Pool); and eventually the summer residence of a wealthy native family was engaged. In the pavilions of its lovely garden ample room was found for all the members of the expedition, and they settled down to await the arrival of Clark and Sowerby, with the supplies and extra outfit. necessary for the intended extension of work along the Tibetan border.

The city of Lan-chou Fu is of considerable size and importance. It is situated on the right (south) bank of the Huang Ho, at the point where the great high road into Chinese Turkestan crosses that river. Its population has been estimated at half-a-million, several sections having been built on to the western wall to take in and protect the buildings forming an overflow outside the main city. The streets, which at the time of our visit were being macadamized, are narrow; the houses well-built and very closely packed. The walls and gate-towers are in excellent repair, though several salients guarding the western approaches of the city have been allowed to sink into disrepair. The chief industries carried on are the manufacture of waterpipe tobacco, for which Lan-chou is famous all over China, and the curing of furs brought in from the west. Gold and silversmiths and jade-merchants do a good trade, whilst curio shops are very numerous.

The valley in which Lan-chou is situated is of comparative fertility, due mainly to the supply of water readily obtainable from the Yellow River. For 
PLATE 29.

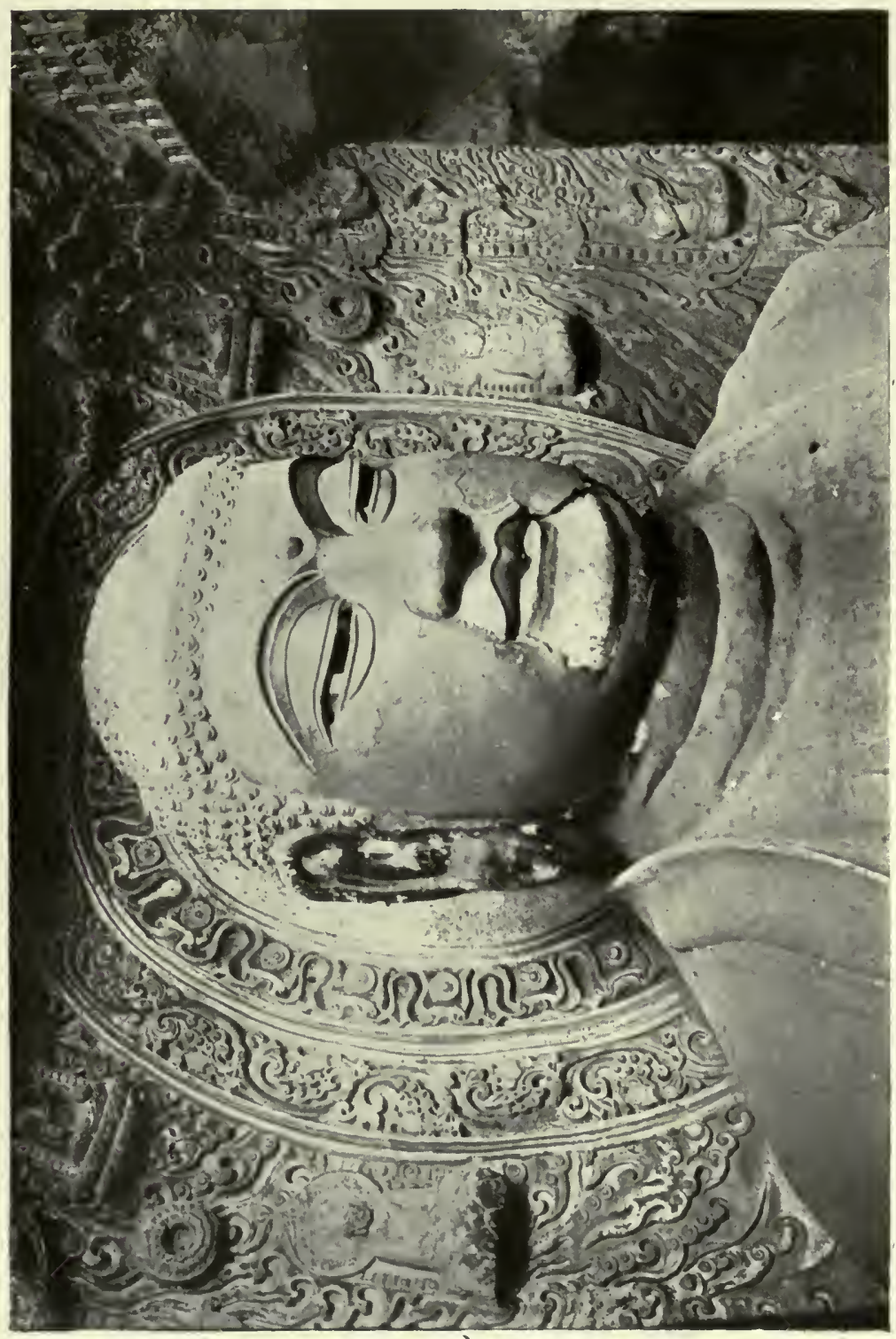

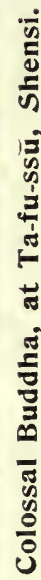




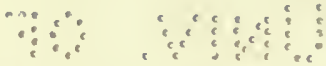

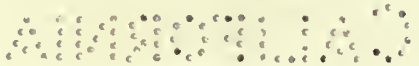


purposes of irrigation the farmers resort to the method prevalent in Ssŭch'uan; immense wooden wheels with buckets attached are placed so that the current of the river causes them to revolve; the water is thus automatically carried up in the buckets, and being emptied into troughs flows into canals thus fertilising the thirsty fields, which would otherwise be of necessity useless. A considerable amount of opium is grown in the valley; tobacco, vegetables, and a little wheat forming the rest of the crops produced. Immediately adjoining the city are some fine orchards, one of which was within the grounds of our residence. For the rest, the surrounding countrysave for perennial streams along the ravine-bottoms-seems to be utterly dessicated and sterile; indeed, Europeans who have been long resident in the district state that the desert is approaching slowly but surely from the north, and engulfing the country. Of the truth of this there can be but little doubt, and were it not for the Yellow River, Lan-chou would certainly cease to exist. The river, at this point some 300 yards wide and 25 feet deep, was formerly crossed in summer by means of an extensive but very shaky pontoon, liable to breakage in the rainy season by any more than usually heavy rush of water. An iron bridge was in process of construction during our visit, and was completed at the end of the same summer, so that the old boat-bridge is now a thing of the past. Great anxiety was felt by Mr. Coltman, the engineer in charge, as to how the bridge would stand the severe strain of the autumn floods; but though the rains, which commenced in July, were the heaviest that had been experienced in the district for many years, and the river in consequence rose far above the usual high-water-mark, the well-planned and strongly-built structure stood the test, and remains a fine example of modern engineering skill.

We saw the first samples of woollen cloth produced in Lan-chou. More than thirty years ago, Tso Ching-t'ang, an official of the city, had decided to start an industry in the manufacture of woollen goods. All the machinery necessary for a large factory was bought and transported overland from the sea-coast at great cost, only to be dumped down and allowed to rust on reaching its destination. Rockhill (author of "The Land of the Lamas") speaks of seeing the chimney of the wool-factory at Lan-chou, which was at that time (1888) abandoned. It is only quite recently that an official, more enterprising than his predecessors, has engaged European experts, and completed the building of the factory and the installation of the machinery. The Belgians employed in this have had their work cut out, but after untold labour they have succeeded in getting everything into working order. The 
wool itself is certainly on the spot, and it will be interesting to see whether the enterprise succeeds, or fails, as all other large financial speculations undertaken and controlled by the Chinese have hitherto done. Lan-chou $\mathrm{Fu}$, though throbbing with life and energy, owes its importance, not to any of the industries already mentioned, but to its geographical position and official rank. It forms the regular stopping-place and exchange for a vast amount of traffic, and countless commerce-laden caravans, situated as it is at the point where the main road from Sinkiang, Western Mongolia, Northern Tibet, and Siberia enters China proper. The administrative area of Lan-chou is greater than that of any other Chinese city except Peking. Its Viceroy controls an area of over 750,000 square miles, embracing the whole of Sinkiang, as well as Kansu and Shensi, or Shen-kan (as the two provinces in combination are called), and containing a population of about twenty millions.

The population of Lan-chou Fu is largely made up of Mohammedans, who are viewed with suspicion by the officials. In theory they are not allowed to reside within the walls of the city, but only on the north bank of the river. This regulation, like so many other laws and regulations in China, is practically a dead letter. Since the quelling of the Mohammedan rebellion in I878, Sinkiang, or "The New Dominion" as Chinese Turkestan is called, has been rapidly peopled with settlers from other provinces, and is in consequence steadily increasing in importance, and in trade with China generally, and with Siberia.

No place in China offers better opportunity than does Lan-chou of studying and comparing the various types that go to form the great Celestial Empire. The heavily-built Mongol rubs shoulders with the wild and savagelooking Sifan (Tibetan), or the Turco-Mongol from Kashgar; here a Chinaınan from one of the southern provinces, easily distinguishable by his short stature, slight figure, and sallow skin; there a man from Ssŭch'uan, with characteristic turban surmounting the equally characteristic moon-face. A Kansu Mohammedan with long curly beard, and clear-cut features, may be seen haggling with a broad-nosed, dull-faced native of the province; or a hotheaded, rowdy carter from Honan, quarrelling over two grains of sorghum found in a manger, with a placid, but canny Shansi muleteer. 
PLATE 30.
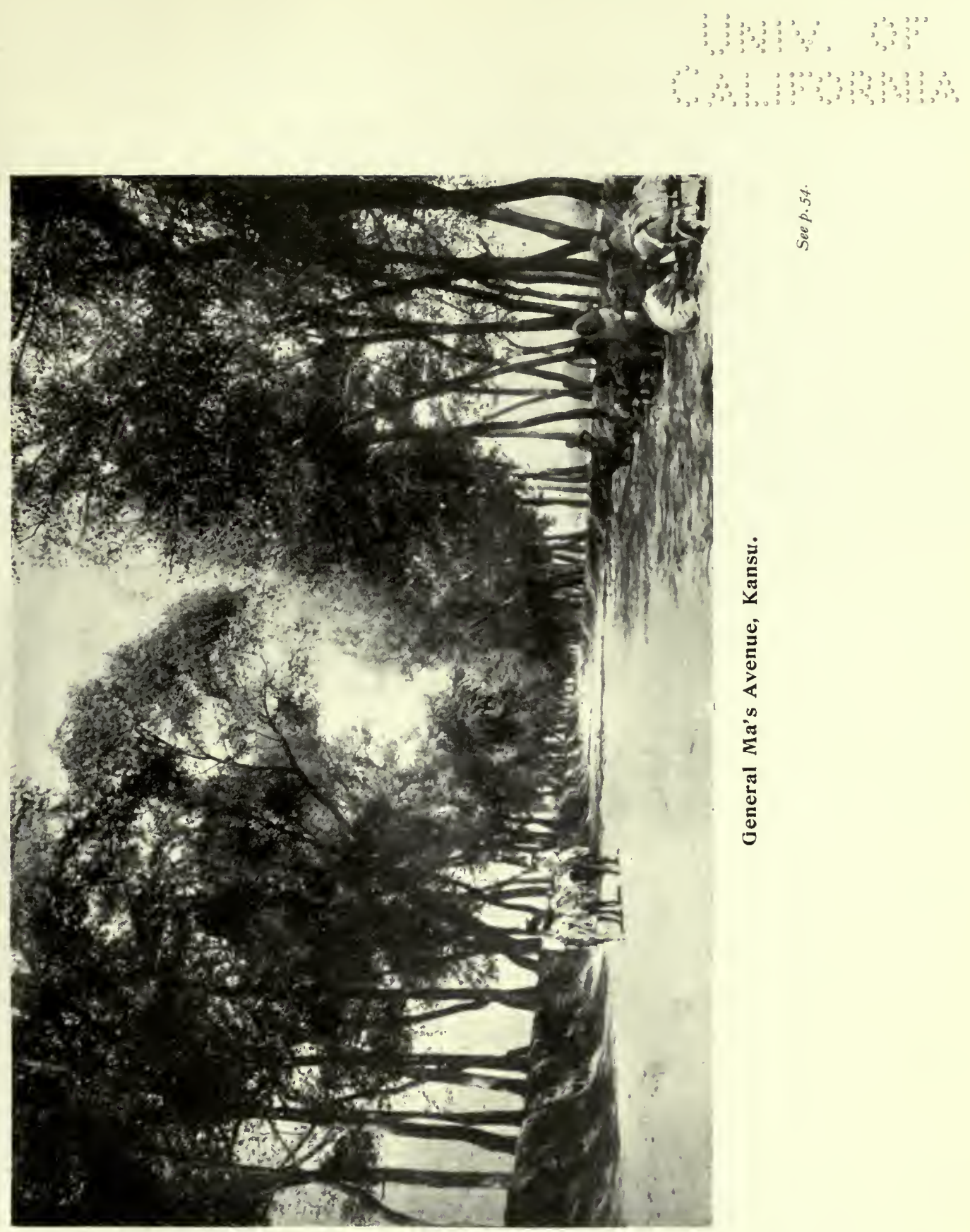

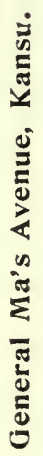




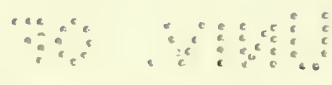

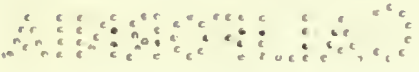




\section{CHAPTER VIII.}

\section{MURDER OF HAZRAT ALI.}

NOW occurred the unfortunate murder of our surveyor, Hazrat Ali, who was wantonly killed by the Chinese during the course of his survey duties. This outrage, which was committed without the least provocation on the part of the victim, or of any other member of the expedition, brought our journey to an untimely end. How bitterly we all regret the loss of one who was ever a faithful friend and a devoted worker, it is impossible to say.

The sad occurrence is best described by extracts from the diary of Sowerby, who was the only foreigner travelling with Hazrat Ali at the time :

"I left Lan-chou on June 2oth with Hazrat Ali, his servant, Muhammad Husein, and a small following of Chinese, with half-a-dozen mules, escorted by two Chinese soldiers.

"Our objective was Min Chou, a town about five days' journey to the southward, and we expected to be caught up by Clark's party en route.

"Our road skirted a dry watercourse, which passes close to the west gate of Lan-chou, and at about five miles from the city we met a caravan of Tibetans. They were a picturesque-looking set of ruffians, some mounted on camels or shaggy little ponies, whilst others, including all the women of the party, trudged on foot. The ladies looked as ferocious as the men and were equally ready to engage us in conversation, which was an easy matter as both parties were familiar with Chinese.

"All the Tibetans took great interest in our equipment; saddles and guns particularly causing much excited comment.

"One, who appeared to be the leader of the party, was very anxious that I should present him with my rifle, and, indeed, tried to draw the coveted weapon from its case. Unfortunately I did not feel disposed to fall in with his somewhat extravagant demand, though it is possible that, had we not been so close to Lan-chou; the party might have attempted to help themselves by. force. 
"Later on we met a wealthy Kashgari, who had been trading in the south of the province. He was seated in a large cart, evidently not of Chinesc build, to which three horses were harnessed abreast, in Russian fashion.

"We continued to pass numerous carts and strings of camels and mules, which testified to the popularity of the road as a trade route.

"At Wa-kang-ch'êng, a large village about ten miles from Lan-chou, the inhabitants were engaged in the manufacture of rough earthenware vessels, clay being plentiful in the district and fair coal obtainable in the neighbouring ravine.

"About thirteen miles from Lan-chou, vegetation became denser and the watercourse, which had been dry up to now, commenced to hold a streamlet of water. We wound up the ravine for another two miles and then began a steep ascent to the summit of the pass ( 6500 feet), whence we descended a steep ravine to the village of Ma-chia-k'ou. Here we decided to halt for a day, as the surveyor wished to visit some of the neighbouring peaks for purposes of triangulation.

"Although everyone appeared perfectly friendly, I thought it better to re-iterate my warnings to Hazrat Ali never to work unarmed and always to take one of the Chinese soldiers with him on his excursions, as a sign that the party was travelling under official sanction.

"On June 2rst, Hazrat Ali started at an early hour to commence his survey from one of the high peaks about six miles to the east of our camp.

"Unfortunately I was called away on some camp duty and missed seeing him before he left. I was consequently much annoyed to find later on that he was not accompanied by one of the escort. His servant assured me, however, that he had gone out well armed, so that there appeared to be no cause for anxiety.

"Rain fell heavily during the day, and, as I knew this would interfere considerably with the progress of the survey, I did not expect Hazrat Ali to return until towards nightfall, as I knew how conscientiously he always carried out his day's work.

"As night drew in without his returning, I decided to take out guides to his assistance, in case he should lose his way in the darkness.

"As our party was on the point of setting out, one of the plane-table coolies crawled into camp, covered with wounds and with his arm broken.

"The poor fellow informed us that the survey party had been attacked, without warning or provocation, by a large gang of natives from the villages 

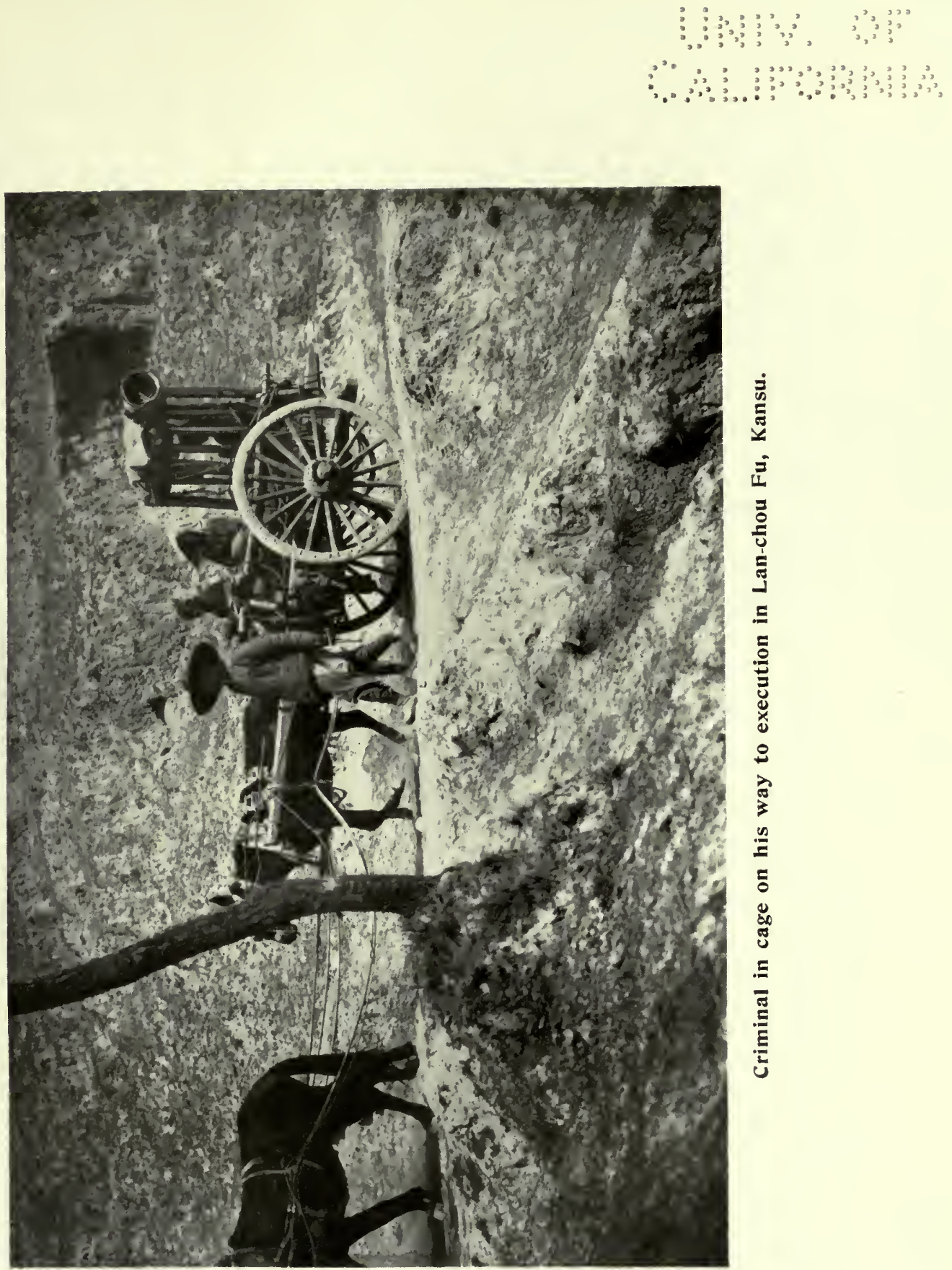


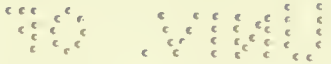

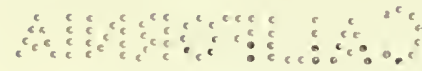


on a plateau about six miles east of our camp. The man himself had been severely assaulted and robbed of his watch, but had made good his escape. He knew nothing of the fate of the surveyor or of the other plane-table coolie. His assailants had informed him that they intended to make an immediate attack on our camp at Ma-chia-k'ou, in order to kill all the foreigners. On hearing this, the servants became panic-stricken, and vainly implored me to return forthwith to Lan-chou. The night was now pitch dark and the guides flatly refused to assist me in searching for traces of the surveyor, and without their aid it was impossible for me to find Hazrat Ali, as I knew nothing of the neighbourhood.

"I therefore sent back a mafoo (groom) towards Lan-chou with a letter to Clark, urging him to obtain search-parties from the officials to look for the missing man.

"Meantime I prepared against the threatened attack on our camp by distributing all available firearms amongst my party. I was now further disquieted to find that Hazrat Ali, in spite of my express injunctions, had left his weapons behind, and had not even a revolver with him.

"Our defensive preparations became known to the villagers of Ma-chiak'ou and they probably warned our intending assailants, for although at about 2 a.m. we heard a considerable beating of drums, the noise died away and we were not molested during the night.

"As soon as it was light enough to see, I collected a search-party to beat the ground to the east of our camp, and at the same time sent back the mules and baggage to Lan-chou.

"Just as our search-party was starting, the second survey-coolie arrived in camp, covered with blood and showing signs of severe ill-usage. He had contrived to escape whilst the mob were pursuing Hazrat Ali, but of the latter's fate he knew nothing. After attending to the wounded man, I set out accompanied by Muhammad Husein and three servants. The official escort declined to come with us, and returned to Lan-chou with the baggage. We started to ascend the hills to the east, but had not gone far when we were overtaken by the mafoo, bringing Clark's reply to my letter of overnight. I was relieved to learn that the officials had promised every assistance in searching for Hazrat Ali, and that soldiers were probably even then on their way.

"After a march of some miles through a broken and difficult country, much intersected by precipitous ravines, we came upon traces of Hazrat Alieasily distinguishable by his hob-nailed boots. There were also footprints of a 
crowd of Chinese, evidently bent on his pursuit. The tracks showed that the surveyor had been headed off in more than one direction, but had finally made his way to the end of a deep ravine, where all signs of him were lost, though there were the marks of a crowd of Chinese at this spot. From these indications I concluded that the unfortunate man had been captured, and had probably been taken to one of the neighbouring villages. I therefore decided to make for Wa-kang-ch'êng, a distant village on the high plateau where Hazrat Ali had been first attacked, to see if any traces of the surveyor could be found there, and also to effect a possible junction with the promised searchparty.

"En route we arrived at a village, all the able-bodied inhabitants of which were absent, and were informed by some old men and women that they had heard rumours of the murder of a foreigner but were ignorant of any details.

"As darkness was now coming on we headed for Wa-kang-ch'êng, which was reached about II p.m. Here we learned that Clark's party had passed through about five hours before and were now at Ma-chia-k'ou. I found a lady-missionary in the village, and, in view of the disturbed state of the vicinity, told off Muhammad Husein and one of my servants to escort her to Lan-chou. I myself with one servant hurried to Ma-chia-k'ou, only to find on arrival that Clark's party had passed through an hour before. By pushing on rapidly, I managed to catch them up about $4 \mathrm{a} . \mathrm{m}$. Clark informed me that in spite of strong representations to the officials, the promised search-party had never been sent, and that, fearing for the surveyor's safety, he had been obliged to ask the four available Europeans to push off with him at once in relief. Clark, before leaving Lan-chou, had informed the officials of his intentions, but they acted in the usual dilatory manner and afforded him no assistance."

The party, now united once more, determined to make a thorough search through the neighbouring villages, and at the first one entered found several $Y a-m e n$ runners comfortably smoking in one of the huts, whilst their horses were tethered outside. When questioned, they said they had been sent out to investigate the affair but had as yet discovered nothing. This was hardly surprising, as, except for themselves, the village was absolutely deserted! These loafers having flatly declined to assist us in the search, we visited several of the neighbouring villages, all of which we found deserted except for the women and children, who disclaimed any knowledge of the affair.

We now came to a tableland, intersected by deep ravines, and on several commanding positions we observed parties of men collecting. With a view to 
extending our inquiries as widely as possible, the party was now split up, each of us making for a different isolated group of men.

Emboldened by the fact that they had only a single man to deal with, the natives in some cases assumed the offensive, and it was unfortunately necessary to have recourse to firearms in self-defence. Two of our party received injuries in this unfortunate affair, whilst one native was killed and two wounded. The use of force was much regretted by us all, but the attitude of the natives was extremely threatening and our revolvers were only used as a last resource.

On reassembling, two of the party brought in apparently reliable reports that Hazrat Ali had been murdered, but no information was forthcoming as to where his body might be found.

The whole position was now so serious that it became imperative to telegraph at once from Lan-chou a full report to the British and American Ministers at Peking. Whilst awaiting their instructions, the leader of the expedition made repeated representations, in person, to the local authorities, the remainder of the party continuing to prosecute inquiries in the neighbourhood of the tragedy. Warned by recent experience, they kept together, a course which, though practically dictated by circumstances, had the disadvantage of delaying the rate of search. But more clearly, almost hour by hour, the sickening conviction was borne in upon us that hope was slipping away, and that we must prepare our minds to accept the worst. The story told by the natives, as it began to disentangle and shape itself-or be shaped-was that the surveyor had been alarmed by a crowd of peasants chasing a runaway cow, that he had thought the demonstration directed against himself, that he had tried to escape from his imaginary danger and had fallen over a precipice. All the versions agreed in these two points: that he was dead, and that his body was irrecoverable.

At Lan-chou the officials received Mr. Clark with effusive civility and every protestation of friendliness, coupled indeed with edifying homilies on the virtues of patience, and with these for some time he had to be content; for although every persuasion was tried to arouse them to action, it did not appear that they had any intention whatever of taking practical steps in the affair. However, after a little, it became evident that they had in reality been engaged in satisfying themselves, through the reliable channels of information at their disposal, that Hazrat Ali had in truth met his death. This heart-breaking confirmation of our fears carried with it but one consolation, and that of a 
poor sort; he was at least no longer in the hands, or at the mercy, of Chinese captors.

Sympathy, of an official sort, was freely proffered; 'It had been an accident, no doubt, and most regrettable; but one of their own countrymen had been killed as well, making one each side, so that we were now quits.' It was in vain that $\mathrm{Mr}$. Clark appealed for such redress as was possible and for punishment of the guilty parties; the formula of reply was always the same: 'An accident no doubt, and most regrettable,' and concluding invariably with the cold-blooded balancing of human lives. It was just one of those situations where he who cares least comes off best; and the man, who had lost not only a faithful fellow-worker but a personal friend, was at great disadvantage in face of hide-bound officials, who could treat the fate of their own countryman with the bland unconcern of chess players discussing the sacrifice of a gambitpawn. That they were not altogether so easy in mind as they would have had it believed, was evident, and they would have given much to be able to produce Hazrat Ali alive; for, after all, some very searching interrogatories were bound to come from Peking. That they were a little doubtful about the truth of its being an accident was indicated, perhaps, by a tendency to postdate the surveyor's death till after the shooting of the Chinaman; but this was not very clear, and discussion through interpreters may easily lead to misunderstanding. Eventually it became quite obvious that, if any sort of reparation was to be obtained, this would only be forthcoming at the Capital. However, before there had been time to decide on a course of action, the replies to Mr. Clark's telegrams arrived from the Ministers. These, whilst promising full enquiry, strongly counselled-in fact, allowing for diplomatic forms, peremptorily demanded-the return of the expedition. There was, of course, no alternative but to comply.

It should be mentioned that on obtaining trustworthy official confirmation of the surveyor's death, Mr. Clark had at once withdrawn the search-party to Lan-chou, as no further good could be done, and the risk of bloodshed was ever present. In spite of the fact that the entire party were now concentrated in Lan-chou, it would have been inconvenient for the whole expedition to start at once on its long march, and the actual details of withdrawal required some little consideration. Mr. Clark's presence in Peking was urgently necessary, and Captain Douglas, as a British officer, had to comply with the Ambassador's instructions at the earliest possible moment ; but at the same time the recent tragedy had opened our eyes to the risks run by a small party travelling in Kansu. However, after due consideration, it was decided that, well-armed 
PLATE 32.
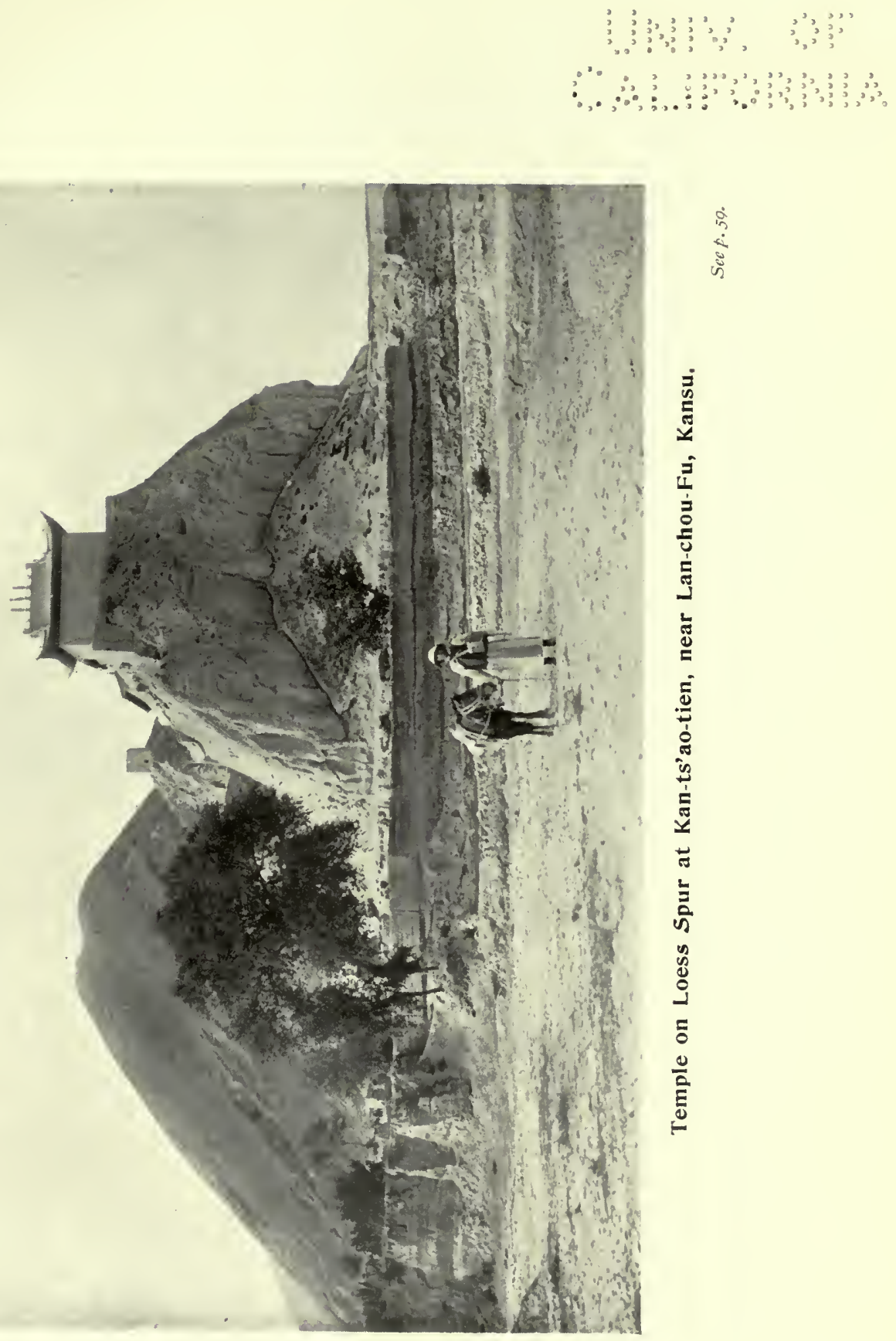

क्ष

है 


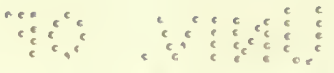

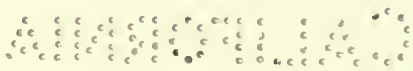


and well-mounted, the little body would run no unjustifiable risk of attack; and accordingly Clark and Douglas started on July 2nd, and travelling via Hsi-an Fu and Ho-nan Fu reached Peking by the end of the month. Grant and Sowerby, after a fortnight spent in getting matters ship-shape for the return journey, started for the capital viâ Ch'ing-yang, Yen-an, and T'ai-yiian on July 15 th.

Thus the sad occurrence described above forced us to retrace our steps just as we had reached the threshold of what promised to be the most interesting part of our travels. The death of Hazrat Ali was a deep loss to the whole party, and a real blow to everyone of us. Besides being a first class surveyor, he was a faithful and loyal friend, cheerful under all circumstances, and had endeared himself to his comrades of the expedition.

It is regrettable that, although every sort of pressure was brought to bear upon the Chinese Foreign Office, no reparation has ever been made for this deliberate murder of a British subject. 


\section{CHAPTER IX.}

RETURN MARCH OF GRANT AND SOWERBY FROM LAN-CHOU 'TO T'AI-YÜAN.

HAVING disposed of as much of the ammunition, photographic materials, and provisions as the European community in Lan-chou could take, Grant and Sowerby, with a train of fifty heavily-laden mules, left the city on July 15 th. Their instructions were to follow the road leading through Chingning Chou, Ku-yüan Chou, and Ch'ing-yang. $\mathrm{Fu}$ to Yen-an $\mathrm{Fu}$, and thence proceed viâ Sui-tê Chou and Fên-chou Fu to T'ai-yüan Fu. En route they were to take astronomical observations for latitude and time at the following places : Ching-ning, Ku-yüan, Ch'ing-yang, Yen-an, and Fên-chou.

In addition, meteorological observations were taken twice daily, thrce aneroid barometers, checked from time to time by the mercurial barometer, being used. Boiling-point readings were also taken, and the humidity of the air tested with wet and dry bulb thermometers.

A good deal of attention was devoted to photography. Grant made some very successful attempts at photographing small living animals, and the results are given in the chapters dealing with the biographical work of the expedition. A large number of quarter-plate pictures of Chinese countrywomen were taken with the handy Reflex camera, in the use of which Grant became an expert ; and a unique collection of portraits were obtained. The utmost ingenuity was necessary in dealing with the fair sitters. Far less trouble was experienced in dealing with the case of Sowerby's nervous little animals, for these were usually tied by a string, and willy-nilly had to come into the picture. The ladies, on the other hand, at the slightest sign of an attempt to snap them, would seek their homes, whence nothing could dislodge them. Anything striking in the way of feminine head-gear was sought after most eagerly; whilst scenery and peculiarities in geological formation were not neglected.

Sowerby kept a sharp look-out for anything of biological interest : snakes, frogs, and lizards all finding their way into his alcohol tanks; and butterflies being eagerly chased and captured to be packed flat in specially made envelopes. In one place a large collection of Mammals was made, containing three new species. But all these will be dealt with in their right place, and it is best to return to the commencement of the journey, taking events in their proper sequence. 
PLATE 33.
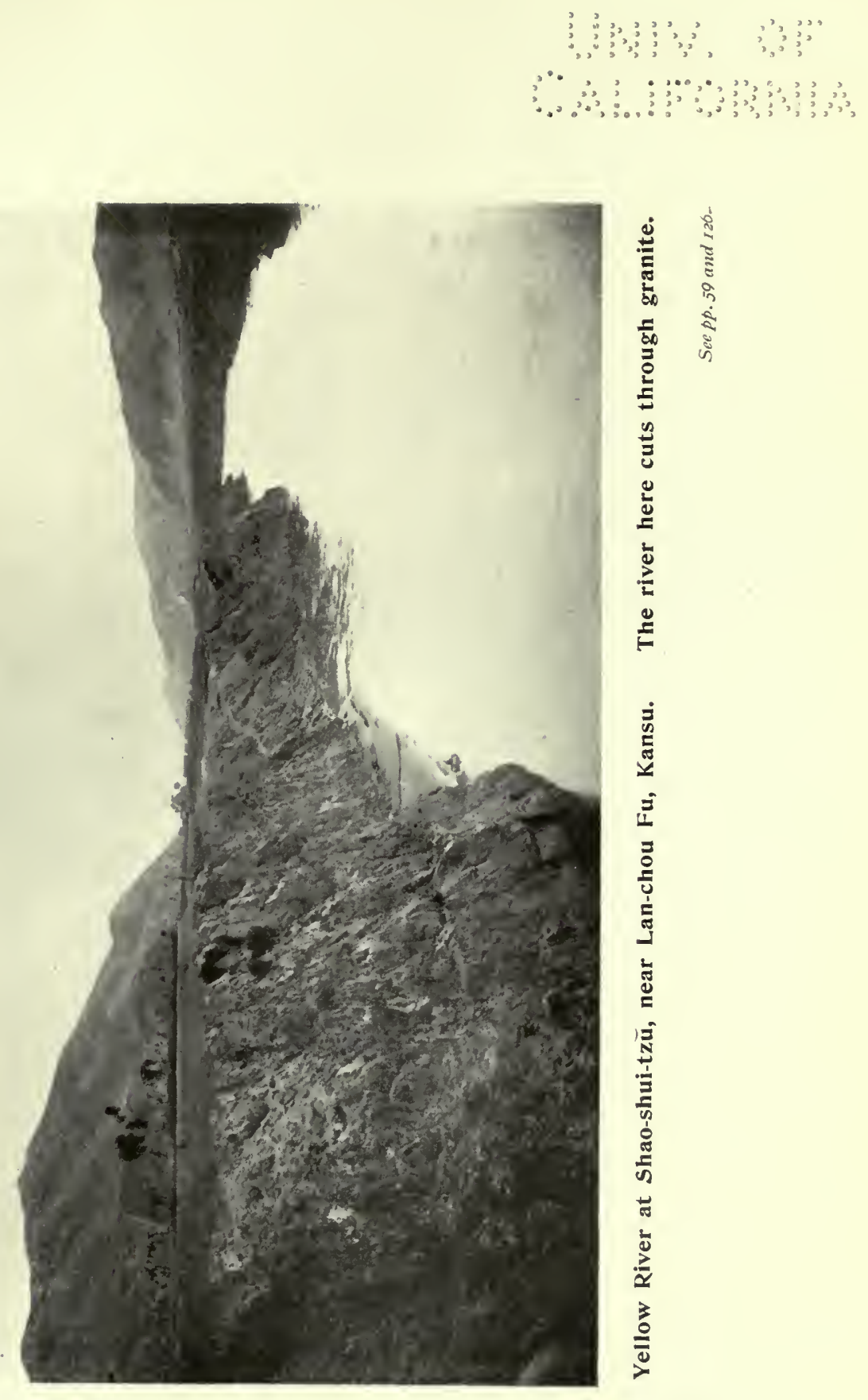


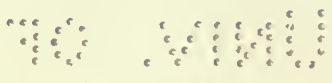

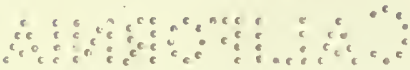


For the first few miles of the road we had the company of Messrs. Coltman and Dello, two Europeans resident in Lan-chou, who came to speed us on our way. The expedition moved eastward until it reached a small place named Hsiao-shui-tzŭ, situated on the right bank of the Yellow River, which here cuts through thick strata of igneous rock. This was the last we saw for many days of that mighty river, which, having its birth in the eternal snows of the Tibetan highlands, flows through Western Kansu, divides the Ordos from the rest of Mongolia, forms the boundary between the provinces of Shansi and Shensi, and after draining Northern Honan, Southern Chihli, and the Shantung peninsula, ultimately pours its water into the Gulf of Pei-chih-li.

For the first thirty miles there was ample evidence of heavy rains; in places the old roads over the loess were completely cut away, new routes having been hastily chosen by recent travellers. Notwithstanding the abundance of water since the middle of June, the crops for the first five days of the journey were in a very poor condition. In many places, instead of the fields of ripening wheat or tall millet, bare, yellow, sun-baked loess alone was visible. From time to time we passed the sawed-up remains of telegraph poles; and in one place came upon the scene of further depredations committed but a few hours earlier. Poles recently pulled down and stripped of their wire lay about, whilst the fresh tracks of the perpetrators of this mischief must have led to inevitable discovery and arrest in any district adequately policed; however, here it meant nothing but that another fifteen miles of line had been rendered useless.

On July 23rd we reached Ching-ning Chou, the first large town since leaving Lan-chou. This town is at the junction of the two roads eastwards; the one taken by our party leading away to the north-east, that taken by Clark and Douglas leading in a slightly southerly direction. Some successful astronomical observations were made, and Sowerby secured a new polecat, the pet of a market-gardener, from whom it was bought. The little animal was very tame, and submitted with good grace to being photographed.

On July 24th the expedition left Ching-ning, and after passing through a deep gorge penetrating a range to the north of the city, entered a broad and fertile valley, where the rich crops of cereals afforded a pleasing contrast after the meagre productions of the famine-stricken wilds west of Ching-ning. There was no sign of opium, and this was partly explained by the fact that the inhabitants of the valley were all Mohammedan. Indeed, on this journey it was noticed that, wherever the ordinary Chinese tilled the soil, the best land was devoted usually to the cultivation of the poppy ; whereas the Mohammedans 
used all their land for cereals, hemp, and other useful products. The result was a marked difference in the prosperity of the two classes, Buddhist and Moslem; the former showed signs of much want and degradation, whilst the latter were comparatively prosperous and healthy-looking people, their homes cleaner and better appointed, their faces less haggard and less careworn. The scenery, too, became more beautiful at every step. In place of bare yellow loess mountains-only pleasing towards the end of the day when the soft lights of evening clothe them in delicate shades of mauve and blue-there now spread out on either hand broad fields and lofty slopes resplendent in rich coats of verdure. Hurrying rivulets and sparkling brooks took the place of yellow sluggish streams, so alkaline as to be useless for the watering of sheep.

We put up that night at a pretty little village named Ch'ang-t'ai-p'u. This consists of two sections, each surrounded by a high and crenellated wall. The larger boasts of two gates and a moat, and one long broad street running from gate to gate with the houses on each side symmetrically arranged. The smaller section was perched upon some high ground overlooking the larger, which in other ways it closely resembled. As a result of the symmetry, so carefully adhered to by the designer, the village presented a very pleasing picture, especially when viewed from the eastern gate. That night another heavy deluge rendered the road unfit for travel. For several hours the rain came down in sheets, and a fall of nearly $\mathrm{I}_{2}{ }^{*}$ was recorded. Sowerby took advantage of the delay thus afforded to persuade the natives of the village to go out into the surrounding country and dig up small quadrupeds, for which he paid them sums varying from five to fifteen cents. (I $\frac{1}{4} \mathrm{~d}$. to $3 \frac{3}{4} \mathrm{~d}$.). By this method a large and valuable collection was obtained.

After leaving Ch'ang-t'ai-p'u, we continued up the valley to the foot of a high mountain chain, and encamped in a beautiful spot close to a small village named Ch'ang-yi-p'u. An excursion into the mountains was undertaken by the two Europeans; but, though some deer were seen, little in the way of specimens for the collection could be secured.

From Ch'ang-yi-p'u the road turns northward, skirting the high mountains till it reaches a conveniently low pass, when it again turns east. Following this route we reached the large walled town of Ku-yüan Chou, where astronomical observations were again taken. Close to Ku-yüan lie the remains of Tung Fu-shang, the famous Kansu general, whose lawless troops came to the aid of the Empress Dowager in the coup d'état of 1897 , and took their share in the Boxer atrocities of Igoo. It is no uncommon thing in Kansu to see substantial, well-appointed residences, which have been recently erected by 
PLATE 34.
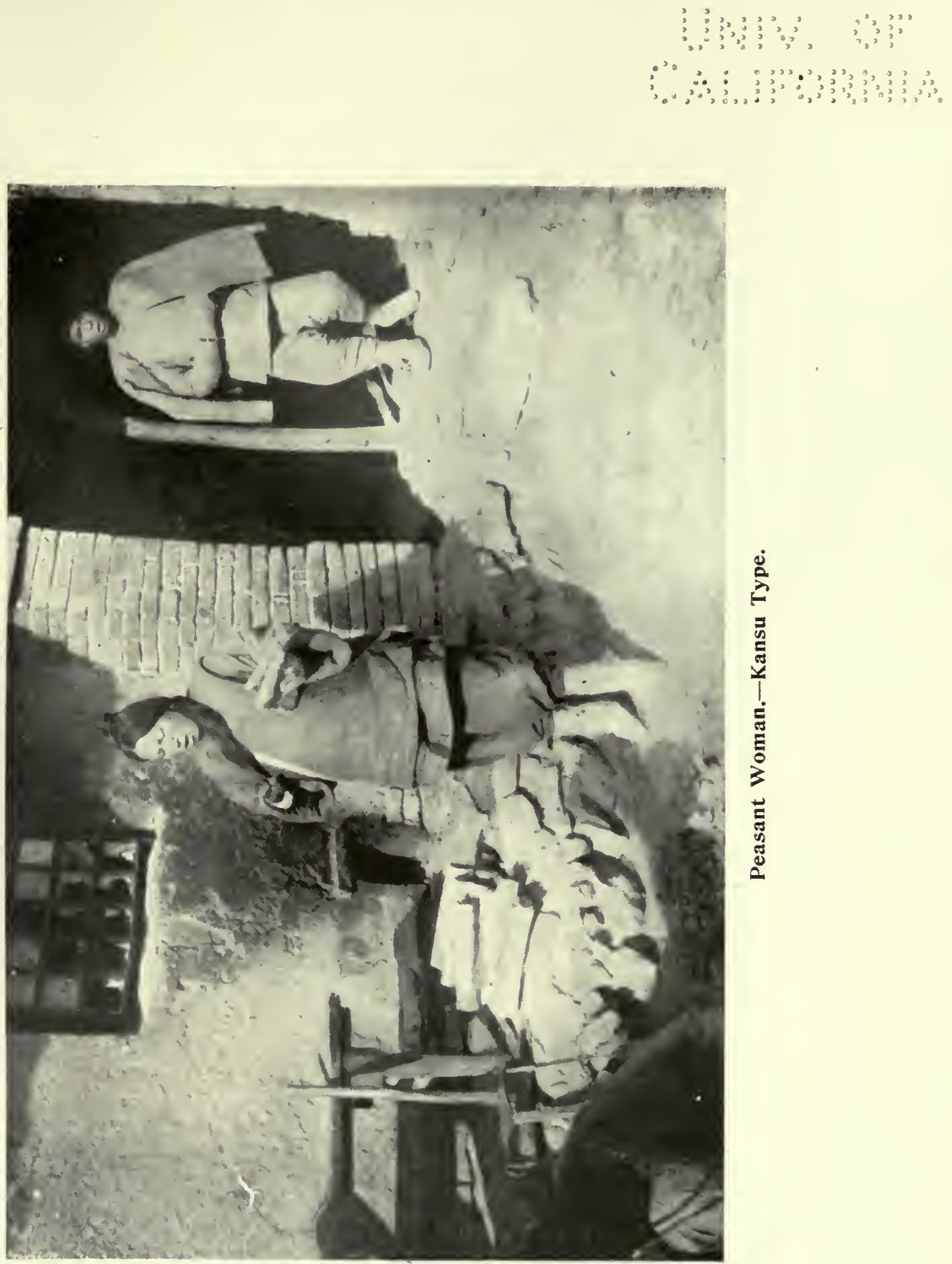

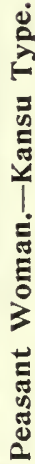


wat मmMan 
followers of Tung Fu-shang, who "made their fortunes in the East." The undisciplined hordes looted far more from the natives of Chihli than they did from Europeans. During the troublous times when all communication between the Capital and the outer world was cut off, unspeakable scenes of horror were enacted in the interior, besides the siege of the Legations in Peking and the massacres of missionaries in Shansi. The brutal soldiery, called in from the wilds, indulged themselves in every form of pillage and rapine at the expense of their countrymen; the proceeds of which they carried back to their homes in Kansu.

From Ku-yüan Chou to Chên-yüan Hsien, the next walled town, the country seemed comparatively prosperous. For Kansu, the crops were good, and the people seemed less poverty-stricken; in some places the farmers were already harvesting. The road lay along broad valleys running through more or less hilly country. At Chên-yüan Hsien the party were hospitably entertained by Miss Petersen, a Swedish missionary, who, with another lady, lived alone in this out-of-the-way place. Miss Petersen had a school of some twenty or thirty girls, who, much to their delight, were photographed by Mr. Grant. Pages of eulogy would not do justice to the heroism and devotion of such women as Miss Petersen and her colleague, whose lives are spent in patient, unremitting toil, far from all their loved ones, and surrounded by a dirty thankless people, to whom they have consecrated their lives.

On leaving Chên-yüan, the party ascended a long slope and came out upon a broad loess plateau, exactly similar to the one met with two days' journey south of Yen-an Fu, which has been described in chapter v. The road continued over this sort of country for two and a half days. From time to time steep and difficult descents were made into broad valleys, only to be followed by equally bad ascents. At last, at mid-day on August 8th, the plateaux were left behind, and, winding for the rest of the day along valleys and gullies, the expedition reached Ch'ing-yang $\mathrm{Fu}$ late in the afternoon. In this district were many Ssŭch'uanese settlers, and their well-tended fields of flourishing crops formed a significant contrast to the bare and neglected land owned by the lazy, opiumsmoking men of Kansu. These immigrants were in all respects similar to those met by Clark and Sowerby in January, travelling through the bitterest cold and snow, badly clad and with bare feet, in search of land whereon to settle. Here they had settled, and the same thrift and perseverance which had carried them through the privations of that terrible winter journey, were now earning the reward of plentiful harvests in a land whose natives were starving for lack of rain! 
About half-way between Chên-yüan and Ch'ing-yang we came upon a most remarkable cave-village, evidently long deserted. All the dwellings had been hewn out of the solid sandstone cliff forming one side of a broad valley. There was now not a scrap of woodwork left, whilst rank foliage had covered the courts, and in some cases great masses of rock had fallen away, leaving the higher caves inaccessible. The rooms, cubical in shape, were not large, but showed traces of kangs and broken stone mangers. The scene was suggestive, of the Stone Age, and this impression was enhanced when two children, naked and unkempt, ran out of one of the caves, attracted no doubt by the strange voices. These little troglodytes were not in the least embarrassed at the invasion of their sanctum, but eagerly took the biscuits and cake offered them. They looked in need of better nourishment. So thoroughly did the spot conjure up visions of a remote past, that we decided to rest awhile and enjoy the illusion to the full. But alas! the inevitable staring crowd soon collected - not very large, but none the less annoying-and the last vestige of enchantment was dispelled when someone volunteered the information that the cave-village had only been deserted some thirty years. Whereupon the disgusted travellers mounted their ponies and rode away; not, however, before some photographs had been taken. It may be added that the wretch who had destroyed our day-dreams about the cave-village ascribed its desertion to the massacres that took place throughout the country during the Mohammedan rebellion. On the opposite side of the valley was a temple, wherein were some large caves not unlike those of the Sung dynasty temples at Yen-an Fu. They were said to date from the same period as those at Yen-an Fu, but were in a much better state of preservation, although in this case the sculptures were not so fine, nor were the walls so completely covered with images.

After arrival at Ch'ing-yang $\mathrm{Fu}$ it was necessary to make astronomical observations, and two days elapsed before a suitable set could be obtained. During our short sojourn in the city we received several visits from Father Calbrecht, a Roman Catholic missionary stationed there. Conversation had to be carried on in Chinese, this being the only language equally familiar to both parties. Ch'ing-yang $\mathrm{Fu}$, a city of considerable dimensions, showed none of the prosperity that might have been expected. The greater part of the buildings enclosed within the high strong walls were in ruins; the broad streets in many places overgrown with grass and weeds; the temples and official residences in sad disrepair; the inhabitants few and poverty-stricken. The city, once populous and wealthy, formed one of the chief strongholds of 


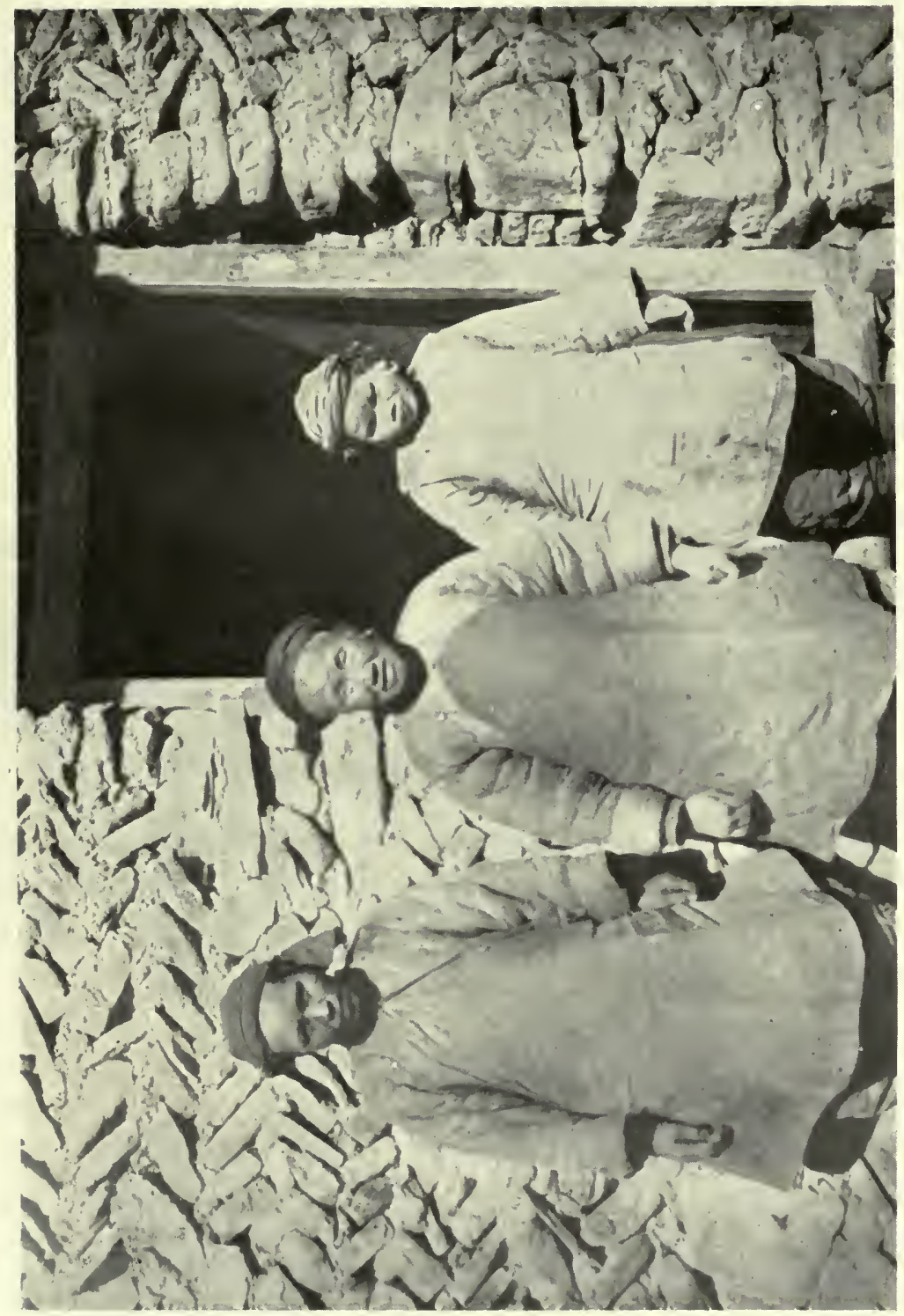

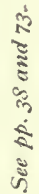

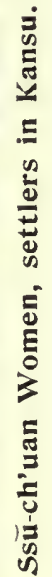




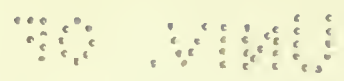

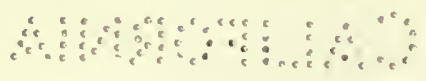


the rebels in the terrible Mohammedan rising that devastated the country in the 'sixties.' It then sustained a long and severe siege, which ended in the massacre of its wretched inhabitants, and from which it has never recovered. At the present time there was not even a blacksmith's forge within its walls, so that several of the ponies and mules of the expedition which had cast shoes were forced to continue their journey as far as Yen-an Fu without being re-shod.

From Ch'ing-yang eastward for some days the scenery was exquisite. The long-abandoned loess hills were overgrown with vegetation almost tropical in its luxuriance, and only down the valleys was any cultivation noticed. There were long stretches of uninhabited country, in which wild life of every kind was abundant. Many kinds of game-birds were to be seen in the valleys and along the streams, including pheasant, partridge, snipe, and several varieties of duck, whilst roedeer in great numbers wandered over the hills. Everywhere the tracks of wild pig were visible, and in places wolf and leopard spoor were noticed.

Along the streams were to be seen two kinds of kingfisher, their radiant colours flashing in the sunlight, as they dived after minnows in the limpid waters, or darted like living gems along the rocky banks. Over these watercourses, too, hung countless dragon-flies of every description. Big pale fellows, with wonderful translucent eyes, hovered high in the air, darting down, ever and anon, to devour one of their smaller relations. Skimming over the rippling surface of the water were others of a slaty blue colour. Here a streak of vivid crimson marked the passage of the beautiful male of yet another species; and there, settled upon a rock-her wings outspread to get the full benefit of the sun's warm rays-sat his little brown mate. There was, in addition, another most striking variety, with shining body, broad wings, and long tapering tail, all ordinarily jet black, but now scintillating with a thousand shades of blue, green, and gold as they caught and reflected the sunlight at various angles. Of this species there was a decided predominance; and at times they collected in swarms over the reeds and rushes on which they sought to settle. Their flight resembled that of the butterfly in its uncertain fluttering course, rather than the graceful evolutions, lightning dashes, and motionless poisings of other dragon-flies. Amongst them were pale brown specimens which lacked the irridescent colours of the darker forms. The insect life was by no means confined to the stream and the dragon-flies. Over hill and dale floated gorgeous butterflies of every hue. Sometimes round a single clump of flowers a dozen different species might be counted. Down one ravine the graceful Swallowtail would abound, whilst on the adjacent hill 
Red Admirals or Painted Ladies would predominate. In the streams were small minnow-like fish, large green frogs, and funny little crabs, which hid beneath the rocks and stones. The natives said that otters were to be found in this district, and Grant saw one creeping through the tall grass on the bank of a large stream. The party enjoyed some good deer-stalking at a place named Miao-ts'un, which was situated right in the heart of this charming sylvan country, and where we stayed a day for the purpose.

The following is an extract from Sowerby's diary for August 15th :-

"This morning we were off by 7 o'clock. A little way down the valley I put up a roedeer. The road to-day has led through beautiful country. Sometimes we would be travelling along the sides of the clear stream where kingfishers could be seen and butterflies and flowers were abundant. At other times we would be skirting the base of the hills. On either side the slopes were wooded, but more especially on the southern side. Occasionally we would pass a farmstead built in the loess on the northern side of the valley (i.e., facing south). The valley bottom was filled for the most part with magnificent fields of hemp and millet and occasionally buckwheat. Numerous flocks of sheep and herds of red cattle could be seen grazing along the slopes. We caught some nice flies during the day. Butterflies, both common and rare, were very numerous. In the afternoon I rode on ahead to select a camping-ground, and put up two more deer not far from here. We have pitched camp on a grassy stretch close to the village of 'T'ai-pei-ch'êng. I shot a duck this evening. I found a beautiful snake down by the water's edge. It is very long and extremely thin. Of a brown colour, it has a white stripe down the middle of the back, with dark mottlings. The natives say there are otters here. I found some crabs in the river higher up."

The following day the border-line between Kansu and Shensi was crossed. The caravan camped that night at a large village named Hai-shui-ssŭ, situated in a picturesque valley, just at the point where it narrows down to a few hundred feet. A peculiar spur of rock rises high beside the village, and on its crest is built a pretty temple. On the road between this place and Fu Chou, two days further east, numerous large flocks of sheep and goats were passed. These poor animals were on their way to Shansi, and had already come a great distance. Before reaching $\mathrm{Fu}$ Chou we crossed another large loess plateau, from which we descended into the broad valley wherein that town is situated. There were no suitable inns, and we pitched our camp in an open space before a large temple.

For the three following days our journey was in a northerly direction, 


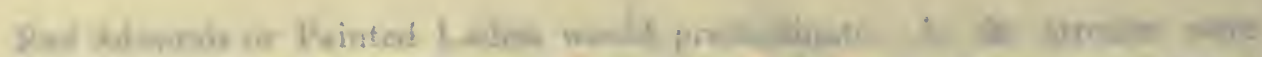

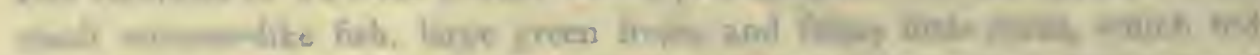

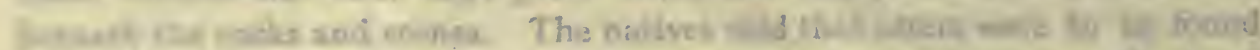

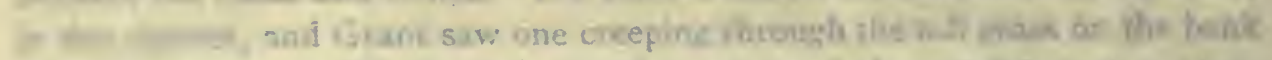

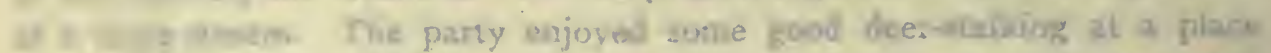

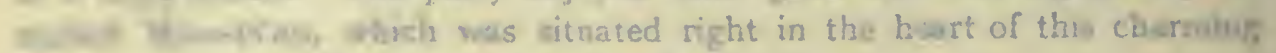

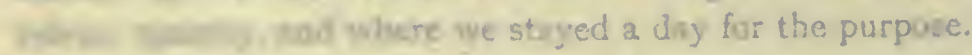

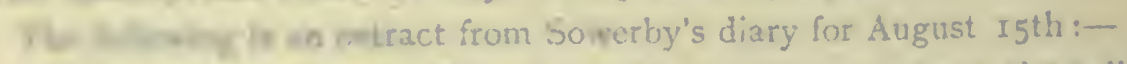

a Thenesing wo wers off by $70^{\circ} \mathrm{clock}$. A little way dow/1 the valloy $I$

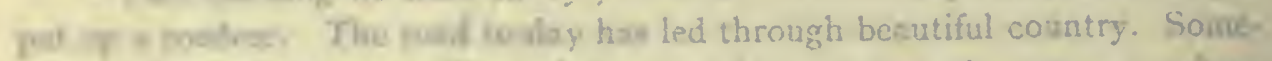

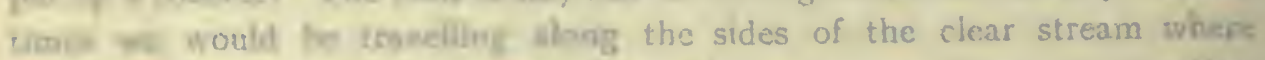

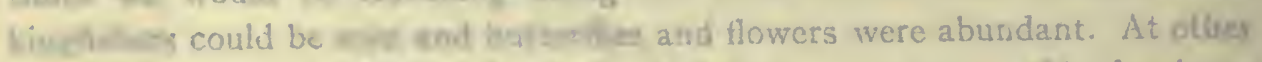

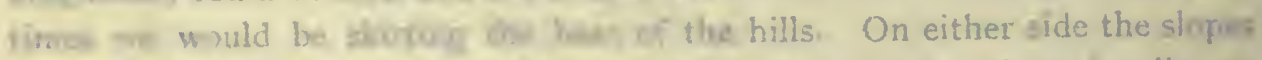

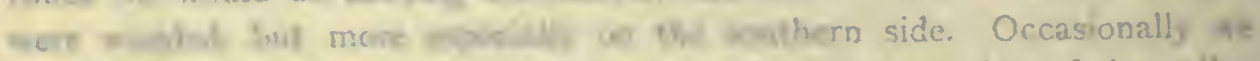

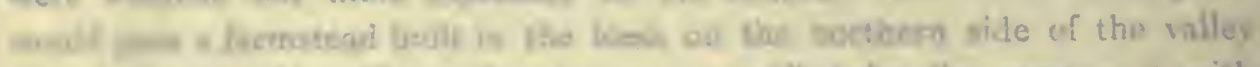

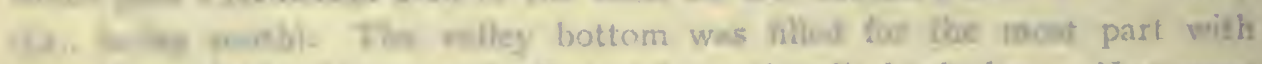

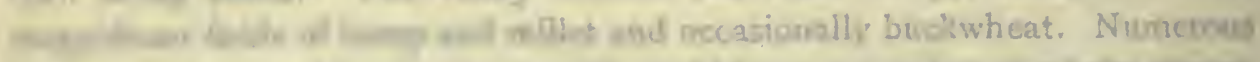

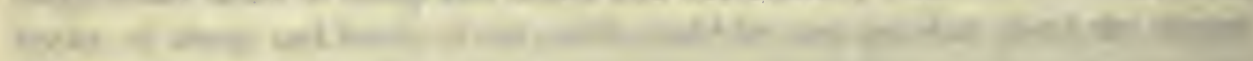
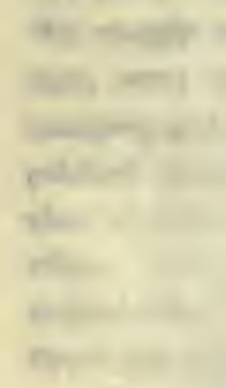

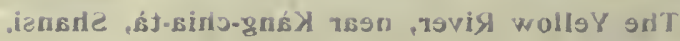

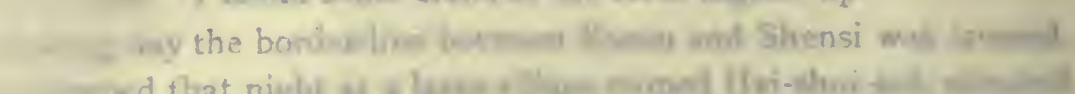

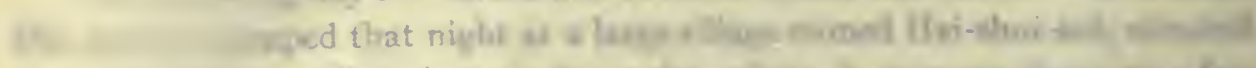

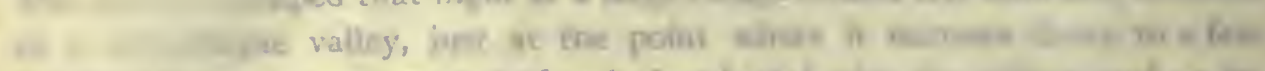

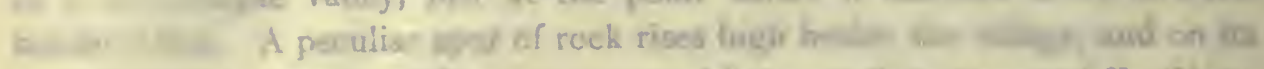

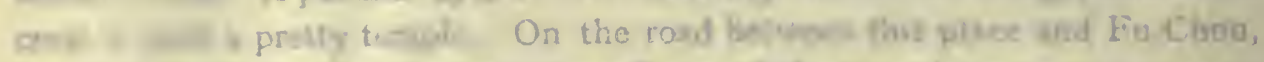

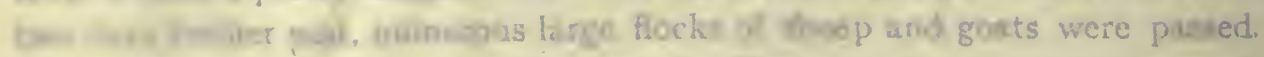

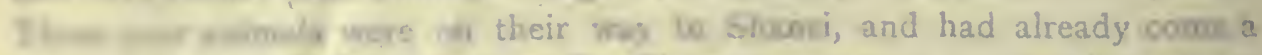

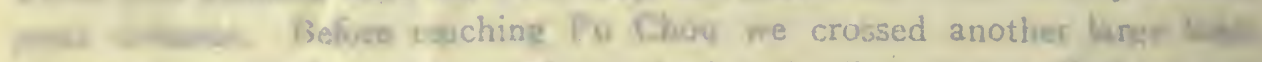

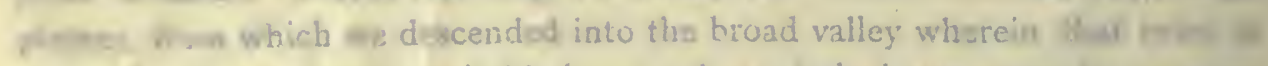

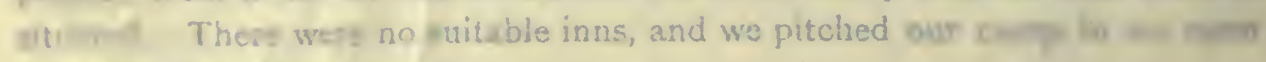
spach yas s large verngle.

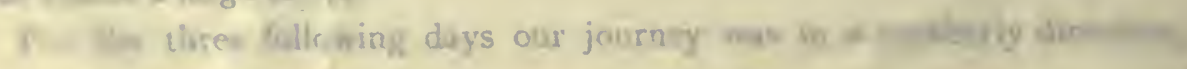




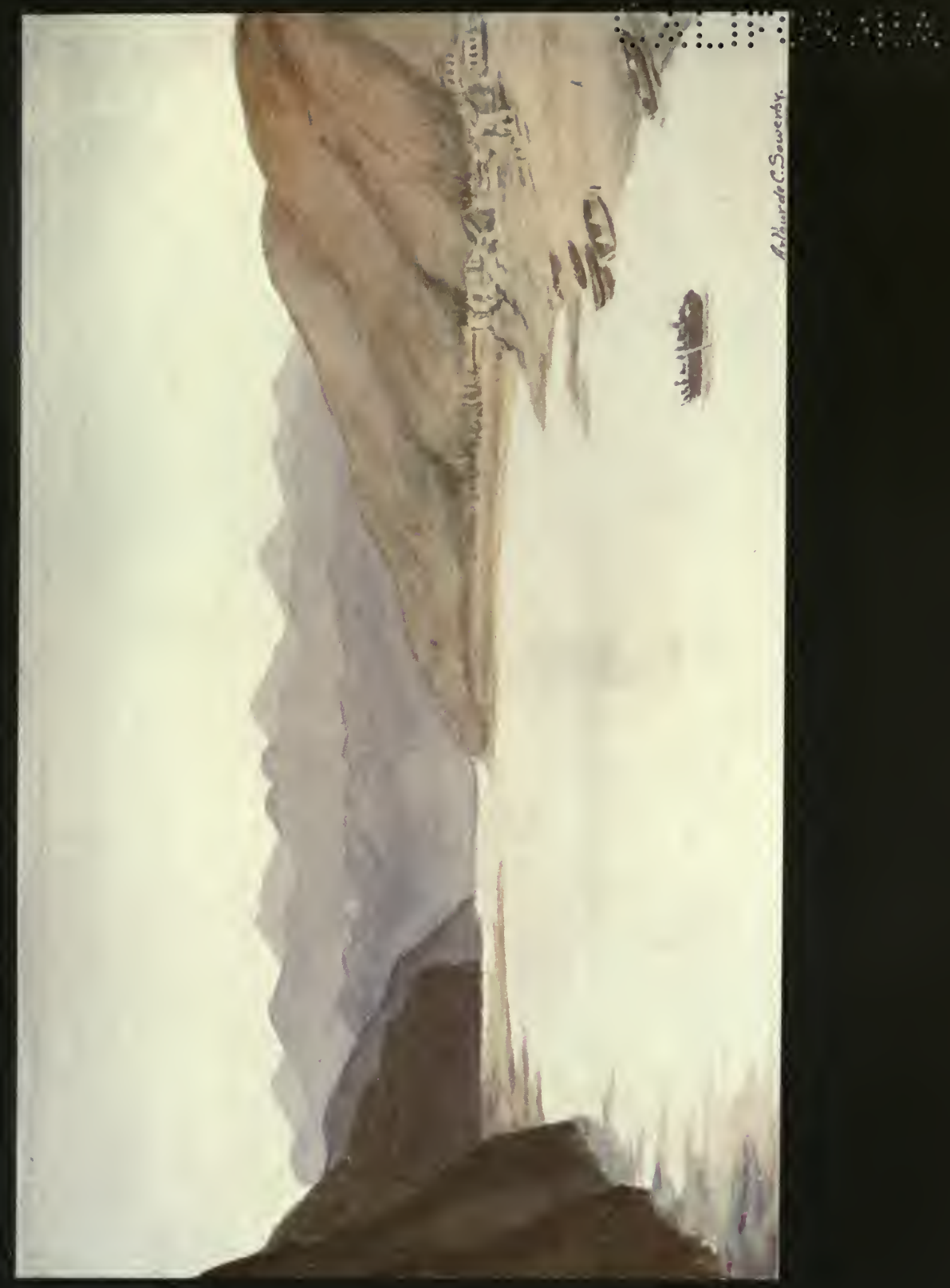




$$
\begin{aligned}
& 52^{2}=8 \div ;
\end{aligned}
$$

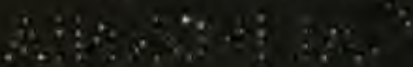


heavy rains being experienced, which rendered the roads very bad. The latter, being cut in the loess, became very slippery and treacherous. So bad was the weather that we were forced to make a halt of one day at Kan-ch'üan Hsien ("The dry fountain town"). In the Lo Shui, which flows down the valley, numerous mud-turtles were seen, and the party indulged in the (to them) novel sport of turtle-shooting. Sowerby, of course, claimed the bag for scientific purposes, and the ugly creatures were carefully preserved in alcohol.

On the third day after leaving $\mathrm{Fu}$ Chou we entered the fine game preserves where deer were shot the previous winter, and we decided to camp there that night and try our luck. We were amply rewarded for our pains, each securing two roedeer that evening, while Sowerby shot a magnificent wild boar next morning, an account of which is given in the chapter on the general biological work of the expedition (Chapter X.).

On August 22nd Yen-an Fu was reached, and astronomical observations were taken. Next day we ascended a peak some distance south of Yen-an Fu, where we made solar observations for latitude. The temperature on this peak was now about $90^{\circ} \mathrm{Fahr}$. in the shade-a striking contrast to that experienced in January, when the party visited the same peak for similar purposes. The thermometer then registered $-\mathrm{r}^{\circ} \mathrm{Fahr}$. at ro a.m.

On August 25th we left Yen-an Fu and travelled northward to Sui-tê Chou. Nothing worthy of mention occurred on this part of the road, which has been dealt with already, except that one of the mules died from the excessive heat. Travelling up the deep loess ravines the caravan was cut off entirely from any cooling breezes, and the heat became insupportable. It is noteworthy that in this same district the travellers had suffered most severely from cold during the previous winter, when the temperature fell to $-6^{\circ} \mathrm{Fahr}$.

After leaving Sui-tê Chou the party turned eastward once more till the Yellow River was reached two days later at a place named K'ang-chia-t'a. The crossing was effected once more in safety, and all rejoiced at setting foot again on Shansi soil. The road now lay along the rocky boulder-strewn valleys so characteristic of Shansi. The first large town passed was a busy, evil-smelling place named Liu-lin-chên. This town should have been called "the city of flies," for nowhere in all our travels had we seen such swarms of these noisome insects. The food on the street stalls was literally buried beneath black masses, which, when disturbed, flew up in dense clouds-the air filled with the hum of myriad wings. They swarmed on the mules and on the naked backs of the natives, who, however, did not seem to mind them in 
the least! They tormented the Europeans beyond endurance, so that it was with considerable relief that we quitted the place on September 3 rd.

The arable land along the valleys was devoted with great success to the cultivation of millet, sorghum, beans, tobacco, indigo, cotton, castor-oil seed, melons, and pumpkins, rich crops of which were seen on either side of the road. Yung-ning Chou, a large but dilapidated town with but a small population, was reached on the evening of the 3 rd, and the following night the travellers put up at a small place named Wu-ch'êng, situated in the midst of high rocky mountains known to be full of game. Time, however, could not be spared for a shooting trip, and, on September 5th, Fên-chou Fu, a large and populous city on the T'ai-yüan plain, was reached. Here astronomical observations were again taken, and we continued our march north-eastward towards T'ai-yüan Fu. The crops in this plain seemed to be very rich indeed, consisting chiefly of millet, sorghum, and beans. Part of the country between Fên-chou and T'ai-yüan is famous as being the finest grape-producing district in North China, and we were able to indulge in the luscious fruit at a halfpenny per pound!

T'ai-yüan Fu was reached on September 8th, and here the ponies and mules were sold and the expedition came to an end, the party proceeding by rail from T'ai-yüan to Peking. 
PLATE 36.
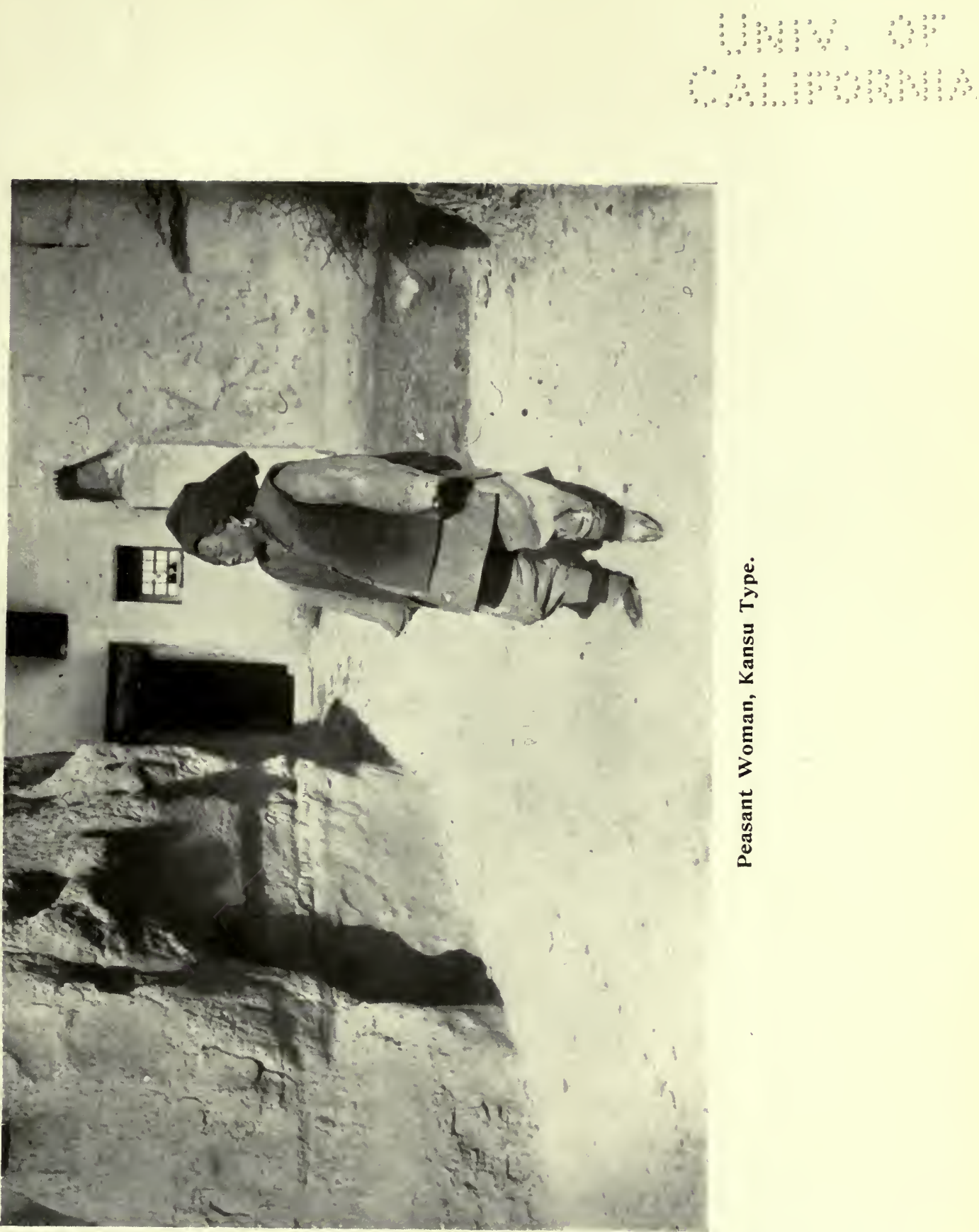

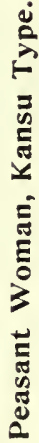




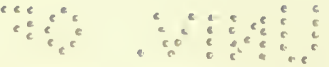

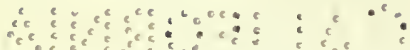




\section{CHAPTER X. \\ BIOLOGICAL WORK-BY A. DE C. SOWERBY.}

$\mathrm{T}^{\mathrm{HE}}$ narrative of the expedition having been set forth in the preceding pages, this chapter takes the form of a general description of the biological work, which was entrusted to me. The specimens which I collected were presented by Mr. Clark to the United States National Museum. Captain Douglas made an interesting collection of insects, which were presented to the British Museum. As our route has already been described, it is needless for me to do more than mention the names of places from which specimens were taken.

My outfit for the work was very simple and somewhat incomplete. Except for a few traps and instruments, which I already had, I was obliged to get all my requisites locally. The chief trouble was the lack of a good supply of traps, especially those for large animals. The main object of my work was the collecting of mammals. Birds were taken whenever interesting species were seen, and I was not too busy with mammals to prepare them. Reptiles, batrachians and fishes were caught whenever met with, and were preserved in alcohol. Captain Douglas confined his attention chiefly to blood-sucking and parasitical insects, such as fleas, ticks, and mosquitoes, but he also collected a few beetles, spiders, and flies. I made a large collection of butterflies and dragonflies towards the end of our expedition in Eastern Kansu and Central Shensi.

Before going into further details of the present work, it might be well to say something about that already done in the same districts. In connection with.the Duke of Bedford's Exploration of Eastern Asia in the early part of 1908, Mr. Malcolm P. Anderson and the writer had already made collections of mammals in Shensi, at Yen-an Fu and Yü-lin Fu. We also collected in thé mountains of Shansi, north-west of T'ai-yüan Fu. Mr. Anderson visited the Chiao-ch'êng Shan district towards the latter part of 1907 . From these 
collections the following new species and sub-species were described by Mr. Oldfield Thomas, F.R.S., in papers read before the Zoological Society of London :-

\section{In SHANSI.}

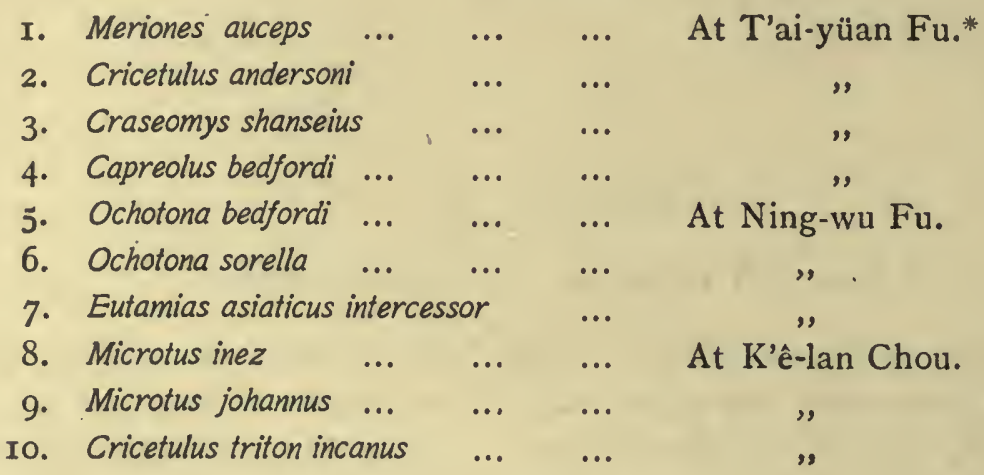

IN SHENSI.
I. Erinaceus miodon
At Yü-lin Fu.
2. Eutamias asiaticus ordinalis
3. Cricetulus bedfordiz...

... $\quad$...
,
4. Dipus sowerbyi
5. Lepus swinhoei subluteus
6. Mus confucianus luticolor
$\cdots \quad \cdots$
",
"
In South Ordos Desert.

Previous to these explorations the mammalogy of Shansi, Shensi, and the Ordos Desert had not been touched. Many of the mammals mentioned in the following pages have been described from other parts of China.

For scientific descriptions of the various species of mammals mentioned in this chapter, I must refer the reader to the following sources:-

I. Récherches sur les Mammifères, par M. Milne Edwards.

2. Papers by Mr. Oldfield Thomas, F.R.S., F.Z.S., published in the Proceedings of the Zoological Society from time to time during the years 1907 to 1909 .

3. Descriptions by Mr: Gerritt S. Miller, of the United States National Museum, of five new species and sub-species discovered on the present expedition. These descriptions, which have already been

- The localities here cited are those of the type-specimen only. Many of the species and sub-species were subsequently captured elsewhere, and some occur both in Shansi and Shensi. (See Proc. Zool. Soc., 1908, pp. 635-646, 963. 983 ; also Ann. Mag. Nat. Hist. (8), 11., rgo8.

A species of Myospalax collected by Messrs. Anderson and Sowerby at Ning.wu Fu and identified in 1908 as $M$. fontanieri, Mr. Thomas bas recently discovered to be new and described as M. fontanus (Ann. Mag. Nat. Hist. Jan.; rgrz, p. 93). 
PLATE 37.

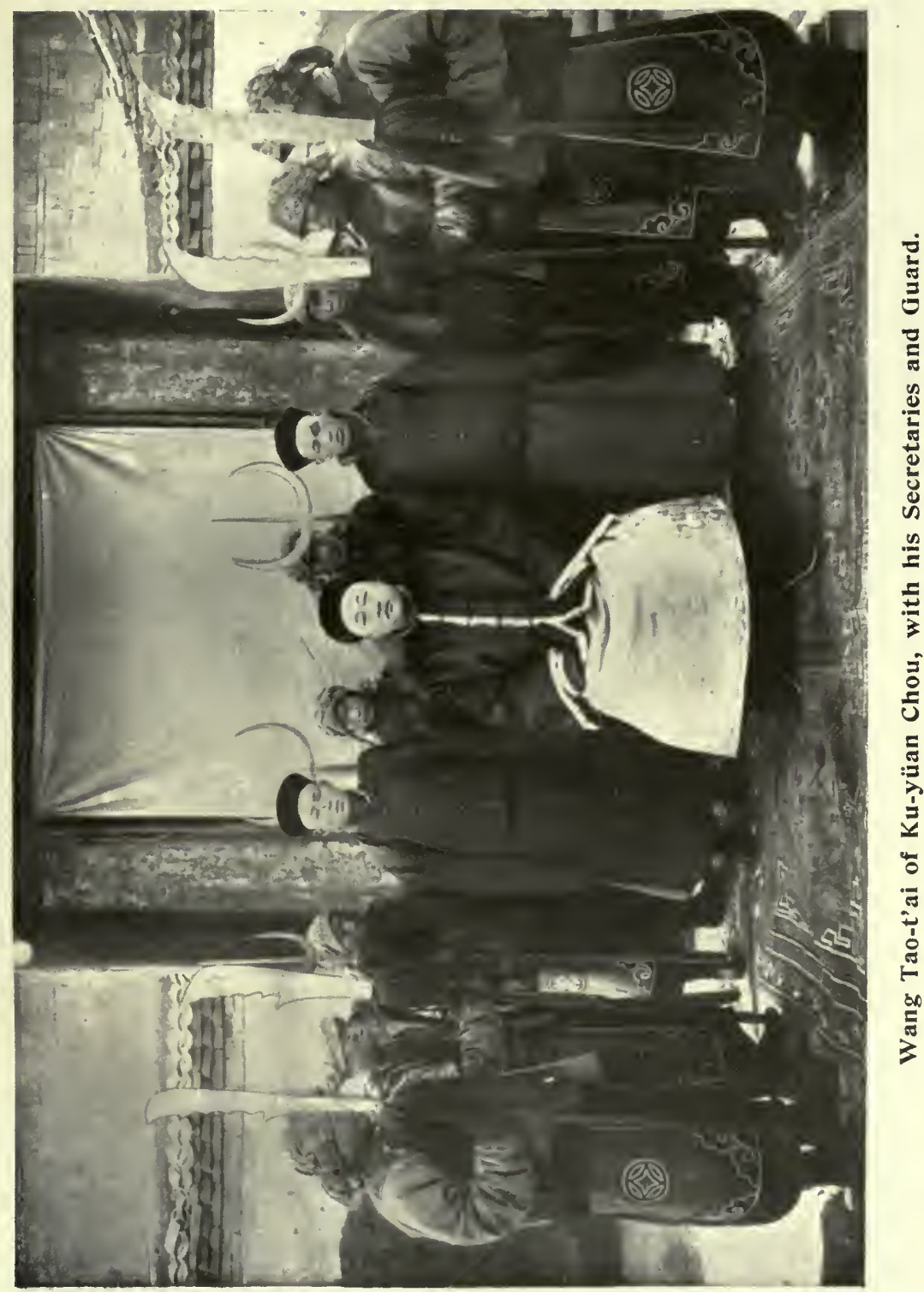


$\because \because \quad \because \quad \because a^{\circ}$

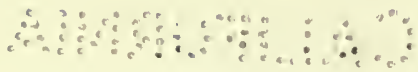


published by the Smithsonian Institution, have been embodied in a detailed report on the mammals collected by me, and they appear in Appendix II.

I must direct the readers' attention to a paper by Paul Matschie, "Ueber Chinesische Säugethiere besonders aus den Sammlungen des Herr Wilhelm Filchner," containing many interesting photographs of the skulls of certain Chinese mammals.

The birds of China are undoubtedly much better known than the mammals. Nevertheless, there seems to be no record of any work hitherto done in the districts traversed by our expedition. Mr. Anderson and I collected a few birds on the expedition referred to above, but no new species were discovered. A very complete account of the birds of China has been written by Armand David and E. Oustalet, and published under the title of "Les Oiseaux de la Chine."

As far as I know, the only reptiles, batrachians, and fishes collected hitherto in these districts were those obtained by Mr. Anderson and myself. Here again there is nothing new to report, the few species secured having been recorded from other parts of Asia. The number of new species of ticks, spiders, and fleas discovered on the present expedition shows that in this branch of zoology little had previously been done.

On our leaving T'ai-yüan Fu, I began my work at once. A single woodmouse (Apodemus speciosus) trapped in the mountains immediately west of T'ai-yüan Fu, and a few chipmunks (Eutamias asiaticus senescens) shot en route were the only specimens secured till we reached the Chiao-ch'eng Shan district. This country has already been described as consisting of high, rugged and heavily forested mountains. It is excellent from the collector's point of view, and during our stay a good collection of rodents was made. I soon had out a long line of traps, which were visited daily. The woodmouse was again secured, besides Anderson's hamster (Cricetulus anaersoni) and two species of voles (Craseomys shanseius and Microtus pullus). The last has been described as a new species by Mr. Miller; while Craseomys shanseius and Cricetulus andersoni were first discovered by $\mathrm{Mr}$. Anderson in this district. The woodmouse and Anderson's hamster were common almost everywhere. Craseomys shanseius was found in or near the heavy forests, which commenced at an altitude of about 8000 feet. One specimen was secured on the summit of Mo-êrh Shan, the highest peak in the district. Microtus pullus is closely related to $M$. johannus, a species first found by me in the K'e-lan Shan, about sixty miles north of the present locality. Both species are found on open hill 
sides, where their burrows are made conspicuous by the quantity of new earth thrown up at the mouths. A single specimen of the molerat (Myospalax cansus) was bought from a native (Plate 48 ). This specimen presents some peculiarities of its own, and, further, is the only one of the species hitherto recorded from Shansi. The type locality of this species is in Kansu.

I noticed evidences of the existence of some form of pika, a small rabbitlike rodent, on the rocky summit of Mo-êrh Shan; but although I climbed this peak three times, in my endeavour to secure specimens, I failed to do so. I have always found members of this genus (Ochotona) most difficult to trap. Some more chipmunks were shot in the mountains and valleys. The only other mammal secured in the district was a much decomposed shrew (probably Crocidura corex). The specimen was too far gone to identify properly.

Other mammals seen in the district were the roedeer (Capreolus bedfordi), the wild pig (Sus moupinensis), the wolf (Canis lupus), the fox (Vulpes vulpes), and the hare (Lepus suinhoei subluteus). The country is known to contain muskdeer, and many musk-hunters live in the district. Leopards have frequently been shot in these mountains, and the natives say that tigers also exist.

There are quite a number of birds in the vicinity. Those noticed were eagles, vultures, hawks, nutcrackers, timelines, accentors, woodpeckers, tits, and finches. I was too busy with the mammals to spend time on these. We found pheasants and partridges very common, while I noticed the feathers of the Manchurian eared pheasant lying about. The season was too far advanced for collecting reptiles, but Captain Douglas secured a few flies and spiders.

The forests consisted mainly of spruce, larch, and pine, whilst some of the slopes and ravines were thickly overgrown with scrub-oak, birch, and hazel. Close to the summit of Mo-êrh Shan I found some red-currant bushes, with the half-dried fruit still hanging. In the valleys there were a very thorny variety of gooseberry and also some raspberry canes. Along the banks of the streams, numerous late flowering herbs were noticed, including several varieties of anemones and gentians. Some of the unwooded slopes were covered with low bushes of a thorny le guminus shrub, whilst elsewhere rich grass was abundant.

On the journey between this rich and fertile district, and the sandy country round $\mathrm{Yu}$ ülin $\mathrm{Fu}$, in North Shensi, very little collecting was done. I shot a few more chipmunks, and also secured a few specimens of a small species of frog. The latter were found in the little streams, which ran along the ravine-bottoms in the loess country near the Yellow River. At one place a magnificent golden eagle was shot, and some ibis-billed curlews were secured near the Chiao-ch'êng Shan. 
In company with $\mathrm{Mr}$. Cobb, I left the main expedition at Kan-tsao-k'ou and hurried on to Yü-lin $\mathrm{Fu}$, reaching that place on October 26th. Knowing from previous experience that trapping would be useless in this sandy region, I at once set the natives to work digging up specimens; and a comparatively good collection was thus made. The lateness of the season, however, interfered considerably with my work: many species of small mammals were already hibernating, and in this way we missed the Ordos hedgehog (Erinaceus miodon), and the common suslik or ground-squirrel (Citellus mongolicus), (Plate $5 \mathrm{I})$. The first specimens brought in were some little sandhamsters (Phodopus bedfordiz), (Plate 49). This species was first secured in this district in the spring of the same year by Mr. Anderson and myself. It was placed in the genus Cricetulus by Mr. Thomas, and named after Her Grace the Duchess of Bedford. Mr. Miller has, however, since made for this species a new genus, Phodopus, based upon some unique peculiarities in the foot of this little creature. A large series of specimens of this little rodent was obtained, and a photograph was secured as well.

A single specimen of Cricetulus griseus was collected. This hamster closely resembles Anderson's hamster in shape, size and appearance. It differs, however, in being of a lighter, more buffy colour, and also in having a black line down the middle of the back. The tail is considerably shorter, and the feet are more hairy in C. griseus than in C. andersoni. The latter is an inhabitant of the hilly or mountainous districts of Shansi, Shensi, and at least the eastern part of Kansu. C. griseus, on the other hand, is usually met with on the grassy or sandy plains on the borders of Mongolia. Both species differ greatly in appearance from Phodopus bedfordiz, though all three forms are characterised by the possession of large cheek-pouches opening into the mouth.

A good series of the three-toed jerboa (Dipus sowerbyi) was secured, (Plate 50). This jerboa, the only three-toed species hitherto recorded from China, was discovered by me in this region on my previous visit. A purely sand-loving animal, this jerboa inhabits the dunes which exist in, and on the borders of, the Ordos Desert. Like those of the sand hamster, its burrows are almost impossible to find. It is a question whether this species fills up the mouth of its burrows purposely, as do the American Dipodidx, or whether this is done naturally by the loose sand. It was too late in the year for me to investigate this problem, as the jerboa was hibernating. On my previous visit I often saw the tracks of this lively little creature in the sand. From these I gathered that the animal is capable of jumping eight feet. Two living 
specimens which were placed in a jar some three feet deep jumped out without touching the sides. When asleep, they lie on their sides for the better accommodation of their long hind legs. If proceeding slowly, they hop rabbitfashion on all four feet. It is only when progressing at some speed that they use their hind legs alone. When hopping, one foot precedes the other, instead of both being kept together. Many of the specimens caught were torpid, but they soon became active in a warm room. Their bodies were loaded with thick layers of fat.

Some molerats belonging to the Shensi species, Myospalax cansus, were brought in (Plate 48). This rodent is an extremely interesting animal: it combines, as the name suggests, the attributes of the mole and the rat. The different species vary in size, the present one being roughly about seven inches long, not including the tail. In appearance the molerat also bears some resemblance to the American pocket gopher. It is covered with a soft, grey fur. The fore feet are large, being armed with powerful claws for burrowing. The tail is short, and, like the feet, of a pink colour. Both are naked, except for a few stray hairs. The head is flattened above and resembles a spade in shape; it is used for shovelling loose earth, when the powerful muscles of the neck are brought into play with great effect. The eyes are small and almost hidden, whilst the ear is little more than a small round hole. The jaws are armed with thick and powerful incisor teeth, which suggest that the animal feeds on roots. The molerat seldom comes above ground, but that it does so occasionally may be gathered from the fact that I have found its remains in owl pellets. The Chinese peasants declare that by watching the mouth of a molerat's burrow they can foretell the weather. The burrows, they say, are left open when fine weather may be expected, and closed before the advent of rain.

A single mole (Scaptochirus gilliesei) was bought from a native. This mole resembles the Peking species, but is much smaller. At that time it was unknown to science, but it was described from a specimen from south Shensi by Mr. Thomas, before my specimen could be identified as belonging to a new species.

Two skins of a new and interesting polecat (Vormela negans) were secured. Resembling the common polecat in shape, this species is characterised by a peculiarly marked and brightly coloured pelt. The face is black and white, whilst the throat, legs and belly are of a shiny black. The nape of the neck is of a pale cream colour, which becomes a bright yellow on the back shading into a rich orange on the sides, and towards the base of the tail. From the 
PLATE 38.
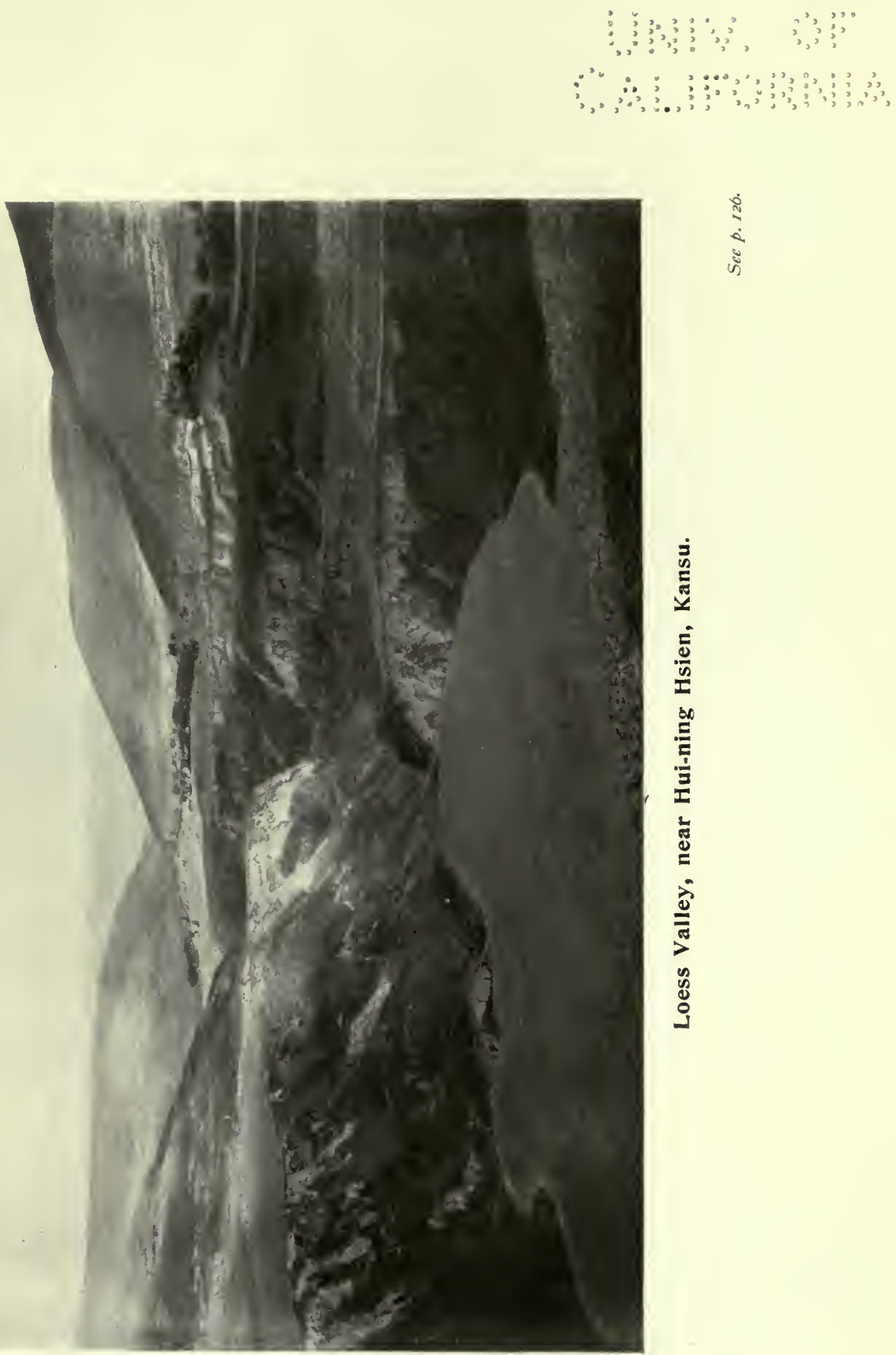

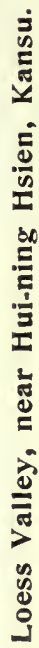




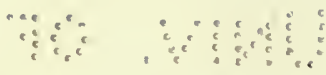

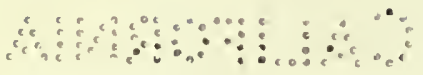


shoulders backwards there are spots and mottlings of a deep brown colour. In this respect it differs from the western form, Vormela peregusna. In this species the ground colour is brown, while the mottlings are of yellow. For this reason Mr. Miller gave this new species the specific name of negans. The Chinese call this animal Ma-nai-ho. I could not get the meaning of the first two words, local authorities disagreeing as to the proper characters to apply. All were agreed that the last syllable ho is that for monkey. This, doubtless, indicates a semi-arboreal life at least. Yü-lin Fu marks, as far as is at present known, the extreme eastern limit of the range of vormela.

A couple of specimens of Meriones auceps were trapped by me amongst the sand-hills. This beautiful gerbil was first described by $\mathrm{Mr}$. Thomas from specimens taken by Mr. Anderson in T'ai-yüan $\mathrm{Fu}$. Another form also exists in the Ordos Desert and other parts of Mongolia, and is known as $M$. unguiculatus. The two species differ in colour and skull measurements, and also in their habits. $M$. auceps is strictly nocturnal, while $M$. unguiculatus is as purely diurnal. During my previous travels in the Ordos, I saw great numbers of the latter animal playing about the mouths of their burrows. These gerbils do not hibernate, and may be trapped even in the coldest weather.

The pale desert chipmunk (Eutamias asiaticus ordinalis), originally described from this locality, was secured. In size and form this chipmunk does not differ from the ordinary North China form, but it is paler and decidedly more yellow in colour.

Foxes, wolves, badgers, and wild cats $I$ knew to be in the district, but none were secured. Some antelopes were seen by two members of the expedition. The skins of these animals were very common in the fur shops in the city. The poor people use them in the manufacture of clothes. Not many species of birds were seen, but a heron, an eagle-owl, a woodpecker, and some pheasants were secured.

On the sandy flats of the river there were large flocks of cranes, mallards, teal, and ruddy sheldrake. The last would allow of a close approach, so that an opportunity of tasting their coarse and oily flesh was afforded. A few small flocks of geese were seen on our arrival, but a few days later these had gone south. Black storks were also seen during the first part of our stay in the district. Magpies, crows, kites, pigeons, shrikes, and larks were the only land birds remaining as the severe North China winter closed down upon us.

Before the streams which feed the river at this point froze over, I secured some specimens of fish and frogs. In all there were some five species, four of 
the former and one of the latter. Some little sand-inhabiting lizards (Phrynocephalus frontalis) were secured, and also two varieties of non-poisonous snakes. These were Tropidonotus tigrinus, a green water snake, and Coluber dione, a brown species which inhabits the sand-hills and loess country.

Some interesting insects were also secured, amongst others being a new flea and a new tick, both from one of the molerats. There was very little to record in the way of plant life. Elms and willows were the only trees noticed, while small patches of a sort of sage bush were scattered over the sand dunes. I found one sprig of parsley, whilst a very coarse and straggly grass existed in some parts.

Yen-an Fu was the next place where I made collections. Between Yü-lin $\mathrm{Fu}$ and this city the country was very desolate and void of animal life. Not far from Yü-lin Fu a flock of bustards was observed. Elsewhere the common rock dove and stock dove were seen in large flocks. A few coveys of partridges were also noticed, whilst here and there a lonely golden eagle would be sighted. In the ravine bottoms some dippers were visible, and one was secured. A specimen of the peculiar wagtail-like bird called Henicurus sinensis was obtained at Shih-ts'ui-yi.

The only mammals seen were two David's squirrels (Plate 49), both of which were secured, and a few hares. The latter were not observed till we were in the valley of the Yen Shui, close to Yen-an Fu. Here pheasants were very plentiful.

At Yen-an Fu I again took to trapping with good results. I soon secured some more specimens of Cricetulus andersoni and Meriones auceps, both of which species were very common in the locality. Besides these I caught some specimens of the sulphur-bellied rat (Mus or Epimys confucianus luticolor), which was described from the locality. This rat seems to be a purely rock-inhabiting species, and is caught in the same places as David's squirrel. It somewhat resembles the common brown rat, but is not quite so large, is of a conspicuous tawny tinge, and has much longer ears and tail. The latter is white towards the end, and on the under surface. The fur of the belly varies from a rich cream to a pale sulphur-yellow. The latter colour soon fades, however, in preserved specimens. This new subspecies was first discovered by me earlier in the same year.

A field mouse (Apodemus agrarius pallidior) was also trapped. This mouse has a dark stripe down the middle of the back. It is usually to be caught in open bushy fields, either in the valleys or upon the hill-tops. Two or three specimens can usually be trapped at the same hole. 
The large grey hamster (Cricetulus triton) was caught. This rat resembles C. andersoni in colour, but is considerably larger. It is a pugnacious and predatory animal, storing up large quantities of beans and millet in its deep burrows. Many of the poor people dig up these stores of grain in the districts where this rat is abundant. In Shansi a still larger form, C. triton incanus, is found. It is particularly abundant on the T'ai-yuian plain.

I secured a couple of good specimens of the local hare (Lepus swinhoei subluteus), which was first described from a specimen shot by me in the Ordos Desert. This hare is considerably paler than its cousin (Lepus swinhoei) from the Shantung Peninsula.

I tried trapping for wolves and foxes, but without success. The only traps I had were some native-made ones from Yü-lin Fu. These were excessively clumsy and difficult to conceal.

Not being very well satisfied with the country immediately around Yen-an Fu I decided to go further afield. Taking a few stores and necessaries with me, I visited a valley about twelve miles south of the city, putting up at a small inn. The country here was much more to my liking, and I was able to secure a few more species. Roedeer were plentiful, and I soon managed to shoot a good specimen. Mr. Grant also secured one, and later on some more were shot in the same locality. The North China roedeer differs from the European forms in being larger, with a much yellower coat. This tendency to yellow in the fauna of Shansi, Shensi, and Kansu, is doubtless due to the uniform yellowness of the loess country which composes the greater part of the three provinces. The roedeer is extremely common in suitable country, and not much hunted by the natives.

My traps here yielded poorly, a result no doubt of the excessive cold. I secured a specimen of the pika (Ochotona bedfordi). It was at Yen-an Fu that I first discovered this interesting species, which was subsequently described as new from specimens obtained in Shansi at Ning-wu Fu. The burrows of these pikas are usually deep and intricate, and are situated where the thorn scrub grows thickest, or up the sides of the deep loess gullies. I did not see any stores of hay like those made by the Siberian and American species, neither did I hear any sound from these interesting little creatures. They live in little communities like rabbits, the ground surrounding their burrows being covered with a network of little paths.

A single specimen of the little vole Microtus inez, was trapped in one of the ravines. This interesting little vole was discovered by Mr. Anderson in the mountains near K'ê-lan Chou, North Shansi. This is, as far as I know, the 
only vole hitherto recorded in North Shensi. It differs from the other voles already mentioned in being smaller and of a rich reddish brown colour. It is trapped usually amongst the dead leaves, or on mossy banks at the bottom of loess ravines in well vegetated country. Some more wood-mice and David's squirrels were also secured here, besides a fine specimen of the hare. David's squirrel (Sciurotamias davidianus), (Plate 49), is a rock-inhabiting species. It is about the size of the common European red squirrel. Its fur is of a dull earth-brown colour above and creamy beneath. The ears are not tufted, though the tail is very bushy. Like the chipmunk it possesses cheek pouches. It also resembles the chipmunk in its habits and mode of life, except that it does not hibernate. This squirrel enjoys a very wide range being recorded from the mountains near Peking, from various places in Shansi, Shensi and Kansu and also from Ssŭch'uan.

Birds were more plentiful in this district. Some specimens of the beautiful blue magpie (Urocissa sinensis) were secured and Azure-winged magpies (Cyanopolius cyanus) were also plentiful, springing my traps and making themselves generally disagreeable. A pretty timeline (Pomatorhinus gravivox) was also very common. The country was teeming with pheasants and I saw the tracks of wild pigs, wolves and leopards.

This country had not been under cultivation since the great famine of I877-79 when parts of North China were terribly depopulated. As a result in this and many other localities the mountains, hills and valleys have become scrub-covered and even well wooded. Good cover for game and wild animals of all kinds is thus afforded. It is possible that many species owe their existence in North China to-day to these periodical famines, which check the ever increasing human population. Where conditions are favourable to cultivation in North China, it is extremely difficult for the naturalist to find suitable collecting grounds. Every foot of land is utilised. It is only in such spots as these whence man has been driven out, and which have lain fallow for a generation or so, or in places like the Chiao-ch'êng Shan, precipitous, rocky and cold, that one finds animals at all plentiful.

After a week's stay in this country I returned to Yen-an Fu. Here I secured a nice specimen of the spotted wild-cat (Felis chinensis) and another of the large marten (Martes flavigula borealis). Both of these animals were said to be fairly common in the district though very hard to secure.

Nothing in the way of reptiles; batrachians or fishes was secured, but a new and interesting flea was taken from one of the roedeer. The female of this flea was found in large numbers in the nostrils of the deer. The insects were 
PLATE 39.
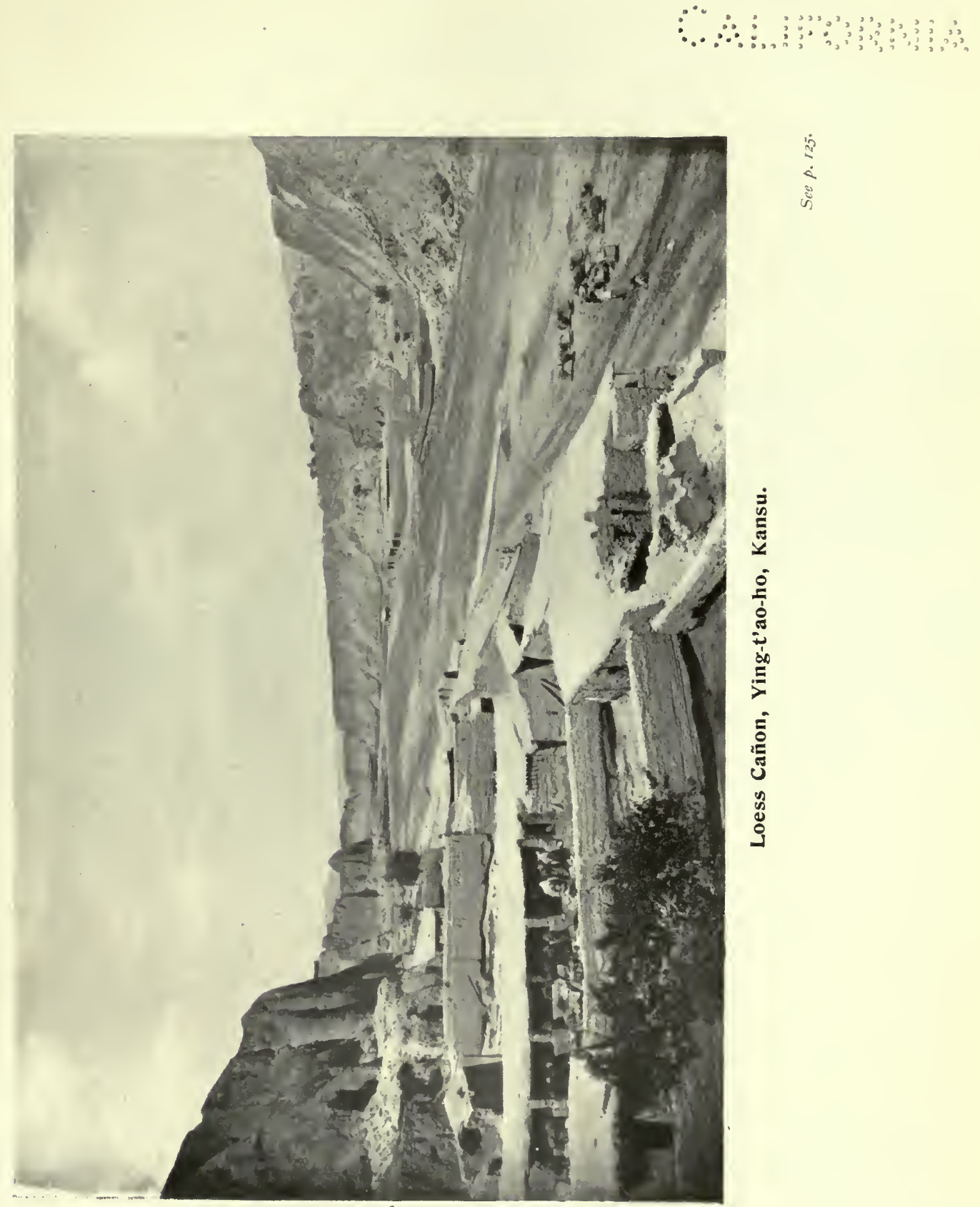

¿ุ

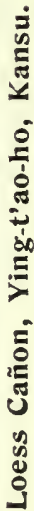




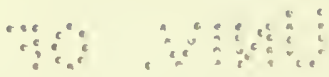

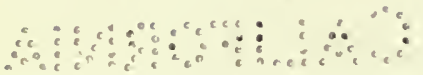


much swollen, and were at first taken for maggots. Detailed descriptions of this and two other fleas discovered appear elsewhere* in this volume. On the same deer a new species of tick was also secured.

This completed the zoological work done in this district.

Mr. Clark and I left Yen-an Fu on January 28th, 1909, on our way south to $\mathrm{Hsi}$-an $\mathrm{Fu}$. The journey was accomplished as rapidly as possible, so that no collecting could be done. About five days journey south of Yen-an Fu we passed through a belt of uncultivated country, also a result of the famine. Here again game was abundant. Roedeer were seen close to the road, and a wild boar was chased across in front of our mule-train by a hunter and his dogs.' Pheasants were so numerous that we amused ourselves by taking shots at them with our revolvers as we rode along.

As we neared Hsi-an Fu we came down upon some great loess steps. Here we saw large flocks of bustards. I managed to secure one of these handsome birds with a rifle shot. It weighed $16 \mathrm{lbs}$. At last we reached the great Hsi-an Fu plain and shortly found ourselves in a veritable fowler's paradise. The banks and flats of the rivers we crossed were black with wild fowl, while great flocks of geese were seen feeding on the fields of early wheat. They were easily shot from horseback. Here and there were small flocks of stately cranes, whilst in the irrigation canals and marshy rice fields were feeding numbers of Chinese ibises (Nipponia nippon), pink, white, or grey.

We spent two days in Hsi-an Fu, and then went to a small town called Lin-t'ung, where there are some famous hot springs. Here Mr. Clark left me, hurrying on eastward to Ho-nan $\mathrm{Fu}$ in Honan, and thence to Shanghai. I spent a few days trapping round Lin-t'ung but secured nothing more than a specimen of the common mouse (Mus wagneri mongolium). On the plain I shot geese, duck, hare, snipe, and bustard. In the course of a single morning's shooting I was able to make the respectable bag of five geese, three mallard, a fifteen pound bustard, and a hare.

I next tried a place at the foot of the high mountains about fifteen miles due south of $\mathrm{Hsi}$-an $\mathrm{Fu}$, finding quarters in a temple in a little village named Liu-ts'un, at the mouth of a long ravine, and began trapping again, this time with more success. The sulphur-bellied rat, the field-mouse, the wood-mouse, and David's squirrel, were the only rodents secured.

Two minks (Lutreola sibirica) were caught in the temple, after repeatedly stealing game from my larder. These animals displayed the utmost ferocity when caught. I have never witnessed such fury incarnate even in much larger animals of more sinister repute. 
Just before I left the locality the old priest of the temple showed me the horns of a goral (Urotragus galeanus), and told me that this animal was to be found on a high peak some five miles away. I could not leave without making an effort to secure a specimen, so decided to postpone my departure and visit the peak in question. I was successful in my hunt. Taking a native with me to carry my shot-gun, in case some small animal presented itself, I went up the ravine, and after a hard climb reached the summit of the peak, where, perched at an altitude of about $4000 \mathrm{ft}$. we found a quaint Buddhist temple. The top of the peak was conical in shape, and covered with cypress and other conifers. A long and steep flight of stone steps led up to the temple. The priests told me that there were several gorals living on the peak free from persecution; they themselves as Buddhists, not being allowed to take life. However, they had no objection to my killing these animals, which habitually fed upon the little patches of wheat and maize kept by the priests half-way down the mountain slope.

In a scramble through the woods round the sides of the peak we soon put up a handsome goral, which bounded up the steep slope with wonderful agility, and made its escape round the top of the peak. Its tracks after rounding the peak vanished over the edge of a precipitous peak, which fell away almost perpendicularly for hundreds of feet. Carefully I climbed down making use of the little cypress trees that sprang from the cracks in the rocks. When about half way down I heard something scrambling above and to the left of my position. I looked up and once more caught sight of the goral climbing towards the top of the precipice. Balancing rnyself with one foot on a ledge, the other on the trunk of cypress, empty space beneath me, I took a rapid aim, and fired just as he gained the top of the cliff. I missed, but the animal passed within twenty yards of my bearer, who was lying exhausted from the severity of the climb and chase. He heard my shot, and looking up saw the goral. He let drive with a dose of buckshot, killing the animal on the spot.

The goral, of which there are many species, is a goat-like animal that inhabits, in China, the highest and rockiest mountain-ranges of the central and western provinces. It is a daring climber, bounding up precipitous cliffs that a man would hesitate to attempt. The present species differs but little from the Yang-tzŭ form. In appearance this goral is something between a goat and an antelope. It has thick heavy legs, with large hoofs, a slight crest down the neck, and small, sharply sloping, and very pointed horns. It is of a dark-grey colour, with cream-coloured legs, and a creamy patch on the throat. 
PLATE 40.
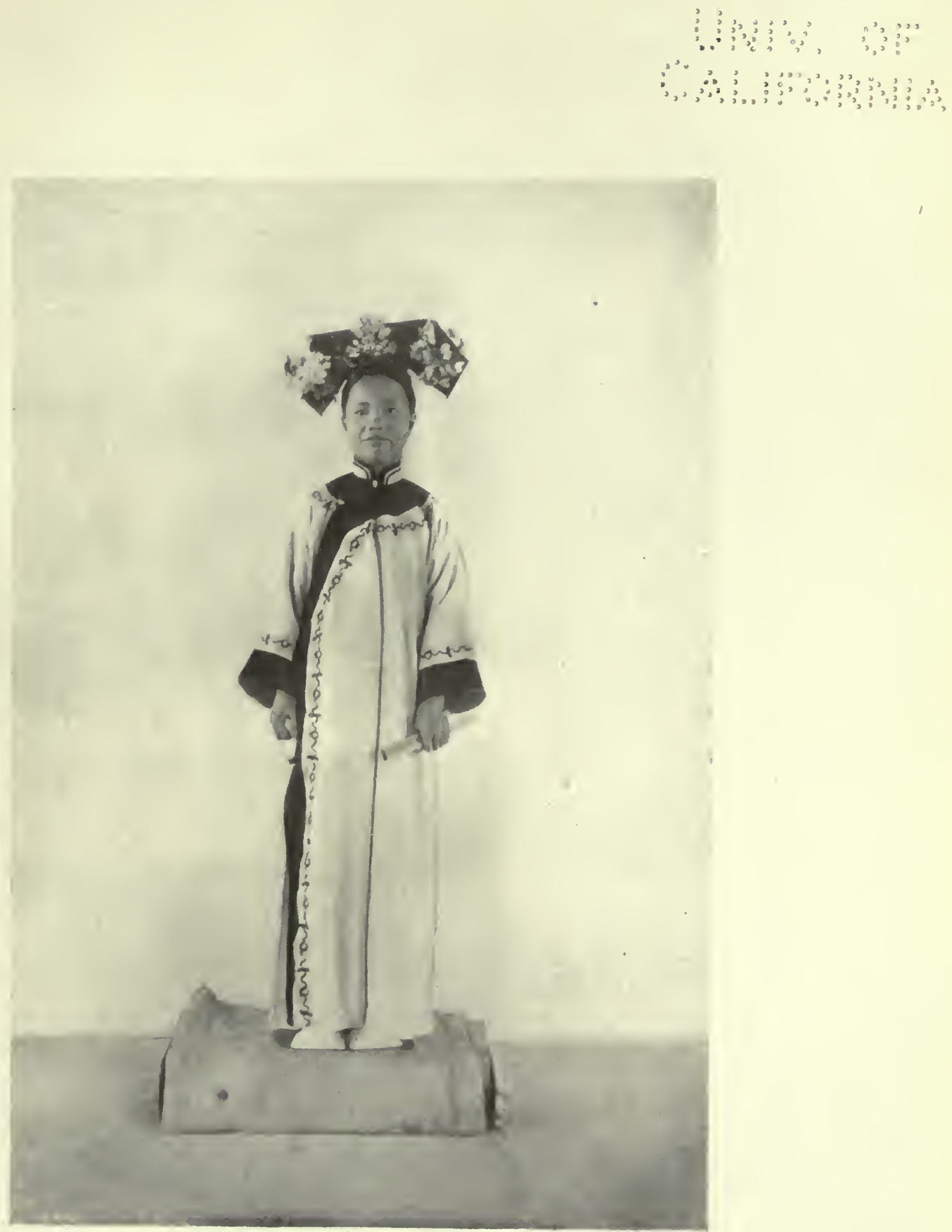

Manchu Lady. 


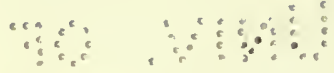

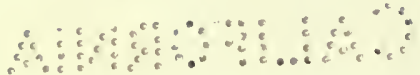


There were some interesting birds in the vicinity. I collected some prettily coloured timelines, including a large dusky one named Dryonastes perspicillatus. A beautiful Chinese representative of the common jay (Garrulus sinensis) was also secured, besides the graceful blue magpie (Urocissa sinensis), the tiny wren (Anorthura fumigata), the green woodpecker (Gecinus canus), and the redstart (Phoenicurus auroreus). The beautiful sweet-voiced wall-creeper (Tichodroma muralis) was also seen, but I failed to secure a specimen. The golden eagle, pheasant, and partridge were again met with.

In the mountain-stream that flowed down the ravine I caught an interesting freshwater crab (Potamon $s p$.) and some small fish too young to identify. In the ravine were numerous varieties of ferns, mosses, and rock plants, while here and there in sheltered nooks were small clumps of dwarfbamboo.

After leaving this locality my collecting work was discontinued till the beginning of May. I hastened to Ho-nan Fu, where I received word to go to Hankow to meet Mr. Clark. On the road between IHsi-an Fu and Ho-nan Fu I saw great numbers of geese and ducks. At Ho-nan Fu I was told of great forests in the mountains a few miles southward where, the natives said, flying squirrels, monkeys, and bears were abundant.

Mr. Clark and I returned from Hankow with all speed, and early in May left Hsi-an Fu for Lan-chou Fu. Along the road I shot some ground squirrels (Citellus mongolicus), (Plate 5I), and a single chipmunk, which resembled that from $\mathrm{Yu}$ ü-lin $\mathrm{Fu}$ in the pale colour of its pelt. Travelling at the rate we were, there was no opportunity of trapping. Such specimens as were obtained were shot near the road.

As the greater part of the country in Kansu was suffering from a protracted drought, there was little to be seen, hares, squirrels, chipmunks, foxes, and some roedeer being the only mammals noticed. Pheasants, partridges, snipe, and a few small waders were seen from time to time.

We reached Lan-chou Fu, in Kansu, on May 24th. While here I tried to induce the natives to bring in specimens, but without success. Five specimens of Citellus mongolicus were the only things obtained. The country had been suffering from a severe drought for three years, and no doubt this had much to do with the scarcity of animal life.

About the middle of June I went south to some mountains where conditions were a little better. Though I trapped and shot on several days, the only specimen secured was one of Apodemus speciosus. I might here draw attention to the great range of this species. On the present expedition 
it was the most easterly species obtained, as well as the most westerly. It was trapped at Liu-ts'un, our most southerly point, and also in the Chiaoch'êng Shan, almost our most northerly point. It is recorded from Ning-wu $\mathrm{Fu}$, in North Shansi, and from the Imperial tombs, sixty miles east of Peking, in Chihli. Whilst in the country south of Lan-chou I saw a large wolf one morning, and in our daily excursions we came across fresh tracks of pigs and musk-deer. There were quite a number of pheasants, but little else.

The reasons for the termination of the expedition at Lan-chou have already been mentioned. I was forced to return to that city, and my work ceased till, on July I5th, Grant and I started on our homeward journey with the main division of the expedition. We travelled almost continuously till we reached T'ai-yüan $\mathrm{Fu}$ on September 8th, with a few short halts en route to take astronomical observations, or when we were held up by rains. We took the unfrequented route which runs in an easterly direction from Lan-chou, collecting what material we could along the road. For the first few days our path lay through utterly barren and sun-scorched mountains, so that a few ground-squirrels only were seen. At Ching-ning Chou, where we stayed two days, I secured two specimens of an interesting eastern polecat (Mustela larvata), (Plate $5 \mathrm{I}$ ), which is superficially like the European animal, but with larger teeth. A new pika (Ochotona annectens), (Plate 52), was shot close to this place by one of our men. This species is similar to Ochotona bedfordi, but is smaller and with differences in the skull. Several chipmunks (Eutamias asiaticus senescens), (Plate 48), were also obtained. The type of this chipmunk was described from specimens from near Peking by Mr. G. S. Miller, and like Apodemus speciosus, it seems to enjoy a very wide range.

On July 25th we left Ching-ning Chou and reached a small place to the north-east called Chang-t'ai-pu. That night rain fell in such torrents that we were unable to proceed next day. Accordingly I enlisted the villagers into my service, sending them out to catch or dig up specimens. All that day and the next I was inundated with specimens, the following species being well represented:-Myospalax cansus, Allactaga mongolica longior (new to science, Plate 52), Eutamias asiaticus senescens and Ochotona annectens (new to science, Plate 52). A single specimen of Cricetulus anaersoni and another polecat were also amongst the animals brought in. I refused to take any more specimens of Citellus, having my hands full of more important material.

The "allactaga" which has been described by Mr. Miller as a new form is a species of jerboa. It differs from Dipus sowerbyi in having five toes on the hind foot instead of only three, while its ears are considerably longer. 
In colour it is greyer than the three-toed jerboa, and it is a larger animal. The " allactaga" is not so essentially a sand-inhabiting animal as the jerboa. The present species differs from Allactaga mongolica in having appreciably longer ears, longer feet, and a slightly different skull.

After leaving this locality, bats were seen for the first time on the expeditions, and between here and Yen-an Fu in Shensi several specimens of a large brown bat (Eptesicus serotinus pallens) and a single specimen of a very small bat (Pipistrellus sp.) were shot. The large bat has been described by Mr. Miller as a new subspecies.

From Ching-ning Chou eastward the country was much more favourable for collecting. There were plenty of vegetation and water so that-we were able to do good work considering the rate at which we were travelling. Grant and I devoted our attention to entomology as we travelled, and made large collections of butterflies and dragon-flies. Frogs were also secured from the streams, besides some more fresh-water crabs and some snakes. Two varieties of kingfisher were shot. One was a large handsome bird named Halycon pileatus and the other a small brilliant little fellow named Alcedo ispida. This species resembles the British form but is smaller.

We saw more roedeer; and specimens, in their red summer pelts, were obtained.

Two day's journey south of Yen-an Fu a mud turtle (Trionyx sinensis), (Plate 54), was shot. As we travelled along beside the river we saw great numbers of these ugly creatures basking in the sun on the mud flats. On our approach they made for the water and were lost to view before we were in shot-gun range. Looking at them through a powerful pair of field-glasses, we could see every head pointed in our direction.

On August the 2Ist we reached the spot, south of Yen-an Fu, where I had collected the previous winter. Here some more roedeer were obtained and I was fortunate enough to put up and shoot a large wild boar (Sus moupinensis). (Plate 53). Rising early in the morning I made my way up a long loess ridge where I had seen pig-rootings the previous evenings. I was accompanied by a native and we tramped a long way without seeing anything. Just as I was about to return to camp, there was a hoarse roar in some dense scrub on the left, and a huge pig broke cover and scampered off tossing his head in a vindictive manner. I caught a glimpse of his wicked little eye glaring at us as he tore his way through the dense scrub. I tried to draw a bead on him, but his course was too erratic and the abrupt way in which he had appeared upon the scene had somewhat disconcerted me. Presently however he stopped to 
listen and I could see his round back showing above the tall gently waving grass. Aiming low I fired, hitting the pig, as I afterwards found, in the flank, More grunts followed and he plunged away apparently unhurt. We followed in hot pursuit and presently the native spied our quarry standing in the shade of some young poplars about 200 yards away. Taking careful aim I fired and when the smoke cleared away we saw the boar spinning round like a terrier after his tail. As I rushed up he plunged about wildly, but I managed to put a bullet into his shoulder as he vanished into a small ravine, from which now began to issue a deafening noise. The ravine opened abruptly into a hugh chasm the sides of which were perpendicular for about $200 \mathrm{ft}$. Towards this chasm the badly wounded animal struggled, and reaching the edge rolled over. He would have disappeared into a deep water tunnel yawning below, but for some stout birches which caught and held him. From my position above the madly struggling brute I fired a final shot into his chest, and soon he lay quiet. A long tramp back to camp for breakfast and to secure men to help me carry home my prize was necessary, (Plate 47). The day was far spent before we finally laid the huge animal on the grass outside the tent. He looked very peculiar in his short summer coat. He was a fine specimen measuring $6 \mathrm{ft}$. $2 \mathrm{in}$. from the tip of the snout to the end of the tail, and weighed 240 catties. One catty is supposed to be equal to a pound and a third, which would bring the weight of the pig up to 320 lbs. But I have since had reason to doubt the accuracy of the native scales used, and believe that the weight above stated is somewhat over the mark.

The range of the wild pig in North China is considerable. It is very plentiful in the mountains of Shansi, where of late years it has been hunted by European residents. Nothing very striking in the way of records have been obtained, however, 350 lbs. being probably the outside weight of the largest animal shot up-to-date. The largest tusk that I have seen measured $9 \frac{1}{8}$ inches along the curve and $I$ inch in thickness. The average length of tusks secured in Shansi up to the present would be about 8 inches. The nocturnal and destructive habits of this pig agree with those of the European and Indian species, to which it is closely related. It does great damage to crops, and we frequently saw little booths beside the fields, wherein the farmers kept watch against this troublesome pest. Sus moupinensis was first discovered by the indefatiguable Père David, in the principality of Moupin in Eastern Thibet, from whence it derives its name. It is of some economic value. The flesh of a good fat female will fetch a fair price, but that of the male is coarse and of a strong flavour. The thick hide is used in the 
PLATE 41.
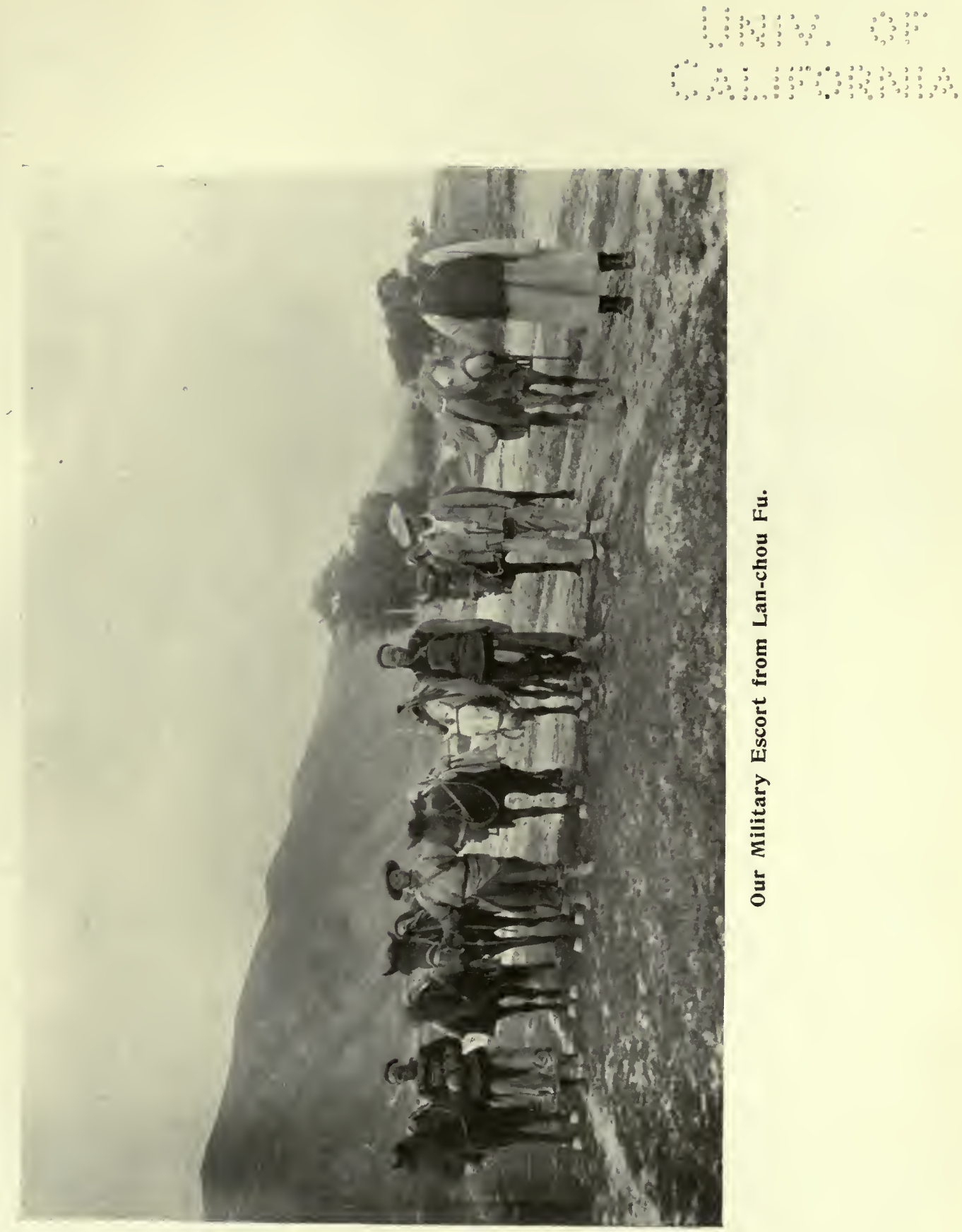


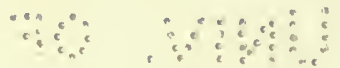

$\therefore$ 
manufacture of large drums, and also of the better class of saddles. The guns used by native hunters are so inferior that little is done in the way of hunting this formidable beast, which when only slightly wounded seriously menaces the life of its assailant. It seldom attacks unless provoked, but I have more than once heard of a pig charging some harmless woodcutter and inflicting serious wounds. I have frequently come across pigs' nests in the form of great heaps of dried branches piled over a pit in the ground. In this the sow produces her large litter of prettily striped young.

With a few odd roedeer skulls and a fine specimen of David's squirrel the collection was completed. The country between Yen-an $\mathrm{Fu}$ and T'ai-yüan $\mathrm{Fu}$ in Shansi presented no facilities for collecting. In all some 250 mammals were taken representing thirty-four species and sub-species, of which five have been described as new by Mr. Miller in the appended paper. (Appendix ii.). Several species in the collection, though possessing peculiarities, were so poorly represented that it was not deemed advisable to describe them as new. 


\section{CHAPTER XI.}

BIRDS OF NORTH CHINA-BY A. DE C. SOWERBY.

THE provinces of Shansi, Shensi, and Kansu through which the expedition passed are comparatively rich in feathered inhabitants, though there seems to be little, if any, likelihood of new discoveries being made in this line. Birds being easily collected owing to their diurnal habits and conspicuousness, are naturally the first to be studied by naturalists in a new country. For these reasons, it was decided that I should devote my energies more especially to mammals.

As, however, there are many interesting features attached to the study of birds in a new country, especially during the migratory seasons, a chapter dealing with those noticed on the expeditions may not be out of place in this volume.

Space will not permit of a very detailed treatment of the subject, and I shall do little more than give the names of the birds, mention their haunts and breeding-places, and describe the general appearance of the more remarkable species.

In North China, as in all other north temperate regions, birds belonging to the great order of Passeres (perching birds) predominate. Crows, larks, finches, wagtails, flycatchers, or thrushes are met at every turn. Let us take the family Corvidæ (crows) as a starting point. During some years of travel in the six northern provinces of China, I have noted some twelve species belonging to this family. The raven (Corvus corax), carrion crow (Corvus corone), white necked crow (Corvus torquatus), black crow (Corvus sinensis), Chinese jackdaw (Coloeus dauuricus), rook (Frugilegus pastinator), and chough (Graculus graculus), are common everywhere. Closely related to the black and white Chinese jackdaw (Coloeus dauuricus), is an entirely black variety (Coloeus neglectus) which is somewhat rare in the north. It may sometimes be seen in company with the former.

In some provinces, the raven acts as scavenger in towns and villages, but usually it prefers the high mountainous districts or remote desert regions. Amongst the Chinese who live on the borders of the Ordos Desert and out in north-western Kansu, this evil-looking bird goes by the name of "The Mongol's Coffin." That it deserves this name may be gathered from the fact that the 
PLATE 42.
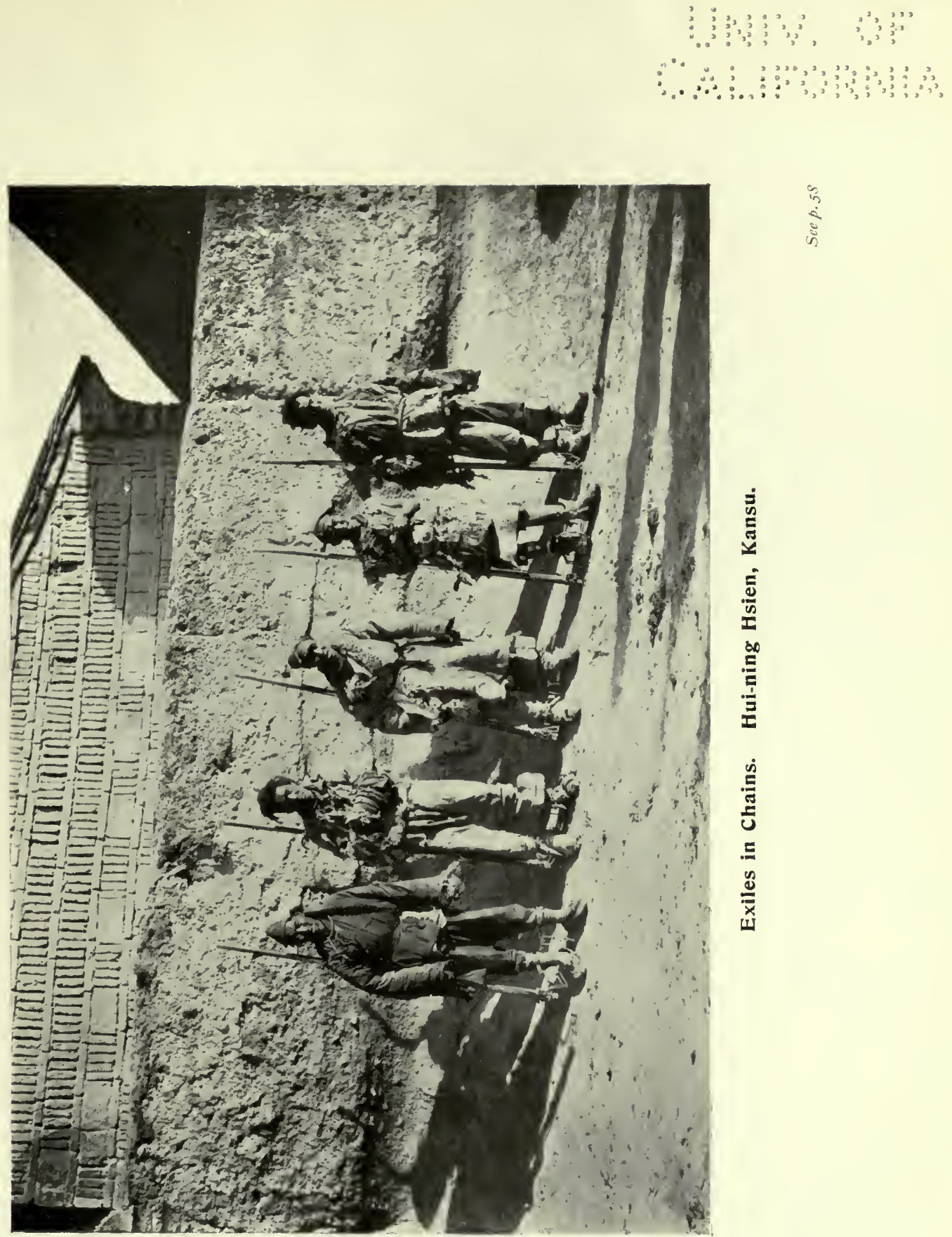
4 का

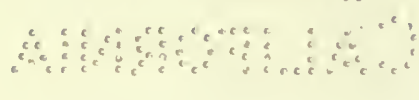


Mongols do not bury their dead, but drag them out into the desert, where they leave them to be devoured by the fowls of the air or the beasts of the field.

The pretty little Chinese jackdaw, whose clean white collar and breast and shiny black head, back, wings and tail give it a neat, clerical appearance, often associates in large flocks with the handsome red-billed chough. They frequent the same localities and both build their nests in crevices and holes in high loess or rocky cliffs.

The white-necked crow is never seen in mountainous regions, and even on the fertile plains is not over abundant. It is a very solitary bird, and is seldom seen except singly. Its near cousins, the carrion crow and the black crow, are on the other hand more common and gregarious, being found in flocks wherever there is a chance of obtaining sustenance.

The common magpie (Pica caudata) and the azure-winged magpie (Cyanopolius cyanus), a beautiful little pie with delicate mauve-grey body, white throat, black head and azure blue wings and tail, seldom fail to appear in every locality. The graceful blue magpie (Urocissa sinensis), not unlike the last mentioned species but larger, with crimson beak and legs, more blue and purple on the body, and proportionately longer tail, is less widely distributed. It is found only in central and southern Shensi, southern Shansi and parts of Kansu.

In the mountains of Shansi and in southern Shensi, a handsome jay (Garrulus sinensis) is found, while in the pine forests of Shansi and Kansu the noisy nutcracker (Nucifraga caryocatactes) sends forth its rollicking, laughter-like call. All these species nest in the country, but some only are partially migratory. This is noticeable chiefly in the case of the rooks, which at the approach of winter, leave the northern parts of the provinces, where they build their nests in the trees of the towns, and villages, accepting the protection of man. They fly to the warmer plains of the south or to the flat coastal regions of Chihli.

Finches in vast numbers cross these provinces during the migratory seasons, nesting in the remote mountainous regions of the north and west. Few if any remain to breed on the plains. Amongst the most noticeable of these are the crossbill (Loxia curvirostra), hawfinch (Coccothraustes japonicus), Chinese goldfinch (Ligurinus hawarahiba), brambling (Fringilla montifringilla), rosefinch (Carpodacus roseus), and a beautiful scarlet-tinted finch named Propasser pulcherrimus.

Three species of bunting, Emberiza ciopsis, E. rustica and E. elegans might also be added to this group, but they are non-migratory, nesting in the 
mountains and wintering in the foothills and on the plains. The Chinese capture these finches with the aid of bird-lime made from hempseed oil. In the spring and autumn the bird-catcher repairs to some wooded, hilly district, and having made his preparations, he takes up his position on the top of some ridge. He is armed with several long rods, on the ends of which are fastened branching twigs, carefully smeared with bird-lime. Several call-birds in cages are hung in the leafy parts of some suitable young pine, and the rods are placed in such a position that the twigs stick out just above the highest branch of each respective tree. The protruding twig offers a tempting perch for any passing finch and many a wretched bird thus falls into the ruthless hands of the snarer, who has been quietly waiting a few yards distant. The birds are sold according to their value as songsters or trick birds. Crossbills, hawfinches, and bramblings are readily trained to do various tricks, whilst the Chinese goldfinch and the rosefinch are valued for their vocal powers.

A large and handsome grosbeak, named Eophona melanura, is also caught during the migrations and is especially valued by the Chinese as a trick bird. This bird is of a dull grey colour with shiny black head, wings and tail. It possesses a large very thick and strong beak of a bright yellow colour. We saw many larks, the exact names of which I was not able to ascertain.

Soft-billed birds are very numerous. These are found throughout the summer, but most of them migrate to the south in winter.

The first to appear in the spring are the starling (Sternus sinensis), and the redstarts (Phoenicurus auroreus and Ruticilla rufiventris). These are shortly followed by great numbers of other species, which scatter over the country, taking up their abodes where conditions are most congenial to their modes of life. Thus we find a variety of wheatear (Saxicola morio) repairing to the desert areas, such as exist in and on the borders of Mongolia. Here it shares the burrows of the ground-squirrel (Citellus), and brings up a lively brood of from four to six hungry squawking fledglings.

The pied wagtail (Motacilla alboides) finds a suitable nesting-place in the bushes that line the ravines and gorges of the mountains, whilst a beautiful yellow-headed variety ( $M$. citreolides), after swarming along the rivers and over the marshes during the spring, travels north to the rich Siberian plains.

A third very common wagtail $(M$. alba) seems to find suitable nesting places everywhere, and many may be seen from March till October.

The redstarts resort to old temples and disused buildings, making their nests in suitable holes in the masonry. The black redstart (Ruticilla rufiventris) is much rarer than the other species and nests in out-of-the-way ravines, either of loess or rock. 
Many kinds of warblers pass through the country, the most noticeable of which are the ruby-throated warbler (Erythacus calliope) and the blue-throated warbler (Erythacus caeruleculus).

The little green wren or Silver-eye (Zosterops erythropleura) is very common during the summer, while in the spring the pipit (Anthus spinoletta) abounds on the plains and in the valleys, especially where marshy ground exists.

The nuthatch (Sitta amurensis) keeps mainly to the pine forests of the mountains, where it scrambles like a woodpecker up and down the great treetrunks, or hangs upside down from the cones. Tits are very common in the same districts, the chief of these being the tomtit (Parus minor), the coletit ( $P$. hensont), the bluetit ( $P$. venustulus), the crested tit (Lophophanes dichrous), and the long-tailed titmouse (Acredula glaucogularis). The foregoing species, together with the larks, timeline birds and hedgesparrows, are non-migratory.

The timelines are thrush-like birds, all more or less gifted with song, and many a sweet note rising above the countless pleasant sounds of the wilderness may be attributed to these birds. The commonest member of this family is a graceful though sombre-coloured bird called Pterorhinus davidi, sometimes known as the "seven sisters bird." This peculiar name is derived from the fact that birds of this species are frequently found in little groups of five, six or seven playing about in the underbrush.

A much smaller species, with proportionately longer tail, goes by the name of Rhopophilus pekinensis, and, like the foregoing species, is very common in the mountains of the north, where it builds a compact, deep nest in the low bushes of the valleys.

Pomatorhinus gravivox, a very handsome species, is found in wooded districts, further south. It has a particularly sweet song. In the mountains south of Hsi-an Fu in Shensi, I came across two other species, one of which, called Dryonastes perspicillatus, is a large dusky coloured bird. The other, Trochalopteron prjevalskii, resembles Pterorhinus davidi in size and form but is characterised by having the wing and tail feathers of a peculiar metallic lustre which show either a brassy yellow or steely blue colour according to the way the light falls on them.

Two species of thrush, namely Turdus ruficollis and $T$. naumanni are winter visitors only. Both are characterised by having reddy brown tails and breasts, but the breast of the latter is spotted with black. Their heads, backs and wings are of a grey-brown, whilst their bellies and rumps are white. These birds are seen throughout the winter in large flocks. During the spring, however, ere they betake themselves northward, they split up into smaller groups of three and four. 
A third species, the beautiful rock thrush (Monticola erythrogastra) inhabits the deep loess gullies during the summer. The head, back and wings of this bird are of a light slaty blue colour, while the tail and breast are of a deep brick-red.

The dipper, an entirely brown species named Cinclus pallasi, is very common along the clear streams that flow at the bottom of every ravine in the loess country of Northern Shensi, which localities it shares with the pretty little brown wren (Anorthura fumigata) and a large wagtail named Henicurus sinensis. This handsome bird is pied somewhat after the fashion of the pied wagtail but is larger and has a long widely-forked black tail, and also long flesh-coloured legs.

The high cliffs of loess, shale, or granite in all three provinces form the home of the beautiful wall-creeper (Tichodroma muralis), a small grey bird with crimson spotted wings, long slender curved beak, and long sharp claws, which enable it to climb about the flat surfaces of the rocks with the utmost ease. The wall-creeper has a long, sweet, vibrant song, which it utters as it flits butterfly-like across the valleys.

The accentor (Accentor nipalensis), a pretty little soft-billed bird, somewhat smaller than the starling, inhabits the stony cairns and rocky summits of the highest mountains; while its near relation, a smaller, though as prettily marked, hedge sparrow (Tharrhaleus moitanellus) frequents the valleys.

The graceful waxwing (Ampelis garrulus) may be seen during the migrations in large flocks, when it subsists chiefly upon the glutinous mistletoe berries, yellow and red, that abound in the poplar and elm trees.

Three species of shrikes, or butcher-birds, namely, Lanius sphenocercus, $L$. bucephalus, and $L$. superciliosus, are found throughout the three provinces. Of these, only the first, commonly known as the great grey shrike, is at all plentiful. This somewhat striking bird may be seen in winter on any large plain, where it loves to perch upon the top of some spare and solitary shrub, sorghum stem, or giant reed. From this coign of vantage it pounces upon any unsuspecting insect that may have been tempted above ground by the warmth of the brilliant winter sun.

The beautiful golden oriole (Oriolus indicus) inhabits during the summer the groves of the plains and foothills. not fearing to take up its abode in temple-grounds close to the habitations of man. Its hanging nest, built high up in the tree and at the end of some yielding branch, is free from the attacks of small boys and cats.

On the plains also, the jet black drongo (Dicrurus cathoecus) is very 
PLATE 43.
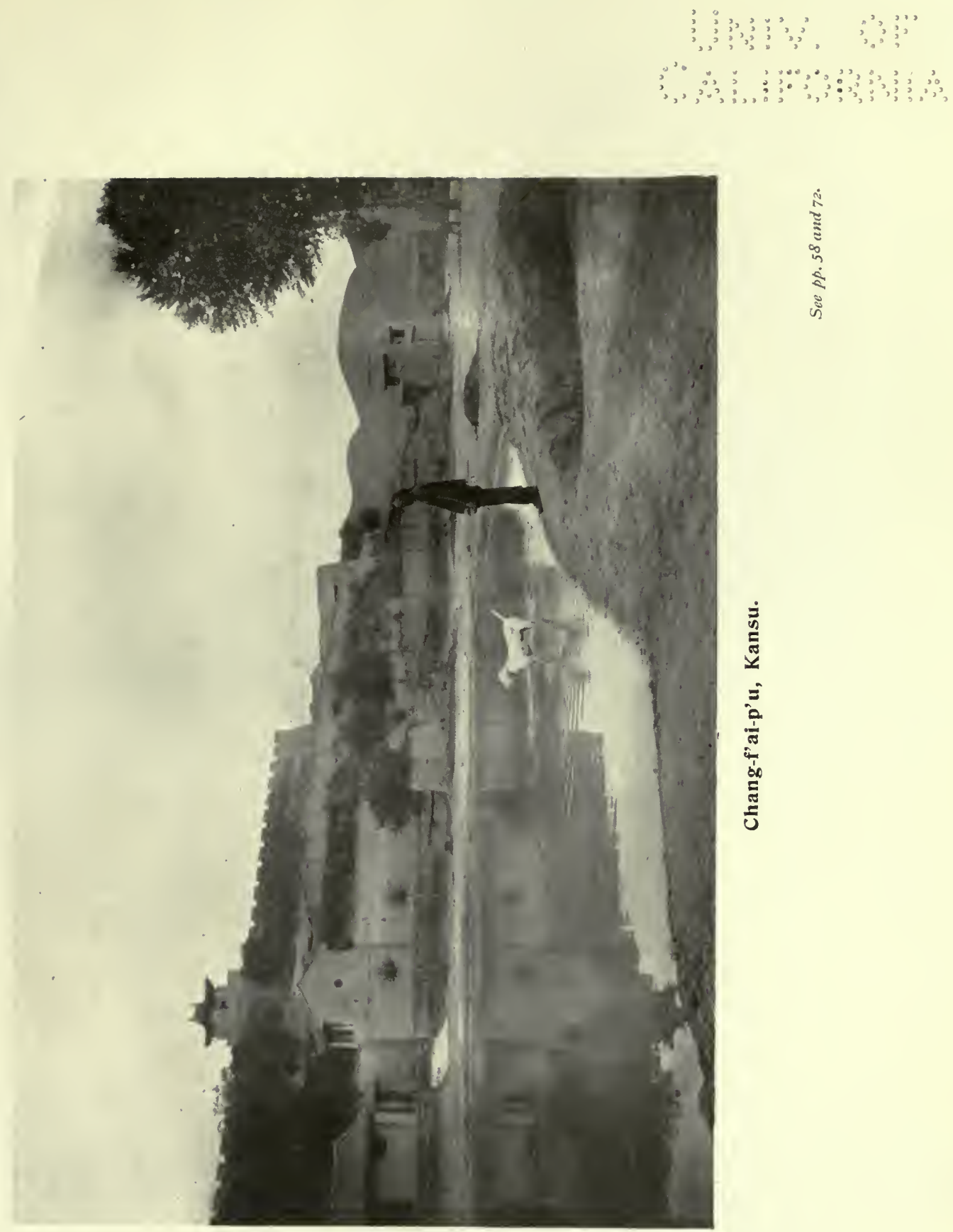
“4 4hand a 
common. It may frequently be seen dashing out from the willows lining the roads or river banks, to seize some passing insect, when its long black deeply forked tail give it a most graceful appearance.

Amongst the first arrivals in spring are the swallows and martins. The former belong to the species Hirundo striolata, and are characterised by having spotted breasts. They are welcomed wherever they choose to build their nest, both by the Chinese and the Mongols, who consider them to be birds of good omen.

The martin (Cotyle sinensis) resorts to the high rocky cliffs of the foothills, where it builds its nest well out of reach of the passer by.

Leaving the perching birds, we will next turn our attention to the birds of prey, such as eagles, hawks, and owls. These groups are fairly well represented in the ornithology of Shansi, Shensi, and Kansu. One's mind naturally turns first to the golden eagle (Aquila chrysaetus) whose regal poise and fierce far-seeing eye have won for their owner the name of King of Birds. Alas for romance, this powerful bird, though a first class hunter, often descends to the useful, but disgusting, level of scavenger, and many are the times it robs the ignoble kite or the croaking raven of their lawful food, and gorges to repletion on the remains of some leprous beggar considered unworthy of decent burial.

In fact, its taste for food, other than that of its own killing, is so marked, that I have known native hunters turn it to their advantage in an ingenious way. A beast or bird having been shot and lost in dense scrub, the hunter at once makes his way to a neighbouring eminence. Immediately, as if from nowhere, a golden eagle appears and commences to circle round and round above a spot in the scrub. Noting the spot, the hunter makes for it, and -the eagle has made no mistake about that anyway-the game is there.

The speed of the golden eagle is prodigious, and it is with a keen thrill of pleasure that I recall to mind an exhibition of feathered speed witnessed by me on the present expedition.

I was out on a hillside collecting my rodent traps, when a golden eagle sailing overhead disturbed several pheasants that had been feeding a few yards up the slope. All the birds sought cover in a small copse of stunted cypress, except one, which broke away towards a wood some two hundred yards distant on the level ground below. Like lightning the eagle swooped down upon his prey. The pheasant had, however, gained a high speed on her downward course, and now frantically struggled to reach the friendly wood. The pace was terrific, but the great marauder was slowly gaining upon his 
intended victim. The flight of the fastest duck would have been slow compared with such speed, for the birds were not only gaining impetus from their rapidly descending course, but adding to their motive power by a vigorous use of their powerful wings. The chase must have ended disastrously for the pheasant, but for the wood which suddenly loomed up in front of the terrified bird. Without wavering she dashed into the wood, crashed through some hindering branches and fetched up with a sickening thud against a stout trunk, coming to the ground like a stone mid showers of twigs, leaves and feathers. The eagle, with a supreme effort shot upwards, narrowly missing the tops of the trees, and rose high into the air before the momentum generated by the headlong downward swoop gave out. Hurrying to the spot where the pheasant had fallen I was surprised not to find her, but there were several souvenirs of her devastating journey through the upper branches of the stately pines.

A bald-headed eagle (Haliaetus leucocephalus) and a white-tailed eagle ( $H$. pelagicus) also inhabit North China, though the former is rather rare, two only being seen on the present expedition. The latter is found along the rivers of the large plains, generally as the ice is breaking up in the spring.

Two vultures are found in the highest mountain ranges. One of these, the lammergeier (Gypaetus barbatus) is comparatively common, while the other, the cinereous vulture (Vultur monachus), a large black species, is very rare. One specimen measured by me was $9 \frac{1}{2}$ feet across the wings.

The kite (Milus melanotis) is very common, not only in the country, but also in the large cities, where, together with pigs and dogs, it renders valuable services to yellow humanity, as a scavenger of undoubted efficiency. These birds may frequently be seen in large flocks circling continuously at great altitudes and at the same time moving steadily in one direction till they disappear from view. This is suggestive of a migration, but is in no way connected with the regular spring and autumn migrations of other birds.

The North China kite also seems to migrate in sandstorms. This act may, however, be involuntary, the birds overtaken when at a considerable height above the earth, being driven helplessly by the fury of the gale till they succeed in reaching the ground. Whatever the explanation, the fact remains that the traveller overtaken by one of these sandstorms-which come down from Mongolia with the appearance of mighty walls thousands of feet high, and blotting out the landscape as they approach-will shortly see the dark forms of innumerable kites in every direction.

The sacred falcon (Falco sacer), the peregrine (Falco peregrinus), and the 
sparrow hawk (Accipiter nisus), all comparatively common, are trapped by the natives of the country and trained to the ancient and noble sport of falconry. The kestrel (Cerchneis tinnunculus), and the red-footed falcon (Erythropus vespertinus) are abundant on every plain, whilst the fierce but somewhat clumsy buizzard (Buteo hemilasius) takes heavy toll of the hares, partridges, and ground squirrels of the broad valleys.

Over the marshes the elegantly shaped hen harrier (Circus cyaneus) glides in its search for small aquatic fauna of all kinds, whilst occasionally the osprey (Pandion haliaetus), king of fishing hawks, visits the larger ponds and lakes. Here he may be seen circling high in the air, till some large fish coming to the surface, catches the marauder's eye. Down he comes like a bolt from the blue, cleaves the surface of the placid waters, scattering wide the shimmering spray, and, burying his talons deep into the quivering flesh of his prey, carries it off to the nearest pinnacle of rock or lofty tree.

Owls are represented by the five following species. The great eagle-owl (Bubo maximus), the long-eared owl (Otus vulgaris), the short-eared owl (Otus brachyotus), the little owl (Athene plumipes), and the scops owl (Scops stictonotus). The last mentioned is somewhat rare and is found usually round old temples. The little owl may frequently be seen in the loess gullies and ravines of the foothills, or out on the plains, where some lofty hollow tree affords adequate shelter.

The long-eared and short-eared owls are inhabitants of the plains, while the great eagle-owl frequents the highest and wildest mountains.

Following the owls, I might mention the night-jar (Caprimulgus jotaka), a bird that is not often seen, but which inhabits the bush-covered slopes of the lower mountain ranges. At dusk on warm summer evenings it flits on noiseless wings over the hazel scrub and waving oatfields, chasing the large pink-winged grasshopper, which always seems more active and noisy at this time of the day.

The nearest relative to the night-jar in North China is the white rumped swift (Cypselus pacificus) which appears rather late in the spring, rears it young in the hollow eaves of temples and gate-towers, and is away again long before the cold sets in.

We may now take a rapid survey of the game birds of the country, and ornithologists must forgive me if I place pheasants, bustards, ducks, pigeons and snipe in one large category.

Belonging to the phasianidae are some half dozen species, any of which may give the traveller welcome relief from the monotony of the long 
journey, and a diet of tinned food, by appearing within easy and tempting range of the road. From the sides of the loess ravines or the bare shale foothills, the rowdy cackling chukar, or red legged partridge (Caccabis chukar) sends forth its taunting call to the passer by, who, if he be a sportsman, fails not to take up the challenge. Rapidly climbing the steep cliff, he is likely to find himself in the centre of a large covey of birds, which break cover with terriffic whirr and whistling of wings, and rocket away in every direction. The novice frantically swings the muzzle of his gun first in one direction and then in another, and usually ends by making a double miss.

In the broad valleys out on the plains or again upon the great grassy slopes of the high mountains, the little bearded partridge (Perdix daurica), a bird not unlike the common partridge in size and appearance, but characterised by having a peculiar beard of ochreous feathers, may often be found in large flocks. The migratory quail (Coturnix coturnix) seeks refuge in the stubble of the plains and valleys, whence it is easily ' walked up,' affording a good mark for the quick gun.

The common pheasant (Phasianus torquatus) abounds wherever there is any cover at all, whilst in the great pine forests of the highest and most inaccessible mountain ranges the handsome eared pheasant (Crossoptilon) wanders in large flocks of from twenty to forty birds. There are two varieties of the latter, one being found in Shansi and the other away out in western Kansu. The Shansi variety (C. manchuricum), is a large gamy bird, with black breast, head and wings, greyish white back and tail, the long curved feathers of which end in black. There is a white patch on the throat which is continued on either side of the head in the form of ear-like tufts. These give the bird a sinister and bellicose appearance. The Kansu variety (C. auritum); commonly known as Pallas' eared pheasant, differs from its Shansi cousin in being almost uniformly of a slate blue colour, there being but little white in the tail, though the white throat and ear tufts are present. In both species the face is naked and scarlet as in the common pheasant, while the legs are of a dull crimson.

The eared pheasant runs with considerable speed, taking to its wings with great reluctance. Dogs only succeed in treeing this handsome game, whilst it is almost impossible to shoot them in the dense dark woods that they frequent. If, however, a flock can be induced to break cover, the sportsman may enjoy the time of his life, as the large birds after fluttering clear of the trees, spread their wings and sail up and down the valley, crossing and re-crossing each other in their mad endeavour to find safety. They seem to lose their 


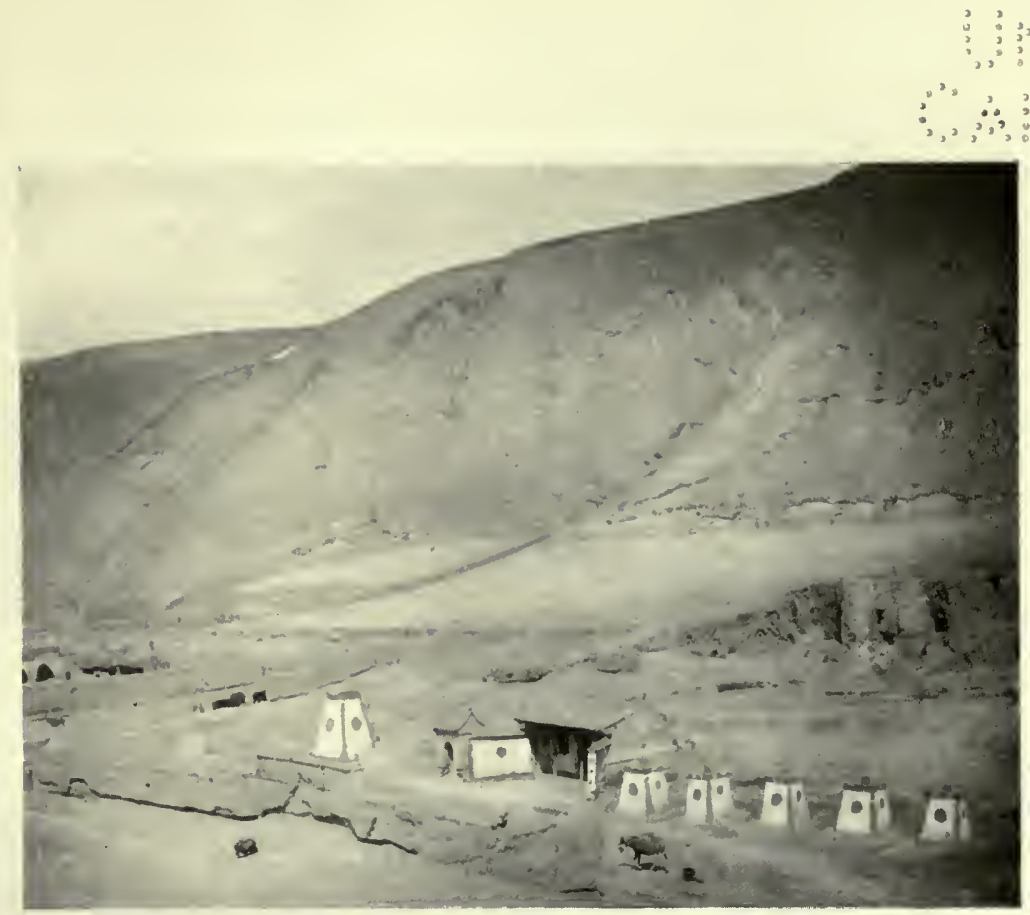

Guard House on Hsi-an to Lan-chou Road, Kansu.

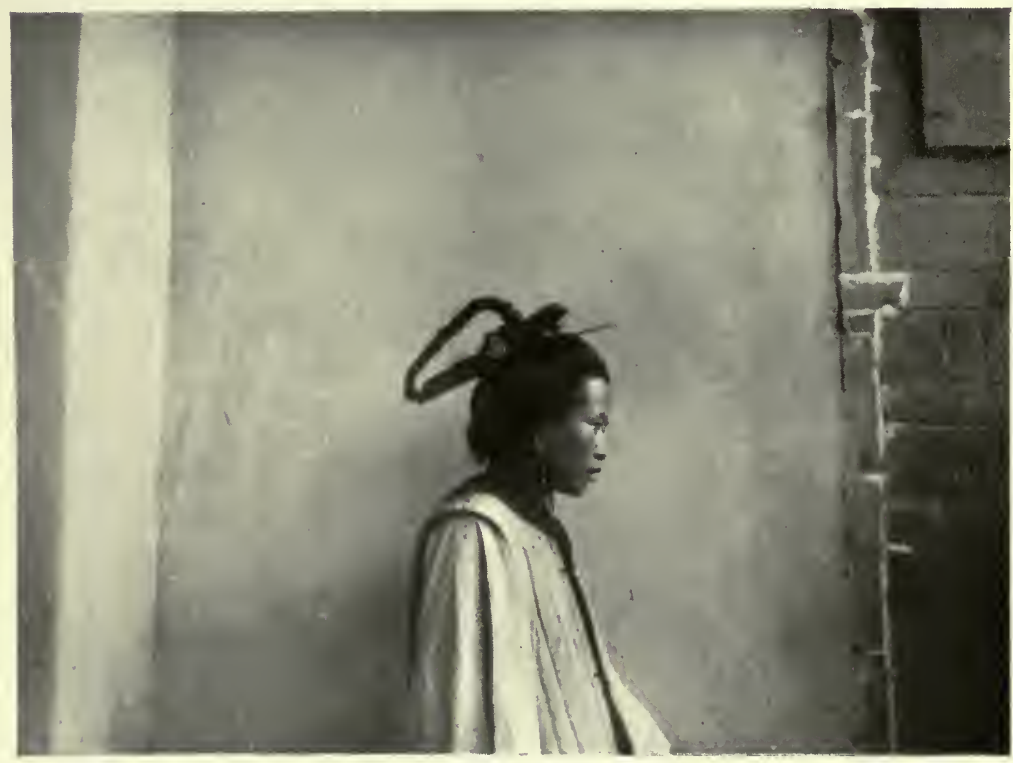

Peculiar Head-dress.

Only worn in the vicinity of Chên-yüan Hsien, Kansu.

See pp. 70 and 73 . 
की mathon 
heads completely at the first shot and will often fly straight towards the guns, discovering their mistake in time, only to swerve to right or left, offering the while an excellent mark. On alighting, the frightened birds scurry up through the woods with wonderful agility and gaining the summits of the ridges once more break cover and sail away across to the opposite ridge. In this way they very soon outdistance the sportsman, who will shortly lose all traces of them.

There seems to be but one representative of the grouse family in these provinces. Pallas' three-toed sand grouse (Syrrhaptes paradoxus) is found on the great plains during the winter months. This bird is really an inhabitant of the great Mongolian Desert and Southern Siberia, but in severe winters it frequently seeks the slightly less bitter weather of the Chihli and Shansi plains. Its flight is very swift and is accompanied with a shrill whistling, caused by the rapid beating of the long pointed wings. The feet of this pretty little bird look very much like those of a rabbit, the toes being short, padded and covered with hairlike feathers, which are continued up the leg.

Two varieties of pigeons may be classed with the game birds, but one of these, the stock dove (Columba intermedia) is practically a domesticated breed frequenting the habitations of man. The other, a variety of rock dove ( $C$ rupestris) differing from the European form in having a broad white band across the tail, inhabits the loess gullies and rocky ravines of the foothills. These two species may often be seen in vast flocks feeding together by hundreds on the cultivated fields, along the roads, or in the boulder-strewn mountain valleys.

Two other members of the dove family also frequent the woods and groves, one (Turtur decaocta) inhabiting the plains, and the other, a turtle dove (Turtur chinensis), preferring mountainous regions.

In certain localities the lordly bustard (Otis dybowskil) is very common. Wherever large level tracts exist, be they uplands or lowlands, plateau or plain, there this, the prince of game birds, is to be found. The sandy stretches of the Ordos, the watery plain of Hsi-an Fu, the loess plateaux of central Shensi, and the Shansi tableland-all are equally favoured by this handsome bird. It does not, however, breed in these localities, but at the approach of summer flies northward to the solitudes of the Gobi Desert or Southern Siberia, where the female raises a large brood.

We now come to the geese and ducks, a group so large that justice cannot be done to them in the limited space at my disposal. During the spring and autumn the bean goose (Anser segetum) appears in vast flocks. Spreading over the plains in their hundreds and thousands they resemble an 
invading army. In squadrons and battalions they march over the fields of winter wheat, uprooting and devouring the tender seedlings, till the ground is left bare and brown behind them. Whether taken with rifle or shot gun, stalked, or shot as they pass in long chains overhead, they afford excellent sport. Closely allied to the bean goose is the grey lag goose (Anser ferus). The latter is a much rarer bird in North China, and is only met with in the more out of the way places, such as the lonely marshes of the Ordos Desert.

The ruddy sheldrake (Casarca ferruginea) is extremely common in some places. We found this duck most numerous on the Hsi-an Fu plain in South Shensi and in Honan. Here they were seen in pairs in every field, but at Yü-lin $\mathrm{Fu}$ they occurred in large flocks. We seldom paid any attention to these birds as they were easy to shoot and their flesh was coarse and oily. The common sheldrake (Tadorna cornuta) is only occasionally met with. The wild swan (Cygnus ferus) is also an occasional visitor.

Coming to the ducks we find that the commonst species are the mallard (Anas boscas), the teal (Nettion crecca), the pochard (Nyroca ferina), the shoveller (Spatula clypeata), the golden eye (Clangula glaucion) and the pin-tail (Dafila acuta). There are other less common species such as the exquisite mandarin duck (Aex galericulata) and Swinhoe's duck (Anas zonorhyncha).

Of all the foregoing the only species that remain north of Hsi-an $\mathrm{Fu}$ throughout the winter are the mallard and teal.

The mallard and Swinhoe's duck not infrequently breed in the marshes of Shansi.

The Baikal teal (Nettion formosum) may sometimes be seen during the migratory season together with the smew (Mergus albellus), the red-breasted merganser (Merganser serrator), and the goosander (Merganser castor). The redbreasted merganser often remains for the winter, when it may be found in the valleys of the high mountain ranges where open streams not infrequently exist even in the dead of winter.

It is but a step from ducks to waders and aquatic birds in general, in which branch of bird life the provinces of North China are particularly rich.

A small species of gull (Larus crassirostris) follows up the course of the Yellow River and many of its larger tributaries. It may be seen flitting over ponds and marshes wherever these exist. On the present expedition these birds were noted in Shansi, on the T'ai-yiaan plain, again on the Hsi-an Fu plain in Shensi, and also near Lanchou, in Kansu. The tern is a summer visitor only.

The bittern (Botaurus stellaris), the heron (Ardea cinerea), the black stork 
PLATE 45.
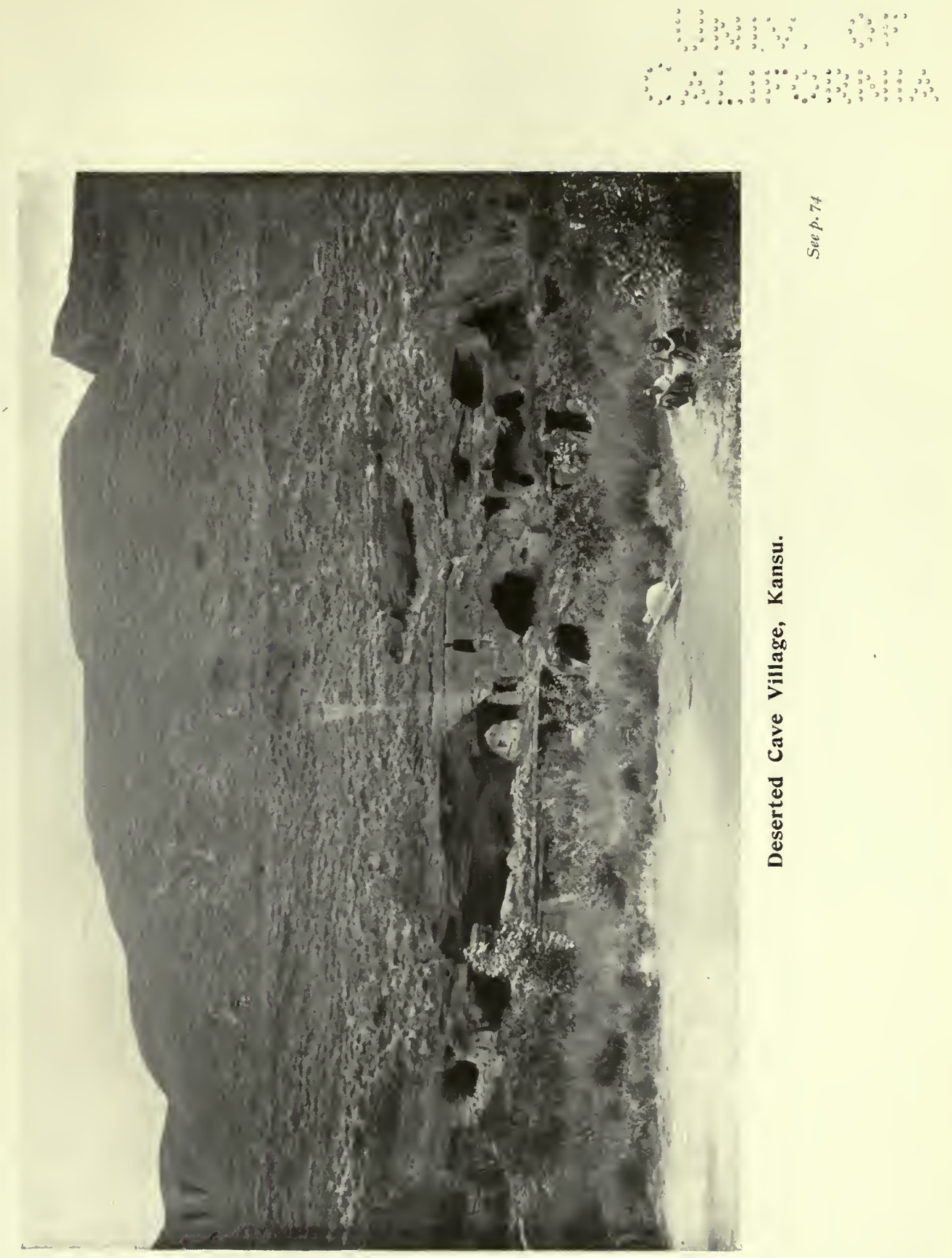

से
ตัँ

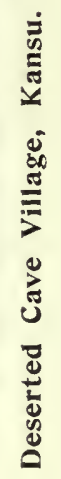




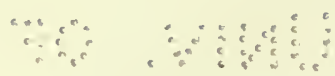

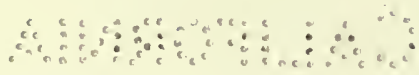


(Ciconia nigra), the night-heron (Nycticorax nycticorax), the spoonbill (Platalae leucorodia), and the curlew (Numenius arquatus), together with lesser waders, such as red shanks, sandpipers, turnstones, sanderlings, stints, and sand plovers*, congregate in little flocks, or disperse in pairs over the sandy flats of the large rivers, along the shores of ponds and lakes, or even upon the cultivated fields of the plains. The black stork (Ciconia nigra) is found along the rivers. It builds its nest on crags of high precipitous cliffs.

On the waters of the lakes and marshes the cormorant (Phalacrocorax carbo), the coot (Fulica atra), the moorhen (Gallinula chloropus), the great crested grebe (Podiceps cornutus), the little grebe (Colymbus ruficollis), disport throughout the summer, building their nests in the rushes, where skulks the water-rail (Rallus indicus).

Snipe are very common and many a good bag can be made in the ricefields and reed-beds. There are two species of snipe in North China, the little jacksnipe (Limnocryptes gallinula), and the pin-tailed snipe (Gallinago stenura). The latter is frequently found along the banks of streams in mountainous districts.

One must not forget to mention the common crane (Grus grus) which passes north or south during the spring and autumn respectively in immense flocks containing from twenty to two hundred birds. They are usually very shy, and the hunter finds great difficulty in approaching them, but as they get further north they seem to lose their fear of man and can easily be brought down with a shot gun. The demoiselle crane (Anthropoides virgo) may also be seen occasionally.

In the boulder strewn valleys of the high mountains may be heard the plaintive cry of the remarkable ibis-billed curlew (Ibidorhynchus struthersi), as it fits along the stream beds, while the pretty little ringed plover (Egialitis alexandrinus) deposits its clutch of eggs amongst the pebbles that they so exactly resemble.

The crested plover (Vanellus vanellus) and the grey-headed plover (Microsarcops cinereus) may be seen during the spring and autumn.

The Chinese ibis (Nipponia nippon) builds its nest in the large trees that grow on the margins of the rice-fields, seeking sustenance for itself and young in the muddy waters of the latter. Its chief food is a large water-snail, together with mussels, frogs and aquatic insects.

Before drawing to a close, it will be well to mention various other families represented throughout the mountains, plains, hills and valleys of the provinces by not more than one or two species.

Here, where the mountain stream plunges into deep defile, or stays to

- The species to which these belong I have as yet been unable to determine. 
wander in rich meadow, we may mark the little emerald-hued kingfisher (Alcedo ispida); or there, watching for his prey from some branch over the glassy pool, the larger long-tailed variety (Halcyon pileatus), easily distinguishable by his black head and purple back.

The handsome hoopoe (Upupa epops), with its golden crown, pied wings and long curved bill, abounds in Shansi. It is found in the other provinces, but is less common. Its peculiarly characteristic call, "ho poo poo," uttered at short intervals with three nods of the head, announces to the worthy celestial the approach of spring, but it is not till the voice of the cuckoo (Cuculus canorus) resounds o'er hill and dale that he commences to sow his seeds. The Chinese call the cuckoo " chung-ku" (pronounced 'joong goo'), which means "plant (your) millet." These syllables, they aver, form the notes of the bird's call, which is intended for a direct message to the husbandman. Almost simultaneously with the cuckoo comes the wryneck (Iynx torquilla), but it is a comparatively rare bird, keeping away from the beaten tracks of man.

Three or four species of woodpecker are found in the country, and of these the great spotted woodpecker (Dendrocopus major) is decidedly the most common. The green woodpecker (Gecinus canus) comes next, while the little spotted woodpecker (Iyngipicus doerriessi) may also be seen from time to time.

A bird which would appear to be the great black woodpecker (Picus martius) was described to me by some of the mountain people of Shansi, but it must be very rare indeed. 


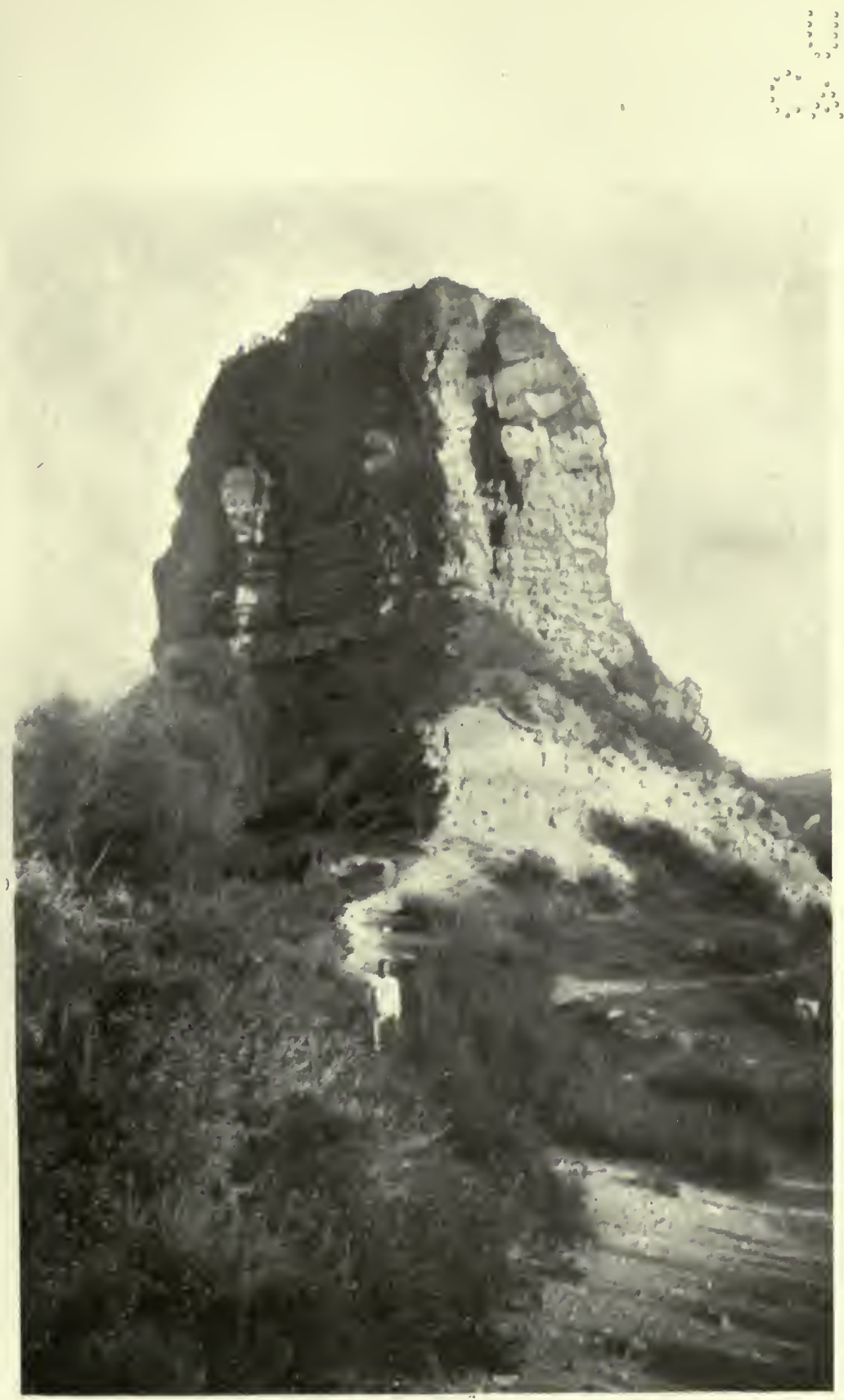

Isolated column of Sandstone, Hai-shui-ssŭ, Kansu and Shensi border. 


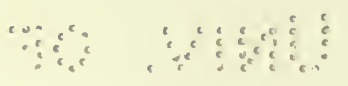

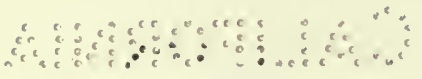




\section{CHAPTER XII.}

REPTILES, BATRACHIANS AND FISHES-BY A. DE C. SOWERBY.

IN these branches of the Biological work of the Expedition comparatively

little was done chiefly because there was so little to collect. North China is very poor in cold-blooded vertebrates and the whole collection included not more than sixteen species, which were presented by Mr. Clark to the U.S. National Museum.

The explanation for this can be expressed in three words: unfavourable climatic conditions.

In the first place the excessive cold of the North China winter tells very severely against snakes and lizards. For three months the thermometer nightly registers from twenty to forty degrees of frost. The ground is frozen hard as a rock to a depth of several feet. Rivers and lakes are covered with layers of ice from two to four feet thick, whilst marshes and mountain streams become solid.

Following the severe winter frosts, comes a long period of drought lasting through the spring into early summer. Sometimes this drought is prolonged through the whole of the latter season. This terrible dryness is very hard on batrachians, especially as it usually occurs during the spawning season, when they need water most. Apart from one or two small varieties, fish do not exist, except in permanent streams, rivers or lakes.

There is little wonder then, that North China boasts so few species belonging to these classes of vertebrates. As was shrewdly remarked about them, they have to hibernate in winter and aestivate in summer.

\section{Reptiles.}

On the present expedition three species of snakes only were secured.

The commonest of these was the olive water-snake (Tropidonotus tigrinus), a beautiful reptile of a bright sap-green colour. On the throat are patches of orange red which extend down either side of the body, growing smaller till 
they vanish somewhere near the tail. Alternating with these are patches of black, which commence just behind the jaw, two being larger than the rest. The sides of the head are striped with black, while the lower jaw and throat are white. In the shape of the head and general appearance, this snake resembles the common British grass snake. Specimens of this species were taken in all three provinces. One was caught in the temple yard at Yü-lin $\mathrm{Fu}$, but usually they were found along the banks of streams and rivers.

The second species (Coluber-or Elaphis-dione) was secured only at Yü-lin Fv. This is a prettily-marked variety, which varies in colour from a rich orange-brown to a dull grey-brown according to the time since the skin was shed. The markings commencing in the shape of a $U$, behind the head, extend in transverse bars down the back. The edge of each bar is darker than the rest. On either side of the body occur rows of dots, also with darkened edges. These alternate with the ends of the transverse bars. Besides these markings, two broad lines of a slightly darker shade than the ground colour extend from the head along either side of the back to the tail. This species is very common in the Ordos Desert and in the loess country of the adjacent provinces. It may frequently be found in the houses of towns and villages, to which it is probably attracted by the abundance of rats, mice and sparrows (see coloured plate).

The third species (Zamenis spinalis) was secured only in Kansu. Here a single specimen was caught on the bank of a large stream. This species somewhat resembles Coluber dione in colour, but is more whip-like in shape and is differently marked. It has three white stripes down the back, and there are white markings on the head. Though the specimen in question was caught on the side of a stream in a valley, the snake cannot be said to frequent such places. I have seen it in mountainous country in Shansi, on the top of rocky ridges far removed from any water. It is, however, rather a rare species.

All these three species are non-poisonous. There seems to be only one poisonous snake in North China, namely, a species of viper (Ancistrodon intermedius). This is the common Central Asiatic form. Fortunately for the inhabitants it is very rare in these provinces. No specimens were met with on the present expedition.

Three species of lizards were added to the collection.

The dullard lizard (Eremias argus) was noticed in all three provinces, though very few specimens were taken. A very common species, it is particularly abundant in the Ordos. It is frequently seen along the sides of the road in the loess country. The species is very widely distributed. 
Brown Snake (Coluber dione).

Toad-headed Lizard (Phrynocephalus frontalis).

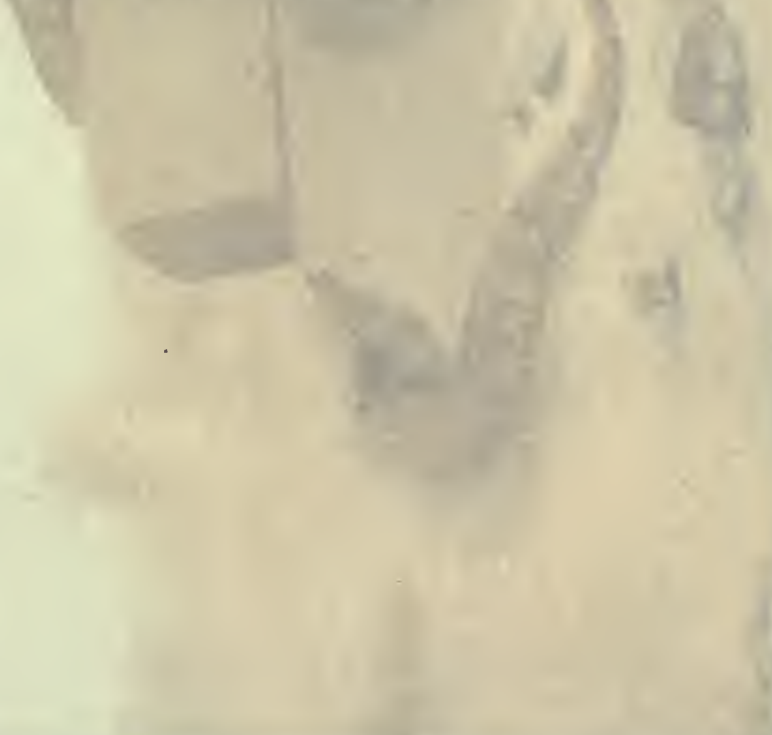




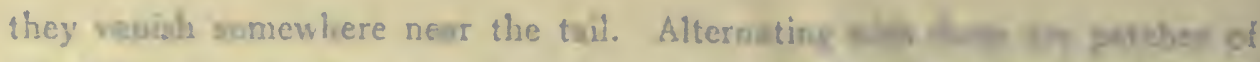
blukk which commence just behind the jew, wo ket lot

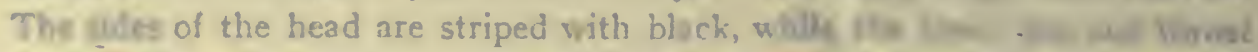

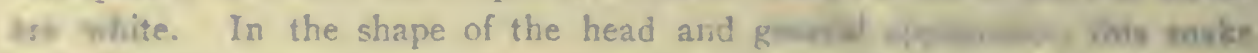
rasulles the common British grass snake. Sprimas at bis pesios wer

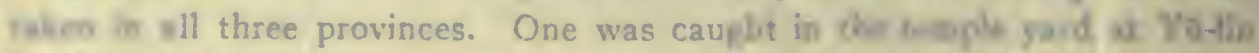

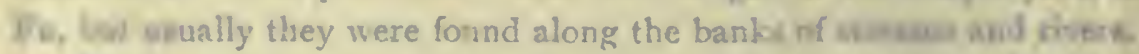

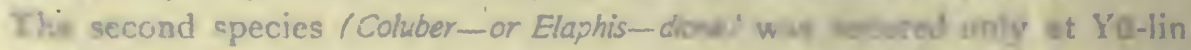
Fu. This is a prettily-marked variety, which varies at exlows from a rich ornsgobrowe to a dull grey-brown according to the tion cibos the allin was thed. The markings commencing in the shape of a $U$, bebinst the heod, exterd in innindate lars down the back. The edge of 5 , ch hur is darker than the rat 0 en wilur side of the body occur rows of dots, aiso with

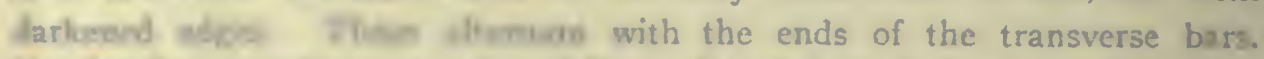
Besides thew maken tse isoul Hes of a slightly darker shade than the

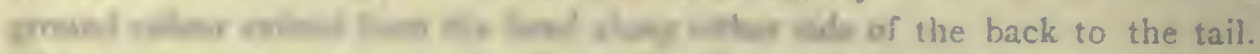

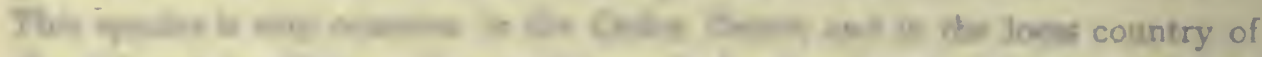
an: athe 6.

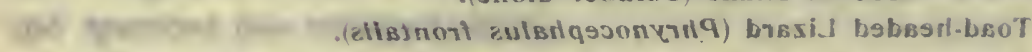

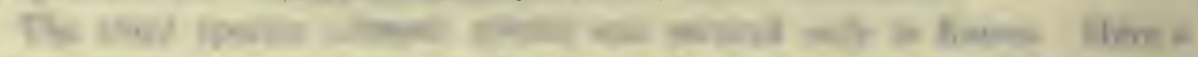

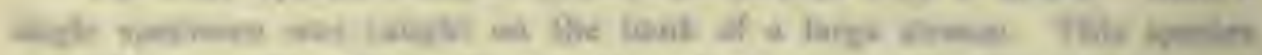

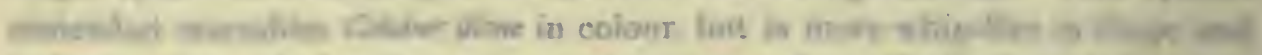

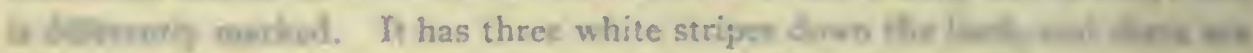

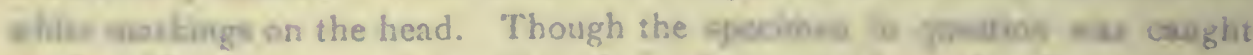

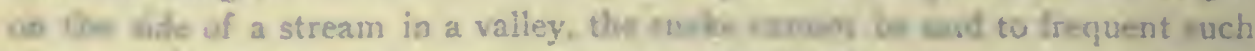

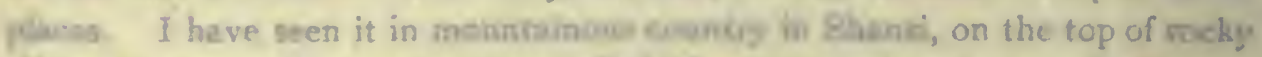

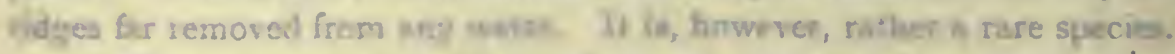

All theie threespois are bum-poisonous. Tbens sems to be inly one

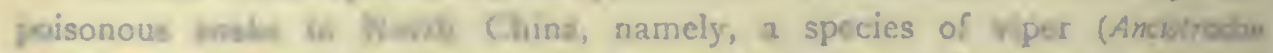
Niermodiun). This is Whe datnmon Central Asiatic form. Fortunately for the inhabitants a be vare in these provinces. No specimens were met with co the prosent expedition.

Torves species of lizards were added to the collection.

The dullard lizard (Enemias argus) was noticed in all three provisioes. thoust very few specimens were tiken. A very common wocks is is perticalody abundient in the. Ordos. It is frequently setn alone bie maks af the mad in the luess country. The species is very widely abtubuted. 


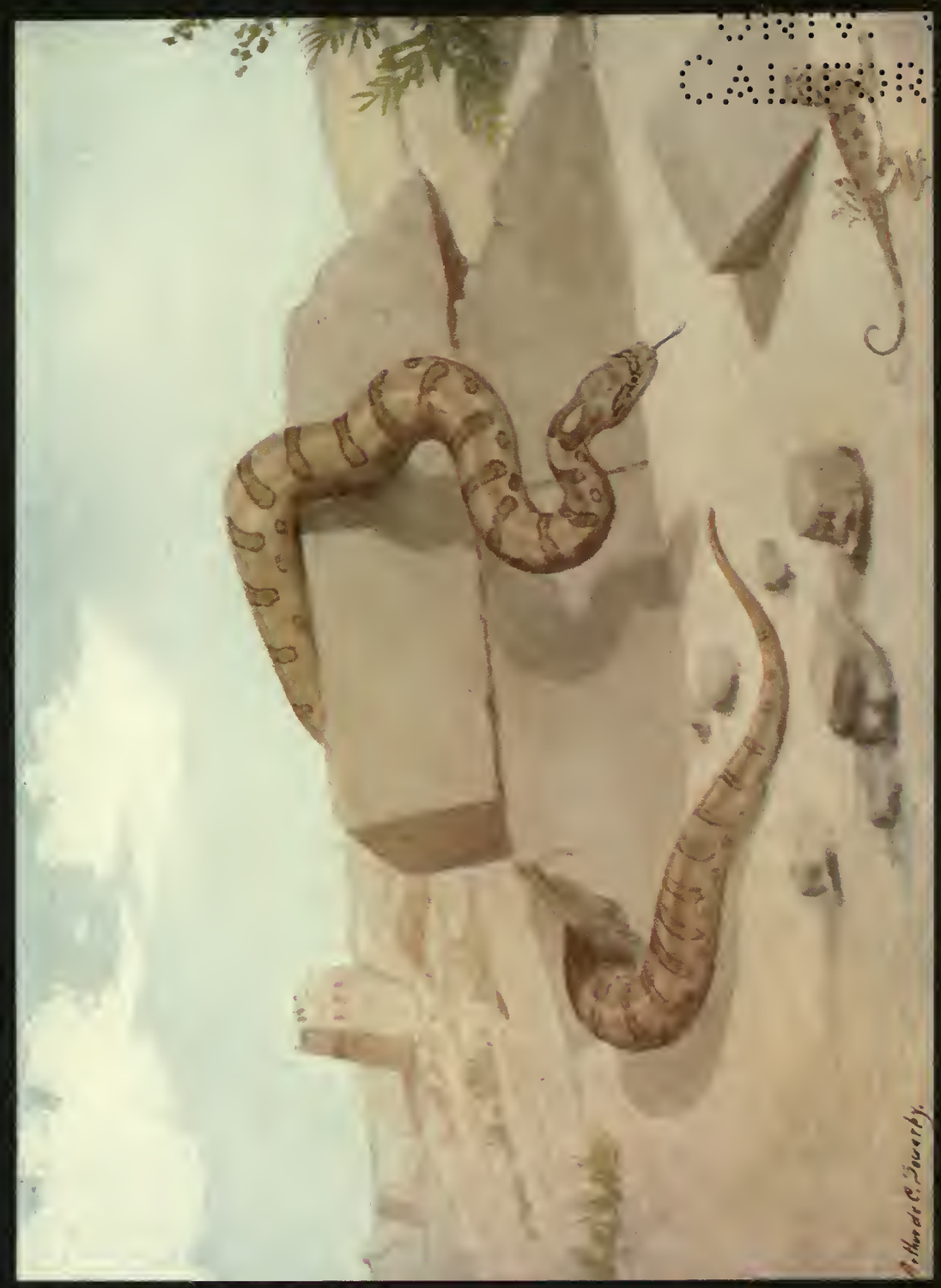




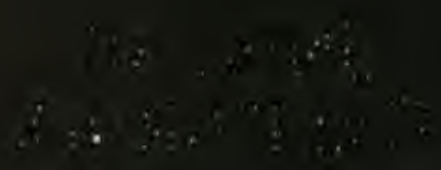


In the country round Yü-lin Fu a good series of the little sandinhabiting lizard (Phrynocephalus frontalis) was secured. I have not met this little lizard anywhere but in, and on the borders of, the Ordos Desert. Here it may be seen in great numbers during the warmer months of the year. These little creatures are very pugnacious, and indulge in desperate battles with one another. They have a peculiar habit of rapidly curling and uncurling their tails over their backs. This action looks very venomous, and is strongly suggestive of the vicious swishing of the scorpion's deadly caudal weapon. This lizard is of a general sandy colour above, with creamy underparts. Blotches of a darker shade occur over the body, and extending along the tail grow darker, finally ending in a series of black rings. The last half inch of the tail is black. The under surface of the tail is pale vermilion, while a crimson-mauve patch occurs behind each fore-limb. The head is shaped like that of a toad, the eyes being black with white eyelids. It makes holes in the sand in which it shelters at night, or when threatened with danger.

The remaining species of lizard is the little gecko (Gecko japonicus), which frequents buildings, temples, and caves. It may also be found in crevices in loess or rocky cliffs. It is perfectly smooth-skinned, and is free from frills of any sort. In colour it is a dull mottled grey, admirably adapted to protect it from discovery, as it clings to the surface of brick wall or rocky cliff. Some eggs of this species were found in a temple. Several of these were hatched out in the course of a few weeks. The Chinese greatly fear this little creature, crediting it with being venomous. In reality it is a great boon, as it keeps the houses clear of all kinds of vermin. It is nocturnal in its habits. The Chinese name is "Hsieh-hu," meaning "scorpion tiger." This name is given because the gecko is supposed to eat scorpions.

The only other reptile secured on the expedition was a species of mud-tortoise (Trionyx sinensis). This species abounds in some of the tributaries of the Yellow River in Shensi. Here it may be seen floating in the quiet waters below rapids, or basking in the sun on the muddy banks. It also exists in the Yellow River itself. Some were secured in the fish market in Ho-nan $\mathrm{Fu}$, in Honan. Others were taken in the rivers near Yen-an $\mathrm{Fu}$, in Shensi. The Chinese esteem these ugly creatures a great delicacy; and certainly, when properly cooked, they are quite palatable. At the same time, it is considered a foul beast, and is emblematic of all that is vile. These mud tortoises are extremely vicious, snapping angrily at the hand when disturbed. They are capable of making a noise, and I have heard them scream when being killed for the table. 


\section{Batrachians.}

In this branch of cold-blooded vertebrates, the provinces passed through are very poor. Only two species of frogs and two of toads were secured.

The large edible frog (Rana esculenta) was common in places where there was a good supply of water. In the small streams joining the Yü-lin Ho, at Yü-lin $\mathrm{Fu}$, these frogs were very common. They were also met with in great numbers in the few fertile valleys of Eastern Kansu and West Central Shensi. This handsome frog is not unlike the common British form (Rana temporaria), but is somewhat larger and of a beautiful green colour, either dark or light. It possesses a bladder on the side of the head, which distends and contracts as the frog emits its loud, hoarse croaks. It is very agile and difficult to catch. The flesh of the legs is edible and is a great delicacy.

The small brown frog (Rana japonica) was frequently met with in the ravines of the loess country of North Shensi. It is capable of withstanding long periods of drought, burying itself deep down in the beds of the streams and pools. In colour this frog varies considerably in different places. Some were of a deep brown colour above, yellowish-pink beneath, shading into red on the under surfaces of the legs. Others were of a light fawn colour, and cream or yellow beneath. The former was secured at Yü-lin $\mathrm{Fu}$, while the latter were found in the streams of the loess country in all three provinces. All specimens agreed, however, in having a black or dark brown band crossing the eye on either side of the head.

Of the two toads met with Radde's toad (Bufo raddei) is characteristic of the country. This amphibian does not attain any great size. The female is very prettily marked, somewhat resembling the natterjack toad of Europe; the male is of a dull greenish-brown colour, and does not possess the beautiful marking of the female. There can be no doubt of this animal's powers to withstand drought. I have found it amongst the sand-dunes of the Ordos, as well as in the loess hills of other parts. Specimens were secured in Kansu, within the famine area near Lan-chou Fu. Here, the natives said, there had been no rain for three years. In spite of its frequenting such dry places, it thoroughly appreciates an abundant supply of water, as I have found them in the ponds and backwaters of rivers, not only while spawning but at all times of the year, excepting winter. The spawning season is regulated by the rains, and in a dry year I have known it to be postponed till July.

The other toad obtained is identical with the common European species (Bufo vulgaris). It is much less common than $B$. raddei. Only very young specimens were secured on the present expedition. 


$$
\begin{aligned}
& 0 \\
& 0
\end{aligned}
$$

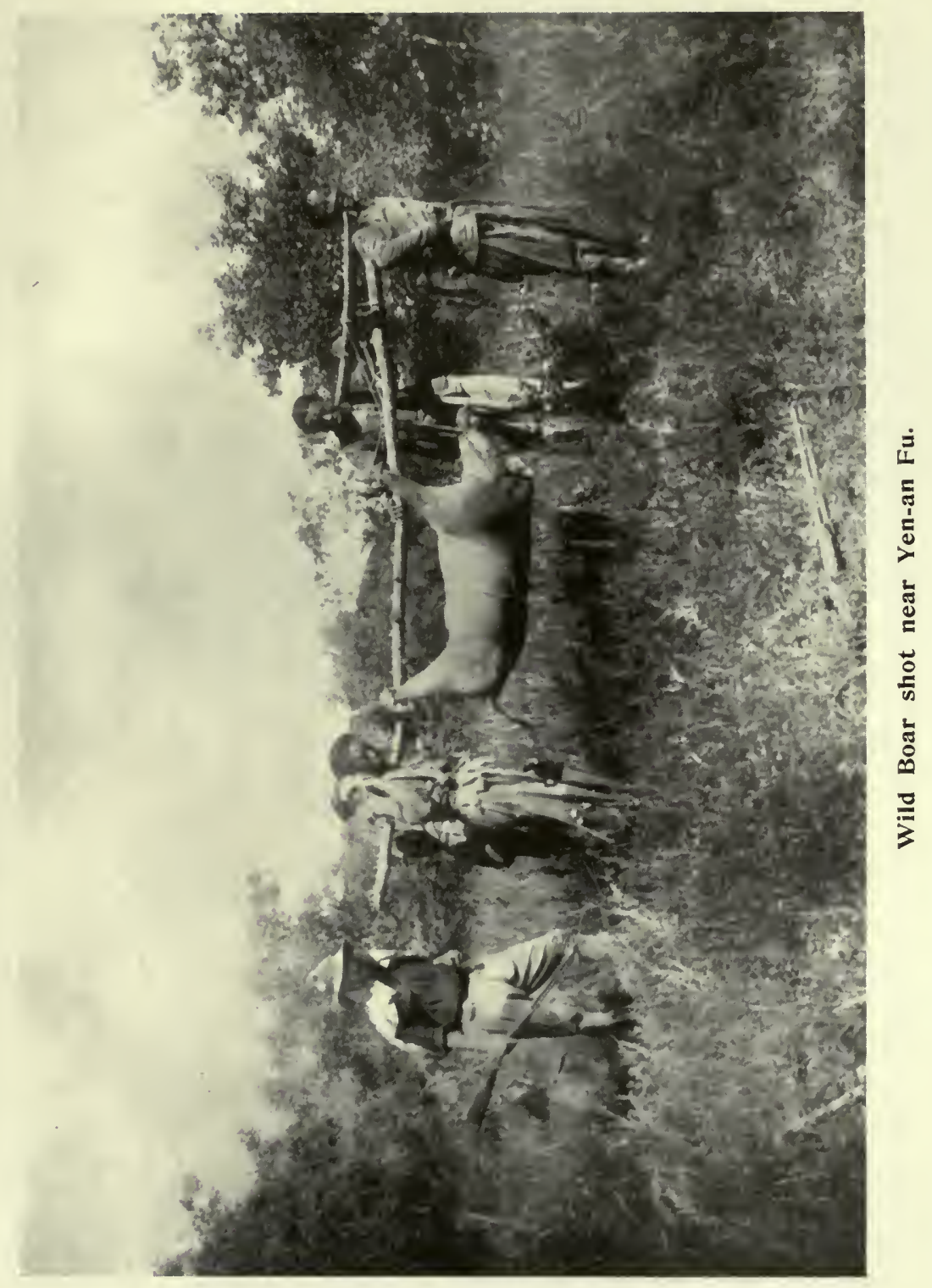


की 
Nothing in the way of salamanders or newts were seen, and I do not believe that they exist in these provinces north of the 35 th parallel of latitude.

\section{Fishes.}

On the expedition very few fish were secured. Constant watch was kept for anything in this line in the mountain streams but with poor success. No doubt the Yellow River would have yielded a fair number of species if we had had the means and opportunity of exploring its muddy depths. However, its commonest denizens are undoubtedly the cat-fish (Silurus asotus) and the carp (Cyprinus carpio). Both these species attain a large size, and are eagerly fished for by the natives who transport them to various large centres.

The cat-fish is usually transported alive. The carp on the other hand are not transported till winter, when they are frozen and covered with a layer of ice to preserve them.

Cyprinus carassius is the species from which the Chinese and Japanese have bred the gold fish. Specimens (young) were obtained from the streams at $\mathrm{Yü}-\mathrm{lin} \mathrm{Fu}$. This is a comparatively common fish, being found in most lakes, ponds and rivers. It often finds its way to the tables of Chinese gentlemen, but has a muddy taste and is excessively bony. The serving of such a fish at a feast, where such expensive luxuries as bird's nest soup and white fungus are on the menu, speaks volumes for the scarcity of fish in North China.

In the fish-markets of Hsi-an Fu and Ho-nan Fu I noticed one or two other species of fish, but as I could get no satisfactory statement as to where they came from, I did not consider it worth while to secure specimens.

Monopterus javanensis, a species of eel, was secured at Hsi-an Fu where it was commonly found in the black oozy mud of the rice-fields and irrigation ditches. It is remarkable for the total absence of fins. Its gills are very small and inconspicuous. It might thus be easily mistaken for a snake. It is of a dark olive-brown colour, with mottling of a darker shade closely dotted all over it. The head is very snake-like. Large specimens were for sale in the market at Hsi-an Fu.

Misgurnus anguillicaudatus is an eel-like loach, specimens of which were secured at Yü-lin Fu. I noticed larger specimens for sale in the fish-market in Ho-nan Fu and round Hsi-an Fu. As far as I could gather, it is an inhabitant of large rivers and their affluents, and occurs in flat country, but is never seen in mountain streams.

Cobitis tinia is the only species of fish which is really abundant in the 
the northern parts of the three provinces of Shansi, Shensi, and Kansu. It is found in most streams, whether in the high rocky mountains or in the loess hills. This loach was secured in large numbers at Yü-lin Fu. Specimens were also captured in Kansu, and at other places, but these unfortunately were spoiled.

It is highly probable that this species can survive the drying up of the streams in which it lives, as I have found it in places where such conditions must frequently prevail.

Specimens of a minnow (Phroxinus Sp.) were caught at Yü-lin Fu and again in the mountain streams south of $\mathrm{Hsi}-a$ an $\mathrm{Fu}$; but I have been unable to identify the species. 

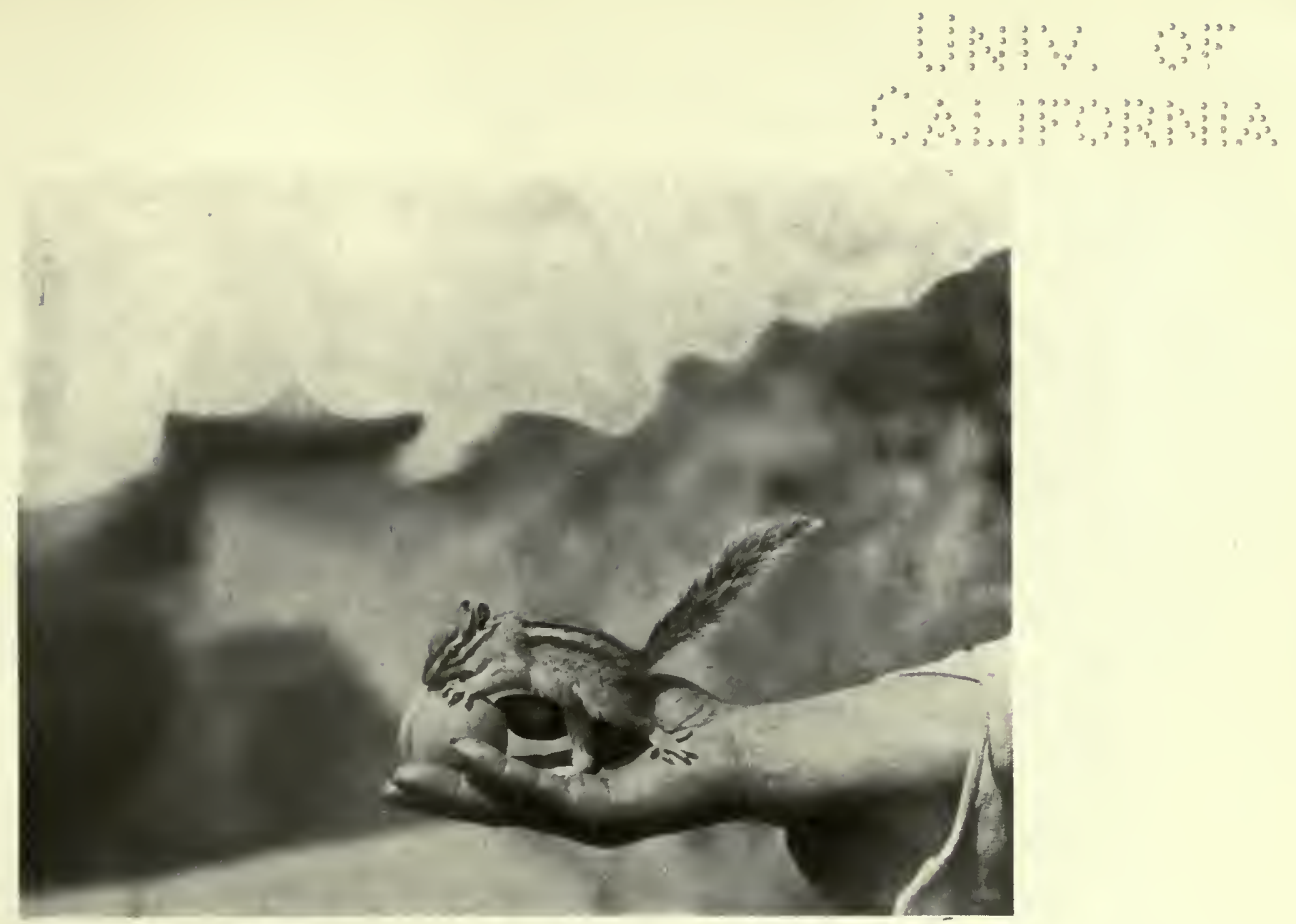

Chipmunk. (Eutamias asiaticus senesceus).

See pp. 92 and 176.

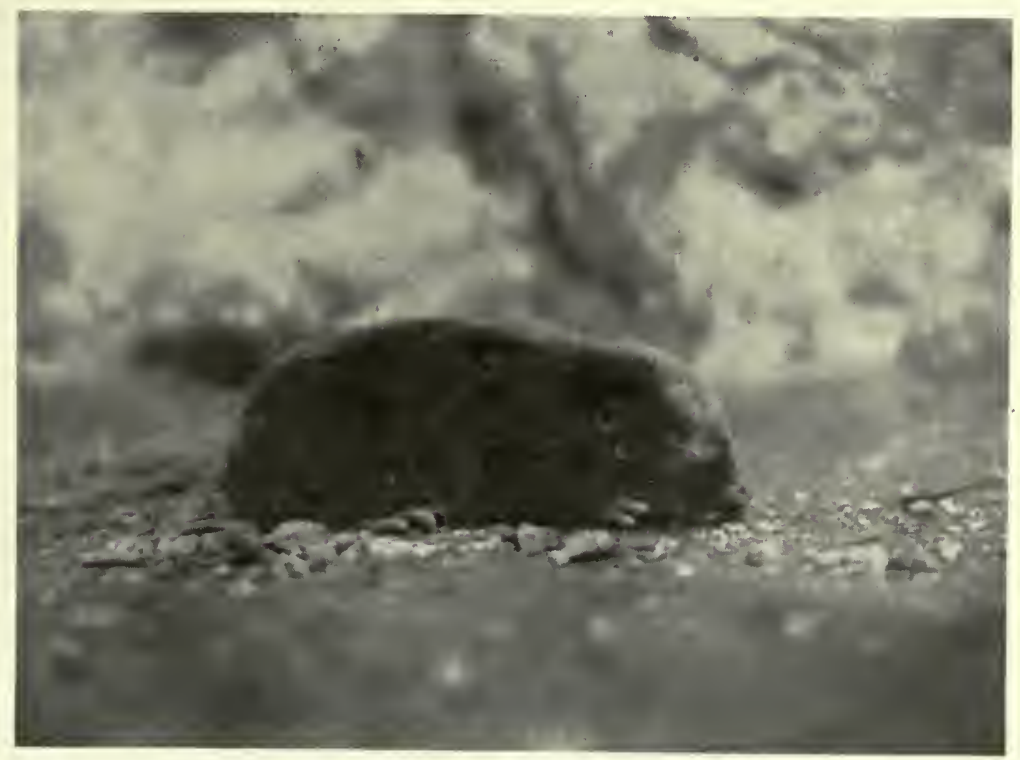

Mole-rat. (Myospalax cansus). 
er

and 


\section{CHAPTER XIII.}

\section{GEOLOGICAL NOTES-BY A. DE C. SOWERBY.}

$\mathrm{I}^{\mathrm{T}}$ is with some hesitation that I set forth the following notes and remarks on the Geology of the country traversed by the Expedition. With but a mere smattering of knowledge, picked up from text-books whilst on the march, I realise my unfitness for the task of giving anything like a Geological description of the Provinces passed through. Nevertheless it would seem to be a pity were I to shelve even such meagre notes as I have been able to gather about a country so little known. Eminent authorities on Geology have travelled in North China, but the route taken by the present Expedition seems to have been almost altogether through districts entirely new, so far as this science is concerned. That part of Shansi west of 'T'ai-yüan Fu, and the whole of Shensi north of the Wei Ho were out of Richthofen's path. This interesting country was missed too by the members of the Carnegie Expedition 1903.4. It seems, however, to present features not found elsewhere in China, a proper study of which would throw light upon many problems in connection with the great loess deposits of North China.

Throughout this Chapter I adopt the momenclature used by the authors of "Research in China." This book (published by the Carnegie Institution of Washington) deals with the results of the Carnegie Expedition already mentioned, and in it, where dealing with this subject, Mr. Bailey Willis calls the whole of the Yellow Aeolian deposits, so extensively found in all the northern provinces, the Huang-t' $u$ formation. In Chinese, the word Huang-t' $u$ means literally "yellow earth." It refers to the true wind-deposited loess, as well as to the fluvial deposits of the Chihli plain and elsewhere. Bailey Willis took the name, which is a very happy one, from Huang-t'u-tsai, a village situated about ten miles north of T'ai-yüan Fu.

Another substance containing a large percentage of clay, and occurring in many places with the loess, is called Shao-t' $u$ which means literally "baking earth." It derives this name from the fact that it is suitable for mixing with coal-dust to form a good burning substance. The mixture is either dried into cakes, or is put on the kang-fire wet. It burns well, but slowly, forming a very economical fuel.

Throughout this Chapter I shall use the word Shao-t' $u$ in its real Chinese sense, and the word Huang-t' $u$ in the sense given to it by Bailey Willis. I shall thus have three terms to use in connection with yellow deposits :- 
(I) Huang-t'u referring to all deposits, whether Aeolian or fluvial.

(2) Loess, the pure æolian or sub-aerial deposit.

(3) Shao-t' $u$, that substance, which resembles Loess, but contains a certain proportion of clay.

The last usually contains more carbonate of lime than the second,* and generally occurs at the bottom of the deep ravines in the Huang-t'u formations. So far as I have been able to gather, the lime nodules mentioned by various writers occur in the Shao-t' $u$. The origin of the latter is difficult to determine, $\dagger$ but it is believed by some to be the result of decomposed Felspathic rock. For want of any other name, I call the sedimentary beds of Shensi "the Shensi formation," but the exact relationship between this and the Shansi formation I cannot define, though it certainly resembles the formation between Chiao-ch'êng Shan and the Huang Ho.

The country in the immediate vicinity of T'ai-yüan $\mathrm{Fu}$, our startingpoint, has been investigated by the members of the Carnegie Expedition, so that I will commence drawing on my note book at the western bank of the Fên Ho. In the preparation of this Chapter I have had frequent recourse to "Research in China"; the line of march followed by the authors of that work was from Pao-ting Fu in Chihli westward to Wu-t'ai Shan in Shansi; thence southward through the middle of Shansi as far as T'ung-kuan Hsien, just beyond its south-western border; and from this point westward again in exploration of the Ch'in-ling range and the country south of the Wei Ho in Shensi.

After continuing westward from T'ai-yüan Fu, in Shansi, to Yü-lin Fu, in Northern Shensi, our own route lay in a direction roughly parallel to that of the Carnegie Expedition, extending as it did from North to South down the middle of Shensi. The Carnegie Expedition did not enter Kansu at all, and the country we traversed seems to have been visited by no geologist. We thus had the opportunity of seeing a mountainous country, namely the Chiaoch'êng Shan, dividing the Fên Ho from the Yellow River, the existence of which seems to have been unsuspected by Richthofen, and only guessed at by the members of the Carnegie Expedition. Both parties apparently confined themselves to the valley of the Fên Ho, and formed their opinions of what lay to the westward from what they saw of the small range of mountains forming the north-western boundary of that valley.

Richthofen speaks of the country between the Fên Ho and the Yellow

- The loess has a large proportion of clay, bat disseminated and not separated as appears to be the case with the Shao-i' $u$. † The $\mathrm{CaO}_{2} \mathrm{CO}_{2}$ of the calcareous nodules is prohably derived from the upper beds by water action. 
River as a plateau of nearly horizontal coal-bearing strata; whilst Bailey Willis suspects that the rock below the Sinian Limestone, together with the Sinian Limestone itself, forms the mass of the mountains west of the small range already mentioned. Neither of these observers mentions the great divide of Igneous, and Metamorphic rock, which extends in a more or less complete line from Ning-wu Fu, five days journey (about roo miles) northwest of T'ai-yüan Fu, to Yung-ning Chou, four days journey south-west. Having penetrated these mountains at five different points I can vouch for its existence. Professor Lyman of the Shansi University discovered Granite and Gneiss in the mountains west of Wên-shui Hsien, a town about fifty miles south-west of T'ai-yüun Fu.

From my notes it will be seen that Richthofen was not altogether wrong when he discussed the country west of the Fên Ho as a plateau of horizontal coal-bearing strata. There are undoubtedly great stretches of country marked by beds of this nature; but on the other hand there are large areas where, but for the Loess, the Sinian Limestone would form the surface. I have found this to be the case in the mountains west of K'ê-lan Chou a town about sixty miles north-west of T'ai-yüan $\mathrm{Fu}$, and again at Wu-ch'êng a village half-way between Yung-ning Chou and Fên-chou Fu. It also forms certain high peaks situated physiographically between the Shansi formation and the pre-Cambrian rocks in the Ning-wu district. Of course the outcrops of Pre-Cambrian (Igneous and Metamorphic) rock, already referred to, form a large area.

The folding and vertical dips mentioned by Bailey Willis occur, as far as I can make out, only in the small range-not more than twenty miles widewhich extends from north-east to south-west along the north-western edge of the T'ai-yüan $\mathrm{Fu}$ plain. Westwards from this range till the Chiao-ch'êng Shan are reached the strata are horizontal. Further north, as the Ning-wu district is approached, these strata are arranged in a series of ridges having a north-east to south-west trend and formed by dip-slopes on the south-eastern and scarps on the north-western side. The dip-slopes vary generally from $30^{\circ}$ to $80^{\circ}$, some being almost perpendicular. As already stated, between these ridges of Shansi formation and the great outcrop of pre-Cambrian rock, occur very high and precipitous ridges of Sinian limestone. These form very pointed peaks, varying in altitude from 7,000 to 8000 feet above the sea-level. 'Their dips slope to the south-east at angles of from $45^{\circ}$ to $60^{\circ}$, becoming almost perpendicular as the crests of the ridges are reached. The escarpments are due, doubtless, to erosion on the eastern side of an immense fold; the softer rocks on the anti-cline of this fold have been carried away by denudation, 


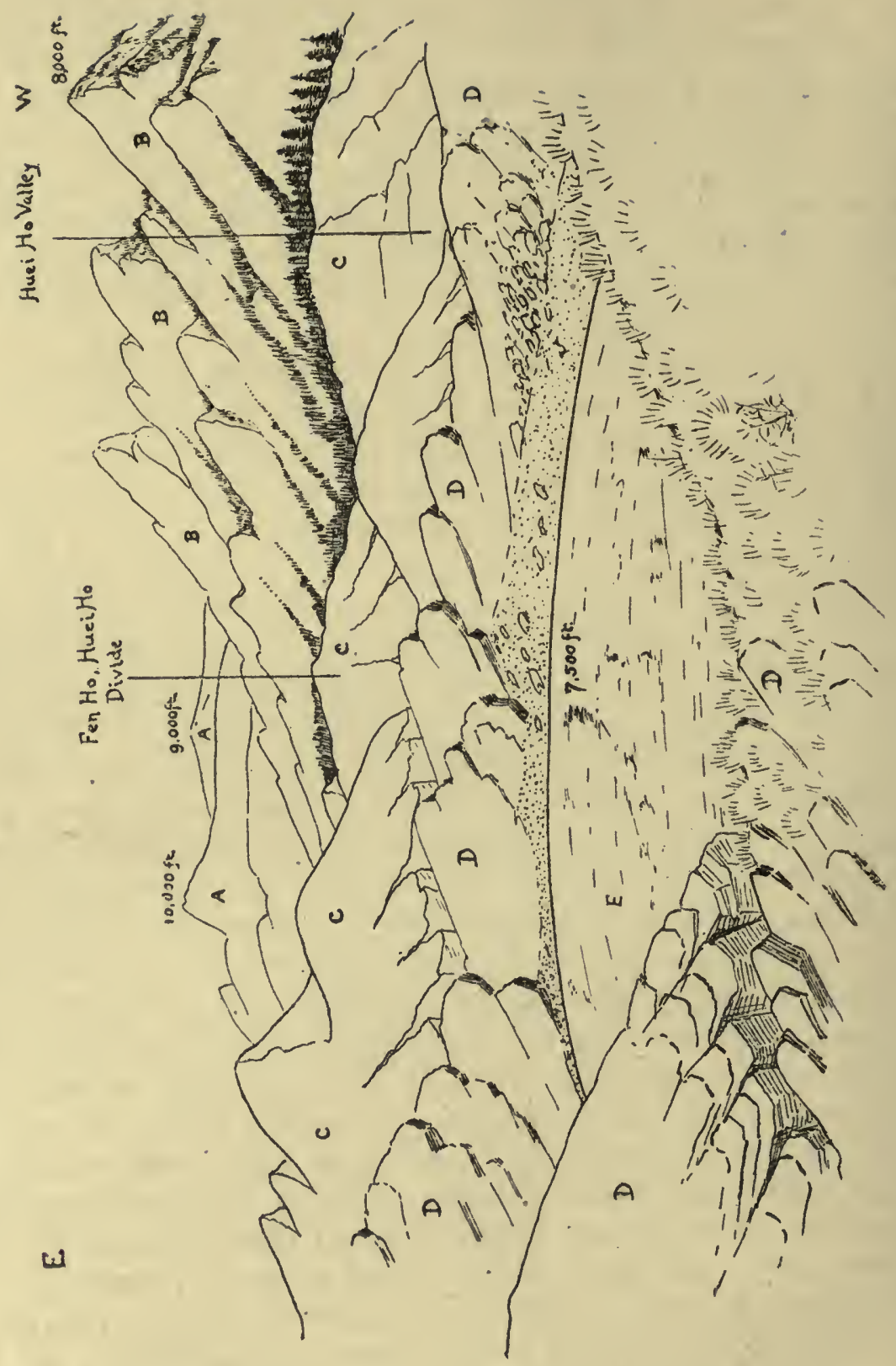


leaving exposed the Plutonic rocks, which now form the crest of the great divide between the Fên and Yellow Rivers.

There is plenty of good coal in the district, as well as a certain amount of silver ore. The former is mined, but the mining of the latter is prohibited by the local officials, who fear the imposition of heavy taxes by the central Government.

In the Ning-wu district I discovered a series of small lakes situated at an altitude of about 7,000 feet above sea-level along the summits of the shale ridges of the Shansi formation. They occur in hollows formed by scarps on the one side, and dip-slopes on the other: their existence bearing testimony to the impervious nature of the shale. The accompanying sketch shows one of these lakes, and other physiographical features of the district. The lakes are very deep and contain clear, sweet water. Their overflows join the Fên $\mathrm{Ho}$, in spite of the fact that they are much closer to the Huai Ho, which flows northward, and ultimately joins one of the rivers traversing Chihli. (An account of the discovery of these lakes was published in "Travel and Exploration," October, I9ro).

The foregoing remarks refer chiefly to those parts of the mountains west of the Fên Ho which lie outside the path of the present Expedition. I will now take in more detail the rocks and formations noticed along our own line of march. On entering the mountains west of T'ai-yüan Fu, the first rock encountered was the dark limestone (Cambro-Ordovician) dipping slightly to the west. This is deeply cut through by water-courses which enter the plain from the west. At Lan-ts'un, a village about fifteen miles north-west of T'ai-yuan Fu, the Fên Ho cuts through this formation. The height of the limestone cliffs here must be between 300 and 400 feet. A similar formation occurs again about three miles north-east of the same village. Here a narrow winding gorge cuts deeply through the limestone for a distance of about fifteen miles. The limestone, in places, exhibits a pale creamy colour. This outcrop appears to form the eastern edge of a great, but shallow synclinal fold. The western outcrop appears along the eastern side of the great divide of igneous rock, already mentioned.

At a level of about 300 feet above the plain, the Limestone formation gives place to the Sandstone and Shale formations typical of Shansi. These continue the crest of the range to an altitude of 2,500 feet above the level of the plain. The shale deposits in this small range are horizontal and free from faults, and are inter-stratified with beds of Pyrites, Conglomerates, and thick seams of coal. The colours of these shales vary considerably, being blue-grey, dark madder, yellow ochre, greenish yellow, or green. 
The Conglomerates, formed of well-worn and rounded pebbles, occur at an altitude of about 500 feet. The Pyrites, a grey and friable variety, occurs at an altitude of between 300 and 400 feet. The sulphur is extracted by the natives, who roast the pyrites in perforated clay vessels, the residue being a soft, earthy substance the colour of yellow ochre. When roasted again, this turns into a bright red powder, largely used in the manufacture of paint for houses and furniture. In places, where the second roasting is carried on, the whole of the surrounding ground, for a considerable distance, becomes stained a bright red. Many such patches mark the slopes of these mountains, and might at first sight be mistaken for outcrops of Red Hæmatite.

The coal from this district is also very sulphurous, and unpleasant to use in open grates, being very smoky and giving a large percentage of ash. In places, where the seams were exposed to the air, we often noticed an efflorescence of pure sulphur.

There is also a considerable amount of iron-ore in these mountains; and some of the streams in the range are strongly alkaline : a fact especially noticeable when they are frozen.

After crossing this ridge, we descended first through loess and then through shale to the bed of the Fên Ho at Ku-chao. Here, a little way up the ravines, which join the river, iron-smelting is carried on; brown ironore being easily mined. Iron, coal and clay occur together in these spots; otherwise, there would be no smelting done. The price of pig-iron is too low to allow of any one of these materials being transported for use from a distance. Baron von Richthofen has described the native method of smelting so well that any further remarks would be superfluous.

The formations, from Ku-chao westward for a distance of twenty miles, are entirely of Sandstone, Shale and Huang-t' $u$. As already stated, the strata of these sedimentary rocks were found to be horizontal, and free from foldings and faults.

At Ts'a-k'ou, about forty-five miles west of T'ai-yüan Fu, Sinian Limestone again makes its appearance, and a little further on the Pre-Cambrian rocks, which form the Chiao-ch'êng Shan district, commence. We first travelled up a long valley leading westward, the sides of which were composed of precipitous limestone peaks. As we ascended the pass at the head of this valley, we crossed a dyke of Pegmatite exposed in the cutting of the bridlepath, the rest of the slopes being composed of Mica Schists. On the western slope of the pass, masses of white Felspar with large pieces of embedded Muscovite were noticed. Large stones of both fine and coarse-grained Granite, 


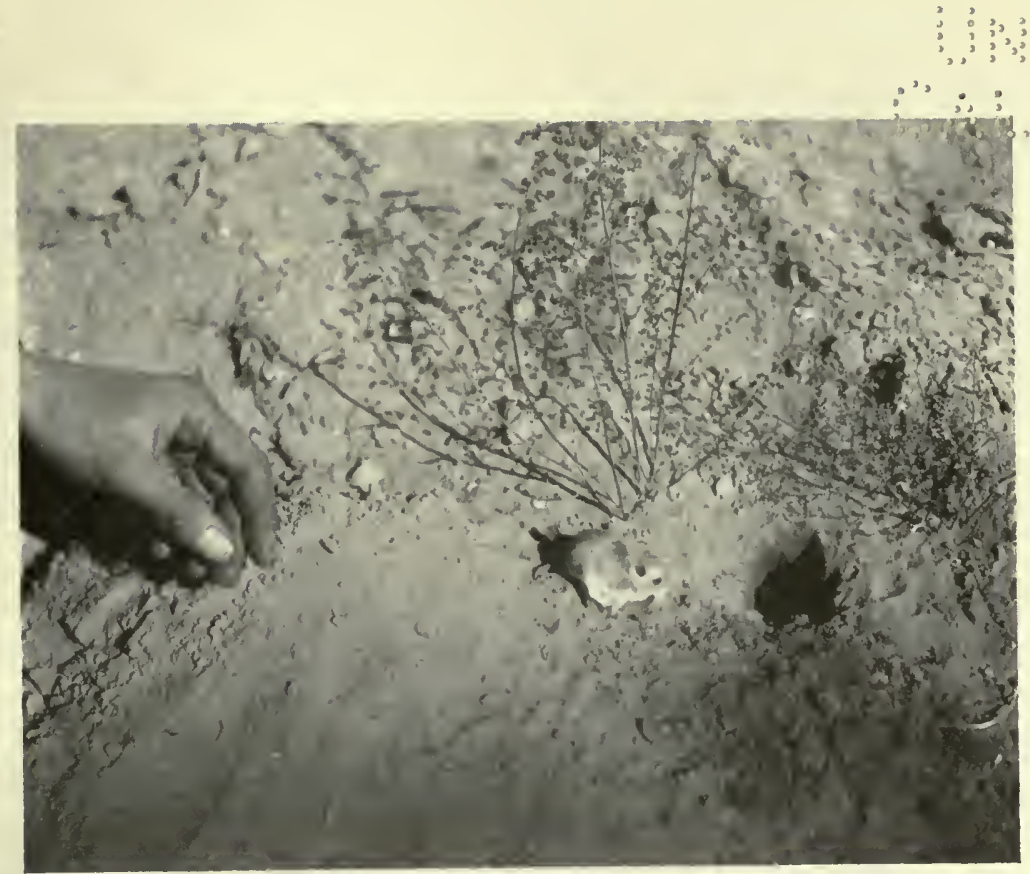

Sand Hamster. (Phodopus bedfordia). See pp. $\mathcal{S}_{3}$ and 1 So.

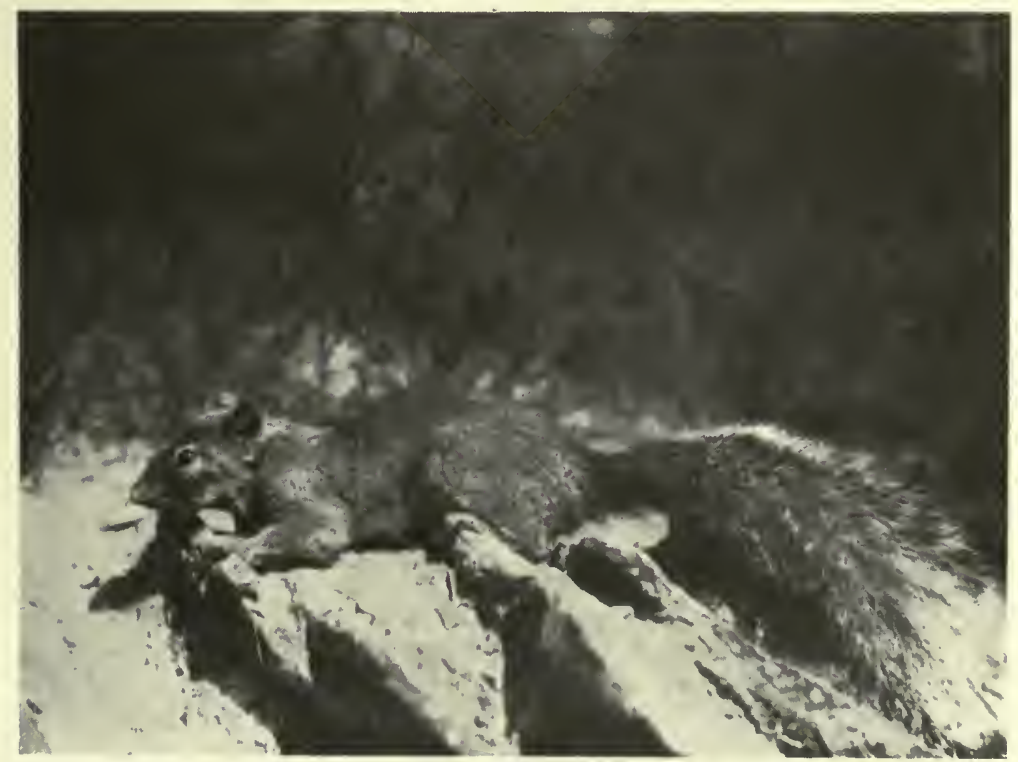

David's Squirrel. (Sciurotamias davidianus).

Sie pp. SS and 76. 


$$
\text { 4han }
$$


besides Pegmatite, Feispathic and Micaceous rocks, and Gneisses were plentiful in the valley-bottoms on either side of the pass.

With my limited knowledge, it would be hopeless to attempt a full description of the complicated structural formation of the Chiao-ch'êng Shan district : the most I can do is to mention the names and the positions of the rocks which I noticed. So far as I could gather, these mountains, like those in the Ning-wu district, are formed by a great fold, the softer rocks of which have been denuded, thus laying bare the Plutonic rocks. The tops of the peaks and ridges are undoubtely of granite, which varies in colour from grey to pink, and in texture from a fine to a coarse grain. The summit of Mo-êrh Shan $(9,200$ feet), the highest peak in the district, is in the form of a hugh cone of grey granite, slowly breaking up into large blocks-roughly cubical-many of which lie scattered down the mountain's side. Slightly curved jointsvery noticeable in our illustration (Plate 55)-cut across the summit, and appear to form an anticline. On the next highest peak Yün-t'ing Shan, red granite appears, as well as the grey. To the north, the peaks and ridges seem to be composed of gneiss and other metamorphic rocks, with ribs of granite here and there. The valley-bottoms are strewn with boulders, and stones of all kinds of crystalline rock; the minerals quartz, mica, and felspar predominating.

On descending the western slope of this great ridge, which divides the basin of the Fên Ho from the Yellow River, we soon reached again the beds of shale and sandstone. They present here features similar to those east of Chiao-ch'êng Shan. Huang-t' $u$ is very widely distributed, and in many places hides all other formations by extending right down to the valley-bottoms.

At a distance of about fifteen miles from the Chiao-ch'êng Shan range, we crossed another small divide, the summit of which was composed of shale protruding through the Huang-t' $u$. Between here and the next pass-about twenty miles further west-lies the river valley, in which the town of Lin Hsien is situated. The valleys between these three divides run from northeast to south-west, eventually joining the Yellow River.

The Lin Hsien valley is filled with vast deposits of Huang-t' $u$ so that only at the ravine-bottoms is the substratum of sandstone exposed.

One might consider the chain of mountains, which divides the Fên Ho from the Yellow River, as forming the eastern boundary of a vast flat basin. which takes in the whole of Northern Shensi, and the adjacent parts of Shansi, and Kansu. This basin is underlain by the Sinian Limestone, upon which lie Sandstone and Shale formations, which in turn are covered by a thick layer 
of loess. Except at the edges, these successive layers are practically horizontal. I will refer to this as the North Shensi basin, and will deal with it more closely in my remarks on the Huang-t'u formation.

About fifteen miles west of Lin Hsien a very peculiar formation occurs. Three peaks, composed chiefly of granite, pierce through the Huang-t' $u$ mantle, and rise to an altitude of from 6000 to 7000 feet. The peaks, which go by the name of Ch'ing-ting Shan ("clear summit mountains") run roughly in a line, north and south, their bases covering a square of five miles to the side. All round are loess hills. So far as could be gathered, these isolated peaks are the result of folding; but on this point I would not care to offer a positive opinion.

Westward, to the Yellow River, the country consists of loess lying upon a thick layer of sandstone. Through the latter, streams flowing towards the Yellow River in a general westerly direction have cut down to a depth commencing at from 20 to 30 feet and gradually increasing to about 300 feet in its bed. This sandstone doubtless belongs to the Shansi formation; it is perfectly horizontal in stratification, and nowhere were any faults noticed. It is in the form of freestone, and is admirably illustrated in the accompanying photograph (Plate 9).

On the western bank of the Yellow River, the same formation extends to the borders of the Ordos, though the depth of the sections exposed along the sides of the river-valleys becomes less and less till only along the largest rivers is there any outcrop.

At Yü-lin $\mathrm{Fu}$ the loess formations give place to a peculiar, hard, purplish rock containing a certain percentage of sand. Though not nearly so hard, it closely resembles shale, and doubtless only requires pressure to be converted into it. This hardened, sandy mud, or mudstone, protrudes through the thick layer of loose sand in the form of low rounded hills; one of which appears in the photograph of the sand-dunes (Plate ro).

The sand that exists in this district, is of the same yellowish fawn tint as the loess, and is from fifty to one hundred feet deep. It is very soft and loose, and in the river-beds and damp ravine-bottoms forms dangerous quicksands. About $\mathrm{Yu}$ u-lin $\mathrm{Fu}$ itself the sandstone, where visible, is of a pale greenish colour; but further to the south-west along the Ordos border it is of a brick-red. A deep bed of this red sandstone occurs at the head of the Yen Shui valley, a few miles south of Ching-pien. Here the cliffs rise to the height of some 200 feet, whilst the waters of the Yen Shui are stained a deep red. Red sand is deposited along the valley near Yen-an Fu. 
PLATE 50 .

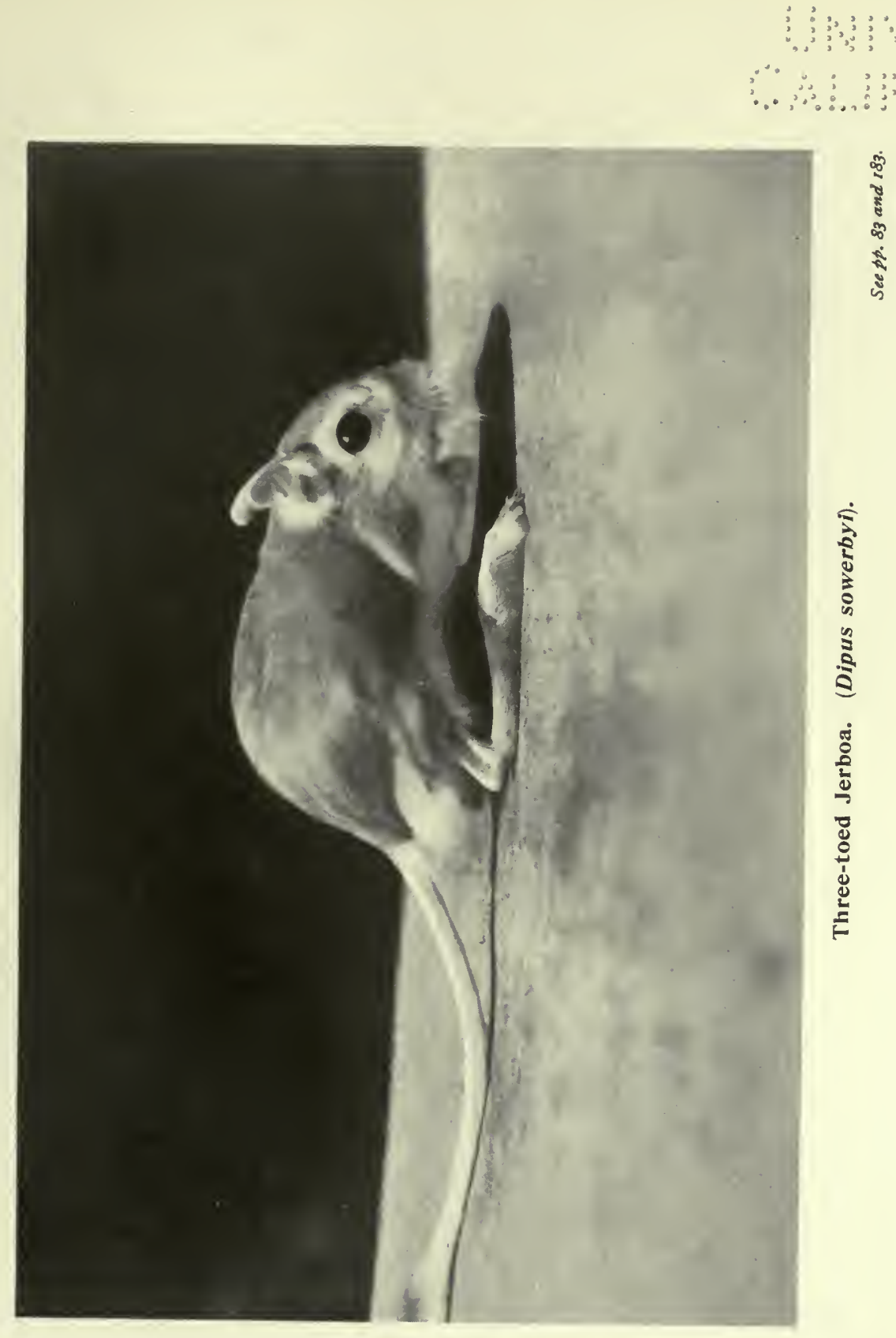


aقe

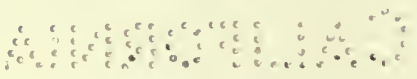


Travelling southward from Yü-lin Fu to Yen-an Fu we encountered Huang-t' $u$ formation upon horizontal strata of sandstone and shale. The sandstone in places shows very marked bedding, and, owing to the deposition of mica between the layers, can be split without difficulty. This stronglybedded sandstone occurs chiefly between Sui-tê Chou and Ma-chia-k'ou. A good illustration of this may be seen in the photograph of icicles, taken about three miles south of Ch'ing-chien Hsien (Plate I7). The photograph shows too a typical source of the plentiful water-supply to be found in every ravine of North Shensi.

At Yen-an Fu, the sandstone, still of a pale greenish colour, continues to show marked bedding. At low levels a pink and green cross-bedded sandstone was noted. In the region of Yen-an, the sandstone contains many crystals of Iron Pyrites. These, of course, where exposed, are very much oxidised, but some fine unoxidised specimens were secured at Lao-shan.

There is little to say about the Huang-t' $u$ of this vicinity, except that at the ravine-bottoms it is inclined to be clayey, resembling Shao-t' $u$ rather than loess. In the wooded area-which extends in a great belt, east and west, some twelve miles south of Yen-an $\mathrm{Fu}$-there is an even greater predominance of Shao-t'u. Here also finely-laminated, dark blue-grey shale occurs just above the sandstone.

Coal is mined at various places along the route from Yü-lin Fu to Yen-an Fu. Seams, reached by rather deep vertical shafts and showing no outcrops, occur within a mile of the former place. These mines produce a goodburning, but rather smoky, bituminous coal. At Sui-tê Chou, a peculiar coal was secured: it was said to have been transported from Ning-hsia, on the western border of the Ordos. It is very heavy and dirty, but absolutely smokeless, and smoulders like charcoal. Once ignited, it will continue to burn with a dull glow till the mass is reduced to soft white ash. The substance is certainly not charcoal, and those who sold it said that it was mined like coal. It has neither the appearance, nor the lustre of graphite. At Ch'ingchien a fine quality of lignite is obtainable. This comes from mines at Anting Hsien, a town situated some twenty miles to the north-west of Ch'ingchien. At Ma-chia-k'ou a very poor quality of coal occurs. This ignites only with the greatest difficulty, and leaves an enormous percentage of ash.

Yen-ch'ang Hsien, a town situated about forty miles east of Yen-an Fu, is famous for its petroleum wells; which are worked with European machinery, and produce a high grade of oil. We bought a supply of the oil, and found it burn well. It is sold at the rate of $2 \frac{1}{2} \mathrm{~d}$. per catty ( $\mathrm{I}$ catty $=\mathrm{I} \frac{1}{3} \mathrm{lbs}$.) and finds 
a ready market. The poor people use the crude oil, which they purchase at half the price of the refined. There was no evidence of any other useful minerals in this district. The coal-beds however must be very extensive and valuable.

Working southward from Yen-an $\mathrm{Fu}$, the same horizontal sandstone bedrock without faults is encountered, whilst the loess deposits are in the form of great plateaux, all uniform in height (Plate 22). These continue from $\mathrm{Fu}$ Chou to near Chung-pu Hsien, a distance of about seventy miles. South of the latter town the rock-beds, in the form of shale, rise considerably above their normal level, and the loess mantle is very much reduced in thickness, being in some places entirely denuded. Continuing southward, we found the shale strata very much contorted. Still further south again, at Yao Chou, we passed through a great outcrop of grey limestone, dipping sharply to the north. This seems to mark the southern boundary of the great North Shensi basin.

From here the country gradually slopes down to the Hsi-an plain. The loess on the southern side of the limestone ridge is very thick, completely hiding the under-lying rock, and extending right over the plain. The country south of the Wei Ho was visited by the Carnegie Expedition, and a good account of its geology appears in the book subsequently published by the Carnegie Institution. I will not do more than draw attention to the variable temperature of the hot springs at Lin-t'ung Hsien. Bailey Willis found them to be $40^{\circ}$ Centigrade $\left(104^{\circ} \mathrm{F}\right.$.). Rockhill records their temperature at 106 $6^{\circ} \mathrm{F}$. When we visited them they were at $108^{\circ} \mathrm{F}$. whilst Dr. Jenkins, a resident missionary of $\mathrm{Hsi}-\mathrm{an}$. Fu says that he has known them to reach II $2^{\circ} \mathrm{F}$. In the mountains immediately south of Hsi-an Fu I found granite occuring at very low levels. Viewing the mountains southward from the top of the peak, about 5000 feet in altitude, I could make out nothing but igneous rock masses.

Leaving this vicinity we will now follow the westward course of the main division of our Expedition on its way to Lan-chou Fu in Kansu, and for this we must return to $\mathrm{Fu}$ Chou. From that point westwards for about thirty-four miles the same loess plateaux as lie to the south and east were encountered. Then a stretch of very moist country : deep and clear streams in every valley and ravine $:$ the hills clothed with luxuriant vegetation. Denudation must have been at one time very extensive, for not only is the loess low and well roundedoff, but the sandstone and shale substrata also show marked wearing.

At Hai-shui-ssŭ, a peculiar column of sandstone-all that is left of a 
great bluff cutting across the valley--rises to a height of about 200 feet above the stream-bed (Plate 46).

At Ho-shui Hsien the bed-rock is chiefly in the form of dark-maroon or grey shale, finely laminated. This gives place at Ch'ing-yang $\mathrm{Fu}$ to grey sandstone with marked bedding. Immediately west of this city the loess plateaux commence again. The country is noticeably drier than that to the east, and the plateaux continue for about sixty miles, ending abruptly at Chên-yüan Hsien.

From here westward, the loess formations become much deeper and less regular. The bed-rock rises gradually and is no longer perfectly horizontal. Immediately west of Chên-yüan Hsien, the sections exposed on the side of the valley show a red sandstone with marked bedding. It dips towards the west at an angle of $20^{\circ}$. This is very clearly shown in the accompanying photograph (Plate 57) of a view looking westward about five miles west of Chên-yüan Hsien.

The sedimentary formations from Chên-yüan westward rise steadily in altitude till the Liu-p'an Shan are reached. This great range of mountains ( 8000 to I0,000 feet high), composed of crystalline rocks, and extending from north-west to south-east, lies to the west of Ku-yüan Chou and Wa-t'ing and may be considered as the western rim of the great North Shensi basin. The highest peaks are very precipitous, and resemble the Chiao-ch'êng Shan of Western Shansi in their formation. The lower peaks are composed of limestone, through which run many deep ravines.

Ku-yüan Chou is situated in an immense loess basin, bounded north, east and south by hills of sedimentary origin, and on the west and south-west by the Liu-p'an Shan. On the western side of this range the formation is chiefly of limestone, at a higher level than the sedimentary rocks to the east of the range.

From Ku-yüan the path lies in a general south-westerly direction till Ching-ning Chou is reached. Immediately north of this city the limestone formations are deeply cut through by a stream coming down from Liu-p'an Shan. Westward from Ching-ning Chou the loess deposits increase enormously in depth. High loess-covered mountains occur, divided by deep ravines, and the substratum appears in only a few places. A photograph of one of the deep cañons is given (Plate 39). This was taken at Ying-t'ao-ho immediately east of a high loess pass, and about sixty miles west of Chingning. It is typical of the formations that occur throughout this area as far as Hsiao-shui-tzŭ, near Lan-chou Fu. In places the loess is replaced by a dark, 
alluvial clay strongly impregnated with alkali, through which run deep cañons : an especially large one occuring to the east of Hui-ning Hsien (Plate 38).

As Hsiao-shui-tzŭ is approached, a system of high mountains makes its appearance to the south and south-west. From these mountains the streams bring down great quan tities of pebbles and boulders of limestone and crystalline rocks.

At Hsiao-shui-tzŭ (or Shao-shui-tzŭ) itself the Yellow River is again reached, at this point cutting through a thick dyke of granite to a depth of 200 feet (Plate 33). On this granite lies a layer of green sandstone and on this again a deep deposit of loess. The loess here seems to contain a certain amount of whitish clay, and becomes extremely hard under the influence of the hot sun.

The formations round Lan-chou Fu are very complex. There is a good deal of felspathic rock, especially north of the river, which here flows through a long valley, from two to three miles wide.

To the south of the city, sedimentary rocks are first encountered, but these give way to crystalline rocks, which rise to a height of from 10,000 to Ir, 000 feet. Westward, the mountains to all appearance are formed of igneous rocks, and very complicated. Gold, silver-ore, jade and precious stones are obtained in this range.

The sedimentary strata, which occur some ten miles south of Lan-chou Fu, namely at Wa-kang-ch'êng, are coal bearing ; whilst a plentiful supply of clay-derived probably by decomposition from igneous rocks-allows of extensive pottery-works being carried on.

There is a good deal of grey crystalline limestone in the mountains south of the city. These are more or less rounded, no very prominent peaks existing. Loess occurs at an altitude of over 7000 feet.

The next stretch of country to be discussed is that along the road taken by the Expedition on its return journey from Sui-tê Chou, in North Shensi, eastward to Fên-chou Fu, in Shansi, and thence north-eastward to T'ai-yüan Fu. Between Sui-tê and the Yellow River very deep deposits of loess and Shao-t' $u$ occur. The latter is found usually at the bottoms of the deep ravines and is of a deep brick-red colour. In places the ravine-bottoms are formed of the usual sedimentary strata (Shensi formation) with marked horizontal bedding. Within five miles of the Yellow River the loess gets very shallow, and in many places the sandstone substrata are exposed in the form of rounded hills with precipitous ravines. The depth ( 500 to 600 feet), to which the river has cut through the sedimentary formation, is much greater here than at the spot further north where the Expedition crossed on its journey westward. 


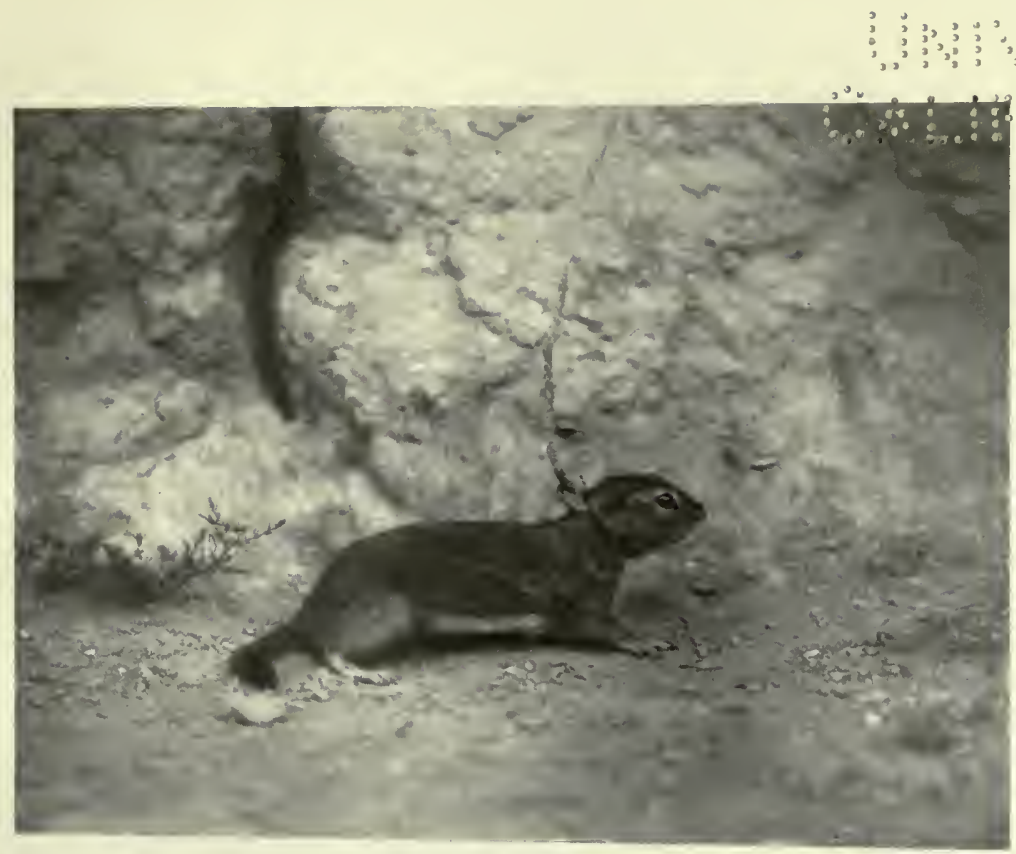

Suslik. (Citellus mongolicus).

See pp. gl and 177 .

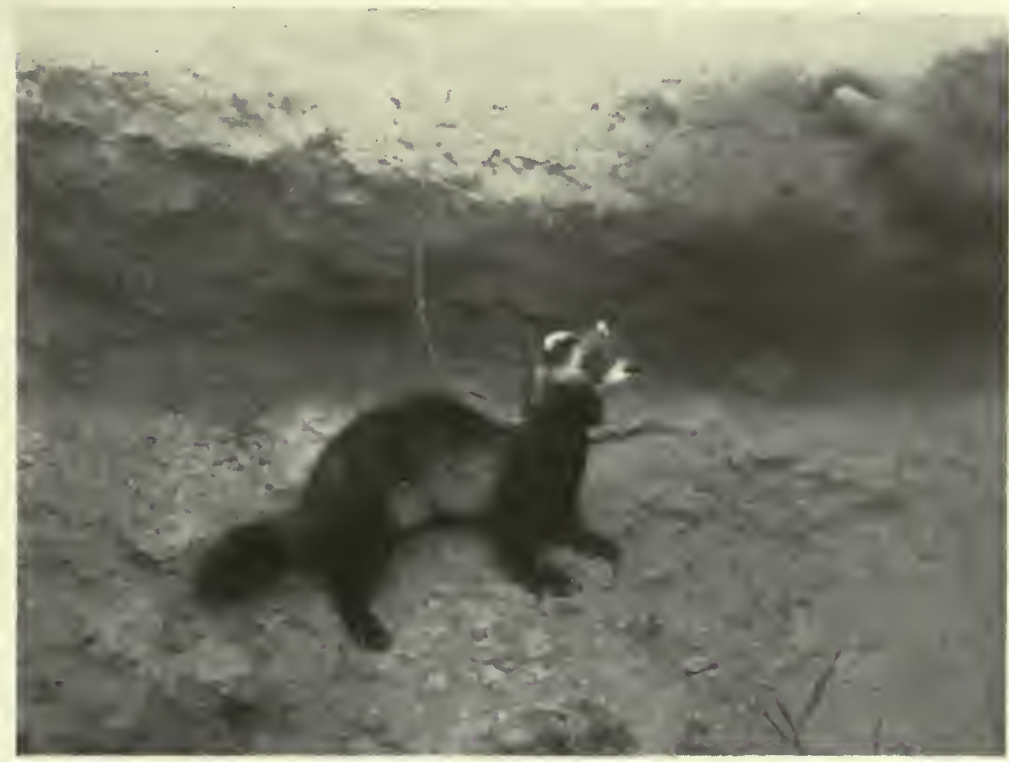

Polecat. (Mustela larvata). 


$$
\text { and }
$$


Our course lay in a north-easterly direction up the right bank of the river for about six miles, and the sections exposed were carefully noticed. The strata on the left bank (Shansi side) seem to be chiefly of red-brown and green shales, arranged for the most part in slightly folded beds of varying thickness, dipping slightly to the south-west. Near Wu-pao Hsien, where the caravan effected a crossing, this folding is rather more pronounced than elsewhere. On the right bank the strata are composed of yellow-grey sandstone arranged in horizontal beds, and rise to a height about two hundred feet lower than those on the left.

After crossing the river, we continued up a deep ravine through strata of green and red-brown shale, finally crossing a ridge upon the summit of which loess to a depth of fifty feet occurs. The descent from the crest is first through loess, and then through shale till a small river-valley is reached. Here the section showed nothing but horizontally stratified shale, and sandstone $\mathrm{x}$ ith thick superimposed loess beds. Our road lay up this valley as far as Yungning Chou where the granite and gneisses, which occur in the Chiao-ch'eng district, again appear. Working east from Yung-ning, we approached Wu-ch'êng, a large village situated about twenty miles distant, and again encountered the Sinian limestone, dipping in a north-westerly direction at a slight angle. On crossing a divide we descended into a deep ravine cutting through the limestone, which extends to within ten miles of Fên-chou Fu. Here the strata are perfectly horizontal, as shown in the accompanying photograph (Plate 58), which also gives a good idea of the depth of the limestone beds. Between the end of these beds, which form a surface free from loess, and the valley of the Fên Ho, the ordinary Shansi coal-bearing series occur covered by a thick deposit of Huang-t' $u$ formation. The latter comprises here both loess, and Shao-t'u.

The road from Fên-chou Fu to T'ai-yüan Fu has been traversed by several geologists, so that I will not presume to offer any remarks about it.

\section{THE Huang-t'u Formation.}

One of the most characteristic features of the provinces of Chihli, Shansi, Shensi, and Kansu is afforded by the vast Aeolian deposits, commonly called the "Chinese Loess." This has also received the name of "the Huang-t" Formation," and is divisible into two classes:-

(I) That which is purely wind-deposited, and may be called Loess.

(2) That deposited by rivers in the form of great plains, such as those of Pao-ting Fu and T'ai-yüan Fu, and conveniently termed Fluvial Loess. 
We will not do more than mention the latter, which is of course derived from the former : it resembles in its characteristics, such as vertical cleavage and compactness, the true Loess.

The true Loess, which forms the bulk of the Huang-t' $u$ formation encountered by us on our journey, is again divisible into two classes, containing a greater and lesser proportion of separated clay respectively. To the former I give the name of Shao-t' $u$, which has already been explained in the earlier part of this Chapter; for the latter we may still use the name Loess.

The extent of the Huang-t'u formation is very great : it covers, roughly speaking, an area of 200,000 square miles. Occurring as a sort of mantle overlying the greater part of Shansi, Shensi, and Kansu, it extends into Honan and forms also the great plains of Chihli. But nowhere are such vast deposits found as in the Province of Shensi, north of the Wei Ho.

The physiography of North Shensi has already been likened to a great basin, and it is in this basin that we can see loess at its best. It covers the whole of the sedimentary rocks to an average depth of rooo feet. In some places-notably along the sides of the Yellow River-it gets rather thin, but in the country immediately south of the Ordos Desert the depth increases to about 2,000 feet. The greater part of these Loess deposits are cut up by the action of water into rounded hills of uniform height.

To the east, south and west of Fu Chou, in North-Central Shensi, the $H$ uang-t' $u$ formation assumes the form of immense plateaux, divided from one another by deep valleys, and cut up along their edges by deep and narrow ravines (Plate 56). The surfaces of these plateaux are perfectly flat; and all are equal in height to one another, and to the loess hills extending over the rest of the basin. The hills immediately adjoining the plateau-area are the more flattopped, showing a gradual transition from the plateau to the hill form. From these facts it may be argued that the whole of the North Shensi basin was at one time in the form of a great loess plain, formed during a long period of drought, when little or no erosion was taking place. I cannot conceive of such a plain having been formed under the weather-conditions prevailing at the present time. It is certain that deposition is going on nowadays, but I do not think its rate can be in any way equal to that of erosion. Many facts may be cited to show the enormous rate at which the present torrential rains, occurring in summer, erode the soft Loess. Some twenty miles north-east of Yu-lin Fu, where deep deposits of loess occur along the Ordos border, huge ravines or cañons, many miles in length and hundreds of feet deep, cut through the Great Wall into the Ordos. Everything points to the fact that these have 


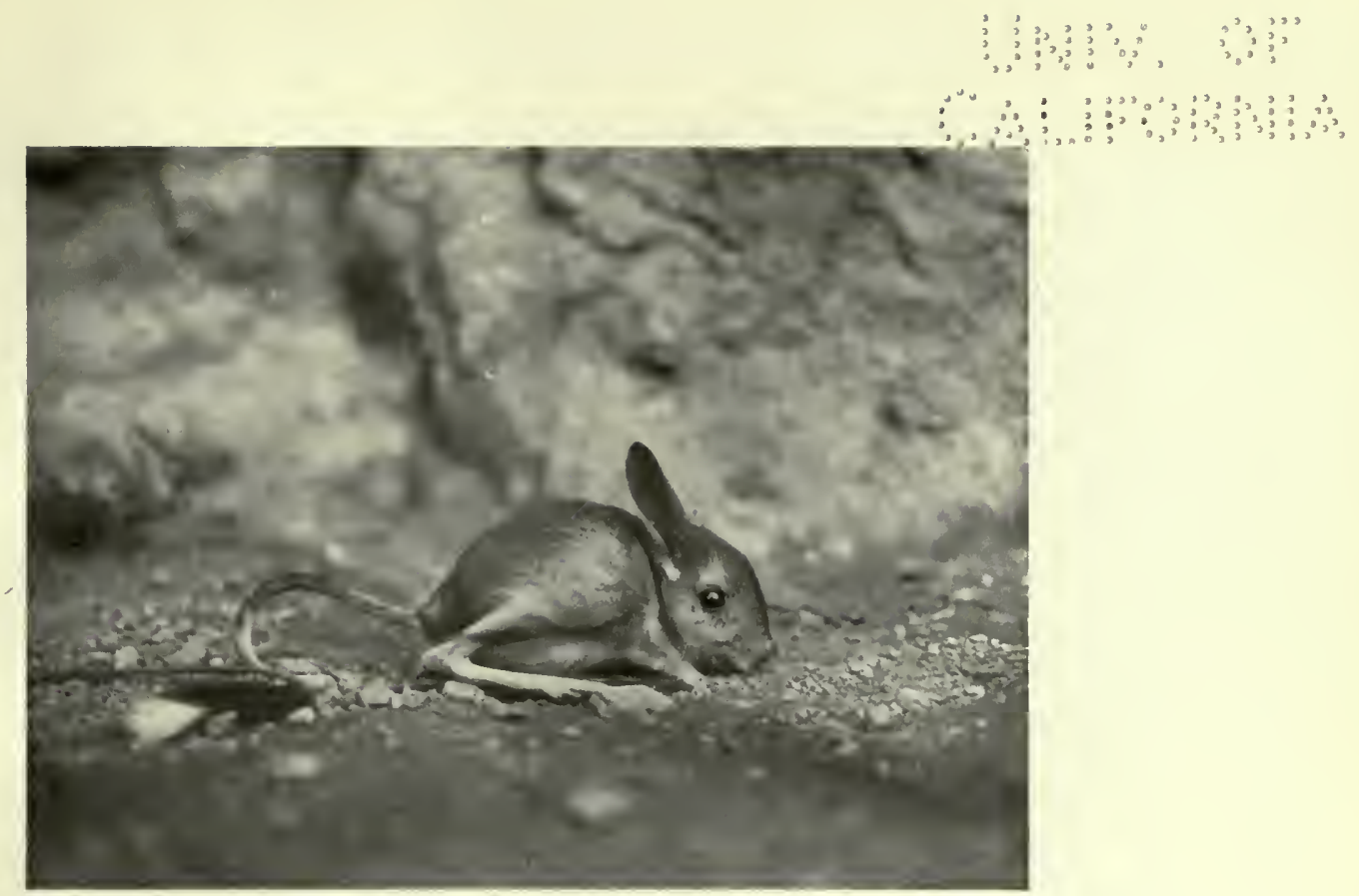

Allactaga. (Allactaga mongolica longior).

See pp. 92 and 183 .

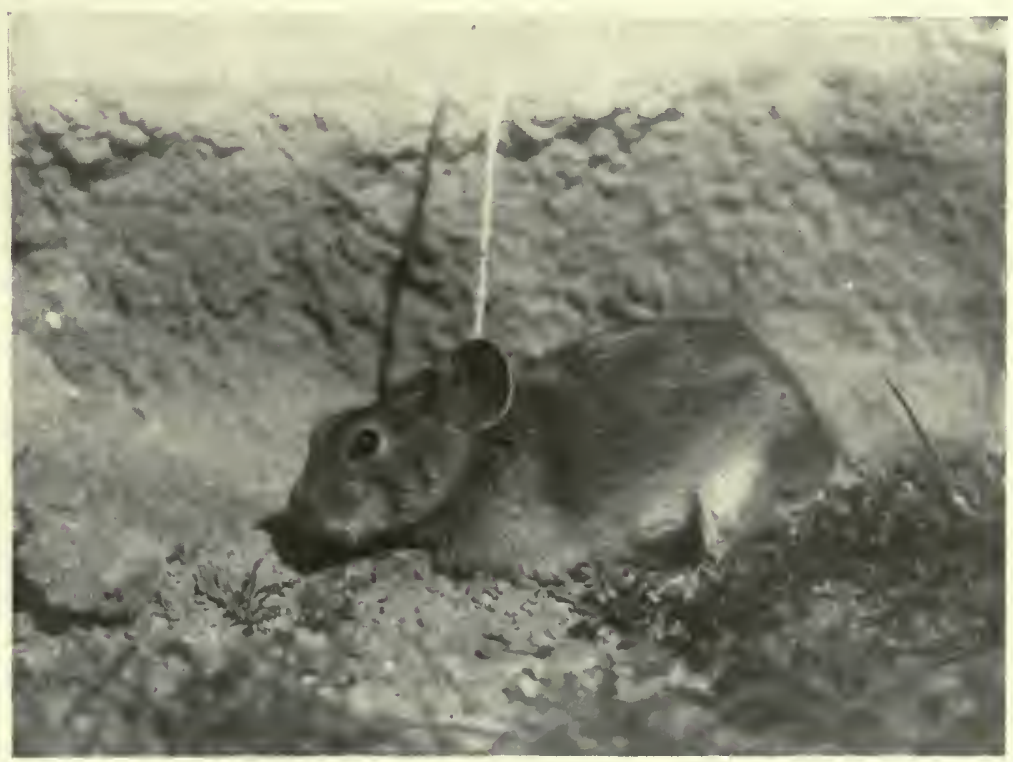

The Pika. (Ochotona annectens). 


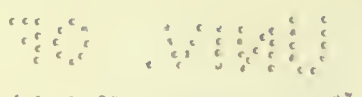

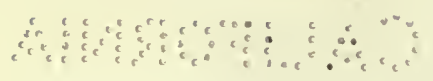


been formed since the Wall was built. The city of San-yüan Hsien, situated twenty miles north of Hsi-an $\mathrm{Fu}$, has been cut in two, since it was built, by a ravihe 200 feet deep and over 200 feet wide. Again, in the Loess country of North Shansi one may often notice the remains of a succession of old roads, one below the other, along the side of a ravine. The ravine in these instances marks the original trace of the road. This was washed away, so that it became necessary to form a new road along the margin of the first. This in turn became dangerous or unfit for use, owing to the continual falling-away of great masses of loess, and again a new road had to be made. To-day a yawning chasm remains, which has swallowed up each successive road, leaving perhaps, remnants of the last two or three. The whole process has taken place within the memory of the older iuhabitants of the district, who can testify to the facts. Places like this occur along the roads from T'ai-yüan Fu to Shou-yang Hsien, and Hsin Chou. Of course the practice of the inhabitants, who each winter root up or cut down every trace of vegetation, greatly accelerates the denudation of the loess deposits; but even taking this into consideration, we must conclude that the rainfall, during the time when the loess plain was forming, was far less than it is now.

It may be suggested that these loess deposits were laid down at the bottom of a lake, but there is no proof of this; nor is there any reason to suppose that it is a fluvial deposit such as the Chihli plains. The north Shensi basin is open to the north, and there can be no doubt that the loess was originally brought down from the Gobi Desert, of which the Ordos is but an arm.

During our stay in Yü-lin Fu we had excellent opportunities of noting how the wind, which we found to prevail from the north, carries southward the material of which the Loess is composed. The inhabitants of North China are familiar with terrible dust-storms, which sweep down from the Gobi Desert at all times of the year.

The Loess sometimes shows stratification. A good example of this appears in the accompanying photograph (Plate 56$)^{*}$, which was taken a few miles west of the Chiao-ch'êng Shan in Shansi. The strata occur in alternate layers of brick-red, and light-coloured loess; the former having rather the constitution of Shao-t'u.

In many places we noticed, embedded in the loess, shells of a little snail inhabiting the country at the present time; whilst bones of the Mole-rata rodent with an underground mode of life like the mole's-were also found. No fossils of any kind were discovered in the Loess.

- cf. Plate 55. 


\section{CHAPTER XIV.}

\section{SURVEY WORK OF THE EXPEDITION-BY R. S. CLARK.}

THE Map* accompanying this volume is based on the plane-table work carried out by Hazrat Ali, of the Survey of India, the ill-fated member of our party, whose death at the hands of the Chinese near Lan-chou brought the expedition to an untimely close. A short description of the means and methods employed on the survey will, we trust, be found of interest.

Commencing with a list of the instruments used, and remarking where necessary as to their pattern etc., we give a few notes to indicate briefly the methods employed for fixing our base, for carrying out the whole survey and for determining certain check-measurements; finally connecting up the results of our work with such records of previous surveys as are available. For the benefit of future travellers itineraries of the routes traversed are given in Appendix I., together with a table containing Latitude, Longitude, and-in most cases-Altitude of every important place visited.

Instruments, etc.

The instruments and appliances used were :-

I 3-inch Astronomical Field Telescope. (Cary London)

2 5-inch Micrometer Theodolites. (", )

3 Half-Chronometer Watches. (Blockley, Kew certificated)

I Half-Chronometer Watch with Chronograph.

1 3 Aneroid Barometers.

I Boiling-point Thermometer.

I Georges Mercurial Barometer.

(Cary)

I Ioo-foot Invar Tape.

I Plane-table.

I Road-wheel.

Base-lines.

(A) As described in Chapter I, the party went into camp a few miles out of T'ai-yüan $\mathrm{Fu}$ to measure a base-line, the site chosen for

- In a pocket at the end of volume. 
Sunset on the Ordos Border.

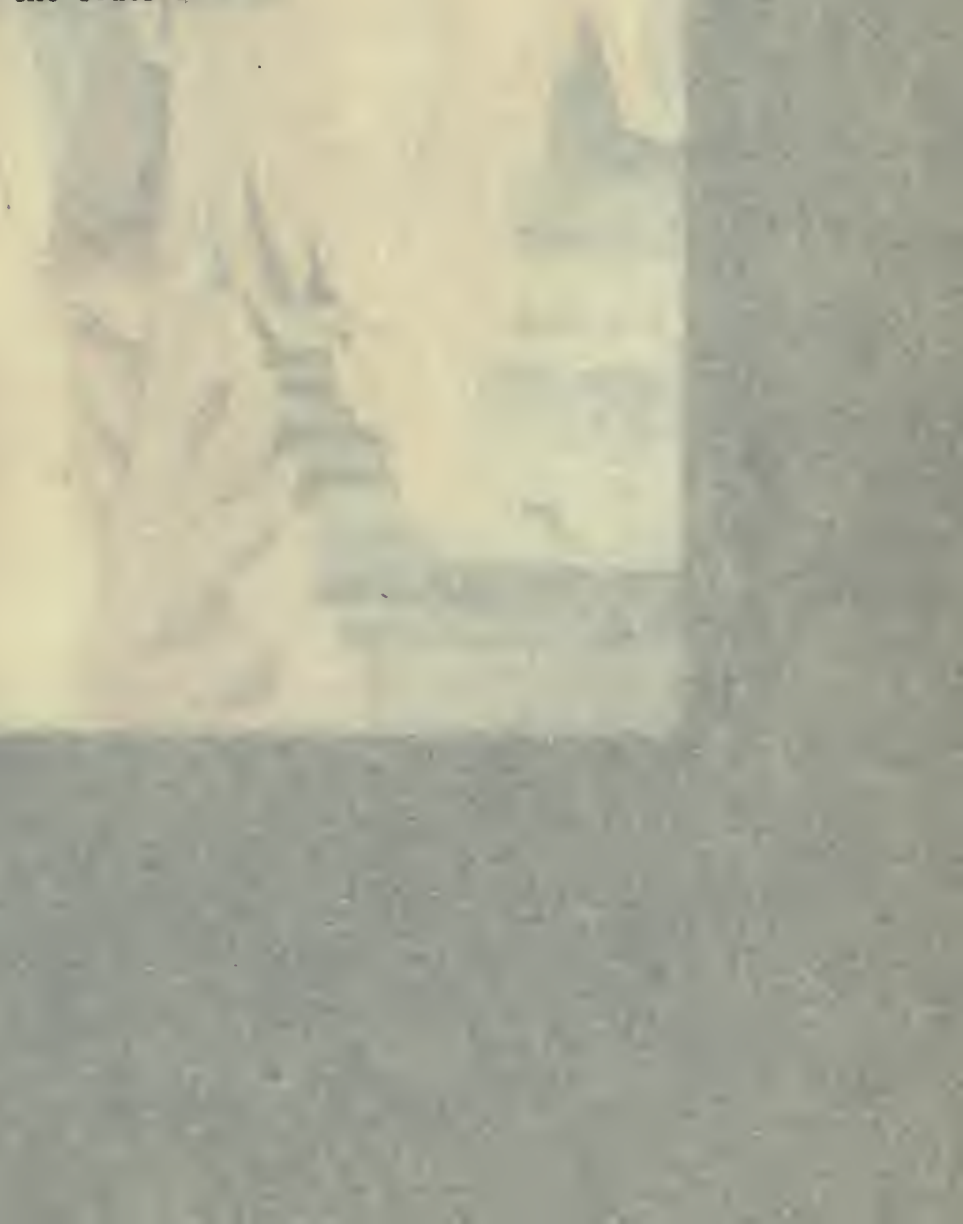




\section{CHAPTER XIV.}

SURVEY WORK OF THE EXPEDITION-BY R. S. CWME.

THE Mop* accompanying this volume is based on the pleacestain vork carried out by Hazrat Ali, of the Survey of India, the ill-fated mambers of our party, whose death at the hands of the Chinese near Lan-chou brouk hit whes sxpedition to an untimely close. A short description of the mens ond mellente enginyed on the survey will, we trust, be found of interest.

fom with a list of the instruments used, and rounating

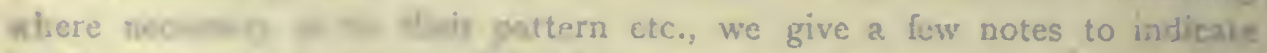

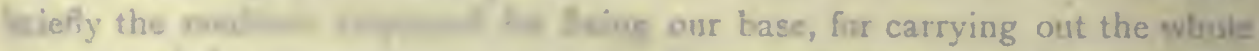
aney and for an:

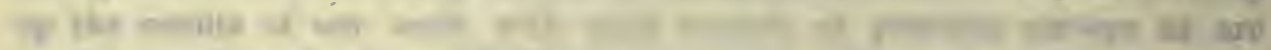

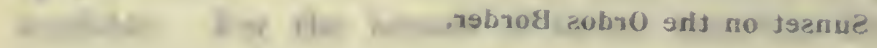

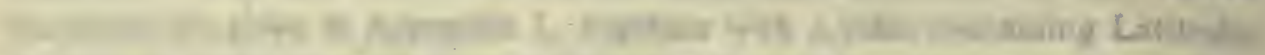

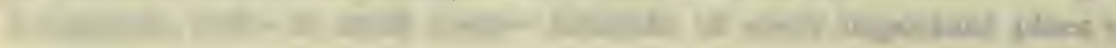

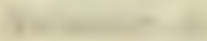

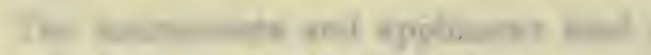

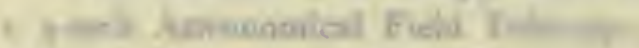

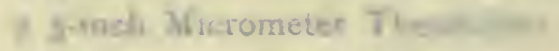

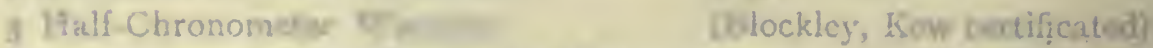

I Half-Chromometer what wha Chronograph.

3 haeroil tow eless.

I Bollearonet Toemometer.

x Compe Mercuria! Barcmeter.

(Cary)

$x$ xoof foot Invar Tege:

I. Ylane-table.

I Road-wheel.

Bole-lines.

(A) As deacribed in Chapter I, the pasty went into caing a hew miles out of $T$ ai-yusan Fu to measure a base-line, the rite exmen the

- 1t i mal et at ale end of nilime 


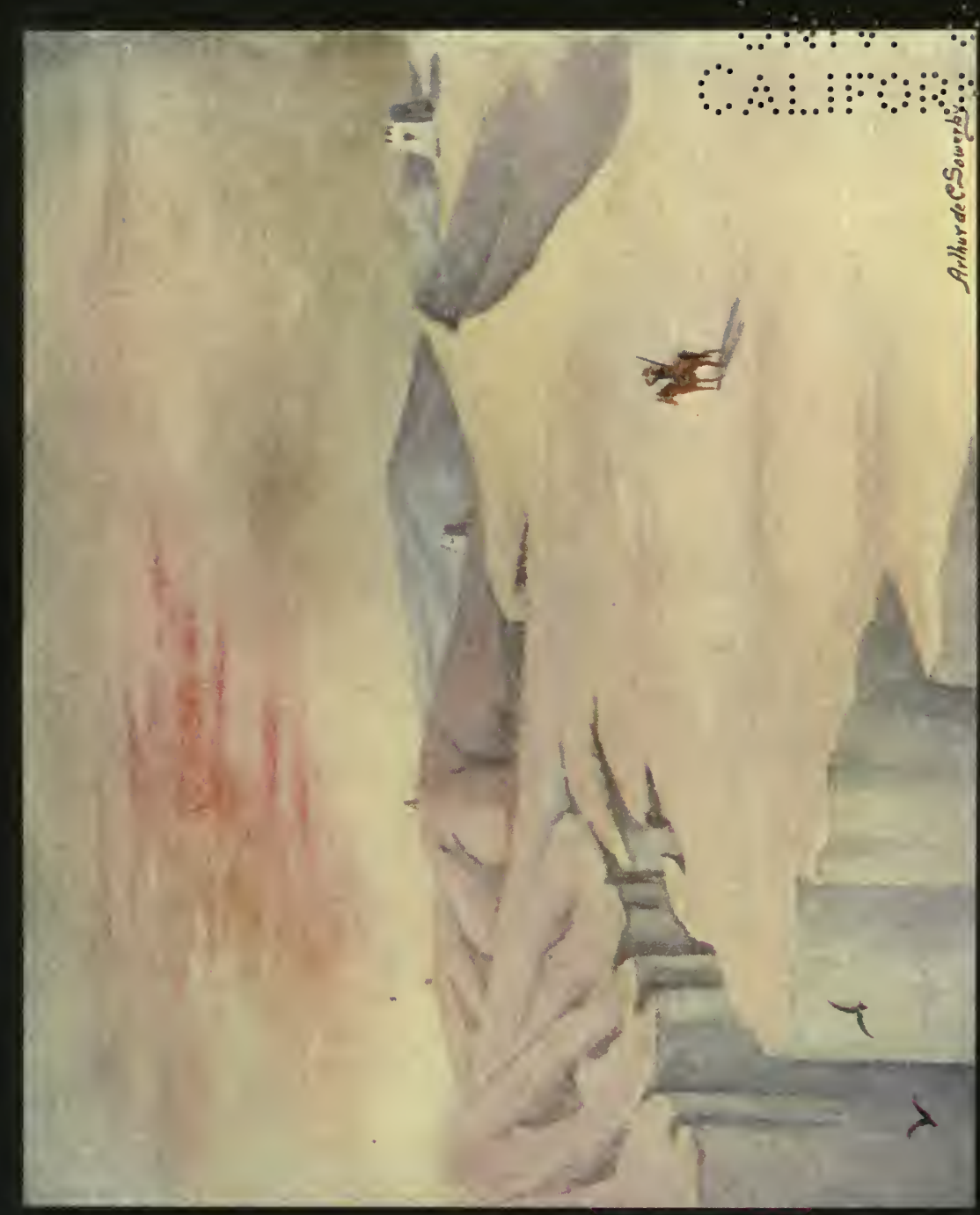




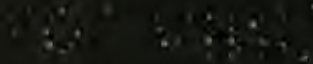

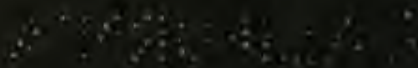


actual measurement being about two miles north of the town. The base was 2400 feet long and was measured twice by means of the Invar Tape; the probable error being $1 / 50,000$. The longitude of one end of the base was assumed, and the latitude calculated from astronomical observations. This was subsequently corrected by the telegraphic longitude reduced to the South East Gate of the City.

(B) On our arrival at Yen-an Fu, the surveyor found himself at fault, and it was considered advisable to measure a new topographical base. This base was 8 miles long and connected with the longitude by occultation.

Datum Level.

From the T'ai-yüan base-line, five elevated points were fixed by triangulation, their vertical angles were taken with the theodolite, and their altitudes determined trigonometrically. The altitude of the end of the base from which they were determined was assumed to be 2700 feet. As there is only a very gradual rise to this point from T'ai-yüan Fu (alt. 2600 feet as found by the French Railway Survey) we think that the height assumed may be taken as correct to within 50 feet.

\section{Plane-table Survey.}

The plane-table work was executed by Hazrat Ali on the $\frac{1}{4}$-inch scale. The country traversed was, generally speaking, of the very hardest that could be found for the plane-table. With the exceptions of the mountain country extending 80 miles west of 'T'ai-yüan, the range immediately to the west of Ku-yuaan Chou in Kansu, and the mountains in the vicinity of Lan-chou $\mathrm{Fu}$, the whole terrain was covered with loess. Such a surface with its bare, rounded hill-tops-all usually of the same level and rarely varying more than roo feet-affords no salient features suitable for triangulation; whilst the deep gullies cutting it in every direction make access difficult. In addition the valleys of even the larger water-courses offer but very little better fields of view, being never more than a mile, and but seldom more than a few hundred feet, wide. In every way, a loess country taxes the abilities and patience of a surveyor to the utmost, and I do not believe that too much praise can be given to Hazrat Ali for the consistent and conscientious accuracy of his work. Never was he seriously out but once. At Yü-lin Fu the work checked out to within $5^{\prime}$ of Long. and $4^{\prime}$ of Lat. ; but our last three marches before 
reaching Yen-an Fu were hurried-owing to various circumstancesand the survey got in consequence considerably out, $I 6^{\prime}$ of Long. and $8 \frac{1}{2}$ ' of Lat. It was adjusted by the distance as measured by road-wheel -incidentally showing to advantage this less ambitious apparatus-and a new base was established as described above in (B), from which the survey was begun afresh.

At Lan-chou Fu, where I again joined the main body, the planetable results checked out to $12^{\prime}$ of Long. and $6^{\prime}$ of Lat.

The map, which is based on the plane-table sheets, has been adjusted to the correct positions of the various towns, as determined by observations.

\section{Latitudes.}

The Latitudes in the Table (on Page I70) are always the mean of at least two observations, and more often of from four to six. As the greatest variation never exceeded 8 ", we think they can be taken safely as correct.

In taking the Latitudes for the ends of the base (B) the two theodolites were used, both Grant and myself reading 30 faces on each instrument. In one case the results checked to within ${ }^{\prime}{ }^{\prime \prime}$ and in the other to $0.8^{\prime \prime}$.

Longitudes.

By the co-operation of Major H. R. Davies, General Staff, who kindly offered to take the Tientsin end, we were able to determine the telegraphic Longitude of T'ai-yüan Fu. One set of six taps at ro second intervals, and another set of six at irregular intervals were sent and received on three nights. Four persons received at T'ai-yüan $\mathrm{Fu}$, and two at Tientsin. The mean result was unexpectedly good, working out to a probable error of 4 seconds of arc.

In taking the Longitudes by occultation at Yen-an $\mathrm{Fu}, \mathrm{Hsi}-\mathrm{an} \mathrm{Fu}$ and Lan-chou $\mathrm{Fu}$, never less than three observers took the time. The greatest variation between the times of two observers was three-quarters of a second. The immersions were always on the dark limb. These results can be taken safely to a quarter of a mile.

The Longitudes by Chronometer can, we think, be considered as exceptionally good. All but that of Fên-chou Fu were between two points fixed by occultation or telegraph. Two separate Longitudes of Yü-lin $\mathrm{Fu}$, one connected with the Longitude of T'ai-yuan $\mathrm{Fu}$ and the other with the Longitude of Yen-an Fu checked to I'. 
In going to Lan-chou Fu from Yen-an Fu the Longitudes of Ch'ingyang $\mathrm{Fu}$ and $\mathrm{Ku}$-yüan Chou were not satisfactory, as Grant only had two watches and the time consumed was too great. In coming back he took a second set, which worked out exceptionally well, the rates of the watches having been very regular, and the time consumed by the journey being comparatively short. The Longitude of Yen-an Fu, as determined by the watches, was $109^{\circ}-27^{\prime}-33^{\prime \prime}$, and that as calculated from occultation previously taken $109^{\circ}-26^{\prime}-49^{\prime \prime}$. However; calculating the Longitudes back from Yen-an $\mathrm{Fu}$, as a starting point, the biggest variation was $2^{\prime}$. We consider the chronometer Longitudes correct to I mile.

The position of Lan-chou $\mathrm{Fu}$ (South Gate) was fixed as Lat. $3^{\circ}-3^{\prime}-6^{\prime \prime}$; Long. $103^{\circ}-40^{\prime}-54^{\prime \prime}$. This was the only place on our trip where we had a subsequent opportunity of comparing our determinations with those of another traveller. Mr. Clementi, who travelled from Kashgar to Kowloon in $1907-8$, gives the position of Lan-chou $\mathrm{Fu}$ as Lat. $36^{\circ}-3^{\prime}-1 I^{\prime \prime}$; Long. $103^{\circ}-46^{\prime}-7^{\prime \prime}$. His latitudes were taken by $N$. and $S$. stars and his longitudes by chronometric differences.

Altitudes.

After leaving T'ai-yüan $\mathrm{Fu}$ all determinations to within 30 miles of the Yellow River were trigonometrical (i.e., obtained by vertical angles with a theodolite). All subsequent heights are barometric. For barometric determinations they can be taken as reasonably accurate, as the aneroids were frequently compared with the mercurial barometer. The mean of the barometer and the boiling-point readings was taken as the correct height.

\section{Previous Surveys.}

Without pretending to give any exhaustive record of previous foreign surveys of the country traversed, we offer a slight summary of such as we have been able to trace.

Early in the Eighteenth Century the Emperor Kang-hsi ordered a survey of the Eighteen Provinces to be carried out. In this he most probably had the assistance of the Jesuit Fathers, whose influence during this reign was very great. The Chinese method of map-making is to give a separate sheet for each "Fu" or "Hsien" district, and it is of course possible to piece together a number of these sheets to form a survey of the whole country. This however leads to a thoroughly untrustworthy map, as it is vital "to work from the whole to the part, 
and not from the part to the whole ";* and it may have been a realisation of the necessity of a framework on which to hang the detail which led the Fathers to determine the positions of many towns in China. Their observations, especially when the inadequacy of their early instruments is borne in mind, are entitled to the very greatest credit.

In $1877-80$ Count della Szechenyi published an Atlas of a Portion of East Asia (Scale $I / I, 000,000$ ). The Lan-chou sheet takes in a part of our route, viz., Lan-chou to P'ing-liang Fu viâ An-ting Hsien.

In I903-5 Herr Wilhelm Filchner, made a trip into Kansu, subsequently publishing a map of Kansu (Scale $\mathrm{I} / \mathrm{I}, 000,000)$. No hills shown.

In Igo6 Major C. D. Bruce travelled in company with a Rurkitrained surveyor from Lan-chou to Peking. Starting from Lan-chou he proceeded viâ Hai-ch'êng Hsien to Ch'ing-yang $\mathrm{Fu}$, thence following the same route as that taken by us, viz., Fu Chou, Kan-ch'üan Hsien to Yen-an Fu; then bearing east and crossing the Yellow River at Yenshui-kuan he reached T'ai-yüan by Yung-ho Hsien and Fên-chou Fu. An account of this trip, with a route sketch map (Scale $\mathrm{I} / 3,500,000$, based on a plane-table traverse), appeared in the Royal Geographical Society's Journal, I907.

In 1907, as mentioned above, Mr. Clementi travelled from Kashgar to Kowloon, taking astronomical observations with the theodolite throughout his line of march, which however intersected our own at Lanchou only.

In Igro, the Russian Geographical Society published routes of their expedition into Kansu (Scale 40 versts to $\mathrm{I}$ inch).

The German Karte (Scale $\mathrm{I} / \mathrm{r}, 000,000$, sheet $H$ si-ngan and $Y \ddot{u}-$ lin $F u$ ). takes in a great proportion of our route, but the sheet giving Lan-chou $\mathrm{Fu}$ has not yet made its appearance.

- Vide Text Bojk of Topographical and Geographical Surveying by Colonel C. F. Close, C. M. G., R. E. 


\section{In the T'sing-ling Shan.}




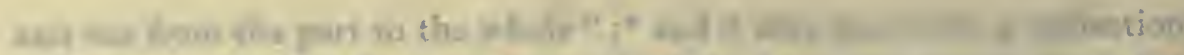

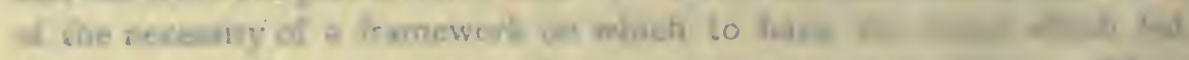
Whe Fathers to determive the postions of meay tors by the ther

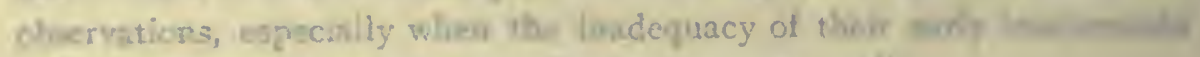
is burse in mind, sre extitled to the very greated coldit.

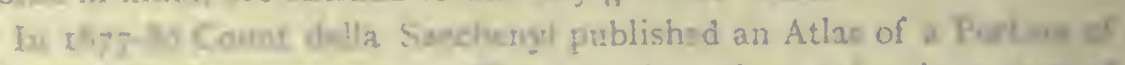

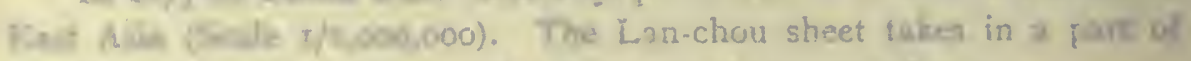

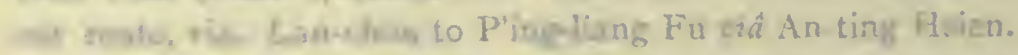

to ryoba Heas Writseln Bilchner, made a trip into Kanns. saboon maly poblishing $x$ mup of Kansu (Scale $1 / 1,000,000$ ). Xn. hatls allom

In roce Major $C$ If Hruce invelled in company with a Burli-

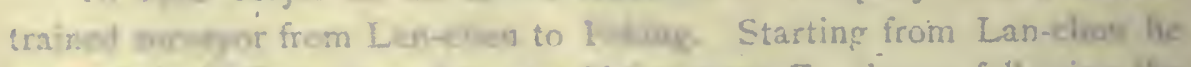

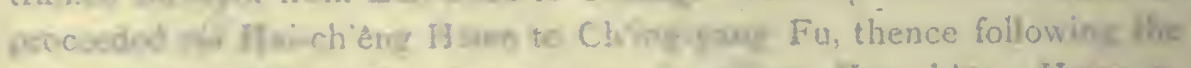

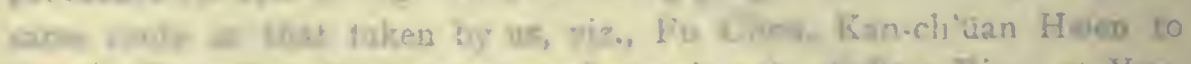

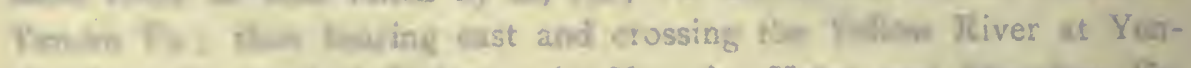

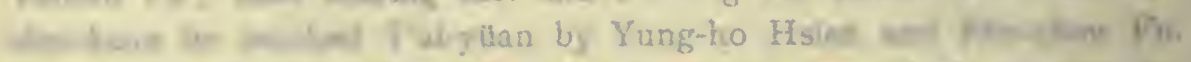

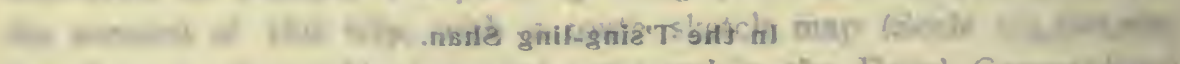

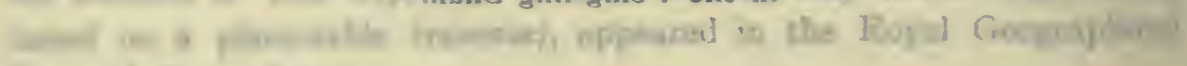

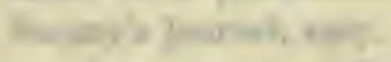

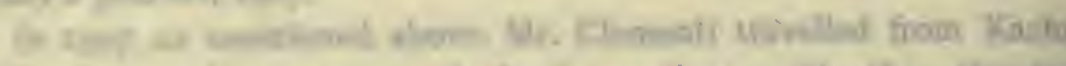

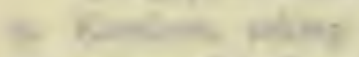

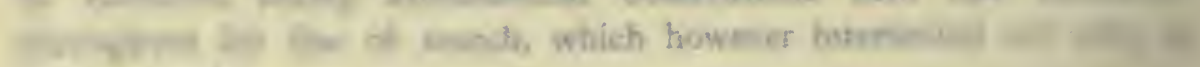

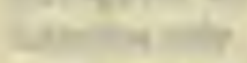

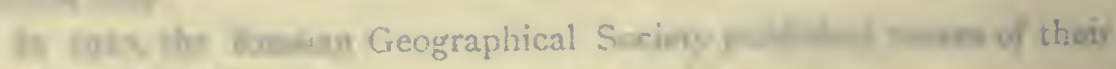

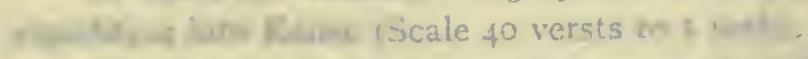

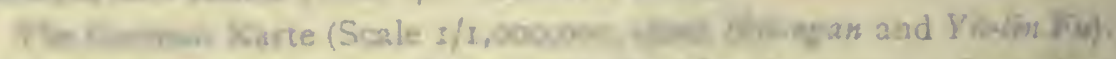

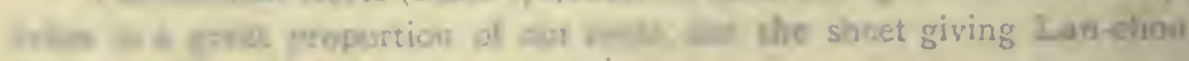

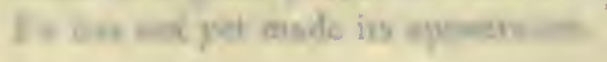

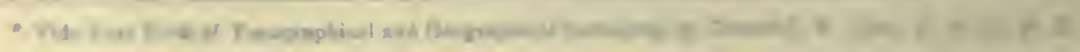




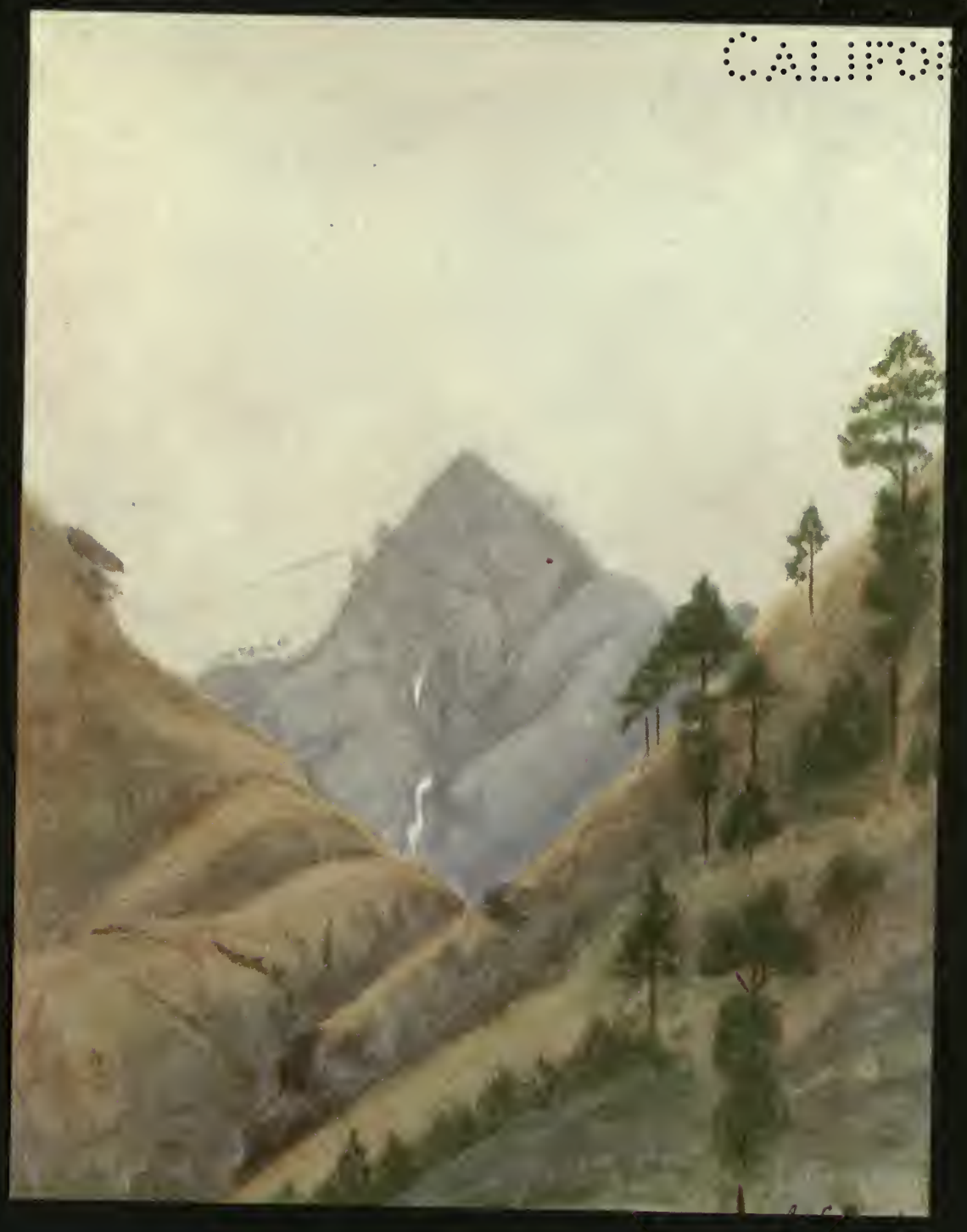




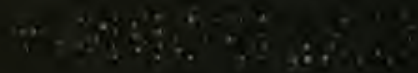




\section{CHAPTER XV.}

METEOROLOGICAL REPORT-BY A. DE C. SOWERBY.

METEOROLOGICAL observations were commenced at T'ai-yüan $\mathrm{Fu}$, in Shansi, on May 16th, 1908, and were kept up-with as much care and regularity as circumstances would permit-throughout the whole duration of the expedition, i.e., till September 12th, rgog. The instruments used were :One portable mercurial barometer.

Three aneroid barometers.

One hypsometer, with spare thermometer.

One small psychrometer (wet and dry bulb thermometers).

Three swing psychrometers.

Six swing thermometers.

One maximum and one minimum thermometer.

One six-inch diameter rain gauge.

All thermometers were graduated on the Fahrenheit system, while the barometers, boiling point thermometers, and swing thermometers were provided with Kew certificates.

The barometer observations were made either with the mercurial barometer or with an aneroid. In the former case the readings have been corrected for temperature, so that they represent the true air pressure at station level; and in the latter case, comparisons between the mercury barometer and the aneroids were carried out at intervals, in order to guard against errors due to changes of zero in the aneroids.

The readings of dry and wet bulbs printed in the diary were made with swing thermometers. This was necessary on account of the inevitable absence of a suitable screen for the exposure of the instruments. The reduction of the readings in order to determine the humidity of the air will therefore require tables appropriate to the well-ventilated psychrometer. The tables commonly used in England, which are based on. Glaisher's Factors, are not suitable for the reductions, and would give values of the relative humidity lower than the true values. The tables of the U.S. Weather Bureau, which were prepared for use with sling psychrometers, are more appropriate.

The readings of the maximum and minimum thermometers are probably less reliable than those of the dry and wet bulbs, because it was necessary to improvise some shelter for them, and some of the readings may be affected by 
radiation. In the case of the maximum thermometer, it was impossible to expose the instrument during the day when the expedition was on the march. Frequent readings of the thermometer were, however, made during brief halts at the hottest time of the day, and the highest of these readings was taken to be the maximum temperature for the day. In the diary, the readings of the maximum and minimum thermometers are printed opposite the first observation for each day for the sake of uniformity. It is to be noted, however, that the maximum reading refers to the same day as that against which it is printed, whilst the minimum refers to the lowest temperature of the preceding night.

The highest temperature recorded on the expedition was on July 5 th, rgog, at Chên-yüan Hsien, in Eastern Kansu, when the thermometer registered $102^{\circ} 2^{\circ} \mathrm{F}$. in the shade. On July 5 th, I908, at Chao-chuang, near T'ai-yüan $\mathrm{Fu}$, the thermometer registered $100^{\circ} 0^{\circ} \mathrm{F}$. in the shade. On August 5th, I908, the same temperature was recorded within the walls of T'ai-yüan Fu, while on the 8 th of the same month a temperature of $100^{\circ} 2^{\circ} \mathrm{F}$. in the shade was recorded.

The lowest temperature on record was at Kan-ku-yü, near Yen-an Fu, in Shensi, when the thermometer went down to $-60^{\circ} \mathrm{F}$. on December Igth, I908. At Yen-an $\mathrm{Fu}$, on January Igth, $20 \mathrm{th}$, and 2 Ist respectively $-3^{\circ} 5^{\circ} \mathrm{F}$. and $-2 \cdot 5^{\mathrm{Q}} \mathrm{F}$. and zero were recorded. These records were made within the shelter of the town walls, and it is probable that far lower temperatures prevailed in the open valleys outside.

The greatest rainfall occurred on July I8th, I908, at T'ai-yüan Fu, when $3^{.66}$ inches fell in twenty-four hours. On July $I 7$ th and 18 th, I909, at Ch'êng-k'ou-yi, in Kansu, I'32 inches, the next heaviest rainfall, was recorded.

Cloud formations, and the strength and direction of the wind were also noted daily:

Good sets of observations were secured at the following places:-

I. In and near T'ai-yüan $F u$, Latitude $37^{\circ} 51136^{\prime \prime} \mathrm{N}$., Longitude II $2^{\circ} 33^{\prime} 56^{\prime \prime}$ E., altitude $2600 \mathrm{ft}$., from May I6th to September 28 th, 1908.

2. Yün-t'ing Shan, Latitude $37^{\circ} 54^{\prime}$ "n N., Longitude $11 I^{\circ} 33^{\prime} 4^{\prime \prime}$ E., altitude $6950 \mathrm{ft}$. in the mountains 90 miles west of T'ai-yüan $\mathrm{Fu}$, in Shensi, from October 4 th to I6th, I908.

3. Yü-lin Fu, Shensi, on the borders of the Ordos Desert, Latitude $3^{\circ} 16^{\prime} 54^{\prime \prime} \mathrm{N}$., Longitude $109^{\circ} 45^{\prime} \mathrm{O}^{\prime \prime} \mathrm{E}$., altitude $3170 \mathrm{ft}$., from November $5^{\text {th }}$ to December $5^{\text {th }}$, Ig08. 


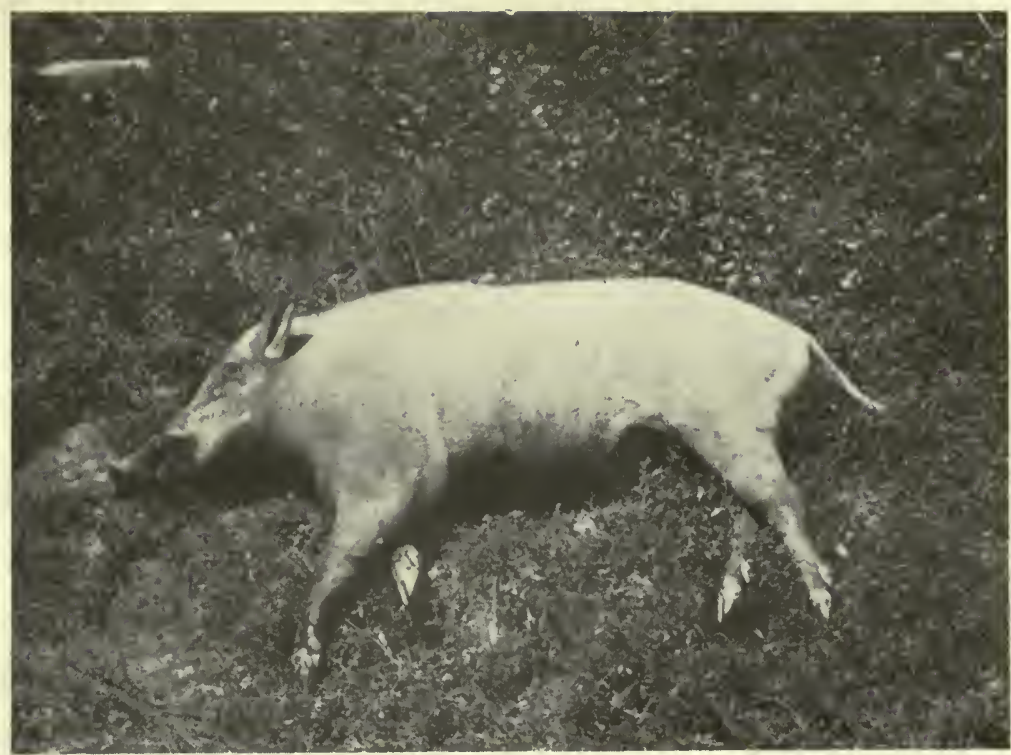

Wild Pig. (Sus moupinensis). Shot near Yen-an Fu. Shensi.

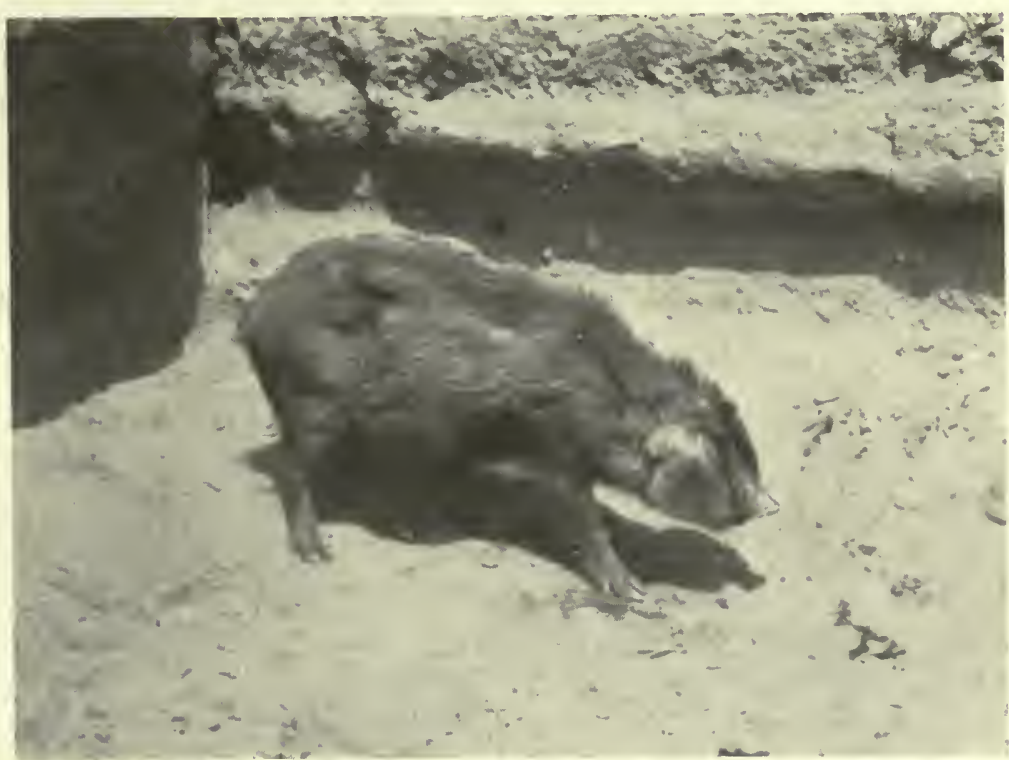

Domestic Pig. 


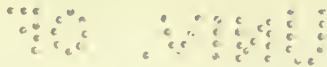

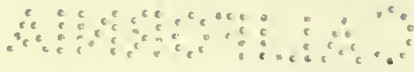


4. Yen-an $\mathrm{Fu}$, Latitude $36^{\circ} 35^{\prime} 33^{\prime \prime} \mathrm{N}$., Longitude $108^{\circ} 26^{\prime} 49^{\prime \prime} \mathrm{E}$., altitude $2769 \mathrm{ft}$., in north central Shensi, from December I9th, I908, to January 30th, I909.

6. Lan-chou Fu, Latitude $36^{\circ} 3^{\prime} 6^{\prime \prime}$ N., Longitude $103^{\circ} 40^{\prime} 54^{\prime \prime}$ E., altitude $5106 \mathrm{ft}$., in western Kansu, from April 5th to July I5th, I909.

In this chapter an endeavour will be made to deal with the meteorological observations month by month as they come; but at the same time stress is laid upon the periods enumerated above, when sets were taken during lengthy stays at various places.

May, 1908. T'ai-yüan Fu, Shansi (Altitude 2600 ft.) and neighbourhood.

As already stated, observations were commenced on May I6th, from which date to the end of the month daily maximum and minimum temperatures were recorded, besides somewhat erratic observations for the pressure and humidity of the atmosphere. The maximum temperature noted was on the 27 th, $98^{\circ} 2^{\circ}$ F. being recorded. The minimum temperature occurred on the 3 Ist, when the thermometer stood at $47^{\circ} 0^{\circ} \mathrm{F}$. Both these records were taken at Chaochuang, a small village on the plain some fifteen miles north-west of T'ai-yüan $\mathrm{Fu}$. The average maximum temperature for the period is $81 \cdot 2^{\circ} \mathrm{F}$., average minimum, $56.5^{\circ} \mathrm{F}$. The lowest barometrical observation, 26.84 inches, was made on the 26 th, at T'ai-yüan Fu, the highest, $27^{\circ} 05$ inches on the $23 \mathrm{rd}$, and again on the 3oth, both at T'ai-yüan Fu.

The first part of the second half of the month was marked with considerable dryness, the difference between the wet and dry bulb readings being as much as $19^{\circ} 2^{\circ} \mathrm{F}$. on the $2 \mathrm{Ist}$. Towards the end of the month rain and thunder were noted.

June, 1908. T"ai-yüan Fu (Altitude $2600 \mathrm{ft}$.) and neighbourhood.

Throughout June, the members of the expedition were encamped at Chao-chuang, where daily observations were made. From time to time the mercurial barometer, which was left in T'ai-yüan $\mathrm{Fu}$, was read. Much hotter weather was experienced than in May. The maximum temperature, $980^{\circ} \mathrm{F}$. was recorded on the Ioth, and the minimum, $42^{\circ} 9^{\circ} \mathrm{F}$. on the 7 th. The average maximum temperature for the month, excluding the last four days which were spent in the hills west of T'ai-yüan $\mathrm{Fu}$, was $90^{\circ} 0^{\circ} \mathrm{F}$., the average minimum was $58.4^{\circ} \mathrm{F}$. The barometer was at its lowest on the 24 th, the reading being $26^{\circ} 67$ inches, whilst the highest reading $27^{\circ} 08$ inches occurred 
on the 2oth, both at Chao-chuang. The month was comparatively dry, though thunderstorms occurred at Chao-chuang on the 3 rd and 4 th, and at Tou-fu-ssŭ, a temple, in the hills north-west of T'ai-yüan $F u$ on the 27 th, 28 th and 29th. The last three storms were accompanied by very heavy rain, and the Fên Ho rose several feet and became unfordable. Thunderstorms were also noted from Chao-chuang in the mountains to the north-west on the 18 th, and to the south-west on the Igth. Rain, varying from a few drops to gentle steady showers, was recorded on seven other days during the second half of the month. The amount was not registered.

The presence of wind of varying degrees of strength was recorded on seventeen days, from the I2th to the end of the month. Previous to this hardly any weather notes were made. A strong gust of wind, accompanied by dust, and lasting only half an hour almost demolished the camp on the IIth. On the I2th, strong wind, accompanied by dust, blew from the north-west during the greater part of the day. On the I8th, a heavy wind from the north-east blew for a few hours. The direction of the wind was usually from the north-east or north-west, though it also blew at one time or another from the east, south, south-west and west.

Cloud formations of all kinds, except nimbus, were recorded, though cumulus and cirrus were the most frequent. No connections between the various cloud formations, and the humidity or dryness of the air could be established.

\section{July, 1908. T"ai-yiian Fu (Altitude $2600 \mathrm{ft}$.) and neighbourhood.}

Half of July was spent in camp at Chao-chuang, and the rest of the month in T'ai-yüan Fu. During this time observations were taken from three to eight times daily; whilst detailed notes on the very varied weather were kept.

July and August may be considered the rainy season of North China, and the present month was no exception to the rule. Rain more or less heavy fell on eight days, and thunderstorms occurred on four others. Thunderstorms occurred in the surrounding hills on five days. The total rainfall for the month was over 6.29 inches, the rain that fell on the third not having been recorded.

The heaviest rain fell on the 18 th, when 3.66 inches in 24 hours was recorded.

The highest barometrical reading was taken on the 7 th, and the lowest on the Igth and 22nd, when 27.09 inches and 26.67 inches respectively were 
recorded. The average barometrical reading was $26^{\circ} 92$, some 8 points higher than that of June.

The average maximum temperature of this month was lower than that of the previous one, though some very hot weather was experienced. The maximum temperature was recorded on the 5 th, when the thermometer stood at $100^{\circ} \mathrm{F}$. in the shade. Oddly enough $57^{\circ} 7^{\circ} \mathrm{F}$., almost the minimum temperature for the month was recorded on the same day, thus giving a variation in about twelve hours of $42^{\circ} 3^{\circ} \mathrm{F}$. The actual minimum temperature, which was $55^{\circ} 4^{\circ} \mathrm{F}$. occurred on the 15 th, whilst the average minimum temperature was $65^{\circ} 8^{\circ} \mathrm{F}$., or $124^{\circ} \mathrm{F}$. more than that of June.

It may be noted here in connection with the thunderstorms of this district, that they usually come in the afternoon after very hot days. Thus on the 5 th, when the maximum temperature was $100^{\circ} 0^{\circ} \mathrm{F}$. in the shade, a thunderstorm occurred at 6.30 p.m. The same thing occurred on the 8 th, I2th, I3th, and 28 th of this month, and also on the 3 rd, 4 th, rgth, and 23 rd of June. A heavy downpour is not a necessary and inevitable result of a hot day, but it is safe to say that the one is usually preceded by the other. On the other hand continuous steady rains such as occurred on the 3 rd, the $I 7$ th, and the 18 th of July are usually accompanied by comparatively low temperatures such as $74^{\circ} 2^{\circ} \mathrm{F}$. on the $3 \mathrm{rd}, 75^{\circ} 6^{\circ} \mathrm{F}$. on the $\mathrm{I} 7 \mathrm{th}$, and $74^{\circ} 0^{\circ} \mathrm{F}$. on the $\mathrm{I} 8 \mathrm{th}$.

This month cirrus clouds seemed to predominate, though cumulus, stratus, cirro-cumulus, nimbus, cirro-stratus, and strato-cumulus were also noted, coming in the above order as regards their frequency of occurrence. On two out of three days on which nimbus clouds were recorded, they were followed by rain; whilst rain almost invariably followed stratus clouds.

It can hardly be said that there was any prevailing wind during this month, though it was most often recorded as blowing from the west. Wind blew from the north-east, north-west and south-west with almost equal frequency. Rain was most frequently brought up by south winds, though it was recorded from all parts of the compass.

The month ended with less rain, and with finer and more settled weather than that with which it commenced, whilst the maximum temperatures of the last few days were considerably above the average, as also were the mininum readings.

August, 1908. T'ai-yiian Fu. Altitude $2600 \mathrm{ft}$.

The whole of the observations this month were made in T'ai-yuan Fu where the members of the expedition were busy with astronomical observations 
and general preparations for the forthcoming journey westward. Under these circumstances, weather notes were entirely neglected, though all other records were kept.

The maximum temperature occurred on the $8 \mathrm{th}$, the thermometer registering $100^{\circ} 4^{\circ} \mathrm{F}$. On the 5 th, $100^{\circ} 0^{\circ} \mathrm{F}$. was recorded. $6 \mathrm{r}^{\circ} 3^{\circ} \mathrm{F}$. the minimum temperature for the month occurred on the 28 th. The average of the maximum temperature readings works out at $83^{\circ} 2^{\circ} \mathrm{F}$, or $5^{\circ} 4^{\circ} \mathrm{F}$. less than that of July. As in July the average minimum temperature showed an increase on the month before, that for the present month being $7 \mathrm{I}^{\circ} 4^{\circ} \mathrm{F}$. compared with $65^{\circ} 8^{\circ} \mathrm{F}$. in July. Thus in the three months June, July and August, we have a steady decrease in the average maximum temperatures and a steady increase in the average minimum temperatures. It is doubtless the increased night temperatures of August that make it seem the hottest month of the year in this part of China.

August, this year, did not keep up to its reputation for heavy rains. There were only seven days on which rain was recorded, whilst the total rainfall for the month was $I^{\circ} 94$ inches. The heaviest fall occurred on the r 5 th, when 0.6 of an inch was measured.

No records of wind, or cloud formations were kept.

\section{September, 1908. T'ai-yüan Fu. Altitude $2600 \mathrm{ft}$.}

From the Ist to the 28 th the expedition remained in T'ai-yüan $\mathrm{Fu}$, when the usual observations were taken. On the 28 th the journey westward was commenced, and as the last three days of the month were spent in travelling, and the observations in consequence were taken at varying altitudes, they cannot be included in the following averages and remarks.

The weather during the month was, generally speaking, fine, though no notes to this effect were made.

The average temperatures were distinctly lower than those of August, especially at night. The highest temperature occurred on the 6 th, when the thermometer stood at $860^{\circ} \mathrm{F}$., and the lowest on the $23 \mathrm{rd}$, when $46^{\circ} 5^{\circ} \mathrm{F}$. was recorded. The average maximum temperature was $77^{\circ} 5^{\circ} \mathrm{F}$, and the average minimum was $58 \cdot \mathrm{I}^{\circ} \mathrm{F}$.

The atmospheric pressure was considerably less than that of August; $27^{\circ} 22$ inches on the $23^{\text {rd }}$ being the highest reading, $26^{\circ} 79$ inches on the roth the lowest, and $27^{\circ} 05$ inches the average for 28 days.

Contrary to what one might expect, judging by the barometrical records, the rainfall of the month was greater than that of August. The total rainfall 
PLATE 54.
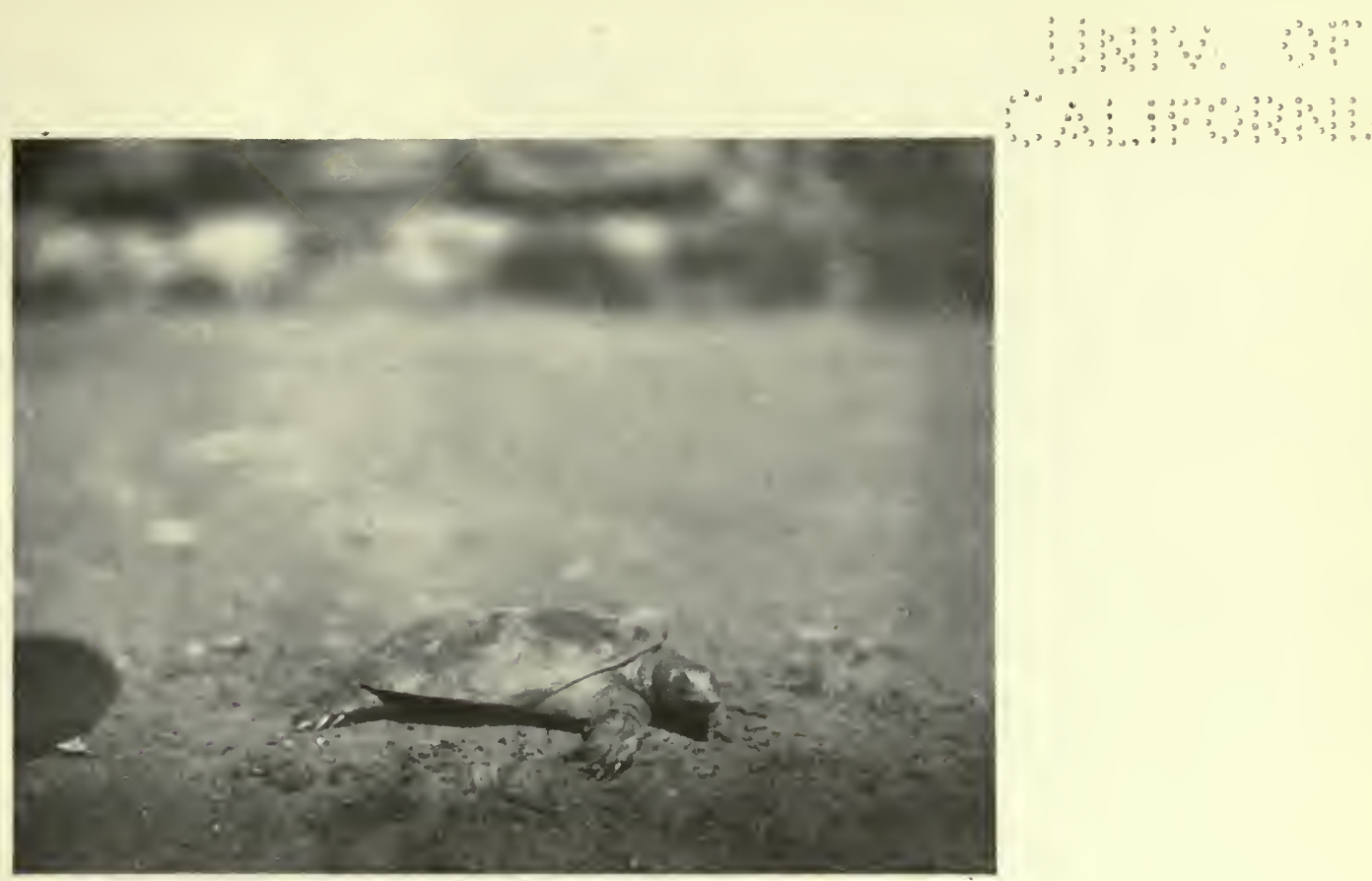

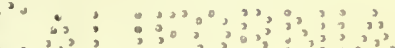

Mud Turtle. (Trionyx sinensis).

See pp. 93 and 111 .

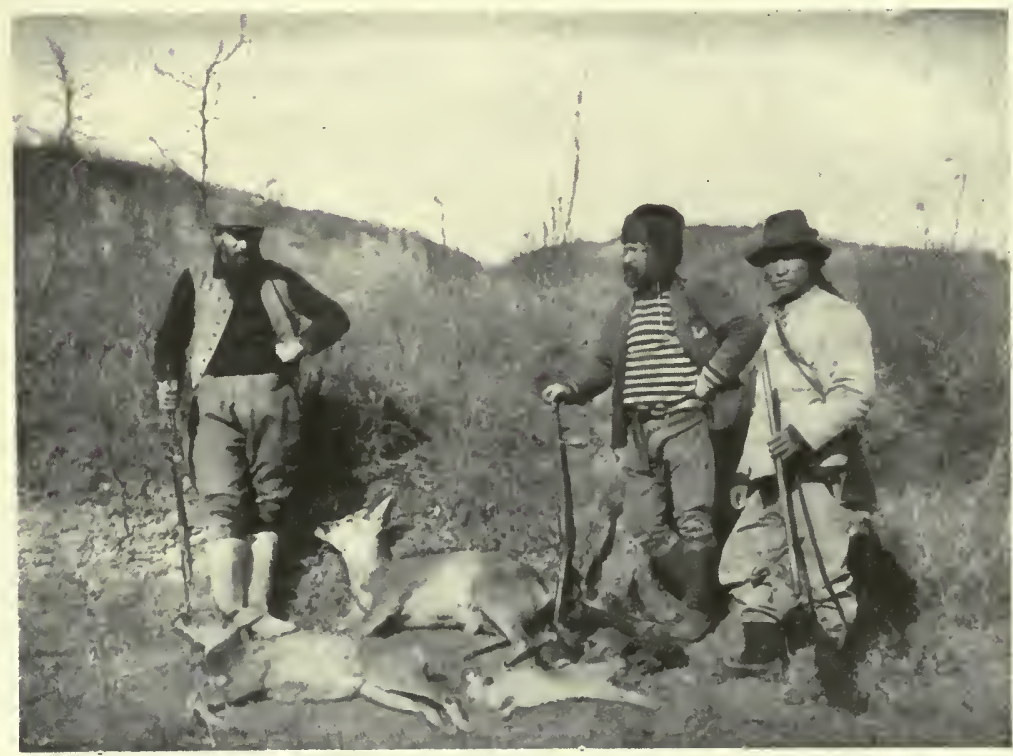

Day's Bag near Yen-an Fu. Roedeer, pheasants and hare. 
?

6.4. 
was $2^{\circ} 02$ inches, the heaviest rain occurring on the 15 th, when 0.94 inch fell. On the and $0.9 \mathrm{I}$ of an inch was recorded. Though rain fell on two other days the amount was recorded on these two only.

No wind or cloud notes were made.

From the morning of September 28 th till the evening of October $4^{\text {th }}$, the expedition was travelling in a general westerly direction, first up the valley of one affluent of the Fên Ho, and then up that of another, till the Chiao-ch'êng Shan district was reached, where camp was pitched in a ravine at the base of a high mountain named Yün-t'ing Shan. During these seven days all observations were kept up, including notes on the clouds and wind. The caravan mounted slowly from an altitude of $2600 \mathrm{ft}$. to one of $6950 \mathrm{ft}$., which rise, as might be expected, was accompanied by a steady decrease in the temperature of the atmosphere. Cirro-cumulus, cumulus, and cirrus clouds were noticed on the and and 3 rd of October, strong wind from the east on the last day of September and light wind from the west on two other occasions. For the rest, the sky was clear and the weather fine.

\section{October, 1908. Yiin-t'ing Shan. Altitude $6950 \mathrm{ft}$.}

The expedition remained at this spot, close to the great divide between the basin of the Fên Ho and the Yellow River, for twelve days, so that good sets of observations were secured. The average maximum temperature during this time was $57^{\circ} 2^{\circ} \mathrm{F}$, whilst the average minimum was $32^{\circ} 7^{\circ} \mathrm{F}$. The maximum and minimum readings taken at Yün-t'ing Shan were $6 \mathrm{I}^{\circ} 0^{\circ} \mathrm{F}$. and $26.0^{\circ} \mathrm{F}$.

The barometer ranged between $23^{\circ} 66$ inches the highest reading, and $23^{\circ} 45$ inches the lowest, while it averaged 23.57 inches.

Rain was recorded on the $4^{\text {th, }} 5^{\text {th }}$ and $13^{\text {th, }}$ though the amount was not noted; while a heavy fall of snow occurred on the nights of the IIth-I2th. Cirrus, cirro-cumulus or cumulus clouds were noted almost every day, and mists occurred twice, each time following rain. There was little or no wind felt in the ravine where camp was pitched, though a very cold wind blew over the pass, about a mile east of the camp on the day of arrival. Wind from the west was also noted on the summits of Yün-t'ing Shan and Mo-êrh Shan the highest peaks in the district, both of which were thickly covered with snow on the I3th. An ascent was made to the summit of Mo-êrh Shan (Alt. 9200 ft.) on the I2th, and observations for temperature and pressure taken. The two aneroid barometers showed an average reading of $2 I^{\circ} 5^{8}$ inches, the hypsometer $195^{\circ} 5^{\circ} \mathrm{F}$. and the thermometer $39^{\circ} 2$ between 3.00 and 4.00 p.m. 
On October I6th the expedition left Yün-t'ing Shan and from that date travelled in a westerly direction slowly, and with frequent halts till November 5th, when $\mathrm{Yü}$-lin $\mathrm{Fu}$ was reached.

On the first day a descent of over two thousand feet was made after which the altitude varied between $5300 \mathrm{ft}$. the height of one of the passes, and $2400 \mathrm{ft}$. the bed of the Yellow River.

The highest temperature was recorded on October Igth at Lin Hsien (Alt. $3269 \mathrm{ft}$.) where the party stayed two days. Here the maximum thermometer registered $674^{\circ} \mathrm{F}$, the highest temperature experienced since the T'ai-yüan Fu plain was left behind on September 2gth.

From the evening of the 20 th till the morning of the 27 th the expedition was encamped in a deep ravine, at the foot of some isolated granite peaks called Ch'ing-ting Shan, that towered above the surrounding loess hills to a height of from $6000 \mathrm{ft}$. to $7200 \mathrm{ft}$. The camp was situated close to a village named Kan-tsao-k'ou, and its altitude was estimated at $4664 \mathrm{ft}$.

Two members of the party pushed on to Yü-lin Fu, reaching that city on the 26th. They reported rain every day from the 2 Ist to the 26 th, and experienced a severe sandstorm from the west on the 26 th.

Meanwhile the rest of party, which remained at Kan-tsao-k'ou recorded rain on the 21st, 22nd, 23rd, and 26th, the fall on the first three days being I'97 inches. On the 26th a strong wind from the west blew all day, though neither sand nor dust was recorded. Hoar-frost occurred for the first time on the 3oth at Liu-chia-mo in Shensi, after which time it was frequently noticed till the temperature became too low in December.

Light variable winds were noted most of the time between Yün-t'ing Shan, and Yü-lin Fu, while strong winds blew from the east and the west on the $3^{\text {rd }}$ and $4^{\text {th }}$ of November respectively. Cirrus and cumulus clouds, as usual, were most frequent, nimbus clouds were noted on the 23 rd of October, and stratus on the 3 rd of November. Mists and dust hazes also occurred from time to time.

November 5th to December 5th, 1908. Yiu-lin Fu. Altitude $3170 \mathrm{ft}$.

The expedition spent a month at Yü-lin Fu, from November 5 th to December 5 th. The following remarks and averages will include the whole of this period.

Situated as it is on the border of a great sandy desert, Yü-lin Fu exhibits, as might be expected, meteorological conditions somewhat out of the common. The district was chiefly remarkable for its dryness, neither rain nor snow 
occurring once throughout the thirty days during which observations were taken. The only signs of moisture were hoar-frosts which occurred every few days. Frequently the temperature was below the freezing point, and the humidity was not always recorded, but strange to say when it was, the difference between the bulbs was never very great.

From this, one would gather that there was a certain amount of moisture in the atmosphere, but that other conditions prevented the formation of rain clouds. In fact, clouds of any kind were extremely uncommon. The observations were taken in a temple, situated outside the city, not more than three-hundred yards from the Yü-lin Ho, a fair-sized river. The writer can state from previous experience in this district, and along the Ordos border generally, that dew is not infrequent, though rain and snow are very rare, and clouds uncommon. On the other hand scarcely a day passes without steady wind from some direction or other.

From November $5^{\text {th }}$ to December 5 th, wind was recorded every day. The prevailing direction was from the north, the wind being in this quarter fifteen days, in the north-west four and in the north-east three. On only five occasions did it blow from the south, and twice from the west. Once it was recorded as variable.

On November rgth and 2Ist, strong wind from the north was recorded, and again from the north-west on the 25th. These brought down quantities of sand, which, being thus driven against the surfaces of buildings and monuments in exposed positions, would in time wear away the softer materials used in their construction. On examination, several dagobas, pagodas and monuments situated on some high ground to the east of the city, showed much wear on their northern sides, whilst their southern sides-as well as the eastern and western to a less degree-were in good condition, even the pointing of the brick-work remaining intact. From this it is reasonable to assume that the strongest winds which prevail in this district are northerly.

The barometer, in spite of the lack of rain and clouds, varied considerably from day to day, and even between the two daily readings. 'The highest reading was 26.88 inches on November 27 th, and the lowest was $26 \cdot 28$ inches on December $4^{\text {th. }}$ The readings of the last three days at Yü-lin Fu were all very low, but no change in atmospheric conditions resulted. It will be noticed that the difference between the extreme readings during the time spent at Yü-lin Fu was greater than that of any of the preceding months. The average of all barometrical readings for the thirty days was $26^{\circ} 6 \mathrm{I}$ inches.

The temperature during this time steadily decreased, and hygrometer 
readings became fewer, ceasing almost entirely on October 24 th, not to be renewed till February, rgog.

The maximum temperature was $57^{\circ} 0^{\circ} \mathrm{F}$. on November roth, and the minimum was $12.5^{\circ} \mathrm{F}$. on November 27 th. The average maximum and minimum readings were $46.8^{\circ} \mathrm{F}$. and $20^{\circ} 5^{\circ} \mathrm{F}$. respectively.

On December $5^{\text {th }}$ the expedition left Yü-lin $\mathrm{Fu}$ and commenced the journey to Yen-an Fu, about I70 miles to the south. The country passed through was chiefly of low loess hills cut up in every direction by deep ravines and valleys, along which the roads chiefly lay. The observations were kept up as usual. The lowest temperature experienced during the whole winter occurred on this journey at Kan-ku-yü, just before reaching Yen-an Fu, on the night of December 18 th-Igth. The thermometer registered 38 degrees of frost $\left(-6 \cdot 0^{\circ} \mathrm{F}\right.$.).

The wind was from the south on the day that the expedition left Yü-lin $\mathrm{Fu}$, but blew from the north each of the three days following. It veered round to the south-east on the 9 th, and then to the north-west on the Ioth. After this date it was recorded almost daily as variable. These winds, which seem to come from every quarter at once, are typical of North China. It is impossible for the traveller to find any bank or crevice in the loess which will shelter him from this cold and searching wind.

Cirrus and cumulus clouds predominated as usual, stratus and nimbus being each recorded but once. Slight hoar frost was recorded on the Igth, on which date Yen-an Fu was reached.

December 19th to 31st, 1908. Yen-an Fu. Altitude $2769 \mathrm{ft}$.

During these twelve days fine but cold weather was experienced. A light wind blew continually, but its direction was only recorded thrice, namely, once from the south, once from the south-west, and once from the north-east. At other times it was the same variable wind experienced on the journey from Yü-lin Fu to Yen-an Fu. Frequently the sky was clear, though cirrus and cumulus clouds were noted.

The maximum temperature experienced was $40^{\circ} 0^{\circ} \mathrm{F}$. on the 29 th, whilst the minimum was $3.5^{\circ} \mathrm{F}$. on the 2oth. Average maximum and minimum temperatures were $34^{\circ} 3^{\circ} \mathrm{F}$. and $12^{\circ} 2^{\circ} \mathrm{F}$. respectively. The highest barometrical reading was $27^{\circ} 26$ inches on the 3 Ist, the lowest was $26^{\circ} 7^{2}$ inches, and the average of the twenty-five readings was $26^{\circ} 90$ inches.

No observations for humidity were made, while neither snow nor hoar-frost occurred. Rain, of course, was out of the question with such low temperatures. 
PLATE 55.
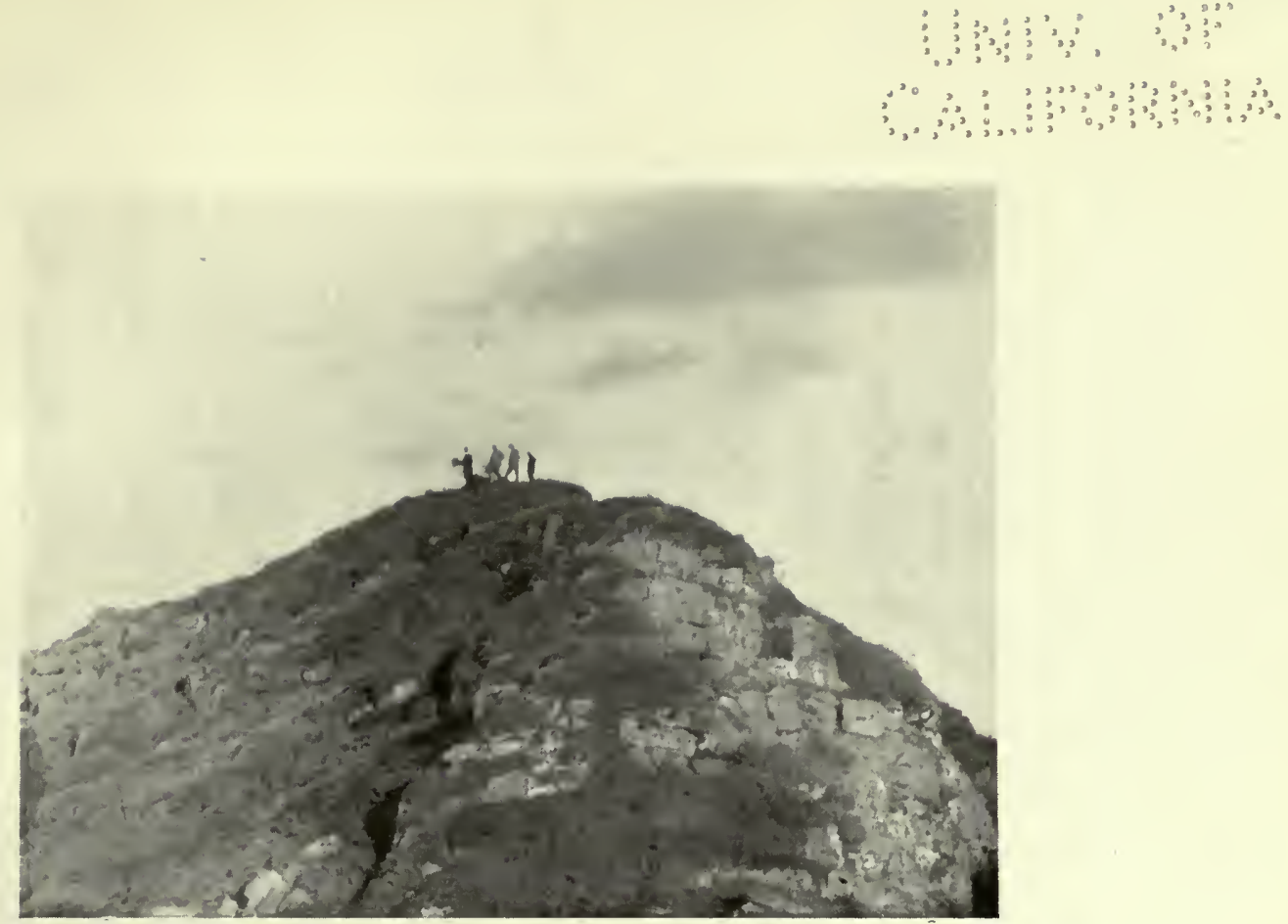

The Summit of Mo-êrh Shan, Shansi.

Sec PP. $q$ and I2I.

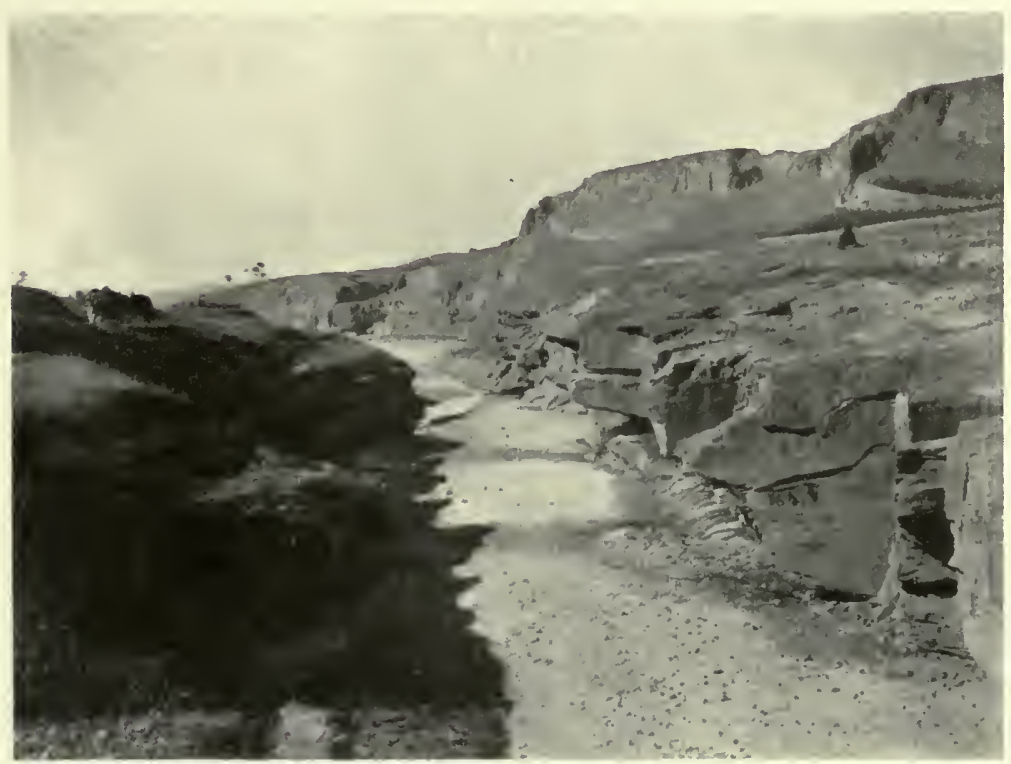

Sandstone Beds, west of the Chiao-ch'êng Shan, Shansi.

See p. 129 . 


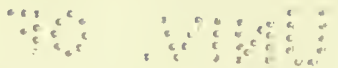

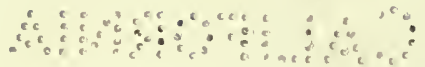


Junuary, 1909. Yen-an Fu. Alt. $2769 \mathrm{ft}$.

January again was a month of extremely cold, but on the whole fine weather. The proportion of cloudless days was not quite so great as in the last twelve days of December, while light falls of snow, usually following stratus clouds, were recorded on the Ioth, IIth, I2th, I 3 th, I6th, and 3 oth, Hoar-frosts were recorded daily from the 23 rd to the 27 th inclusive. In cloud formations there was a decided predominance of cumulus, or cirro-cumulus clouds, over anything else. Cirrus also occurred with comparative frequency, whilst stratus were also recorded more frequently than usual, being generally followed, as already stated, by snow. Again the light variable wind was the rule, though from time to time it freshened, when its general direction was at once discernible. It was then recorded from the north-west, west, and south. Wind was not once recorded from an easterly direction.

From the I 1 th to the 2znd some very low temperatures were experienced. The minimum temperature for the month was $-3.5^{\circ} \mathrm{F}$. on the rgth, while the average minimum was $12^{\circ} 2^{\circ} \mathrm{F}$.

The maximum reading for the month was $39.0^{\circ} \mathrm{F}$, which temperature occurred on the 4 th, 5 th, and 28 th. The average maximum was $32^{\circ} \mathrm{I}^{\circ} \mathrm{F}$.

The highest, lowest, and average barometrical readings were $27^{\circ} 16$ inches. $26 \cdot 64$ inches, and $26 \cdot 86$ inches respectively.

Yen-an Fu to Lan-chou Fu.

On January 30 th the expedition left Yen-an $\mathrm{Fu}$ for Lan-chou $\mathrm{Fu}$, in Kansu. The journey, including many stoppages, was accomplished in a little over two months.

Observations were regularly taken at altitudes, ranging from $2769 \mathrm{ft}$., the altitude of Yen-an Fu to $7468 \mathrm{ft}$. in the high loess country of Kansu.

Temperatures remained comparatively low till the commencement of March, when the weather began to get distinctly warmer. On April 3 rd, just before Lan-chou $\mathrm{Fu}$ was reached, the maximum thermometer registered $68.0^{\circ} \mathrm{F}$., and the minimum $32.0^{\circ} \mathrm{F}$, and on the morning of April 5th, the day on which the expedition entered Lan-chou $\mathrm{Fu}$, the minimum temperature was $4 \mathrm{I}^{\circ} 0^{\circ} \mathrm{F}$. This was the highest minimum temperature recorded since

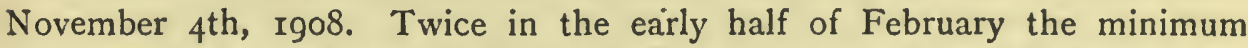
thermometer registered $20^{\circ} \mathrm{F}$., but no temperature lower than that was experienced.

Owing to the various altitudes of which observations were taken, nothing 
much can be remarked about the barometrical readings, except that when a number of readings were taken at one place, owing to a longer stay than usual being made at that place, considerable fluctuations were noticeable. Thus at Ch'ing-yang $\mathrm{Fu}$, on February $\mathrm{I} 7 \mathrm{th}$, the barometer stood at $26^{\circ} \mathrm{I} 3$ inches. On February I 9 th, it stood at $26^{\circ} 55$, giving a difference of forty-two points. Again at Ku-yüan Chou, the barometer varied from $24^{\circ} 05$ on March gth to $24^{\circ} 47$ on the I6th, also a difference of forty-two points. No atmospheric disturbance, or changes followed these fluctuations.

Wind was recorded every day. During most of the time it was but a light wind, but on nineteen occasions it freshened up, being recorded as moderate, whilst on eight occasions it was noted as strong.

On sixteen days the wind blew from a north-westerly direction. It was from this direction that it generally blew when it was of more than usual strength. On nine days it blew from the north, and it freshened up usually when in this quarter. When the wind was in the south-west or west, as it was on eight and seven days respectively, it was never very strong, whilst a southerly wind was generally fresh. The prevailing wind during this time of the year may be considered to have been from a general northerly direction, though it frequently shifted to other points of the compass.

An analysis of the weather notes leads roughly to the following deduction:-North winds usually meant fine weather with cloudless skies, while north-westerly winds brought decidedly more clouds. West wind brought snow or rain, and was invariably cloudy. South-west winds brought snow, clouds, or fog, while south winds again invariably brought up clouds. Any thing might be expected if the wind was in the south-east, east, or north-east, but it was so seldom in these quarters that no certain deductions could be drawn.

Clouds were recorded very frequently during these months of travel, every variety being noticed. Cumulus clouds predominated, being recorded thirty-two times, and were brought up from the north-west, and south-west most frequently. Cirrus clouds were also very frequently recorded, being brought up by north-westerly or southerly winds. Cumulus and cirrus were almost always noted when the wind was variable. Stratus clouds occurred on sixteen occasions, most frequently when the wind was from some westerly quarter, whilst nimbus clouds were noted seven times from all directions.

Hygrometer readings were commenced on February I4th, as soon as the temperature was high enough, and were kept up with increasing regularity. Usually no very great difference between the two bulbs was recorded, but on 

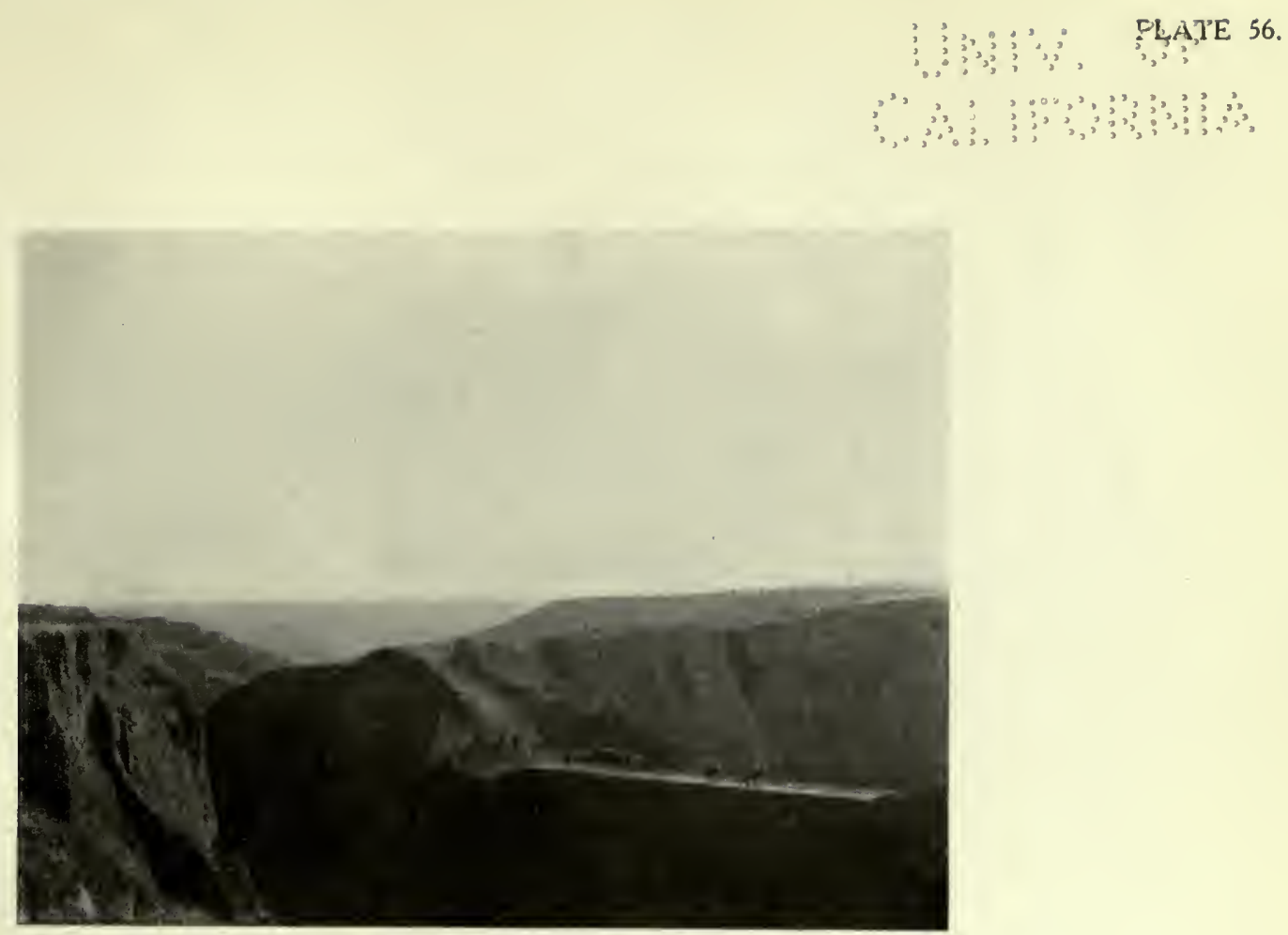

Loess Plateaux, east of Fu-chou, Shensi.

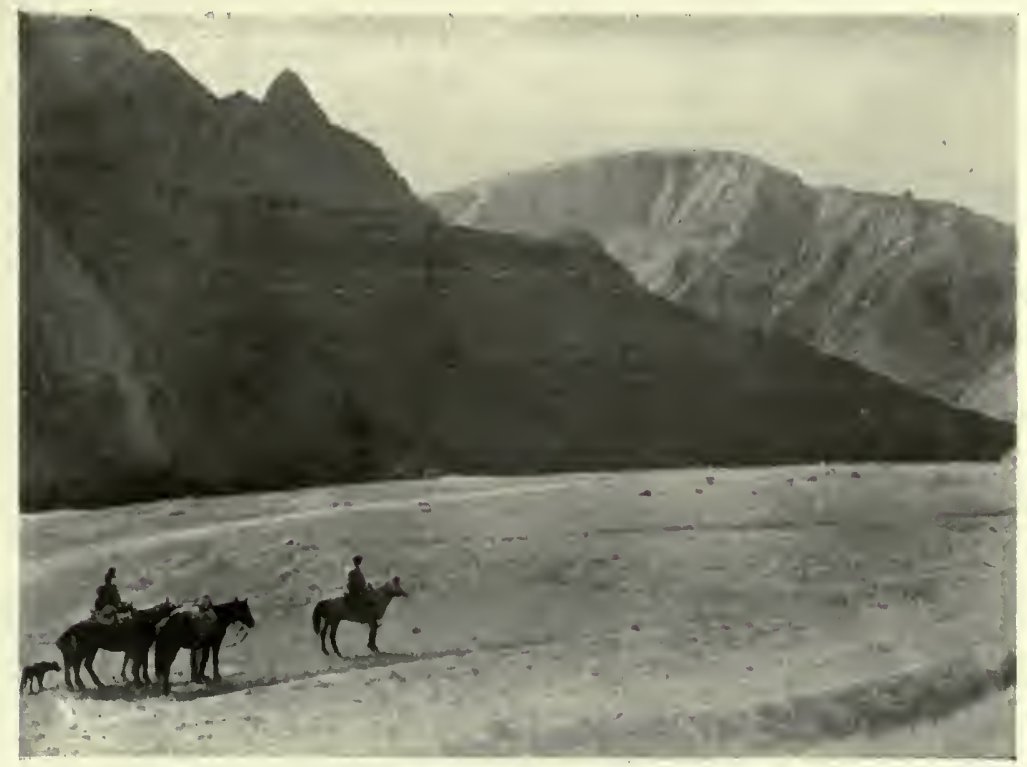

Loess shewing stratafication, Shansi. 


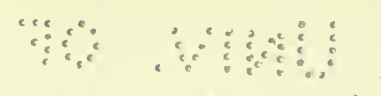

and a de 
March the $g^{\text {th }}$ when an east wind was blowing, the difference between the bulbs was $34^{\circ} 2^{\circ} \mathrm{F}$.

Snow was recorded eleven times and rain three times during the journey. As already stated, both were proportionately more frequent when the wind was in the west, in which direction lies Kokonor, the great lake of Eastern Thibet. It may be that the snow clouds originate in this district. Hoar-frost was recorded from time to time.

\section{April, 1909. Lan-chou Fu. Alt. $5106 \mathrm{ft}$.}

When the expedition reached Lan-chou Fu on April 5th, that city, and the district generally were suffering from a protracted period of drought. According to native reports there had been no rain to speak of for three years. Judging from the extreme bareness of the country with its parched sun-baked hills and valleys this might well be the case.

It seems as if the desert were slowly creeping in from the north and north-west. It was stated by more than one of the Europeans, long resident in the district, that ten years ago the country immediately north and northwest of the city for ten or more miles was fertile. Year by year this fertile area has decreased till the whole of the country north of the Yellow River, which flows under the northern wall of Lan-chou, has become a howling wilderness, without a vestige of green anywhere. The expedition found the country south of the river for some twelve miles in a condition scarcely better than that of the country to the north and north-west.

During the months that the expedition spent at Lan-chou the drought broke up, and towards the end of June and in the beginning of July rain fell in great quantities.

Thus the season cannot be considered as a normal one, its commencement being towards the end of a three years' drought and its termination coinciding with that of the drought, and with general atmospheric disturbances.

During April the weather was dry, and generally speaking fine. Wind was recorded daily, whilst clouds were noted most of the time. The prevailing wind was from the east, which blew with more or less strength on fourteen days. Once it shifted to the south-east but at other times it was either from the west or north-west.

Cumulus and cirro-cumulus clouds prevailed throughout the whole month, cirrus and stratus clouds being recorded but once each. Dust hazes were frequent and on the $13^{\text {th }}$ a dust-storm was recorded.

Towards the end of the month a little rain fell. 
Again the barometer showed considerable fluctuations, the highest readings being $25^{\circ} 27$ inches, and the lowest $24^{\circ} 72$ inches. The average of all readings was $25^{\circ} 00$ inches.

The highest temperature during the month was $83^{\circ} 0^{\circ} \mathrm{F}$. on the $25^{\text {th }}$, and the lowest was $30^{\circ} 0^{\circ} \mathrm{F}$. on the 7 th. The averages were $68.6^{\circ} \mathrm{F}$. for the maxima and $4 \mathrm{I}^{\circ} 2^{\circ} \mathrm{F}$. for the minima. The temperature steadily increased throughout the month, though one or two cold days were experienced towards the end.

May, 1909. Lan-chou Fu. Alt. $5106 \mathrm{ft}$.

With the exception of six days, which were spent in the mountains to the south of Lan-chou, a very complete set of observations was made during the month of May.

The observations differed but little from those made in April.

The temperature was increasingly warmer, the barometer averaged a little higher, but was perhaps a trifle more unsteady; whilst there was more rain, more strong winds, and slightly greater variety in cloud formation, stratus clouds appearing more frequently.

The prevailing wind was again in the east, though winds from the northeast and north-west were recorded with some frequency.

Rain fell on eight occasions; the rainfall, which was recorded on four days only, being $0^{\circ} 09$ of an inch. Late in the afternoon of the rith a remarkable phenomenon was noticed. Two strong winds, blowing from the west and east respectively met over Lan-chou, when hail and rain fell for about an hour. This was followed by rain during the night, fog next day, and snow upon the surrounding hills, and it may be noted that a wind from the west was largely responsible for the latter. Most of the rain that was recorded fell during these few days of atmospheric disturbance. The temperature fell to considerably below the average, whilst the barometer ran up to the highest level recorded during the three and a half months' stay in Lan-chou. It may here be noted that whenever the temperature was unusally low the barometer was high, and vice-versâ.

The average maximum temperature was $75^{\circ} 5^{\circ} \mathrm{F}$., and the average minimum was $48.7^{\circ} \mathrm{F}$., the highest and lowest temperatures being respectively $880^{\circ} \mathrm{F}$. on the 3 oth and $35^{\circ} 0^{\circ} \mathrm{F}$. on the $13^{\text {th }}$.

The barometrical readings averaged $25^{\circ} 07$ inches, a slight increase on that of the April readings, while the highest point reached was $25^{\circ} 30$ on the I3th and the lowest, $24^{\circ} 78$ inches, on the 28 th. 
The relative humidity of the atmosphere was usually very small, the difference between the wet and dry bulbs generally exceeding ten degrees, and not infrequently exceeding fifteen degrees.

June. 1909. Lan-chou Fu. Alt. $5106 \mathrm{ft}$.

June was decidedly hotter than May, and the rainfall was greater. The prevailing wind was no longer in the east, but blew from the north-east.

On the gth, at 3.30 p.m., a fierce gale swept up from the west, tearing branches off the trees and carrying them for considerable distances. No serious damage was done, however. A strong wind and a dust storm were recorded on the roth; a strong wind on the IIth; and another on the I2th. During these three days of disturbance the barometer fell from $24^{\circ} 90$ inches to $24^{\circ} 68$ inches, rising once more to 25.06 inches. On the I2th rain fell, and continued intermittently till the $I 7$ th. Heavy rain was also reported by two members of the party at work in the mountains to the south of Lan-chou on the I2th and $13^{\text {th }}$; whilst a heavy deluge, preceded by a violent wind, was recorded by one of them on the I4th. Rain was again recorded on the $15^{\text {th }}$ in the same district, while a little to the east of this position heavy rain was recorded on the 20th. On the 22nd a west wind was noted, followed by rain, and again on the 26 th a west wind brought up rain clouds, when 72 of an inch of rain was recorded in sixteen hours. The wind continued to blow from the west for two days, then, shifting right round to the east, seemed to bring back the rain clouds.

It must here be noted that rain was frequently brought up by a northeasterly wind. The fact that the Yellow River flows in a north-easterly direction from Lan-chou $\mathrm{Fu}$ may account for this. It cannot be doubted that the Kokonor has some effect upon this district, but it is equally certain that it is not the only agency at work, and an analysis of the wind direction and corresponding periods of rain leads to the idea that the large volume of water flowing down the bed of the Yellow River is another powerful element in the meteorology of the district. Only on very rare occasions (in April) was rain recorded from any quarter but north-east and west. The total rainfall for the month was I'I4 inches, notwithstanding the fact that on five occasions the fall was not measured.

Clouds appeared every day of the month. Cumulus formations predominated, though stratus clouds were not infrequent, cirrus clouds occurred more often than in May.

The maximum temperature was $90^{\circ} 0^{\circ} \mathrm{F}$. on the 26 th and 29 th. The 
minimum was $43^{\circ} 0^{\circ} \mathrm{F}$. on the $\mathrm{I} 3$ th. This temperature, it will be noted, occurred on the night after the highest barometrical reading, $25^{\circ} 06$ inches was taken. The lowest barometrical reading occurred on the 28 th, between the two maximum temperatures for the month. This seems to bear out the rule regarding the inverse relationship between the thermometer and barometer.

The average maximum and minimum readings were $8 \mathrm{I}^{\circ} \mathrm{I}^{\circ} \mathrm{F}$., and $57^{\circ} 9^{\circ} \mathrm{F}$. respectively, whilst the average barometrical reading was $24^{\circ} 87$ inches.

The psychrometer showed differences between the two bulbs of $10^{\circ} 0^{\circ}$ or more, more frequently than not; but only once on the $25^{\text {th }}$, did the difference reach $15^{\circ} 0^{\circ}$. This was followed on the 26 th by absolute saturation in the air, no difference between the bulbs being discernible. The rainfall on the 26 th, as already stated, was 72 of an inch.

July, 1909. Lan-chou Fu. Alt. $5106 \mathrm{ft}$.

Observations were made at Lan-chou Fu from the Ist to the 15 th of this month, when the expedition left the district.

During these fifteen days the average temperatures were slightly higher than those of June. The barometer remained correspondingly low, never once reaching $25^{\circ} \mathrm{Oo}$ inches. The humidity of the air varied from saturation to a dryness showing a difference between the bulbs of $195^{\circ}$.

Rain fell on six of the fifteen days, making a total fall of $I \cdot 29$ inches, considerably more than that of the previous month.

The direction from which the rain came was not properly recorded this month, but the last wind recorded before each period of rain was from the north-east.

Wind was of less frequent occurence than during the preceding months, calm being recorded on seven days, whilst no reference whatever was made to the subject on three others. What wind there was came usually from the north-east.

Cumulus and stratus clouds were prevalent till the 15 th, when cirrus clouds were recorded. Nimbus clouds appeared on the 2 nd.

The maximum temperature for the fifteen days occurred on the 9 th when $87^{\circ} 8^{\circ} \mathrm{F}$. was registered. The minimum was $53^{\circ} 0^{\circ} \mathrm{F}$. on the 2 nd. The highest barometer reading occurred on the Ist close to the date on which the minimum temperature was recorded, whilst the lowest barometrical readings occurred on the same date as the maximum temperature for the month.

The highest and lowest barometrical readings were $24^{\circ} 98$ inches, $24^{\circ} 70$ 


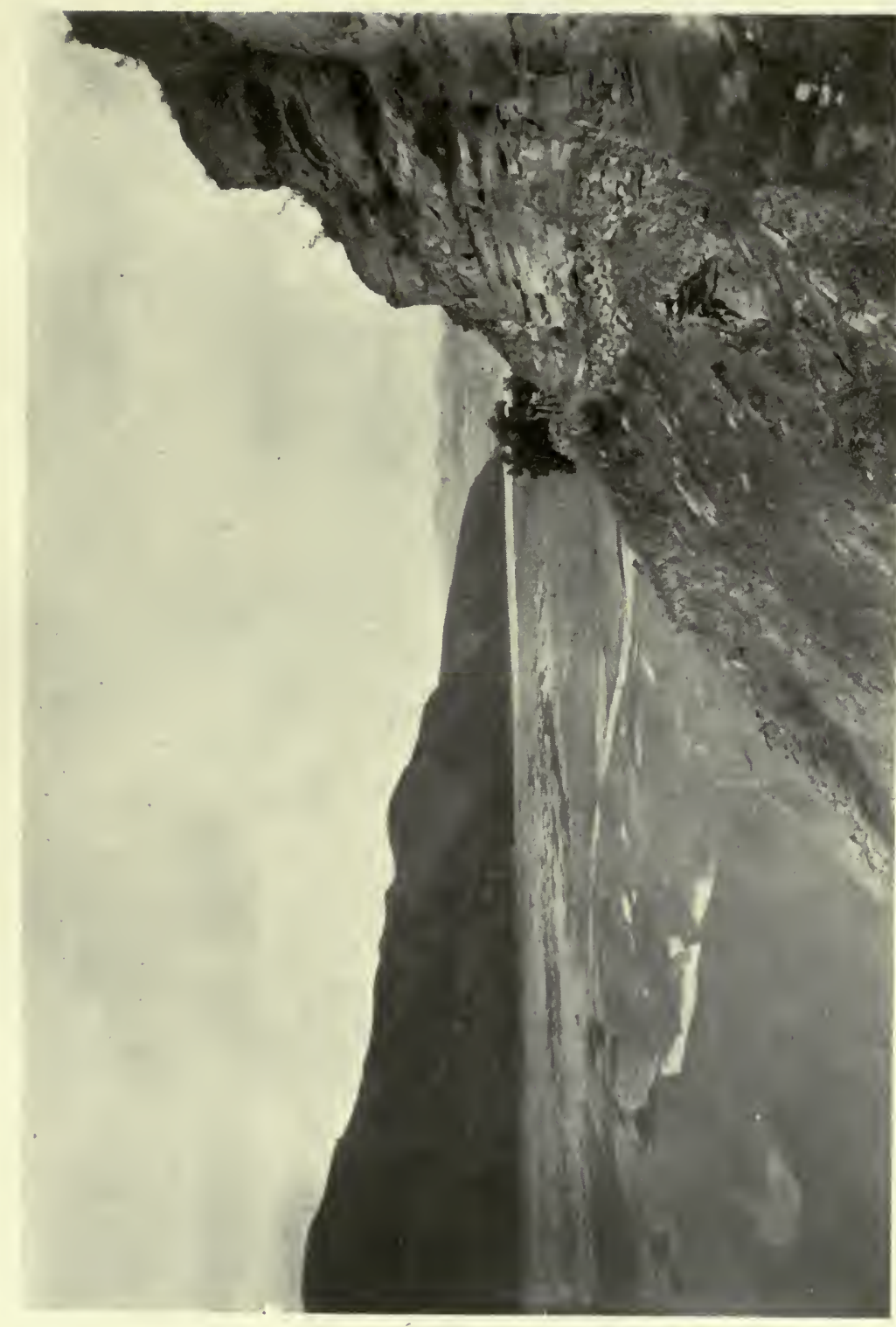

$\%$

음

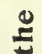

.

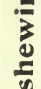

:

I

틀

2

造

兘

光 

inches, whilst the averages for maximum temperatures, minimum temperatures and barometrical records were $82^{\circ} \mathrm{O}^{\circ} \mathrm{F}$., $6 \mathrm{r}^{\circ} 2^{\circ} \mathrm{F}$., and $24^{\circ} 8 \mathrm{I}$ inches respectively.

During the three and a half months spent at Lan-chou the barometer varied from $24^{\circ} 60$ inches to $25^{\circ} 30$, an extreme variation of $0^{\circ} 7$ inch. The barometer at T'ai-yüan during the three months ending July 3 Ist shewed an outside variation of only $0^{\circ} 42$ inches.

On July I5th the expedition left Lan-chou Fu on its way back to T'aiyüan $\mathrm{Fu}$, by the same road which it had travelled in the spring. The journey occupied nearly two months, during the whole of which time careful observations were kept. No long stoppages were made.

On the I7th the party was held up for two days at Ch'êng-kou-yi by very heavy rains, which rendered the roads through the soft loess country impassable. The rainfall recorded on this occasion was $I^{\cdot} 32$ inches in ten hours. Unfortunately the rain gauge overflowed during the night so that it was impossible to estimate the exact amount that fell. The head native of the expedition said that it was the heaviest rain he could remember since the time (about I888) when the Fên Ho overflowed. It then flooded the T'ai-yüan plain, and, entering that city, demolished the Tartar quarter in the southwestern corner.

At Ch'ang-t'ai-p'u the expedition was again held up by rains from the evening of the $25^{\text {th }}$ to the 28th. During this time a total of $r^{*} 45$ inches fell. Altogether the total rainfall for the month was $4^{\circ} 33$ inches. The weather was usually bright and calm, though frequently very hot.

August found the expedition once more at Ku-yüan Chou, and for some days the weather was fine and calm. Rain fell on the 4th, after which the party experienced intermittent rain, overcast skies, heavy dews and mists till the 25th. The total rainfall for the month was $x^{\cdot} 63$ inches. From the $25^{\text {th }}$ to the 3 rst the weather was again clear and calm. During the whole month there was scarcely any wind.

On the $5^{\text {th }}$ the thermometer registered a maximum temperature of ro2.2 ${ }^{\circ}$ F. at Ching-yüan Hsien, and $99^{\circ} 0^{\circ} \mathrm{F}$. was recorded at Ch'ing-yang $\mathrm{Fu}$. four days later.

From this date the temperature seemed to fall steadily though some very hot days were experienced in the loess ravines of the country between Yen-an Fu and Sui-tê Chou, which place was reached on the 2gth.

The first three days of September were wet, the rainfall being ${ }^{52}$ inches. From then onwards the weather was clear, with but little wind. The 
temperature was distinctly cooler than that which had been experienced for some months.

On the 8th, T'ai-yüan Fu was reached, but observations were kept up till the. 12th, when the expedition officially came to an end.

SUMMARY OF METEOROLOGICAL OBSERVATIONS.

May, 1908.

Maximum $98^{\circ} 2^{\circ}$, 27 th

Average max. $85^{\circ} 6^{\circ}$

Minimum $47^{\circ} 0^{\circ}$, 3 Ist

Average min. $56 \cdot 5^{\circ}$

June, 1908.

Maximum $980^{\circ}$, roth

Average $\max .90^{\circ} 0^{\circ}$

Minimum $42.9^{\circ}$, 7 th

Average min. $53^{\circ} 4^{\circ}$

July, 1908.

Maximum $100^{\circ} 0^{\circ}$, $5^{\text {th }}$

Average max. $88.6^{\circ}$

Minimum $55^{\circ} 4^{\circ}, 15^{\text {th }}$

Average $\min .65^{\circ} 8^{\circ}$

August, 1908.

Maximum $100^{\circ} 4^{\circ}$, 8 th

Average $\max .83^{\circ} 2^{\circ}$

Minimum $6 \mathrm{r}^{\circ} 3^{\circ}, 28$ th

Average min. $71^{\circ} 4^{\circ}$

Highest Bar. $27^{\circ} 09$ inches, 7 th

Lowest Bar. 26.67 inches, Igth and 22nd

Average Bar. $26^{\circ} 92$ inches

Rainfall over 6.29 inches

Heaviest fall, I 8 th, $3^{.66}$ inches

Highest Bar. $27^{\circ} I 7$ inches, 30th

Lowest Bar. 26.82 inches, 6th

Average Bar. 26.97 inches

Rainfall $I^{\prime} 94$ inches

Heaviest fall, I5th, $\cdot 6$ inch

September, 1908.

Maximum $860^{\circ}$, 6th

Average max. $77^{\circ} 5^{\circ}$

Minimum $465^{\circ}, 23$ rd

Average min. $5^{8} \cdot \mathrm{I}^{\circ}$

Highest Bar. 27.22 inches, 23rd

Lowest Bar. 26.79 inches, Ioth

Average Bar. $27^{\circ} 05$ inches

Rainfall 2.02 inches

Heaviest fall, I 5 th, '94 inches 
November 5th, 1908 to December 5th.

Maximum $57^{\circ} 0^{\circ}, 7$ th and Ioth

November

Average max. $46 \cdot 8^{\circ}$

Minimum $125^{\circ}, 27$ th November

Average min. $20^{\circ} 5^{\circ}$
Highest Bar. 26.88 inches, 30th

November

Lowest Bar. $26 \cdot 28$ inches, $4^{\text {th }}$

December

Average Bar. 26.61 inches

Wind recorded 30 days :- 15 from N., 3 from N.E., 4 from N.W., 5 from S., 2 from W., one variable.

Strong wind, 3 times, N.W. I., N. 2, moderate once N.

December 19th to 31st, 1908. Yen-an Fu. Alt. $2769 \mathrm{ft}$.

Maximum $40^{\circ} 0^{\circ}$, 29th

Average max. $34^{\circ} 3^{\circ}$

Minimum $35^{\circ}$, 2oth

Average $\min .12 \cdot 2^{\circ}$
Highest Bar. $27^{\prime} 26$ inches, 3 Ist

Lowest Bar. 26.72 inches, 20th

Average Bar. $26^{\circ} 90$ inches

January, 1909. Yen-an Fu. Alt. $2769 \mathrm{ft}$.

Maximum $39^{\circ} 0^{\circ}$, $4^{\text {th }}, 5^{\text {th }}$ and 28 th

Average max. $32 \cdot 1^{\circ}$

Minimum $-3.5^{\circ}$, rgth

Average $\min .12^{\circ} 2^{\circ}$
Highest Bar. $27^{\circ} 16$ inches, 19th Lowest Bar. 26.64 inches, 3rd Average Bar. 26.86 inches

April, 1909. Lan-chou Fu. Alt. $5106 \mathrm{ft}$.

Maximum $83^{\circ} 0^{\circ}, 25^{\text {th }}$

Average max. $68^{\circ} 6^{\circ}$

Minimum $30^{\circ} 0^{\circ}$, $7^{\text {th }}$

Average $\min .4 \mathrm{I}^{\circ} 2^{\circ}$ r Highest Bar. $25^{\circ} 27$ inches, 5th Lowest Bar. $24^{\circ} 72$ inches, 15 th Average Bar. $25^{\circ} 00$ inches

May, 1909. Lan-chou Fu. Alt. $5106 \mathrm{ft}$.

Maximum $880^{\circ}$, 3oth

Average max. $75^{\circ} 5^{\circ}$

Minimum $36^{\circ} 5^{\circ}$, I5th

Average min. $487^{\circ}$
Highest Bar. $25^{\circ} 30$ inches, $13^{\text {th }}$ Lowest Bar. $24^{\circ} 78$ inches, 28 th Average Bar. $25^{\circ} 07$ inches 
June, 1909. Lan-chou Fu. Alt. $5106 \mathrm{ft}$.

Max. $90^{\circ} 0^{\circ}$, 26th and 29th

Average $\max .8 \mathrm{I}^{\cdot} \mathrm{I}^{\circ}$

Min. $43^{\circ} 0^{\circ}$, $13^{\text {th }}$

Average min. $57^{\circ} 9^{\circ}$
Highest Bar. 25.06 inches, 12th

Lowest Bar. 24.60 inches, 28th

Average Bar. $24 \cdot 87$ inches

July, 1909, 15 days. Lan-Chou Fu. Alt. 5106 ft.

Maximum $87 \cdot 8^{\circ}$, gth

Average max. $82^{\circ} 0^{\circ}$

Minimum $53^{\circ} 0^{\circ}$, 2nd

Highest Bar. $24^{\circ} 98$ inches, Ist

Lowest Bar. $24^{\circ} 70$ inches, gth

Average $\min .6 \mathrm{r}^{\circ} 2^{\circ}$ 

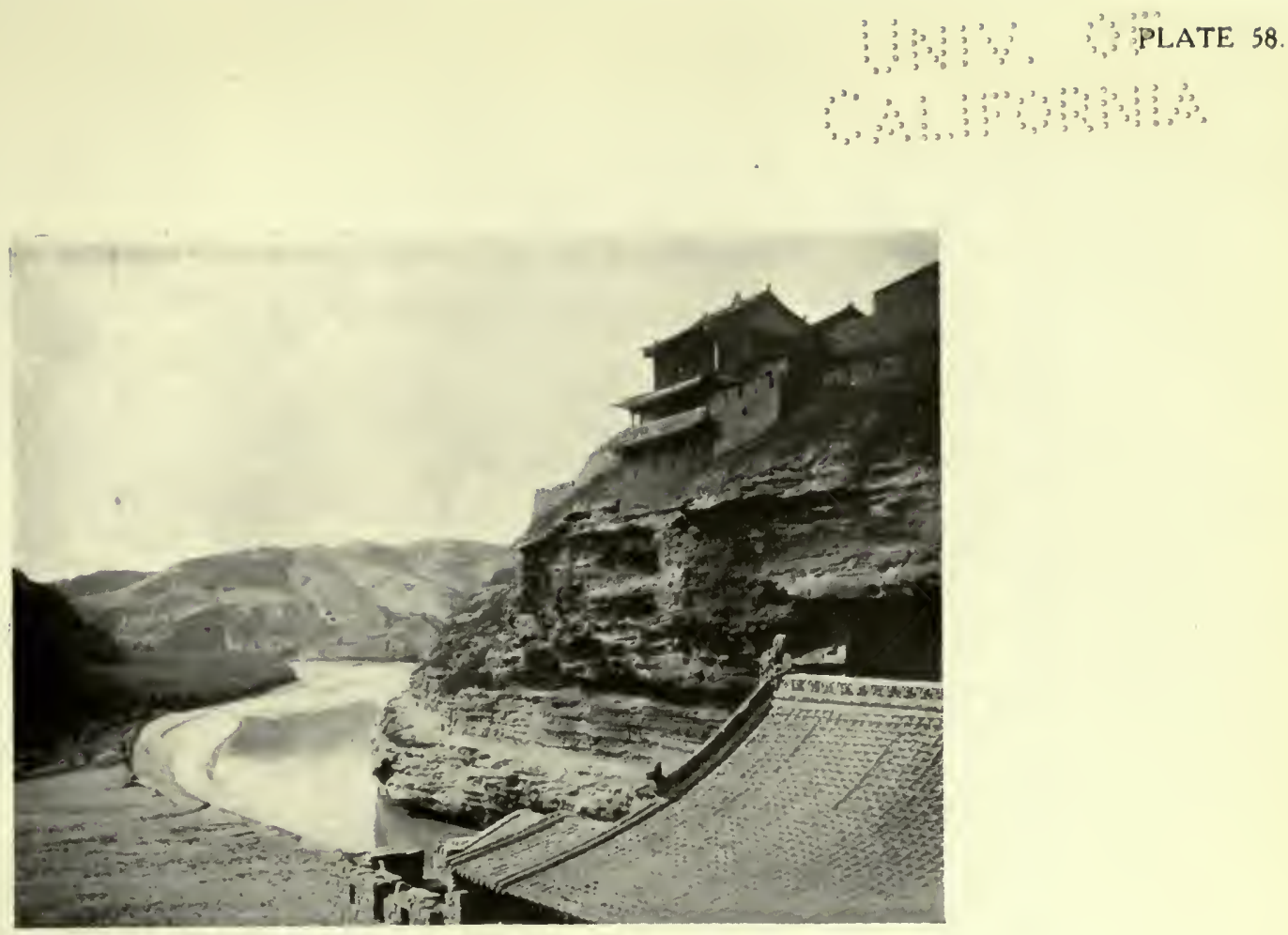

Sandstone strata at Sui-tê Chou, Shensi.

See pp. 26 and 123.

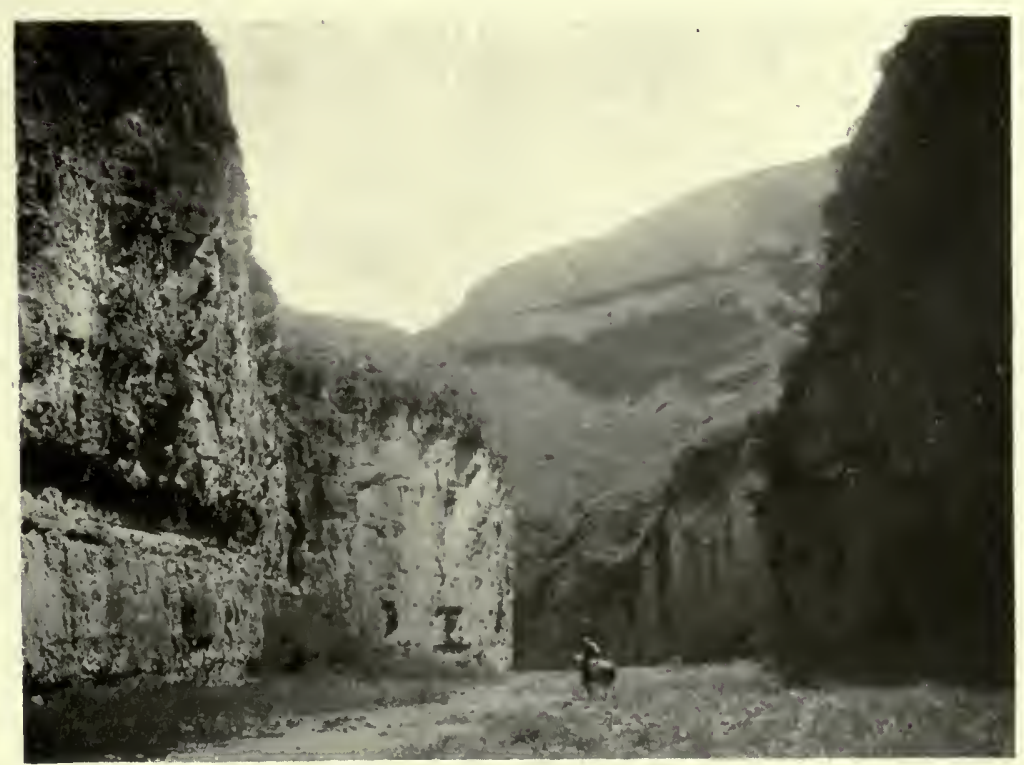

Cañon in Limestone Formation west of Fên-chou Fu, Shansi.

See p. 127. 
嗮

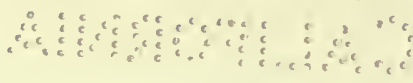


APPENDIX I. (A).

ITINERARIES.

\begin{tabular}{|c|c|c|c|c|}
\hline No. & From & To & $\begin{array}{c}\text { Distance } \\
\text { IN } \\
\text { Miles }\end{array}$ & REMARKS. \\
\hline I & T'ai-yüan Fu & Yü-lin Fu - & 220 & viâ $L$ in Hsien. \\
\hline 2 & Yü-lin Fu - & Yen-an Fu & 176 & viâ Sui-tê Chou. \\
\hline 3 & Yen-an Fu & Fu Chou - & 48 & viâ Kan-ch'üan Hsien. \\
\hline 4 & Fu Chou - & Ch'ing-yang $\mathrm{Fu}$ - & 112 & viâ Ho-shui Hsien. \\
\hline 5 & Ch'ing-yang $\mathrm{Fu}$ - & Ku-yüan Chou & 129 & viâ Chên-yüan Hsien. \\
\hline 6 & Ku-yüan Chou & Ching-ning Chou & 58 & viâ the Hai-tzŭ Pass. \\
\hline 7 & Ching-ning Chou & Lan-chou Fu & I54 & $\begin{array}{l}\text { viâ Hui-ning Hsien } \\
\text { and An-ting Hsien. }\end{array}$ \\
\hline
\end{tabular}

ITINERARY No. I.

T'ai-yüan Fu to Yü-lin Fu (viâ Lin Hsien).

Distance 220 miles; 17 stages.

Communication between rail-head at T'ai-yüan $\mathrm{Fu}$ and $\mathrm{Yü}-\mathrm{lin} \mathrm{Fu}$, on the northern borders of Shensi.

Generally speaking, the road is a fair mule track, with some steep gradients and for the most part stony. The Yellow River is crossed by ferry in Stage 13.

From T'ai-yüan there is telegraphic communication with Peking viâ the Railway and S. to T'ung-kuan Hsien (Shensi). There is also a Head Post Office (Taiyüanfu).*

- The place-name in brackets is the spelling adopted by the Postal Service and does not agree with the "Wade" system. To ensure delivery of latters and telegra ns, the postal system of spelling should always be carefully followed, in addressing all communications. 
Stage I. Shêng-yi (I6 miles). General Direction: West.

Cross Fên Ho (3 feet deep in September) and pass over level plain to Nan-shih (5 miles). Then ascend narrow, stony gorge, passing Pei-hai-ts'un ( $6 \frac{1}{2}$ miles), Hsi-ming-ts'un ( 8 miles), and reaching summit at Ho-shih-ts'un (I2 miles). Thence road bends S.W. and runs easily along a ridge to Shêng-yi (population roo).

Stage 2. Ku-chao ( $13 \frac{1}{2}$ miles). General Direction: N.W.

A stony road runs easily along the ridge, and at Chao-chia-li (4 miles) bends N.W. and becomes less stony. At 8 miles a steep descent is made to the Fên Ho and the road runs along the left bank for 3 miles to Ku-chao (population 500). Good supplies of coal here.

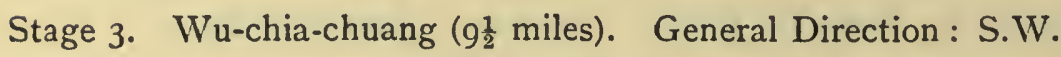

A good mule-road ascends the Fên Ho for 2 miles to its junction with a tributary and then ascends valley of latter, passing Hsiao-êrh (3 miles), Mu-kou ( 5 miles) and Chi-ya ( 7 miles).

Stage 4. Tsa-k'ou (Io miles). General Direction: W.

Good mule-road continues easily up the valley, passing Yi-la ( 2 miles), Chao-san ( $6 \frac{1}{2}$ miles), and Ma-ho-chuang ( 8 miles).

Good crops of millet, buckwheat, corn, potatoes and oats in the valley.

Stage 5. Mi-yüeh-ch'êng (I7 miles). General Direction: N.W.

A rough, stony road ascends $I 600$ feet to the summit of the valley at II miles, passing Kuan-t'ou (4 miles), Shan-t'ou-p'u ( 6 miles), and Ti-tzŭ-t'ou (7 miles). Thence a steep, stony descent is made to Mi-yüeh, on the left bank of the Nan-fan Ho.

Stage 6. Camp in Mo-an Valley (II miles). General Direction: S.W.

Road ascends valley of Nan-fan Ho in southerly direction and at 3 miles becomes narrow and steep. At Ta-shih-ho ( 6 miles) it bends west, and crossing a col at 8 miles, descends to the Mo-an valley, where camp can be formed in a wide ravine, on the north slopes of Yün-ting Shan. There are no villages convenient for camping in.

Stage 7. Ma-fêng (12 miles). General Direction: N.W.

Road descends the Mo-an valley, and for the first three miles is rough, afterwards improving, passing Wan-chia-chuang $(7$ miles) and

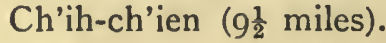

Population of Ma-fêng about 300. 
Stage 8. Sung-chia-k'ou (I6 miles). General Direction: W.

A good cart-road to Yung-ning Chou descends the Mo-an valley, passing Liu-chia-chuang (4 miles) and the large village of Fêng-hsiangch'êng ( 6 miles), and a mile beyond the latter, at Chou-chia-yüan, the main route is left and a rough, stony mule-road turns W. and ascends 900 feet to summit of a pass at I2 miles. Thence a steep descent is made to Sung-chia-k'ou, on a small tributary of the Lin Ho.

Stage 9. Lin Hsien (r3 miles). General Direction: W.S.W.

A good mule-path descends the valley to the Lin Ho, where 2 miles down stream on the left bank is Lin Hsien, a walled town of about 3000 inhabitants. The following villages are passed en route: Miao-chia (2 miles), Ch'ien-ch'ang (6 miles), K'ang-chia-wan ( $7 \frac{1}{2}$ miles),

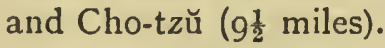

Lin Hsien contains a Roman Catholic Mission, and supplies are numerous. There is a Postal Agency here Linhsien Sha).

Stage ro. Kan-tsao-k'ou (15 miles). General Direction: N.W.

The road ascends the Lin Ho valley for 3 miles and then strikes W. up a ravine, gradually narrowing as it ascends. Tu-chia-kou is passed at 8 miles, after which the road is steep and rocky, ascending the eastern slopes of Ch'ing-ting Shan.

Stage II. Ts'ai-chia-wei (I4 miles). General Direction: N.W.

Road ascends fairly easily for 4 miles to a pass between two peaks of the Ch'ing-ting Shan, and thence by easy gradients descends a small valley to Ts'ai-chia-wei, passing Sha-p'o ( $8 \frac{1}{2}$ miles), Chuang-t'ou (10 miles), and Yang-p'i (r2 miles).

Stage 12. Huang-ho-yeh (14 miles). General Direction: N.W.

A good mule-track descends the valley easily for ro miles, and then, at Lung-wang-miao, a steep, winding ascent is made to the head of the valley, whence the road descends steeply to the valley of the Huang Ho (Yellow River), on the left bank of which is Huang-ho-yeh. There is a ferry over the river here and several large ferry-boats are available.

Stage I3. Ch'i-chia-wei (ro miles). General Direetion: W.

Crossing the Huang Ho, the road ascends 700 feet steeply, and, crossing a pass at Liu-chia-mo ( $5 \frac{1}{2}$ miles), traverses a small plateau and descends to Ch'i-chia-wei, on the left bank of the Tui Ho, a tributary of the Yellow River. 
Stage 14. Chin-chia-k'ou (II miles). General Direction: S.W.

The road makes a bad, rocky ascent up the valley of the Tui Ho, passing Wang-chia-shan (4 miles), Hsü-chia-mo $(7$ miles), and Fêng-huang ( 9 miles).

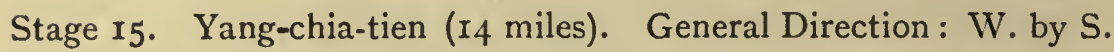

Crossing a low, sandy plateau, the road descends to the Chia-lu Shui, a stream about 15 feet wide, at the village of Chiu-ts'ai ( $5 \frac{1}{2}$ miles), and thence an excellent mule-track ascends the valley, passing Yao-êrh-wan ( 8 miles), Tsao-chia (Io miles), and Shang-ts'ai (II $\frac{1}{2}$ miles).

Stage 16. Liu-chien-hua (9 miles). General Direction: W.

The road ascends the Chia-lu valley and at K'ang-chia-wan ( 2 miles) becomes a narrow path, only 2 feet wide in places, skirting an overhanging cliff for 3 miles, when a low sandy ridge is crossed and the road descends easily to Liu-chien-hua (population 200).

Stage 17. Yü-lin Fu (15 miles). General Direction: W.

A good mule-road descends the valley easily, passing An-chia-kou at 2 miles, and at Yang-chia-shan, a mile beyond, crosses a low, sandy plateau, passing Ta-li-kou ( 4 miles) and Tien-wa-mao (8 miles). Traversing two successive low, sandy ridges, the road reaches the S. gate of Yü-lin Fu.

Yü-lin Fu contains a small garrison and is the centre of a flourishing fur trade. There is a branch Post-Offlce here (Yülinfu).

\section{ITINERARY No. 2.}

Yü-lin Fu to Yen-an Fu (viâ Sui-tê Chou).

Distance I76 miles; 13 stages. General Direction: S.

An excellent mule-road, and wide enough for carts, though in some places the gradients are too steep for the use of wheeled transport, notably in the vicinity of the Kuan-t'i Pass in Stage 9 and of the T'ien-mên Pass in Stage I2.

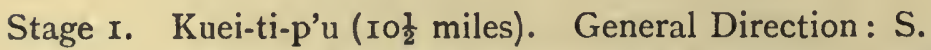

The road, which is level and in excellent condition, though sandy in places, descends the left bank of the Yü-lin Ho, passing San-ts'a-wan (5 miles) and Niu-kuo-tsai ( 8 miles). 
Stage 2. Yü-ho-p'u (II miles). General Direction: S. by E.

The road, which is still in excellent condition, continues to skirt the Yü-lin Ho, passing Mi-chia-yüan ( 2 miles), Kao-chia-wa (6 miles), and $\mathrm{Li}$-chia-kou ( 8 miles). Yü-ho-p'u is a small walled market-town; population 200.

Stage 3. Ch'i-chia-p'o (I4 miles). General Direction: S.E.

Road continues in excellent condition down the Yü-lin Ho valley and is no longer sandy. The following villages are passed en route: Yü-hua-mao (6 miles), Tang-chia (8 miles), Shang-yeh-wan (Io miles), and Liu-chia-p'o (I2 miles).

Stagé 4. Mi-chih Hsien (I3 miles). General Direction: S.E.

A good mule-road down the Yü-lin Ho valley, passing through the following villages: Shui-chi (I mile), Liu-hsien-chuang (2 miles), Kao-lien ( $4 \frac{1}{2}$ miles), Chên-chia-p'o (6 miles), and Chiang-chia-kou (II miles).

Mi-chih Hsien is a town of about 2000 inhabitants, with wall and buildings in good repair. There is a Postal Agency here (Micheh).

Stage 5. Ssŭ-shih-li-p'u (I2 miles). General Direction: S. by E.

Road is still good and descends the Yü-lin Ho (or Wu-ting Ho) valley, passing through Fêng-chia-chuang at 3 miles and Ma-chia-hsin at 9 miles.

Stage 6. Sui-tê Chou ( 15 miles). General Direction : S. by E.

An excellent road, descending the fertile $\mathrm{Wu}$-ting valley, here $\frac{1}{2}$ to $\frac{3}{4}$ mile wide, and passing en route: Chiao-chia-kou (I mile), Pai-chiach'u (6 miles), Yen-chia-ts'a ( $7 \frac{1}{2}$ miles), Tung-chia-shan (9 miles), Liu-chia-wan (II miles), and Lung-wang ( $13 \frac{1}{2}$ miles). Just before reaching Liu-chia-wan a road branches $\mathrm{E}$. to T'ai-yüan $\mathrm{Fu}$ viâ Yungning Chou and Fên-chou Fu. There is a Postal Agency here (Suitehchow).

The Wu-ting Ho is crossed just before reaching Sui-tê Chou (which lies on the right bank) by a shaky trestle-bridge.

Stage 7. T'ien-chuang ( 12 miles). General Direction: S.W.

Leaving Sui-tê Chou by the S. gate, the road ascends a narrow gorge and is wide enough for carts, though some of the gradients are too steep for wheeled transport. Passing Pien-shang at 2 miles, the the road ascends steeply for 900 feet to the summit of a small spur at 4 miles, descending steeply thence to Ma-chia-p'ing ( 6 miles), on the 
Huai-ting Ho, a tributary of the Wu-ting Ho, which it joins about 5 miles below Sui-tê. The road now bends W.S.IW., and ascends the Huai-ting valley through a narrow gorge to T'ien-chuang (population I50).

Stage 8. Mu-chia-ho (12 miles). General Direction: S.

The road which is generally in good condition, ascends the fertile

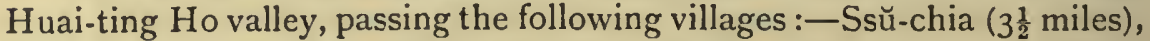
Kang-chia-wan (5 miles), Wang-chia-p'u ( 6 miles), P'ing-tzŭ-ko (8 miles), and Shih-ts'ui-yi (II miles). Mu-chia-ho is situated 2 miles below the crest of the Huai-ting valley.

Stage 9. Ch'ing-chien Hsien (I5 miles). General Direction: S.

The road, which is generally good, ascends steeply for 600 feet to the head of the Huai-ting valley at 2 miles, and, crossing the Kuan-t'i Pass, descends steeply to Lao-to-p'u ( 4 miles). Thence the road descends with occasional steep gradients to Ch'ing-chien Hsien, passing

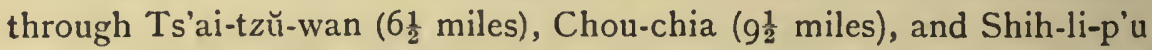
(II $\frac{1}{2}$ miles). Ch'ing-chien is a dirty, dilapidated town, with little commercial activity.

Stage ro. Yen-ch'uan Hsien (1 $4 \frac{1}{2}$ miles). General Direction: S. by E.

An excellent road, fit for wheeled traffic, descending the Hsien Ho. Just below Ch'ing-chien, the road crosses to the right bank of the river. The following villages are passed :-Êrrh-shih-li-p'u (5 miles), Ying-tieh (8 miles), and Ho-chia-wan (12 miles).

Stage Ir. T'ou-chia (I7 miles). General Direction: W.S.W.

The road ascends a tributary of the Hsien $\mathrm{Ho}^{\circ}$ and is in good condition, though stony in places. The following villages are passed :Hsing-shan-ku (2 miles), Ma-chia-tien (4 miles), Ma-chia-k'ou (6 miles), Wên-an-yü (Io miles), and Ju-tsui (I2 miles).

Stage 12. Yao-tien (I5 miles). General Direction: S.W.

Ascending with some steep gradients to the head of the valley, the road crosses the T'ien-mên Pass at $4 \frac{1}{2}$ miles, and descends thence steeply to the Yèn Shui valley, passing Lao-chia-wan at 7 miles, and reaching the Yên Shui at Kan-ku-yü (II miles). Thence a good cartroad ascends the left bank of the river to Yao-tien.

Stage 13. Yen-an Fu (15 miles). General Direction: S.W.

An excellent cart-road skirts the left bank of the Yen Shui, passing through Ssŭ-shih-li-p'u (I $\frac{1}{2}$ miles), Kuai-mao-shang (4 miles), Nai-li-chia 
(7 miles), Liu-shu-kou (9 miles), and Yang-chia-wan (I I miles).

There is a Postal Agency here (Yenanfu).

ITINERARY No. 3 .

Yen-an Fu to $\mathrm{Fu}$ Chou (viâ Kan-ch'üan Hsien).

Distance, 48 miles; 4 stages. General Direction: S.

A good mule-road, generally practicable for wheeled transport.

Stage I. Hsia-ho (I $2 \frac{1}{2}$ miles). General Direction: S.

A good mule-road ascends easily in a S. direction up the valley of a small tributary of the Yen Shui, through a sparsely-populated and poorly cultivated country. The following villages are passed:-Nanch'i-li-p'u (2 miles), Shih-li-p'u (4 miles), Kao-mao-shang (7 miles), San-shih-li-p'u (9 miles), and Ma-p'u (II miles). Hsia-ho is at the head of the valley ascended during the march.

Stage 2. Kan-ch'üan Hsien (I4 miles). General Direction: S. by W.

Crossing a low spur just S. of Hsia-ho, the road descends into the valley of a small tributary of the Lê or Lo Ho, through a thinlypopulated district. The following villages are passed:-Su-chia-ho (3 miles), Lao-shan ( $7 \frac{1}{2}$ miles), Pai-t'u-p'o (ro miles), and Yang-chiapien (I2 miles). Kan-ch'üan Hsien is a walled town, situated on the left bank of the Lo Shui.

Stage 3. Tao-tso-p'u (ro miles). General Direction: S.

The road is good and fit for carts, skirting the left bank of the Lo Shui and passing Liu-shu-ying ( $\mathrm{I} \frac{1}{2}$ miles), An-chia-p'ing (4 miles), Chêng-chia-wan ( 7 miles), and San-liu-mao ( $8 \frac{1}{2}$ miles). Tao-tso-p'u is a walled village, formerly of considerable importance, but now containing only about I $_{50}$ families. The Lo Shui is here ro yards wide and 3 feet deep (in January), and there is a trestle bridge at the village.

Stage 4. Fu Chou (II miles). General Direction: S.

A good cart-road continues down the left bank of the Lo Shui, passing the following villages :-Ts'ui-chia-kou ( $3 \frac{1}{2} \mathrm{miles}$ ), Yü-linch'iao ( 5 miles), Ma-fang ( 7 miles), and Ts'a-fêng ( $9 \frac{1}{2}$ miles). At Ts'a-fêng a road goes $\mathrm{E}$. to Yi-ch'uan $\mathrm{H}$ sien, up the valley of a small tributary of the Lo Shui. This road is in places too steep for carts. Fu Chou is a clean, prosperous town of about 500 families. 
ITINERARY No. 4.

Fu Chou to Ch'ing-yang Fu (viâ Ho-shui Hsien).

Distance, II2 miles; 7 stages.

Good mule-road, except in stage I, where there are some steep, rough gradients.

Stage I. Ch'ang-ts'un-yi (I7 miles). General Direction: S.W.

After skirting the right bank of the Lo $\mathrm{Ho}$ for about a mile, the road bends $W$. and becomes steep and rough. It ascends, winding round the hillside, with several steep descents to streamlets, until at 6 miles a plateau is reached. The road then descends the hillside, skirting the Ch'ing-shui Ho, a tributary of the Lo Ho, the gradients being steep in places. Ch'ang-ts'un-yi is a prosperous village, situated on the right bank of the Ch'ing-shui Ho. The following villages are passed en route: Sha-hsi-kou ( 2 miles), T'ai-ch'i ( 4 miles), T'u-ling (5 miles), Yang-chüan (7 miles), Shan-huo (9 miles), Yao-shang-wan (I5 miles), and Hsin-ch'êng ( 16 miles).

Stage 2. Hai-shui-ssŭ (I7 miles). General Direction: N.W.

The road ascends the right bank of the Ch'ing Shui and is in good

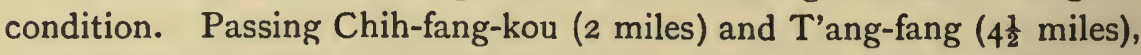
the road at the village of Tai-shih-tien ( 6 miles) crosses a small steep

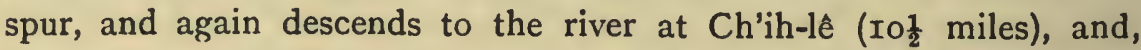
crossing to the left bank, passes An-chia-shan ( 15 miles) and reaches Hai-shui-ssŭ, a village of about 250 , surrounded by ruined walls.

Stage 3. T'ai-pei-ch'êng (20 miles). General Direction: W.N.W.

A good mule-road skirts the left bank of the Ch'ing Shui through a well-wooded but sparsely-populated valley, which has suffered greatly from famine and is poorly cultivated. The following villages are

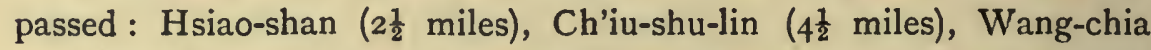
(5 miles), Ch'uan-chuang ( 7 miles), Chang-chia-wan (9 miles), Ma-chia (ro miles), and Ho-shang-yüan (1 $2 \frac{1}{2}$ miles). T'ai-pei-ch'êng is a ruined village of roo souls, on the right bank of the Ch'ing Shui, just below its junction with a small tributary-the Miao Ho. The boundary between Shensi and Kansu is crossed about a mile to the east of the village.

Stage 4. Miao-ts'un (I7 miles). General Direction: W.

The road, which is in good condition, ascends the left bank of the Miao Ho through densely-wooded and poorly populated country. The 
following villages are passed: Wang-mao-chuang (3 miles), Ning-huankou (4 miles), Yang-chia-pien (9 miles), Chang-chia-p'u (I I $\frac{1}{2}$ miles),

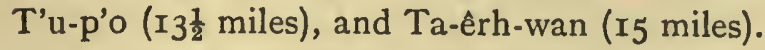

Stage 5. Pai-chia-lao (II miles). General Direction: W. by S.

The road ascends to the summit of the Miao Ho valley, and at 4 miles descends through a pass to the valley of the Ma-lien Ho and descends the right bank past Chien-shui-p'u (7 miles) and Chia-chiakou (8 miles) to Pai-chia-lao.

Stage 6. Ho-shui Hsien (I2 miles). General Direction: S.W.

A good mule-road descends the right bank of the Ma-lien Ho through sparsely-cultivated country to Ho-shui Hsien, passing the following villages: Ch'ên-chia-ho (I mile), Chang-chia-lao (3 miles), Hao-hsü-p'u (6 miles), Shih-ch'iao ( $8 \frac{1}{2}$ miles), Chiu-chan (Io miles), and Chüan-chia (II miles).

Stage 7. Ch'ing-yang Fu (I8 miles). General Direction: W.

The road continues to ascend the right bank of the Ma-lien Ho, passing Pai-chia-kou (2 miles) and Hsü-chia-yüan ( 5 miles) and at Yao-tzŭ-t'ou (Io miles) crosses a small ridge and descends to the Huan Ho at Mêng-chia-ch'iao (r3 miles). Thence it ascends the left bank of the Huan Ho past Kan-kuo-tien (I4 miles) and Wu-li-p'u (I7 miles) to Ch'ing-yang $\mathrm{Fu}$, formerly a prosperous commercial town. There is a R.C. mission here.

ITINERARY No. 5 .

Ch'ing-yang $\mathrm{Fu}$ to Ku-yüan Chou (viâ Chên-yüan Hsien).

Distance, 129 miles; 8 stages. General Directions: W. by S.

A good mule road with some steep gradients and in stage 2 a good cart-road.

Stage I. Pai-ma-p'u (I $4 \frac{1}{2}$ miles). General Direction: S.W.

Crossing from the town to the right bank of the Huan Ho, the road ascends the left bank of a small tributary, passing Ch'i-li-p'u at $2 \frac{1}{2}$ miles, and Shih-li-p'u at 4 miles. At 6 miles, the stream is left and the road ascends S.S.W. up a steep ridge passing Hsü-chia-yüan at Io miles. At II miles, at San-chia-tien, the road reaches the summit of a loess plateau and turning W., runs easily to Pai-ma-p'u, a poor village of 25 families. 
Stage 2. Hsi-fêng-chên (20 miles). General Direction : W. for 8 miles then S.

A good, much-used cart-road with easy gradients, passing through a prosperous and well-cultivated country. The road ascends easily up the plateau, passing Miao-ling at 3 miles, Hsiao-lo-p'u at 4 miles, Hsia-chia at 5 miles, and Tang-chia at 7 miles, and at 8 miles turns S. and runs over a level plain, passing Yi-ma-kuan (9 miles), Ts'ao-fan-p'u (I2 miles), Hua-chia-k'êng (I4 miles), Li-chia (I5 miles), and Yen-ssŭmiao (I8 miles).

Hsi-fêng-chên is a prosperous, walled village, peopled chiefly by immigrants from Ssŭch'uan and Shensi. From the village, roads run N. to Huan Hsien, S. to Fêng-hsiang Fu, and E. to Ning Chou and Pin Chou (Shensi).

Stage 3. T'ai-pei-ch'êng ( 15 miles). General Direction: W.

A good cart-road runs W. along the plateau passing Ma-chia at $2 \frac{1}{2}$ miles, and at 5 miles becomes an ordinary mule-track, descending, fairly steeply in places, to the valley of the P'u Ho and crossing by a footbridge to the right bank at Ts'ai-yüan (Io miles). Thence the road ascends fairly easily up a loess ridge to T'ai-pei-ch'êng (70 families), passing en route through Yang-ts'un (II miles), and Liu-chia-kou ( $\mathrm{r}_{3}$ miles). All the country passed through is well cultivated.

Stage 4. Chên-yüan Hsien (I $4 \frac{1}{2}$ miles). General Direction: W. by S.

From camp the road ascends by a mule-track to a small streamthe Chiao-ko Ho-which is crossed at Pao-chia (3 miles). Thence the road ascends fairly easily up a plateau, passing T'ang-chia-wan (5 miles), and reaching the summit at Mao-chia-p'u ( 8 miles). After running level along the plateau for 3 miles, the road descends to the valley of the Chien-tsai Ho, on the left bank of which stands Chên-yüan, a prosperous walled town, containing a Protestant Mission Station. Carpets are woven here on a small scale.

Stage 5. Yang-shu-wan (I9 miles). General Direction: W. by N.

The road ascends the left bank of the Chien-tsai Ho, through fairly well-cultivated country, passing Wu-li-kou ( 3 miles) and Chiu-lung (6 miles). Just after passing K'ai-pien (I2 miles), the road bends S.W. and passing Chi-chia (13 miles) and Ch'ên-chia-p'ing ( 6 miles), reaches Yang-shu-wan ( 80 families).

Stage 6. Liu-chia-hua (I $7 \frac{1}{2}$ miles). General Direction : W.

A good mule-road continues to ascend the left bank of the Chien-tsai 
Ho, with considerable windings. The country is well cultivated, and the following villages are passed en route:-Wang-chia-p'ing (3 miles), Han-chia-chai (5 miles), Yü-chia-kou (9 miles), Jên-chia-wan (I2 miles), and Wang-chia-wan (I6 miles).

Stage 7. Jên-sa-ho ( 5 miles). General Direction: W. by N.

A good mule-road continues to skirt the left bank of the Chien-tsai Ho for $\mathrm{I} \frac{1}{2}$ miles, and then strikes W. up the valley of the Hsien Ho, a small tributary. Many small villages are passed en route, including :Kao-chia-wa (4 miles), Ta-shih-kou (7 miles), Ts'ao-chia-p'o (ro miles), and Huang-chia ( $\mathrm{r}_{3}$ miles). Jên-sa-ho contains about 25 familiẹs.

Staǵe 8. Ku-yüan Chou ( $3 \frac{1}{2}$ miles). General Direction : N.W.

A good mule-road still ascends the left bank of the Chien-tsai Ho to the head of the valley at 8 miles, and, traversing the Hua-mao Pass, descends the valley of a small tributary of the Ku-yüan Ho, reaching the main river a mile below Ku-yüan Chou. The following villages are passed:-Liu-chia-wa ( 2 miles), Ta-ho-tien ( 3 miles), Liu-chia-yao (6 miles), Wang-chia-hsin ( 7 miles), and Ching-shih-hsiang (12 miles). $\mathrm{Ku}-y$ üan Chou is a prosperous commercial town of about 5000 inhabitants. There is a telegraph office here, and lines run N. to Ninghsia $\mathrm{Fu}, \mathrm{S}$.E. to $\mathrm{Hsi}$-an $\mathrm{Fu}$, with offices en route at P'ing-liang $\mathrm{Fu}$ and Chin Chou, and W. to Lan-chou Fu.

There is also a Postal Agency (Kuyüan).

\section{ITINERARY No. 6.}

Ku-yüan Chou to Ching-ning Chou (viâ the Hai-tzŭ Pass).

Distance, 58 miles; 3 stages.

A good cart-road throughout with easy gradients. The telegraph line from $\mathrm{Ku}$-yüan to Lan-chou follows this road.

Stage I. Hsiao-ch'êng (I 7 miles). General Direction: S.W.

A good mule-road, fit for carts, ascends S.W. easily over a plain, passing Yang-fang ( 3 miles) and Mao-chia-lao (5 miles), and reaching the edge of the plain at $\mathrm{K}$ 'ou-chia (8 miles) crosses a small ridge and descends to the valley of a streamlet, up which it ascends fairly easily in a S. direction. Passing Hai-tzŭ-ho ( $\mathrm{r}$ miles), and Ta-wa-tien ( $\mathrm{I}_{4}$ miles), the road just beyond the latter village traverses the Hai-tzŭ Pass, r 700 feet above Ku-yüan, penetrating the Liu-p'an Shan range at 
this point. Thence it descends to a tributary of the Ku Shui and passes through Sung-chia-wa ( 15 miles) to Hsiao-ch'êng.

Stage 2. Ch'ang-t'ai-p'u (I7/ miles). General Direction: W.

A good mule-road, practicable for carts, continues to descend the valley, which is grassy and well-cultivated, passing Ch'ang-yi-p'u at 3 miles. Here it bends W., and skirting the right bank of the stream, past Hsi-lien-p'u ( 5 miles), Ch'i-chia (8 miles), and Ma-lien (I3 miles), to Ch'ang-t'ai-p'u, a small walled village on the left bank of the $\mathrm{Ku}$ Shui. The village contains about 30 families and a small military post.

Stage 3. Ching-ning Chou (23 miles). General Direction: S. by W.

A good level cart-road descends the Ku Shui valley, which is wellcultivated (wheat chiefly) and dotted with prosperous villages, mostly inhabited by Mahommedans. Passing Wang-chia-p'u at 7 miles, and Shan-chia at ro miles, the road at $\mathrm{Ir} \frac{1}{2}$ miles crosses to the right bank, and traversing Kao-chia-ch'êng (I 2 miles), T'uan-chuang (I4 miles), and Hsia-p'u (20 miles), reaches Ching-ning Chou, a prosperous town of about 5000 inhabitants.

\section{ITINERARY No. 7 .}

Ching-ning Chou to Lan-chou Fu (viâ Hui-ning Hsien and An-ting Hsien).

Distance, 154 miles; II stages.

A good mule-road, but rough in places. The telegraph line from Ku-yüan to Lan-chou follows this road.

Stage I. Chieh-shih-p'u (I3 miles). General Direction : W.N.W.

A rough mule-road with steep gradients in the first six miles. From Ching-ning the road goes N., skirting the left bank of a tributary of the Ku Shui, and at $2 \frac{1}{2}$ miles crosses to the right bank and ascends a steep spur to the summit at Têng-chia-p'u ( $3 \frac{1}{2}$ miles). Crossing a narrow pass, the road then descends steeply to the Hei-lung Ho, which is reached at the village of Sung-chia-kou (6 miles). The road now ascends the left bank of the stream, passing Ch'i-li-p'u at 8 miles, and Hsia-chia-p'u at ro miles.

Stage 2. Ch'ing-chia-yi (I miles). General Direction: N.W.

A rough mule-track continues to ascend the left bank of the Heilung $\mathrm{Ho}$, the loess hills bounding the valley being fairly well cultivated. At 4 miles the road branches N.W. up the valley of a small tributary, 
passing Kuan-chih-hsiang (5 miles), Han-chia (6 miles), and Wu-lich'iao (9 miles). Ch'ing-chia-yi is a small village in bad repair, but contains numerous inns.

Stage 3. Kao-chuang (13 miles). General Direction: W.

A rough mule-track, much cut up in places, ascends to the head of the valley, passing Pai-chia-chi at 2 miles, and reaching the summit at the village of Ta-shan-ch'uan at 4 miles. Traversing a pass in the mountain-range, the road descends into a narrow valley, flanked by loess hills, and skirts the stream, which it crosses and re-crosses several times. T'ai-p'ing-chên is passed at 7 miles, T'ai-p'ing-tien at 8 miles, and Man-yang-chuang at 9 miles. Kao-chuang is a fair-sized walled village.

Stage 4. Hui-ning Hsien (13 miles). General Direction: W.

The road continues to descend the valley, which now opens out, and passing Wu-li-p'u (3 miles), Chang-ts'un-p'u ( 5 miles), San-li-p'u (6 miles), and Wên-chia-chuang ( 7 miles), reaches Hui-ning Hsien, a busy town on the right bank of the Lan Ho, with one long main street containing many shops. There is a Postal Agency here (Hweining).

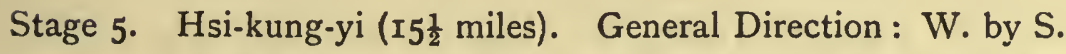

A fair cart-road, but rough in places. Descending the valley of the Lan $\mathrm{Ho}$ in a N.W. direction, the road at $2 \frac{1}{2}$ miles crosses to the left bank and passes Yang-chia-ts'ai (3 miles), Chang-chia-ho ( 4 miles), and Tung-êrh ( 5 miles). At Chi-êrh-ts'ai $(6$ miles) the road reaches the junction of the Lan Ho with a tributary stream, and, skirting a small fort, turns S.W. up the valley of the tributary and skirts the left bank of the stream, which is bounded by high loess cliffs. The road passes Ts'ao-chia-p'u (7 miles), Ts'ao-chia-ho-p'ang (9 miles), Hsiachia-ying (II miles), and Liang-chia-hua (I4 miles), and reaches Hsi-kung-yi, a village of about 70 families, surrounded by a ruined wall.

Stage 6. An-ting Hsien (I4 miles). General Direction: W.S.W.

A good mule-road ascends the valley, passing Ma-chia (2 miles), and thence begins to ascend the loess slopes of the Ching-liang Shan, passing Shan-t'ou-shang at 4 miles and Ching-liang-shan at 9 miles. The summit of the pass is reached at Ssŭ-fang-p'u (II miles), and the road then winds easily down the hillside, passing Ch'ên-chia-chuang (II $\frac{1}{2}$ miles) and Chia-ho-kou (I5 miles). An-ting Hsien is a busy town 
of about 3000 inhabitants, on the left bank of the An-ting Ho. There is a telegraph office here and a Postal Agency (Anting Kan).

Stage 7. Ch'êng-k'ou-yi ( $16 \frac{1}{2}$ miles). General Direction: N.N.W. Crossing by a bridge to the right bank of the An-ting Ho, a good level mule-road descends the river northwards, passing Wu-li-p'u (2 miles), Shih-pa-li-p'u (4 miles), and several other prosperous villages. At $\mathbf{2}$ miles the road leaves the main stream and strikes W. up a small tributary, passing Ch'a-k'ou ( 13 miles), and Liao-chia-p'ing (I $\frac{1}{2}$ miles), Ch'êng-k'ou-yi has a population of about 200 and an official rest-house, but the inns are poor.

Stage 8. Kan-tsao-tien (I4 miles). General Direction: N.W.

The road, which is rough in places, ascends the stream for $I \frac{1}{2}$ miles, and then strikes N.W. up the hillside for 4 miles, passing Tuan-chia-yao

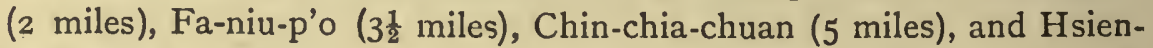
tzŭ-shang ( 7 miles). Just beyond the last-named, it traverses a low pass $(8050 \mathrm{ft}$.$) , and runs level along the ridge to a mile beyond Ta-wan-$ lou ( 8 miles), where it begins to descend to the well-cultivated valley of a tributary of the Yellow River, and passing Pai-t'u-yao at II $\frac{1}{2}$ miles, reaches Kan-tsao-tien, a prosperous village on the left bank of the stream, containing many inns, and enjoying a considerable trade with Lan-chou Fu.

Stage 9. Ta'i-ya-p'u (I6 miles). General Direction : N.N.W.

A good mule-road continues to descend the left bank of the stream, through a well-cultivated valley, passing Shan-tung-ying at $I \frac{1}{2}$ miles, and Ch'ing-shui-yi at $6 \frac{1}{2}$ miles. At Hsü-chia-t'ai (ro miles) a road goes S.W. to Chin Hsien, 8 miles distant, viâ Shuang-tien. The route continues to descend the left bank, crossing a small spur and tributary at II miles, and passing Hsia-kuan-ying at 15 miles, crosses to the right bank of the stream at T'ai-ya-p'u.

Stage 1o. Sang-yüan (15 miles). General Direction: N.W.

A good mule-road continues to descend the right bank of the stream, passing Yüeh-chia-lao at $4 \frac{1}{2}$ miles, and Chin-chia-yai at 6 miles, and crossing to the left bank of the stream at $8 \frac{1}{2}$ miles. Passing Hsiao-shui-tzŭ at $\mathrm{I} 3$ miles, the road at I4 miles reaches the Yellow River where it joins a route coming in from the N.E. from Ching-yuian Hsien. The road now skirts the right bank of the river to the village. 
Stage II. Lan-chou Fu (Io miles). General Direction: W.

The road continues to ascend the right bank of the Yellow River, passing Tung-kuang at 5 miles, and K'uei-hsing-t'un at 6 miles, and crosses a sandy; poorly-cultivated plain to the town.

Lan-chou Fu is the capital of Kansu, and the seat of the Viceroy of Shênkan. It has a population of about half-a-million. It is a busy commercial centre, and a considerable amount of cloth is manufactured in the neighbourhood. There is a telegraph office at Lan-chou, and communication eastwards with $\mathrm{Hsi}$-an $\mathrm{Fu}$, viâ $\mathrm{Ku}$-yüan $\mathrm{Chou}$, and north-westwards with Kuldja and Kashgar, viâ Liang-chou Fu, Yungchang Hsien, Kan-chou Fu, Kao-t'ai Hsien, Su Chou, and An-hsi Chou, at all of which towns there are telegraph offices. There is also a Branch Post Office (Lanchowfu). The Yellow River is crossed N. the town by an iron bridge. 


\section{APPENDIX I (B).}

TABLE OF LATITUDES AND LONGITUDES.

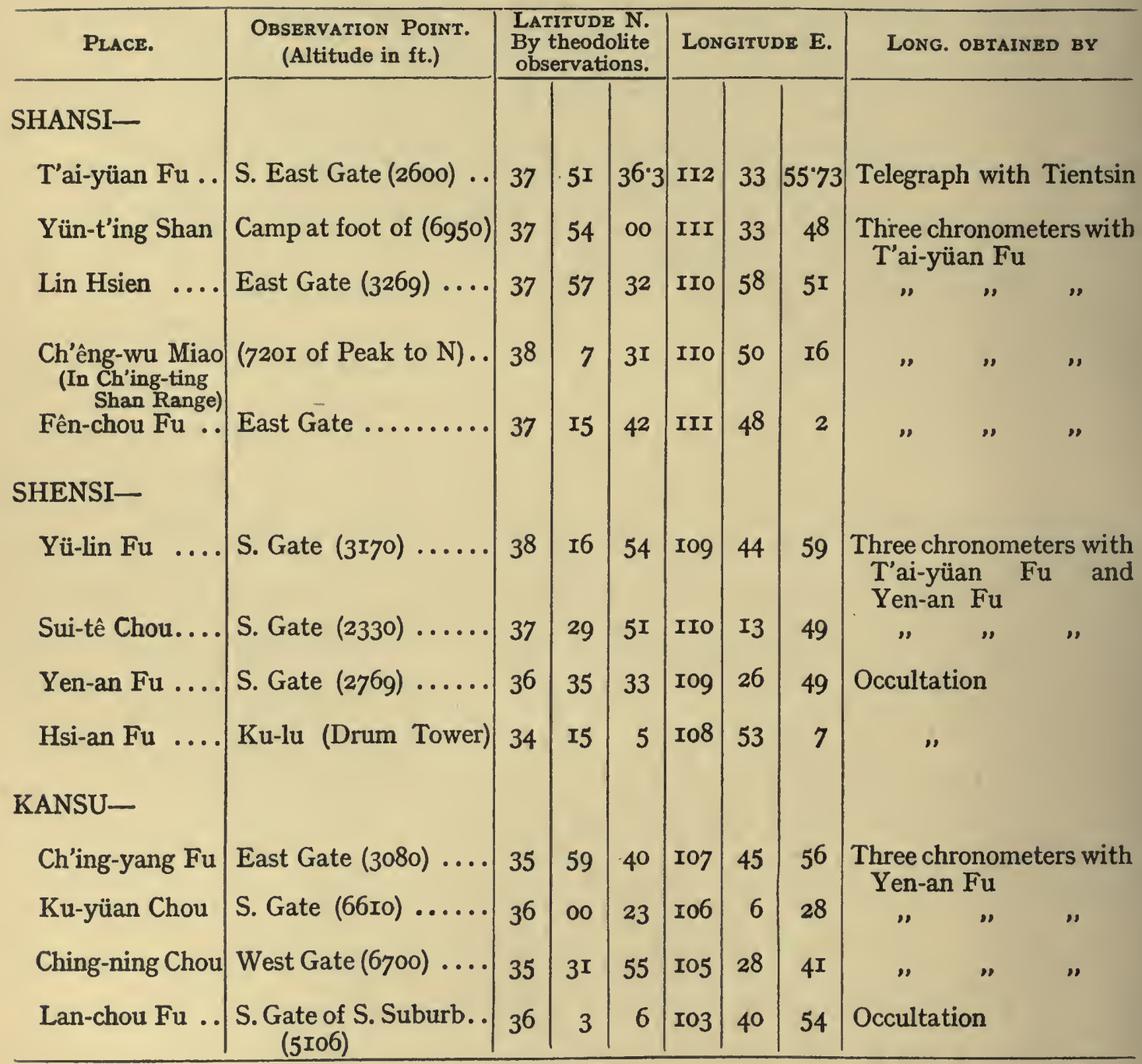




\title{
APPENDIX II.
}

\author{
MAMMALS COLLECTED IN SHANSI, SHENSI AND KANSU \\ -BY A. DE C. SOWERBY.
}

THE Mammals collected during the expedition, and presented by Mr. Clark

to the United States National Museum, number 220 specimens. Following are details of the 33 species represented, besides the number, sex and locality of each specimen.

A series of these, representing all the species taken, was brought to London in the summer of IgIo by Mr. Gerrit S. Miller, in whose company I compared them with the Chinese material in the British Museum. Complete facilities for this work were courteously granted by Mr. Oldfield Thomas, F.R.S., Curator of Mammals at South Kensington. The new forms which the collection contained have already been described by Mr. Miller in two papers issued August, IgIo and February, IgII. The first of these is entitled "A New Carnivore from China" (from the proceedings of the United States National Museum, vol. xxxviii., pages $385-386$ ), and it deals with the new species Vormela negans from the Ordos Desert. The second paper is entitled "Four New Chinese Mammals" (from the Proceedings of the Biological Society, Washington, vol. xxiv., pages 53-55). This deals with the four new species and sub-species Eptesicus serotimus pallens, Microtus pullus, Allactaga mongolica longior, and Ochotona annectens, from Shansi and Kansu.

The descriptions are embodied in this report.

The determinations and names of the other species dealt with in this paper have been kindly verified and revised for me by Mr. Miller. The new species or subspecies are underlined.

I. Eptesicus serotinus pallens, Miller.

rgIr. Proc. Biol. Soc., Washington, xxiv., page 58.

б 244. I8 miles east of Ku-yüan Chou, Kansu. Alt. $530 \mathrm{ft}$. August Ist, I909.

đ 246 . Chên-yüan Hsien. 70 miles west of Ch'ing-yang $\mathrm{Fu}$, Kansu. Alt. $4000 \mathrm{ft}$. August 4 th, Igog. Type of sub-species.

万 249 \& 250. 80 miles south-west of Yen-an Fu, Shensi. Alt. $3500 \mathrm{ft}$. August I7th, I909. 
Type.-Adult male (skin and skull) No. 155, 156. U.S. Museum. Collected at Chên-yüan Hsien, 70 miles west of Ch'ing-yang $\mathrm{Fu}$, Kansu, China. August 4th, I909, by Mr. Sowerby.

Original number 246 .

Diagnosis.-In general, like the European Eptesicus serotinus, but colour somewhat less dark, particularly below, the contrast between that of dorsal and ventral surfaces evident enough to produce a slight line of demarcation along side of neck; forearm shorter than in true serotimus; skull tending to be rather short and broad.

Measurements in mm.-Type : head and body, 70 ; tail, 50 ; tibia, 22 ; foot, 13.8 ; forearm, 49; thumb, 10.6 ; third finger, 90; fifth finger, 65; ear, 19; Skull : condylo-basal length, I9 ${ }^{\circ}$; zygomatic breadth, $14^{\circ} \mathrm{O}$; interorbital constriction, $4^{\circ} 6$; breadth of brain case, $9^{\circ} 6$; mandible, 15 ; maxillary tooth-row, exclusive of incisors, $7^{\circ} 2$; mandibular tooth-row, exclusive of incisors, $8 \cdot 2$.

Specimens examined.-Four, from the following localities: Chên-yüan Hsien, 70 miles west of Ch'ing-yang $\mathrm{Fu}$, Kansu (altitude 4000 feet), I ; 18 miles east of Ku-yüan Chou, Kansu (altitude 5300 feet), I ; 80 miles south-west of Yen-an Fu, Shensi (altitude 3500 feet), 2.

All shot flying round camp at dusk in loess country.

2. Pipistrellus sp.

ð 245. 60 miles east of Ku-yüan Chhou, Kansu. Alt. $4500 \mathrm{ft}$. August 3rd, rgog.

An immature individual, too young to be positively identified.

Shot on bank of river under loess cliff at dusk.

3. Scaptochirus gillesei, Thomas.

\& Ior. Yü-lin Fu, North Shensi, on border of Ordos Desert. Alt. $3000 \mathrm{ft}$. November 8th, 1908.

This mole is somewhat rare and one would hardly expect to find it in so dry and sandy a country as the vicinity of Yü-lin Fu and the Ordos Desert.

It has since been recorded from the plain of Wu-chai in NorthWestern Shansi ; also a dry and sandy locality. It has also been recorded from T'ai-yüan $\mathrm{Fu}$, North Central Shansi ; while the type locality is Southern Shansi. 
4. Felis chinensis, Gray.

J 158 Yen-an Fu, Shansi. Alt. $2800 \mathrm{ft}$. January I9th, Igog. Skin and skull only brought in by natives. I2 caudal vertebrae remaining, measured I 46 m.m. Measurement of ear while still fresh and soft was $50 \mathrm{~m} . \mathrm{m}$.

This cat, though common over the greater part of China, is here very seldom seen, and is difficult to capture. The Mongols of the Ordos trap it in large iron gins, usually set for wolves and foxes. The fur is valued by the Chinese.

The present specimen was killed while it was raiding a chicken coop, and it displayed great ferocity.

5. Vormela negans, Miller.

Proc. U.S. National Museum, xxxviii,, page 385, August Igth, Igro. Among some mammals collected in North-Western China and the Ordos Desert were two spotted polecats, readily distinguishable from the western Vormela peregusna by a peculiar inversion of the colour pattern of back.

The larger skin was brought to me in a very poor condition. The skull was missing, as were also the leg bones, while the tail was torn in two, and one eye was torn. I offered large rewards for a complete specimen; but though several Mongols and Chinese were induced to enter the Ordos in search of them, I obtained nothing more than a small dry skin which accompanies the above-named specimen. From what I could gather the animal is not at all common. It frequents spots where trees exist, and climbs freely. The Chinese name "Ma-nai-hou" would also signify this fact, the last syllable " hou" meaning "monkey" or "ape." They are sometimes caught in traps set for foxes. Their skins, however, have no market value. They are very savage when caught. The above-mentioned facts were given and confirmed repeatedly by natives who had traded in the Ordos.

Type specimen.-Adult male (skin only).

Cat. No. 155,001. U.S. National Museum.

Taken bv natives in the Ordos Desert about roo miles north of Yü-lin $\mathrm{Fu}$, Shensi. Original number 92.

Diagnosis.-Like Vormela peregusna, but light markings paler and more extensive, those on posterior half of back confluent, so that this region is yellow mottled with brown, instead of brown mottled with yellow; under parts, fore-legs, and inner surface of hindlegs black instead of dark brown. 
Measurements in mm.-Type (from skin, apparently not much stretched).

Head and body, 340; tail, 2 IO.

Spccimens examined.-Two, both from the Ordos Desert.

6. Martes flavigula borealis, Radde.

\& $\mathrm{r}_{57}$ (skin only). Yen-an Fu, Shensi. Alt. $2800 \mathrm{ft}$. January I6th, I909.

Ig caudal vertebrae remaining measured $333 \mathrm{~m} . \mathrm{m}$.; hind foot, fresh and soft, measured roo m.m. ; ear, fresh and soft, measured 42 m.m.

Common, but hard to secure, this handsome marten is seldom seen. It inhabits the deep ravines of the loess country. The Chinese name "huang-yao" means "yellow marten," a name given in consequence of the brilliant yellow throat of this animal.

7. Mustela sibirica, Pallas.

उ 178 , I79. Liu-ts'un, foot of mountains I $_{5}$ miles south of Hsi-an Fu, Shensi. Alt. $1500 \mathrm{ft}$. March 7 th, 1909 .

Both specimens trapped in drain in temple yard, after stealing game from larder. Very savage. Common all over North China, especially in large towns, where they live upon rats and other vermin. The two specimens were markedly different in shape and colour, also in skull proportions. Chinese name, "huang-shu-lang," meaning "yellow rat wolf."*

8. Mustela larvata, Hodgson. (Plate $5 \mathrm{I}$.)

J I96, 248. Ching-ning Chou, I50 miles east of Lan-chou Fu, Kansu. Alt. $5500 \mathrm{ft}$. July 24 th and 25 th, Igog.

उ 212. I5 miles north-east of Ching-ning Chou, Kansu. Alt. $6200 \mathrm{ft}$. July 26 th, I909.

The three specimens are all immature, and their determination can be regarded as no more than provisional. Specimens bought from natives, who used them to capture small rodents in the same way that ferrets are used in Europe to capture rabbits and rats. Chinese name, "Sao-hu," meaning "ermine fox."

9. Capreolus bedfordi, Thomas.

I 49. I2 miles south of Yen-an Fu, Shensi. Alt. $400 \mathrm{ft}$. January 8th, I909.

i 247. 30 miles east of Ch'ing-yang Fu, Kansu. Alt. $4500 \mathrm{ft}$. August I4th, Igog.

- Giles gives the name "Huang-shu-lang" to the North China polecat or Siberian weasel 
đ 25I. Near Yen-an Fu, Shensi. Alt. $4000 \mathrm{ft}$. August 21st, rgog.

3 254, 255, 256 (skulls and horns only). Yen-an Fu, Shensi.

Specimen 149 was in winter pelage, and specimens 247 and $25 \mathrm{I}$ were in summer pelage. The skulls were picked up by natives in the hills near Yen-an Fu.

These deer are very plentiful wherever sufficient cover exists, whether it be in the low loess hills prevalent in North Shensi and Eastern Kansu, or in the high rocky mountains elsewhere.

This species is somewhat larger than the European forms, and decidedly more yellow in colour. It is not so large as the Siberian form. Roedeer horns, when in velvet, have a certain market value amongst the Chinese as medicine for female complaints.

I0. Urotragus galeanus, Heude.

1894. Kemas galeanus, Heude. Mem. Hist. Nat. Emp. Chinois ii., part 4, page 243 .

J I80. Mountains near Liu-ts'un, $\mathrm{I}_{5}$ miles south of $\mathrm{Hsi}$-an $\mathrm{Fu}$, Shensi. Alt. $4000 \mathrm{ft}$. March 7 th, I909.

Essentially a topotype of the species. Resembles $U$. arnouxianus, Heude; but the head and ears are lighter, and the throat patch appears to be less extensive.

The status of this animal, like that of other Chinese members of the genus, is far from being clearly understood.

Dimensions measured in the flesh.-Head and body, Ir60 mm.; tail, I70 mm. ; hind feet, $300 \mathrm{~mm}$.; ear, $150 \mathrm{~mm}$.

This goral inhabits the highest and most precipitous peaks of the range south of Hsi-an Fu.

II. Sus moupinensis, M. Edwards. (Plate 47.)

3 252. I2 miles south of Yen-an Fu, Shensi. Alt. $4000 \mathrm{ft}$. August 2and, rgog.

A fine adult male in its peculiar summer pelt. I have examined Père David's specimen in the Natural History Museum, Paris. This specimen seems to be a fully adult male, and as such is much smaller than the present form. It is also considerably darker in colour, and has smaller tusks. However, it has not been thought advisable to separate the two.

Dimensions measured in the flesh. Head and body, $1555 \mathrm{~mm}$.; tail, $290 \mathrm{~mm}$. ; hind foot, $270 \mathrm{~mm}$.; ear, $120 \mathrm{~mm}$. 
Other measurements.-Height at shoulder, $2 \mathrm{ft} .6$ ins.

Weight, 320 lbs. (about).

This pig is a great scourge to the natives of the country, as it destroys acres of crops. It is common in must mountainous or hilly districts with good cover. Its range extends at least from Shansi to Tibet.

12. Sciurotamias davidianus, M. Edwards. (Plate 49.)

* Irg. 9 miles south of Ch'ing-chien Hsien, Shensi. Alt. $2600 \mathrm{ft}$. December I6th, I 908 .

i I20. I5 miles east of Yen-an Fu, Shensi. Alt. $2500 \mathrm{ft}$. December Igth, Ig08.

đ I7I, I73, I77, \& I8I, I82. Liu-ts'un, foot of mountains I5 miles south of Hsi-an Fu, Shensi. Alt. $1500 \mathrm{ft}$. March, Igog.

उ 253. I5 miles south of Ch'ing-chien Hsien, Shensi. Alt. $2600 \mathrm{ft}$. August 27th, Ig09.

Found in rocky hills and mountainous country from near Peking in the east to the furthest limits of Kansu in the west. It is recorded from Ning-wu Fu, Shansi, and also from Ssŭch'uan.

It resembles in habits and mode of life, the chipmunk, but does not hibernate as does the latter.

13. Eutamias asiaticus senescens, Miller. (Plate 48.)

उ 2. Shêng-yi mountains 18 miles west of $\mathrm{T}$ 'ai-yüan $\mathrm{Fu}$, Shansi. Alt. $5000 \mathrm{ft}$. September $30 \mathrm{th}$, Ig08.

उ 6 , $q 3$, 4. Ku-chao, 30 miles west of T'ai-yüan Fu, Shansi. Alt. $4000 \mathrm{ft}$. October Ist, I908.

+ 7. 60 miles west of T'ai-yüan Fu, Shansi. Alt. $4450 \mathrm{ft}$.

October 3 rd, Igo8.

$\checkmark 34,24,44$. Chiao-ch'êng Shan, mountains 90 miles west of T'ai-yüan $\mathrm{Fu}$, Shansi. Alt. $7000 \mathrm{ft}$.

उ 45,46 . 30 miles west of Lin Hsien, Shansi. Alt. $4000 \mathrm{ft}$. October 2 Ist, 1908 .

đ I85. Chien-ch'uan-ch'êng, 50 miles north-west of Hsi-an Fu, Shensi. Alt. $3100 \mathrm{ft}$. May 9 th, I 909.

i 197, 198, 199. Ching-ning Chou, 150 miles east of Lan-chou Fu, Kansu. Alt. $5500 \mathrm{ft}$. July 25 th, I 909. 
- ${ }^{2}$ 232, 233, 236, $q$ 234. I5 miles north-east of Ching-ning Chou, Kansu. Alt. $5200 \mathrm{ft}$. July 27 th, rgog.

A very common and widely distributed species.

I4. Eutamias asiaticus ordinalis, Thomas.

ð Ir8. Yü-lin Fu, Shensi.

A pale desert race found round the borders of the Ordos Desert, where it inhabits the deep ravines, which take the place of loess gullies further south and east. It has not been recorded from the desert itself. It might be noted that specimen No. 185 of the preceeding species closely resembles in the lightness and yellowness of its pelt $E$. a. ordinalis. Similar agencies may have been at work in both cases to cause this lightening of colour, for specimen No. 185 was taken close to country, which bore some resemblance to that round, and in, the Ordos. Wide stretches of flat, somewhat sandy land, was there, inhabited chiefly by Citellus mongolicus, and Lepus swinhoei subluteus, two other Ordos forms.

15. Citellus mongolicus, M. Edwards. (Plate $5 \mathrm{I}$ ).

d 184 , + r83. 18 miles west, north-west of Hsi-an Fu, Shensi. Alt. I700 ft. May 7 th, rgog.

б I86. Lung-tê Hsien, 40 miles west of P'ing-liang Fu, Kansu. Alt. $6800 \mathrm{ft}$. May I8th, 1909 .

o I88, \& I87, I89, r9o. Lan-chou Fu, Kansu. Alt. $5500 \mathrm{ft}$. June $4^{\text {th, }}$ 1909.

i 192. I5 miles south, south-east of Lan-chou Fu, Kansu. Alt. $8500 \mathrm{ft}$. June 20 th, I909.

万 200, $q$ 193. 52 miles east of Lan-chou Fu, Kansu. Alt. $6700 \mathrm{ft}$. July 26 th and I8th, I909.

\& 195. I25 miles east of Lan-chou Fu, Kansu. Alt. 6300 ft. July 22nd, rgog.

J 2 II, $\&$ 23I. I5 miles north-east of Ching-ning Chou, Kansu. Alt. $6200 \mathrm{ft}$. July 26 th, Igog.

\& 248. 25 miles north-east of Ching-ning Chou, Kansu. Alt. $7000 \mathrm{ft}$. July 28 th, rgog.

Common in dry or sandy districts as well as on flat plains. Particularly plentiful in and round the Ordos Desert. The only thing alive in the famine-stricken area round Lan-chou Fu, in Kansu. Chinese name, "Sha-shu," meaning " sand-rat." 
16. Meriones auceps, Thomas.

б 98, +97 . Yü-lin Fu, Shensi. Alt. $3000 \mathrm{ft}$. November 17 th, I908.

б I22, I26, I38, \& I23, I25, I36, I37. Yen-an Fu, Shensi. Alt. $2800 \mathrm{ft}$. December 2 Ist to 23 rd, I908.

This species is nocturnal in its habits, in which respect it agrees with $M$. psammophilus, and differs from $M$. unguiculatus. Usually found in colonies. $M$. auceps seems to prefer bushy country, and its burrows occur in patches of thorn scrub or other protective bushes.

M. unguiculatus is found on the open plains of Mongolia, away from all bushes, and $M$. psammophilus on plains and in river valleys of the northern provinces. The latter seems to prefer sandy places. Chinese name, "Huang-shu," meaning." yellow rat."

I7. Epimys confucianus luticolor, Thomas.

ð I21, I29, \& I27, I28, I31, I34. Yen-an Fu, Shensi. Alt. $2800 \mathrm{ft}$. December 2 rst and 23rd, Ig08.

These form a series of topotypes, the subspecies having originally been described from this locality by $\mathrm{Mr}$. Thomas.* J $162,163, I 64, I 67$, \& $16 \mathrm{I}$. Liu-ts'un, foot of mountains 15 miles south of Hsi-an Fu, Shensi. Alt. I500 ft. February 26th to 28th, I909.

This rat is a rock-loving species, being found usually along the rocky sides of ravines and valleys in both Shansi and Shensi. Easily trapped, and frequently found to be covered with fleas and ticks. A new flea (Ceratophyllus subcaecatus) + was taken from one of the Yen-an Fu specimens. The stomach of another was found to contain parasitical worms.

18. Mus wagneri mongolium, Thomas.

उ I59. Lin-t'ung Hsien, near Hsi-an Fu, Shensi. Alt. I500 ft. February I4th.

Caught on hillside on very barren ground.

19. Apodemus speciosus, Temminck.

ð I. Shêng-yi mountains, 18 miles west of T'ai-yüan Fu, Shensi. Alt. $5000 \mathrm{ft}$. September $30 \mathrm{th}$, I 908 .

đ $28,30,38$, \& I7. Chiao-ch'êng Shan, 90 miles west of T'ai-yüan Fu, Shansi. Alt. 7000 to $8000 \mathrm{ft}$. October 7 th to 18 th, 1908 .

- Abstr. P.Z.S., 1908, page 45, December 15th, also P.Z.S., 1908, p. 972 (under Mus). $\uparrow$ Described by the Hon. N. C. Rothschild, and published in present volume, Appendix iv. 
J I 45, I54, $+148,153$. I2 miles south of Yen-an Fu, Shensi. Alt. $4000 \mathrm{ft}$. January 6 th to IIth, I909.

б I74, I75, I76. Liu-ts'un, foot of mountains I5 miles south of Hsi-an Fu, Shensi. Alt. I500 ft. March 2nd and 3rd, rgog.

J IgI. Mountains I5 miles south of Lan-chou Fu, Kansu. Alt. $7000 \mathrm{ft}$. June I7th, Ig09.

A very widely distributed species, common wherever scrub or woods are at all extensive.

20. Apodemus agrarius pallidior, Thomas.

J 135, + I40. Yen-an Fu, Shensi. Alt. $2800 \mathrm{ft}$. December 23rd and 27 th, 1908 .

\% $160,165,166,168,169,170.1$ Liu-ts'un, foot of mountains 15 miles south of Hsi-an Fu, Shensi. Alt. I $500 \mathrm{ft}$. February 26th to March Ist, I909.

Usually found in low, bushy country, on hill tops, or in open valleys. Those taken at Liu-ts'un were caught on hill side amongst loose stones, in small cypress wood, or along the bottom of a deep ravine. Enjoys a comparatively wide range.

2I. Cricetulus triton, de Winton.

万 I30. Yen-an Fu, Shensi. Alt. $2800 \mathrm{ft}$. December 22nd, Ig08.

Apparently not $C$. triton incanus, as described by Mr. Thomas.* True C. triton incamus has hitherto only been found in Shansi, though the present species seems to be an inhabitant of both Shansi and Shensi, as well as of Shantung.

It is just possible that in all three provinces two forms exist, one a large form (incanus) with ridges on the skull, and the other a smaller one with smooth skull. Both $C$.t. incanus and $C$. triton are abundant on the T'ai-yüan Fu plain.

Chinese name, "Pan-ts'ang." "Ts'ang" means a "granary," and refers to this animal's habit of storing away large quantities of grain and beans for winter consumption. A very fierce and pugnacious animal.

22. Cricetulus andersoni, Thomas.

ð $9,15,22, q$ I0, II, I2, I4, 23. Chiao-ch'êng Shan mountains, 90 miles west of T'ai-yüan Fu, Shansi. Alt. 7000 to $8000 \mathrm{ft}$. October 6th to 8 th, 1908 .

- Abstr. P.Z.S., 1908, page 45 (December 15), also P.Z.S., 1908, p. 973. 
J 139. Yen-an Fu, Shensi. Alt. $2800 \mathrm{ft}$. December 27 th, 1908.

J 242. I5 miles north-east of Ching-ning Chou, Kansu. Alt. $6200 \mathrm{ft}$. July 27 th, rgog.

Those of the above mentioned specimens that were taken from Chiao-ch'êng Shan form a topotypical series. This little hamster was first secured from this district by Mr. M. P. Anderson, whose name it bears. This species is very common in Shansi and Shensi, but is comparatively rare in Kansu. Chinese name, "Tsang-êrh," means "storer."

23. Cricetulus griseus, M. Edwards. (Plate 49).

\& I03. Yü-lin Fu, Shensi. Alt. $3000 \mathrm{ft}$. November 18 th, I908.

This hamster seems to take the place of $C$. andersoni in and on the borders of desert country. It is also recorded from Chihli and Shantung.

Its burrows are usually to be found along the sides of cultivated fields, irrigation ditches, and watercourses. Chinese name, "Ts'angkuan," or "granary official," from its storing habits.

24. Phodopus bedfordiæ, Thomas.

子 $49,54,55,59,60,65,66,72,73,77,81,82,83,88,90,91$, \& 48, 53, 58,6 r, 68, 7r, 74, 75, 76, 78, 80, 84, 85, 87, 89. Yü-lin Fu, Shensi. Alt. $3000 \mathrm{ft}$. November 2nd to I 4 th, I 908 .

This hamster was originally placed in the genus Cricetulus by Mr. Thomas. It was noticed, however, by Mr. Miller that the sole of the foot instead of having several small distinct pads, as is the case in other hamsters, has a single large pad formed by the coalescence of the usual pads. For this reason he created a new genus Phodopus.

In appearance this species differs markedly from the hamsters hitherto mentioned. In colour, it is pinkish buff above and pure white beneath. The tail is very short, and the soles of the feet are thickly covered with white hairs, which enable the little animal to progress with ease over the deep loose sand. Extremely common. Present series are topotypes. Specimens have also been recorded from Wu-chai Hsien, a town situated on a plain on the west of the Ning-wu Fu mountains, in Shansi. Chinese name, "Mi-tsang," meaning "storer of millet."

25. Microtus pullus, Miller.

Proc. Biol. Soc., Washington, xxiv., page 53. February, Igrr.

đ. I8, 20, 32, 42. Chiao-ch'êng Shan mountains, 90 miles west of T'ai-yüan Fu, Shansi. Alt. 7000 to $8000 \mathrm{ft}$. October IIth to I4th, I908. 
Type.-Adult male (skin and skuli), No. 155,047. U.S. National Museum. Collected at Chiao-ch'êng Shan, go miles west of T'ai-yüan Fu, Shansi. Alt, $7000 \mathrm{ft}$. October IIth, I908.

Original number, 32.

Diagnosis.-Size and general characters as in Microtus (Phaomys) johannes, approaching mars-brown instead of dull ochraceous-buff.

Colour.-Upper parts a uniform fine grizzle of cream buff and black, with a distinct brownish wash on crown and along middle of back, the general effect suggesting Ridgway's mars-brown, and not in the least resembling the pallid ochraceous-buff of Microtus johannes. Sides not so dark as back, the grizzling less evident. Under part light cream-buff, much clouded by the blackish-slate under colour. Feet dull buffy-white, with an evident brownish wash. Tail whitish below, brownish above, not sharply bi-colour.

Skull and Teeth.-The skull and teeth do not differ appreciably from those of Microtus johamnes. They are conspicuously smaller than in M. mandarimus.

Measurements in mm.-Type : head and body, I04; tail, I8; hind foot, without claws, $15{ }^{\circ} 5$; ear, 9 ; skull, condylobasal length, $24^{\circ} 8\left(27^{\circ} 4\right)^{*}$; zygomatic breadth, $16^{\circ} 2\left(17^{\circ} 8\right)$; interorbital constriction, $3^{\circ} 6\left(4^{\circ} 0\right)$; occipital breadth, I $3^{\circ}$ O (13.0); occipital depth, $7^{\circ} 0(7.2)$; nasal, $6{ }^{\circ} 2\left(7^{\circ} 0\right)$; diastema, $7^{\circ} 8\left(9^{\circ} 2\right)$; mandible, $16.4(\mathrm{I} 8.2)$; maxillary tooth-row, $5.8 \quad(6.4)$; mandibular tooth-row $5.8(6 \cdot 4)$.

Specimens examined.-Four, all from the type locality. Caught on grassy hillside, away from woods. Much earth thrown up in front of burrows. In both these respects this vole agrees with $M$. johannes. The latter, however, seems to be an inhabitant rather of loess mountains than of the high rocky mountains that form the habitat of this species. It has also been recorded from similar country near Ning-wu Fu, Shansi.

26. Microtus inez, Thomas.

万 I52. I2 miles south of Yen-an Fu, Shensi. Alt. $4000 \mathrm{ft}$. January gth, Igog.

The only vole hitherto recorded from Shensi, north of Hsi-an Fu. Very rare here, though plentiful enough in similar districts in Shansi. Inhabits the bottoms of well vegetated loess ravines.

- Measurements in parenthesis are those of an adult male Microtus mandarinus from the vicinity of T'ai-yüan Fn, Shansi. 
27. Craseomys shanseius, Thomas.

J $27,29,36,39$, \& 4I. Chiao-ch'êng Shan, 90 miles west of T'ai-yüan Fu, Shansi. Alt. 8000 to $9200 \mathrm{ft}$. October 9 th to 13 th, 1908 .

All trapped amongst moss-grown rocks in or near dense spruce or larch woods. Specimen No. 4I was caught on the summit of Mo-êrh Shan, the highest peak in the district $(9200 \mathrm{ft}$.). Common in mountainous and well-wooded districts; but not found elsewhere. These specimens form a topotypical series, the first known specimens having come from this same district. Also recorded from mountains near K'ê-lan Chou and from those near Ning-wu Fu, further north in the same province.

This vole feeds upon leaves of young plants growing amongst the rocks, underneath which its burrows ramify. It can easily be tempted into traps with a little grain or millet.

28. Myospalax cansus, Lyon. (Plate 48).

ð 35. Chiao-ch'êng Shan, mountains 90 miles west of T'ai-yüan $F u$, Shansi. Alt. $7000 \mathrm{ft}$. October 12 th, 1908.

б II5, II7, \& 99, I00, I02, Ir6. Yü-lin Fu, Shensi. Alt. $3000 \mathrm{ft}$. November I7th to 21 st, 1908 .

đ I43. Yen-an Fu, Shensi. Alt. $2800 \mathrm{ft}$. January 2nd, I909.

J 201, 202, 209, 2I $4,215,216,217,218$, $\& 203$. I5 miles north of Ching-ning Chou, Kansu. Alt. $6200 \mathrm{ft}$. July 26 th and 27 th, r909.

Specimen No. 35, an adult male, is the only one of this species recorded from Shansi. In some ways this specimen differs from those secured from Shensi and Kansu. The skull is heavier throughout, with more pronounced ridges. It is not considered advisable to separate it from $M$. cansus, which it most resembles, especially as there is only the one specimen from this locality. The Shensi and Kansu specimens are identical and cannot be separated.

With these facts in view it would seem that the two species, $M$. cansus and $M$. fontanierii, overlap each other in their distribution. A specimen of $M$. fontanierii was secured in the Southern Ordos, at a point lying almost exactly between Yü-lin $\mathrm{Fu}$, in Shensi, and Ching-ning Chou, in Kansu, at or near both of which places $M$. cansus has been secured.

At the same time, here is a specimen of $M$. cansus which has encroached upon the acknowledged habitat of $M$. fontanierii in Shansi. More material is needed before this and other points can be cleared up. 
Chinese names "Ha-lao," "Ha Hui" or "Hsia-lao." " $\mathrm{Ha}$ " and "Hsia " mean "blind," "lao " means " old," and "Hui" means "grey." The above names may be translated "the blind old one" or "the blind grey one."*

29. Dipus Sowerbyi, Thomas. (Plate 50).

đ 57, III, II2, \& I04, I08, I09, IIO, II3. Yü-lin Fu, Shensi. Alt. $3000 \mathrm{ft}$. November 2nd to Igth, Igo8.

\& 86. Ordos Desert, I5 miles north-west of Yü-lin Fu. Alt. $3000 \mathrm{ft}$. November 12th, I908.

A good topotypical series of a race of three-toed jerboas inhabiting the Ordos Desert and immediate vicinity, the only three-toed jerboa hitherto recorded from China.

Their food seems to consist of delicate shoots and seeds of such scrubby plants as can find sustenance in the arid desert.

Chinese name "T'iao-êrh" (The Jumper).

30. Allactaga mongolica longior, Miller. (Plate 52).

Proc. Biol. Soc., Washington, xxiv., page 54, February, IgII.

उ $205,206,207,208,213,219,220,223,224,239,241, q 204,221$ (in alcohol), 222, 240 .

I5 miles north-east of Ching-ning Chou, Kansu. Alt. $6200 \mathrm{ft}$. July 26 th and 27 th, I909.

Type.-Adult female, skin and skull, No. I55, I83, U.S. National Museum. Collected 15 miles north-east of Ching-ning Chou, Kansu. Alt. $6200 \mathrm{ft}$. July 26 th, I909.

Original number, 204.

Diagnosis.-Similar to true Allactaga mongolica (Pallas), but ear and hind foot longer and audital bulloe larger.

Measurements in mm.-Type : head and body, 150; tail, 230 ; hind foot without claws, 76 ; skull : condylobasal length, $38^{\circ} 4$; zygomatic breadth, $26^{\circ} 0$; interorbital constriction, $\mathrm{II}^{\circ} 4$; breadth of brain case, 19.8 ; depth of brain case at middle, $13^{\circ} 6$; nasal (median), 15.4; diastema, 12.6; mandible, $24^{\circ} 8$; maxillary tooth-row, alveoli, $8^{\circ} 0$; mandibular tooth-row, alveoli, $7 \cdot 8$.

Specimens examined.--Twelve all from the type locality. Dug up by natives. Apparently very numerous in this district, though not met with else-

- Giles gives "Hsia-lao-shu" as the "Mole-rat." 
where. Reported to exist round Lan-chou Fu in Kansu, but none were seen. Chinese name T'iao-t'u-tzŭ, meaning "Jumping Hare." This is ascribed by Giles to the Siberian Jerboa.

31. Lepus swinhoei subluteus, Thomas.

$\delta$ I4I. Yen-an Fu, Shensi. Alt. $2800 \mathrm{ft}$. December 27 th, 1908.

\& I5I. I2 miles south of Yen-an Fu, Shensi. Alt. $4000 \mathrm{ft}$. January 8th, I909.

Very common.

32. Ochotona bedfordi, Thomas.

\& I55. I2 miles south of Yen-an Fu, Shensi. Alt. $4000 \mathrm{ft}$. January IIth, Igog.

On a previous visit to this locality, several specimens were secured, but on the present visit I could scarcely find any inhabited burrows, and had much difficulty in trapping this single specimen.

This species was described by Mr. Thomas from specimens in their summer pelage, taken in Shansi at Ning-wu Fu, in Igo8. Those taken from Yen-an $\mathrm{Fu}$ on the same expedition being in their winter coats. The U.S. National Museum now possesses specimens in winter pelage - from both localities. Those from Shansi are found to be somewhat darker and more ochraceous in colour than those from Shensi. In other respects the specimens from both places agree closely.

The present specimen from Yen-an Fu agrees exactly with those taken from almost the same locality in March, Igo8.

Chinese names "Hao-t'u" meaning "rat-hare" and "Ti-t'u" meaning "ground-hare."

33. Ochotona annectens, Miller. (Plate 52).

Proc. Biol. Soc., Washington, xxiv., page 54. February, I9II.

б I94. II6 miles east of Lan-chou, Kansu. Alt. $6300 \mathrm{ft}$. July 18th, Igog.

J $225,226, \& 227,228,229,230$. I5 miles north-east of Ching-ning Chou, Kansu. . Alt. $6200 \mathrm{ft}$. July 27 th, I909.

Type.-Adult male (skin and skull) No. I55, I64, U.S. National Museum. Collected $I_{5}$ miles north-east of Ching-ning Chou, Kansu. Alt. $6200 \mathrm{ft}$. July 27 th, I909. Original number 225 . 
Diagnosis.-Similar to Ochotona daunica, Pallas, from the Mongolian Plateau, but dorsal outline of skull less converse and audital bulloe slightly larger. Differs from $O$. bedfordi, Thomas, of Shensi and Shansi, in smaller size (particularly of skull) more convex upper cranial outline, and much smaller audital bulloe.

Colour.-As in the related species the general colour is a light buff darkened by a plentiful sprinkling of black hair tips, the buff everywhere predominating, and becoming clearer and more yellowish, along sides, particularly in region of shoulder. A faintly indicated pale area between ear. Underparts and feet dull white with a slight buffy tinge; throat crossed by a broad band of dull buff, this area sometimes extends backward along median line.

Ear with the usual dark marking on outer side.

Measurements in mm.-Type : head and body, I8I ; hind foot, $29(26)$; ${ }^{*}$ ear 20 ; skull, condylobasal length, $40^{\circ} \mathrm{O}\left(42^{\circ} 4\right)$; zygomatic breadth, $20^{\circ} 4\left(2 \mathrm{I}^{\circ} 2\right)$; interorbital constriction, $4^{* 2}\left(4^{\circ} 2\right)$; postorbital constriction, $13^{*} 2\left(13^{\circ} 8\right)$; mastoid breadth including bulloe, $20^{\circ} 8\left(20^{\circ} 0\right)$; depth of brain case at middle, $\mathrm{Ir}^{\circ} \mathrm{O}\left(\mathrm{Ir}^{\circ} 4\right)$; nasal, $\mathrm{I}^{\circ} \mathrm{\circ}\left(\mathrm{I}^{\circ}{ }^{\circ} \mathrm{O}\right)$; diastema, $9^{\circ} 8$ (I0.8); mandible, $27^{\circ} 2\left(30^{\circ} 2\right)$; maxillary tooth-row, alveoli, $7^{\circ} 4(8 \cdot 6)$; mandibular tooth-row, alveoli, $7{ }^{\circ}\left(8^{\circ} 4\right)$.

Specimens examined.--Seven, six from the type locality and one from Ts'ai-chiawei, II6 miles east of Lan-chou, Kansu (altitude $6300 \mathrm{ft}$.). This species inhabits the deep loess gullies and ravines of central Kansu. Probably common. Habits similar to those of $O$. bedfordi. Very shy and hard to secure.

* Measurements in parentbesis are those of an adult male Ochotona bedfordi from Wu-cbai Hsien, Sbansi (No. 172, 601). 


\section{APPENDIX III.}

\section{INVERTEBRATES COLLECTED ON THE EXPEDITION-}

BY ARTHUR DE C. SOWERBY.

IN this branch of zoology the work done was not very extensive, though the results have proved to be of some interest. The greater part of the work was carried out by Captain H. E. M. Douglas, V.C., D.S.O., R.A.M.C., who made collections at T'ai-yüan $\mathrm{Fu}$ and in the Chiao-ch'êng Shan district in Shansi, and also in northern Shensi.

The collections contained representatives of nine orders, viz.:-Coleoptera, Hymenoptera, Hemiptera, Mallophaga, Diptera, Siphonaptera, Scorpiones, Araneæ, Acari. The Lepidoptera and Neuroptera were collected by $\mathrm{Mr}$. Grant and myself.

It was unfortunate that the season was so far advanced when the expedition commenced. As a consequence this work suffered considerably.

The collection was sent first to the Royal Army Medical College, but was subsequently presented to the British Museum (Natural History) in exchange for the identification of the specimens it contained. Many species, represented by single specimens only, have been left undetermined, while the bad condition of some specimens has rendered their identification impossible.

For the identification of the various species contained in this collection, thanks are due to the following specialists :-
E. E. Austen (Diptera).
C. J. Gahan (Coleoptera).
G. Meade-Waldo (Hymenoptera).
S. Hirst (Scorpiones and Acari).

-all of the British Museum.

The Hon. N. C. Rothschild very kindly undertook the identification of the Siphonaptera, while Mr. H. R. Hogg, has been equally kind in working out the Araneæ.* Good results have been obtained in the two last orders, some eight new species having been described.

Altogether the following new species were contained in the collection.

In the Acari, two undetermined species belonging to the genera Hæmaphysalis and Leiognathus.

- Appendices IV. and V. 
In the Araneæ, five species-

I. Lycosa clarki.

2. Lycosa ordosa.

3. Evippa douglasi.

4. Pardosa shansia.

5. Pardosa sowerbyi.

In the Siphonaptera, three species-

r. Ceratophyllus subcæcatus.

2. Neopsylla anoma.

3. Vermipsylla dorcadia.

In the case of the two new species of Acari, Mr. Hirst has been unable to publish descriptions, but he hopes to do so later.

The chief interest attached to the collection is the locality in which it was made. No previous collections have been made in the same district.

Most of the species are representative of very widely distributed genera.

On the return journey from Lan-chou Fu to T'ai-yüan Fu, Mr. Grant and I made a collection of butterflies and dragonflies. This was forwarded, with the mammals, to the Smithsonian Institution. A description of this journey and the country where these insects were most prevalent appears in another chapter so it need take up no space here. At the end of the present chapter appears a list of the butterflies. I received no report on the collection from the Smithsonian Institution, and have been forced to make up the list myself, trusting largely to memory, and to the coloured plates and descriptions in Leech's "Butterflies of China."

In northern Shensi where the climate is dry and vegetation scarce, butterflies and dragonflies are comparatively rare, while scarcely any were seen west of Ching-ning Chou in Kansu. In the mountains of Shansi butterflies are plentiful and the marshes and rivers of the plains in the same province support many species of dragonflies. Nowhere however, on the line of march, were either of these orders seen in such quantities as in the loess valleys of eastern Kansu and central Shensi.

Whether any of the species collected in these localities are new I cannot say.

Specimens of a fresh water crab were obtained by me in the mountain streams south of Hsi-an Fu in Shensi and also near T'ai-pei-ch'êng in eastern Kansu. They belong to the genus Potamon. 


\section{List of Insects, etc.. collected in N. China \\ By Captain H. E. M. Douglas, V.C., D.S.O., R.A.M.C.}

\section{DIPTERA.}

By E. E. Austen, F.E.S.

Fam. Mycetophilidae (Fungus Midges).

Sciophila sp. incert. (a fragment).

Yün-t'ing Shan : in open ground 6,974 ft., 5-X-Igo8.

Fam. Bibionidae.

Bibio sp. incert. (Near B. johannis L.) I $q$

Yün-t'ing Shan: in village 6,974 ft., 5-X-Igó8.

Fam. Chironomidae (Midges).

Chironomus sp. incert. I \&

T'ai-yüan : in grass, near pond (no date mentioned).

Fam. Culicidae (Mosquitoes).

Culex fatigans Wied I $q$

T'ai-yüan Fu: in Chinese courtyard, 9-VIII-Igo8.

Grabhamia sp. incert. I $\delta 6$ \& $q$

T'ai-yüan : feeding on horse, 28, 29-VIII-rgo8; in grass, near pond, 30-VIII-rgo8.

Some 9 or Io other mosquitoes, including I Anopheles (sensu stricto) were brought back, but the condition of these specimens is such as to. render definite determination impossible.

Fam. Stratiomyidae.

Stratiomys sp. incert. 2 larvae.

Yü-lin Fu: I4-XI-I908. The larvae of species belonging to the genus Stratiomys are aquatic.

Fam. Asilidae (Robber-flies).

Genus et sp. incert. allied to Cyrtopogon. Lw. I $\delta$

Kan-ts'ao-kou : caught in open ground, 4,226 ft., 20-X-I908.

Fam. Syrphidae (Hover-flies, etc.).

Catabomba pyrastri L. I $q$

Yü-lin Fu: on sand, 3,I69 ft., Ir-XI-I908.

A common and very widely distributed palaearctic hover-fly, which also occurs in N. America.

Sphaerophoria sp. incert. 2 む ठ I 9

T'ai-yüan : in grass, near pond, 24-VIII-Igo8. 
Eristalis tenax L. (the Drone fly) I $f$

Yü-lin Fu : on sand, near river, $3169 \mathrm{ft}$., $\mathrm{I}_{5}$-XI-I908.

This very common and widely distributed species, to which it is believed that the Bugonia-myth* of the ancients referred, besides being found in most parts of Europe, is known to occur in India, China, Japan, South Africa, and North America, and in recent years has become fairly common in New Zealand.

FAM. TACHINIDAE.

Pycnosoma remuria Walk. I $q$

Yün-t'ing Shan. I4-X-I908.

Lucilla sp. incert. I ?

Yün-t'ing Shan. I4-X-Igo8.

Calliphora sp. incert. (Blow-fly) I +

Yü-lin Fu. I5-XI-I908.

Hypoderma sp. incert. (a Warble-fly, allied to H. diana. Brauer), 9 larvae from beneath the skin of a roebuck.

Yen-an Fu. I9-XII-Igo8.

FAm. Muscidae.

Musca domestica $L$. (the common House-fly) I $\delta$ I $q$

Yün-t'ing Shan. 8-X-Igo8.

This species, which has undoubtedly been carried about the world by human agency, is now almost universally distributed.

Muscina stabulans Fln. $3 \delta$ ठ

Yü-lin Fu. I5-XI-Igo8

A common palæarctic species, which also occurs in North America; frequently found in houses in England.

Fam. Scatomyzidae.

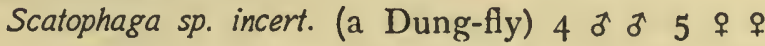

Yün-t'ing Shan : in village 6,974 ft., 5-8-X-1908.

Fam. Helomyzidae.

Genus et sp. incert. I $q$

Yü-lin Fu. I6-XI-rgo8.

Fam. Hippoboscidae.

Hippobosca capensis von Alfers (The Dog-fly) 2 б $\sigma^{\pi} 3 q$ ?

T'ai-yüan $\mathrm{Fu}$ : from dog. II-I7-VIII-Igo8.

This species is a parasite of domestic dogs from South Europe to North China. It also occurs in parts of Africa.

* The ancient belief that bees were generated in decaying carcases of cattle, etc. (c.t., Judges xiv., 12-18, and Vurgil's Fourth Georgic). The facts are, that the fly Eristalis tena.x resembles the honey-bee, and that its larva are carrion-eat:rs; hence when they have finished a carcase they pupate beneath the skin and debris that remain, emerging eventually as perfect insects in crowds which were mistaken for swarms of bees. 


\section{Coleoptera.}

By C. J. Gahan, M.A., F.E.S.

Fam. Tenenbrionidae.

Anatolica sp. incert. Several specimens from Yü-lin Fu, Shensi, on border of Ordos Desert, I2-I6-XI-Ig08. Impossible at present to identify species. New to British Museum collection.

Extremely common amongst the sand hills of the Ordos, and together with the four following species, forms the chief food of the Ordos hedgehog (Erinaceus miodon).

Anotolica augustata St. Two specimens from Yü-lin $\mathrm{Fu}$, Shensi, on border of Ordos Desert, I2-I6-XI-Igo8.

A larger species than the above, and equally common.

Blaps rugosa Gebl. One specimen from Yü-lin Fu, Shensi, on border of Ordos Desert, I2-I6-XI-Igo8.

A very common species, chiefly found in old buildings, but also in open country.

Akis fumestra Fald. One specimen from Yü-lin $\mathrm{Fu}$, Shensi, and one from T'ai-yüan $\mathrm{Fu}$, Shansi. No date.

As common as Blaps, but found more often in open country.

Fam. Meloidae.

Meloe sp. incert. One badly damaged specimen labelled N. China. Very common throughout North China, frequenting low shrubs and bushes. Sometimes seen in great numbers.

Fam. Chrysomelidae.

Chrysomela sp. incert. One specimen from Yün-t'ing Shan mountains, 90 miles west of T'ai-yüan Fu, Shansi, 8-X-I908.

A small herbivorous beetle.

In addition there are a few species of Carabidae, predaceous beetles depending for their subsistence upon their power to run down and kill animals weaker or less protected than themselves: and of Staphylinidx, commonly called "cocktail beetles," usually found in rubbish heaps, or where decaying animal or vegetable matter exists. These few species cannot be determined. 


\section{HYMENOPTERA.}

Fam. Vespidae.

By G. MEAde-Waldo.

Polistes jadwigae D.T. One specimen from T'ai-yüan Fu, Shensi.

This species was first described as "japonicus" but later was changed to jadwigae by Dalla Torre. A rare species, of which the British Museum possessed but one specimen previous to the present addition. A much darker species than $P$. hebraeus $\mathrm{F}$., of which it is possibly a subspecies.

Polistes hebraeus F. Two specimens from Yü-lin Fu, Shensi, on border of Ordos Desert.

This species is much commoner and more widely spread than $P$. jadwigae and may be found all over North China. Inhabits towns and villages, gathering material for its nest from the paper windows of the houses.

Fam. Sphegidae.

Ammophila tydei Guill. One specimen from Yü-lin Fu, Shensi, on - border of Ordos Desert.

A sand-loving race. In the British Museum collection there are specimens from Sfax in Tunis, Spain, Madeira, Cyprus, Teneriffe, Karachi, in North-West India, and from South-Western Persia.

Fam. Pompilidae.

Pompilus sp. incert.

Fam. APIDAE.

Sphecodes sp. incert. I ठ

Fam. Formicidae.

Camponotus sp. incert.

Fam. ICHNEUMonidae.

Coelichneumon sp. incert.

Ophion sp. incert.

Both these genera are widely distributed, and the species, which it is impossible to identify, are not unlike those found in Europe and even in Great Britain.

HEMIPTERA.

Lygaeus equestris Linn. Several specimens from Yü-lin Fu, Shensi, on borders of Ordos Desert, II-XI-rgo8. 
A very common and widely distributed form, recorded from both the old and new worlds.

Corizus hyalinus Fab. Several specimens from Yün-t'ing Shan Mountains, 90 miles west of T'ai-yüan Fu, Shansi, 8-X-rgo8.

A widely distributed species. Specimens from Mexico City, West Indies, and Budna and Cattaro in Dalmatia being in the British Museum.

Tettigoniella viridis Linn. Several specimens from T'ai-yüan Fu, Shansi, 26-VIII-I908. Taken near river.

Commonly known as Cuckoo's spit, owing to the larva surrounding and protecting itself with a little mass of froth, which is lodged in the fork at the base of leaf-stem or grass-blade. In China this species is commonly found in chrysanthemum gardens. It appears in great swarms in the autumn, and may be seen in clouds round lamps at night.

\section{Mallophaga.}

Hæmobothrion sp. incert. Several specimens of an indeterminable species of this large bird-louse were taken off an eagle.

\section{SCORPIONES AND ACARI.}

Fam. Buthidae.

\section{By S. Hirst.}

Buthus martensi Karsch. Yü-lin Fu, Shensi.

Very common throughout North China. Found in old buildings, used and dis-used, as well as in open country.

Fam. IxodidaE (Ticks).

Argas reflexus Fabr. Yü-lin $\mathrm{Fu}$, Shensi.

Two specimens from wall of temple.

Haemaphysalis. Yen-an $\mathrm{Fu}$, Shensi.

A number of specimens taken from a roedeer (Capreolus bedfordi). A very common species in North China. Closely related to $H$. japonica Warb., but somewhat smaller in size.

Fam. Gamasidae (Gamasid mites).

Leiognathus. Yü-lin Fu, Shensi.

Several specimens taken from the body of a mole-rat (Myospalax cansus), a rodent with the underground mode of life of a mole. These mites are somewhat uncommon, as many mole-rats were examined for them without any more being found. 
Laelaps agilis Koch. Yen-an Fu, Shensi.

Several specimens taken from Mus confucianus luticolor, a rat related to the common sewer rat, on which Laelaps agilis usually occurs. These specimens cannot be separated from the above species, though in some respects they differ slightly.

\section{LEPIDOPTERA AND NEUROPTERA.}

BY A. DE C. SOWERBY.

I. Mycalesis gotama. Several specimens. Very common, especially on loess hill tops.

2. Mycalesis sericus. Several specimens. Also very common.

3. Lethe rohria. Several specimens. Common.

4. Athyma sulpitia. Two specimens. Very rare. Found only amongst bushes on hill side.

5. Callerebia phyllis. Common in loess gullies near Yen-an Fu, Shensi.

6. Melanargia halimede var. montana. Rare.

7. Pararge deidamia. Very common everywhere.

8. Apatura here. Coinmon only in valley-bottoms near Yen-an Fu, Shensi.

9. Argynnis aglaia. Not very common.

10. Grapta c. aureum, var pryeri. Common.

II. Chrysophanus dispar $q$ and $\lesssim$. Very common. Recorded from Kansu by Potanine.

12. Lycaena argus $q$ and $\delta$. Common everywhere.

13. Sericinus telamon. var. telamon. Very common in certain valleys of Eastern Kansu.

14. Sericinus telamon, var. greyi. Less common. Inhabits same district as I3.

15: Colias hyale. Very common everywhere.

16. Papilio machaon. Comparatively common. A few specimens caught in well watered valleys.

17. Gonepteryx rhamni. A yellow leaf-like butterfly. Fairly common in valleys. 18. Leucophasia sinapis, var. sinensis. Rare. Very few specimens seen.

19. Pieris cisseis. Very common.

Amongst the commonest of the dragonflies which were collected were various species belonging to the genus Matrona. These beautiful insects, as stated elsewhere,* abounded in the watery valleys of Eastern Kansu. 


\section{APPENDIX IV.}

\section{DESCRIPTION OF THREE NEW SPECIES OF SIPHONAPTERA}

OBTAINED BY CAPT. H. E. M. DOUGLAS, V.C., D.S.O., R.A.M.C., ON THE CLARK EXPEDITION IN NORTH CHINA-

BY THE HON. N. CHARLES ROTHSCHILD, M.A. F.L.S.

THE collection of fleas contains three species, which all prove to be new. The most interesting of them is the one found on a roedeer. Its nearest ally is a flea which occurs in Turkestan on horses, cattle, etc., and does a great deal of damage. The types of the species are in the British Museum.

I. Ceratophyllus subcaecatus spec. nov. (Fig. I and 2).

of $f$ The chief peculiarities of this species are the non-pigmented eye and the large eighth abdominal sternite of the $\delta$, which characters remove the species from true Ceratophyllus. There is, however, in that genus another species, C. silantiewi Wagner (1898), which is closely related to subcaecatus, although abundantly distinct. This $C$. silantierei has the eye non-pigmented in the centre and its clasper is very similar to that of $C$. subcaecatus, the eighth sternite being small. The two species, however, may easily be distinguished by the shorter rostrum of subcaecatus, the pointed genal lobe, the very short bristles of the second segment of the antennae in both sexes (these bristles being long in the $f$ of silantiewi), the smaller number of bristles on the abdomen and by other characters as well.

Head.-Frons vertical from the tubercle downward, the latter a little nearer to the central sensory organ (pale dot) than to the oral corner. Eye round, very feebly pigmented, excepting the anterior and postero-inferior edges, at a certain focus appearing excised. A row of three large bristles before the eye, the central one slightly nearer to the lowest, in between these bristles some minute hairs, and in front of the row another row of three, the uppermost of which is placed close to the antennal groove in the $\delta$, and is absent in the $q$. Genal lobe more or less pointed. The occiput has one large bristle above the antennal groove before the centre, and a subapical row of 6 on each side, of which only the most ventral one is large. Along the 
antennal groove there is a row of about twelve short hairs in the $\delta$ and about six in the $q$. In the $q$ there is no trace of a suture from the antennal groove to the vertex. The groove is posteriorly open in both sexes and extends well on to the propleura in the $\delta$. The bristles of the second segment of the antenna are minute in both sexes; the club of the antenna is half as long again as it is broad in the $q$. The maxillary palpus nearly reaches to the apex of the forecoxa, and the rostrum extends to the trochanter, but not beyond it, as is the case in silantiewi.

Thorax.-The pronotum bears a comb of 18 pointed spines and a row of Io to I2 long bristles. The mesonotum has a posterior row of Io to I2 bristles, and before it about 8 to II small bristles on the two sides together ; on the inner side, before the apex, there are 6 to 8 bristle-like spines. The mesopleura have 6 or 7 bristles, and at the upper anterior corner a few small hairs. The metanotum has 2 rows of bristles, the anterior one containing 9 to I2 and the posterior one II or I2. The metepisternum bears 2 bristles, the sternum I, and the epimerum 6 to 8 ( 2 to $4,3, I$ ). Metanotum on each side with 2 dark brown spines, one such spine being similarly placed on the 2 or 3 anterior abdominal tergites.

Abdomen.-The stigmata are situated above the first bristle of the posterior row, excepting the seventh segment of the $q$, where this bristle is absent. The position of the spiracles is different in the sexes, the stigma being close to the row of bristles in the $\delta$, and at a considerable distance in front of the row in the $q$. The numbers of bristles on the tergites are in the anterior and posterior rows of the two sides together in the specimens before us: in the $\delta, 4$ to 8,$10 ; 4$ to 6,$12 ; 3$ to 5,12 ; I to 5,12 ; I to 4,12 ; 2 to 7,$12 ;-$ in the $q: 6$ to 7,$8 ; 4$ to 9,$12 ; 2$ to 4,$12 ; 2$ to 4 , II or I2; 2,$12 ; 2,2,10 ; 4$ or 5,8 . The sternites bear one row, there being no additional bristles in front of the row; the numbers are on the two sides together, in the $\delta: 2,5,6,6,6,6 ;$-in the $q: 2,6,6,6,6,8$ to $\mathrm{II}$. The basal sternite has in addition one or two lateral bristles on each side. There are two antepygidial bristles in the $\delta$, the upper one measuring about onethird of the other. In the $q$ there are three, the upper being about one-fourth and the lower four-fifths the length of the central bristle.

Legs. - The hind coxa has about 7 bristles on the outer side, a row of 8 to Io on the inner, and 5 to 7 at the edge, apart from the apical bristles. The hind femora bear on the outside I to 3 lateral bristles anteriorly, and one subapical bristle posteriorly. On the inner surface there is a row of 4 or 5 bristles on the mid femur and of 5 to 7 on the hind femur. The hind tibia 
bears on the outer side a row of 7 to Io bristles (inclusive of one placed close to the apex), and on the inner side an oblique (or broken) row of 4 to 6 , there being also several small bristles at the anterior edge, apart from the thick apical and subapical ones. The longest apical bristle of the hind tibia extends to the subapical notch of the first hindtarsal segment, or a little beyond it. The longest apical bristle of the second hindtarsal segment reaches nearly to the middle of the fifth in the $q$, while in the $\delta$ there are three apical and one subapical bristles on the second segment which extend to near or beyond the middle of the fifth segment, the third segment also bearing a long apical bristle in the $\delta$. The fifth segment has in all the tarsi five pairs of lateral bristles

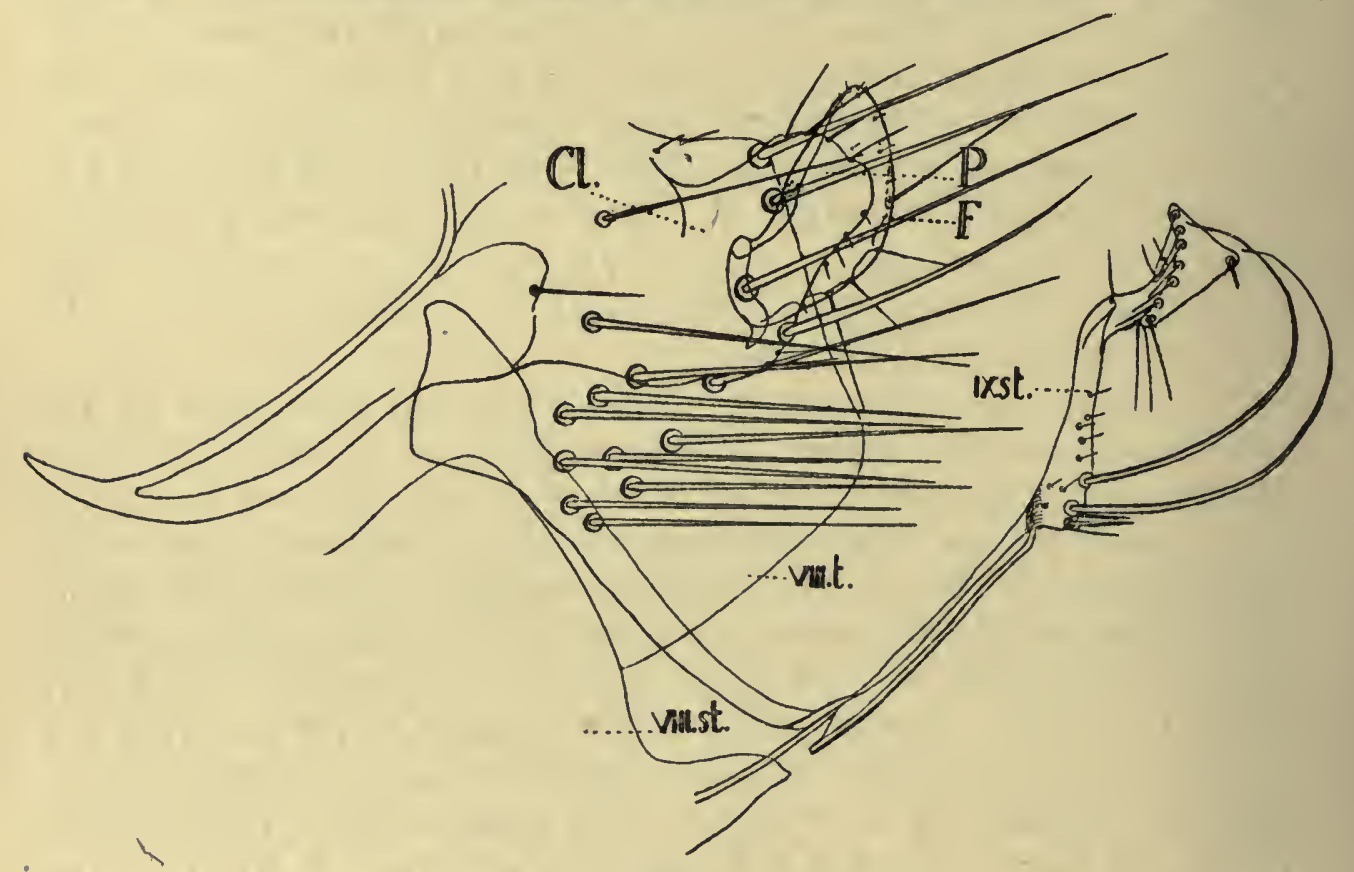

Fig. 1.

and two short stout apical ventral ones. Lengths of the tarsal segments :-

Foretarsus ... $\delta$ II, II, 8, 7, I7 - क 13, 13, I0, 8, I8.

Midtarsus ... $\delta$ I9, I7, 10, $8,18-q 23,20,13,9$, I9.

Hindtarsus... क $43,30,17,10,20-$ \& $50,36,18$, II, 22.

Modified Segments. $-\tau$. The eighth tergite (Fig. I, viii. t.) bears about 8 small hairs above the stigma, and is characterised by 16 to $I 8$ strong bristles, of which 8 to ro are grouped together on the side of the segment as shown in the figure. The eighth sternite is not very much smaller than the tergite. It 
resembles the preceding sternite, but is longest ventrally as shown in the figure (Fig. I, viii. st.), and bears on each side only one long bristle, which is accompanied by a few hairs. The clasper (Fig. I, Cl.) is not separated by a suture from the internal portion of the ninth tergite, and this internal portion of that segment is produced into a kind of manubrium. The manubrium of the clasper itself terminates in a slender point. The dorsal posterior portion of the clasper forms a broad process (P), which is about as long as it is wide. The moveable process (F) is almost shaped like a thumb in side view, the distal margin being much more strongly rounded than the proximal margin. The distal margin bears one slender bristle at one-third or one-fourth from the base and a much longer one beyond the centre or at two-thirds, besides a number of short ones as indicated in the figure. In the second $\delta$ the "finger" is more rounded at the apex than in the one figured. There is only one long bristle at the edge of the clasper below the insertion of the finger and several small hairs. The ninth sternite (Fig. I, ix. st.) is exceedingly slender, the vertical arm as well as the horizontal one, excepting the apex of the vertical arm. The distal half of the horizontal arm is about twice the width of the proximal half, and its peculiar shape reminds one a little of a rocking horse reversed. This portion of the sternite is elbowed beyond the centre, the apical two-fifths being curved downwards and bearing at the proximal ventral corner on each side two long bristles, which are evenly curved and are accompanied by two more, which are short and spine-like in shape. The tip of the sternite is truncate, the apical portion being triangular and bearing along the upper edge a row of hairs on the outer side and two hairs on the inner side, and at the ventral angle one short spine-like bristle on the inner side. The tenth tergite is distinctly separated from the ninth by a suture, which is situated at some distance from the sensory plate. The tenth tergite bears about 6 short hairs on each side and a row of short bristles along the apical edge. $-q$. The apex of the seventh abdominal sternite is very slightly incurved twice (Fig. 2). The eighth tergite bears 5 to 7 short hairs above the stigma, and one or two long bristles, accompanied by one or two small hairs below the stigma. The apical margin is rounded and slightly undulate, with the lower angle projecting (Fig. 2). There are only 8 or 9 bristles on the outer side of the lower half of the eighth tergite and 4 on the inner side. The bristle at the tip of the stylet is much shorter than the bristles of the posterior row on the sixth tergite, but longer and thicker than the longest bristle of the anal sternite. This latter sternite bears ventrally in the centre, where it is slightly elbowed, a cluster of short, thick, spine-like bristles, which are separated from the subapical 
bristles by a small gap. The stylet is about twice as long as it is proximally broad, and bears two bristles besides the apical one. The receptaculum seminis has a short globular head and a broad tail, which is thinnest at the base.*

Length (mounted specimens): o $2.2 \mathrm{~mm}$.; \& $2.4 \mathrm{~mm}$.

Two $\delta$ and $9 q q$ from Yen-an Fu, Shensi, taken off Mus confucianus luticolor on December 22nd, 1908.

"The host is a rock-inhabiting rat, very often with numerous ticks and fleas. In some cases this rat is trapped in small caves in rocks where human remains have been deposited, and it is possible that they feed upon these dead bodies."

"Yen-an Fu, a city situated in North Central Shensi."

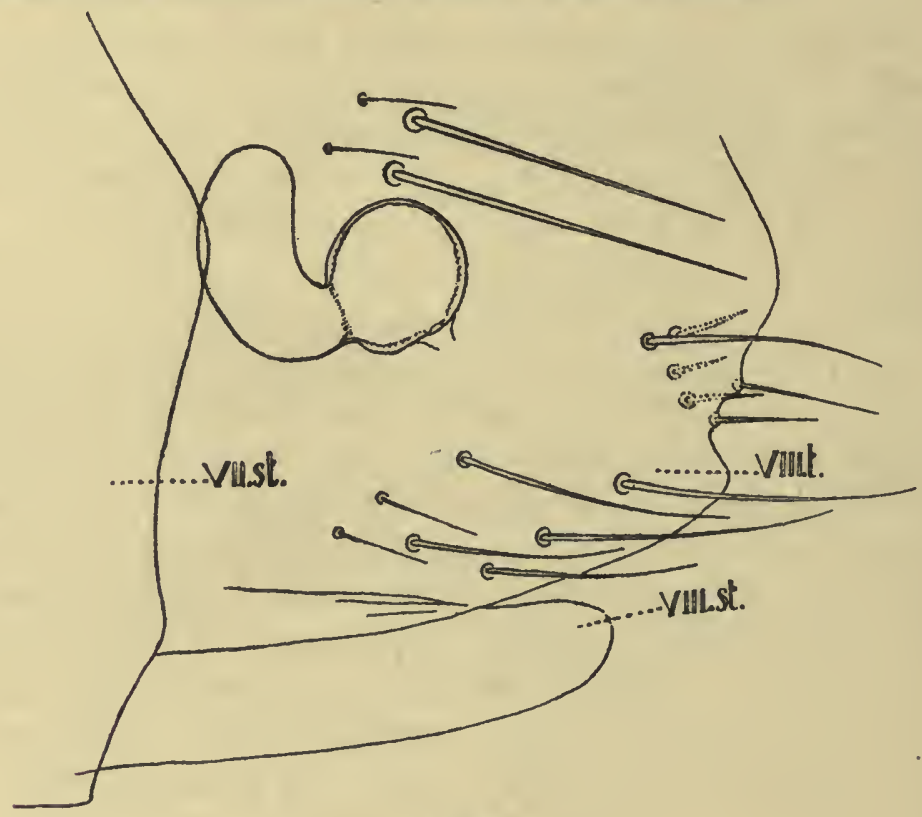

Fig. 2.

2. Neopsylla anoma spec. nov. (Fig. 3 and 4).

J \& Similar to $N$. bidentatiformis Wagner (I893), but at once distinguished by the hind coxa bearing a patch of short spines on the inner surface.

Head.-Frons evenly but so strongly rounded that the oral corner points obliquely backwards. Eye absent, being only indicated by a bar projecting

* For the sake of economy of space the receptacle is drawn lying in the eighth segment. 
from the incrassate margin of the antennal groove. There are two rows of bristles on the frons, the anterior one containing 6 to 8 and the posterior one 4 longer bristles, one of these 4 being placed at the edge of the antennal groove. The occiput bears three rows of bristles, the numbers of the bristles being on each side 3,5 or 6,6 . The second segment of the antenna bears a row of bristles, of which the longest is one-third the length of the club in the $\delta$, while in the $q$ there are 4 bristles which are as long as the club or nearly so. The genal angle bears two spines, the outer one being short, broad, triangular, and crossing the inner one, which is long and narrow. The lobe of the genal angle itself (partly covered by the spines in lateral aspect) is lanceolate. The rostrum is about one-fourth shorter than the forecoxa. The maxilla reaches to the apex of the third segment of the rostrum, and the maxillary palpus to the base of the fifth segment.

Thorax. - The pronotum has a comb of 18 spines and a row of $\mathrm{I}_{2}$ or $\mathrm{I}_{3}$ bristles on the two sides together, there being no bristles in front of this row. The mesonotum has two rows of bristles, the anterior row containing 17 or 18 and the posterior row I2, there being also 3 or 4 additional small bristles in front of the rows, numerous small hairs at the base, and Io bristle-like spines before the apex on the inner side. The mesopleura have seven bristles. The metanotum also bears two rows of bristles, the numbers being 20 and 12 . The metepisternum has two bristles, the sternum one, and the episternum II to I4 (in $\delta 5,2,5$ or 6,2 ; in $q 5,4$ or 5,2 ). There are no apical spines on the metanotum in the two specimens before us.

Abdomen.-The first three or four tergites bear two or three apical spines on the two sides together. All the tergites have two rows of bristles, there being usually a few additional bristles in front of the rows, the numbers being as follows: in the $32,16,15 ; 2,14,18: 1,7,17 ; 0,6,17 ; 1,4,18 ; 0,4$ $16 ; 1,6,15$; and in the $+5,15,12 ; 2,21,16 ; 2,16, I 7 ; 0,15,16 ; 0,15$, $15 ; 0,15,14 ; 3,12,13$. The sternites bear one row of bristles and a few small hairs before the row as follows; in the $22,4,6 ; 2,7,6,6 ; 6,7$; and in the $f 2 ; 5,7 ; 6,8 ; 5,8 ; 14,12$. The first sternite of the $q$ bears in addition 2 or 3 small bristles on each side. There are three antepygidial bristles in the $q$, the upper and the lower bristles being about one-third the length of the middle one. In the $\delta$ there are two bristles above the long one, the two being about the same in length as the fourth on the one side, while on the other side the one nearest the long bristle is apparently (its tip being broken off) nearly as long as the large bristle.

Legs. - The hind coxa bears posteriorly before the apex 3 bristles and 
about forty bristles on the outer and inner sides together, apart from the short spine-like bristles of the inner surface and the bristles placed at the apex. The hind femur has two subapical bristles on the outer side, and one on the inner side, this side bearing also one or two lateral hairs in the basal half. The hind tibia has on the outer surface in the $\delta$ Io or II, and in the $q 7$ or 8 bristles, the latter arranged in one row only, while in the $\delta$ there are some bristles ventrally (or anteriorly) to this row. The bristles at the outer edge of the hind margin are nearly all of the same length and thickness, being all very strong; they number $I I$ if the apical ones are included. At the inner edge there are 4 long bristles, one of them being placed at the apex and extending somewhat beyond the apex of the first tarsal segment. The first mid tarsal

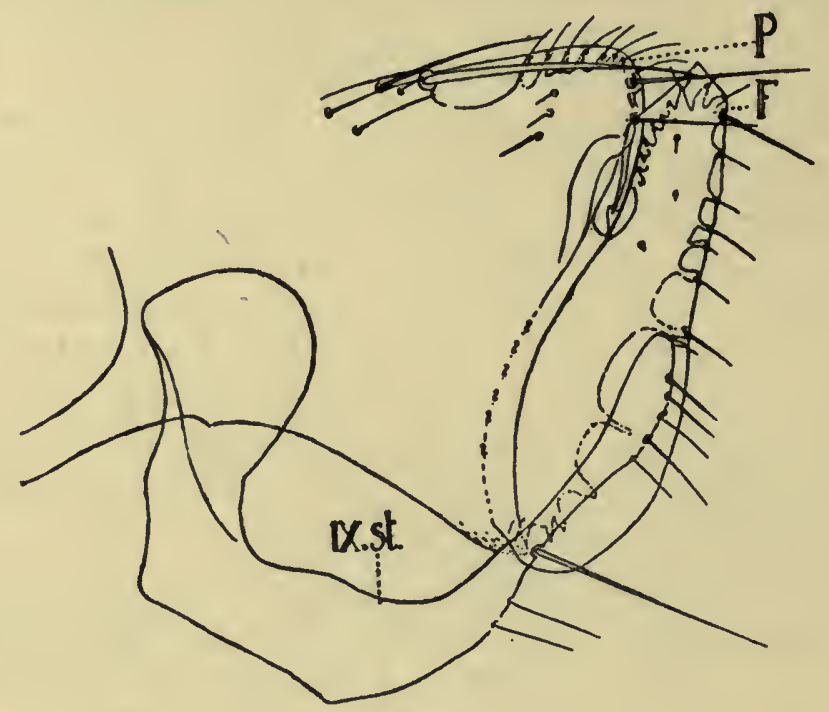

Fig. 3.

segment is one third longer than the second; the bristles placed at its hinder edge are short and thick, as are the corresponding bristles of the hind tarsus, while the bristles at the anterior edge of the segment are much thinner (apart from the apical ones) and fewer in number. The longest bristle of the second hind tarsal segment extends to the apex of the third segment. The fifth segment bears in all the tarsi 4 pairs of lateral bristles and two short apical ventral bristles. The lengths of the tarsal segments are in both sexes:-

$\begin{array}{lll}\text { Foretarsus } & \ldots & \text { I0, } 9,8,6,14 . \\ \text { Midtarsus } & \ldots & 21,16,10,7,14 . \\ \text { Hindtarsus } & \ldots & 30,22,15,9,16 .\end{array}$


Modified Segments. $-\Im$. The eighth tergite, which is quite small in this genus, bears about 6 short hairs above the stigma. The sternite, which is large, is apically truncate-emarginate in side-view, with the angles strongly rounded off, and bears along the ventral margin and near it about 15 or 16 bristles, of which 5 or 6 ventral ones are especially large and are arranged in a row. The clasper (Fig. 3 ) is about as long above as beneath. Its upper distal angle is rounded off and the lower angle acute. The upper edge bears a number of bristles, of which one is considerably longer than the others. The manubrium is slender, of nearly even width and gently curved upwards. The moveable process $(F)$ projects but little above the upper angle of the clasper and extends far down, as is the case also in several allied species. It

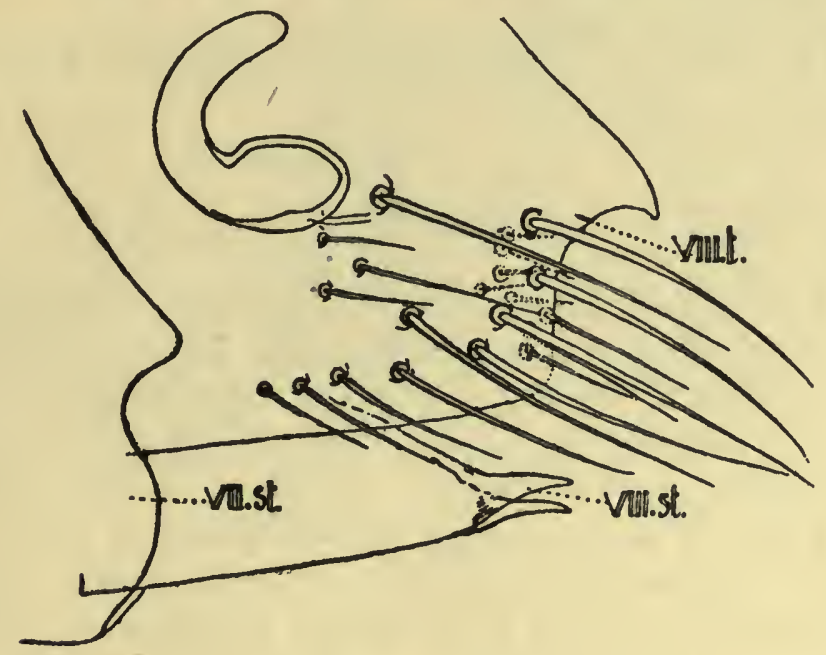

Fig. 4.

is almost the shape of a sugar loaf, with the lower end rounded. The bristles which it bears are all small, the longest one being placed near the apex, and being about as long as the process is broad at that point. The internal arm of the $9^{\text {th }}$ sternite (Fig. 3, ix. st.) is elbowed and very broad, while the horizontal arm is narrow, being narrowest about the centre and widening a little in the apical half, where the gently rounded ventral edge bears a row of short bristles. One long bristle is placed proximally to the middle of the horizontal arm and several smaller ones are still further proximal.q. The apical margin of the seventh sternite is incurved below its upper angle and then excurved (Fig. 4). The eighth tergite bears about 6 short hairs above the stigma. There is no bristle below the stigma. The lower 
portion of the segment bears 6 or 7 long and strong bristles, 4 or 5 of which are placed near the edge, there being 3 to 8 additional smaller bristles proximally to the large ones. On the inner side there are about 8 to Io bristles. The eighth sternite is sharply pointed. The sensory plate is convex as in the allied species (not in Mesopsylla). The head of the receptaculum seminis is longer than it is broad, while the tail is about half as long again as the head in the view represented by our figure.

Length (mounted specimen) : $2.5 \mathrm{~mm}$.

One pair from Yü-lin Fu, Shensi, taken off Myospalax consus on November $24^{\text {th, }}$ Ig08.

"Yü-lin Fu, a town situated on border of the Ordos Desert. Surrounding country very dry and sandy."

"Myospalax consus, a rodent with the underground habits of a mole. Fleas very rare on the animal."

\section{Vermipsylla dorcadia spec. nov. (Fig. 5).}

$\delta$. As we are preparing a fuller account of this very interesting species, we confine ourselves here to pointing out some of the more striking characters by which both sexes of the new species are distinguished from its nearest known ally, $V$. alakurt. The tergites of the thorax and abdomen bear two rows of bristles, the anterior row being dorsally more or less incomplete and the bristles of both rows being short with the exception of the two bristles situated on each side below the stigma, which are fairly long. The female has even less bristles on the tergites than the male, the anterior row being almost completely absent. The sternites of the abdomen bear only one bristle on each side. The legs are very different from those of $V$. alakurt, especially the tibiae and tarsi, in which character the two sexes are practically identical. The mid tibia has four and the hind tibia only three pairs of long bristles at the dorsal edge, including the apical bristles, the other bristles being reduced to the size of the slender bristles situated on the outer surface, which are no longer than the lateral bristles of the femora. The thin dorsal bristles and those lateral ones which are placed between the dorsal edge and the centre of the tibia are directed backwards. The first segment of the fore tarsus as well as the mid tarsus is much shorter than the second. The bristles at the hinder edge of the first hind tarsal segment are thin and short ; this segment is only one third the length of the hind tibia and has a pale base. The second to fourth hind tarsal segments have each several apical bristles which are very 
long and extend beyond the fifth segment, these bristles being thinner and shorter than the corresponding long bristles of $V$. alakurt.

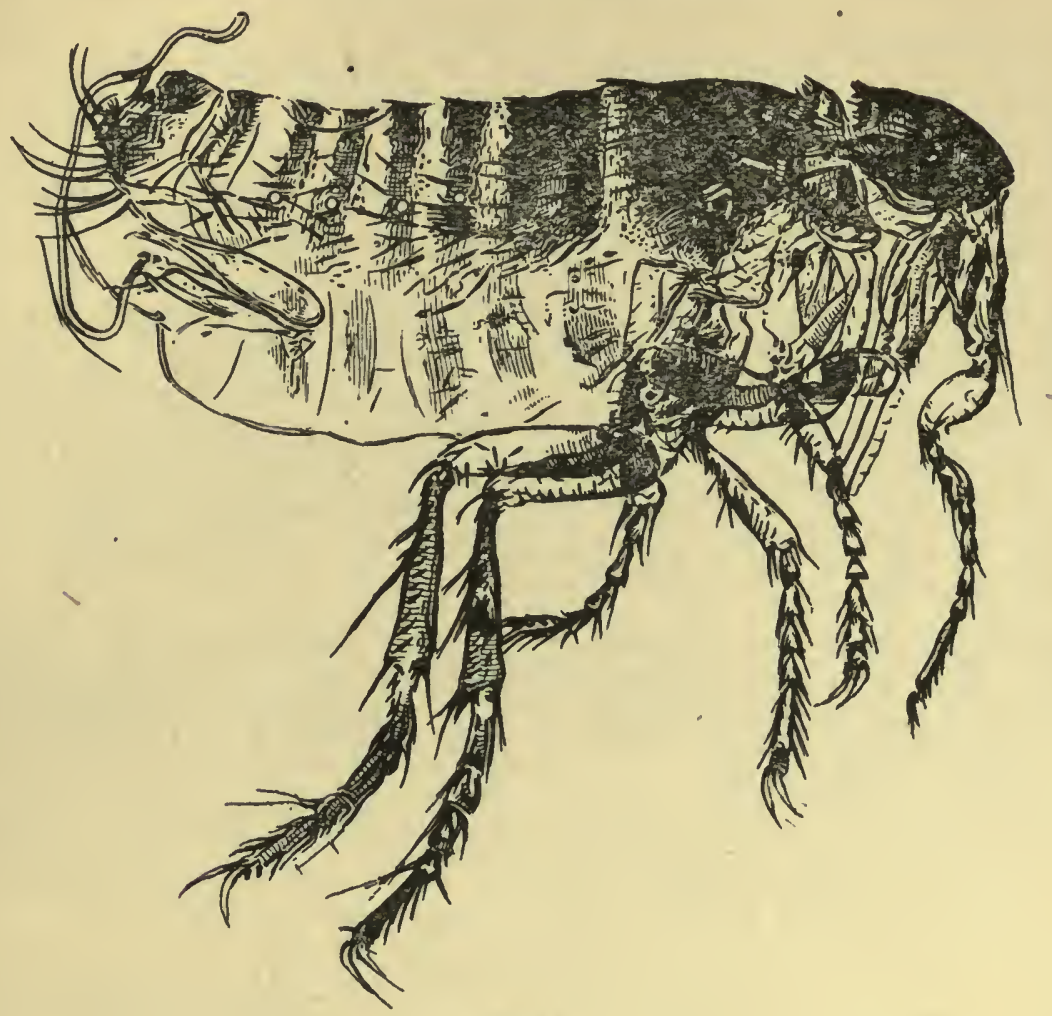

Fig. 5.

The species was discovered on a roedeer at Yen-an Fu, Shensi, by Capt. H. E. M. Douglas on January Igth, Igog. The much distended females were "taken from the nostrils of the Roedeer. . . . . . Several roedeer were shot in the district, but nothing more of the kind was noticed."

The males were "taken from the skin of the same Roedeer" on which the distended females were found.

A small series of both sexes was obtained. 


\section{APPENDIX V.}

ARANEIDAE OF THE CLARK EXPEDITION TO NORTHERN CHINABY H. R. HOGG, M.A., F.Z.S.

THE small collection of spiders herein described were taken during the

R. S. Clark expedition to Northern China, in the autumn of I908 and early part of 1909, by Captain H. E. M. Douglas, V.C., D.S.O., R.A.M.C.

The districts from which they came were Yün-t'ing Shan, in the Chiaoch'êng Shan, a mountainous forest-country ninety miles west from T'ai-yüan $\mathrm{Fu}$, Shansi, and Yü-lin Fu, in North Shensi, a dry sandy area on the borders of the Ordos desert.

Owing probably to the time of year, the specimens taken cannot be supposed to represent the Arachnid fauna of the district, an outlying part of what is known as the Indo Malay. A large proportion of the number have not reached the adult stage.

They comprise eight species of four families, and two of the latter, Argiopidae and Drassidae, are represented by a single specimen only of the genera Araneus, Clerck, and Drassodes, Westring.

There are three specimens of Thomisidae of the genus Diaea, Thorell, the remainder being all Lycosidae of the genera Lycosa, Latreille, Pardosa, C. Koch, and Evippa, Simon.

Evippa is a small genus whose members are recorded from the deserts of N. Africa, Palestine, and China; but the distribution of the others are world-wide.

The Drassodes appears to agree closely with $\mathrm{D}$. lapsus, described by Rev. O. P. Cambridge, from Yarkand,* and the Diaea is perhaps D. subdola Cambr., but none of the others seem to have been previously noted from India, China, Burma, or the neighbourhood. The known species of Araneus and the Lycosidae are so numerous, and many so widely spread, that they may have been recorded from even so far as Japan on the one side, or Western Europe on the other. As I cannot trace them I have taken them to be new species.

* Second Yarkand Mission, pt. VIII., Arachn : O.P. Cambridge, 1885. 


\section{Family Drassidae, Sub-fam Drassodinae, Group Drassodeae, Genus Drassodes, Westring. \\ D. ? LAPSUS. O.P.CAMBR.}

Female.-The Cephalothorax is bright orange yellow thickly covered with downlying grey plumose hair interspersed with a few upstanding hairs or bristles. The Mandibles, somewhat darker orange, are thickly covered with short upstanding grey bristly hair. Fangs reddish yellow.

The Lip, Maxillae, Sternum, and Coxae all orange yellow with rather long grey bristly hair, thickest on the latter. The Legs and Palpi similar, but rather paler. The Abdomen above is yellow at the base, the remainder pale yellow grey with brownish grey thin short hairs. Underneath it is a pale yellow, almost white at the edges, with short downlying grey hair in transverse ridges. The Spinnerets darker yellow, one jointed, cylindrical.

The Cephalothorax is convex, rounded at the sides and straight in front, where it is rather more than half its greatest breadth, which is two-thirds its length.

The front row of Eyes is straight, the median pair half their diameter apart, and the same distance from the margin of the Clypeus. The laterals, touching them, are nearly the same diameter, but placed sideways look oval. The rear row of eyes are sessile, the median, oblong, are half their shorter diameter apart at the upper corners, and their long diameter away from the laterals, the whole row being procurved and slightly longer than the front. The front and rear median are rather more than the diameter of the former apart, the long diameter of the rear ones being slightly shorter.

The Mandibles are kneed at the base and straight at the sides, as broad in the front as at the base. The fangs are broad at the base, thence tapering to a fine point. There are two quite small blunt teeth on the inner margin of the falx sheath.

The $L i p$ is longer than broad, tapering from the base to a narrow rounded upper margin. It is two-thirds the length of the Maxillae. The latter are rounded both at the base and in front, impressed in the middle and slope over the lip.

The Stermm is oval and flat, with thick upstanding bristles all round the margin and downlying flat hairs in the middle. The rear Coxae are close together.

The Legs are short, fairly thick in the femoral joints, tapering to the tarsi, which are quite fine. The front two pairs are without spines, and have scopulae, thin in the middle, on the tarsal and metatarsal joints. The Tibia 
and Metatarsus of the rear pairs are thickly bespined, with a bunch at the posterior end of the latter, but have no scopulae.

The Abdomen is oval, rather flat above and below, thickly covered with short fine hair. The Epigyne consists of two nearly circular hollows, open on the outer sides and separated by a flat longitudinal bridge. The Spinnerets are one jointed cylindrical, the inferior pair longest three-fourths their diameter apart.

The measurements in millimetres are as follows:-

Long. Broad.

$\begin{array}{lll}\text { Ceph. } & 2 \frac{1}{2} . & x \frac{3}{4} \text { (I in front). } \\ \text { Abd. } & 4 & 2 \frac{1}{2} \\ \text { Mand. } & I\end{array}$

Coxae. Tro. \& Fem. Pat. \& Tib. Metat. \& Tar.

$\begin{array}{rllllll}\text { Legs } & \mathrm{I} & \frac{3}{4} & 2 \frac{1}{2} & 2 \frac{1}{2} & 2 & =7 \frac{3}{4} \\ 2 & \frac{1}{2} & 2 & 2 & \mathrm{I}^{\frac{3}{4}}=6 \frac{1}{4} \\ 3 & \frac{1}{2} & \mathrm{I}^{\frac{3}{4}} & \mathrm{I}^{\frac{3}{4}} & 2=6 \\ 4 & \frac{3}{4} & 2 & 2 \frac{1}{2} & 2 \frac{1}{2}=7 \frac{3}{4}\end{array}$

(Palpi : Pat. longer than Tars.).

I female from Yü-lin Fu, North Shensi.

\section{Family Argiopidae, Group Argiopeae. \\ Genus Araneus, Clerck. ? SP.}

Cephalothorax pale yellow on the cephalic part, dark yellowish grey on the thoracic, scantily clothed with short white hair. The Mandibles are yellow blotched with grey, similar white hair, and fangs yellow brown. Maxillae yellow with grey fringes. Lip and Sternum yellow brown with grey hair and a pale longitudinal median stripe on the latter. The Legs pale yellow with white hair on the upper joints, brown bristles on the tarsi, which are themselves brown at the anterior end. The Abdomen is greyish green all over, the Spinnerets olive green.

The Cephalothorax is convex and one-fourth longer than broad. The cephalic part obtusely rounded in front and straight at the sides, the thoracic part rounded at the sides. The rear row of Eyes is straight, the rear median pair equal in size to the front median are only half their diameter apart. The front pair are one-and-a-half diameter apart and the same distance from the rear, thus forming a trapezium considerably broadest in front. The front laterals are rather smaller than the median, and two diameters of the latter away from them. They are half their diameter from the rear laterals, 
which are three diameters of their median distant from them. The Clypeus is the breadth of a front median eye. Both lateral eyes are nearly sessile:

The Mandibles are slightly kneed at the base, the fangs short and weak. The Lip is broader than long, less than half the length of the Maxillae, which are rather widely divergent at their anterior ends. The Stermum is broad shield shaped, convex, hollowed at the margin for the coxae, and pointed at the rear end, where the coxae are contiguous.

The Legs are tapering to the tarsal joints, which are fine, cylindrical, and rather short. The tarsal joint of the Palpi is flat and dilated at the base, and the palpal claw has about four pectinations. The tibial and patellar joints are of equal length.

The Abdomen is nearly globular, but one-fifth longer than broad, the surface is silky and rather finely granulated. The Spinnerets conical, two jointed, rather large.

The measurements in millimetres are as follows:-

Long. Broad.

\begin{tabular}{|c|c|c|}
\hline Ceph. & 2 & $I_{2}^{\frac{1}{2}}\left(\frac{3}{4}\right.$ in front $)$ \\
\hline $\begin{array}{l}\text { Abd. } \\
\text { Mand. }\end{array}$ & $\begin{array}{r}2 \frac{1}{2} \\
3\end{array}$ & 2 \\
\hline
\end{tabular}

Coxae. Tro. \& Fem. Pat. \& Tib. Metat. \& Tar.

\begin{tabular}{|c|c|c|c|c|c|c|}
\hline Legs & I & $\frac{3}{8}$ & $\mathrm{I} \frac{3}{4}$ & I $\frac{3}{4}$ & $\mathrm{I} \frac{3}{4}$ & $=$ \\
\hline & 2 & $\frac{3}{8}$ & $\mathrm{I}_{2}^{\frac{1}{2}}$ & $\mathrm{I}_{2}^{\frac{1}{2}}$ & $\mathrm{I}_{\frac{1}{2}}$ & $=$ \\
\hline & 3 & $\frac{3}{8}$ & I & I & I & $=$ \\
\hline & 4 & $\frac{3}{8}$ & I $\frac{1}{4}$ & I $\frac{1}{4}$ & $\mathrm{I} \frac{1}{4}$ & $=$ \\
\hline Palpi & & $\frac{1}{4}$ & $\frac{1}{2}$ & $\frac{1}{2}$ & $\frac{1}{2}$ & $=$ \\
\hline
\end{tabular}

One non-adult female from Yün-t'ing Shan, North China, to which it is not desirable to attach a name, although the species belongs to a series in the genus of the type represented by A. hirtus C. Koch.

Family Thomisidae, Sub-family Misumeninae, Group Diaeee, Genus Diaea, Thor. Species ? subdola, Cambr.

The Cephalothorax has a wide oblong area of pale yellow reaching from the margin of the Clypeus to the top of the rear slope. A similarly coloured narrow stripe passes round the edge of the cephalic part with fine white hairs thereon, the space intervening between the two being blotchy brown. The Mandibles, Lip, Maxillae, and Sternum bright canary yellow; Legs and Palpi the same, with clusters of brown spots on the femora and tibiae, grey spines and grey scopulae on the tarsi. The Abdomen is pale yellow on both upper 
and under sides, including the Spinnerets; it is sparsely clothed with short flat white hairs. On the underside are two longitudinal rows of impressed spots.

The Cephalothorax is glabrous, as broad as long, tapering to a bluntly rounded front, it is strongly convex, much rounded at the sides of the thoracic part, a very distinct broad fovea separating the cephalic part from the thoracic. Viewed from above both rows of Eyes are recurved and all about equal in size; the front median are twice their diameter apart and rather more than their diameter from the laterals. The rear row is longer than the front. The median eyes are four times their diameter apart, and more than half that distance from the laterals. The two rows are three diameters apart, and the Clypeus as wide as a back and front median eye and the space between.

The Mandibles are conical with thin weak fangs. The $L i p$ is as broad as long, tapering from the base to a rounded point, and more than half the length of the Maxillae which lean over it. The Sternum is as broad as long, straight in front, and passing with a straight stem between the rear coxae, which are widely separated.

The Abdomen is ovate, smallest and nearly straight in front, and almost circular at the rear.

The Legs are long and fine. Scopulae on all tarsi, two spines above on the femora of the rear two pairs.

The measurements in millimetres are as follows :-

$$
\text { Long. Broad. }
$$

$\begin{array}{lll}\text { Ceph. } & \text { I } & \text { I ( } \frac{1}{2} \text { in front). } \\ \text { Abd. } & 2 & 2 \\ \text { Mand. } & \frac{1}{2} & \end{array}$

Coxae. Tro. \& Fem. Pat. \& Tib. Metat. \& Tar.

\begin{tabular}{|c|c|c|c|c|c|}
\hline Legs I & $\frac{1}{4}$ & $2 \frac{1}{2}$ & $2 \frac{3}{4}$ & $2 \frac{3}{4}$ & $=$ \\
\hline 2 & $\frac{1}{4}$ & $2 \frac{3}{4}$ & 3 & 3 & $=$ \\
\hline 3 & $\frac{1}{4}$ & $\mathrm{I}_{4}^{3}$ & I $\frac{1}{4}$ & $\mathbf{r} \frac{3}{4}$ & $=$ \\
\hline 4 & $\frac{1}{4}$ & 2 & $\mathrm{I} \frac{3}{4}$ & $\mathrm{I} \frac{3}{4}$ & $=$ \\
\hline Palpi & $\frac{1}{8}$ & $\frac{5}{8}$ & $\frac{1}{2}$ & $\frac{3}{8}$ & $=$ \\
\hline
\end{tabular}

Two females from Yün-t'ing Shan, Shansi, North China, ninety miles west of T'ai-yüan $\mathrm{Fu}$.

This species resembles in size and some points the Rev. O.P. Cambridge's Diaea subdola from Tarkand (loc. cit.), but his description is too meagre to render it certain. 
Family Lycosidae, Group Lycoseae, Genus Lycosa Latr.

L. CLARKI SP. N.

The Cephalothorax is orange yellow, with white downlying hair, darkening into brown in the well marked fovea separating the cephalic and thoracic parts, round the margin of the thoracic part, and in a row of rather large spots a little above the margin. The sides of the Eyespace are black, but not the middle part. The Mandibles are yellow brown with short white hairs. The Maxillae are yellow with long upstanding brown hair. Lip yellow brown. Sternum and Coxae bright yellow with brown upstanding hair, the other joints of the Legs canary yellow with white hair and faint grey rings, the hair darkening to grey on the tarsal joints.

The Abdomen is yellow on the upper side, mottled with rather large brown spots and short downlying white hairs, underneath pale yellow covered with rows of rather coarse downlying white hair.

The Cephalothorax is rather broad in front, rounded at the sides with a short thin longitudinal fovea at the top of the rear slope. The front row of Eyes are straight, the median pair larger than the side, half the diameter of the latter away from them, and twice that distance from one another. They are their own diameter from the margin of the Clypeus, and two-thirds that distance from the cyes of the second row. The latter are nearly twice the diameter of the front median, and their own diameter apart. They are the same distance from the rear row, which are rather smaller, and three of their diameters apart.

The Mandibles are as long as the front of the Cephalothorax is broad. They are sparsely covered with fine hairs, thickest at the outer margin. The fangs are long, not much curved. On the inner margin of the falx sheath are two equal teeth followed by one small.

The Lip is as broad as long hollowed in front, about half the length of the Maxillae which are broadest in front where they nearly meet.

The Stermum is convex ovate pointed at the rear end, where the Coxae do not quite meet. There is also a space between the second and third pairs. It is moderately covered with downlying fine hair and upstanding bristles at the sides.

The Legs are of moderate length and tapered to a fine point at the tarsus, there are no scopulae and the front two pairs have only a few short spines on the tibia. The two rear pairs rather long spines. The superior claws are pectinated at the basal end, the lower smooth. 
The Palpi are short, the femoral joint curved inwards and widening anteriorly, the tibial joint is as long as the patellar.

The Abdomen is oval and is thickly covered with short downlying hair, the Spinnerets are two jointed and of moderate length. The male and female are coloured alike.

The measurements in millimetres are as follows:-

Long. Broad.

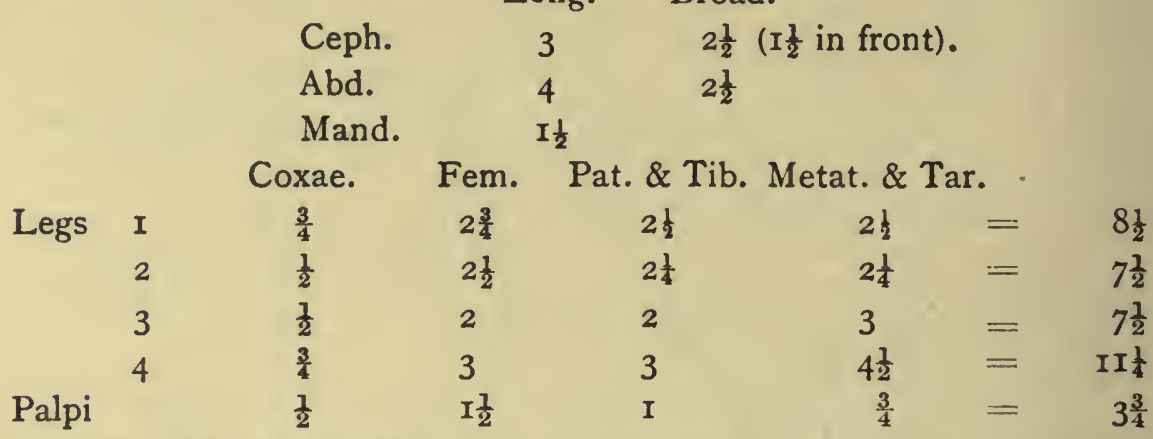

A few specimens from Yü-lin Fu on the borders of the Ordos desert.

LYCOSA, ORDOSA SP. N.

The Cephalothorax is dark yellow brown, black on the eye area, thickly covered with downlying white hair on the slightly lighter median stripe, reddish on the side slopes, and white again on the marginal border. The Mandibles are brighter yellow brown with upstanding white bristles on the basal half, brown bristles on the lower half, and black fangs. The Lip is dark yellow brown, paler at the front margin, the Maxillae brighter yellow, both with long upstanding hairs and bristles. The Sternum is black brown, with a short wedge shaped longitudinal, yellow patch in front, and long upstanding bristly hairs. Legs bright orange, thickly covered with downlying white hair, grey rings on the femoral joints and brown spines. The Abdomen both on upper and under surfaces is darkish yellow thickly covered with flat white pointed hairs. The Spinnerets rather darker yellow brown.

The Cephalothorax is convex rounded at the sides square in front with a short narrow longitudinal fovea at the top of the rear slope. The front row of Eyes are slightly procurved, the median larger than the side-rather more than half their diameter apart, and less than half of the same from the laterals. The Clypeus is three fourths the diameter of the front median and they are the same distance from the eyes of the second row. These are nearly twice the diameter of the front median and slightly more than their own diameter 
apart. The eyes of the rear row are the same distance away, a little smaller and twice as far apart as their distance from the second row.

The Mandibles are kneed at the base, have stout moderately long fangs, and two equal sized teeth on the inner side of the falx sheath.

The Lip is as broad as it is long, hollowed in front, and half as long as the Maxillae which are upright, broad in front, and have a few upstanding hairs on the outer side.

The Stermum is broad, truncate in front and pointed at the rear, where the coxae are contiguous.

The Legs are moderately thick at the base, tapering to the tarsal joint, the femora bent to the side of the body, no scopula but numerous upstanding bristles on the tarsi of III. and IV., a scopula on tarsus I. and II., and spines on all legs. There are two spines above on the femur of all legs, two single and two pairs above on tibia III. and IV., one inside the patella of III. and IV.

The Abdomen is oval, the Spinnerets two jointed, the first cylindrical the second hemispherical.

Measurements in millimetres as follows:-

Long. Broad.

$\begin{array}{llll}\text { Ceph. } & 3 \frac{1}{2} & 2 \frac{1}{2} & \text { (I } \frac{3}{4} \text { in front). } \\ \text { Abd. } & 4 & 2 \frac{1}{2} \\ \text { Mand. } & I^{\frac{3}{4}} & \end{array}$

Coxae. Tr. \& Fem. Pat. \& Tib. Metat. \& Tars.

\begin{tabular}{|c|c|c|c|c|c|c|}
\hline Legs & I & I & $3 \frac{1}{2}$ & $3 \frac{1}{2}$ & $3 \frac{1}{2}$ & $=$ \\
\hline & 2 & I & $3 \frac{1}{2}$ & 3 & $3 \frac{1}{2}$ & $=$ \\
\hline & 3 & I & 3 & $2 \frac{1}{2}$ & 3 & $=$ \\
\hline & 4 & I $\frac{1}{4}$ & 4 & 4 & $5 \frac{1}{2}$ & $=$ \\
\hline Palpi & & $\frac{1}{2}$ & $I_{2}^{\frac{1}{2}}$ & $I_{1}^{\frac{1}{2}}$ & I $\frac{1}{4}$ & $=$ \\
\hline
\end{tabular}

Three males not quite, adult and several females doubtfully so from Yü-lin $\mathrm{Fu}, \mathrm{N}$. Shensi.

\section{Group Pardoseae, Genus Pardosa. \\ P. SHANSIA SP. N.}

The Cephalothorax is black brown with a grey haired marginal stripe, a median grey longitudinal stripe on the thoracic part only, and grey haired side stripes radiating from the thoracic fovea. The Mandibles are black brown with reddish hairs on the basal half, dark brown on the anterior, fangs black. The 
Lip and Maxillae are black brown. The Sternum and inner part of the Coxae intensely black with long dark brown hairs, but at the anterior end of the Coxae pale yellow grey hair. The Abdomen is without pattern above, the skin dark brown, the hairs sandy yellow. Underneath, a broad black area extends from the epigyne to just in front of the spinnerets. The sides and rear are yellowish grey. The Legs and Palpi have the femoral joint red brown with yellowish grey hair, the other joints black brown with the same coloured hair over the main portions, but a black haired spot on the inside of the patella, at the anterior end underneath the tibia, and a black bare streak along the inner side of the Metatarsus. The Scopula on the Tarsus and Metatarsus of the front two pairs is grey, that on the rear tarsi black, spines black.

The Cephalothorax, 2mm. longer than broad, is convex, rounded at the sides, the cephalic part raised. At the Clypeus it is nearly two thirds the greatest breadth of the thoracic part but only half that width at the upper eye space which is the same height above the clypeus margin. The front row of Eyes is straight, the median larger than the side, half their diameter from one another and rather more from the second row pair, slightly less from the laterals. The Clypeus is the breadth of a front median eye. The diameter of the eyes of the second row is equal to the breadth of one of the front median eyes together with its distance from its lateral. They are not quite their diameter apart, and the whole row is shorter than the front row. They are their diameter distant from the third row pair, which are oval when viewed from above, as broad as the front median, and $3 \frac{1}{2}$ times that distance apart.

The Mandibles are stout and broad, rather flat at the base and clothed with long shaggy bristly hair. The fangs are stout and blunt. Low down on the inner margin of the falx sheath are three large blunt equal size teeth, and on the outer margin one smaller and then one larger also low down. The Lip is rather cup shaped, broader than long, hollowed in front and less than half the height of the Maxillae which are upright, convex, rounded at the upper and outer margins and thickly covered with long stout bristles.

The Sternum is a broad shield shape straight in front pointed at the rear where the Coxae are close together; it is thickly covered with long upstanding bristly hair. The Legs are moderately long and stout, they are thickly covered with very bristly hair, more especially on the underside of the femora. There are thick scopulae on the tarsi and metatarsi of the front two pairs, and on the tarsi only of the rear two pairs. There are no spines on the upper side of any of the tibial joints, but short stout ones at the side edge. 
The Abdomen is oval and convex, fairly thickly covered with short smooth downlying hair on the upper side, thick and coarser at the sides and underneath.

The Spinnerets are two jointed, the lower joint broadly cylindrical the upper hemispherical. The Epigyne is roughly triangular the upper edge straight with a median ridge descending therefrom into a sloping hollow.

The measurements in millimeters are as follows :-

Long. Broad.

$\begin{array}{lll}\text { Ceph. } & \text { II } & 9\left(2 \frac{3}{4} \text { to } 5 \frac{1}{2} \text { in front }\right) \text {. } \\ \text { Abd. } & \text { I } 4 & \text { ro } \\ \text { Mand. } & 5\end{array}$

Coxae. Tr. \& Fem. Pat. \& Tib. Metat. \& Tar.

\begin{tabular}{|c|c|c|c|c|c|c|c|}
\hline \multirow[b]{2}{*}{ Legs } & \multirow[b]{2}{*}{$I$} & \multirow[b]{2}{*}{$3 \frac{7}{2}$} & \multirow[b]{2}{*}{$8 \frac{1}{2}$} & \multirow[b]{2}{*}{$8 \frac{1}{2}$} & \multicolumn{2}{|c|}{$\frac{1}{2} \quad 4 \frac{1}{2}$} & \multirow[b]{2}{*}{$30 \frac{1}{2}$} \\
\hline & & & & & ro & $=$ & \\
\hline & 2 & $3 \frac{1}{2}$ & 8 & 8 & $9 \frac{1}{2}$ & $=$ & 29 \\
\hline & 3 & $3 \frac{1}{2}$ & 8 & 7 & 9 & $=$ & $27 \frac{1}{2}$ \\
\hline & 4 & $3 \frac{1}{2}$ & ro & $8 \frac{1}{2}$ & $12 \frac{1}{2}$ & $=$ & $34 \frac{1}{2}$ \\
\hline Palpi & & 2 & 5 & - $4 \frac{1}{2}$ & 3 & $=$ & $14 \frac{1}{2}$ \\
\hline
\end{tabular}

(Pat. shorter than Tibia).

One female from the mountainous forest country of Yün-t'ing Shan, N. China. Captain Douglas, V.C.

\section{PARDOSA, SOWERBYI SP. N.}

On the Cephalothorax is a red brown median stripe from the rear row of eyes to the rear and a similarly coloured marginal stripe, both with white downlying hair; between these on the sides it is black brown with dark brown hair on the upper part, on the lower margin reddish, and the same at the sides of the eye space. The eye space itself is black brown. The Mandibles are red brown with short greyish yellow bristles at the base and outer margin, and longer upstanding brown hair on the remainder, the fangs are red at the base, darker at the point, but nearly black in the middle. Lip and Maxillae are orange with paler edging. Sternum rich yellow brown at the sides with a paler longitudinal median stripe thickly clothed with white, and a few brown bristly hairs. The Coxae and Femora underneath are bright orange with white hair and grey spines; the upper sides of the legs are dark brown with brown and white hairs. There is a grey Scopula on the tarsi and lower end of the metatarsi of the front two pairs, and brown hairs on the two rear pairs. The Abdomen is a uniform red brown above with downlying short reddish yellow hair, black brown at the sides, underneath pale 
yellow-brown, thickly covered with downlying white hair interspersed with long upstanding brown hair. The spinnerets are brown with yellow tips.

The Cephalothorax is strongly convex, straight in front and straight along the median line; from the second row of eyes to the rear slope there is a long deep fovea. The Eyes of the front row are slightly procurved, the median only a little larger than the side, they are about their diameter apart, and the row is shorter than the second row. The Clypeus is a little broader than the front median eyes, but the latter are nearly twice their diameter from the second row. The latter are more than one and a half times their diameter apart, and the same distance from the third row of eyes, which are two-thirds as broad as those of the second, and five times their diameter apart.

The Mandibles are long and stout, but not much curved at the base. There are two very large teeth on the inner margin of the falx sheath. The Lip is straight but slightly hollowed in front, rounded at the sides, not quite as long as broad, and a little less than half the length of the Maxillae.

The Sternum is ovate, rather pointed at the rear where the rear Coxae are contiguous.

The Legs are fairly long and powerful, with very long stout spines above on Metatarsus iii. and iv., and a single long spine on the inside of the patella of same, and two above on the femur. There is a scopula on the Tarsus and lower end of the Metatarsus of the front two pairs, but none on the rear pairs. The claws are strong and well pectinated.

The Abdomen is oval, only slightly rounded in front. The Spimerets cylindrical, two jointed, the second joints being apparently protusible.

The measurements in millimetres are as follows :-

Female.

Long. Broad.

Ceph. $\quad 4 \frac{1}{2} \quad 3$ ( 2 in front).

Abd. $\quad 5 \frac{1}{2} \quad 3$

Mand. 2

Female.

Coxae. Tr. \& Fem. Pat. \& Tib. Metat. \& Tar.

\begin{tabular}{|c|c|c|c|c|c|c|}
\hline \multirow[t]{4}{*}{ Legs } & I & $\mathrm{I}_{4}^{\frac{1}{4}}$ & 4 & 4 & $4 \frac{1}{2}$ & $=$ \\
\hline & 2 & It & $3 \frac{1}{2}$ & $3 \frac{1}{2}$ & 4 & $=$ \\
\hline & 3 & I & $3 \frac{1}{4}$ & 3 & 4 & $=$ \\
\hline & 4 & I吾 & $4 \frac{1}{4}$ & 4 & $\begin{array}{c}4,2 \\
6\end{array}$ & $=$ \\
\hline Palpi & & $\frac{3}{4}$ & It & It & I & $=$ \\
\hline
\end{tabular}




\section{Male (not quite aduit).}

Coxae. Tr. \& Fem. Pat. \& Tib. Metat. \& Tar.

\begin{tabular}{|c|c|c|c|c|c|c|}
\hline Legs & I & $\mathrm{I}_{4}^{1}$ & $3 \frac{1}{2}$ & $3 \frac{1}{2}$ & 4 & $=$ \\
\hline & 2 & I & 3 & 3 & $3 \frac{7}{2}$ & $=$ \\
\hline & 3 & I & 3 & 3 & $3 \frac{1}{2}$ & $=$ \\
\hline & 4 & I支 & 5 & $4 \frac{1}{4}$ & $\begin{array}{c}4,2 \\
6\end{array}$ & $=$ \\
\hline Palpi & & $\frac{3}{4}$ & I & I $\frac{1}{4}$ & $\mathrm{I}_{2}^{\frac{1}{2}}$ & $=$ \\
\hline
\end{tabular}

I Male, I Female and three quite small from Yün-t'ing Shan, Shansi, N. China. I have named them after Mr. A. de C. Sowerby.

Genus EvipPa, Simon.

E. DOUGLASI NOV. SP.

Female.-The cephalic part of the Cephalothorax is black brown with flat downlying white or reddish hairs. The thoracic part is dark yellow brown in the median area, with two broad black patches reaching therefrom to the margin, and a thin paler streak quite at the margin, the whole covered with thick downlying reddish white hair. The Mandibles are dark yellow brown with long white bristly hair on the upper half, nearly smooth with long brown bristles on the lower, the fangs reddish yellow. The Lip and Maxillae have broad pale yellow margins, the outer and lower parts yellow brown, with thin upstanding brown hair. The Sternum is deep chocolate brown with downlying flat white hair. The Legs and Palpi are bright yellow, with a black streak on the inner side of the femur and small black spots on the other joints, on the upper surface are black spots in transverse bars. The Abdomen on the upper side is pale greyish yellow, thickly mottled with black spots, a black median scolloped pattern pointed at the rear end reaches from near the base to half-way down, at the sides of the last scollop are two pairs of black spots, and below them two pairs of transverse bars made up of smaller spots. It is thickly covered with short thick hair white and reddish white. The sides and underneath are yellow mottled with black spots, short thick downlying white hairs and upstanding brown bristles.

The cephalic part of the Cephalothorax, which is square in front and straight at the sides, rises abruptly from the thoracic at an angle of 45 degrees and is separated therefrom by a deep and broad crescentic fovea. The thoracic part is convex and rounded at the sides with a deep longitudinal fovea running from the junction with the cephalic to the rear slope. The hairs are flat and wedge shaped. The front row of Eyes is procurved, the 
median pair, their diameter apart are one and a half times the diameter of the laterals, from which they are distant the diameter of the latter. The second row pair are twice the diameter of the front median, one and a half diameters apart, they are twice their diameter from the rear pair, which are slightly smaller and four times their own diameter apart. The Clypeus is rather wider. than the front median eyes. The Mandibles are longer than the breadth of the front margin of the Cephalothorax, kneed at the base and thickly covered on that portion with long upstanding thick bristly hair, the lower part is narrower and nearly smooth. On the inner margin of the falx sheath are two teeth.

The $L i p$ is nearly twice as broad as long, hollowed in front and with a rather wide sloping front margin. The Maxillae are upright, broad, rather square at the top, and the palpal trochanters rather remarkably long. The Sternum is broadly ovate, straight in front and pointed at the rear. It is thinly clothed with flat plumose bristles.

The $A b d o m e n$ is ovate, truncate in front, the Spinnerets remarkably short, conical, and flat at the anterior end.

The Legs and Palpi are fine and only moderately long. The distal end of the tarsal joint has a sloping troncature, the superior claws being long and only slightly curved, the outer one has two or three short pectinations right at the base; a slight compression of the sides, and a ring of bristles therefrom, conveys the impression of an onychium, which, however, seems to me to be false. Several not quite adult males are of the same colouration as the females.

The measurement in millimetres are as follows :-

\section{Long. Broad.}

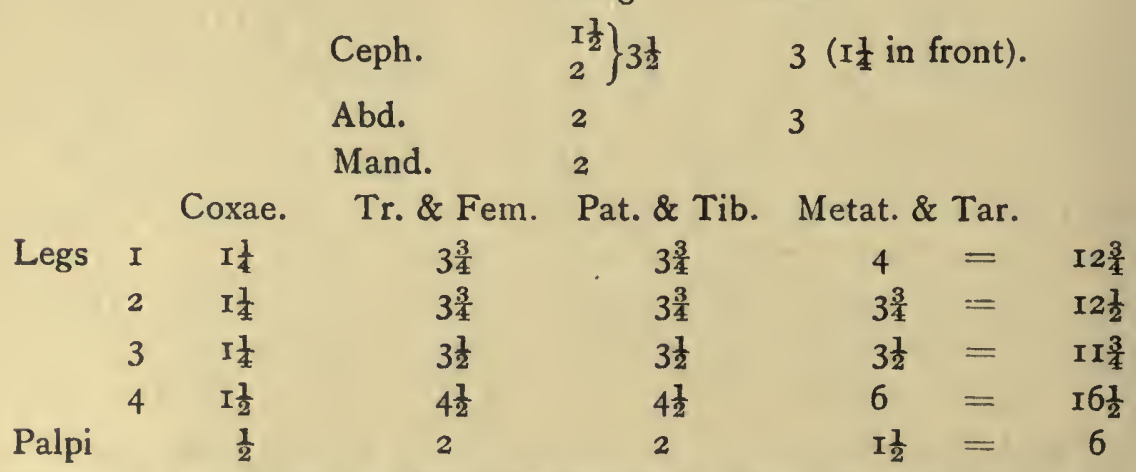

These specimens came from Yü-lin Fu, N. Shensi, on the border of the Ordos desert. 
This species is somewhat near Rev. O. P. Cambridge's E. benevola from Yarkand (Yarkand 2nd Mission, Pt. viii., Arach p. 95). He does not mention the size of his specimen, but this would appear to differ from it in the darker colour of the whole of the pars cephalica, the lighter median area not passing thereto, the clypeus not so broad as twice the front median eyes, paler lip and darker sternum. There are no cretaceous white spots on the abdomen, the median longitudinal marking only reaches half way, and there is no longitudinal band or other marking on the underside.

I have named it after Capt. Douglas, V.C., D.S.O., R.A.M.C., the collector of all the specimens brought home. 

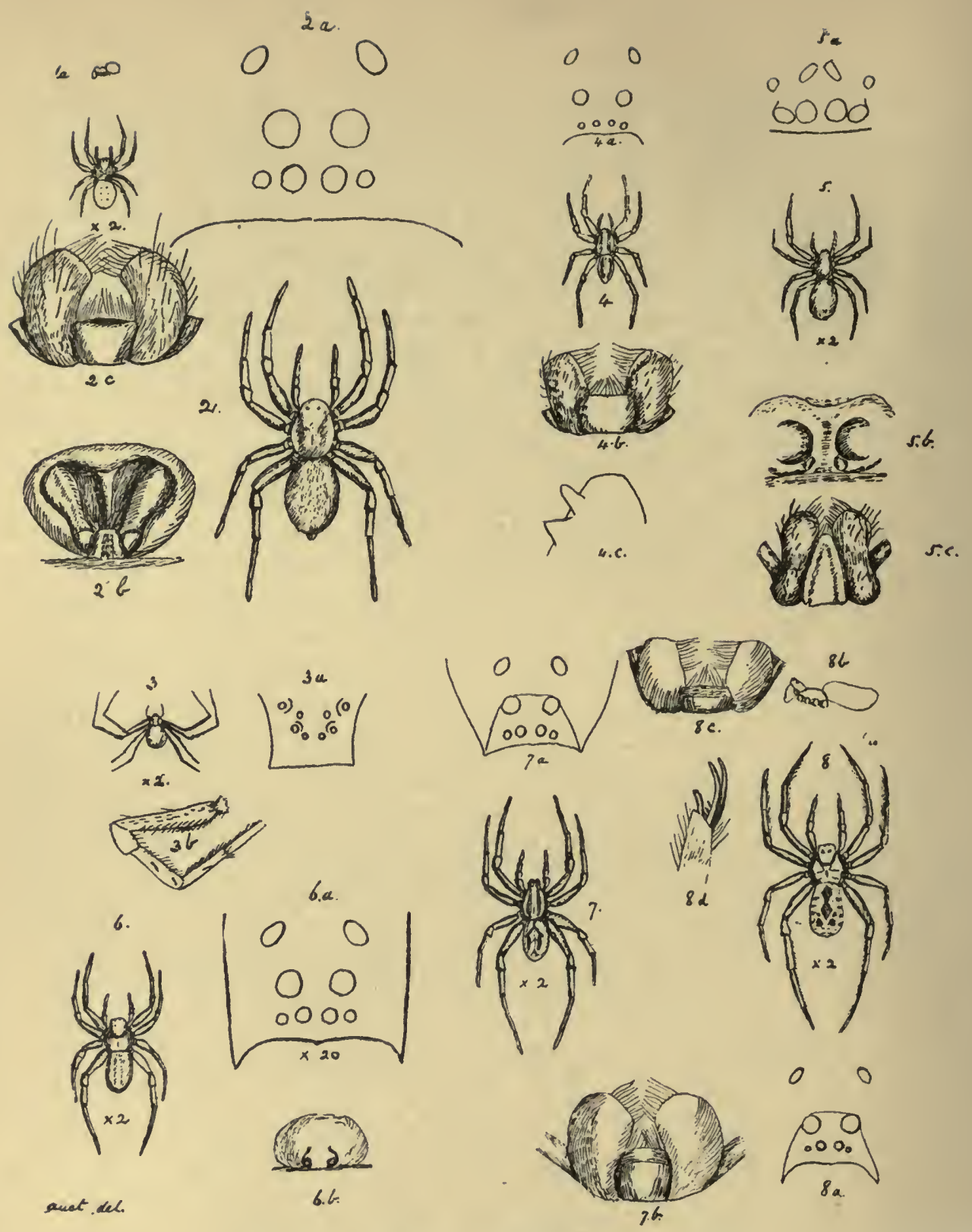

EXPLANATION OF ABOVE DIAGRAMS.

1. Araneus ? sp. $\times 2$ 우 la, profile, nat. size.

2. Pardosa shansia, sp. n. nat. size. $2^{2}$, eyes. $2 b$, epigyne. $2 c$, lip and maxillae.

3. Diaea ? subdola. Cambr. $+\times 2$. 3a, eyes. $3 b$, leg of 4 th pair (enlarged).

4. Pardosa sowerbyi, sp. n. 9 nat. size. $4 a$, eyes. $4 b$, lip and maxillae. $4 c$, teeth on inner margin of faix sheath.

5. Drassodes ? lapsus. Cambr. $9 \times 2$. 5a, eyes. 5b, epigyne. 5c, lip and maxillae.

6. Lycosa clarki, sp. n. 우 $\times 2$. $6 a$, eyes. $6 b$, epigyne.

7. Lycosa ordosa. sp. $n$. $9 \times 2$. $7 \mathrm{a}$, eyes. $7 \mathrm{~b}$, lip and maxillae.

8. Evippa douglasi. sp. n. $+\times 2$. $8 \mathrm{a}$, eyes. $8 \mathrm{~b}$, profile, $8 \mathrm{c}$, lip and maxillae. $8 \mathrm{~d}$, tarsal claws. NOTE.-The original drawing of this plate having been reduced in size by $\frac{1}{3}$ rd linear, the sizes shown herein must be increased by one-half, to agree with above explanation. 


\section{APPENDIX VÍ.}

DIARY OF METEOROLOGICAL OBSERVATIONS

MADE ON EXPEDITION IN NORTH CHINA IN I908 AND I9Og.

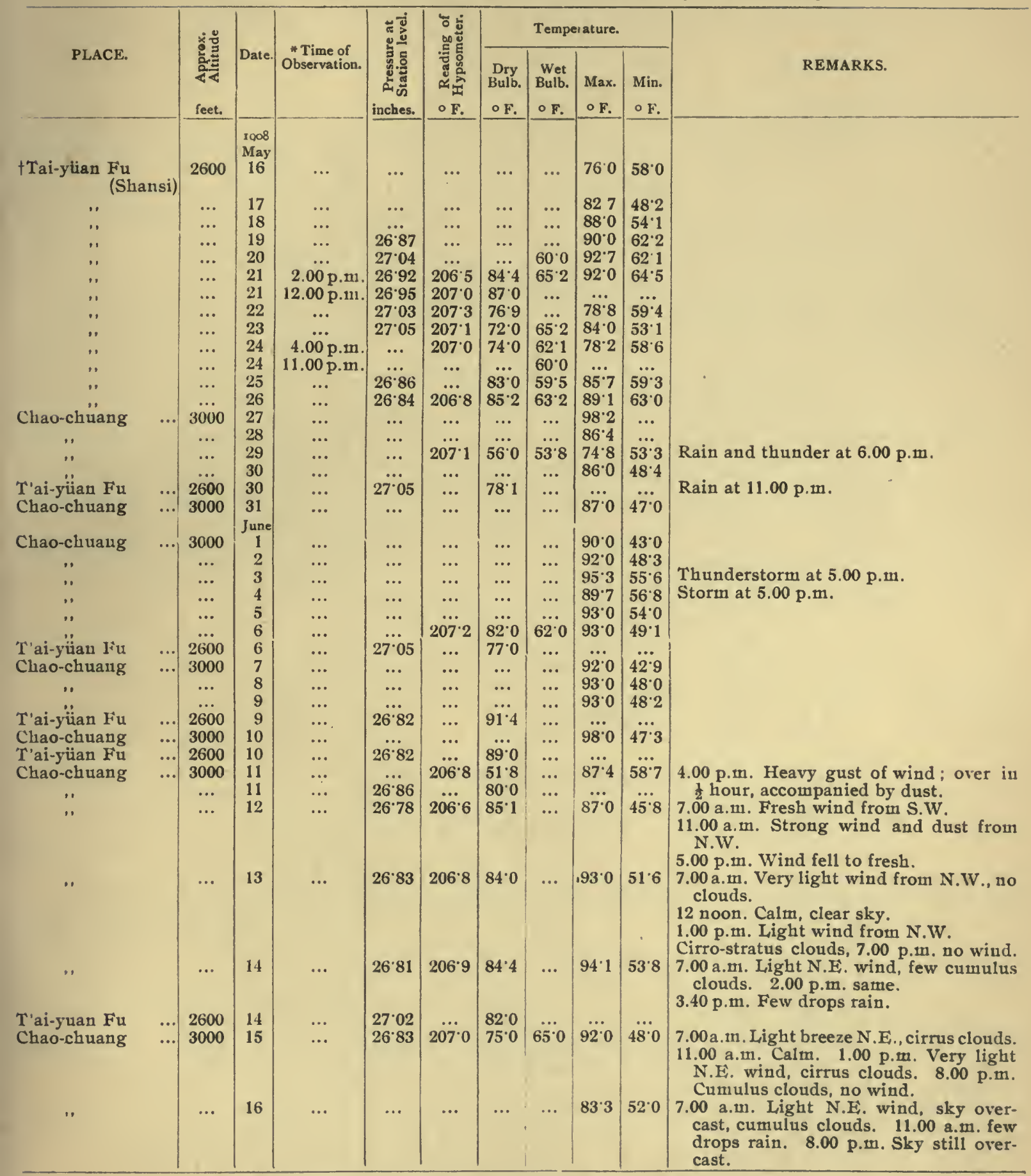

* In hours and minutes after midnight (a.m.), or after noou (p.m.).

t Latitude $37^{\circ} 51^{\prime} 36^{\prime \prime}$ N., Lougitude $112^{\circ} 33^{\prime} 56^{\prime \prime}$ E. 


\section{METEOROLOGICAL OBSERVATIONS-continued.}

\begin{tabular}{|c|c|c|c|c|c|c|c|c|c|c|c|}
\hline \multirow[b]{2}{*}{ PLACE. } & \multirow{2}{*}{\multicolumn{2}{|c|}{ 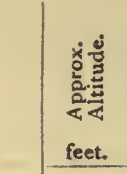 }} & \multirow[b]{2}{*}{ Date. } & \multirow[b]{2}{*}{$\begin{array}{l}\text { Time of } \\
\text { Observation. }\end{array}$} & \multirow{2}{*}{ 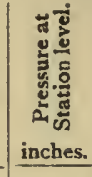 } & \multirow{2}{*}{ 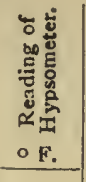 } & \multicolumn{4}{|c|}{ Temperature. } & \multirow[b]{2}{*}{ REMARKS. } \\
\hline & & & & & & & $\begin{array}{l}\text { Dry } \\
\text { Bulb. } \\
\text { of. }\end{array}$ & $\begin{array}{l}\text { Wet } \\
\text { Bulb. } \\
\text { of. }\end{array}$ & $\begin{array}{l}\text { Max. } \\
\text { of. }\end{array}$ & $\begin{array}{l}\text { Min. } \\
\text { of. }\end{array}$ & \\
\hline T'ai-yüan Fu & & 2600 & $\begin{array}{l}\text { rgo8 } \\
\text { June } \\
16\end{array}$ & & 26.85 & & 74.5 & & & & \\
\hline $\begin{array}{c}\text { Chao-chuang } \\
\text {," }\end{array}$ & & $\begin{array}{l}3000 \\
\ldots\end{array}$ & 17 & $\begin{array}{l}10.00 \text { a.m. } \\
12 \text { night }\end{array}$ & $\begin{array}{c}26 \cdot 81 \\
\ldots\end{array}$ & $\begin{array}{c}206 \cdot 7 \\
\ldots\end{array}$ & $\begin{array}{l}65 \cdot 3 \\
62 \cdot 6\end{array}$ & $\begin{array}{l}61 \cdot 3 \\
58 \cdot 7\end{array}$ & $\begin{array}{c}79 \cdot 7 \\
\cdots\end{array}$ & $\begin{array}{l}58 \cdot 0 \\
\cdots\end{array}$ & $\begin{array}{l}\text { 7.00 a.m. Very dull, and few drops rain. } \\
\text { Calm. Gentle shower on and off all } \\
\text { day. Cleared up at } 9.00 \text { p.m. }\end{array}$ \\
\hline " & & ... & 18 & 12 noon & $26 \cdot 75$ & $206^{\prime} 6$ & $87 \cdot 0$ & $72 \cdot 9$ & $92 \cdot 0$ & $51 \cdot 3$ & $\begin{array}{l}8.00 \text { a.m. Calm, clear. Noon Light N.W. } \\
\text { wind, clear. } 6.00 \text { p.m. Clouding over, } \\
\text { light S.W. wind. } 8.00 \text { p.m. Light } \\
\text { N.W. wind, thunderstorm to N.W. } \\
10.00 \text { p.m. Heavy wind, N.E. } 12 \text { night } \\
\text { Clear, light W. wind. }\end{array}$ \\
\hline ". & & $\cdots$ & 19 & $9.00 \mathrm{a} . \mathrm{m}$ & $26 \cdot 85$ & $206 \cdot 9$ & $72 \cdot 0$ & $69 \cdot 8$ & $96 \cdot 3$ & $53 \cdot 3$ & 8.00 a.m. Calm, cirrus clouds. 1211001 \\
\hline ". & & ... & 19 & 11.00 p.m. & ... & ... & $74 \cdot 4$ & 65.0 & ... & $\cdots$ & $\begin{array}{l}\text { Calm, cirrus clouds. } 5.00 \text { p.m. Cumu- } \\
\text { lus, fresh S. wind, dust. } 7.00 \text { p.m. } \\
\text { Thunderstorms to S.W. and N.W. } \\
11.00 \text { p.m. Still cloudy. }\end{array}$ \\
\hline " & & .. & 20 & 8.00 a.m. & $27^{\circ} 08$ & $207 \cdot 0$ & $71 \cdot 6$ & 63.5 & $74 \cdot 7$ & 60.8 & $\begin{array}{l}\text { 7.00 a.m. Calm, cumulus clouds. } 10.30 \\
\text { a.m. Light wind and rain from S. } \\
\text { Noon Cumulus clouds, light wind } \\
\text { N.E., thunderstorms along hills from } \\
\text { S.W. to N.W. } 2.00 \text { p.m. Rain stopped, } \\
\text { heavy stratus clouds. } 3.00 \text { p.m. Rain } \\
\text { re-commenced, continued to midnight. }\end{array}$ \\
\hline , & & ... & 21 & $6.00 \mathrm{a} . \mathrm{m}$. & $27 \cdot 00$ & $207 \cdot 2$ & 64.0 & $62 \cdot 0$ & $87 \cdot 6$ & $57 \cdot 6$ & $\begin{array}{l}6.00 \mathrm{a} . \mathrm{m} \text {. Calm, overcast, stratus clouds. } \\
\text { Noon, Cumulus, light } \mathrm{N} \text {. W. breeze. } \\
6.00 \text { p.m. Strato-cumulus, Iight } \mathrm{E} \text {. wind. }\end{array}$ \\
\hline ." & & $\ldots$ & 22 & 7.00 a.m. & $\ldots$ & $207 \cdot 0$ & $81 \cdot 1$ & $67 \cdot 6$ & $85 \cdot 9$ & 60.0 & $\begin{array}{l}7.00 \text { a.m. Very light N. W. wind, cloudless. } \\
\text { Noon Light S. wind, cirrus clouds. }\end{array}$ \\
\hline "' & & ... & 22 & 8.00 p.m. & 26.81 & 2067 & $79 \cdot 5$ & & & & 8.00 p.m. Fresh E. wind, sky overcast. \\
\hline ". & & .. & 23 & 7.00 a.m. & $\cdots$ & ... & $78 \cdot 7$ & $69^{\circ} 0$ & 924 & 58.9 & $\begin{array}{l}7.00 \text { a.m. Cloudless, very light N.W. } \\
\text { breeze. }\end{array}$ \\
\hline 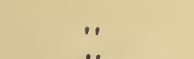 & & $\cdots$ & $\begin{array}{l}23 \\
23\end{array}$ & $\begin{array}{l}8.00 \text { a.m. } \\
\text { noon }\end{array}$ & $\ldots$ & $\begin{array}{c}206 \cdot 8 \\
\ldots\end{array}$ & $\begin{array}{l}76 \cdot 8 \\
85 \cdot 3\end{array}$ & $79 \cdot 4$ & $\begin{array}{l}\ldots \\
\ldots\end{array}$ & $\begin{array}{l}\cdots \\
\ldots\end{array}$ & $\begin{array}{l}\text { Noon Cloudless, very light N.W. breeze. } \\
8.00 \text { p.m. Cumulus clouds, E. wind. }\end{array}$ \\
\hline T'ai-yüan $\mathrm{Fu}$ & & 2600 & 23 & & $26 \cdot 90$ & $\cdots$ & 89.7 & & $\ldots$ & & Midnight Steady rain (all night). \\
\hline Chao-chuang & ... & 3000 & 24 & 11.00 a.m. & $26 \cdot 76$ & 206.4 & $70 \cdot 1$ & 68.7 & ... & 64.4 & 8.00 a.m. Steady gentle rain. \\
\hline ", & & $\cdots$ & $\begin{array}{l}24 \\
24\end{array}$ & $\begin{array}{l}1.00 \text { p.m. } \\
8.00 \text { p.m. }\end{array}$ & $\begin{array}{l}26 \cdot 70 \\
26 \cdot 67\end{array}$ & $\begin{array}{l}206 \cdot 3 \\
206 \cdot 2\end{array}$ & $\begin{array}{l}69 \cdot 0 \\
72 \cdot 0\end{array}$ & $\begin{array}{l}68^{\circ} 0 \\
69^{\circ} 2\end{array}$ & $\begin{array}{l}\cdots \\
\cdots\end{array}$ & $\ldots$ & $\begin{array}{l}\text { Noon Rain stopped, damp, overcast. } \\
1.00 \text { p.m. Rain re-commenced. } 8.00 \text { p.m. } \\
\text { Heavy clouds, no wind. }\end{array}$ \\
\hline ," & & $\cdots$ & 25 & 6.00 a.m. & $26 \cdot 68$ & $206 \cdot 3$ & $68 \cdot 5$ & 68.0 & $91 \cdot 5$ & $58 \cdot 6$ & 6.00 a.m. Very misty, mackerel sky. \\
\hline$"$ & & $\ldots$ & 25 & & $\ddot{0} 6$ & 2065 & & 71.0 & ... & $\cdots$ & Noon Cirro-cumulus, light wind N.W. \\
\hline 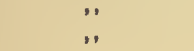 & & $\cdots$ & 25 & $\begin{array}{c}\text { midnigbt } \\
\ldots\end{array}$ & $\begin{array}{c}2686 \\
\ldots\end{array}$ & $\begin{array}{l}206.5 \\
2067\end{array}$ & $\begin{array}{l}65 \cdot 0 \\
75 \cdot 5\end{array}$ & $\begin{array}{l}64 \cdot 9 \\
65 \cdot 1\end{array}$ & $91 \cdot 0$ & 53.7 & $\begin{array}{l}3.00 \text { p.m. Clear, fresh breeze N.W. } \\
7.00 \text { a.m. Clear, calm. Noon Heavy }\end{array}$ \\
\hline & & & & & & & & & & & stratus clouds, calm. 7.30 p.m. Fresh \\
\hline Tou-fü-ssŭ & . & $\dddot{4527}$ & 27 & $\cdots$ & $25: 58$ & $204 \cdot 1$ & $7 \dddot{2} 6$ & $\ddot{66} \cdot 7$ & $\begin{array}{l}84.0 \\
75 \cdot 7\end{array}$ & $\begin{array}{c}621 \\
\ldots\end{array}$ & $\begin{array}{l}7.00 \text { a.m. Dull, rain during night. } \\
\text { Noon Dull, light wind from N.W. } \\
5.00 \text { p.m. Cumulus clouds, calm. }\end{array}$ \\
\hline ". & & $\cdots$ & 28 & 8.00 a.m. & $25 \cdot 53$ & $204 \cdot 1$ & $65 \cdot 3$ & $62 \cdot 0$ & 76.0 & $62^{\circ} 0$ & $\begin{array}{l}7.00 \text { a.m. Cumulus clouds, light N.W. } \\
\text { wind. }\end{array}$ \\
\hline " & & .. & 28 & 12.30 p.m. & $25 \cdot 51$ & $204 \cdot 1$ & $75 \cdot 0$ & & ... & ... & Noon Cirro-cumulus clouds, calm \\
\hline & & ... & $\begin{array}{l}28 \\
28\end{array}$ & $\begin{array}{l}4.00 \text { p.m. } \\
9.00 \text { p.m. }\end{array}$ & ... & $\cdots$ & $\begin{array}{l}75 \cdot 0 \\
72.0\end{array}$ & $\begin{array}{l}68 \cdot 3 \\
64 \cdot 9\end{array}$ & $\ldots$ & $\begin{array}{l}\cdots \\
\ldots\end{array}$ & 8.00 p.m. Cir \\
\hline Station $\mathbf{H}$. & $\ldots$ & $49 \ddot{984}$ & 28 & $10.00 \mathrm{p.m}$. & $25 \cdot 11$ & $203 \cdot 4$ & 68.0 & & $\ldots$ & $\ldots$ & $\begin{array}{l}\text { 9.40 p.m. Thunderstorm since } 0.00 \text { p.m. } \\
\text { River flooded. }\end{array}$ \\
\hline Tou-fu-ssŭ & & 4527 & 29 & 8.00 a.m. & 25.46 & $\ldots$ & $70 \cdot 6$ & 64.4 & $\ldots$ & $62 \cdot 7$ & 8.00 a.m. Stratus clouds, calm: \\
\hline , & & 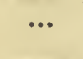 & 29 & 3.00 p.m. & $25 \cdot 37$ & & $82 \cdot 0$ & $65^{\circ} 0$ & ... & $\ldots$ & $\begin{array}{l}3.00 \text { p.m. Strato-cumulus, light S.W. } \\
\text { wind. }\end{array}$ \\
\hline Station $\mathrm{H}$. & ... & 4984 & 29 & $\ldots$ & $25 \cdot 05$ & $\ldots$ & $70 \cdot 7$ & ... & ... & ... & $\begin{array}{l}5.30 \mathrm{p} . \mathrm{m} \text {. Thunderstorm from } \mathrm{S} . \text { W., river } \\
\text { risen from } 3 \mathrm{ft} \text {. to } 8 \mathrm{ft} \text {. between } \\
\text { morning and afternoon. }\end{array}$ \\
\hline Tou-fu-ssü & . & 4527 & 30 & 6.00 a.m. & $25 \cdot 42$ & ... & 624 & ... & $78 \cdot 3$ & $59 \cdot 6$ & 6.00 a.m. Clear, fresh wind W. \\
\hline
\end{tabular}


METEOROLOGICAL OBSERVATIONS-continued.

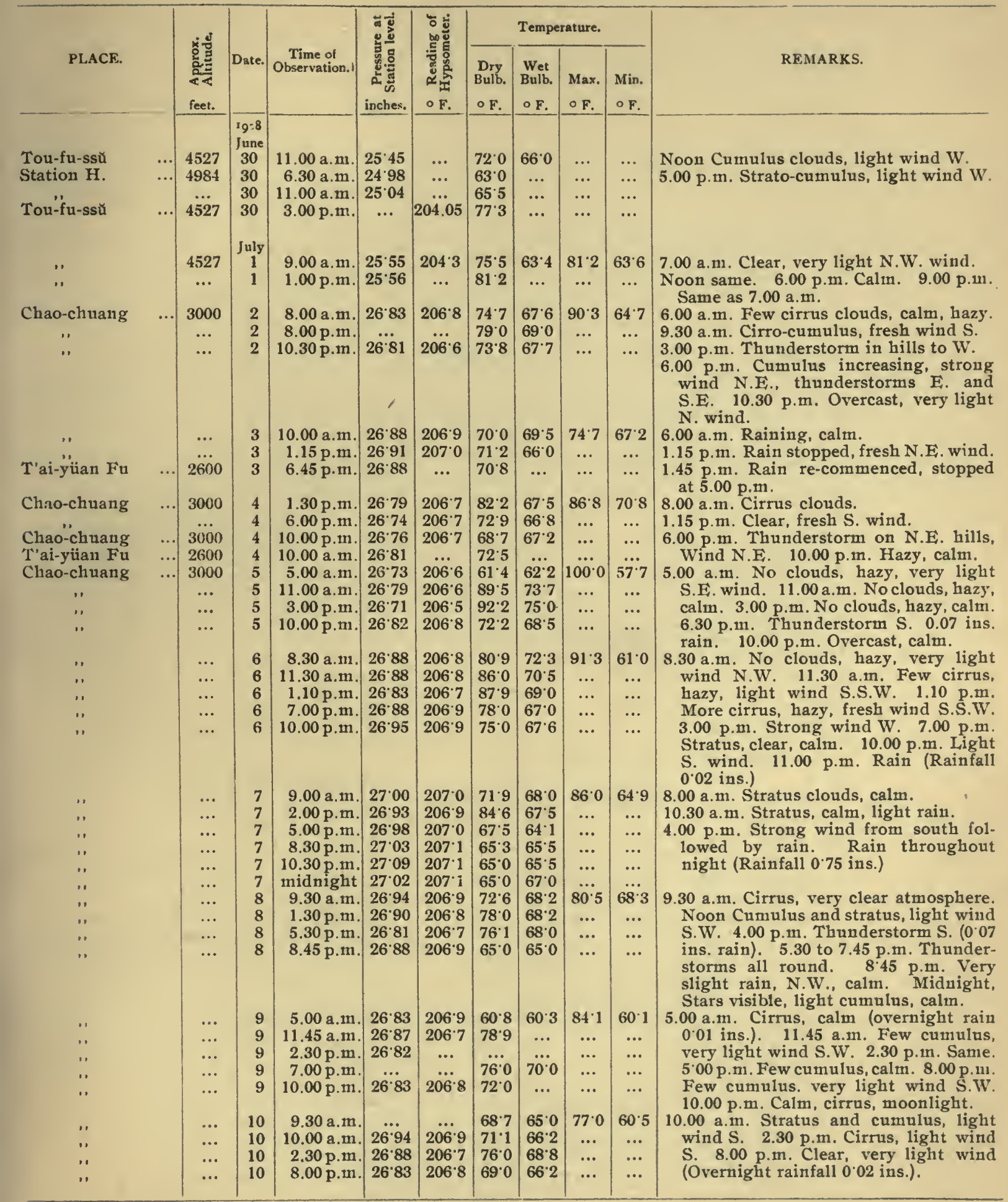


METEOROLOGICAL OBSERVATIONS-continuea.

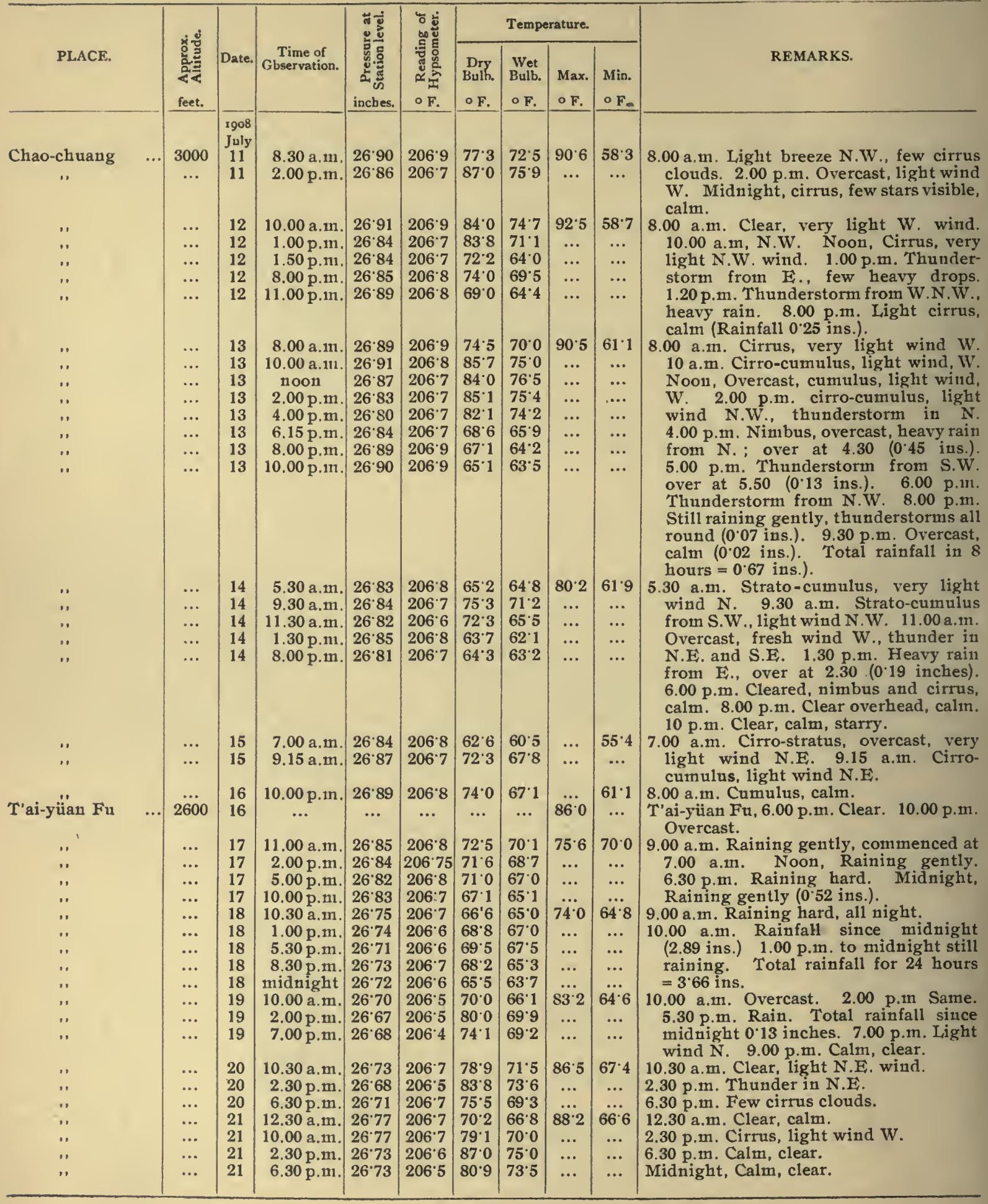


METEOROLOGICAL OBSERVATIONS-continued.

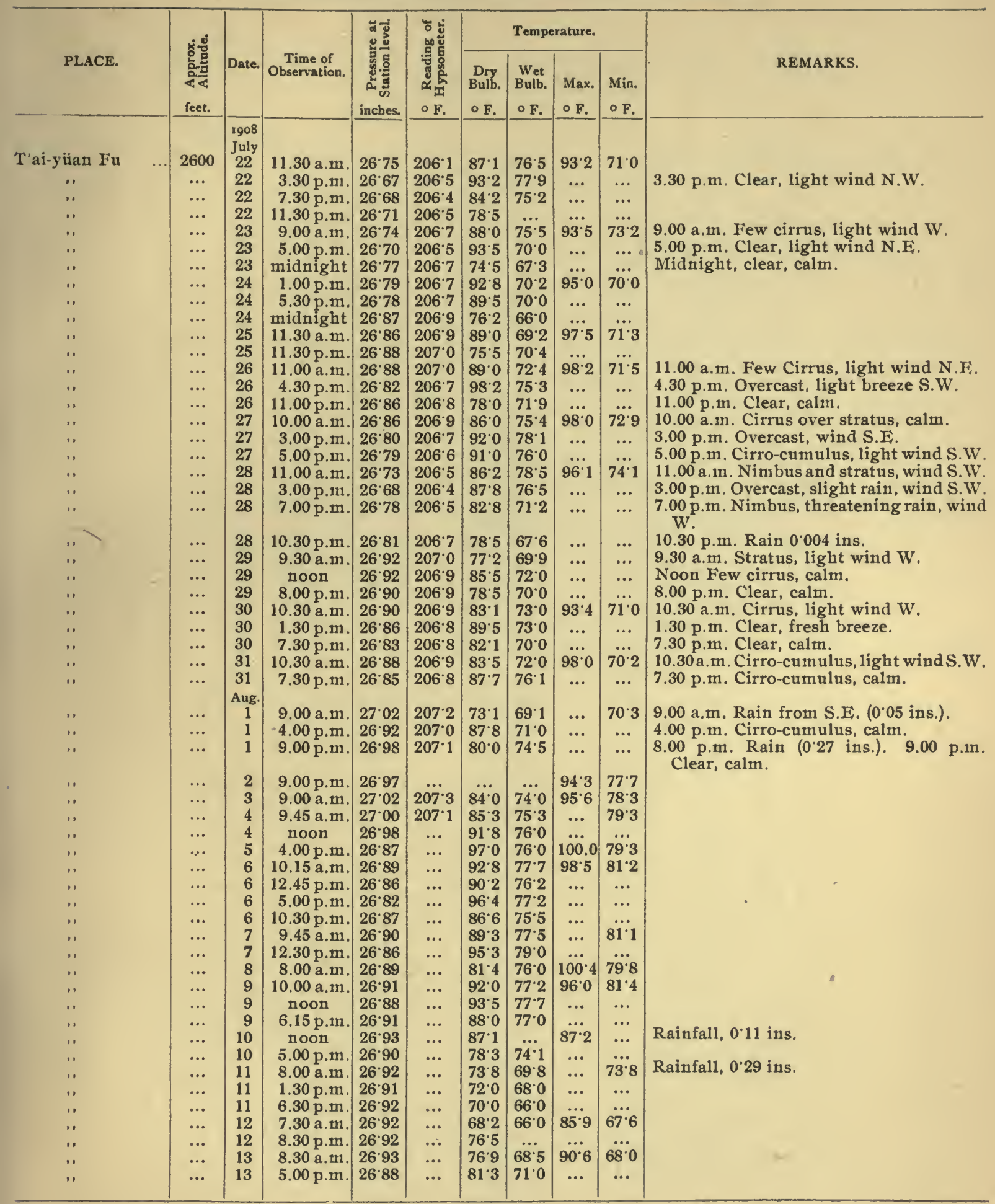


METEOROLOGICAL OBSERVATIONS-continued.

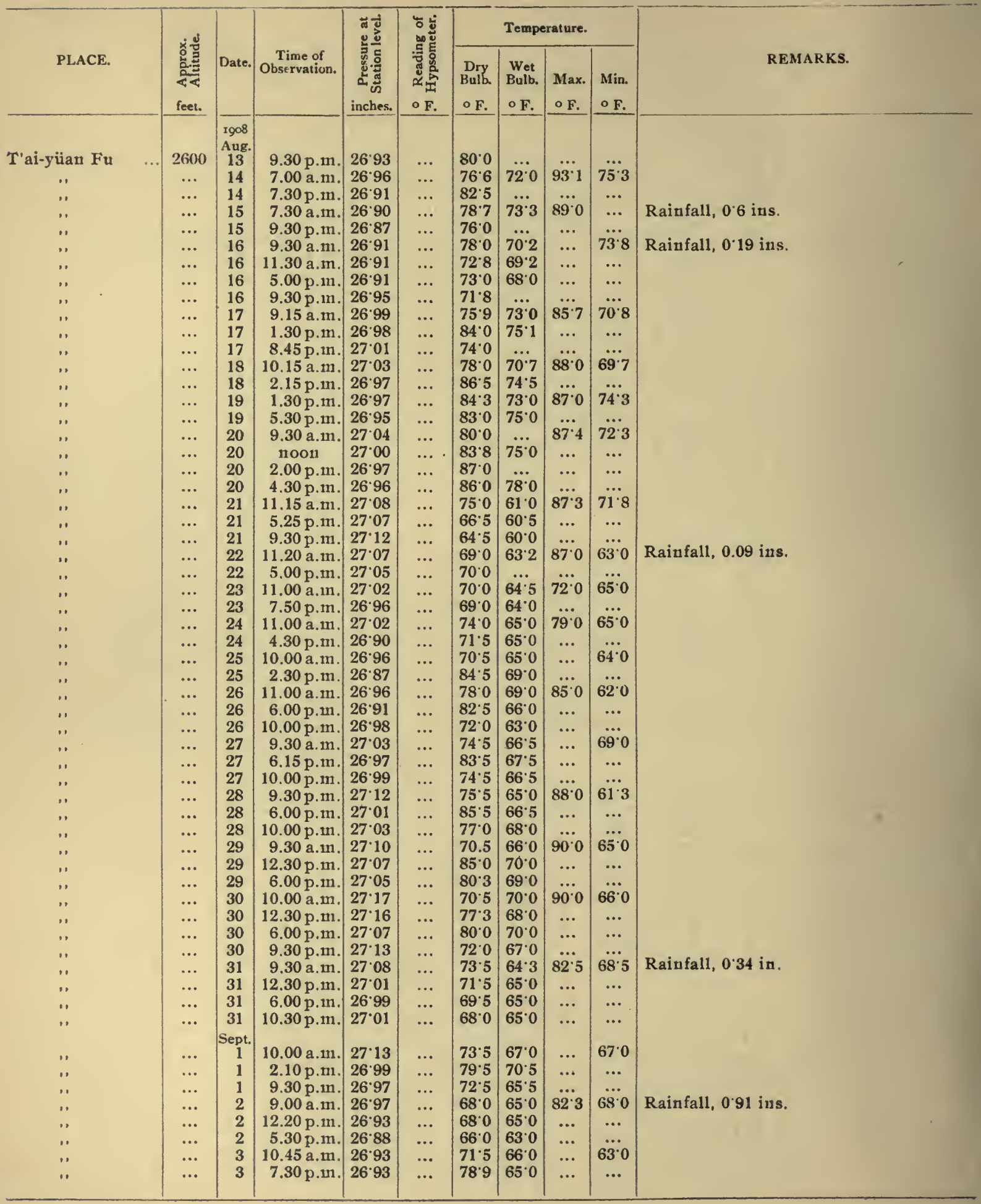


METEOROLOGICAL OBSERVATIONS—continued

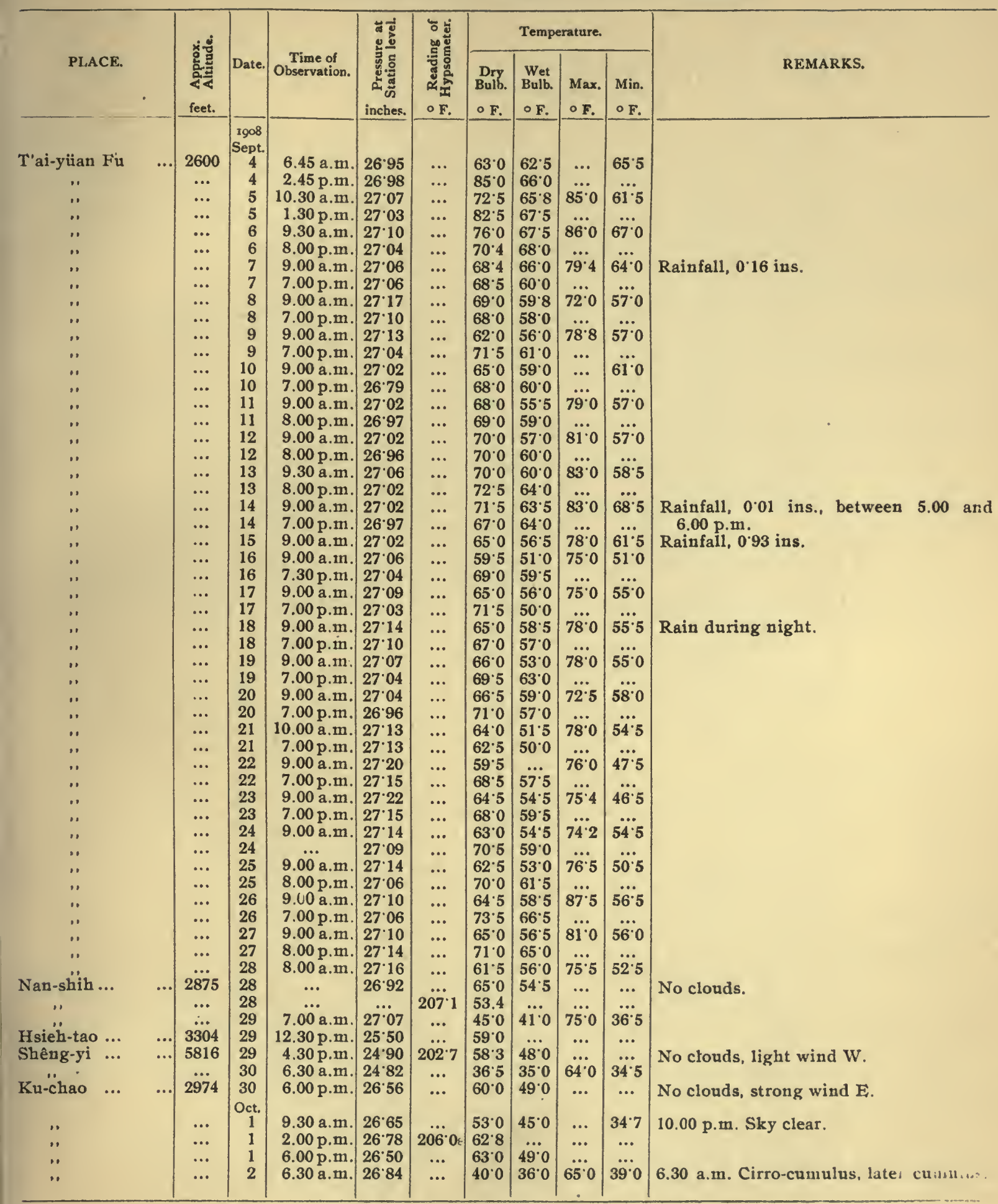


METEOROLOGICAL OBSERVATIONS-continued.

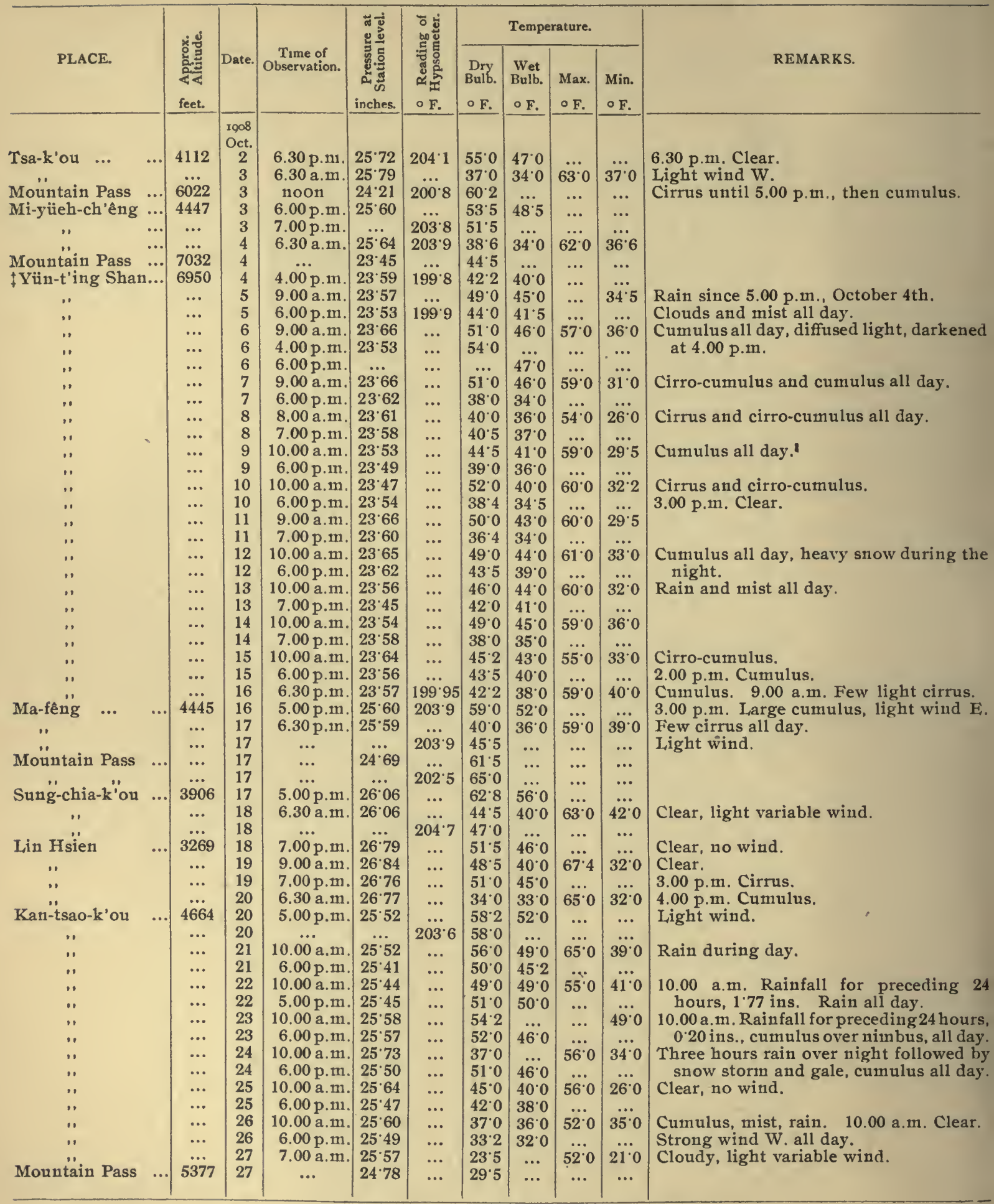


METEOROLOGICAL OBSERVATIONS-continued.

\begin{tabular}{|c|c|c|c|c|c|c|c|c|c|c|}
\hline \multirow{2}{*}{ PLACE. } & \multirow{2}{*}{ 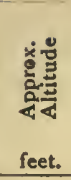 } & \multirow{2}{*}{ Date. } & \multirow{2}{*}{$\begin{array}{l}\text { Time of } \\
\text { Observation. }\end{array}$} & \multirow{2}{*}{ 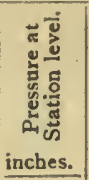 } & \multirow{2}{*}{ 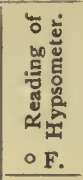 } & \multicolumn{4}{|c|}{ Temperature. } & \multirow[b]{2}{*}{ REMARKS. } \\
\hline & & & & & & $\begin{array}{c}\text { Dry } \\
\text { Bulb. } \\
\text { OF. }\end{array}$ & $\begin{array}{c}\text { Wet } \\
\text { Bulb. } \\
\circ \text { F. }\end{array}$ & $\begin{array}{l}\text { Max. } \\
\circ \mathrm{F} \text {. }\end{array}$ & $\begin{array}{l}\text { Min. } \\
\circ \mathrm{F} \text {. }\end{array}$ & \\
\hline Ts'ai-chia-wei & 3396 & $\begin{array}{l}1008 \\
\text { Oct. } \\
27\end{array}$ & 5.00 p.m. & $26 \cdot 70$ & $206^{\circ} 0$ & 42.5 & $39^{\circ} 0$ & & & \\
\hline & & 28 & 7.30 a.m. & 26.75 & & 33.0 & & $49: 0$ & 23.5 & Cirrus. 9.00 a.m. Clear, light variable \\
\hline $\begin{array}{l}\text { Huang-ho-yeh } \\
\text { (Shensi, on }\end{array}$ & 2406 & 28 & 6.00 p.m. & $27 \cdot 68$ & $207 \cdot 7$ & 46.5 & $40^{\circ} 0$ & & $\ldots$ & wind. \\
\hline Yellow River) & & 29 & 8.00 a.m. & $27 \cdot 76$ & $\ldots$ & $32 \cdot 0$ & & $52 \cdot 0$ & $25 \cdot 0$ & Clear, light variable wind. \\
\hline Liu-chia-mo $\quad$... & $\begin{array}{c}3103 \\
\ldots\end{array}$ & $\begin{array}{l}29 \\
29\end{array}$ & 6.00 p.m. & 26.96 & $206 \cdot 3$ & $\begin{array}{l}43.0 \\
37 \cdot 0\end{array}$ & $\begin{array}{c}38 \cdot 0 \\
\ldots\end{array}$ & $\ldots$ & $\ldots$ & \\
\hline ", & $\cdots$ & 30 & $8.00 \mathrm{a} \cdot \mathrm{m}$ & 2682 & & $36^{\circ} 0$ & $\cdots$ & $5^{\circ} \cdot 0$ & $23: 0$ & Hoar-frost during nigh \\
\hline in-chia-k'ou & & 30 & & & $206 \cdot 3$ & $37^{\circ} 0$ & & $\cdots$ & ... & Clear, light variable wind. \\
\hline & 3390 & 30 & $\begin{array}{l}7.00 \text { p.m. } \\
8.00 \text {. }\end{array}$ & 26.56 & $205^{\circ} 6$ & 43.0 & $37^{\circ} 0$ & $55^{\circ} 0$ & $23 \cdot 5$ & Hoar-frost during nioht clear. \\
\hline Chiu-ts'ai ... & $\dddot{3328}$ & 31 & $\begin{array}{l}8.00 \mathrm{a} . \mathrm{m} \\
5.00 \mathrm{p} . \mathrm{m}\end{array}$ & $\begin{array}{l}26 \cdot 61 \\
26.62\end{array}$ & ... & $\begin{array}{l}32 \cdot 5 \\
54 \cdot 5\end{array}$ & $\ddot{48} \cdot 0$ & 550 & $\begin{array}{c}235 \\
\ldots\end{array}$ & $\begin{array}{l}\text { Hoar-frost during night, clear. } \\
3.00 \text { p.m. Cirrus, light variable wind. }\end{array}$ \\
\hline " & $\cdots$ & $\begin{array}{l}31 \\
\text { Nov. }\end{array}$ & $\ldots$ & $\ldots$ & $205 \cdot 8$ & 45.5 & $\ldots$ & $\ldots$ & $\ldots$ & \\
\hline & & 1 & 8.00 a.m. & 26.66 & ... & 400 & $36 \cdot 0$ & $59 \cdot 0$ & 33.5 & Heavy dew during nigh \\
\hline $\begin{array}{l}\text { ang-chia-tien } \\
\text {,. }\end{array}$ & 3634 & 1 & $6.00 \mathrm{p} . \mathrm{m}$ & $26 \cdot 36$ & & $44 \cdot 5$ & $40 \cdot 0$ & & & at \\
\hline & $\cdots$ & 2 & 1000 & & 2054 & 372 & 응 & 56.0 & $31^{\circ} 0$ & 4.00 a.m. Light rain, later heavy mists \\
\hline 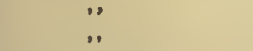 & $\cdots$ & $\begin{array}{l}2 \\
2\end{array}$ & $\begin{array}{r}10.00 \mathrm{a} .1 \mathrm{n} \\
5.00 \text { p.m. }\end{array}$ & $\begin{array}{l}2638 \\
26.34\end{array}$ & $\cdots$ & $\begin{array}{l}41 \cdot 2 \\
49 \cdot 2\end{array}$ & $\begin{array}{l}39.0 \\
44 \cdot 0\end{array}$ & $\cdots$ & $\cdots$, & till noon, followed by clear sky. \\
\hline & $\cdots$ & 3 & 8.00 a.m. & 26.34 & $\ldots$ & 34.0 & 33.0 & 610 & $\ddot{29} 0$ & $\begin{array}{l}\text { Light variable wind. } \\
\text { Hoar-frost during night, cumulus. }\end{array}$ \\
\hline Liu-chien-hua & 3418 & 3 & 6.00 p.m. & & $\cdots$ & 46.0 & 42.0 & $\ldots$ & ... & $\begin{array}{l}10.00 \text { a.m. Stratus. } 11.00 \text { a.m. and } 3.00 \\
\text { p.m. Little rain, strong wind } \mathrm{E} \text {. }\end{array}$ \\
\hline " & $\ldots$ & 4 & $10.00 \mathrm{a} . \mathrm{m}$ & 26.39 & .. & $45^{\circ} 0$ & $41 \cdot 0$ & 56.0 & $\ldots$ & Cumulus all day, dust haze. \\
\hline 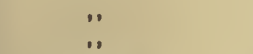 & $\cdots$ & 4 & 6.00 p.m. & $26 \cdot 32$ & $00=1$ & $44 \cdot 0$ & $41^{\prime} 0$ & ... & ... & Strong wind W. \\
\hline$\ddot{\prime \prime}$ & $\cdots$ & $\begin{array}{l}4 \\
5\end{array}$ & 8.00 a.m. & $26: 38$ & $\begin{array}{c}205 \cdot 4 \\
\ldots\end{array}$ & $\begin{array}{l}38.5 \\
36.0\end{array}$ & $34^{\circ} 0$ & $52 \cdot 0$ & $35^{\circ} 0$ & ust haze all day, light variable wind. \\
\hline ü-lin Fu & 3169 & 5 & 5.00 p.m. & $26 \cdot 66$ & $\ldots$ & $45 \cdot 0$ & 40.5 & 020 & 000 & ust haze all day, ligat vanable wind. \\
\hline$\because$ & $\cdots$ & 6 & $10.00 \mathrm{a} . \mathrm{m}$ & 26.65 & ... & 40.0 & $\begin{array}{l}35 \cdot 0 \\
39 \cdot 0\end{array}$ & $56^{\circ} 0$ & $23 \cdot 0$ & Clear, light wind $\mathrm{N}$. \\
\hline$\ddot{~}$ & $\begin{array}{l}\cdots \\
\cdots\end{array}$ & 7 & $10.00 \mathrm{a} . \mathrm{m}$. & $\begin{array}{l}2655 \\
26.54\end{array}$ & $\begin{array}{l}\cdots \\
\ldots\end{array}$ & $\begin{array}{l}44.4 \\
36.5\end{array}$ & $\begin{array}{l}39.0 \\
34^{\circ} 0\end{array}$ & $5 \dddot{7}_{0} 0$ & 23.5 & Slight hoar-frost duri \\
\hline ., & $\ldots$ & 7 & 6.00 p.m. & 26.52 & $\ldots$ & 44.0 & 40.0 & & & $\begin{array}{l}\text { Slight hoar-frost durin } \\
\text { Clear. Noon Light wi }\end{array}$ \\
\hline ." & $\ldots$ & 8 & $9.00 \mathrm{a} . \mathrm{m}$. & 26.69 & ... & $31 \cdot 4$ & & $55^{\circ} 0$ & $27^{\circ} 0$ & Few cirrus all day. \\
\hline ". & $\ldots$ & 8 & 6.00 p.m. & $26 \cdot 68$ & $\cdots$ & $38 \cdot 2$ & 36.0 & & & \\
\hline ., & $\ldots$ & 9 & $10.00 \mathrm{a} . \mathrm{m}$. & 26.72 & 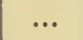 & $37 \cdot 0$ & $35 \cdot 0$ & 56.0 & $27 \cdot 0$ & - Slight ho \\
\hline ". & ... & 9 & 6.00 p.m. & 2668 & $\cdots$ & $42 \cdot 2$ & $37 \cdot 0$ & & & \\
\hline ." & $\ldots$ & 10 & $10.00 \mathrm{a} . \mathrm{m}$ & $26 \cdot 74$ & $\ldots$ & $38 \cdot 2$ & 36.0 & $57 \cdot 0$ & $25 \cdot 0$ & Slight hoar-frost during night. \\
\hline .. & ... & 10 & p.m. & 26 & • & 4 & 36.0 & & & light wind $\mathrm{N}$ \\
\hline .. & $\ldots$ & 11 & $10.00 \mathrm{a} . \mathrm{m}$ & 26.78 & $\ldots$ & $36^{\circ} 0$ & $34^{\circ} 0$ & $55 \cdot 0$ & $25 \cdot 0$ & Clear, light wind $\mathrm{N}$. \\
\hline 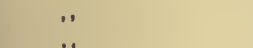 & $\cdots$ & 11 & 5.30 p.m. & 26.76 & $\cdots$ & 43.0 & $38^{\circ} 0$ & : & $\because=0$ & \\
\hline 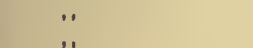 & $\cdots$ & $\begin{array}{l}12 \\
12\end{array}$ & $10.00 \mathrm{a} . \mathrm{m}$. & $\begin{array}{l}26 \cdot 72 \\
26.62\end{array}$ & $\cdots$ & $\begin{array}{l}31^{\circ} 0 \\
32 \cdot 0\end{array}$ & $\cdots$ & $52 \%$ & $15 \cdot 0$ & at wind $S$. \\
\hline ", & $\ldots$ & 13 & $\begin{array}{l}5.30 \mathrm{p} . \mathrm{m} \\
9.30 \mathrm{a} . \mathrm{m}\end{array}$ & $\begin{array}{l}26.62 \\
26.66\end{array}$ & $\cdots$ & $\begin{array}{l}32 \cdot 0 \\
34.0\end{array}$ & $\begin{array}{l}\cdots \\
\cdots\end{array}$ & 490 & $21 \cdot 5$ & Clear, light \\
\hline ." & ... & 13 & 5. & 26 & $\ldots$ & $42 \cdot 0$ & $38^{\circ} 0$ & & & \\
\hline ". & ... & 14 & $10.00 \mathrm{a} . \mathrm{m}$. & $26 \cdot 60$ & .. & $37 \cdot 0$ & $34^{\circ} 0$ & 50.0 & $21 \cdot 0$ & Clear, light wind S. \\
\hline 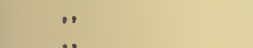 & $\cdots$ & 14 & 5.00 p.m. & 26 & $\cdots$ & $44 \cdot 5$ & $40^{\circ} 0$ & $50 \cdot 0$ & 00.0 & \\
\hline 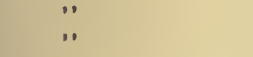 & $\cdots$ & 15 & $\begin{array}{l}10.00 \text { a.m. } \\
5.00 \text { p.m. }\end{array}$ & $\begin{array}{l}26 \cdot 64 \\
26 \cdot 64\end{array}$ & $\begin{array}{l}\cdots \\
\cdots\end{array}$ & $\begin{array}{l}35^{\circ} 0 \\
45^{\circ} 0\end{array}$ & $\begin{array}{l}33.0 \\
38^{\circ} 0\end{array}$ & ... & 220 & $\begin{array}{l}\text { Slight hoar-trost durng night. } \\
2.30 \text { p.m. Heavy cumulus, light winc }\end{array}$ \\
\hline & $\cdots$ & 16 & 10.0 & $26 \cdot 70$ & $\cdots$ & & ... & 46.0 & 20.0 & Clouds disappe \\
\hline ., & $\ldots$ & 16 & 6.00 p.m. & $26 \cdot 70$ & $\cdots$ & & $\ldots$ & & & Light winc \\
\hline ." & ... & 17 & 9.30 a.m. & 26.64 & ... & $33 \cdot 0$ & & 46.0 & 20.0 & Slight hoar-frost duri \\
\hline 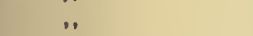 & $\ldots$ & 17 & 5.00 p.m. & & ... & $43 \cdot 0$ & $38^{\circ} 0$ & & & , light wind W \\
\hline .. & $\ldots$ & 18 & $10.00 \mathrm{a} . \mathrm{m}$. & $26 \cdot 36$ & .. & $35^{\circ} 0$ & 33.0 & $47^{\circ} 0$ & 20.0 & Clear, light wind S. \\
\hline ". & ... & 18 & 5.00 p.m. & & $\cdots$ & & 41.0 & & & \\
\hline ", & ... & 19 & 10.00 a.m. & 26.40 & $\ldots$ & $41 \cdot 5$ & $36^{\circ} 0$ & $54 \cdot 5$ & $25^{\circ} 0$ & Hoar-frost during night, clear, lig \\
\hline ." & .. & 19 & 5.30 p.m. & $26 \cdot 48$ & & $48^{\circ} 0$ & 40.0 & ... & $\ldots$ & $\begin{array}{l}\text { wind N. } 2.00 \text { p.m. Cirrus, strong } \\
\text { wind N., dust haze. }\end{array}$ \\
\hline "' & $\cdots$ & 20 & $11.00 \mathrm{a} . \mathrm{m}$. & 26.58 & $\ldots$ & $34 \cdot 5$ & ... & $54^{\circ} 0$ & $23 \cdot 5$ & Slight hoar-frost during night, clear. \\
\hline$\because$, & ... & 20 & 6.00 p.m. & 26.58 & & & & & & Evening. Few cirrus, light wind S. \\
\hline & ... & 21 & 10.00 a.m. & $26 \cdot 72$ & $\ldots$ & $36^{\circ} 0$ & $34^{\circ} 0$ & $45^{\circ} 0$ & 23.5 & Cirrus and cumulus. 2.00 p.m. Clear. \\
\hline
\end{tabular}

* Latitude $38^{\circ} 16^{\prime} 54^{\prime \prime} \mathrm{N}$., Longitude $109^{\circ} 44^{\prime} 59^{\prime \prime} \mathrm{E}$. 
MËTEOROLOGICAL OBSERVATIONS-continued.

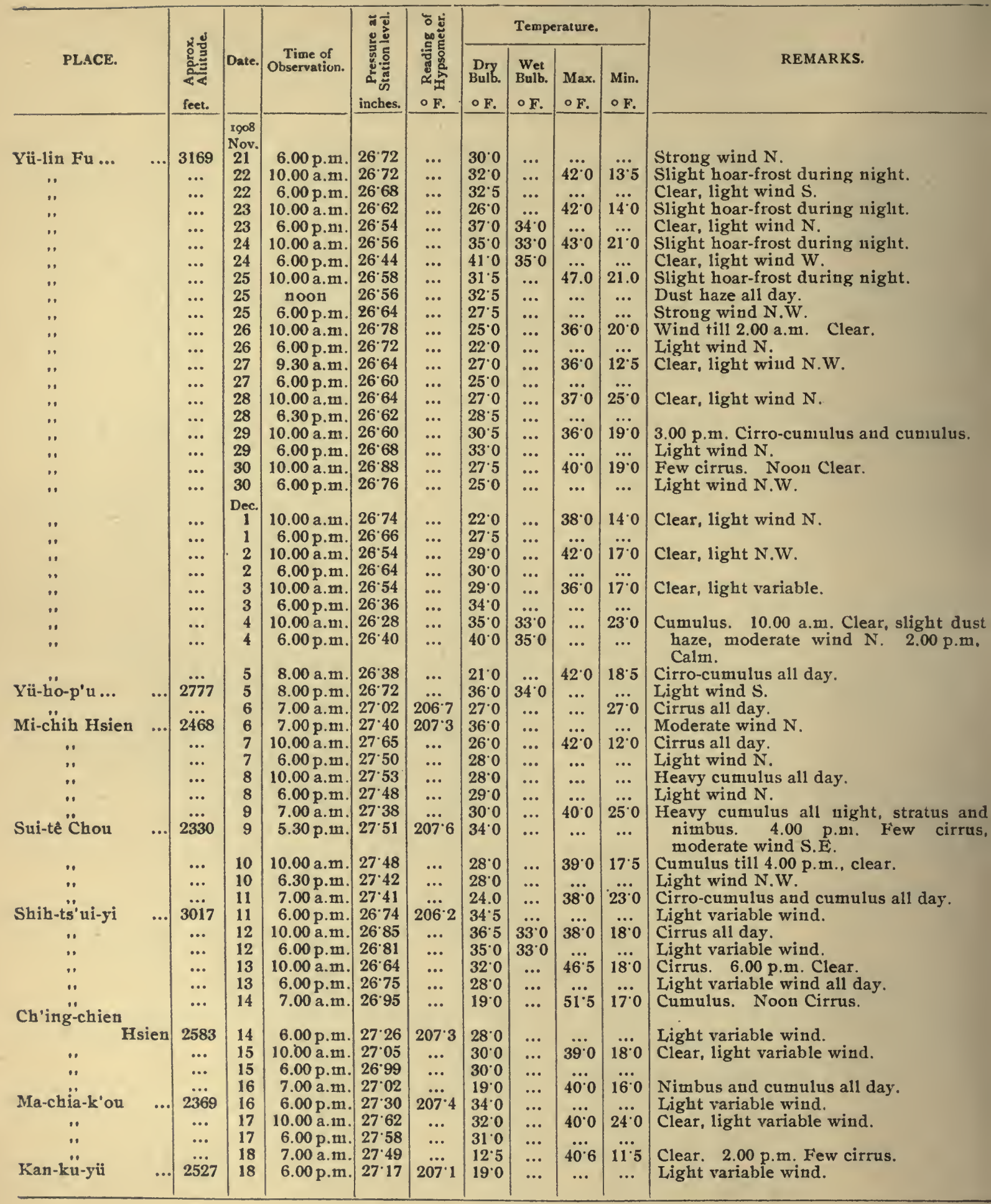


METEOROLOGICAL OBSERVATIONS-continued.

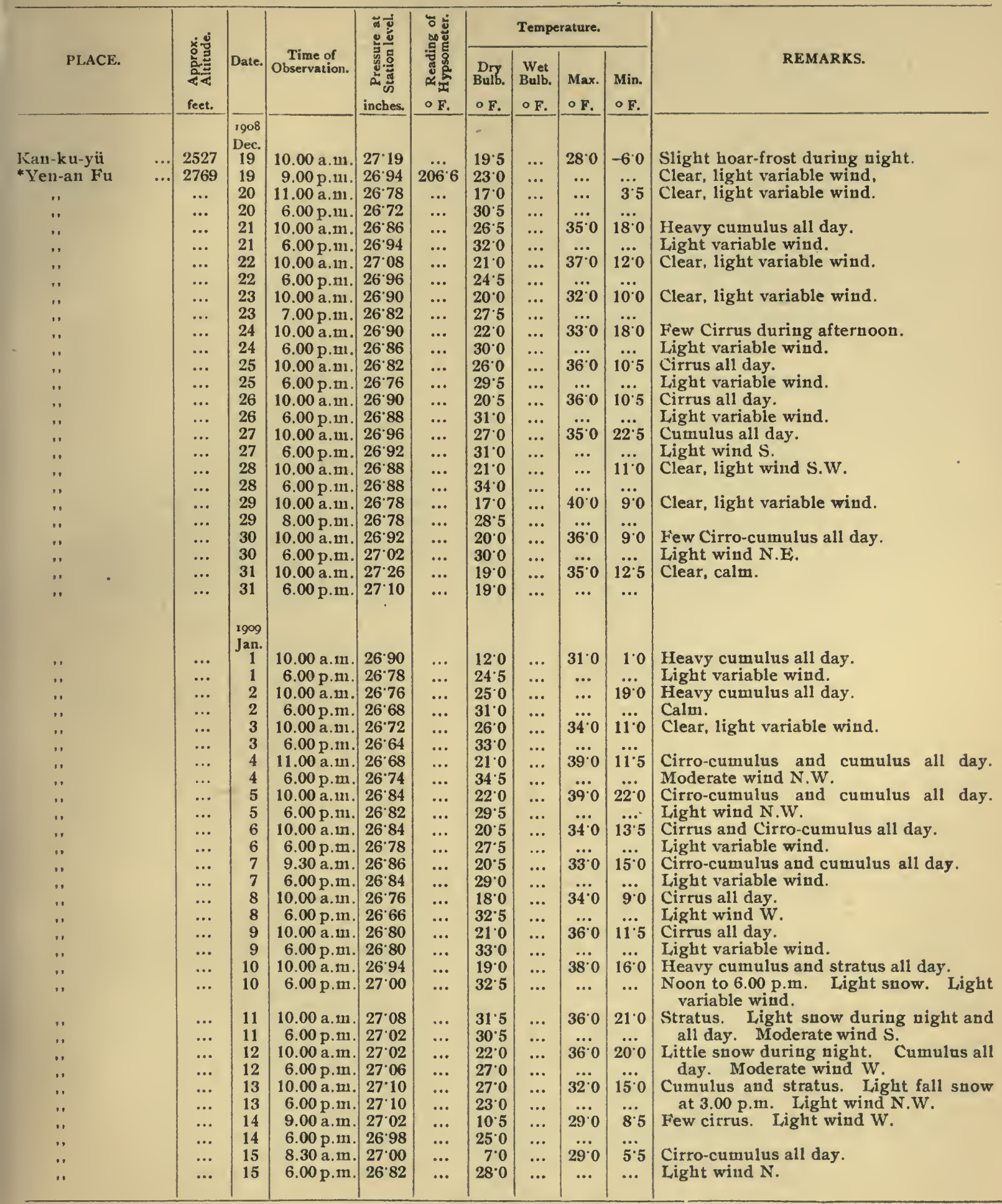


METEOROLOGICAL OBSERVATIONS-continued.

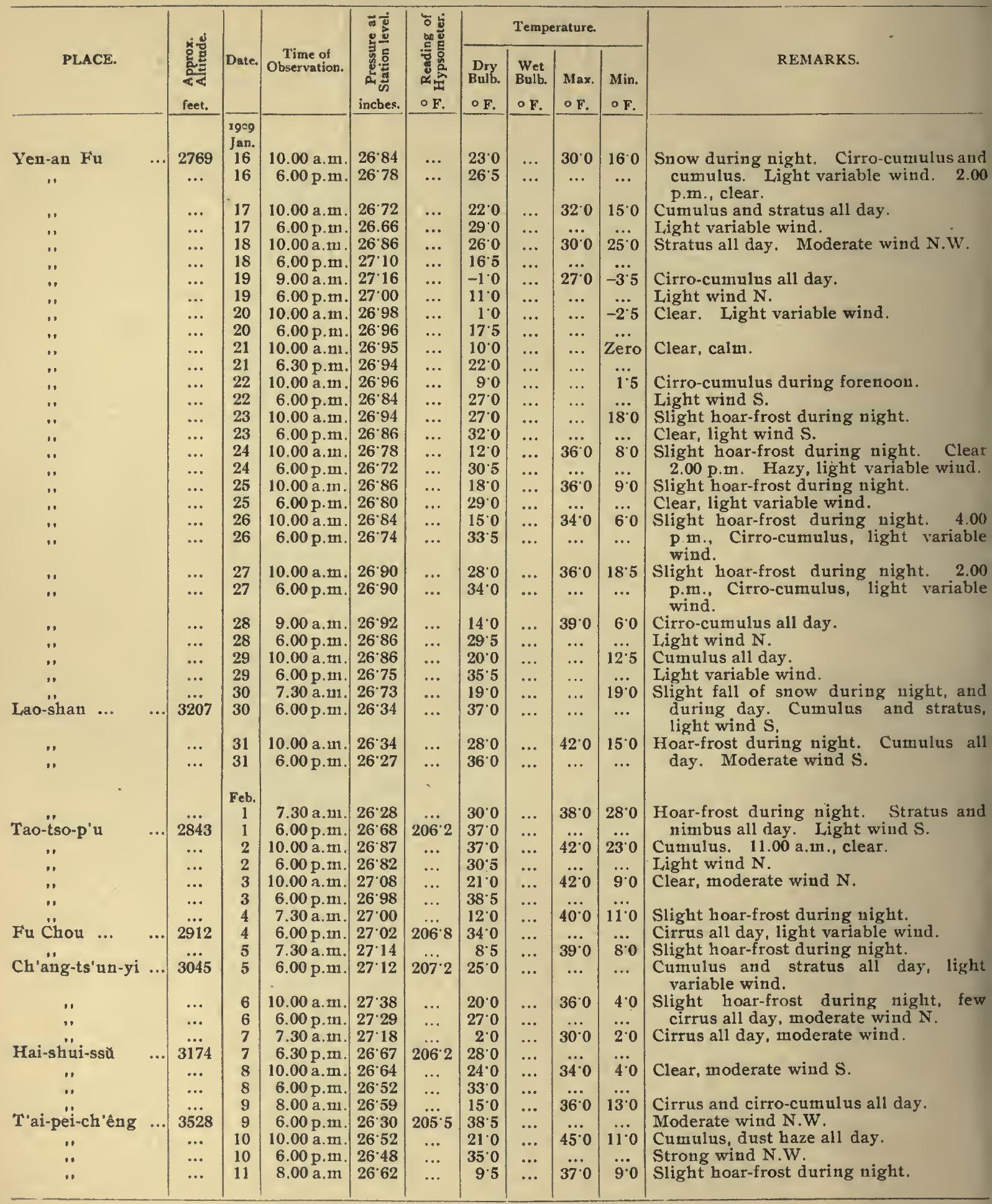


METEOROLOGICAL OBSERVATIONS-continuea.

\begin{tabular}{|c|c|c|c|c|c|c|c|c|c|c|c|}
\hline \multirow{2}{*}{\multicolumn{2}{|c|}{ PLACE. }} & \multirow[b]{2}{*}{ 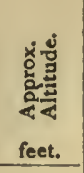 } & \multirow[b]{2}{*}{ Date. } & \multirow[b]{2}{*}{$\begin{array}{c}\text { Time of } \\
\text { Observation. }\end{array}$} & \multirow{2}{*}{ 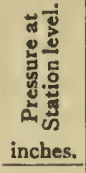 } & \multirow{2}{*}{ 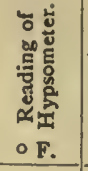 } & \multicolumn{4}{|c|}{ Temperature. } & \multirow[b]{2}{*}{ REMARKS. } \\
\hline & & & & & & & $\begin{array}{c}\text { Dry } \\
\text { Bulb. } \\
\text { OF. }\end{array}$ & $\begin{array}{c}\text { Wet } \\
\text { Bulb. } \\
\text { o F. }\end{array}$ & $\begin{array}{l}\text { Max. } \\
\text { OF. }\end{array}$ & $\begin{array}{l}\text { Min. } \\
\text { o F. }\end{array}$ & \\
\hline & & & 1909 & & & & & & & & \\
\hline Miao-ts'un & & 4144 & $\begin{array}{c}\text { Feb. } \\
11\end{array}$ & 6.00 p.m. & $25 \cdot 78$ & 2044 & $28^{\circ} 0$ & $\cdots$ & & & Few cirrus all day, moderate wind N.W. \\
\hline .. & & $\ldots$ & 12 & 10.00 a.m. & $25 \cdot 76$ & $\ldots$ & $25 \cdot 0$ & $\ldots$ & $35^{\circ} 0$ & $2 \cdot 0$ & Clear, strong wind W.N.W. \\
\hline$\because$ & & ... & 12 & 6.00 p.m. & $25 \cdot 68$ & ... & $31^{\circ} 0$ & ... & $\ldots$ & & \\
\hline . & & ... & 13 & 10.00 a.n1. & $25 \cdot 53$ & ... & $33 \cdot 0$ & ... & $\ldots$ & 10.5 & Clear, strong variable wind. \\
\hline$\because$ & & ... & 13 & 6.00 p.m. & $25 \cdot 49$ & ... & 38.0 & ... & & & \\
\hline & & $\because$ & 14 & 7.30 a.m. & $25 \cdot 52$ & ... & $22 \cdot 0$ & & $45 \cdot 5$ & $21 \cdot 0$ & Cirrus and cumulus all day, dust liaze, \\
\hline Ho-shui Hsien & ... & 4146 & 14 & 6.00 p.m. & $26 \cdot 19$ & $\ddot{0}$ & 430 & $38^{\circ} 0$ & & ... & moderate wind \\
\hline " & & … & 15 & $7.30 \mathrm{a} . \mathrm{m}$ & $26 \cdot 25$ & $205 \cdot 4$ & 18.0 & & $49^{\circ} 0$ & $17^{\circ} 0$ & Few cirrus and haze all day. \\
\hline Ch'ing-yang Fu. & $\cdots$ & 4216 & 15 & 6.00 p.m. & $26 \cdot 29$ & $205 \div 5$ & $44 \cdot 5$ & $39^{\circ} 0$ & & & Light variable wind. \\
\hline$\because$ & & $\cdots$ & 16 & $10.00 \mathrm{a} . \mathrm{m}$ & 26.45 & $\cdots$ & $30^{\circ} 0$ & $\ldots$ & 56.0 & $21^{\circ} 0$ & Few cumulus, noon, clear. \\
\hline थ & & $\cdots$ & 16 & 6.00 p.m. & $26 \cdot 32$ & $\cdots$ & $45^{\circ} 0$ & $39^{\circ} 0$ & $\therefore$ & $\ldots$ & Light win \\
\hline$\because$ & & $\cdots$ & 17 & 10.00 a.m. & $26 \cdot 29$ & ... & $32 \cdot 0$ & $\ldots$ & 50.0 & $24 \cdot 5$ & Clear, light wind S.E. \\
\hline$\cdots$ & & $\cdots$ & 17 & 6.00 p.m. & $26 \cdot 13$ & ... & 48.0 & 420 & & 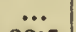 & \\
\hline " & & $\cdots$ & 18 & $10.00 \mathrm{a} . \mathrm{m}$ & $26 \cdot 23$ & ... & $36^{\circ} 0$ & $33^{\circ} 0$ & 520 & $28 \cdot 5$ & Clear, light variable wind. \\
\hline$\because$ & & $\cdots$ & 18 & 6.00 p.m. & $26 \cdot 15$ & ... & 48.0 & $42 \cdot 0$ & & $\ldots$ & \\
\hline$\because$ & & $\cdots$ & 19 & 10.00 a.m. & $26 \cdot 55$ & ... & $31^{\circ} 0$ & ... & $56 \cdot 0$ & $28 \cdot 0$ & Cirrus all day, light wind N.W. \\
\hline 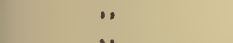 & & $\cdots$ & 19 & 7.00 p.m. & 26.44 & ... & $35^{\circ} 0$ & ... & & $\ldots$ & \\
\hline$\because$ & & $\cdots$ & 20 & 9.30 a.m. & 26.45 & .. & $26^{\circ} 0$ & & $56 \cdot 0$ & $19^{\circ} 0$ & Cu \\
\hline$\because$ & & $\cdots$ & 20 & $6.30 \mathrm{p} . \mathrm{m}$. & $26 \cdot 35$ & & 37.0 & $34^{\circ} 0$ & & & Light \\
\hline Pai-ma-p'u & ... & $5 \ddot{677}$ & $\begin{array}{l}21 \\
21\end{array}$ & $\begin{array}{l}7.30 \mathrm{a} . \mathrm{m} \\
6.00 \mathrm{p} \cdot \mathrm{m}\end{array}$ & $\begin{array}{l}26 \cdot 41 \\
25 \cdot 30\end{array}$ & $\begin{array}{l}205 \cdot 8 \\
203 \cdot 5\end{array}$ & $\begin{array}{l}26 \cdot 0 \\
28 \cdot 5\end{array}$ & $\begin{array}{l}\cdots \\
\cdots\end{array}$ & $\begin{array}{c}42 \cdot 0 \\
\cdots\end{array}$ & $\begin{array}{c}25^{\circ} 0 \\
\cdots\end{array}$ & $\begin{array}{l}\text { Cumulus, stratus and nimbus all day. } \\
\text { Light wind S.W. } 11.00 \text { a.m. to } 2.00 \\
\text { p.m. snow fell. }\end{array}$ \\
\hline & & & 22 & 8.00 a.m. & $25 \cdot 20$ & 203.4 & 23.0 & $\cdots$ & $36^{\circ} 0$ & $21 \cdot 5$ & Snow during night and forenoon. \\
\hline Hsi-fêng-chên & ... & 5546 & 22 & 6.30 p.m. & $25 \cdot 30$ & $203 \cdot 7$ & 30.0 & $\cdots$ & $\cdots$ & $\cdots$ & $\begin{array}{l}\text { Stratus and nimbus all day, light wind } \\
\text { S.W. }\end{array}$ \\
\hline , & & ... & 23 & 10.00 a.m. & $25 \cdot 22$ & ... & $28 \cdot 0$ & .. & $36^{\circ} 0$ & $18 \cdot 0$ & Heavy hoar-frost during night. \\
\hline " & & $\cdots$ & 23 & 6.00 p.m. & $25 \cdot 20$ & ... & 36.0 & ... & $\ldots$ & $\ldots$ & $\begin{array}{l}\text { Fog } 11.00 \text { a.m. Cirro-cumulus. } \\
\text { p.m. cumulus, light wind W. }\end{array}$ \\
\hline$\because$ & & ... & 24 & 10.00 a.m. & $25 \cdot 35$ & ... & $35 \cdot 0$ & .. & $42 \cdot 0$ & $28 \cdot 0$ & Slight hoar-frost during night, cumulus. \\
\hline ” & & $\ldots$ & 24 & 6.00 p.m. & $25 \cdot 30$ & & $28 \cdot 5$ & * & ‥ & $\cdots$ & Haze all day, light wind $\mathrm{W}$. \\
\hline$\because$. & & $\because$ & 25 & 7.30 a.m. & $25 \cdot 26$ & $203 \cdot 6$ & $20 \cdot 5$ & & $36^{\circ} 0$ & $19 \cdot 5$ & Slight hoar-frost during night. \\
\hline T'ai-pei-ch'êng & $\cdots$ & 5119 & 25 & $6.00 \mathrm{p} . \mathrm{m}$ & $25 \cdot 29$ & $203 \cdot 7$ & $28 \cdot 5$ & ... & ... & ... & $\begin{array}{l}\text { Stratus and nimbus all day. } \\
\text { Light wind S.E. }\end{array}$ \\
\hline "' & & .. & 26 & $10.00 \mathrm{a} . \mathrm{m}$ & $25 \cdot 41$ & $\cdots$ & $25 \cdot 5$ & & $\cdots$ & $25^{\circ} 0$ & Snow during night. \\
\hline " & & $\cdots$ & 26 & 6.00 p.m. & $25 \cdot 40$ & ... & $35 \cdot 0$ & & ... & $\ldots$ & $\begin{array}{l}\text { Overcast, stratus and cumulus all day. } \\
\text { light variable wind. }\end{array}$ \\
\hline & & & 27 & 8.00 a.m. & $25 \cdot 44$ & $203 \cdot 8$ & $26: 5$ & & $42 \cdot 0$ & 21.5 & Cirrus, cirro-cumulus and cumulus all \\
\hline Chên-yüan Hsier & & 4478 & 27 & 6.00 p.m. & 26.04 & $205^{\circ} 0$ & $41 \cdot 0$ & 36.0 & & ... & day, light wind N.W. \\
\hline$\because$ & & $\cdots$ & 28 & 10.00 a.m. & $26 \cdot 18$ & $\ldots$ & $41 \cdot 5$ & $37 \cdot 0$ & $42 \cdot 0$ & 29.0 & Cumulus all day, few flakes snow. \\
\hline$\bullet$ & & $\cdots$ & 28 & 6.00 p.m. & $26^{\cdot 10}$ & $\cdots$ & $37 \cdot 0$ & $33 \cdot 0$ & ... & $\cdots$ & light wind N.W. \\
\hline & & & $\underset{1}{\mathrm{Mar}}$ & $7.30 \mathrm{a} . \mathrm{m}$. & $26 \cdot 01$ & $205^{\circ} 0$ & 210 & & 48.0 & $19 \cdot 0$ & Cirro-cumulus and cumulus all day. \\
\hline Yang-shu-wan & ... & 5336 & 1 & 6.30 p.m. & $25 \cdot 54$ & $204^{\prime} 1$ & 440 & $39^{\circ} 0$ & & & Light wind S.E. \\
\hline .. & & ... & 2 & 10.00 a.m. & $25 \cdot 74$ & $\ldots$ & 390 & 360 & 56.0 & 18.0 & Cumulus and haze. \\
\hline " & & ... & 2 & 6.00 p.m. & $25 \cdot 61$ & & 40.0 & $36^{\circ} 0$ & $\ldots$ & & \\
\hline & & & 3 & $7.30 \mathrm{a.m}$. & $25 \cdot 50$ & $204^{\prime} 0$ & $26 \cdot 0$ & $\ldots$ & $52 \cdot 0$ & $22 \cdot 5$ & Cumulus a \\
\hline I,iu-chia-hua & $\ldots$ & 5763 & 3 & 6.00 p.m. & 25.08 & $203 \cdot 2$ & $43^{\circ} 0$ & $\ldots$ & $\ldots$ & $\ldots$ & Moderate wind N.W. \\
\hline •" & & $\cdots$ & 4 & 7.30 a.m. & 25.02 & ... & $311^{\circ}$ & & $48^{\circ} 0$ & $18 \cdot 0$ & Cirro-cumulus and cumulus since noon, \\
\hline 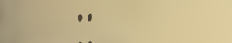 & & $\cdots$ & 4 & 6.00 p.m. & 25.05 & & $45 \cdot 5$ & 40.0 & $\ldots$ & $\ldots$ & N.W \\
\hline Jên-sa-ho & & 6345 & $\begin{array}{l}5 \\
5\end{array}$ & $\begin{array}{l}7.30 \mathrm{a} . \mathrm{m} \\
6.00 \mathrm{p} . \mathrm{m}\end{array}$ & $\begin{array}{l}25 \cdot 10 \\
24 \cdot 55\end{array}$ & $\begin{array}{l}203 \cdot 3 \\
202 \cdot 2\end{array}$ & $\begin{array}{l}30.5 \\
21.0\end{array}$ & $\begin{array}{l}\cdots \\
\ldots\end{array}$ & $\begin{array}{c}56.0 \\
\ldots\end{array}$ & 30.0 & Cumulus and stratus all day. \\
\hline & & $\ldots$ & 6 & 8.00 a.m. & $24 \cdot 52$ & $202 \cdot 1$ & 8.0 & & $\cdots$ & $\dddot{5}: 0$ & Slight hoar-frost during night, few cirrus \\
\hline "Kü-yiaan Chou & $\ldots$ & 6333 & 6 & 6.00 p.m. & $24 \cdot 25$ & $201 \cdot 7$ & $45 \cdot 5$ & 400 & & & all day, light wind N.W. \\
\hline ". & & $\cdots$ & 7 & $10.00 \mathrm{a} . \mathrm{m}$ & $24 \cdot 29$ & $\cdots$ & $45 \cdot 5$ & 40.0 & 56.0 & $25 \cdot 5$ & Cirrus and cirro-cumulus all day, light \\
\hline ". & & $\cdots$ & 7 & 6.30 p.m. & $24 \cdot 20$ & ... & 430 & 36.0 & & & \\
\hline " & & ... & 8 & $10.00 \mathrm{a} . \mathrm{m}$ & $24 \cdot 18$ & $\ldots$ & 530 & 46.0 & $57^{\circ} 0$ & $32 \cdot 5$ & Cumulus all day, dust haze. \\
\hline . & & ... & 8 & 6.00 p.m. & $24 \cdot 19$ & ... & 49.0 & $44 \cdot 5$ & & & Light wind N.W. \\
\hline " & & ... & 9 & 10.00 a.m. & 24.09 & ... & $48^{\circ} 0$ & $42^{\circ} 0$ & $61 \cdot 5$ & $29^{\circ} 0$ & Cirrus and cumulus during afternoon. \\
\hline " & & ... & 9 & 6.00 p.m. & 24.05 & ... & $38 \cdot 2$ & 40 & ... & ... & Moderate wind $\mathbf{E}$. \\
\hline
\end{tabular}

* Latitude $36^{\circ} 00^{\prime} 23^{\prime \prime} \mathrm{N}$., Longitude $106^{\circ} 6^{\prime} 28^{\prime \prime} \mathrm{E}$. 
METEOROLOGICAL OBSERVATIONS-continuea.

\begin{tabular}{|c|c|c|c|c|c|c|c|c|c|c|c|}
\hline \multirow{2}{*}{\multicolumn{2}{|c|}{ PLACE. }} & \multirow{2}{*}{ 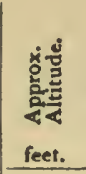 } & \multirow[b]{2}{*}{ Date. } & \multirow[b]{2}{*}{$\begin{array}{l}\text { Time of } \\
\text { Observation. }\end{array}$} & \multirow{2}{*}{ 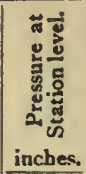 } & \multirow{2}{*}{ 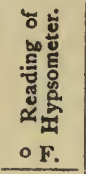 } & \multicolumn{4}{|c|}{ Temperature. } & \multirow[b]{2}{*}{ REMARKS. } \\
\hline & & & & & & & $\begin{array}{l}\text { Dry } \\
\text { Bulb. } \\
\text { of. }\end{array}$ & $\begin{array}{l}\text { Wet } \\
\text { Bulb. } \\
\text { of. }\end{array}$ & $\begin{array}{l}\text { Max. } \\
\text { of. }\end{array}$ & $\begin{array}{l}\text { Min. } \\
\text { of. }\end{array}$ & \\
\hline Ku-yüan Chou & 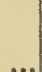 & 6333 & $\begin{array}{c}1909 \\
\text { Mar. } \\
10\end{array}$ & $10.00 \mathrm{a} \mathrm{m}$ & $24 \cdot 15$ & & 36.5 & 35.0 & 57.0 & & tratue and nimbue oll dow \\
\hline 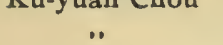 & & $\begin{array}{l}0333 \\
\ldots\end{array}$ & 10 & 10.00 a.m. & $24 \cdot 20$ & $\ldots$ & $\begin{array}{ll}365 \\
39.0\end{array}$ & 35.0 & 370 & $\begin{array}{l}22.5 \\
\ldots\end{array}$ & $\begin{array}{l}\text { Stratus and nimbus all day, } 10.00 \mathrm{a} . \mathrm{m} \text {. } \\
\text { to } 1.00 \text { p.m. Little rain, slight wind } \mathrm{N} \text {. }\end{array}$ \\
\hline ." & & $\ldots$ & 11 & $10.30 \mathrm{a} . \mathrm{m}$ & $24 \cdot 36$ & $\ldots$ & 30.0 & $\ldots$ & $45 \cdot 5$ & 23.5 & 7.00 a.m. to 10.30 a.m. Suow, stratus and \\
\hline ". & & $\ldots$ & 11 & 6.00 p.m. & $24 \cdot 42$ & $\ldots$ & $29 \cdot 0$ & $\ldots$ & 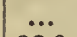 & $\ldots$ & nimbus all day. Light wind $\mathrm{N}$. \\
\hline .• & & $\cdots$ & 12 & $10.00 \mathrm{a} . \mathrm{m}$ & $24 \cdot 39$ & $\ldots$ & 30.0 & ... & 36.0 & 20.0 & Snow. 10.00 a.m. Cumulus and stratus. \\
\hline 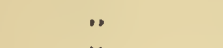 & & $\ldots$ & 12 & 6.00 p.m. & $24 \cdot 42$ & $\ldots$ & $28^{\circ} 0$ & $\ldots$ & ... & & 5.00 p.m. Clear, Light wind F. \\
\hline . & & ... & 13 & $10.00 \mathrm{a} . \mathrm{m}$ & $24 \cdot 41$ & $\ldots$ & 30.0 & & $\ldots$ & $18^{\circ} 0$ & Few cirrus all day. \\
\hline$\ddot{0}$ & & $\cdots$ & 13 & 6.00 p.m. & $24 \cdot 35$ & ... & 40.5 & 36.0 & & & Light wind $S$. \\
\hline 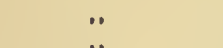 & & $\ldots$ & 14 & 10.00 a.m. & $24 \cdot 26$ & $\ldots$ & 40.0 & $36^{\circ} 0$ & 60.5 & $32 \%$ & Cirrus and cumulus all day. \\
\hline " & & ... & 14 & 6.00 p.m. & $24 \cdot 30$ & $\ldots$ & 40.0 & 36.0 & & & Wind N.W. \\
\hline 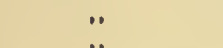 & & $\cdots$ & 15 & $10.00 \mathrm{a} . \mathrm{m}$ & $24 \cdot 26$ & $\cdots$ & 38.0 & & 61.0 & 30.0 & Fog. 11.00 a.m. Cumulus. \\
\hline$\ddot{0}$ & & $\cdots$ & 15 & 6.00 p.m. & $24 \cdot 31$ & & 41.5 & $38^{\circ} 0$ & $\cdots$ & & Light wind N.E. \\
\hline Ch'ang-yi-p'u & & 6813 & $\begin{array}{l}16 \\
16\end{array}$ & 6.00 p.m. & $\begin{array}{l}24 \cdot 47 \\
23 \cdot 37\end{array}$ & $\begin{array}{l}202.0 \\
199 \cdot 7\end{array}$ & 36.0 & $\cdots$ & $\begin{array}{c}65 \\
\ldots\end{array}$ & $\begin{array}{c}31 \cdot 0 \\
\ldots\end{array}$ & $\begin{array}{l}\text { Fog and haze. Noon, Cirro-cumulus } \\
\text { and Cumulus. Wind, a.m., N.; p.m., }\end{array}$ \\
\hline ". & & ... & 17 & 10.00 a.m. & $23 \cdot 43$ & $\cdots$ & $33 \%$ & ... & 42.5 & $19 \cdot 5$ & $\begin{array}{l}\text { S.W. } \\
\text { Snow till } 11.00 \text { a.m. Stratus and } \\
\text { cumulus. }\end{array}$ \\
\hline " & & $\cdots$ & 17 & 6.00 p.m. & $23 \cdot 32$ & & 30.0 & ... & $\cdots$ & & Light wind $\mathrm{W}$. \\
\hline Ch'ang̈-t'ai-p'u & & 6653 & 18 & 7.15 & 23.20 & 199.5 & $31 \cdot 0$ & 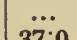 & $\cdots$ & $18 \cdot 0$ & Stratus and nimbus. $11.00 \mathrm{a} . \mathrm{m}$. cumulus. \\
\hline . & & $\begin{array}{c}0003 \\
\ldots\end{array}$ & 19 & $\begin{array}{l}0.00 \mathrm{p} . \mathrm{m} \\
10.00 \text { a.m. }\end{array}$ & 24.08 & 2008 & $38 \cdot 0$ & . & $45 \cdot 0$ & $15 \cdot 0$ & Strong wind during night. Haze all \\
\hline ." & & $\ldots$ & 19 & 6.00 p.m. & 24.06 & & $35 \cdot 0$ & ... & $\ldots$ & & day. Moderate wind S. \\
\hline Ching-n̈ing Cho & & & 20 & 7.00 a.m. & $24 \cdot 10$ & $201 \cdot 3$ & $30 \%$ & & $\cdots$ & $24 \cdot 0$ & Cumulus all day. \\
\hline Caing-ning Cho & & 6276 & 20 & 6.00 p.m. & $24 \cdot 46$ & $201 \cdot 8$ & 46.0 & 40.0 & & & Moderate wind S.W. \\
\hline$\because$ & & ... & 21 & 10.00 a.m. & $24 \cdot 34$ & $\ldots$ & 41.0 & 38.0 & $52 \cdot 0$ & 39.5 & Small amount of rain iu morning. \\
\hline & & $\cdots$ & & 6.00 p.m. & 2429 & $\cdots$ & 450 & 423 & $\cdots$ & ... & $\begin{array}{l}\text { Cumulus and stratus all day. } \\
\text { Light wind } S . W .\end{array}$ \\
\hline " & & ... & 22 & 10.00 a.m. & $24 \cdot 38$ & $\ldots$ & 43.0 & $40 \cdot 0$ & 46.5 & 33.5 & Fog and overcast all day. Light wind \\
\hline . & & ... & 22 & p.m. & $24 \cdot 59$ & ... & $31^{\prime} 0$ & ... & ... & ... & $\begin{array}{l}\text { W. } 5.00 \text { p.m. little snow. Small } \\
\text { amount of rain in morning. }\end{array}$ \\
\hline Ch'ing-chia-yi & 0.0 & & 23 & 7.00 a.m. & $24 \cdot 80$ & $202 \cdot 8$ & 29.0 & $\ldots$ & 46.0 & $17 \cdot 0$ & Little snow during night. Cumulus and \\
\hline .. & & $\begin{array}{l}1+00 \\
\ldots\end{array}$ & 24 & 9.30 a.m. & 24.07 & 2014 & $\begin{array}{l}24.5 \\
28.0\end{array}$ & . & $\begin{array}{l}\cdots \\
\ldots\end{array}$ & $\dddot{6} 0$ & $\begin{array}{l}\text { stratus all day, } \\
\text { clear light wind } w \text {. }\end{array}$ \\
\hline . & & ... & 24 & 6.00 p.m. & $24 \cdot 48$ & & 40.0 & $35 \cdot 0$ & & & \\
\hline & & & 25 & 7.00 a.m. & 24.03 & $201 \cdot 2$ & 20.0 & & $55 \cdot 0$ & $18: 0$ & ulus all day. \\
\hline Hui-ning Hsien & & 6125 & 25 & 6.00 p.m. & 24.49 & $202 \cdot 0$ & 43.0 & 39.0 & & & Light wind $\mathrm{E}$. \\
\hline ", & & $\ldots$ & 26 & 10.00 a.m. & $24 \cdot 37$ & $\ldots$ & 37.0 & 33.0 & 50.0 & $22 \cdot 5$ & Little snow. Strong wind and dust \\
\hline 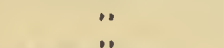 & & $\cdots$ & 26 & 6.00 p.m. & $24 \cdot 28$ & $\dddot{000} 0$ & 39.0 & $35 \cdot 0$ & $51 \cdot 0$ & 01.5 & storm S. Cumulus all day. \\
\hline Hsi-kung-yi & & 6368 & $\begin{array}{l}27 \\
27\end{array}$ & $\begin{array}{l}7.00 \mathrm{a} . \mathrm{m} \\
6.00 \mathrm{p} . \mathrm{m}\end{array}$ & $\begin{array}{l}2437 \\
24 \cdot 16\end{array}$ & $201 \cdot 3$ & 50.0 & $\ddot{38} \cdot 0$ & 010 & 215 & $\begin{array}{l}\text { Cirro-cumulus all day. } \\
\text { Light wind S.W. }\end{array}$ \\
\hline ." & & $\ldots$ & 28 & $10.00 \mathrm{a} . \mathrm{m}$ & $24: 28$ & $\ldots$ & 43.0 & $34 \cdot 0$ & $57 \cdot 0$ & $27 \cdot 0$ & Cumulus all day. Evening overcast. \\
\hline "• & & $\ldots$ & 28 & 6.00 p.m. & $24 \cdot 20$ & & $49 \cdot 0$ & $39^{\circ} 0$ & & & Light wind $w$. \\
\hline An-ting Hsien & & 6762 & $\begin{array}{l}29 \\
29\end{array}$ & $\begin{array}{l}7.00 \mathrm{a} . \mathrm{m} \\
6.00 \mathrm{p} . \mathrm{m}\end{array}$ & $\begin{array}{l}24 \cdot 25 \\
23 \cdot 88\end{array}$ & $201 \cdot 6$ & $\begin{array}{l}34^{\circ} 0 \\
40^{\circ} 0\end{array}$ & $35 \cdot 0$ & $\begin{array}{c}56 \cdot 0 \\
\cdots\end{array}$ & $\begin{array}{c}32.5 \\
\cdots\end{array}$ & $\begin{array}{l}\text { Snow during night and at } 7.00 \text { a.m. up } \\
\text { to noon, fog. Clear towards evening. } \\
\text { Wind N, Noon, wind S.W. }\end{array}$ \\
\hline " & & $\cdots$ & 30 & 10.0 & $23 \cdot 83$ & $\cdots$ & $42 \cdot 0$ & 36.0 & 58.0 & 20.5 & Cirro-cumulus all day. \\
\hline 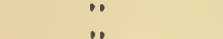 & & ... & & & $\begin{array}{l}23.74 \\
24 \cdot 00\end{array}$ & $\cdots$ & & & $64: 0$ & $\ddot{28} \cdot 0$ & wind \\
\hline$\therefore$ & & $\cdots$ & 31 & $\begin{array}{r}10.00 \mathrm{a} . \mathrm{m} \\
6.00 \mathrm{p} . \mathrm{m}\end{array}$ & 23.95 & $\cdots$ & 43.0 & 34.0 & $\begin{array}{l}040 \\
\ldots\end{array}$ & $\begin{array}{c}280 \\
\ldots\end{array}$ & Cumulus all day. \\
\hline & & & April & & & & & & & & \\
\hline Ch'êng̈-k'ou-yi & & 6839 & 1 & $\begin{array}{l}7.15 \text { a.m1. } \\
6.00 \text { p.m. }\end{array}$ & $\begin{array}{l}23.87 \\
23.75\end{array}$ & $\begin{array}{l}200^{\prime} 9 \\
200.5\end{array}$ & $\begin{array}{l}21.5 \\
51.0\end{array}$ & $38^{\circ} 0$ & $622^{\circ}$ & 14.5 & Cirru \\
\hline & & & 2 & 7.15 a.m. & 23.80 & 200.7 & $30^{\circ} 0$ & & $62 \cdot 0$ & $27 \cdot 0$ & \\
\hline Kan-tsao-tien & & 6781 & 2 & 6.00 p.m. & 23.81 & $200 \cdot 6$ & 58.5 & $39 \cdot 0$ & & & Light wind N.W. \\
\hline • & & ... & 3 & 10.00 a.m. & $23: 86$ & ... & $49 \cdot 0$ & $45 \cdot 0$ & 68.0 & $32 \cdot 0$ & Clear, light variable wind. \\
\hline . & & .. & 3 & 6.00 p.m. & 23.74 & & $54^{\circ} 0$ & $43 \cdot 0$ & & & 0 a.m. \\
\hline o-shui-tzü & & 5559 & $\begin{array}{l}4 \\
4\end{array}$ & $\begin{array}{l}7.00 \mathrm{a.m} \\
6.00 \mathrm{~m}\end{array}$ & $\begin{array}{l}23.83 \\
24.96\end{array}$ & 2009 & $\begin{array}{l}42 \cdot 0 \\
54 \cdot 0\end{array}$ & $\begin{array}{l}35.0 \\
41.0\end{array}$ & $58^{\circ} 0$ & $37 \cdot 0$ & Cuniulus with haze all day. \\
\hline " & & $\because \cdot$ & 5 & 7.00 a.m. & 25.26 & 203.8 & 41.0 & 35.0 & $56: 0$ & 41:0 & Overcast, cumulus. 4.00 p.m. Clear. \\
\hline
\end{tabular}


METEOROLOGICAL OBSERVATIONS - continued.

\begin{tabular}{|c|c|c|c|c|c|c|c|c|c|c|c|}
\hline \multirow[b]{2}{*}{ PLACE. } & & \multirow[b]{2}{*}{ 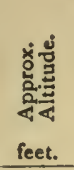 } & \multirow[b]{2}{*}{ Date. } & \multirow[b]{2}{*}{$\begin{array}{l}\text { Time of } \\
\text { Observation. }\end{array}$} & \multirow{2}{*}{ 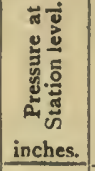 } & \multirow{2}{*}{ 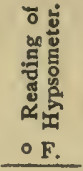 } & \multicolumn{4}{|c|}{ Temperature. } & \multirow[b]{2}{*}{ REMARKS. } \\
\hline & & & & & & & $\begin{array}{c}\text { Dry } \\
\text { Bulb. } \\
\circ \mathrm{F} . \\
\end{array}$ & $\begin{array}{c}\text { Wet } \\
\text { Bulb. } \\
\text { o F. }\end{array}$ & $\begin{array}{l}\text { Max. } \\
\circ \mathrm{F} \text {. }\end{array}$ & $\begin{array}{l}\text { Min. } \\
\text { OF. }\end{array}$ & \\
\hline & & & \begin{tabular}{|l|}
$x 909$ \\
Apr.
\end{tabular} & & & & & & & & \\
\hline $\begin{array}{c}\text { Lan-chou Fu } \\
\text { ". }\end{array}$ & & $\begin{array}{c}5106 \\
\ldots\end{array}$ & $\begin{array}{l}5 \\
6\end{array}$ & $\begin{array}{l}6.00 \text { p.m. } \\
10.30 \text { a.m. }\end{array}$ & $\begin{array}{l}25 \cdot 27 \\
25 \cdot 15\end{array}$ & $\begin{array}{c}203.7 \\
\ldots\end{array}$ & $\begin{array}{l}48 \cdot 0 \\
46 \cdot 0\end{array}$ & \begin{tabular}{|l|}
$37 \cdot 0$ \\
$38^{\circ} 0$
\end{tabular} \mid & $56^{\circ} 0$ & 30.5 & $\begin{array}{l}\text { Light wind N.W. } \\
\text { No clouds, haze. }\end{array}$ \\
\hline "., & & $\ldots$ & 6 & 6.30 p.m. & 25.00 & $\ldots$ & $51 \cdot 5$ & & & & Light wind N.W. \\
\hline ". & & $\cdots$ & 7 & 10.30 a.m. & 24.91 & ... & $55 \cdot 0$ & $44 \cdot 0$ & $60^{\prime} 0$ & 30.0 & 3.00 p.m. Cumulus. \\
\hline ", & & $\cdots$ & 7 & 8.00 p.m. & 2482 & ... & $54^{\circ} 0$ & $45^{\circ} 0$ & & & Light wind N.W. \\
\hline$"$, & & $\cdots$ & $\begin{array}{l}8 \\
8\end{array}$ & $\begin{array}{l}10.00 \mathrm{a} . \mathrm{m} \\
7.00 \mathrm{p.m}\end{array}$ & $\begin{array}{l}24 \cdot 86 \\
24: 84\end{array} \mid$ & $\ldots$ & $\begin{array}{l}44 \cdot 0 \\
60^{\circ}\end{array}$ & \begin{tabular}{|l|}
$37^{\circ} 0$ \\
$51^{\circ} 0$
\end{tabular} \mid & 63.0 & $37^{\circ} 0$ & $\begin{array}{l}\text { Cirro-cumulus and dust haze all day. } \\
\text { Wind } E \text {. }\end{array}$ \\
\hline$"$ & & $\ldots$ & 9 & 10.00 a.m. & 25.00 & $\ldots$ & $51 \cdot 0$ & 41.0 & $63 \cdot 0$ & $\dddot{45} \cdot 0$ & Cirro-cumulus and haze all day. \\
\hline ", & & $\cdots$ & 9 & 7.00 p.m. & 24.91 & $\ldots$ & 60.0 & $51 \cdot 0$ & & & Light wind $W$. \\
\hline ", & & $\cdots$ & 10 & 10.00 a.m. & 24.99 & $\cdots$ & $53 \cdot 0$ & $\begin{array}{r}45 \cdot 0 \\
59 \cdot 0\end{array}$ & 66.0 & $45 \cdot 5$ & Cirro-cumulus all day. \\
\hline ", & & $\cdots$ & $\begin{array}{l}10 \\
11\end{array}$ & $\begin{array}{l}6.00 \mathrm{p} . \mathrm{m} \\
10.00 \mathrm{a} . \mathrm{m}\end{array}$ & $\begin{array}{l}24 \cdot 80 \\
24 \cdot 80\end{array}$ & $\ldots$ & $\begin{array}{l}65 \cdot 0 \\
51^{\circ} 0\end{array}$ & \begin{tabular}{|l|}
53.0 \\
$40^{\circ} 0$
\end{tabular} \mid & 69.5 & $48 \cdot 5$ & $\begin{array}{l}\text { Light variable wind. } \\
\text { Cirro-cumulus } 4.00 \text {. }\end{array}$ \\
\hline$"$ & & $\ldots$ & 11 & 6.30 p.m. & 24.94 & $\ldots$ & 68.5 & 50.0 & 000 & 700 & Light wind E. 4.00 p.m. Moderate wiud E. \\
\hline 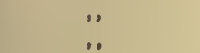 & & $\ldots$ & 12 & 9.30 a.m. & 25.02 & $\ldots$ & $57 \cdot 5$ & $45 \cdot 0$ & $73 \cdot 0$ & $45 \cdot 5$ & Cumulus with haze all day. \\
\hline$\ddot{~}$ & & $\cdots$ & 12 & 6.00 p.m. & 24.84 & ... & $67^{\circ} 0$ & $55^{\circ} 0$ & & & nd E. \\
\hline ", & & $\cdots$ & 13 & 10.00 a.m. & 24.98 & $\cdots$ & 59.0 & $48^{\circ} 0$ & $75^{\circ} 0$ & $45^{\circ} 0$ & Clear. 1.00 p.m. Overcast, Light wind E. \\
\hline$"$ & & $\cdots$ & $\begin{array}{l}13 \\
14\end{array}$ & $\begin{array}{l}7.00 \text { p.m. } \\
9.00 \text { a.m. }\end{array}$ & \begin{tabular}{|l|}
$25 \cdot 02$ \\
$25 \cdot 14$
\end{tabular} \mid & $\begin{array}{l}\cdots \\
\ldots\end{array}$ & $\begin{array}{l}59^{\circ} 0 \\
56^{\circ}\end{array}$ & $\begin{array}{l}40^{\circ} 0 \\
45^{\circ} 0\end{array}$ & $75 \cdot 0$ & 40.0 & $\begin{array}{l}5.00 \text { p.m. Dust storm, duration one hour. } \\
\text { Clear, calm. }\end{array}$ \\
\hline ", & & $\ldots$ & 14 & 6.00 p.m. & $25 \cdot 02$ & ... & $67 \cdot 5$ & 550 & & & clear, callu. \\
\hline$\because$ & & ... & 1. & 9.30 a.m. & 24.9 & ... & $62 \cdot 5$ & 53.0 & $75 \cdot 0$ & $44 \cdot 5$ & 11 day. \\
\hline ": & & $\cdots$ & & 6.00 p.m. & 24. & $\cdots$ & $68^{\circ} 0$ & 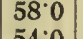 & 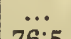 & $\ddot{n}_{5}$ & \\
\hline ". & & $\cdots$ & 1 & $\begin{array}{l}8.00 \mathrm{a} . \mathrm{m} \\
6.00 \mathrm{p} . \mathrm{m}\end{array}$ & $\begin{array}{l}24 \cdot 88 \\
24 \cdot 88\end{array}$ & $\cdots$ & $\begin{array}{l}61 \cdot 5 \\
63 \cdot 0\end{array}$ & $\begin{array}{l}54.0 \\
49 \cdot 0\end{array}$ & 76.5 & 52.5 & $\begin{array}{l}\text { Dust haze all day, light wind } W \text {. } \\
3.00 \text { p.m. Strong wind } W \text {. }\end{array}$ \\
\hline ": & & $\ldots$ & 17 & 9.30 a.m. & $25 \cdot 12$ & ... & $55 \cdot 0$ & 41.5 & $7 \mathbf{7 5} 0$ & $41 \cdot 5$ & Cirro-cumulus \\
\hline ", & & $\cdots$ & 17 & 6.00 p.m. & $25 \cdot 01$ & ... & $62 \cdot 5$ & $51 \cdot 0$ & & & To \\
\hline ", & & $\cdots$ & $\begin{array}{l}18 \\
18\end{array}$ & 10.00 a.m. & \begin{tabular}{|l|}
$25 \cdot 06$ \\
$24 \cdot 78$
\end{tabular} & $\ldots$ & $\begin{array}{l}52 \cdot 0 \\
61 \cdot 0\end{array}$ & $\begin{array}{r}39.5 \\
45.5\end{array}$ & 66.0 & 36.0 & $\mathbf{N}$ \\
\hline$\because$, & & $\ldots$ & $\begin{array}{l}18 \\
19\end{array}$ & $\begin{array}{l}6.00 \text { p.m. } \\
10.00 \text { a.m. }\end{array}$ & 24.96 & … & $\begin{array}{l}61.0 \\
53.6\end{array}$ & $\begin{array}{l}45.5 \\
45.0\end{array} \mid$ & $\dddot{99}_{5}$ & $\cdots$ & wind E. \\
\hline$\because$ & & $\ldots$ & 9 & 7.00 p.m. & $25 \cdot 04$ & $\ldots$ & 50.0 & 48.0 & 000 & $\cdots$ & $\begin{array}{l}\text { Overcast, cumulus all day } \\
\text { Light wind E., } 8.00 \text { p.m. little rain. }\end{array}$ \\
\hline ", & & ... & 20 & 10.00 a.m. & $25 \cdot 10$ & $\ldots$ & 53.5 & $45 \cdot 0$ & $60 \cdot 0$ & $42 \cdot 5$ & Cumulus and haze all day. \\
\hline$\ddot{~}$ & & ... & 20 & 6.00 p.m. & $25 \cdot 01$ & ... & 59.5 & $47 \cdot 0$ & & & \\
\hline ", & & $\cdots$ & 21 & 8.00 a.m. & $25 \cdot 14$ & $\cdots$ & 43.0 & 37.0 & $69 \cdot 0$ & 33.5 & Cirro-cumulus and cumulus. 4.00 p.m. \\
\hline "' & & $\cdots$ & 21 & 7.00 p.m. & 2504 & ... & 600 & $48.0]$ & ... & $\cdots$ & $\begin{array}{l}\text { Overcast. Light wind E. } 4.00 \text { p.m. } \\
\text { Strong wind W. }\end{array}$ \\
\hline "., & & ... & 22 & 9.30 a.m. & $25 \cdot 06$ & ... & 53.0 & 43.0 & $68^{\circ} 0$ & $33 \cdot 5$ & Cirro-cumulus all day. \\
\hline ", & & $\cdots$ & 22 & & & $\cdots$ & & & & & Iin \\
\hline 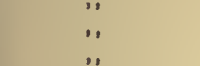 & & $\cdots$ & $\begin{array}{l}23 \\
23\end{array}$ & $\begin{aligned} 10 . \\
6 .\end{aligned}$ & $\begin{array}{l}25 \cdot 06 \\
24 \cdot 86\end{array}$ & $\begin{array}{l}\ldots \\
\ldots\end{array}$ & $\begin{array}{l}62.0 \\
73.0\end{array}$ & $\begin{array}{l}48.0 \\
61.0\end{array}$ & $75 \cdot 0$ & $45 \cdot 0$ & Cirro-cumulus, cumulus and haze all day. \\
\hline "., & & $\ldots$ & 24 & 10.00 & 24.90 & $\ldots$ & 61.5 & 50.0 & $\dddot{78} 0$ & $\ddot{43} \cdot 5$ & Noon, cumulus from E. Light wind. \\
\hline ". & & $\ldots$ & 24 & 6.0 & $24 \cdot 74$ & ... & $72 \cdot 0$ & 68.0 & & & 5.00 p.m. Strong wind one hour. \\
\hline ", & & $\cdots$ & 25 & 10.00 a.m. & 24. & ... & 630 & 53.0 & 83.0 & $54 \cdot 5$ & Heavy cumulus, little rain. \\
\hline 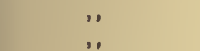 & & $\cdots$ & 25 & 7.00 p.m. & 24.94 & ... & $58 \cdot 5$ & 48.5 & & & noon Ligh \\
\hline. & & 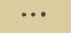 & 26 & 9.30 a.m. & 24.94 & ... & 59.0 & $45 \cdot 0$ & $68^{\circ} 0$ & $41^{\circ} 0$ & Morning Cirrus. Evening Cumulus, \\
\hline ". & & ... & 26 & 6.00 p.nı. & $24 \cdot 90$ & .. & $61 \cdot 5$ & $51 \cdot 5$ & .. & ... & $\begin{array}{l}\text { Light wind E. } 4.00 \text { p.m. Moderate } \\
\text { wind N.W. } 5.00 \text { p.m. Few drops rain. }\end{array}$ \\
\hline 但 & & ... & 27 & $10 .($ & $25 \cdot 14$ & ... & $48 \cdot 5$ & 43.0 & $69 \cdot 0$ & 46.5 & Fog, heavy cumulus, cumulus and stratus \\
\hline $\mathrm{H}$ & & . & & & & & & & ... & & Light wind S.E. Noc \\
\hline .. & & - & 28 & t.m. & 25.22 & 203.3 & 8.0 & 370 & ... & 36.5 & Cumulus all day. Moderate wind varia- \\
\hline 。 & & • & & & & $\cdots$ & & & ... & 010 & ble \\
\hline$\because$ & & & 2 & 9.3 & $\left|\begin{array}{l}25 \cdot 16 \\
24 \cdot 94\end{array}\right|$ & $\cdots$ & $\begin{array}{l}49.5 \\
71 \cdot 0\end{array}$ & $\begin{array}{l}39 \cdot 0 \\
58 \cdot 0\end{array}$ & ... & 31.5 & Clear, light wind E. \\
\hline & & & 30 & $\begin{array}{l}6.00 \mathrm{p} . \mathrm{m} \text {. } \\
6.30 \mathrm{a} . \mathrm{m} \text {. }\end{array}$ & 2 & $\ldots$ & 41.0 & $\begin{array}{l}58.0 \\
38.0\end{array}$ & $75 \cdot 0$ & 39.5 & Clear, light wind $W$. \\
\hline Ch'i & & & 30 & 6.00 p.m. & $23 \cdot 35$ & $\cdots$ & 61.5 & $47 \cdot 0$ & ... & ... & \\
\hline & & & $\begin{array}{c}\text { May } \\
1\end{array}$ & 6.30 a.m. & 23.36 & & & & $75 \cdot 0$ & $33 \cdot 0$ & Cirrus and few cumulus all day. \\
\hline Ch'i-chia-shan & & & $i$ & 6.00 p.m. & $22 \cdot 03$ & $\ldots$ & 60.0 & $44 \cdot 0$ & $\ldots$ & $\ldots$ & Light variable wind. \\
\hline & & & 2 & & & $\ldots$ & 64.0 & 50.0 & $\ldots$ & ... & Cirrus and cumulus all day with haze. \\
\hline 烈 & & & 2 & 6.00 p.m. & 21.93 & ... & 63.0 & $50^{\circ} 0$ & 烈 & ... & Noon, moderate wind $W$ \\
\hline
\end{tabular}

* Latitude $36^{\circ} 3^{\prime}$ N., Longitude $103^{\circ} 41^{\prime} \mathrm{E}$. 
METEOROLOGICAL OBSERVATIONS-continued.

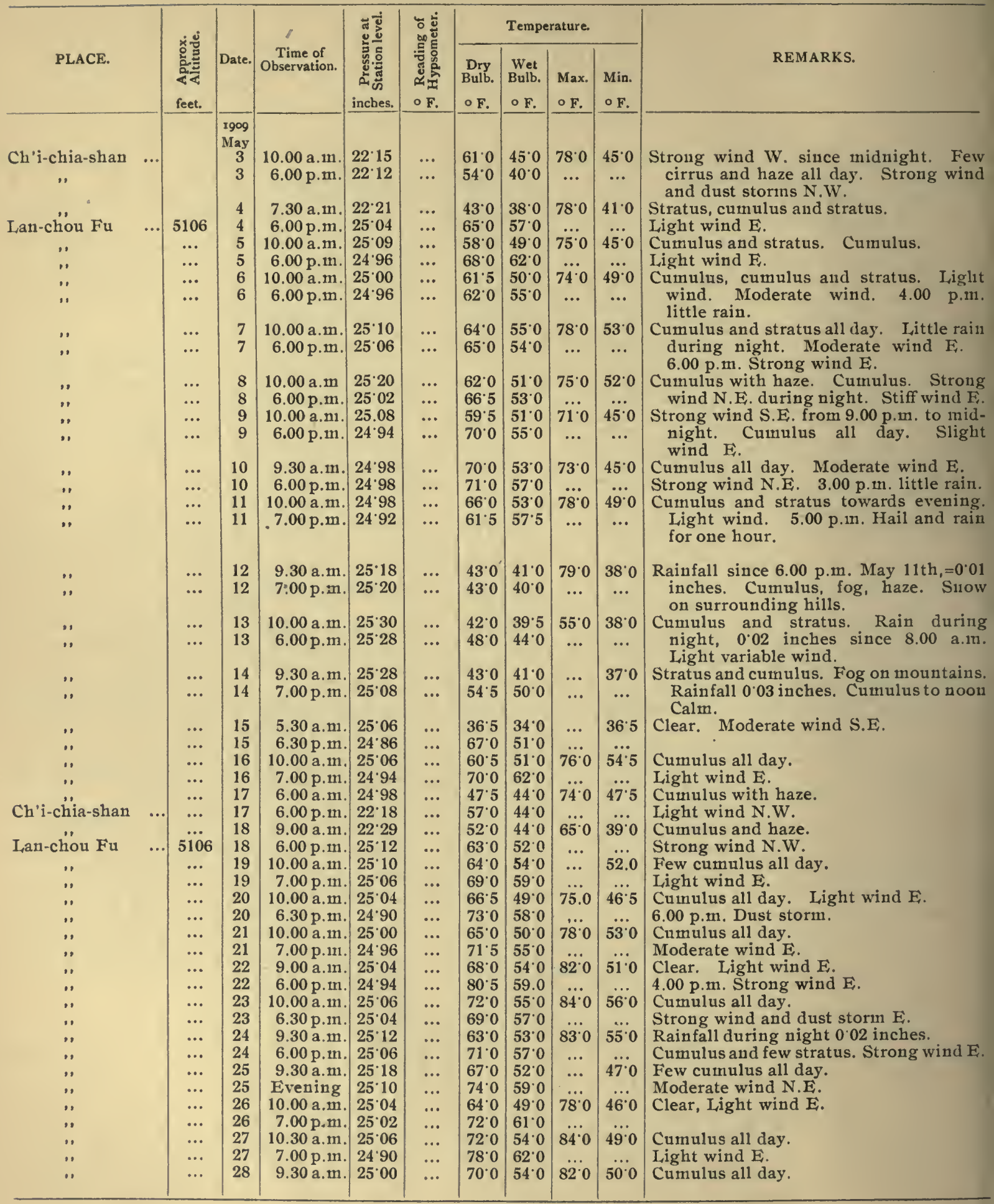




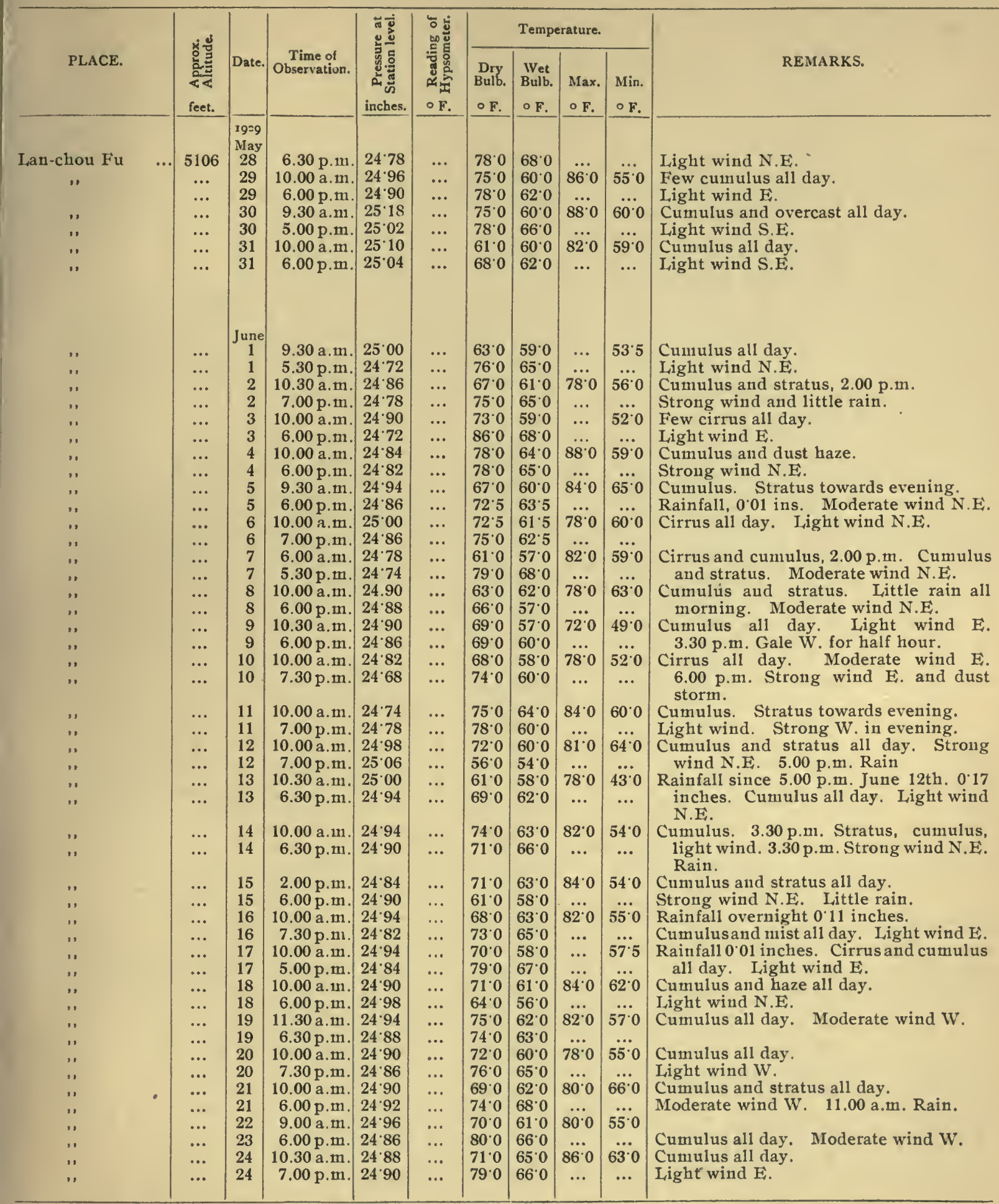




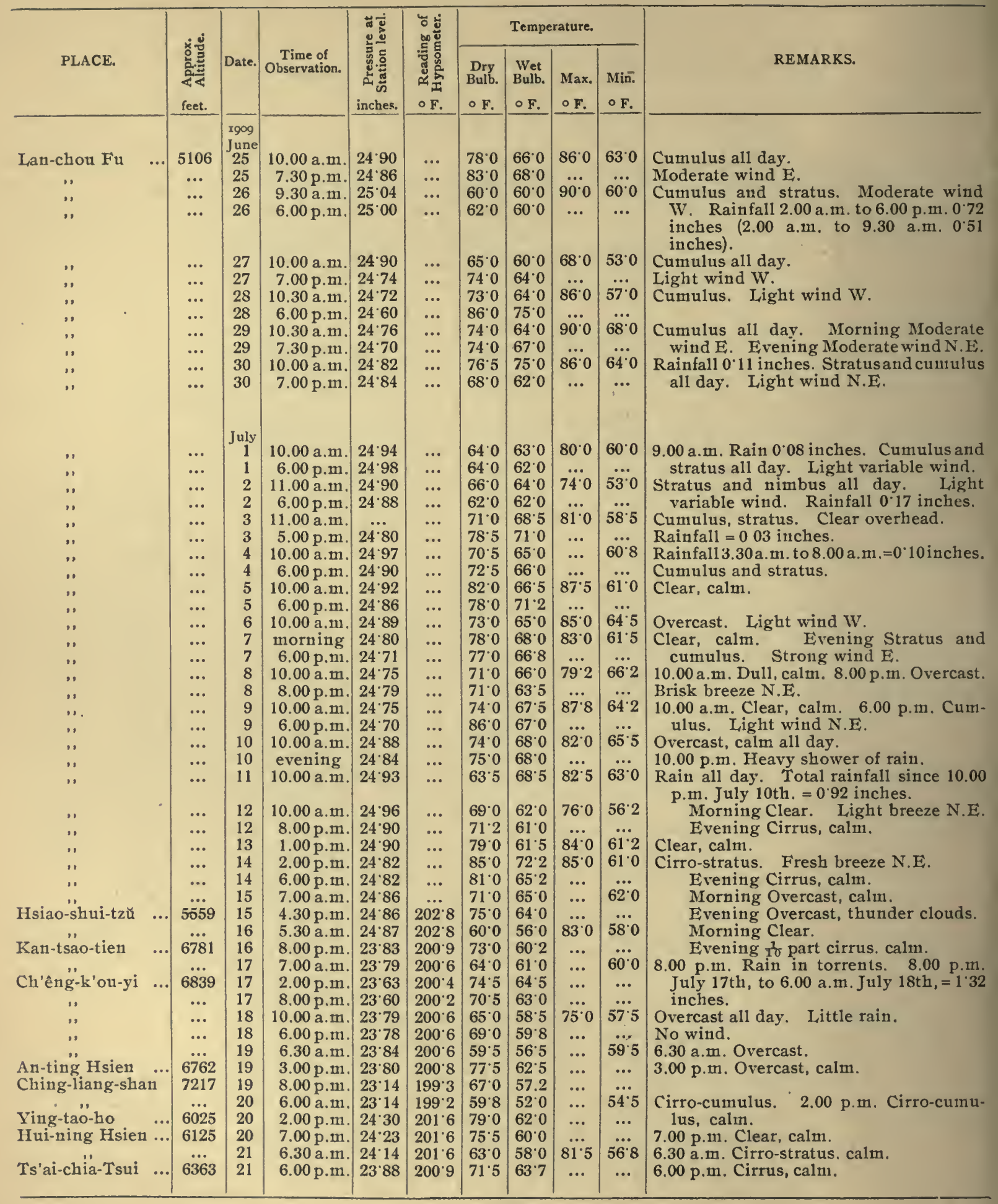


METEOROLOGICAL OBSERVATIONS-continued.

\begin{tabular}{|c|c|c|c|c|c|c|c|c|c|c|}
\hline \multirow[b]{2}{*}{ PLACE. } & \multirow[b]{2}{*}{ 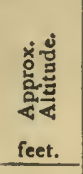 } & \multirow[b]{2}{*}{ Date. } & \multirow[b]{2}{*}{$\begin{array}{l}\text { Time of } \\
\text { Observation. }\end{array}$} & \multirow{2}{*}{ 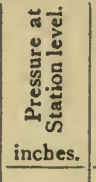 } & \multirow{2}{*}{ 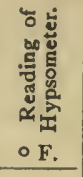 } & \multicolumn{4}{|c|}{ Temperature. } & \multirow[b]{2}{*}{ REMARKS. } \\
\hline & & & & & & $\begin{array}{c}\text { Dry } \\
\text { Bulb. } \\
\text { OF. }\end{array}$ & \begin{tabular}{|c|} 
Wet \\
Bulb. \\
○F. \\
\end{tabular} & $\begin{array}{l}\text { Max. } \\
\text { OF. }\end{array}$ & $\begin{array}{l}\text { Min. } \\
\text { of. }\end{array}$ & \\
\hline & & $\begin{array}{l}x 909 \\
\text { July }\end{array}$ & & & & & & & & \\
\hline $\begin{array}{ll}\text { Ts'ai-chia-Tsui } & \ldots \\
\text { Kao-chia-p'u } & \ldots\end{array}$ & $\begin{array}{l}6363 \\
5862\end{array}$ & $\begin{array}{l}22 \\
22\end{array}$ & $\begin{array}{l}6.30 \mathrm{a} \cdot \mathrm{m} \\
8.00 \mathrm{p} \cdot \mathrm{m}\end{array}$ & $\begin{array}{l}23.93 \\
24.32\end{array}$ & \begin{tabular}{l|l}
$200 \cdot 8$ \\
$201 \cdot 8$
\end{tabular} & $\begin{array}{r}66 \cdot 0 \\
73 \cdot 2\end{array}$ & $\left|\begin{array}{l}60 \cdot 0 \\
64^{\circ}\end{array}\right|$ & $\ldots$ & $48 \cdot 5$ & 6.30 a.m. Clear, calm. \\
\hline & & 23 & 7.30 a.m. & $24 \cdot 32$ & $201 \cdot 9$ & $69 \cdot 2$ & $62 \cdot 8$ & $81 \cdot 5$ & 65:0 & $\begin{array}{l}8.00 \text { p.m. Overcast, threatening rain. } \\
7.30 \text { a.m. Overcast, threatening rain. }\end{array}$ \\
\hline & 6662 & 23 & $11.00 \mathrm{a} . \mathrm{m}$ & $23 \cdot 64$ & 2006 & $71 \cdot 0$ & & - & $\ldots$ & 6.00 p.m. Overcast. \\
\hline $\begin{array}{c}\text { Ching-ning Chou } \\
\text {," }\end{array}$ & 6276 & 23 & 6.00 p.m. & $24 \cdot 34$ & $201 \cdot 7$ & $77 \cdot 5$ & $65 \cdot 5$ & & & \\
\hline$\ddot{\prime \prime}$ & $\ldots$ & $\begin{array}{l}24 \\
24\end{array}$ & $8.00 \mathrm{a} . \mathrm{m}$ & $\begin{array}{l}24 \cdot 46 \\
24 \cdot 36\end{array}$ & $\begin{array}{l}202 \cdot 1 \\
202 \cdot 0\end{array}$ & $\begin{array}{l}71 \cdot 0 \\
77 \cdot 5\end{array}$ & $\begin{array}{l}64 \cdot 5 \\
66 \cdot 0\end{array}$ & $84^{\circ} 6$ & $66^{\circ} 0$ & 8.00 a.m. Calm, overcast. \\
\hline & $\cdots$ & 25 & $6.00 \mathrm{a} . \mathrm{m}$. & $24 \cdot 40$ & $202 \cdot 0$ & $\begin{array}{ll}77.3 \\
70.5\end{array}$ & $\begin{array}{l}660 \\
65.5\end{array}$ & 930 & 60.0 & $\begin{array}{l}6.00 \text { p.m. Clear, calm. } \\
6.00 \text { a.m. Clear, calm. }\end{array}$ \\
\hline $\begin{array}{l}\text { Shan-chia-chieh ... } \\
\text { Ch'ang-t'ai-p'u ... }\end{array}$ & 6203 & 25 & 2.00 p.m. & $24 \cdot 13$ & $201 \cdot 6$ & $84 \cdot 0$ & $67 \cdot 0$ & - & $\ldots$ & 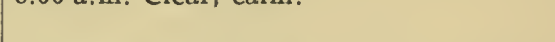 \\
\hline $\begin{array}{c}\text { Ch'ang-t'ai-p'u } \\
\ldots\end{array}$ & 6653 & 25 & 7.00 p.m. & 23.92 & $201^{\circ} 0$ & 68.0 & $62 \cdot 0$ & & $\ldots$ & \\
\hline$\ddot{\prime \prime}$ & $\cdots$ & $\begin{array}{l}26 \\
26\end{array}$ & $\begin{array}{l}9.00 \mathrm{a} . \mathrm{m} \\
6.00 \mathrm{p} . \mathrm{m}\end{array}$ & $\left|\begin{array}{l}24.01 \\
23.98\end{array}\right|$ & $\left|\begin{array}{l}201 \cdot 3 \\
201 \cdot 2\end{array}\right|$ & $\begin{array}{l}64 \cdot 0 \\
72 \cdot 0\end{array}$ & $\begin{array}{l}61 \cdot 5 \\
66 \cdot 0\end{array} \mid$ & $\begin{array}{c}85 \cdot 0 \\
\ldots\end{array}$ & $\ldots$ & $\begin{array}{l}\text { Heavy rain since } 9.00 \mathrm{p} . \mathrm{m} \text {. July } 25 \text { th. } \\
=0.72 \text { inches. } 9.00 \mathrm{a} . \mathrm{m} \text {. Overcast little }\end{array}$ \\
\hline$"$ & $\cdots$ & & 0.00 p.m. & 2398 & 2012 & & & & $\cdots$ & rain. \\
\hline ", & $\ldots$ & $\begin{array}{l}27 \\
27\end{array}$ & $\begin{array}{l}6.00 \mathrm{a} \cdot \mathrm{m} \\
5.00 \mathrm{pm}\end{array}$ & $\begin{array}{l}23.98 \\
23.91\end{array}$ & $\begin{array}{l}201 \cdot 2 \\
201 \cdot 0\end{array}$ & $\begin{array}{r}64 \cdot 0 \\
80^{\circ}\end{array}$ & $\begin{array}{l}60 \cdot 5 \\
65 \cdot 2\end{array}$ & 92.0 & 49.5 & 6.00 a.m. Clear, calm. \\
\hline Ch'ang-yi-p'u & & 28 & $6.30 \mathrm{a} . \mathrm{m}$. & 23.97 & $201 \cdot 2$ & $62: 0$ & $58 \cdot 5$ & 900 & $57 \cdot 8$ & Heavy rain during night. Rainfall since \\
\hline Ch'ang-yi-p'u & 6813 & 28 & 5.30 p.m. & 23.26 & 200.0 & $73 \cdot 6$ & $62 \cdot 9$ & $\ldots$ & $\ldots$ & $\begin{array}{l}11.00 \text { p.m. July } 27 \text { th }=0.73 \text { inches. } 6.30 \\
\text { a.m. Entire cumulo-stratus, calm. } \\
5.30 \text { p.m. Clear, breeze N.W. }\end{array}$ \\
\hline Ku-yüan Chou & & 29 & $6.00 \mathrm{a} . \mathrm{m}$ & $23 \cdot 26$ & 199.8 & $57 \cdot 0$ & $54^{\circ} 0$ & $\cdots$ & $49^{\circ} 0$ & 6.00 a.m. Clear, calm. \\
\hline A & $\begin{array}{c}6333 \\
\ldots\end{array}$ & 29 & 6.00 p.m. & $24 \cdot 08$ & $201^{\circ} 6$ & $77 \cdot 2$ & 660 & & & $6.00 \mathrm{p} . \mathrm{m}$. Overcast, calm. \\
\hline$"$, & $\cdots$ & $\begin{array}{l}30 \\
30\end{array}$ & $\begin{array}{l}8.00 \text { a.m. } \\
6.00 \text { p.m. }\end{array}$ & $\begin{array}{l}24 \cdot 18 \\
24 \cdot 17\end{array}$ & $\begin{array}{l}201 \cdot 7 \\
201 \cdot 6\end{array}$ & \begin{tabular}{|l|}
70.5 \\
$67 \cdot 8$
\end{tabular} & $\begin{array}{l}63 \cdot 8 \\
62 \cdot 8\end{array}$ & $\begin{array}{c}84.5 \\
\ldots\end{array} \mid$ & $\begin{array}{c}59 \cdot 2 \\
\cdots\end{array}$ & $\begin{array}{l}\text { 8.00a.m. Overcast, calm. } 11.00 \text { a.m. Rain, } \\
\text { thumderstorm S. Rainfall }=0.26 \text { iuches. } \\
6.00 \text { p.m. Overcast, calm. }\end{array}$ \\
\hline ". & ... & 31 & 10.00 a.1n. & $24 \cdot 27$ & $201 \cdot 8$ & 63.0 & $60 \cdot 0$ & $86^{\circ} 0$ & $58 \cdot 2$ & Raining, calm. \\
\hline " & $\cdots$ & 31 & $6.00 \mathrm{p} . \mathrm{m}$ & $24 \cdot 28$ & $201^{\circ} 8$ & 71.0 & $64^{\circ} 0$ & $\cdots$ & $\cdots$ & 6.00 p.m. Clear, calm. \\
\hline & & $\begin{array}{c}\text { Aug } \\
1\end{array}$ & 7.00 a.m. & $24 \cdot 32$ & $201^{\circ} 9$ & 59.0 & $57 \cdot 0$ & ... & 51.0 & 7.00 a.m. Clear, calm. \\
\hline $\begin{array}{l}\text { Jên-sa-ho } \\
\text { Jên-chia-wan }\end{array}$ & 5915 & 1 & 2.00 p.m. & $24 \cdot 40$ & $201 \cdot 7$ & 760 & 59.0 & & $\ldots$ & 2.00 p.m. Clear, calm. \\
\hline $\begin{array}{l}\text { Jên-chia-wan } \\
\qquad .\end{array}$ & 5263 & 1 & $8.00 \mathrm{p} . \mathrm{m}$ & 2475 & $202 \cdot 7$ & $66^{\circ} 0$ & $59 \cdot 9$ & & & 8.00 p.m. Clear, calm. \\
\hline Chung-tzŭ-yang- & ... & 2 & 6.30 a.m. & 2471 & 2027 & $56^{\circ} 0$ & 53.0 & 90.5 & $54^{\circ} 0$ & 6.30 a.m. Clear, calm. \\
\hline chia & 4950 & 2 & 6.00 p.m. & $25 \cdot 07$ & $203 \cdot 3$ & $76 \cdot 0$ & $64 \cdot 0$ & $\cdots$ & & 6.00 p.m. Clear, calm. \\
\hline K'ai-pien & 4454 & 3 & $6.00 \mathrm{a} . \mathrm{m}$ & $25 \cdot 10$ & 203.4 & 59.0 & $57 \cdot 0$ & ... & $49^{\circ} 0$ & 6.00 a.m. Cle \\
\hline & $\begin{array}{l}4454 \\
\ldots\end{array}$ & 3 & 6.00 p.m. & 25.53 & $204^{\circ} 4$ & $77^{\circ} 0$ & $\begin{array}{ll}65 \cdot 5 \\
63.0\end{array}$ & ... & & 6.00 p.m. Overcast, calm. \\
\hline Chên-yüan Hsien & $\dddot{4478}$ & 4 & $\begin{array}{l}6.00 \mathrm{a} . \mathrm{m} \\
6.00 \mathrm{p} . \mathrm{m}\end{array}$ & $\begin{array}{l}25 \cdot 64 \\
25.90\end{array}$ & $\begin{array}{l}204 \cdot 4 \\
204 \cdot 8\end{array}$ & $\begin{array}{l}67 \cdot 0 \\
73 \cdot 2\end{array}$ & $\begin{array}{l}63.0 \\
65.0\end{array}$ & $\begin{array}{l}\cdots \\
\cdots\end{array}$ & $59 \cdot 0$ & 6.00 a.m. Light rain, calm. \\
\hline ". & ... & 5 & $8.00 \mathrm{a} . \mathrm{m}$ & 25.93 & $204 \cdot 9$ & $74 \cdot 0$ & 64.0 & 1022 & $64^{\circ} 0$ & 8.00 a.m. Almost clear, calm \\
\hline 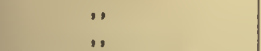 & $\cdots$ & $\mathbf{5}$ & 6.00 p.m. & 25.85 & $204 \cdot 9$ & 79.8 & 67.4 & $\cdots$ & & 6.00 p.m. Strato-cumulus, calm. \\
\hline T'ai-pëi-ch'êng & 5ï9 & $\begin{array}{l}6 \\
6\end{array}$ & $\begin{array}{l}6.00 \mathrm{a} . \mathrm{m} \\
6.00 \mathrm{p} . \mathrm{m}\end{array}$ & $\begin{array}{l}25 \cdot 89 \\
25 \cdot 30\end{array}$ & $\begin{array}{l}205^{\circ} 0 \\
203 \cdot 6\end{array}$ & \begin{tabular}{|c|}
$66 \cdot 8$ \\
$67 \cdot 0$
\end{tabular} & \begin{tabular}{l|l}
$63 \cdot 8$ \\
$62 \cdot 0$
\end{tabular} & $\cdots$ & $64 \cdot 5$ & 6.00 a.m. Overcast, stratus, calm. \\
\hline & $0 \times 10$ & $\begin{array}{l}6 \\
7\end{array}$ & $\begin{array}{l}6.00 \mathrm{p} . \mathrm{m} \\
4.30 \mathrm{a} . \mathrm{m}\end{array}$ & $\begin{array}{l}25 \cdot 30 \\
25 \cdot 28\end{array}$ & $\begin{array}{l}203 \cdot 6 \\
203 \cdot 6\end{array} \mid$ & $\begin{array}{r}67 \cdot 0 \\
64.0\end{array}$ & $\begin{array}{l}62 \cdot 0 \\
62 \cdot 0\end{array}$ & $\cdots$ & $\dddot{57}_{0}$ & $\begin{array}{l}6.00 \text { p.m. Overcast, calm. } \\
4.30 \text { a.m. Overcast, calm. }\end{array}$ \\
\hline Yi-ma-kuan & 5108 & 7 & 6.00 p.m. & 24.98 & $203 \cdot 1$ & $72 \cdot 5$ & 650 & $\ldots$ & & 6.00 p.m. Overcast, calm. \\
\hline i-ma-p'u $\quad .$. & 5082 & $\begin{array}{l}8 \\
8\end{array}$ & $5.15 \mathrm{a} . \mathrm{m}$ & 24.97 & $203 \cdot 1$ & 660 & $62 \cdot 8$ & $\ldots$ & $58^{\circ} 0$ & 5.15 a.m. Entire cirro-cumulus, calm. \\
\hline Ch'ing-yang Fu ... & $\begin{array}{l}5082 \\
4216\end{array}$ & $\begin{array}{l}8 \\
8\end{array}$ & $\begin{array}{c}\text { noon } \\
8.00 \mathrm{pm}\end{array}$ & $\begin{array}{l}25 \cdot 10 \\
26 \cdot 07\end{array}$ & $\begin{array}{l}203: 3 \\
205 \cdot 2\end{array}$ & $\begin{array}{l}80.5 \\
71.5\end{array}$ & $\begin{array}{r}68.0 \\
67.0\end{array}$ & $\cdots$ & $\ldots$ & Noon, Cumulus and light cirrus, calm. \\
\hline " & $\ldots$ & 9 & 7.00 a.m. & 26.11 & $205 \cdot 1$ & $73 \cdot 0$ & $\begin{array}{l}0 \\
65.5\end{array}$ & $93: 0$ & $64 \cdot 5$ & $\begin{array}{l}8.00 \text { p.m. Raining. Fall }=0.08 \text { inches, } \\
7.00 \text { a.m. Cirro-cunuulus, calm. }\end{array}$ \\
\hline " & ... & 9 & 6.00 p.m. & 26.07 & $205 \cdot 2$ & 73.5 & 66.5 & & ... & 6.00 p.m. Heavy rain $S$. \\
\hline " & ... & 10 & 6.00 a.m. & 26.09 & $205 \cdot 2$ & 63.0 & 60.8 & 99.0 & ... & 6.00 a.m. Clear, calm. \\
\hline ", & ... & 10 & 6.00 p.m. & 26.04 & $205 \cdot 1$ & 70.5 & $63 \cdot 6$ & ... & ... & $\begin{array}{l}6.00 \text { p.m. Stratus, calm. } \\
2.00 \text { to } 4.00 \text { p.m. Rainfall }=0.09 \text { inches. }\end{array}$ \\
\hline Ho-shui Hsien & 4146 & $\begin{array}{l}11 \\
11\end{array}$ & $\begin{array}{l}6.00 \mathrm{a} . \mathrm{m} \\
6.00 \mathrm{p.m}\end{array}$ & $\begin{array}{l}26 \cdot 08 \\
26 \cdot 01\end{array}$ & $\begin{array}{l}205 \cdot 2 \\
204 \cdot 9\end{array}$ & $\begin{array}{r}63.0 \\
69 \cdot 8\end{array}$ & $\begin{array}{l}61 \cdot 0 \\
65 \cdot 8\end{array}$ & $\cdots$ & 63.0 & $\begin{array}{l}\text { 6.00 a.m. Cirrus, calm. } \\
6.00 \text { p.m. Raining. }\end{array}$ \\
\hline " & $\ldots$ & 12 & $\begin{array}{l}6.00 \text { p.m. } \\
8.00 \text { a.m. }\end{array}$ & 26.09 & $\begin{array}{l}2049 \\
205 \cdot 1\end{array}$ & 67.5 & $65 \cdot 0$ & $\cdots$ & 648 & $\begin{array}{l}6.00 \text { p.m. Raining. } \\
\text { Heavy rain since } 6.00 \text { p.m. August } 11 \text { th. }\end{array}$ \\
\hline 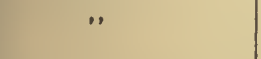 & a. & 12 & 7.00 p.m. & $\cdots$ & $205^{\circ} 0$ & $71 \cdot 5$ & $67 \cdot 5$ & & $\ldots$ & $\begin{array}{l}\text { Rainfall for } 12 \text { hours ending } 6.00 \mathrm{a} . \mathrm{m} \text {. } \\
=0.58 \text { inches. Light cumulus, calm. }\end{array}$ \\
\hline ", & ... & 13 & 6.00 a.m. & 26.05 & $205 \cdot 0$ & $64 \cdot 4$ & $62 \cdot 5$ & ... & $60 \cdot 5$ & Clear, calm. \\
\hline
\end{tabular}


METEOROLOGICAL OBSERVATIONS-continued.

\begin{tabular}{|c|c|c|c|c|c|c|c|c|c|c|}
\hline \multirow[b]{2}{*}{ PLACE. } & \multirow{2}{*}{ 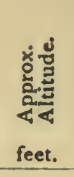 } & \multirow[b]{2}{*}{ Date. } & \multirow[b]{2}{*}{$\begin{array}{l}\text { Time of } \\
\text { Observation. }\end{array}$} & \multirow{2}{*}{ 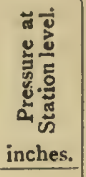 } & \multirow{2}{*}{ 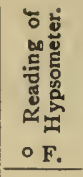 } & \multicolumn{4}{|c|}{ Temperature. } & \multirow[b]{2}{*}{ REMARKS. } \\
\hline & & & & & & $\begin{array}{l}\text { Dry } \\
\text { Bulb. } \\
\circ \mathrm{F} . \\
\end{array}$ & \begin{tabular}{|c|} 
Wet \\
Bulb. \\
o F.
\end{tabular} & $\begin{array}{l}\text { Max. } \\
\text { ○F. }\end{array}$ & $\begin{array}{l}\text { Min. } \\
\circ \mathrm{F} . \\
\end{array}$ & \\
\hline Miao-ts'un & 4144 & $\begin{array}{c}1909 \\
\text { Aug. } \\
13\end{array}$ & 6.00 p.m. & $25 \cdot 39$ & 203.9 & $72 \cdot 0$ & 67.0 & $\ldots$ & $\ldots$ & 6.00 p.m. Few stratus, calm. \\
\hline " & $\ldots$ & 14 & 2.00 p.m. & $25 \cdot 43$ & $204 \cdot 2$ & 70.0 & $66 \cdot 2$ & $\ldots$ & ... & 6.00 p.m. Raining. Fall since noon $=0.23$ \\
\hline 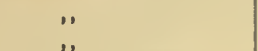 & $\cdots$ & 14 & 6.00 p.m. & 25.41 & 204.2 & $70 \cdot 0$ & 67.0 & ... & & inches. \\
\hline T'ai-pei-ch'êng & $\dddot{3528}$ & $\begin{array}{l}15 \\
15\end{array}$ & $\begin{array}{l}6.00 \mathrm{a} . \mathrm{m} \\
6.00 \mathrm{p} . \mathrm{m}\end{array}$ & $\begin{array}{l}25 \cdot 39 \\
26 \cdot 06\end{array}$ & $204^{\circ} 0$ & $64 \cdot 5$ & $\begin{array}{l}63 \cdot 0 \\
67 \cdot 8\end{array}$ & $\ldots$ & $54 \cdot 4$ & $\begin{array}{l}6.00 \mathrm{a} . \mathrm{m} \text {. Overcast, calm. } \\
6.00 \mathrm{p.m} \text {. Clear, calm. }\end{array}$ \\
\hline & & 16 & 6.30 a.m. & 26.08 & $205 \cdot 1$ & 60.0 & $59 \cdot 7$ & $\ldots$ & $56: 0$ & Heavy dew 6.30 a.m. Cirro-stratus, calm. \\
\hline $\begin{array}{l}\text { Hai-shui-ssŭ } \\
\text { (Shensi) }\end{array}$ & 3174 & 16 & 7.00 p.tn. & 26.24 & $205^{\circ} 6$ & $70 \cdot 5$ & $67 \cdot 5$ & $\cdots$ & $\cdots$ & 7.00 p.m. Clear, calm. \\
\hline Ch'ang-ts'un-yi ... & 3045 & $\begin{array}{l}17 \\
17\end{array}$ & $\begin{array}{l}7.00 \text { a.m. } \\
8.00 \text { p.m. }\end{array}$ & $\begin{array}{l}26 \cdot 32 \\
26 \cdot 58\end{array}$ & $\begin{array}{l}205 \cdot 5 \\
206 \cdot 0\end{array}$ & $\begin{array}{l}61 \cdot 5 \\
71 \cdot 5\end{array}$ & $\begin{array}{l}60 \cdot 8 \\
61 \cdot 5\end{array}$ & ... & $\begin{array}{l}\cdots \\
\cdots\end{array}$ & $\begin{array}{l}7.00 \text { a.m. Overcast, mist, calm. } \\
6.00 \text { p.m. Thunderstorm, without rain, } \\
\text { from N.E. } 8.00 \text { p.m. Clear, calm. }\end{array}$ \\
\hline & & 18 & 8.00 a.m. & $26 \cdot 73$ & $206 \cdot 3$ & $68 \cdot 5$ & $65 \cdot 2$ & ... & $\cdots$ & 8.00 a.m. Entire cirro-stratus, calin. \\
\hline $\begin{array}{l}\text { Yang-ch } \\
\text { Fu Chor }\end{array}$ & $\begin{array}{l}4085 \\
2912\end{array}$ & $\begin{array}{l}18 \\
18\end{array}$ & $\begin{array}{l}\text { noon } \\
7.00 \mathrm{p} . \mathrm{m}\end{array}$ & $\begin{array}{l}25.99 \\
26.76\end{array}$ & $\begin{array}{l}2048 \\
206.4\end{array}$ & $\begin{array}{l}75.5 \\
71 \cdot 5\end{array}$ & 66.0 & $\begin{array}{l}\cdots \\
\ldots\end{array}$ & $\cdots$ & $\begin{array}{l}\text { Noon. Overcast, calm. } \\
7.00 \text { p.m. Overcast, calm. }\end{array}$ \\
\hline & & 19 & 5.40 a.m. & $26 \cdot 79$ & $206 \cdot 4$ & 65.5 & $62 \cdot 0$ & ... & $59^{\circ} 0$ & 5.40 a.m. Entire light cirrus, calm. \\
\hline Kan-ch'üan Hsien & 3416 & 19 & 8.00 p.m. & $26 \cdot 49$ & $206 \cdot 2$ & $65 \cdot 5$ & $62 \cdot 2$ & $\cdots$ & $\cdots$ & $\begin{array}{l}\text { Noon. Commenced to rain heavily. } \\
8.00 \text { p.m. Overcast, calm. }\end{array}$ \\
\hline . & $=$ & 20 & 7.00 a.m. & $26 \cdot 49$ & $206: 2$ & 62.0 & $60 \cdot 0$ & $77 \cdot 0$ & $39 \cdot 0$ & Rain all night. Fall for 12 hours ending \\
\hline " & (2) & 20 & 6.00 p.m. & 26.42 & 205.8 & $67 \cdot 5$ & $67 \cdot 5$ & ... & $\ldots$ & $\begin{array}{l}11.00 \text { a.m. }=0.66 \text { inches. } 6.00 \text { p.m. Few } \\
\text { cirrus, calm. }\end{array}$ \\
\hline a-p'u-tai-ho & 3756 & 21 & $6.30 \mathrm{a} . \mathrm{m}$. & $\begin{array}{l}26 \cdot 42 \\
26 \cdot 15\end{array}$ & $\begin{array}{l}205 \cdot 7 \\
205 \cdot 3\end{array}$ & $\begin{array}{l}62 \cdot 2 \\
62 \cdot 5\end{array}$ & $\begin{array}{l}60 \cdot 8 \\
59 \cdot 5\end{array}$ & $\cdots$ & $60^{\circ} 0$ & $\begin{array}{l}6.30 \text { a.m. Overcast, calm. } 8.00 \text { p.m. } \\
\text { Overcast calm } 10.00 \text { p.m. Raining. }\end{array}$ \\
\hline$a-t$ & ... & 22 & 8.00 a.m. & $26 \cdot 17$ & $205 \cdot 4$ & $\begin{array}{l}020 \\
67 \cdot 0\end{array}$ & $62 \cdot 0$ & $\ldots$ & ${ }_{50}{ }_{5}$ & 8.00 a.m. Clear, calm. Heavy dew. \\
\hline Yen-an Fu & 2769 & 22 & 8.30 p.m. & 26.67 & $206 \cdot 2$ & 70.5 & $64 \cdot 0$ & ... & $\ldots$ & 8.30 p.m. Clear, calm. \\
\hline$"$ & ... & 23 & 8.00 a.m. & 26.72 & 206.4 & $67 \cdot 0$ & 620 & ... & 列 & 8.00 a.m. Calm. \\
\hline ". & $\ldots$ & 23 & $6.00 \mathrm{p.m}$. & $26 \cdot 64$ & $206 \cdot 2$ & 78.0 & $66^{\circ}$ & $\ldots$ & & 6.00 p.m. Calm. \\
\hline ", & . & 24 & 8.00 a.m. & $26 \cdot 75$ & $206 \cdot 3$ & $64 \cdot 5$ & 63.0 & $\ldots$ & 61.5 & 8.00 a.m. Scotch mist. \\
\hline ". & ( & 24 & 6.00 p.m. & 26.62 & $206 \cdot 1$ & 0.0 & $67 \cdot 5$ & ... & & 6.00 p.m. Cles \\
\hline$\ddot{*}$ & & 25 & 6.3 & $26 \cdot 67$ & $206: 3$ & $65^{\circ} 0$ & $61 \cdot 5$ & ... & $59 \cdot 2$ & 6.30 a.m. Cle \\
\hline Yao-tien & 2514 & 25 & 2.00 p.m. & $26 \cdot 68$ & $206 \cdot 2$ & $88^{\circ} 0$ & 69.8 & ... & $\ldots$ & 2.00 p.m. Cumulus, calm. \\
\hline Kan-ku-yü & 2527 & 25 & 7.00 p.m. & 26.81 & $206^{\circ} 4$ & $80^{\circ} 0$ & $67 \cdot 5$ & ... & & 7.00 p.m. Cirro-cumulus, calm. \\
\hline Ma-chia-k'ou & 2369 & $\begin{array}{l}26 \\
26\end{array}$ & 6.00 a.m. & $\begin{array}{l}26 \cdot 81 \\
26.02\end{array}$ & $206^{\circ} 4$ & $63 \cdot 0$ & 60.5 & $\cdots$ & $54 \cdot 0$ & 6.00 a.m. Cle \\
\hline (5) & 2000 & 27 & $\begin{array}{l}7.00 \text { p.m. } \\
5.00 \text { a.m. }\end{array}$ & $\begin{array}{l}26.93 \\
26.98\end{array}$ & $\begin{array}{l}206^{*} 4 \\
206^{*} 6\end{array}$ & $\begin{array}{l}82^{\circ} 0 \\
66.0\end{array}$ & $\begin{array}{l}67 \cdot 5 \\
62 \cdot 0\end{array}$ & $8 \ddot{0} 0$ & $\dddot{59} \cdot 9$ & $\begin{array}{l}7.00 \text { p.m. Entire cumulus, calm. } \\
5.00 \text { a.m. Clear, calm. }\end{array}$ \\
\hline Ching- & 2583 & 27 & 6.0 & 26.74 & $206 \cdot 3$ & 88.2 & $69 \cdot 4$ & & & 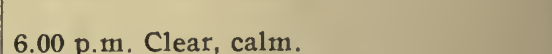 \\
\hline & & 28 & 4.0 & 26.79 & $206^{\circ} 4$ & $69^{\circ} 0$ & $64 \cdot 8$ & 93.0 & 63.0 & m. c \\
\hline Shih-ts'ui-yi & 3017 & 28 & 6.00 p.m. & $26 \cdot 38$ & $205 \cdot 7$ & $87 \cdot 8$ & $70 \cdot 2$ & $\ldots$ & $\ldots$ & 6.00 p.m. Light stratus, calm. \\
\hline & & $\begin{array}{l}29 \\
99\end{array}$ & 3.30 a.m. & 26.45 & 205.8 & $\begin{array}{l}71^{\circ} 0 \\
78^{\circ} 0\end{array}$ & $65 \cdot 8$ & $\cdots$ & $\cdots$ & 3.30 a.m. Clea \\
\hline ," & $\begin{array}{c}2330 \\
\ldots\end{array}$ & $\begin{array}{l}29 \\
30\end{array}$ & $\begin{array}{l}6.00 \text { p.m. } \\
8.30 \text { a.m. }\end{array}$ & $\begin{array}{l}27 \cdot 06 \\
27 \cdot 16\end{array}$ & $\begin{array}{l}206^{9} \\
207 \cdot 0\end{array}$ & $\begin{array}{l}78.0 \\
72.5\end{array}$ & $65^{\circ} 0$ & 900 & 63.5 & $\begin{array}{l}\text { 6.00 p.m. Overcast, heavy cumulus, calm. } \\
8.30 \text { a.m. Overcast, calm. }\end{array}$ \\
\hline " & 然 & 30 & 6.00 p.m. & 27.09 & $206 \cdot 9$ & 79.0 & 69.0 & ... & & $6.00 \mathrm{p} . \mathrm{m}$. Overcast, threatening, breeze $\mathrm{S}$. \\
\hline Yüi-ho-ch'êng & & 31 & 5.45 a.m. & $27 \cdot 17$ & $207 \cdot 0$ & $72 \cdot 0$ & $66 \cdot 2$ & ... & $68 \cdot 2$ & 5.45 a.m. Overcast, calm. 5.00 p.m. Rain. \\
\hline Yü-ho-ch'êng & 2537 & 31 & 6.00 p.m. & 26.88 & 2065 & 70.0 & $60 \cdot 2$ & $\cdots$ & $\cdots$ & 6.00 p.m. Overcast, threatening, calm. \\
\hline & & Sept. & $6.00 \mathrm{a} . \mathrm{m}$. & 26.91 & $206^{\circ} 6$ & $62 \cdot 5$ & $57^{\circ} 0$ & & & $6.00 \mathrm{a} . \mathrm{m}$. Overcast, threatening, calm. \\
\hline $\begin{array}{l}\text { K'ang-chia-t'a } \ldots \\
\text { (on Yellow River) }\end{array}$ & 1822 & 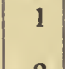 & 6.00 p.m. & $27 \cdot 63$ & $207 \cdot 9$ & 68.5 & 63.5 & 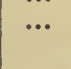 & . & $\begin{array}{l}11.00 \text { a.m. Rain till } 2.00 \text { p.m. } 6.00 \text { p.m. } \\
\text { Overcast, calm. }\end{array}$ \\
\hline $\begin{array}{l}\text { Liu-lin̈-chên } \\
\text { (Shansi) }\end{array}$ & 2316 & $\begin{array}{l}2 \\
2\end{array}$ & $\begin{array}{l}6.00 \text { a.m. } \\
6.30 \text { p.m. }\end{array}$ & $\begin{array}{l}27 \cdot 63 \\
27 \cdot 18\end{array}$ & $\begin{array}{l}208 \cdot 0 \\
207 \cdot 2\end{array}$ & $\begin{array}{l}67 \cdot 0 \\
73 \cdot 0\end{array}$ & $\begin{array}{l}63^{\circ} 0 \\
65.0\end{array}$ & $\begin{array}{l}\ldots \\
\cdots\end{array}$ & $\begin{array}{c}59.4 \\
\cdots\end{array}$ & $\begin{array}{l}6.00 \text { a.m. Overcast, calm. Rainfall for } \\
11 \text { hours euding } 6.00 \text { a.m. }=0^{-} 36 \text { inches. } \\
6.30 \text { p.m. Clear, calm. }\end{array}$ \\
\hline Yung-n̈in & 2738 & $\begin{array}{l}3 \\
3\end{array}$ & $\begin{array}{l}6.00 \mathrm{a} \cdot \mathrm{m} \\
6.00 \mathrm{p} . \mathrm{m}\end{array}$ & $\begin{array}{l}27 \cdot 23 \\
26 \cdot 79\end{array}$ & $\begin{array}{l}207 \cdot 2 \\
206 \cdot 6\end{array}$ & $\begin{array}{l}62 \cdot 0 \\
65 \cdot 5\end{array}$ & $\begin{array}{l}58 \cdot 5 \\
62 \cdot 0\end{array}$ & ... & $\begin{array}{c}55 \cdot 5 \\
\cdots\end{array}$ & $\begin{array}{l}6.00 \text { a.m. Cirro-cumulus, calm. } 6.00 \\
\text { p.m. Raining. Fall since } 3.00 \text { p.m. } \\
=0.16 \text { inches. }\end{array}$ \\
\hline Wu-ch'êng & 4165 & $\begin{array}{l}4 \\
4\end{array}$ & $\begin{array}{l}6.00 \mathrm{a} \cdot \mathrm{m} . \\
6.00 \mathrm{p} . \mathrm{m} .\end{array}$ & $\begin{array}{l}26.84 \\
25.57\end{array}$ & $\begin{array}{l}206 \cdot 4 \\
204 \cdot 0\end{array}$ & $\begin{array}{l}59 \cdot 5 \\
68 \cdot 0\end{array}$ & $\begin{array}{l}58 \cdot 0 \\
62 \cdot 5\end{array}$ & $\begin{array}{l}\cdots \\
\ldots\end{array}$ & $\begin{array}{c}59.0 \\
\ldots\end{array}$ & $\begin{array}{l}6.00 \text { a.m. Entire cirro-cumulus, calm. } \\
6.00 \text { p.m. Overcast, calm. }\end{array}$ \\
\hline$"$ & 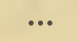 & 5 & 5.30 a.m. & $25 \cdot 58$ & $204 \cdot 1$ & $62 \cdot 0$ & 59.0 & ... & $59 \cdot 2$ & 5.30 a.m. Cirro-cumulus, calm. \\
\hline
\end{tabular}


METEOROLOGICAL OBSERVATIONS-continued.

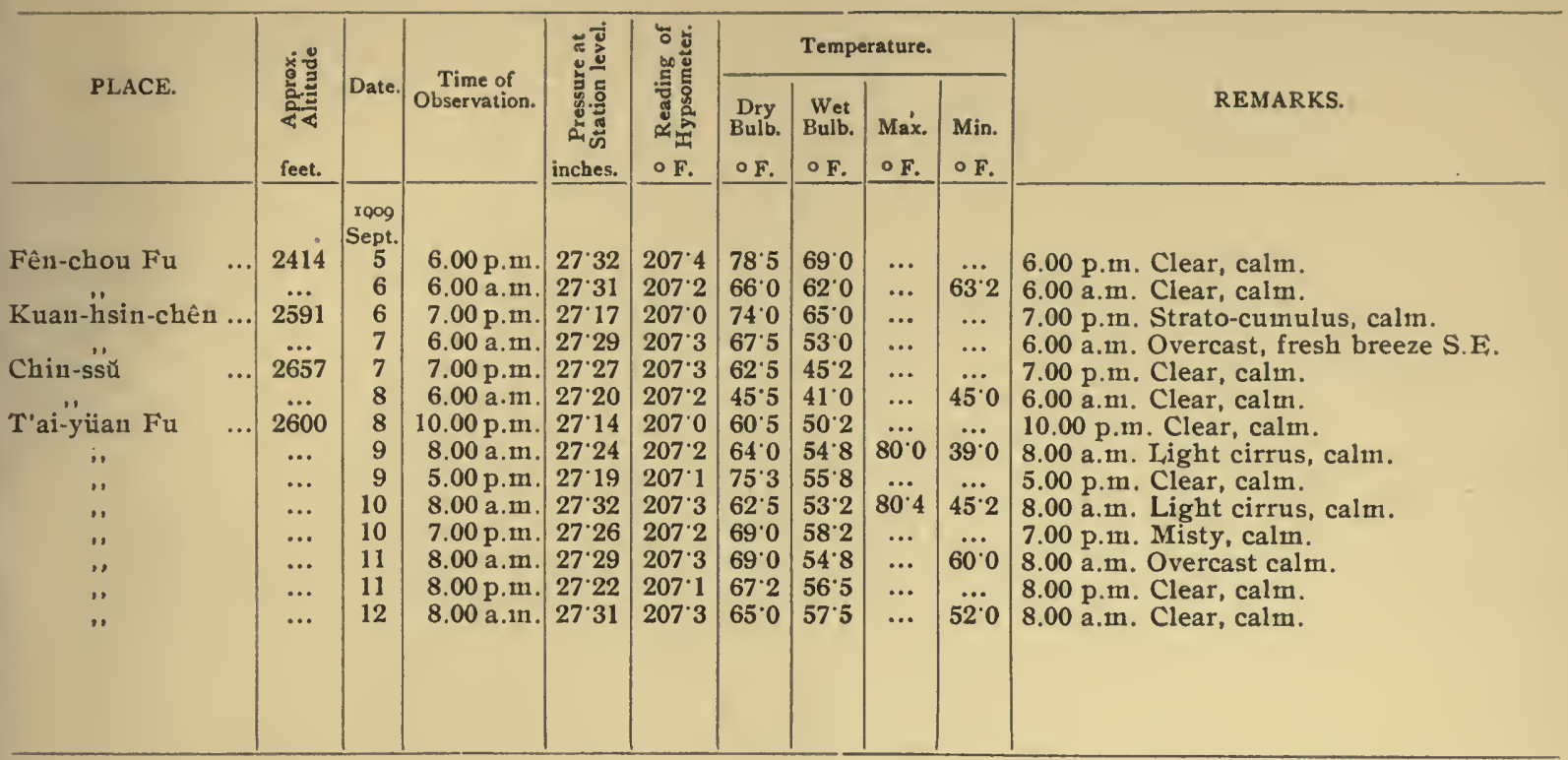



INDEX. 



\section{INDEX.}

Acari

Accento

Accipiter

Acredula

Aigialitis

Aex galericulata

Alcedo .

Allactaga

Altitudes

Ampelis

Anas

Ancistrodo

Anderson (Mr. M. P.)

Anorthura

Anser . .

Anthropoides

Anthus spinoletta

An-ting Hsien (Shensi)

Ap" ", (Kansu)

Aquila

Araneæ (Araneidx)

Ardea cinerea ..

Athene plumipes

Austen (Mr. E. E.)

Badger . .

Base line

Baths (Lin-t'ung H)

Bats

Bear

Bedford (D. of)

Bittern .

Botaurus

Broomhall (Mr. M.)

Bruce (Major C. D.) .

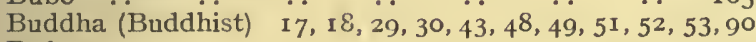

Bufo

Bugonia-myth

Bunting

Bustard

Buteo

Butterflies

Buzzard

Caccabis

Calbrecht (Father)

Cambridge (Rev. O. P.)

Canis lupu

Capreolus

Caprimulgus

Carnegie Expedition (and Institution)

Carp

Carpodacus

Casarca

Catfish

Cave-dwellings

Cerchneis

Ch'ang-t'ai-p'u
PAGE

.. I 86, I 87, I 92

$\begin{array}{lll}\cdots & \cdots & \text { I00 } \\ \cdots & \cdots & \text { I03 }\end{array}$

.. $\quad$. 99

$\begin{array}{lll}. & \ldots & 107 \\ \cdots & \ldots & 106\end{array}$

93, 108

$92,93, I 7 I, I 83$

$\mathrm{I}_{3} \mathrm{I}, \mathbf{1}_{33}, \mathbf{I}_{70}$

....$\quad$ Iо0

.. $\quad$.. 110

$79,81,83,85,87$, I 8 o

91,100

20,85

.. 107

.. 99

53,59,

$8 \mathrm{I}, 86,9 \mathrm{I}, 92,178,179$

.. IOI

I 86, I $87,204-218$

.. $\quad . \quad 106$

. $\quad$ is 103

$\begin{array}{ll}\cdots & 186,188 \\ \cdots & \end{array}$

.. 3, I30, 132

$41, \quad 124$

$\therefore \quad 93$

. 79,83

.. 106

.. 106

.. I34

I03

I 2

I 89 (and Note)

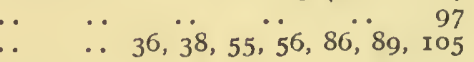

..

$\begin{array}{lllll}\text {. } & \ldots & \ldots & \ldots & 75,76,93\end{array}$

$\begin{array}{llllll} & \cdots & \ldots & \ldots & \ldots & \text { 103 }\end{array}$

$$
\begin{array}{lllll}
\cdots & \cdots & \cdots & \cdots & 104
\end{array}
$$$$
\begin{array}{lllll}
\text {. } & \ldots & \ldots & \ldots & 74
\end{array}
$$$$
\begin{array}{lllll}
\cdots & \cdots & \cdots & \ldots & 74 \\
\cdots & \ldots & \ldots & \ldots & 204
\end{array}
$$$$
\begin{array}{lllll}
. & \ldots & \ldots & \ldots & 82
\end{array}
$$

80,82, r 74,192

.. .. 103

. I I 5, I 16,124

.. $\quad \ldots \quad 113$

$\begin{array}{llr}\cdots & \cdots & 113 \\ \cdots & \ldots & 97\end{array}$

.. .. 106

$\cdots \quad \cdots \quad$ r13

. 36,74

$58,72,92,15$
Ch'ang-ts'un-yi

Ch'ang-wu Hsien

Ch'ang-yi-p'u ..

Chao-chuang ..

Ch'êng (Prince)

Ch'êng-k'ou-yi

Ch'êng-tu Fu ..

Ch'êng-wu Miao

Chên-t'ai

Chên-yüan Hsien

Chia-lu ..

Chiao-ch'êng Shàn

Ch'ien-chou

Chien Shên

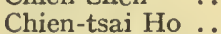

Chih-fu (Prefect)

Chih-hsien (District Magistrate) . $\quad \ldots . \quad \ldots \quad$ I9

Chihli ...71, 73, 92, 97, 105, I15, II6, I19, 127, I 28, I 29

Chin-chia-k'ou

Ching-chia-yi .

Ch'ing-chien Hsien

Ching-liang Shan

Ching-ning Chou

Ching-pien

Ch'ing-ting Shan

Ch'ing-yang Fu

Ch'in-ling Shan

Chipmunk

Chiu-ts'ai

Chou-chih Hsien

Chough

Chung-nan Shan

Chung-pu Hsien

Ciconia..

Cinclus .

Circus cyaneus

Citellus

Clangula

Classics (The Sixteen)

Clementi (Mr.)

Coal $7,17,20,24,28$ (barges, $\ddot{40}$ ), $110,120,123,124$

$\begin{array}{ccc}\text { Coal } & 7,17,20,24,28 & \text { (barges, 40), I 19, 1 20, 1 23, } 124 \\ \text { Cobb (Mr. H. B.) } & \ldots & 5,13,14,19,22,32,34,83\end{array}$

Cobitis tinia

Coccothraustes

Coleoptera

Coloeus . .

Coltman (Mr.)

Coluber dione.

Columba

Colymbus

Confucius

Coot

Cormorant

Corvus . .

Coturnix

Cotyle.

$$
\begin{aligned}
& \begin{array}{llllll}
\cdots & \ldots & \ldots & \ldots & \ldots & 17
\end{array} \\
& \cdots \quad, \cdots \quad \cdots \quad 27,28,123
\end{aligned}
$$

$8,81,82,85,88,91,92$

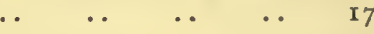

$\begin{array}{lllll}\cdots & \ldots & \ldots & \ldots & 5 \text { I } \\ \cdots & \ldots & \ldots & \ldots & 97\end{array}$

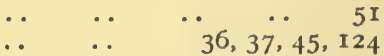

. $\quad$.. 100

$\begin{array}{lll}\cdots & \cdots & 8_{3}, 91,98,177\end{array}$

$\begin{array}{lllll}\cdots & \cdots & \cdots & \cdots & 106\end{array}$
I $33, I_{34}, I_{4} 6, I_{5}$ I
.. 97

I 86, I 90

- 96

. 6r, 79

$86, \mathrm{Ir}_{\mathrm{O}}$

105
$\cdots \quad 107$

.. 47

.. 107

$\begin{array}{rr}\text {.. } & 107 \\ . . & 96\end{array}$

.. $\mathrm{ro}_{4}$

$76,91,93$ 
PAGE

Cranes ..

85,107

$80,8 \mathrm{I}, \mathrm{I} 82$

Cricetulus $\quad \ldots \quad \ldots \quad$ so $, 81,83,86,87,92,179,180$

Crocidura

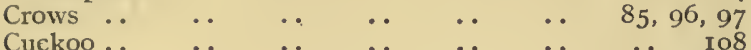

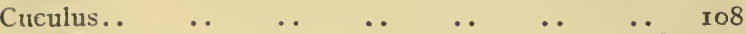

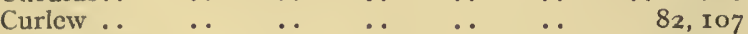

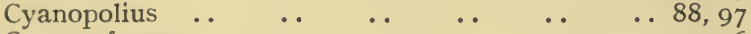

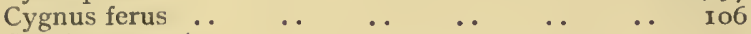

$\begin{array}{lllllll}\text { Cyprinus carpio } & \ldots & \ldots & \ldots & \ldots & \ldots & \text { II } 3\end{array}$

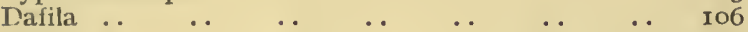

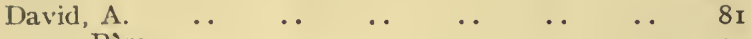

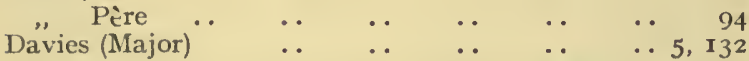

Deer Io, 30, 55, 72, 75, 76, 77, 82, 87, 88, 89, 91, 92, 93

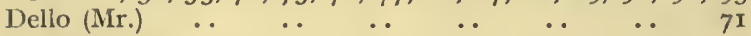

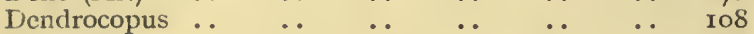

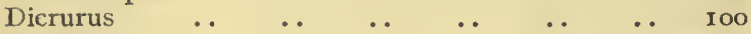

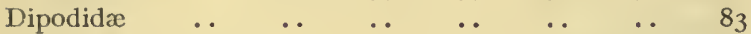

Diptera $\quad \ldots \quad \ldots \quad \ldots \quad \ldots \quad \ldots \quad \ldots 186,188, \mathbf{1} 89$

$\begin{array}{lllll}\text { Dipus sowerbyi } & \ldots & \ldots & \ldots & 80,83,92,183\end{array}$

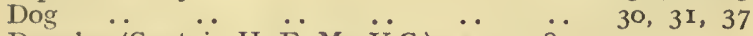

Douglas (Captain H. E. M. ̈.C.) $\ddot{\text { V. }} 5,1 \ddot{8}, 19,20$, $33,55,68,69,71,79,82,186,188,194,203$,

$204,213,217$

.. $\quad \ldots \quad 28,86,105$

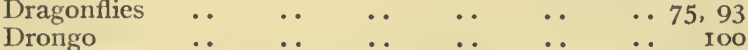

$\begin{array}{llllll}\text { Dryonastes } & \ldots & \ldots & \ldots & \ldots & \ldots\end{array}$

Eagle $\quad \ldots \quad \ldots \quad \ldots \quad \ldots \quad$ 12, 82, 86, 9I, IOI, IO2

Idwards (M. Milne) $\ldots \quad$.. $\quad \ldots \quad$.. $\quad \ldots \quad 80$

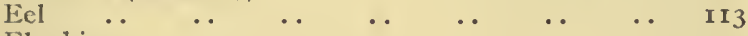

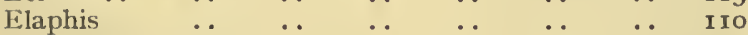

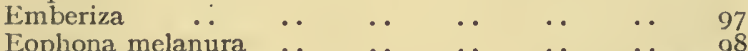

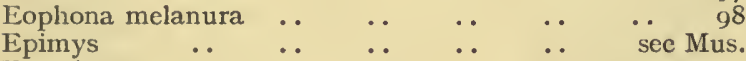

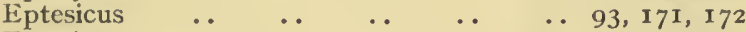

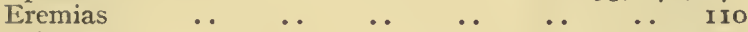

Erinaceus $\quad \ldots \quad \ldots \quad \ldots 80,83$

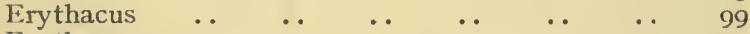

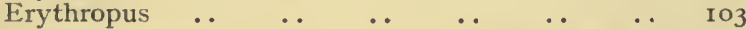

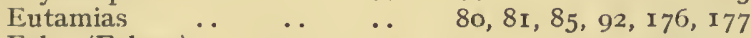

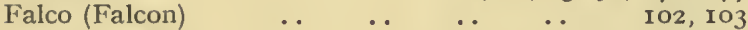

$\begin{array}{llllll}\text { Felis chinensis } & \ldots & \ldots & \ldots & \ldots & 88,173\end{array}$

Fên-chou Fu ... $\quad . . \quad$ I $5,70,78$, I I $7,127,132,134$

Fêng-hsiang-ch'êng $\ldots \quad \ldots \quad \ldots \quad \ldots \quad \ldots \quad$ I I

Fên Ho $3,4,6,8$, I0, I 4, I 5, 34, I I6, I I 7, I I 9,120 ,

I 2 I, I27, I4I, I $5 \mathrm{I}$

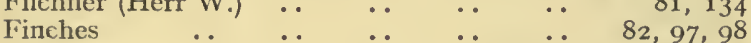

Foxes $\ldots \quad \ldots \quad \ldots \quad \ldots \quad \ldots 20,82,85,87,91$

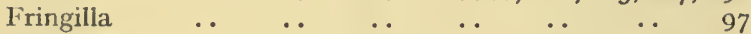

Frogs $\ldots \quad \ldots \quad \ldots \quad \ldots \quad \ldots \quad \ldots \quad 76,82,85$, II 2

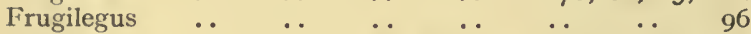

Fu Chou $\quad \cdots 34,35,55,56,76,77,124,126,128,134$

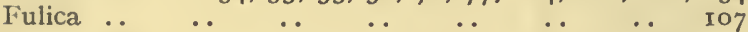

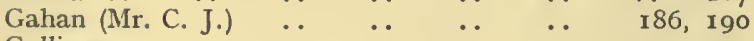

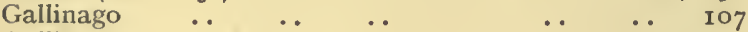

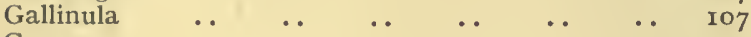

$\begin{array}{llllllll}\text { Ganges .. } & \ldots & \ldots & \ldots & \ldots & \ldots & \ldots & 5 \text { I }\end{array}$

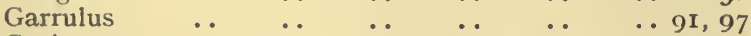

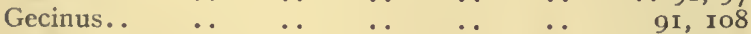

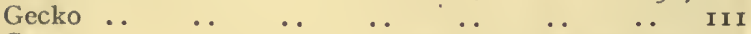

Geese $\quad \ldots \quad \ldots \quad \ldots \quad \ldots \quad 32,40,43,85,89,9$ I, I0 5

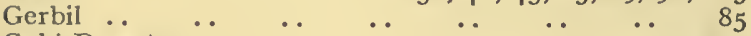

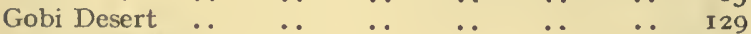

Goddess of Mercy $\quad \ldots \quad \ldots \quad \ldots 29,47$

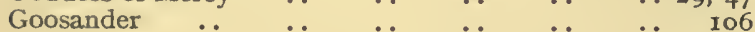

Goral

PAGE

Graculus

$4^{8}, 90$

Grant (Mr. G. A.) $\quad \cdots \quad 3, \ddot{4}, 5,7, \ddot{1} 9,22,32,33$ $34,55,56,69,70,76,87,92,93, \mathbf{1} 32, \mathbf{1} 33, \mathbf{I} 86, \mathbf{1} 87$

Grebe .

Grosbeak

Grouse ..

Grus

Gull

Gypaetus

Hai-ch'êng Hsien

Hai-shui-ssŭ

Halcyon

Haliaetus

Hamster

Han River .

Han-chung Fu. .

Hang Shan

Hankow

Hare

Hawks .

Hazrat Ali

Hedgehog

Hemiptera

Hêng Shan

Henicurus

Heron ..

Hirst (Mr. S.)

Hirundo

Hogg (Mr. H. R.)

Honan (and $\mathrm{H}, \mathrm{Fu}$ )

Hoopoe

Ho-shui Hsien

Hsi-an Fu .. I $4,22,32,33,34,36,38-43$, $44-54,58,69,89,9$ I, 99, I05, I06, I I 3 , I I 4 ,

Hsiao-shui-tzr̆

$124,129,132$

Hsia Yü Ch'ü Shui P

$59,60,71,125,126$

Hsieh-tao-ts'un

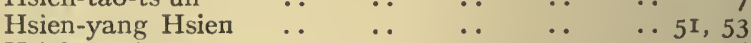

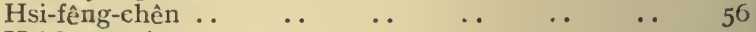

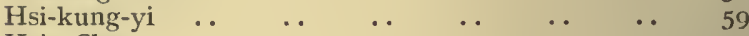

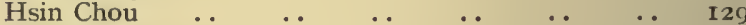

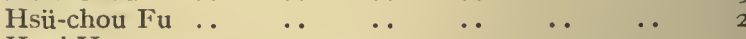

Huang Ho (or Yellow River) $\ddot{I}_{1}, 13,14,15,16, \dot{8}$

$24,43,44,59,60,6 \mathrm{I}, 7 \mathrm{I}, 77,82$, IO6, I I I, II 3 ,

I16, I19, I2 I, I22, I 26, I28, I33, I 34, I 4 I

Huang-ho-yeh

I 42,147, I 49

$\begin{array}{llllll}\text { Huang-ti } & \ldots & \ldots & \ldots & \ldots & 36,45,46 \text { (note) }\end{array}$

Huang-t'u $\quad \ldots \quad$ I I 5, I I 6,120, I $21,122,123,127,128$

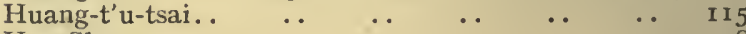

Hua Shan , .. $\quad \ldots \quad \ldots \quad \ldots 43,48$

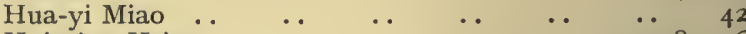

Hui-ning Hsien $\quad \ldots \quad \ldots \quad \ldots \quad \ldots \quad \ldots 53,58,126$

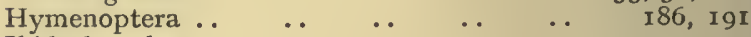

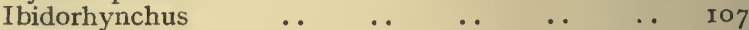

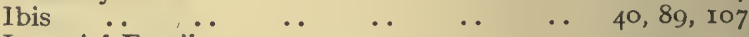

Imperial Family $\quad \ldots \quad \ldots \quad \ldots \quad \ldots \quad \ldots \quad$ 19, 22, 32

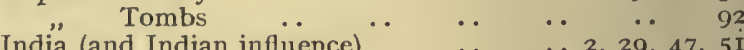

$\ldots \quad \ldots 2,29,47,5$

Inns and Innkeepers .. $\quad \ldots \quad \ldots \quad 24,26,35,53,59$

Instruments (Surveying) $\quad \ldots \quad \ldots \quad \ldots \quad \ldots \quad \ldots \quad 130$

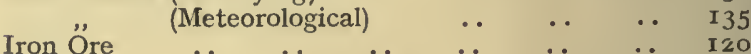

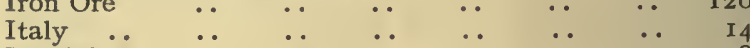

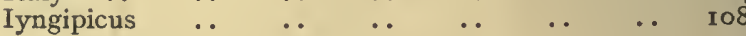


Iynx PAGE

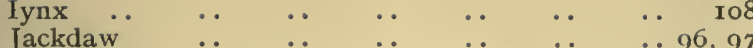

$\begin{array}{llllll}\cdots & \cdots & \cdots & \ldots & \ldots & \ldots 96,97\end{array}$

Jay

Jenkins (Dr.)

Jên-sa-ho

Jerboa

Jesuits .

Josephine

.. $\quad$. 126

$\because \quad \because 91,97$

$\begin{array}{lll}4^{\mathrm{I}}, \mathrm{I} 24 \\ \cdots & \cdots & 57\end{array}$

(see Missionaries)

.. $\quad .30,31$

$5,6,1 \mathrm{I}$

Kan-chou Fu ..

- . 53

.. $34,77, \mathrm{r} 34$

K'ang-chia-t'a

K'ang-hsi (Emperor)

Kan-ku-yü

Kan-tsao-k'ou

Kan-tsao-tien .

Kao-ti .

Kashgar (Kashgari)

K'ê-lan Chou

K'ê-lan Shan ..

Kemas galeanus

Kestrel ..

Kingfisher

Kite

Kokonor

Kowloon

Kuan Li (or Kuan Kung)

Ku-chao $\quad \cdots$.

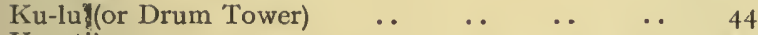

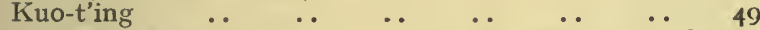

Ku-yüan Chou $57,58,70,72,73$, I25, I 31,133, I 46, I 5 I

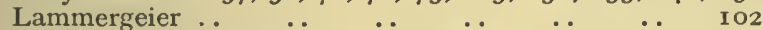

Lan-chou Fu 33, 51, $53,54,55,56,58,6063,65$, $67,70,9 \mathrm{I}, 92$, I06, I I2, 124, I25, I26, I30,

$131,132,133,134,137,145,147,1_{4} 8,1_{49}, 1_{50}, I_{5} I_{1}$

Lanius .

Lan-ts'un

Lao Chao

Lao-shan

Larks

Larus

Latitudes

Leopard

Lepidoptera

Lepus

Li-ch'tian Hsien

Lien-hua-ch'ih

Ligurinus

Limnocryptes ..

Lin Hsien

Lin-t'ung Hsien

Liu-chia-hua .

Liu-chia-mo .

Liu-chien-hua ..

Liu-lin-chên .

Liu-p'an Shan

Liu-pei . .

Liu-ts'un

Lizards

Loach

Lo-ch'uain Hsien

Longitudes

Lophophanes .

Lo Shui. .

Loxia

Lung-k'ou Miao

Lung-wang Shan

Lutreola

Lyman (Professor)

$\mathrm{Ma}$ (General)

$$
\begin{aligned}
& \begin{array}{llllll}
\ldots & \ldots & \ldots & \ldots & \ldots & 100 \\
\ldots & \ldots & \ldots & \ldots & \ldots & 119
\end{array} \\
& \text {.. } \quad \text {.. } 34 \\
& \cdots \quad{ }_{85} \mathbf{1 2 3} \\
& \text {.. .. } 106 \\
& \text {.. 70, I32, I70 } \\
& \text {.75, } 78 \\
& \text { 8o, } 8287,177,184 \\
& \begin{array}{ll}
\cdots & 53 \\
\therefore & 60
\end{array} \\
& \text { - } 97 \\
& \text {. } \quad \cdots \quad 107 \\
& \begin{array}{llr}
\cdots & & 57 \\
\cdots & 17,142
\end{array} \\
& \begin{array}{lll}
\cdots & \ldots & 18 \\
\cdots & \ldots & 77
\end{array} \\
& \begin{array}{lr}
\cdots & 57,5^{8}, 125 \\
\therefore \quad & \ldots
\end{array} \\
& \text {.. } 89,92 \\
& \text {.. } 86 \text {, I IO, I I I } \\
& \therefore \quad \text { II } 3, I_{14} \\
& 5,2 \mathrm{I}, \mathrm{I} 32, \mathrm{I} 7 \mathrm{O} \\
& \text {.. } \quad \text {. } 99 \\
& \begin{array}{lll}
\ldots & \ldots & 77 \\
. & \ldots & 97
\end{array} \\
& \text {.. } \quad \ldots 52,53 \\
& \begin{array}{llr}
\cdots & \ldots & 89 \\
\cdots & \ldots & 117
\end{array} \\
& 54
\end{aligned}
$$

Ma-chia-k'ou (Shensi)

PAGE

(Kansu)

28,123

Madeley (Rev. F.)

$64,65,66$

Ma-fêng

Magpics

Mallard

Mallophaga

Marten .

Martes .

Martins

Matschie (Mr. Paul) .

McCoy (Mr. and Mrs.)

Meade-Waldo (Mr. G.)

Merganser

Mergus . .

Meriones

Miao-ts'un

Mi-chih Hsien

Microsarcops

Microtus

Miller (Mr. G. S.)

Milvus .

Min Chou

Min Ho

Ministers (British and $\ddot{A}$ merican at $\ddot{\text { Peking) }}$

$\cdots 47,50$

$37,85,88,91,97$

$30,32,85,89$, 106

$\cdots$
$\cdots$

Mink

88, I 74

IOI

7

I 86,19 I

106

$80,85,86,178$

$\begin{array}{rrrrrr}\ldots & \ldots & \ldots & \ldots & \ldots 55,76 \\ \ldots & \ldots & \ldots & \ldots & \ldots 26,28 \\ & \ldots & \ldots & \ldots & \ldots & 107\end{array}$

$\begin{array}{llllll}\ldots & \ldots & \ldots & \ldots & \ldots 55,76 \\ \ldots & \ldots & \ldots & \ldots & \ldots 26,28 \\ & \ldots & \ldots & \ldots & \ldots & \text { 107 }\end{array}$

. $\quad \ldots 80,8 \mathrm{I}, 87, \mathrm{I} 7 \mathrm{I}, \mathrm{I} 80, \mathrm{I} 8 \mathrm{I}$

$\ldots 80,8 \mathrm{I}, 83,85,92,93,95, \mathrm{I} 7 \mathrm{I}, \mathrm{I} 8 \mathrm{o}$

102
$\cdots$

Misgurnus

Missionaries $\ddot{8}, 10, \ddot{1} \mathbf{x}, 12, \dot{3} 9,41, \dot{50}, 56,66,73,74,133$

Mi-yüeh-ch'êng

Mo-an .

Mo-êrh Shan

Mohammedan Rebellion

Mole

Mole-rat

Mongolia

Monkey

Monopterus

Monument Grove

Moorhen

Motacilla

Mounds (about Hsi-an Fu)

.. 9, I $5,81,82$, I $21, I 4 I$

Moupin

Mouse (wood, $\ddot{8} \mathbf{r}, 88$ ), (field, $\ddot{86}, 89$ )

Muhammad Husein

$29,54,55,56,62,74,75$

Mullen (Mr.)

Mus

Mustela. .

Myospalax

Nan-shih

Nestorian Tablet

82,84, I 29

Nettion

Neuropter

New Dominion

Ning-hsia Fu.

Ning-ling 'T'ing

Ning-wu Fu

Nipponia

Nucifraga

Numenius

Nutcracker

4, 62, $71,83,85,98$, 102, 105

Nuthatch

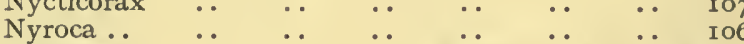

Ochotona $\quad \ldots \quad \ldots \quad \ldots 80,87,92$, I $71, \ddot{1} 8_{4}, 185$

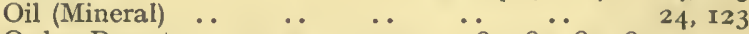

Ordos Desert $10,17,20,21,29,71,80,83,85,87$,

96, I05, I06, I I0, I I I, I I2, I 22, I23, I28, I29, I36, I43

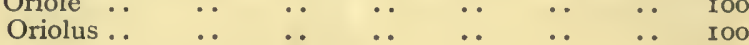


PAGE

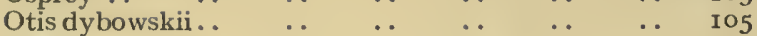

$\begin{array}{lllllllll}\text { Otters } & \ldots & \ldots & \ldots & \ldots & \ldots & \ldots & \ldots & 76\end{array}$

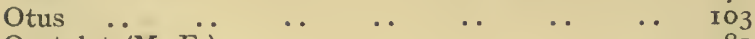

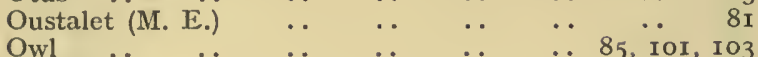

$\begin{array}{llllllll}\text { Pai-ma-p'u } & \ldots & \ldots & \ldots & \ldots & \ldots & \ldots & 56\end{array}$

$\begin{array}{llllllll}\text { Pandion } & \ldots & \ldots & \ldots & \ldots & \ldots & \ldots & 103\end{array}$

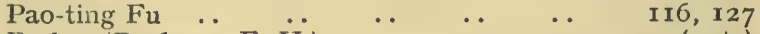

Parker (Professor E. H.) ․ . . . 49 (note)

Partridges $\quad \ldots \quad \ldots \quad 17,28,30,75,82,86,91,104$

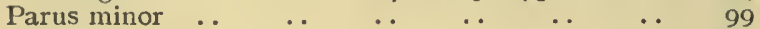

$\begin{array}{llllllll}\text { Pei-chih-li } & \ldots & \ldots & \ldots & \ldots & \ldots & \ldots & 7 \text { I }\end{array}$

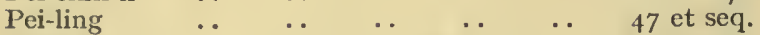

Peking .. $\quad \ldots 3,22,44,62,68,69,73,78,88,92,134$

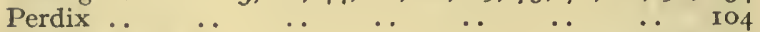

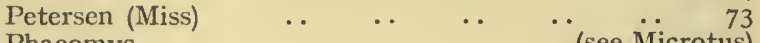

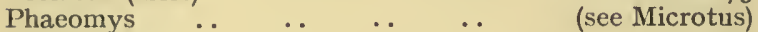

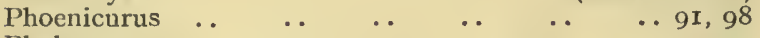

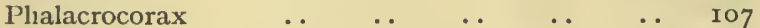

$\begin{array}{llllllll}\text { Phasianus } & \ldots & \ldots & \ldots & \ldots & \ldots & \ldots & 104\end{array}$

Pheasant $28,30,31,32,34,36,37,75,82,85,86$,

Phodopus

$88,89,9$ I, IOI, 104

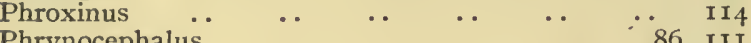

$\begin{array}{rrrrrr}\text { Phrynocephalus } & \ldots & \ldots & \ldots & \ldots & 86, \text { II I }\end{array}$

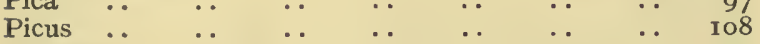

Pig (Wild) $\quad \ldots 30,3 \mathrm{r}, 37,75,77,82,88,89,92,93,94$

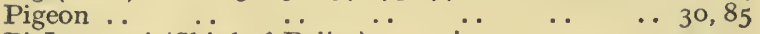

Pi Jung-pei (Chief of Police) $\quad \ldots \quad \ldots \quad \ldots 19,23$

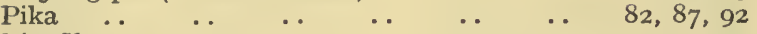

Pin Chou $\quad \ldots \quad$.

P'ing-liang Fu $\quad \ldots \quad \ldots \quad \ldots \quad \ldots 5,53,56,134$

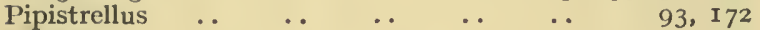

$\begin{array}{llllllll}\text { Platalae } & \ldots & \ldots & \ldots & \ldots & \ldots & \ldots & \text { 107 }\end{array}$

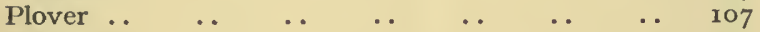

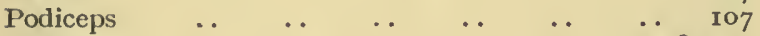

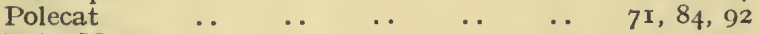

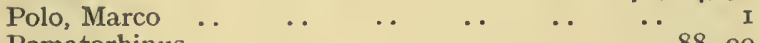

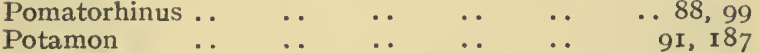

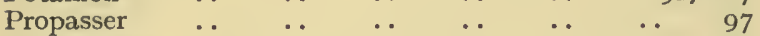

\begin{tabular}{lllllll} 
Pterorhinus & $\ldots$ & $\ldots$ & $\ldots$ & $\ldots$ & $\ldots$ & $\ldots$ \\
\hline
\end{tabular}

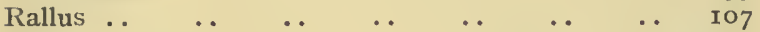

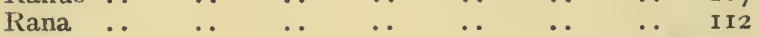

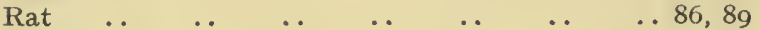

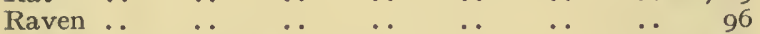

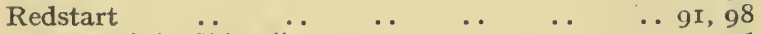

"Research in China " $\quad \ldots \quad \ldots . \quad \ldots \quad$ I 5 , I I6

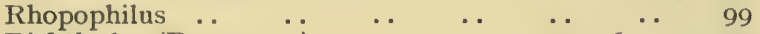

Richthofen (Baron von) .. $\quad \ldots$ I I 5, I I 6, I I 7, I 20

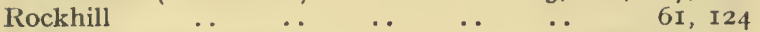

Rothschild (Hon. N. C.) _. $\quad \ldots \quad \ldots 186,194-203$

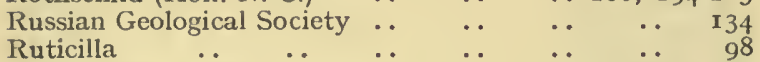

Sacred Peaks (Five) $\ldots \quad \ldots \quad \ldots \quad \ldots 4$ (note) 48,50

Salt

Sandstorm

San-yeh Miao

San-yüan Hsien

Saxicola

Scaptochirus .

Sciurotamias ..

Scops

Scorpiones

Shang Chou

Shanghai

Shantung

Shao-shui-tzŭ ..

Shao-t'u

.. II 5, II $6,123,127,128,129$
Sheldrake

Shêng-yi

Shên-kan

Shensi (North S. basin)

Shih Huang-ti (Emperor)

Shih-ts'ui-yi

Shou-yang Hsien

Shrew

Shrike ..

Siberia .

Silurus .

Silver Ore

Sinkiang (or New Dominion)

Siphneus

Siphonaptera .

Sitta

Smew

Snakes .

Snipe ‥

Spatula

Squirrel

Ssŭch'uan

Starling Emigrants.

Sternus

Stork

Sui-fu ..

Sui-tê Chou

Sung-chia-k'ou

Sung Shan

Suslik

Sus moupinensis

Swallows

Swan

Swifts ..

Syrrhaptes

Szechenyi (Count della)

Tadorna

Ta-fu-ssŭ

Tahkin.

T'ai-pei-ch'êng (2)

T'ai-pei Shan ..

T'ai Shan .. T'ai-yuian Fu $2,3,4,6,7,8$, Io, I 4, I $5,26,30,3$ I,
$\quad 69,70,78,79,80,81,85,87,92,95$, I 66 , I I 5, I I 6 ,

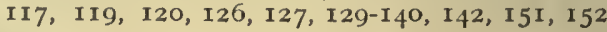

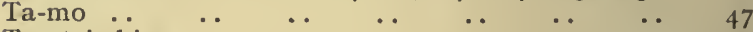

$\begin{array}{llllllll}\text { Tao-tei-ching } & \ldots & \ldots & \ldots & \ldots & \ldots & \ldots & 51 \\ \text { Teal }\end{array}$

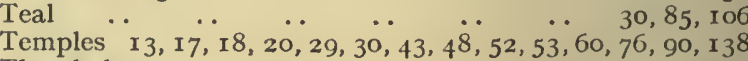

Tharrhaleus $\ldots$.. $\quad \ldots \quad \ldots \quad \ldots$...

Thomas (St.) .

Thomas (Mr. O.)

Thrush ..

$\ddot{80}, 83, \ddot{8}_{4}$, I $7 \dot{1}$, I $79, \ddot{1} 80, r 84$

Tibet (Tibetan)

Tichodroma

T'ien-chuang ..

Tientsin

Timeline

Tits

Toad

Tou-fu-ssư

Trionyx

Trochalopteron

Tropidonatus .

Ts'a-fêng

Ts'ai-chia-wei ..

Tsa-k'ou

Tso Ching-t'ang

$\ddot{22}, \ddot{1}_{12}, \ddot{1}_{28}^{2,},{ }^{2}$

. 27,85

129
$\cdots \quad 82$

62,105

119,126

83 (note)

99
$\mathbf{1} 06$

$75,85,9 \mathrm{r}, \mathrm{IO} 7$

, 88

55,73

$85,106,107$ . $26,27,28,70,77,123,126,151$

sce Sacred Peaks

$82,93,94,95$,

.. IOI

106

I05

I34

106

48

$55,56,76$ $4^{8}$

Tui Ho..
$6,44,62,63,94,57$ 9I, IOO

. $5, \mathrm{r}_{32}$

$. .82,88,91,99$

91,99
$\ldots 82,99$

$\cdots \quad$ II 2

93, III

86,99

. 35,36

$\ddot{8}, 9, \quad$ I 20

. 61
85,100

88, I 86, I 87, I $94-203$

$83,86,88,10$ 
PAGE

Tung Fu-shang

T'ung-kuan

Turdus .

Turkestan

Turtle, Mud

Turtur ..

Upupa ..

Urocissa

Urotragus

Vanellus

Vole

Vormela

Vulpes.

Vulture

Vultur.

Waders

Wagtail

Wa-kang-ch'êng

Wall, Great

Wall Creeper .

Wan Li (Emperor)

Warblers

Water-rail

Wa-t'ing

Waxwing

Wei Ho..

Wên-shui Hsien

Wheatear

Wild Cat

Wild Fowl

Willis, (Mr. B.)

Wolf

Woodpecker

Wool and Woollen Cloth

Wrens

Wryneck

Wu-ch'êng
$54,72,73$

$38,42,43,44,49$, II 6

․ $\quad$.. 99

77, 93, III

.. 105

.. 108

$88,9 \mathrm{I}, 97$

90,175

.. $\quad . \quad 107$

.. xо, $81,87,88$

84,85, I 7 I, 173

.. . 82

.. 82-102

.. 102

- 91, 106, 107

98,100

.. 64,66 , I 26

$20,2 \mathrm{I}, 45, \mathrm{I} 28$

.. 91,100

.. .. 48

.. $\quad$.. 107

$\begin{array}{lll}\cdots & \cdots & 107 \\ \cdots & \cdots & 125\end{array}$

. $\quad \ldots \quad$ 100

. $38,44,50,5$ I, I I 5, I I 6, I 24, I 28

$\begin{array}{rrrrrr}\ldots & \ldots & \ldots & \ldots & \ldots & \text { II } 7 \\ \ldots & \ldots & \ldots & \ldots & \ldots & 98\end{array}$

$\begin{array}{lllll}\ldots & \ldots & \ldots & \ldots & \ldots 85,88\end{array}$

. $\quad \ldots \quad \ldots \quad \ldots 30,32,40,43$

. $\quad \ldots \quad \ldots \quad \ldots 15$, II 7, I 24

. . II I I $2,75,82,85,87,88,92$

. $\quad \ldots \quad 82,85,91,108$

.. $\quad \ldots \quad \ldots \quad \ldots 20,61$

.. $\quad \ldots \quad \ldots 91,99,100$

$\begin{array}{llll}\cdots & \ldots & \ldots & \ldots\end{array}$

$\therefore \quad \ldots \quad \ldots 7$, II 7,127
.. $\quad$.. 99
PAGE

$\begin{array}{lllllll}\text { Wu-pao Hsien } & \ldots & \ldots & \ldots & \ldots & \ldots & \text { I27 }\end{array}$

Wu-t'ai Shan $\ldots \quad \ldots \quad \ldots \quad \ldots \quad \ldots \quad \ldots, \quad \ldots 3$, II6

Wu-ting $\mathrm{Ho} \quad \ldots \quad \ldots \quad \ldots \quad \ldots \quad(\sec Y \ddot{u}-l i n \mathrm{Ho})$

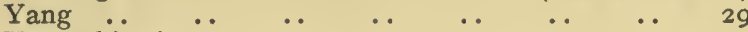

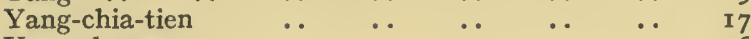

$\begin{array}{lllllll}\text { Yang-shu-wan } & \ldots & \ldots & \ldots & \ldots & \ldots & 56\end{array}$

$\begin{array}{lllllll}\text { Yang-tzŭ } & \ldots & \ldots & \ldots & \ldots & \ldots & 2,49,90\end{array}$

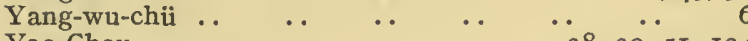

Yao Chou

Yellow Emperor

River .. Yen̈-an Fuver . $38,39,5 \mathrm{r}, \mathrm{I} 24$
(see Huang Ti) , $33,34,36,37$ $89,93,95$, I I I, I 22, I23, I24, I $31, I_{32}, I_{33}$

Yen-ch'ang Hsien I 34, I $36, I 44, I 45$, I 5 I

$\begin{array}{lllll}\cdots & \cdots & \ldots & \ldots & \ldots 24,123\end{array}$

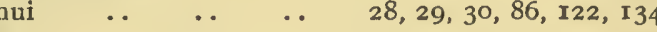

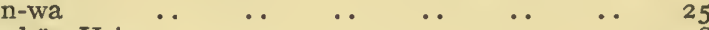

Yi-chün Hsien $\quad \ldots \quad \ldots \quad \ldots 37,38$

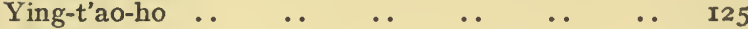

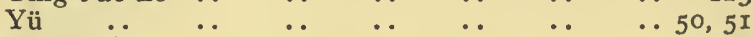

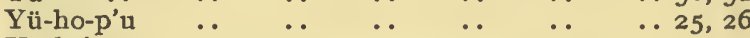

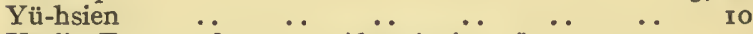

Yü-lin Fu 13, I8, 19, 20, (description of) 22, 24, 25, $26,82,53,79,80,82,83,86,87,91$, I 06 , I I I I I , I I 2, I I 3, I I 4, I I6, I 22, I 23, I 28, I29, I3I,

I $32,136,142,143,144$

Yü-lin Ho (or Wu-ting Ho) 20, 21, 24, 25, 26, 28, I 12, 143

Yung-ho Hsien $\quad \ldots \quad \ldots . \quad \ldots \quad \ldots . \quad \ldots \quad$ I34

$\begin{array}{llllll}\text { Yung Hui } & \ldots & & \ldots & \ldots & \text {. },\end{array}$

Yung-shou Hsien $\quad \ldots \quad \ldots \quad \ldots \quad \ldots \quad \ldots 5,54$

Yung-yao $\quad \ldots \quad \ldots \quad \ldots \quad \ldots \quad \ldots \quad \ldots, \quad \ldots 52,54$

Yün-t'ing Shan $\quad \ldots \quad \quad \ldots 9$, II I I I, I36, I4I, I42

Zamenis $\ldots$... . . . .

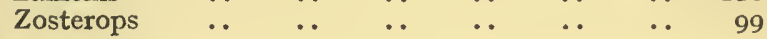

NOTE. - The Index includes all specimens mentioned in Appendices II.-V. (Insects by Orders).

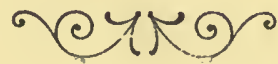


Printed By

W. T. PIKE, Limited,

47 Gloster Road, Brighton ;

AND LONDON. 
THIS BOOK IS DUE ON THE LAST DATE STAMPED BELOW

AN INITIAL FINE OF 25 CENTS WILL BE ASSESSED FOR FAILURE TO RETURN WILL BOOK ON THE DATE DUE. THE PENALTY THIS BOOK ON THE 50 CENTS ON THE FOURTH WILL INCREASE TO SO CENTS SHE SEVENTH DAY DAY AND OVERDUE.

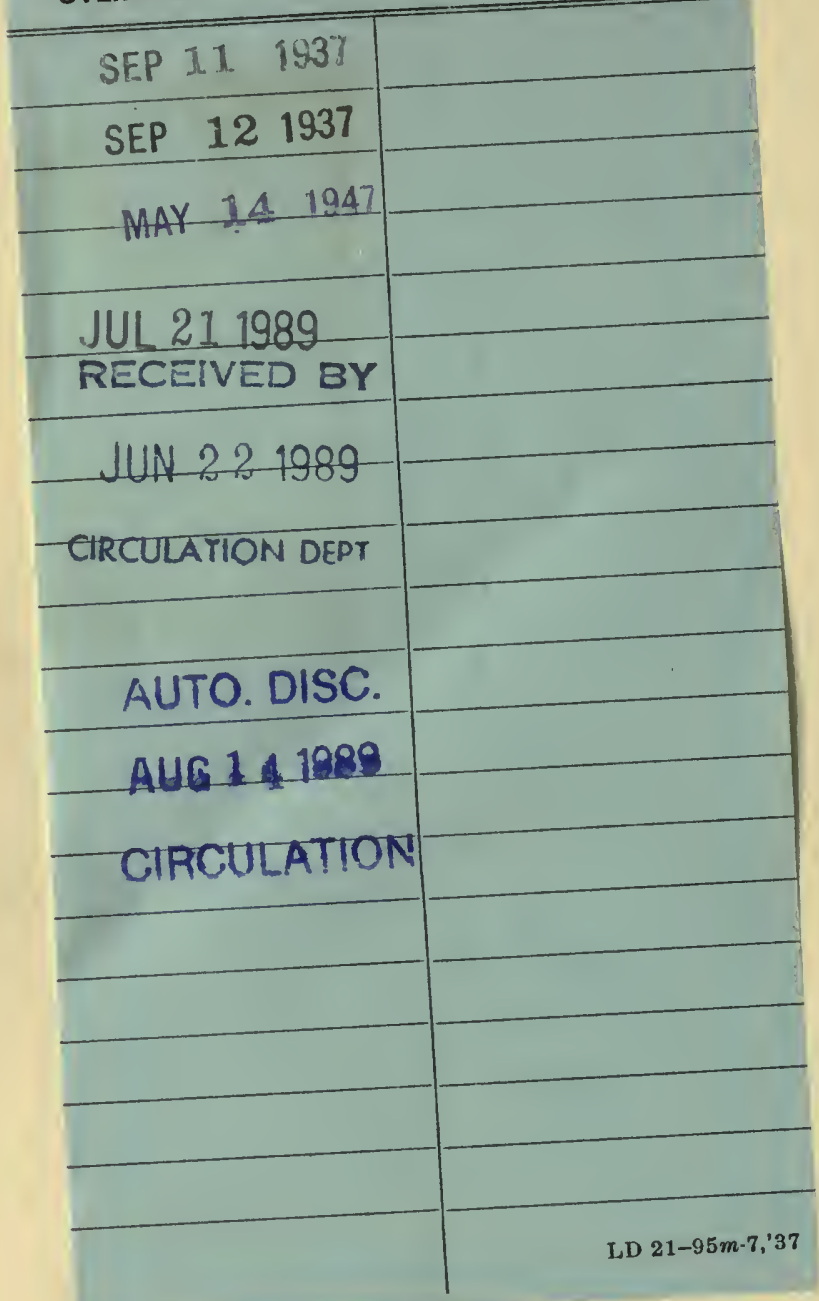




\section{U.C. BERKELEY LIBRARIES}

C006096428

\section{4}




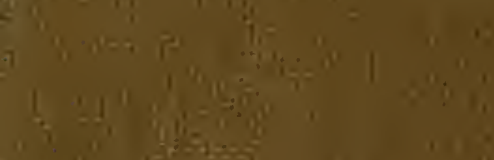

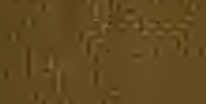

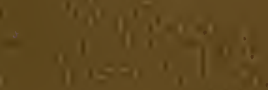

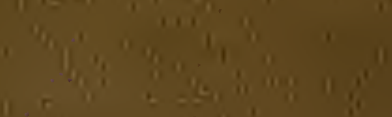

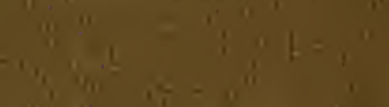

$\frac{1}{1,203}$

207.

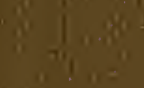

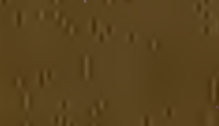

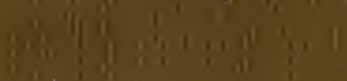

i. $i=0$ :

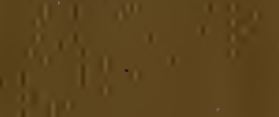

(ini

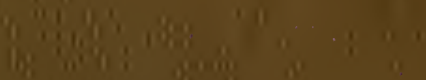

